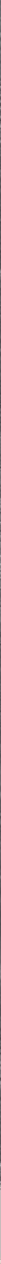

\title{
THE RECEPTION OF \\ THE PRINTED IMAGE IN THE \\ FIFTEENTH AND SIXTEENTH CENTURIES
}

\section{MULTIPLIED AND MODIFIED}

(2) EDITED BY GRAŻYNA JURKOWLANIEC 


\section{The Reception of the Printed Image in the Fifteenth and Sixteenth Centuries}

This book examines the early development of the graphic arts from the perspectives of material things, human actors and immaterial representations while broadening the geographic field of inquiry to Central Europe and the British Isles and considering the reception of the prints on other continents.

The role of human actors proves particularly prominent, i.e. the circumstances that informed creators', producers', owners' and beholders' motivations and responses. Certainly, such a complex relationship between things, people and images is not an exclusive feature of the pre-modern period's print cultures. However, the rise of printmaking challenged some established rules in the arts and visual realms and thus provides a fruitful point of departure for further study of the development of the various functions and responses to printed images in the sixteenth century.

The book will be of interest to scholars working in art history, print history, book history and European studies.

Grażyna Jurkowlaniec is a professor at the Institute of Art History at the University of Warsaw.

Magdalena Herman is a $\mathrm{PhD}$ candidate at the University of Warsaw.

Cover Image: Albrecht Dürer, Adam and Eve, 1504, engraving. Warsaw,

Muzeum Narodowe w Warszawie, 11606 MNW. Photo: (C) Muzeum

Narodowe w Warszawie, Piotr Ligier.

Anonymous painter after Albrecht Dürer, Adam and Eve, early seventeenth century, oil on copper. Warsaw, Muzeum Narodowe w Warszawie, M.Ob.277 MNW. Photo: (C) Muzeum Narodowe w Warszawie, Krzysztof Wilczyński.

Heinrich Aldegrever, Adam with a Lion, before 1561, engraving. Warsaw, Muzeum Narodowe w Warszawie, Gr.Ob.N.6 MNW.

Photo: @ Muzeum Narodowe w Warszawie.

Compiled by Aleksandra Fedorowicz-Jackowska 


\section{Routledge Research in Art History}

Routledge Research in Art History is our home for the latest scholarship in the field of art history. The series publishes research monographs and edited collections, covering areas including art history, theory, and visual culture. These high-level books focus on art and artists from around the world and from a multitude of time periods. By making these studies available to the worldwide academic community, the series aims to promote quality art history research.

Lower Niger Bronzes

Philip M. Peek

Art, Mobility, and Exchange in Early Modern Tuscany and Eurasia

Edited by Francesco Freddolini and Marco Musillo

The Cobra Movement in Postwar Europe

Reanimating Art

Karen Kurczynski

Emilio Sanchez in New York and Latin America

Victor Deupi

Henri Bertin and the Representation of China in Eighteenth-Century France John Finlay

Picturing Courtiers and Nobles from Castiglione to Van Dyck

Self Representation by Early Modern Elites

John Peacock

The Reception of the Printed Image in the Fifteenth and Sixteenth Centuries Multiplied and Modified

Edited by Grazyna Jurkowlaniec and Magdalena Herman

Iconology, Neoplatonism, and the Arts in the Renaissance

Edited by Berthold Hub and Sergius Kodera

For a full list of titles in this series, please visit https://www.routledge.com/RoutledgeResearch-in-Art-History/book-series/RRAH 


\section{The Reception of the Printed Image in the Fifteenth and Sixteenth Centuries \\ Multiplied and Modified}

Edited by Grażyna Jurkowlaniec and Magdalena Herman 
First published 2021

by Routledge

52 Vanderbilt Avenue, New York, NY 10017

and by Routledge

2 Park Square, Milton Park, Abingdon, Oxon, OX14 4RN

Routledge is an imprint of the Taylor \& Francis Group, an informa business

(c) 2021 Taylor \& Francis

The right of Grażyna Jurkowlaniec and Magdalena Herman to be identified as the authors of the editorial material, and of the authors for their individual chapters, has been asserted in accordance with sections 77 and 78 of the Copyright, Designs and Patents Act 1988.

With the exception of Introduction, no part of this book may be reprinted or reproduced or utilised in any form or by any electronic, mechanical, or other means, now known or hereafter invented, including photocopying and recording, or in any information storage or retrieval system, without permission in writing from the publishers.

Introduction of this book is available for free in PDF format as Open Access from the individual product page at www.routledge.com. It has been made available under a Creative Commons Attribution-Non Commercial-No Derivatives 4.0 license.

Trademark notice: Product or corporate names may be trademarks or registered trademarks, and are used only for identification and explanation without intent to infringe.

Library of Congress Cataloging-in-Publication Data

Names: Jurkowlaniec, Grażyna, editor. I Herman, Magdalena, editor.

Title: The reception of the printed image in the fifteenth and sixteenth centuries : multiplied and modified / edited by Grażyna Jurkowlaniec and Magdalena Herman.

Description: New York, NY : Routledge, 2020. I Series: Routledge research in art history I Includes bibliographical references and index.

Identifiers: LCCN 2020014521 (print) I LCCN 2020014522 (ebook) I ISBN 9780367465117 (hbk) I ISBN 9781003029199 (ebk)

Subjects: LCSH: Prints, European-15th century. I

Prints, European-16th century. I Prints, European-17th century. I

Prints, European-Reproduction. I Prints, European-Themes, motives. I

Aesthetics, Modern. I Art and society.

Classification: LCC NE625 .R434 2020 (print) | LCC NE625 (ebook) |

DDC 769.9/031—dc23

LC record available at https://lccn.loc.gov/2020014521

LC ebook record available at https://lccn.loc.gov/2020014522

ISBN: 978-0-367-46511-7 (hbk)

ISBN: 978-1-003-02919-9 (ebk)

Typeset in Sabon

by Apex CoVantage, LLC 


\section{Contents}

List of Figures vii

List of Colour Plates $\quad$ xv

Acknowledgements xviii

List of Contributors xix

List of Abbreviations $\quad$ xxiv

Introduction: People Between Multiplied Things and Modified Images 1

GRAŻYNA JURKOWLANIEC AND MAGDALENA HERMAN

PART I

Things

1 Multiplicity and Absence: The Negative Evidence of Interactive Prints 27 SUZANNE KARR SCHMIDT

2 Playing With Destiny: Three Late Fifteenth-Century Uncut Playing-Card Sheets from Florence and Urbino LORETTA VANDI

3 Cultivating Designs: Early Ornamental Prints and Creative Reproduction JAMES WEHN

4 Gillet and Germain Hardouyn's Print-Assisted Paintings: Prints as Underdrawings in Sixteenth-Century French Books of Hours MAUREEN WARREN

5 A Passion for Prints: Netherlandish Engravings in an Early Sixteenth-Century Prayer Book 
6 Eroticism Under a Watchful Eye: Censorship and Alteration of Woodcuts in Ovid's Metamorphoses Between the Fifteenth and the Sixteenth Centuries

GIUSEPPE CAPRIOTTI

7 Limitations of the Reception and Consumption of Illustrations in Chronica Polonorum by Maciej of Miechów (Cracow, 1521)

KAROLINA MROZIEWICZ

8 A Foreign Affair: Thomas Gemini and His Booklet of Moresque Designs FEMKE SPEELBERG

9 Speaking Images and Speaking to the Images: Inscriptions in Religious Prints Published by Antonio Lafreri ALEXANDRA KOCSIS

PART III

Images

10 Saint George From Greater Poland: Complexities of the Reception of Albrecht Dürer's Engraving JOANNA SIKORSKA

11 Changing Fortunes: Dürer's Nemesis and the Beham Brothers MAŁGORZATA ŁAZICKA

12 The Set of the Four Elements by Hendrick Goltzius and the Use of Engravings in the Seventeenth Century JÚLIA TÁTRAI

13 Different Confessions, Different Visions of Heaven? Visual Eschatology, Cross-Confessional Conformity and Confessional Identity Marking in the Picture Motet The Adoration of the Lamb and in Its Reception ANDRÁS HÁNDL

14 Prints and the Beginnings of Global Imagery 


\section{Figures}

0.1 Crucifixion, woodcut in Missale Gnesnense (Cracow: Jan Haller, 1506). Unpreserved, formerly Poznań, Biblioteka Seminarium Duchownego.

0.2 Flagellation, woodcuts in a) Sposób mówienia psatterzyka (Cracow: Wojciech Kobyliński, 1613), fol. 10v. Kórnik, Polska Akademia Nauk Biblioteka Kórnicka, 126722; b) Stanisław of Radymno, Fasciculus Litaniarum (Cracow: Marcin Horteryn 1622), 139. Cracow, Biblioteka Jagiellońska, 36031; c) Adrian Wieszczycki, Ogród rozkoszny miłości Bożej (Cracow: Walerian Piątkowski, 1650), fol. B4r. Cracow, Biblioteka Jagiellońska, 285484.

0.3 Crucifixion after Peeter van der Borcht and Anton van Leest. Upper row: Piotrkowczyk's block No. 1, woodcuts a) in Marcin Laterna, Harfa duchowna (Cracow: Andrzej Piotrkowczyk I, 1592), 265. Cracow, Biblioteka Jagiellońska, Cim.O.269; b) pasted into Drogi doskonatości chrześcijańskiej (Kalisz: Collegium Societatis Iesu, 1665). Kórnik, Polska Akademia Nauk Biblioteka Kórnicka 126719 (scanned from microfilm: Mf 7798); c) in Marcin Laterna, Harfa duchowna (Cracow: Andrzej Piotrkowczyk I, 1611), 384. Wrocław, Zakład Narodowy im. Ossolińskich, XVII.1175.

Lower row: d) Piotrkowczyk's block No. 2 used in Adrian Wieszczycki, Modus recidandi rosarii (Cracow: Antoni Wosiński, 1629). Cracow, Biblioteka Jagiellońska, 285484; e) Piotrkowczyk’s block No. 3 used in Adrian Wieszczycki, Ogród rozkoszny miłości Bożej (Cracow: Walerian Piątkowski, 1650), fol. C1v. Cracow, Biblioteka Jagiellońska, 285484; f) probably Lob's or Piotrkowczyk's block No. 4 used in unidentified prayer book, fol. K4r. Kórnik, Polska Akademia Nauk Biblioteka Kórnicka, Cim.O.611.

0.4 Saint John the Baptist after Peeter van der Borcht and Paulus van Wtewael, hand-coloured woodcut in Marcin Laterna, Harfa Duchowna (Cracow: Andrzej Piotrkowczyk I, 1612), 575. Kórnik, Polska Akademia Nauk Biblioteka Kórnicka, 126721 adl.

0.5 Aurochs, woodcut in Conrad Gessner, Historiae Animalium Liber I de Quadrupedibus viviparis (Zurich: Christoph Froschauer, 1551), 157. Warsaw, Biblioteka Narodowa, SD XVI.F.1429 I. 
0.6 Wisent, fragment of $P l$. XVI, engraving in Jan Jonston, Historiae Naturalis De Quadrupedibus Libri (Frankfurt/M: heirs of Matthäus Merian [1652?]). Warsaw, Biblioteka Narodowa, SD XVII.4.2278.

0.7 Chapters on aurochs and wisent in Gessner's personal copy of Conrad Gessner, Icones animalium quadrupedum (Zurich: Christoph Froschauer, 1560), 29-31, Zurich, Zentralbibliothek, NNN 44 | F.

0.8 Bull of Florida, woodcut in Gessner's personal copy of André Thevet, Les singularitez de la France antarctique. . . (Antwerp: Christophe Plantin, 1558), fol. 144v. Basel, Universitätsbibliothek Basel, Hx VI 30.

0.9 Pl. IV, engraving in Ulisse Aldrovandi, Quadrupedum omnium bisulcorum Historia (Frankfurt/M: David Johann Zunner and Peter Haubold, 1647), 144. Cracow, Biblioteka Jagiellońska, St. Dr. Zool. 539(a)III.

1.1 Decorative volvelle knot covers from Giovanni Paolo Gallucci, Coelestium corporum, et rerum ab ipsis pendentium accurata explicatio (Venice: Giacomo Antonio Somasco, 1605), 42 woodcut squares on two uncut sheets. Wolfenbüttel, Herzog August Bibliothek, 11.2 Astron. (3).

1.2 a) Third volvelle in Peter Apian, Cosmographicus liber (Landshut: Johann Weyssenburger/Peter Apian, 1524), fol. 24. Munich, Bayerische Staatsbibliothek, Rar. 271, urn:nbn:de:bvb: 12-bsb00064968-2; b) third volvelle from Peter Apian, Gemma Frisius, Cosmographia (Antwerp: Gregorius Bontius, 1550), fol. 11r. Chicago, Newberry Library, Ayer 7. A7 1550b); c) rosette volvelle knot cover from Peter Apian, Gemma Frisius, Cosmographia (Antwerp: Gregorius Bontius, 1550), fol. 11v, applied woodcut and letterpress. Chicago, Newberry Library, Ayer 7. A7 1550b; d) vernicule volvelle knot cover from Peter Apian, Gemma Frisius, Cosmographia (Antwerp: Gregorius Bontius, 1553), fol. 11, applied woodcut and letterpress. Munich, Bayerische Staatsbibliothek, Hbks/R 2 f., urn:nbn:de:bvb:12-bsb10806466-1.

1.3 Sebastian Münster, Ein new lustig und kurzweilig Instrument der Sonnen, mit eingesetzter Landtafel Teutscher nation (Oppenheim: Sebastian Münster, 1528), hand-colored woodcut and letterpress broadsheet. Basel, Universitätsbibliothek Basel, Km XI 13:3 Tafel.

1.4 a) Veronica (Vera Icon) wallpaper from: Sawicka, Einblattdrucke, pl. 1, collotype of woodcut (first quarter fifteenth century). Chicago, Newberry Library, Case folio W 8014.25 v. 74, pl. 1; b) collage of multiple Veronica (Vera Icon) impressions as continuous wallpaper.

1.5 a) German (Augsburg), broadsheet on the conjoined twins of Ertingen, 1512, double-sided woodcut (lacking) inserted in letterpress broadsheet. Munich, Bayerische Staatsbibliothek, Einbl. I, 41, urn:nbn:de:bvb:12-bsb00098155-6; b) German, Wondrously Strange Roman Catholic Wheel of Fortune, 1620, broadsheet with engraving (missing volvelle dial) and letterpress. Nuremberg, Germanisches Nationalmuseum, HB 19894/1336. 
1.6 Anonymous after Matthäus Greuter, a) The Virgin's Mirror and b) Love, You Are Blind, after 1596, paired engravings with flaps (lacking). Halle (Saale), Kulturstiftung Sachsen-Anhalt, Staatliche Galerie Moritzburg, F 755 and F 691.

1.7 Matthäus Greuter (German, 1564-1638), Pride, 1596, engraving with skirt flap. Wolfegg, Kunstsammlungen der Fürsten zu Waldburg-Wolfegg, Album 243, no. 173.

1.8 a) Detail of Figure 1.6a; b) detail of Conrad Goltzius, Male Pride, c. 1600, engraving with flap (lacking). Wolfegg, Kunstsammlungen der Fürsten zu Waldburg-Wolfegg, Album 219, no. 198.

1.9 German, octahedral sundial, early sixteenth century, a) woodblock; b) modern impression. Munich, Bayerisches Nationalmuseum, Clock Department, Vitr. 27, L 72/130.

1.10 Lucas Cranach the Elder, astrolabe for students, 1529, photograph taken by Ernst Zinner before World War II of hand-colored woodcut volvelle. Formerly Jena, Universitätsbibliothek Jena.

2.1 Rosenwald Playing-Card Sheet No. 2, woodcut, late fifteenth to early sixteenth century. Washington, National Gallery of Art, Lessing J. Rosenwald Collection, 1951.16.6.

2.2 a) Centaur of Cups; b) Centaur of Swords, Crippa Playing-Card Deck, woodcut, late fifteenth to first quarter of the sixteenth century. Milan, Crippa Collection.

2.3 Centaurs series, detail of figure 2.1.

2.4 Numeral cards, Rosenwald Playing-Card Sheet No. 1, woodcut, late fifteenth to early sixteenth century. Washington, National Gallery of Art, Lessing J. Rosenwald Collection, 1951.16.5.

3.1 Israhel van Meckenem, Ornamental Engraving with the Jesse Tree, c. 1490, engraving. Washington, National Gallery of Art, 1943.3.169.

3.2 Israhel van Meckenem, Ornamental Engraving with Morris Dancers, c. 1490, engraving. Cleveland Museum of Art, 1952.532.

3.3 Israhel van Meckenem, Ornamental Engraving with the Engraver's Name, c. 1490, engraving. Berlin, Staatliche Museen zu Berlin, Kupferstichkabinett, 45-1884.

3.4 Israhel van Meckenem, after Master ES, Ornamental Engraving, Foliage on Black Ground, c. 1476, engraving. Cambridge, Fitzwilliam Museum, 22.I.2-72.

3.5 Israhel van Meckenem, Ornamental Flowers and a Chimeric Animal, c. 1485, engraving, London, The British Museum, $1925,0406.89$.

3.6 South German, backside of Cross reliquary with the Jesse Tree, 1492, Lindau, Münster Unserer Lieben Frau; digitally reconstructed using photographs of an impression of the engraved silver plate printed on wove paper, c. 1900. Munich, Staatliche Graphische Sammlung, 197000 D.

4.1 Detail of Plate 9.

4.2 Death of the Virgin, metalcut in Hore intemerate virginis Marie secundum usum Romanum (Paris: Jean Pichore and Remy de Laistre, 24 September 1504). Berlin, Kupferstichkabinett, 796. 
5.1 Lucas van Leyden, Lamentation of Christ, 1521, engraving, hand-coloured and pasted into prayer book manuscript c. 1530. Amsterdam, Rijksmuseum, RP-P-2011-115-11.

5.2 Master S, Seven Sorrows of the Virgin, c. 1520, engraving, hand-coloured and pasted into prayer book manuscript c. 1530. Amsterdam, Rijksmuseum, RP-P-2011-115-15.

5.3 Frans Crabbe, Mass of Saint Gregory, c. 1520, engraving and etching, hand-coloured and pasted into prayer book manuscript c. 1530. Amsterdam, Rijksmuseum, RP-P-2011-115-16.

5.4 Frans Crabbe, Adoration of the Christ Child, c. 1520, engraving and etching, hand-coloured and pasted into prayer book manuscript c. 1530. Amsterdam, Rijksmuseum, RP-P-2011-115-18.

6.1 Priapus and Lotis, 1497, woodcut in Ovidius, Metamorphoses (Parma: Francesco Mazali, 1505), fol. 102v. Fermo, Biblioteca Civica Romolo Spezioli, 2V12/17241.

6.2 Peleus and Thetis, 1497, woodcut in Ovidius, Metamorphoses (Parma: Francesco Mazali, 1505), fol. 30v. Fermo, Biblioteca Civica Romolo Spezioli, 2V12/17241.

6.3 Hippomenes and Atalanta, 1497, woodcut in Ovidius, Metamorphoses (Parma: Francesco Mazali, 1505), fol. 116r. Fermo, Biblioteca Civica Romolo Spezioli, 2V12/17241.

6.4 The Childbirth by Alcmene, 1497, woodcut in Ovidius, Metamorphoses (Parma: Francesco Mazali, 1505), fol. 101v. Fermo, Biblioteca Civica Romolo Spezioli, 2V12/17241.

6.5 Narcissus, 1497, woodcut in Ovidius, Metamorphoses (Parma: Francesco Mazali, 1505), fol. 36r. Macerata, Biblioteca Civica Mozzi Borgetti, 9.2.A.20.

6.6 Hippomenes and Atalanta, 1497, woodcut in Ovidius, Metamorphoses (Parma: Francesco Mazali, 1505), fol. 116r. Macerata, Biblioteca Civica Mozzi Borgetti, 9.2.A.20.

6.7 Mercury, Herse and Aglaurus, 1497, woodcut in Ovidius, Metamorphoses (Parma: Francesco Mazali, 1505), fol. 28r. Macerata, Biblioteca Civica Mozzi Borgetti, 9.2.A.20.

6.8 Alpheus and Arethusa, 1522, woodcut in Niccolò degli Agostini, Tutti gli libri de Ouidio Metamorphoseos (Venice: Niccolò Zoppino, 1522), fol. 56r. Parma, Biblioteca Palatina, WW VI.197.

6.9 Giovanni Antonio Rusconi, Salmacis and Hermaphrodite, woodcut in Lodovico Dolce, Le Trasformationi (Venice: Gabriel Giolito de' Ferrari, 1553), 90. Madrid, Universidad Complutense, Library, BH FLL 28284.

7.1 Likeness of Bona Sforza with a mustache, beard and critical comment added by a reader, in Iodocus Decius, Contenta: De vetustatibus Polonorum liber I. . . (Cracow: Hieronim Wietor, 1521), unnumbered page, woodcut, handwritten notes in ink. Warsaw, Biblioteka Uniwersytecka w Warszawie, SD 612.416. 
7.2 Likeness of Bona Sforza with partially scratched off lips, obscured nose and malicious note in Iodocus Decius, Contenta:

De vetustatibus Polonorum liber I. . . (Cracow: Hieronim Wietor, 1521), unnumbered page, woodcut, handwritten notes in ink. Warsaw, Biblioteka Narodowa, XVI.F.44 adl.

7.3 Representation of Sigismund Augustus with a quote from the Ecclesiastes (10:16) in Iodocus Decius, Contenta: De vetustatibus Polonorum liber I. . . (Cracow: Hieronim Wietor, 1521), unnumbered page, woodcut, handwritten notes in ink. Warsaw, Biblioteka Narodowa, XVI.F.44 adl.

7.4 Epitaphia Serenissimi Principis et Domini Sigismundi pasted before the likeness of Sigismund I in Iodocus Decius, Contenta: De vetustatibus Polonorum liber I. . . (Cracow: Hieronim Wietor, 1521), unnumbered page, hand-coloured woodcut, letterpress. Cracow, Muzeum Narodowe w Krakowie, VIII-XVI.264.

7.5 Fragment of the heraldic frame enclosing the likeness of Sigismund I with the handwritten identifications of the coats of arms of the Polish lands in Iodocus Decius, Contenta: De vetustatibus Polonorum liber I. . . (Cracow: Hieronim Wietor, 1521). Cracow, Muzeum Narodowe w Krakowie, VIII-XVI.33 adl, unnumbered page.

7.6 Numbering of the subsequently ruling kings of Poland in the genealogical woodcut (fragment) in Iodocus Decius, Contenta: De vetustatibus Polonorum liber I. . . (Cracow: Hieronim Wietor, 1521), unnumbered page, woodcut, letterpress, handwritten notes in ink. Warsaw, Biblioteka Narodowa, XVI.F.44 adl.

8.1 Thomas Gemini, title page for Morysse and Damashin (London 1548), engraving. Münster, Universitäts- und Landesbibliothek, 1E 8935, urn:nbn:de:hbz:6:1-33206.

8.2 Thomas Gemini, panel with a moresque pattern, engraving in Morysse and Damashin (London 1548). Münster, Universitäts- und Landesbibliothek, 1E 8935, urn:nbn:de:hbz:6:1-33206.

8.3 Thomas Gemini, title page for Compendiosa totius Anatomiae delineatio (London: Thomas Gemini, 1545), engraving. New York, The Metropolitan Museum of Art, Gift of Philip Hofer, 1937 (37.59a, b).

8.4 Jacques Androuet du Cerceau, panel with a moresque pattern, etching in Mauresques de petit format, 5. Paris, Bibliothèque de l'INHA, collections Jacques Doucet, NUM 8 RES 117.

8.5 Thomas Gemini, panel with a moresque pattern, engraving in Morysse and Damashin (London, 1548). London, Victoria and Albert Museum, 19010.

8.6 Agostino Veneziano, Portrait of Barbarossa, 1535, engraving. New York, The Metropolitan Museum of Art, The Elisha Whittelsey Collection, The Elisha Whittelsey Fund, 1949 (49.95.4).

8.7 Cornelis Massys, Portrait of Henry VIII, c. 1547, engraving. New York, The Metropolitan Museum of Art, The Rogers Fund, 1922 (22.42.6). 
8.8 Thomas Gemini, illustration of eyes and surgical instruments, engraving in Compendiosa totius Anatomiae delineatio (London: Thomas Gemini, 1545). Wolfenbüttel, Herzog August Bibliothek, 3.3 Phys. $2^{\circ}(41)$.

8.9 Thomas Gemini, astrolabe for Queen Elizabeth I, 1559, brass. Greenwich, History of Science Museum, 42223.

8.10 Thomas Gemini, eight small moresque motifs, engraving in Morysse and Damashin (London 1548). Münster, Universitäts- und Landesbibliothek, 1E 8935, urn:nbn:de:hbz:6:1-33206.

9.1 Cherubino Alberti, Carrying of the Cross, 1573, engraving. Madrid, Biblioteca Nacional de España, ER/1284 [99].

9.2 Anonymous engraver after Titian (?), Ecce Homo, 1566, engraving and etching. Madrid, Biblioteca Nacional de España, ER/1284 [172].

9.3 Cornelis Cort after Giulio Clovio, Crucifixion, 1568, engraving. Madrid, Biblioteca Nacional de España, INVENT/1541.

9.4 Anonymous copy of the print by Agostino Veneziano after Raphael, Christ Carrying the Cross, engraving. Amsterdam, Rijksmuseum, RP-P-1951-679.

9.5 Anonymous copy of the print by Marcantonio Raimondi after Raphael, Descent from the Cross, after 1521, engraving. Madrid, Biblioteca Nacional de España, ER/1284 [105].

9.6 Copy of Martino Rota's print after Michelangelo, Last Judgment, after 1569, engraving. Madrid, Biblioteca Nacional de España, ER/1284 [147].

Anonymous engraver, The Most Beautiful Virgin, before 1577, engraving. Madrid, Biblioteca Nacional de España, ER/1284 [184].

9.8 The Most Beautiful Virgin, woodcut in Petrus Canisius, De Maria Virgine incomparabili et Dei genitrice sacrosancta libri quinque (Ingolstadt: David Sartorius, 1577), 100. Paris, Bibliothèque nationale de France, FRBNF30192176.

9.9 Cornelis Cort, Virgin Immaculate with Marian symbols, 1567, engraving. Madrid, Biblioteca Nacional de España, ER/1284 [197].

9.10 The Virgin Immaculate with Marian Symbols, woodcut in Petrus Canisius, De Maria Virgine incomparabili et Dei genitrice sacrosancta libri quinque (Ingolstadt: David Sartorius, 1577), 291. Paris, Bibliothèque nationale de France, FRBNF30192176.

10.1 Albrecht Dürer, Saint George on foot, c. 1502-1503, engraving. London, The British Museum 1910, 0212.299.

10.2 Albrecht Dürer, Saint George on horseback, c. 1504, woodcut. New York, The Metropolitan Museum of Art, 1975.653.94.

10.3 Albrecht Dürer, The Standard Bearer, c. 1501, engraving. New York, The Metropolitan Museum of Art, 19.73.99.

10.4 Albrecht Dürer, The Virgin and Child with a Monkey, c. 1498, engraving. Warsaw, Muzeum Narodowe w Warszawie, Gr.Ob.N.4991 MNW.

10.5 Albrecht Dürer, Self-portrait, c. 1499, pen and brush, black ink, heightened with white. Weimar, Schlossmuseum, KK 106. 
10.6 Lucas Cranach the Elder, Saint George, 1506, woodcut. London, The British Museum, 1895,0122.265.

10.7 Tombstone of Ambroży Pampowski, before 1510, sandstone, Środa Wielkopolska, the collegiate church of the Assumption of the Virgin Mary.

10.8 Master of Messkirch, Saint George from the Falkenstein Altarpiece. Stuttgart, Staatsgalerie, 1761.

11.1 Sebald Beham, Fortuna (Fortune), 1520, etching. Amsterdam, Rijksmuseum, RP-P-OB-10.854,0.

11.2 Albrecht Dürer, Nemesis or The Great Fortune, engraving. Amsterdam, Rijksmuseum, RP-P-OB-1240,1.

11.3 Sebald Beham, Fortuna (Fortune), 1541, state II/V, engraving. Warsaw, Biblioteka Uniwersytecka w Warszawie, Gabinet Rycin, Inw.zb.d. 3868.

11.4 Sebald Beham, Infortunium (Misfortune), 1541, state III/IV, engraving. Warsaw, Biblioteka Uniwersytecka w Warszawie, Gabinet Rycin, Inw.zb.d. 3869.

11.5 Barthel Beham, Genius on a Globe, Flying above a Landscape, 1520, state I/I, engraving. Warsaw, Biblioteka Uniwersytecka w Warszawie, Gabinet Rycin, Inw.zb.d. 3749.

11.6 Heinrich Aldegrever after Cornelis Anthonisz, Fortuna (from the series Virtues and Vices), 1549, engraving. Amsterdam, Rijksmuseum, RP-P-OB-2723,2.

12.1 Anonymous engraver after Hendrick Goltzius, Fire, 1586, engraving. Amsterdam, Rijksmuseum, RP-P-OB-10.231.

12.2 Anonymous engraver after Hendrick Goltzius, Air, 1586, engraving. Amsterdam, Rijksmuseum, RP-P-OB-10.229.

12.3 Anonymous engraver after Hendrick Goltzius, Water, 1586, engraving. Amsterdam, Rijksmuseum, RP-P-OB-10.232.

12.4 Anonymous engraver after Hendrick Goltzius, Earth, 1586, engraving. Amsterdam, Rijksmuseum, RP-P-OB-10.230.

12.5 Workshop of Johannes Vest after the models of Georg Vest the Elder, stove stile with the figure of Air, 1605-11, glazed clay. Marburg, Universitätsmuseum für Kunst und Kulturgeschichte.

12.6 Northern Netherlandish, fork and knife from a wedding cutlery, 1597, gold, iron, niello. Amsterdam, Rijksmuseum, BK-1975-79-A, BK-1975-79-B.

12.7 Theodor de Bry (?), design for knife handles with Personifications of the Elements, c. 1598, engraving. Amsterdam, Rijksmuseum, RP-P-1964-4642.

13.1 Joos van Winghe, Jan Sadeler and Andries Pevernage, Adoration of God's Lamb, 1588, engraving. Amsterdam, Rijksmuseum, RP-P-1926-626.

13.2 Matthäus Merian, APOCAIY்PS. IV. in Icones Biblicae, vol. 4: Novi Testamenti . . historiae (Frankfurt/M: Matthäus Merian, 1627), 139, engraving and letterpress. Bamberg, Staatsbibliothek Bamberg, A.symb.q.23\#4, urn:nbn:de:bvb:22-dtl-0000003700\#0139. 
xiv Figures

13.3 Christoffel van Sichem II, Adoration of God's Lamb, 1646.

Amsterdam, Rijksmuseum, RP-P-2015-17-38-2.

13.4 Christoffel van Sichem II, Adoration of God's Lamb (left) in "Oskan Bible” (Uuunnudouznú々) (Amsterdam: Tparan St. Ejmiatsin and St. Sargis the General, 1666), 703, woodcut and letterpess. Washington, Library of Congress, BS95 1666.

14.1 Martin Schongauer, Tribulations of Saint Anthony, c. 1470-75, engraving. New York, The Metropolitan Museum of Art, Rogers Fund, 1920, 20.5.2.

14.2 Jacob of Strasbourg, after Benedetto Bordone, Triumph of Caesar (single sheet), 1504, woodcut. New York, The Metropolitan Museum of Art, Harris Brisbane Dick Fund, 1927, 27.54.124.

14.3 Anonymous Spanish sculptor, Triumph of Caesar from the castle of the Fajardos at Vélez Blanco near Granada (detail of Cesar's chariot), 1506-15, bas-relief, wood. Paris, Musée des Arts décoratifs, D 2007-1-4.

14.4 Sierra Leone sculptor, ivory pyx, 1490-1530, carved ivory. Baltimore, Walters Art Museum, 71.108.

14.5 Arrest of Christ, woodcut in Hore dive virginis Marie secundum verum usum Romanum (Paris: Thielman Kerver, 1511), fol. B4v. Cambridge University Library, SSS.17.14.

14.6 Sri Lanka artist, ivory casket with figurative scenes, 1540-1550, carved ivory, gold, rubies, sapphires. Private collection.

14.7 Israhel van Meckenem, Mass of Saint Gregory, c. 1490-1500, engraving, Washington, National Gallery of Art, Rosenwald Collection, 1954.12.91.

14.8 Aztec artist, Mass of Saint Gregory, 1539, feathers on wood. Auch, Musée des Jacobins.

14.9 Nativity, engraving in Jerome Nadal, Evangelicae historiae imagines (Antwerp, 1593), pl. 3. Los Angeles, Getty Research Institute, 3009-135.

14.10 Anonymous Moghul artist, Nativity, 1605-10, painted and drawn in ink, watercolour and gold on paper. London, Victoria and Albert Museum, D.402-1885.

14.11 Nativity in Giulio Aleni, Explanation of the Images of the Lord of Heaven's Incarnation (Tianzhu jiangsheng chuxiang jingje) (Quanzhou 1637), unnumbered pages, woodblock printing. Munich, Bayerische Staatsbibliothek, Cod.sin.4 23, urn:nbn:de:bvb: 12-bsb00080038-2. 


\section{Colour Plates}

Plate 1 Crucifixion and T(e igitur) prayer in the Missal from St. Servatius in Maastricht (use of Liège), miniature on parchment. The Hague, Koninklijke Bibliotheek I Nationale Bibliotheek van Nederland, ms 78 D 44, fol. 133v-134r.

Plate 2 Lucas Cranach the Elder, Crucifixion [H 28], coloured woodcut on parchment in Missale Cracoviense. Cracow, Biblioteka Jagiellońska, Inc. 2850 , fol. $180 \mathrm{v}$.

Plate 3 South German, Apes Performing on Horseback from Stengel, Unedierte Holzschnitte, 1913, pl. 1, hand-colored relief etching with volvelle and brass attachment. Chicago, Newberry Library, Case folio W 8014 .25 v. 37.

Plate 4 South German, Apes Performing on Horseback, after 1450, hand-colored woodcut with oval volvelle. Nuremberg, Germanisches Nationalmuseum, H5690.

Plate 5 German, Madonna and Child, fragment from The Jesse Tree, Almanac for Austria in the Year 1496, c. 1495-96, hand-coloured woodcut. Munich, Bayerische Staatsbibliothek, Clm 464, fol. 3v.

Plate 6 Hartmann Schedel, decorative collage, 1506, hand-coloured woodcut fragments and fragment of woodcut printed in red ink, with red and blue ink border. Munich, Bayerische Staatsbibliothek, Clm 464, fol. 5r.

Plate 7 Israhel van Meckenem, Man of Sorrows in the Letter O, c. 1475-90, hand-colored engraving. Munich, Bayerische Staatsbibliothek, Clm 386, fol. $1 \mathrm{v}$.

Plate 8 German, sixteenth century, Antiphonale Officii, Proprium de Tempore, ink, tempera, and gold on parchment. Düsseldorf, Universitäts- und Landesbibliothek, MS-D-17, fol. 1r.

Plate 9 Death of the Virgin, metalcut in Heures a l'usaige de Romme (Paris: Germain Hardouyn, 1524). Chicago, Newberry Library, Wing ZP 539. $\mathrm{H} 2241524$.

Plate 10 Death of the Virgin, metalcut in Heures a l'usaige de Romme (Paris: Gillet Hardouyn, c. 1515). Bridwell Library Special Collections, Perkins School of Theology, Southern Methodist University, BRA0841.

Plate 11 Death of the Virgin, metalcut in Heures a l'usaige de Romme (Paris: Guillaume Anabat, Gilles Hardouyn, Germain Hardouyn, 1507). Chicago, Newberry Library, VAULT Wing ZP 539. A54. 
Plate 12 Death of the Virgin, metalcut in Hore divine virginis Marie secundum usum Romanum (Paris: Gilles Hardouyn [printer], Germain Hardouyn [publisher], c. 1512). Chicago, Newberry Library, Wing ZP 539. H2212.

Plate 13 Death of the Virgin, metalcut in Hore Dive Virginis Marie secundum usum Romanum (Paris: Gilles Hardouyn and Germain Hardouyn, 9 August 1514), fol. FIv. Warsaw, Biblioteka Narodowa, SD XVI.O.4101.

Plate 14 Death of the Virgin, metalcut in Officium beate Marie virginis secundum verum usum Romanum (Paris: Gilles Hardouyn and Germain Hardouyn, 9 August 1514. University of Illinois at Urbana-Champaign, Rare Book and Manuscript Library, IUA02546.

Plate 15 Lucas van Leyden, Agony in the Garden, 1521, engraving, handcoloured and pasted into prayer book manuscript c. 1530. Amsterdam, Rijksmuseum, RP-P-2011-115-1.

Plate 16 Lucas van Leyden, Flagellation, 1521, engraving, hand-coloured and pasted into prayer book manuscript c. 1530. Amsterdam, Rijksmuseum, RP-P-2011-115-5.

Plate 17 Lucas van Leyden, Carrying the Cross, 1521, engraving, handcoloured and pasted into prayer book manuscript c. 1530. Amsterdam, Rijksmuseum, RP-P-2011-115-8.

Plate 18 Frans Crabbe, Christ Mocked, c. 1520, engraving, hand-coloured and pasted into prayer book manuscript c. 1530. Amsterdam, Rijksmuseum, RP-P-2011-115-9.

Plate 19 Lucas van Leyden, Crucifixion, 1521, engraving, hand-coloured and pasted into prayer book manuscript c. 1530. Amsterdam, Rijksmuseum, RP-P-2011-115-10.

Plate 20 Lucas van Leyden, Resurrection, 1521, engraving, hand-coloured and pasted into prayer book manuscript c. 1530. Amsterdam, Rijksmuseum, RP-P-2011-115-14.

Plate 21 Liberation of Andromeda, 1522, woodcut in Giovanni Bonsignori, Ovidio Metamorphoseos vulgare (Venice: Giorgio Rusconi, 1522), fol. XXIXr. Fermo, Biblioteca Civica Romolo Spezioli, 2CC13/18593.

Plate 22 Fragment of the heraldic frame enclosing the likeness of Sigismund I with the handwritten identifications of the coats of arms of the Polish lands in Iodocus Decius, Contenta: De vetustatibus Polonorum liber I. . . (Cracow: Hieronim Wietor, 1521), unnumbered page, hand-coloured woodcut, handwritten notes in ink. Cracow, Muzeum Narodowe w Krakowie, VIII-XVI.33 adl.

Plate 23 Willem Jansz Blaeu, Nova Totius Terrarum Orbis Geographica Ac Hydrographica Tabula, 1649 ed., hand-coloured engraving. Budapest, Országos Széchényi Könyvtár, TA 366/1 A-17-20.

Plate 24 English, Ignis (Fire), 1679, tin-glazed earthenware. Alton, Allen Gallery (Hampshire Museums).

Plate 25 Flemish, Fire from a Set of Elements, c. 1600, stained glass decorated en grisaille with details etched with a needle. Cambridge, Fitzwilliam Museum, AA, C.341-1991. 
Plate 26 French, armoire à deux corps, c. 1600, walnut cabinet with carved decoration and inlay of black marble. County Durham, The Bowes Museum, FW.107.

Plate 27 Probably German, epitaph of Fridriech Jürgens, before 1614, oil on panel. Stockholm, Tyska St: a Gertruds Församling, Gemeindesaal.

Plate 28 Polish, Adoration of the Lamb, after 1588, oil on panel. Torun, kościól św. Szczepana. 


\section{Acknowledgements}

The present volume is a result of the research project Reframed Image: Reception of Prints in the Kingdom of Poland from the End of the Fifteenth to the Beginning of the Seventeenth Century. Objects-People-Milieux-Processes, supported by the National Science Centre, Poland, grant no. 2015/17/B/HS2/02469. Most of the chapters stem from a conference, Multiplied and Modified. Reception of the Printed Image in the Fifteenth and Sixteenth Centuries, co-organized by the Institute of Art History, University of Warsaw and the National Museum in Warsaw in June 2018. We would like to thank the scholars and friends who generously shared with us their research and expertise during the conference and in their contributions.

Our deepest gratitude goes to our friends and colleagues: Marcin Bogusz, Piotr Borusowski, Urszula Dragońska, Małgorzata Łazicka, Marek Płuciniczak, Izabela Przepałkowska, Joanna Sikorska and Antoni Ziemba for their intellectual support, organizational assistance and, most importantly, brilliant study visits organized for our guests and speakers in the print collections of the Warsaw University Library and the National Museum in Warsaw. We are indebted to Dr Agnieszka Morawińska, then director of the National Museum, for hosting the conference, and to Professor Eukasz Gawel, the museum's present director, for his consent to reproduce three artworks on the book's cover. Our special thanks go to Aleksandra Fedorowicz-Jackowska, who, with her invariably unfailing aesthetic taste, designed the conference package and the cover image.

Preparation of the publication was also supported by the Ministry of Science and Higher Education, Poland (programme "Strategy of Excellence - Research University" implemented in 2018-2019, no. 0009/SDU/2018/18, the amount granted to the University of Warsaw 968000 PLN). 


\section{Contributors}

Giuseppe Capriotti is an assistant professor of early modern art history at the University of Macerata (Italy). After an interdisciplinary thesis in the history of religionearly modern art history (2000), he won a scholarship for a $\mathrm{PhD}$ at the University of Macerata (2000-2003), during which he studied at the École des Hautes Études in Paris. He gave seminars at the Université Pierre-Mendès-France of Grenoble, at the University of Zagreb and at the University of Oviedo. He has been a visiting professor at the University of Split, Croatia; Marie Curie Fellow Researcher at Pwani University, Kilifi; and visiting professor at the Universidad Nacional de Educación a Distancia of Madrid. He has published several articles or books on anti-Jewish and anti-Turkish painting and on the fortunes of Greek mythology in art (in particular on the fortunes of Ovid's Metamorphosis).

András Hándl is a postdoctoral FWO [PEGASUS]2 Marie Curie Fellow at the History of Church and Theology Research Unit, Faculty of Theology, KU Leuven. He earned his PhD at the University of Basel in 2015 with a dissertation on Bishop Calixtus I of Rome, which is in press at Brill in the Supplements to Vigiliae Christianae series. His actual research project investigates the reception of "Jesus and the adulteress woman" (John 7.53-8.11) in the literature and material culture of late antiquity. In addition, he is the recent founder and principal investigator of an international and interdisciplinary research project exploring the earliest-known Christian free-standing sculpture in history, the so-called Hippolytos statue. He is also interested in religious art in the confessional era.

Magdalena Herman is a PhD candidate at the Faculty of History, University of Warsaw, where she previously gained an MA in history of art (2014). She is a principal investigator of the research project The Print Collection of Jan Ponetowski in the Jagiellonian Library in Cracow supported by the National Science Centre, Poland (2017-2020). In 2018 she received the CENTRAL scholarship at the Humboldt Universität zu Berlin. Her work focuses on the materiality of printed images and on print collecting in the second half of the sixteenth century. Her field of study also encompasses illustrations of Cracovian prayer books published between the sixteenth and eighteenth centuries.

Olenka Horbatsch has been the Curator of Dutch and Flemish prints and drawings at the British Museum since 2017, where she curated "Rembrandt: Thinking on Paper." She received her PhD in art history from the University of Toronto with a dissertation with a study on Lucas van Leyden and his lesser-known contemporaries 
in the northern and southern Low Countries. Her research is focused on sixteenthand seventeenth-century Netherlandish graphic arts.

Grażyna Jurkowlaniec is a professor at the Institute of Art History, University of Warsaw. She specializes in art and artistic patronage between the thirteenth and sixteenth centuries in Europe. She has authored three monographs, several book chapters and articles in journals (i.e. Artibus et Historiae, Barockberichte, Konsthistorisk tidskrift, Print Quarterly and Zeitschrift für Kunstgeschichte); recently she co-edited a collective volume The Agency of Things in Medieval and Early Modern Art. Materials, Power and Manipulation (New York: Routledge, 2017). Currently, she runs two research projects supported by the National Science Centre, Poland: Reframed Image: Reception of Prints in the Kingdom of Poland from the End of the Fifteenth to the Beginning of the Seventeenth Century. ObjectsPeople-Milieux-Processes (2016-2020) and Matrix of Confusion: The Production of Woodcut Illustration in Poland-Lithuania and Prussia until the Early Seventeenth Century (2019-2022).

Suzanne Karr Schmidt has been the George Amos Poole III Curator of Rare Books and Manuscripts at the Newberry since 2017. She holds a PhD in the history of art from Yale University and a BA from Brown University. Previously, she was Assistant Curator in the Department of Prints and Drawings at the Art Institute of Chicago, after completing her postdoctoral Andrew W. Mellon Curatorial Fellowship. In addition to her Art Institute exhibition and catalogue Altered and Adorned: Using Renaissance Prints in Daily Life (2011), Dr Karr Schmidt worked on Susan Dackerman's Prints and the Pursuit of Knowledge in Early Modern Europe (Harvard University Art Museums) and contributed a catalogue essay (2012). She co-edited a Routledge anthology with Edward Wouk, Prints in Translation 1450-1750: Image, Materiality, Space (2016). Most recently, Dr Karr Schmidt published her book Interactive and Sculptural Printmaking in the Renaissance with Brill (2017).

Alexandra Kocsis is an art historian currently working as a freelance translator and copy editor at the Hungarian National Museum-Museum of Fine Arts, Budapest. She completed her doctoral degree at the University of Kent at Canterbury and at the Freie Universität Berlin (in the framework of the Erasmus Mundus joint $\mathrm{PhD}$ programme called Text and Event in Early Modern Europe) with her thesis The Functions of Texts in Printed Images: Text and Image in Reproductive Prints by Hieronymus Cock, Antonio Salamanca, and Antonio Lafreri. She has participated in several conferences, e.g. at the Courtauld Institute in London and the Centre André Chastel in Paris. In 2017, she contributed to a cataloguing project of early seventeenth-century engravings by the De Bry family in the National Maritime Museum, London. She obtained a master's degree in art history at the Eötvös Loránd University in Budapest (2013) and completed a research master's programme in medieval studies at the Central European University in Budapest (2014). During her postgraduate studies, she spent one year at the Humboldt Universität zu Berlin (2011-2012).

Małgorzata Łazicka is an art historian (University of Warsaw, MA in history of art and BA in English language teaching) and the curator of Old Master Prints in the Print Room of the University of Warsaw Library. Her research is focused particularly 
on sixteenth-century northern graphic arts, mainly in German-speaking countries. She has participated in scholarships and training abroad: Programme Erasmus+ (Kupferstichkabinett Berlin, Staatliche Graphische Sammlung Munich, Graphische Sammlung Nuremberg) and the International Scholarship Programme at the Staatliche Museen zu Berlin (Kupferstichkabinett). The results of her research have been presented in publications (articles and catalogue entries) and at conferences in Poland, England and Germany. The outcome of her latest project (National Programme for the Development of Humanities) will be the printed catalogue of Barthel and Sebald Behams's prints from the collection of the Print Room.

Jean Michel Massing is a professor emeritus in history of art and a fellow of King's College, University of Cambridge. He has published widely on numerous topics. His most recent books include From the "Age of Discovery" to the Age of Abolition: Europe and the World Beyond, Cambridge, MA: Belknap Press, 2011 (The Image of the Black in Western Art, vol. 3. part 2); The Slave in European Art: From Renaissance Trophy to Abolitionist Emblem (ed., with Elizabeth McGrath), London: Warburg Institute, 2012; Marfims no Impéro Português/Ivories of the Portuguese Empire (with Gauvin Alexander Bailey and Nuno Vassallo e Silva), Lisbon: Scribe, 2013; and King's College Chapel 1515-2015: Art, Music and Religion in Cambridge (ed. with N. Zeeman), London: Harvey Miller, 2014. He has been a member of the editorial board of Print Quarterly since the beginning and has published extensively in the periodical, most recently, "The Origin of the Iconography of Cannibalism in the Early Modern Period" (Print Quarterly, 2016). His recent article "Jerome Nadal's Evangelicae historiae imagines and the Birth of Global Imagery" appeared in the Journal of the Warburg and Courtauld Institutes (2017).

Karolina Mroziewicz is a philologist and art historian. In 2015, she received her PhD in cultural studies from the Faculty of Artes Liberales, University of Warsaw. Currently, she is an assistant professor at the Institute of Art History of the University of Warsaw. In 2015-2019 she conducted a postdoctoral research project at the Jagiellonian University on the role of illustrated catalogues of rulers in consolidating historical memory in pre-modern Poland, Hungary and Bohemia. Her fields of study encompass early printed books and illustrations, colour and coloured prints, the polemical and identity-building functions of images and self-fashioning practices in the early modern period. Her publications include Imprinting Identities: Illustrated Latin-Language Histories of St. Stephen's Kingdom (1488-1700) (Frankfurt/M: Peter Lang, 2015), co-edited books, book chapters and journal articles in both Polish and English.

Joanna Sikorska is a curator of the Department of Prints and Drawings at the National Museum in Warsaw and a guest lecturer at the Institute of Art History, University of Warsaw. Her PhD thesis focused on pyx reliquaries, a particularity of the Polish goldsmithery of the Late Middle Ages and early modern times. Currently, her research interests include printmaking of the fifteenth and sixteenth centuries, the reception of prints and their relationship with other artistic media. She has co-authored several exhibitions in the National Museum in Warsaw, among them Albrecht Dürer: Response to His Prints in the Sixteenth Century (2002) and Masters of the Pastel: From Marteau to Witkacy (2015-16).

Femke Speelberg is an associate curator in the Department of Drawings and Prints at the Metropolitan Museum of Art in New York, where she is responsible for the 
drawings, prints and books related to historic ornament, design and architecture. Her work focuses on the history of design; the transmission of ideas; and the dialogue between works on paper and related artworks, objects and the built environment. At the Met, she has curated the exhibitions Living in Style: Five Centuries of Interior Design from the Collection of Drawings and Prints (2013), Fashion o Virtue: Textile Patterns and the Print Revolution, 1520-1620 (2015-2016) and Chippendale's "Director": The Designs and Legacy of a Furniture Maker (20182019). Ms Speelberg's publications cover subjects from the Late Middle Ages until the present. She is currently working on a book project about the emergence of the ornament print in the early modern print market.

Júlia Tátrai obtained her MA in art history and Netherlandic studies at the Eötvös Loránd University, Budapest. Since 1997, she has been working as a curator at the Szépmüvészeti Múzeum, Budapest, where she has been Head of the Department of Old Master Paintings since 2015. Her essays have various methodological approaches: iconography (e.g. "Protestant or Loose Morals? The Five Senses in Seventeenth-Century Dutch Art”), provenance (e.g. "Eine 'andere' EsterházySammlung. Die Gemälde des ehemaligen Plettenberg-Esterházy Schlosses in Nordkirchen") and the history of religious cults (e.g. "The Beatified Martyrs of Gorcum: A Series of Paintings by David Teniers the Younger and Wouter Gysaerts"). In 2014, she was the co-curator of the exhibition Rembrandt and the Dutch Golden Age in Budapest. In 2016, she curated with Marrigje Rikken the exhibition Dutch Old Masters from Budapest at the Frans Hals Museum, Haarlem. She is writing her PhD on the History of Collecting of Seventeenth-Century Dutch and Flemish Paintings in Hungary.

Loretta Vandi (PhD, Université de Lausanne, 1998) is a professor of Art History at the Scuola del Libro, Urbino. She studies medieval women artists; the medieval and early modern reception of antiquity; and theories of ornament, printed images, contemporary art and architecture. She has held four Samuel H. Kress fellowships. Her publications include six monographs and articles in international magazines (Gesta, Mediaevalia, Scriptorium, Acta ad Archaeologiam et Artium Historiam Pertinentia, Prospettiva and Medioevo). She has contributed chapters to essay collections and is a reviewer for the College Art Association, Il Giornale dell'arte and www.artevista.eu. Among her publications are La trasformazione del motivo dell'acanto dall'antichità al XV secolo. Ricerche di teoria e storia dell'ornamento (Peter Lang, 2002); Il Manoscritto Oliveriano 1. Storia di un codice boemo del XV secolo (STIBU, 2004); "Performing Perception: A Medieval Miter between Focal and Peripheral Vision," in Les cinq sens au Moyen Âge, ed. Éric Palazzo (Le Cerf, 2016); and Ornament and European Modernism: From Art Practice to Art History, ed. L. Vandi (Routledge, 2017).

Maureen Warren is the Curator of European and American art at Krannert Art Museum at the University of Illinois Urbana-Champaign. She received her PhD from Northwestern University, where she studied early modern Netherlandish art. She was a Mellon Curatorial Research Fellow at the Art Institute of Chicago in the Department of Prints and Drawings and a Kress Institutional Fellow at Leiden University. Recent exhibitions have included Blue \& White Ceramics: An Enduring Global Obsession; Coveting Nature: Art, Collecting, and Natural History in Early 
Modern Europe; and Making and Breaking Medieval Manuscripts. Recent publications include "Paper Warfare: Contested Political Memories in a 17th-Century Dutch Sammelband," in Word \& Image; "Fame's Two Trumpets: Portrait Prints and Politics in Early Modern Europe," in Van Dyck, Rembrandt, and the Portrait Print; and "A Shameful Spectacle: Claes Jansz Visscher's 1623 News Prints of Executed Dutch 'Arminians'", in Death, Torture and the Broken Body in European Art, 1300-1650.

James Wehn is the Van Vleck Curator of Works on Paper at the Chazen Museum of Art at the University of Wisconsin-Madison. James completed his PhD in art history at Case Western Reserve University. His dissertation, Inventing the Market: Authenticity, Replication, and the Prints of Israhel van Meckenem, examines the development of the print market in Northern Europe and its effect on cultural values concerning art, authorship, copying and image-making practices during the late fifteenth century. James has published articles in Print Quarterly and Art in Print, and he has curated exhibitions of prints and drawings at the Minneapolis Institute of Art, the Philadelphia Museum of Art and the Cleveland Museum of Art. 


\section{Abbreviations}

Bartsch Adam von Bartsch, Le peintre-graveur. Vols. I-XXI, Vienna: J. V. Degen, 1803-21

BJ Biblioteka Jagiellońska

BL The British Library

BM The British Museum

BN Biblioteka Narodowa

BNE Biblioteca Nacional de España

$\mathrm{BnF} \quad$ Bibliothèque nationale de France

BSB Bayerische Staatsbibliothek

BUW Biblioteka Uniwersytecka w Warszawie

Einblattdrucke Einblattdrucke des fünfzehnten Jahrhunderts, ed. Paul Heitz

GNM Germanisches Nationalmuseum

GW Gesamtkatalog der Wiegendrucke

$\mathrm{HAB} \quad$ Herzog August Bibliothek

HD Hollstein's Duch and Flemish Engravings, Etchings and Woodcuts, 1400-1700

HG Hollstein's German Engravings, Etchings and Woodcuts, 1400-1700

INHA Institut national d'histoire de l'art

LCI Engelbert Kirschbaum and Günter Bandmann, eds.

Lexikon der christlichenIkonographie. Vols. 1-7.

Freiburg: Herder, 1974

Lehrs Max Lehrs. Geschichte und kritischer Katalog des deutschen, niederländischen und französischen

Kupferstichs im XV. Jahrhundert. Vols. I-IX. Vienna:

MNK Muzeum Narodowe w Krakowie

NGA National Gallery of Art

NHD The New Hollstein Dutch and Flemish Etchings, Engravings and Woodcuts 1450-1700

NHG The New Hollstein German Engravings, Etchings and Woodcuts 1400-1700

OSK Országos Széchényi Könyvtár

PAN BK Polska Akademia Nauk Biblioteka Kórnicka

TIB The Illustrated Bartsch 
The Met

UBB

V\&A

VD16
The Metropolitan Museum of Art Universitätsbibliothek Basel

Victoria and Albert Museum

Verzeichnis der im deutschen Sprachbereich erschienenen

Drucke des 16. Jahrhunderts 


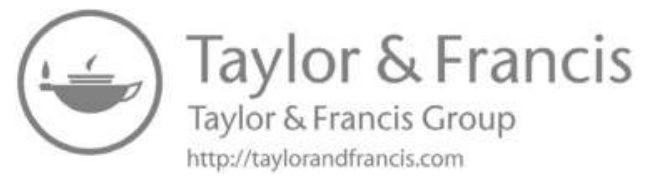




\title{
Introduction
}

\section{People Between Multiplied Things and Modified Images}

\author{
Grażyna Jurkowlaniec and Magdalena Herman
}

On 26 November 1544, the episcopal court in Cracow heard the case of a carver, or rather a woodcutter, named Johannes (Ioannes szniczer), who was accused of possessing and reading heretical books authored by Martin Luther. The bishop sent inquisitors to the defendant's house where, indeed, they found several suspicious volumes. However, Johannes argued quite cunningly that most of the books belonged not to him, but to a certain saddler. An exception, Johannes admitted, was a book he kept not for reading, but as a source of apt images "painted" therein by an Olbricht Direr, as it was noted. ${ }^{1}$ Bearing in mind how imprecise early modern sources are, these images should not be understood as paintings, i.e., miniatures, but instead as graphic impressions, most likely woodcuts. Olbricht Direr certainly stands for Albrecht Dürer, but this name should not be taken literally either. Johannes plausibly wished to strengthen his point by mentioning a name that was famous throughout Europe. Apparently, it was not familiar to the scribe, but might have rung a bell with the inquisitors. However, whether he truly believed that the book included Dürer's works or not, Johannes is more likely to have owned a copy of Luther's writings illustrated by Lucas Cranach the Elder, monogrammist MS or Hans Brosamer.

Whatever work and edition Johannes kept in his house, it was an exemplar of Luther's books that the owner viewed as a collection of pictorial models. These, in turn, might be used to produce further works such as paintings, sculptures and, above all, printing matrices. The latter subsequently would be used to produce woodcuts or engravings, which-be it single-sheet impressions or illustrations in books-would be material objects too. As such, some of these might be variously modified, e.g., coloured, trimmed or pasted onto other objects. The matrices, in turn, likely would be reused several times, which might involve migrations, shifts in ownership or various retouches, often traceable only through comparisons with several almost-identical impressions, consistently regarded as material objects.

Johannes is referred to as a szniczer (Schnitzer in German), which usually is translated as "carver," but might have been understood as "woodcutter" (Formschneider in German) here. His story either mentions or implies not only things but also various human actors. The explicit protagonists are the accused and the envoys of the episcopal court. In retrospect, Luther and Dürer also are mentioned, deemed to be the authors of prohibited writings and illustrations, respectively. The implicit and unnamed supporting actors are the publisher and printer who produced the incriminating book. Finally and most importantly, the story also implies what must have been the inquisitors' main concern: prospective users and beholders, as well as further printers or 
publishers, who would produce subsequent books that are likely to include woodcuts impressed from multiple matrices, thereby disseminating "Dürer's" designs-but above all, the public's interest in either the writings or the illustrations. There are two principal categories of human actors, then: producers and recipients. They play various roles, while they unanimously regard printed illustrations not only as things but also, or even above all, as representations.

Johannes must have been one of innumerable craftsmen who used prints as models in daily practice. Apparently, he was also aware of the reproductive value of prints that multiply and disseminate compositions, notably designs by famous masters, which then can be translated into other works of art using different techniques. Many prospective owners or beholders of paintings, sculptures or graphic illustrations might remain uninterested in these images' material qualities while focussing primarily on what they represent.

Thus, printed images were, on one hand, material objects produced, owned or variously transformed by humans, but on the other hand, they were immaterial representations, conceived and variously received by humans as well. Certainly, such a complex relationship among things, people and images is not an exclusive feature of the premodern period's print cultures. However, the rise of printmaking challenged some established rules in the arts and visual realms. Three short insights may exemplify this and thus introduce the studies presented in this volume. The first insight's point of departure comprises material objects related to Lucas Cranach the Elder's early Crucifixion; the second insight offers a human perspective, starting with Christophe Plantin's working practices; and the third insight is a short story that emphasises the ambiguities surrounding what printed images represent, as epitomised by early modern depictions of wisent, a species now related to the North American bison, but often confused with the Eastern European aurochs.

\section{Things}

Graphic art usually is classified among the paper arts by contemporary museum curators, while printing still is occasionally called the "black art" by press scholars. However, woodcuts and engravings were impressed on various materials and very often coloured and sometimes even gilded. Particularly in the field of book production, the worlds of illuminated manuscripts and woodcut-illustrated prints coexisted for a long time, entering into various relations with each other. This phenomenon is well-researched in relation to books concerning individual piety. Private prayer books became more and more widespread beginning in the late Middle Ages, which led to a certain standardisation. However, the owners simultaneously adapted the books to their needs and expectations, whether religious or purely aesthetic. Various objectsdrawings, pilgrim badges and even Eucharistic hosts, as well as prints-were glued or sewn into the books, sometimes preserved until now, sometimes recognisable only from the traces they left in the objects in which they were included. ${ }^{2}$ However, individualisation of a serial product, be it a repetitively hand-painted design or an engraving in a standardised manuscript or a printed book—typical of devotional images or prayer books - also may be observed in liturgical codes.

The liturgical year is marked by the order of Sundays and holidays, as well as the respective prayers or readings, together with the iconographic tradition, usually determining the choice of topics for possible illustrations for a given section. In the missal, 
the canon is perhaps the most conventionalised place with respect to iconography of decoration, considering that since the High Middle Ages, the Te igitur prayer usually was preceded by a full-page Crucifixion scene, as exemplified by the early fifteenthcentury Missal of the Church of St. Servatius in Maastricht (Plate 1). The Crucifixion also can be found in printed missals in which, at the turn of the sixteenth century, the quire with the canon occasionally was impressed separately on parchment and woodcuts and initials often were coloured. ${ }^{3}$ Most of the woodcuts that precede the Te igitur prayer are of mediocre quality, but exceptional works also exist, such as Lucas Cranach the Elder's two early Crucifixions. ${ }^{4}$ The one catalogued by Hollstein as no. 28 usually is dated to about 1500 and known from several impressions, produced at different times and variously customised. ${ }^{5} \mathrm{~A}$ few of these are preserved in their original contexts, allowing us to address such issues as woodblock dating, its subsequent uses, various features of particular impressions and specific copies of books published in the same place and time.

The woodcut on the sheet inserted in the Missale Cracoviense, preserved in the Jagiellonian Library in Cracow (Inc. 2850, fol. 180v), was impressed on parchment and coloured with opaque paints, also resembling a miniature (Plate 2$).{ }^{6}$ The neighbouring page with the Te igitur prayer also has painted decorations in the margins and in the initial, which also is gilded. This code represents an edition of the Cracow Missal, which, unfortunately, does not contain explicit information about the date and place of publication. On the title page, one can read that the order was placed by the Archbishop of Gniezno and Bishop of Cracow, Cardinal Frederick the Jagiellon, and realised by the Nuremberg printer Georg Stuchs for Jan Haller, a Cracow citizen. Haller, who was from Franconia, lived in Cracow in the early 1480s and was an active publisher and bookseller starting in the late fifteenth century, having operated his own printing house starting in 1505 . The place and date of printing for the missal in question has been debated among scholars actively, but the book most likely was produced in Nuremberg between 1493 and $1500 .^{7}$

However, the place and time of the book's publication and the production of the woodblock might not have been identical, given that Cranach's Crucifixion was impressed on a separate parchment sheet and only subsequently pasted into the missal. Interestingly, copies representing other variants of the Missale Cracoviense, printed by Stuchs for Haller c. 1500, feature another woodcut before the Te igitur prayer, occasionally also coloured, but rather insignificant with respect to artistic value. ${ }^{8}$ The question arises, then, of whether Stuchs had two blocks at his disposal-which would not be unusual-or was Cranach's Crucifixion in the Missale Inc. 2850 impressed from a matrix preserved in Cracow? This is particularly pertinent considering the thesis that Cranach stayed in Cracow between 1498 and 1502, put forth by Fedja Anzelewsky on the basis of, among other aspects, Cranach's two other early woodcut Crucifixions. ${ }^{9}$ Even if one regards Anzelewsky's reasoning as conjecture, one must admit that the Missale Inc. 2850 can be traced to Cracow at least since 1504, when a local canon, Marcin Bełza, bought it from a Polish nobleman.

Therefore, the woodcut on fol. 180v of the Missale Inc. 2850 not only is one of Cranach's earliest prints but also plausibly his first work recorded in Cracow. It is also meaningful that further impressions of Cranach's Crucifixion H 28 cannot be found in Stuchs's later missals, but in books produced in Cracow. The first example is the Missale Vratislaviense, printed by Kasper Hochfeder for Jan Haller and Sebastian Hyber in Cracow in 1505, or to be more precise, one of three variants of this 
missal distinguished by scholars, represented by a copy preserved in the Czartoryski Library in Cracow (1233 III Cim.). ${ }^{10}$ Haller, who launched his own printing shop in late summer 1505, proved also to be the last confirmed user of the Cranach's Crucifixion block. It was impressed in the Missale Gnesnense that Haller printed in Cracow in 1506.

The woodcut before the canon in an unpreserved copy of Haller's Missale Gnesnense in the Seminary Library in Poznan is known now only from an archival blackand-white photo (Figure 0.1). ${ }^{11}$ One can note that this impression was not coloured, while the matrix must have been transformed, mainly by removing background lines. However, it could not have been an act of barbarism, but of minimising the damage, if, for example, some delicate lines had been broken off, and the owner of the block had decided to unify the background by removing all of them. The 1506 Missal of Gniezno is slightly larger than the c. 1500 Missal of Cracow, thereby leaving a considerable margin around the woodcut. The space was not filled by a painted decoration, but by an ornamental frame impressed from a separate block, with the Holy Face presented by angels and medallions, with the evangelists' symbols.

The border is late Gothic in style and plausibly was made in Cracow. Its shape and dimensions prove that it was designed with the intention of complementing Cranach's Crucifixion. Of course, with time, it also could frame another Crucifixion or other scenes impressed from woodblocks matching its format and size, or smaller ones, but it has not been confirmed that it ever did. ${ }^{12}$ The iconography, particularly the Holy Face presented by angels in the bottom margin, predestined this bordure to frame a Crucifixion before the canon, as a similar juxtaposition also may be observed in earlier manuscript missals, as shown earlier (Plate 1). Technical aspects are of interest as well, in that whereas the lower section of the framing with the Holy Face represents a typical black-line woodcut, the three remaining stripes with floral ornaments and medallions, including the evangelists' symbols, feature a more sophisticated white-line woodcut.

Thus, never ultimately parted, the roads of painting and graphic art gradually diverged, as the comparison of these two particular impressions from the same block-one included in the Inc. 2850 copy of Missale Cracoviense, c. 1500, and the other in the Missale Gnesnense of 1506-demonstrates. The former woodcut was impressed on parchment and remains hardly visible under the layer of paint; it also almost was turned into a miniature. The latter, although the elimination of background lines, for whatever reasons, infringed on its original mastery, remained a purely graphic work. Impressed most plausibly on paper, uncoloured and inserted in the bordure and executed using two variants of the woodcut technique, it certainly may be regarded as an example of "the paper arts" and a product of the "black art" of print.

These and other related issues are developed in the contributions collected in Part I of the present volume. In the opening essay, Suzanne Karr Schmidt explores negative evidence of interactive prints. By looking closely for signs of absence, she elaborates on the survival of fragile originals and the functions that they might have served when they were complete. She explores three case studies: Vera Icon, once pasted on the pastedown of a manuscript; a woodcut paper astrolabe (both lost in World War II); and a deficient Memento Mori flap engraving. Studying objects that were 


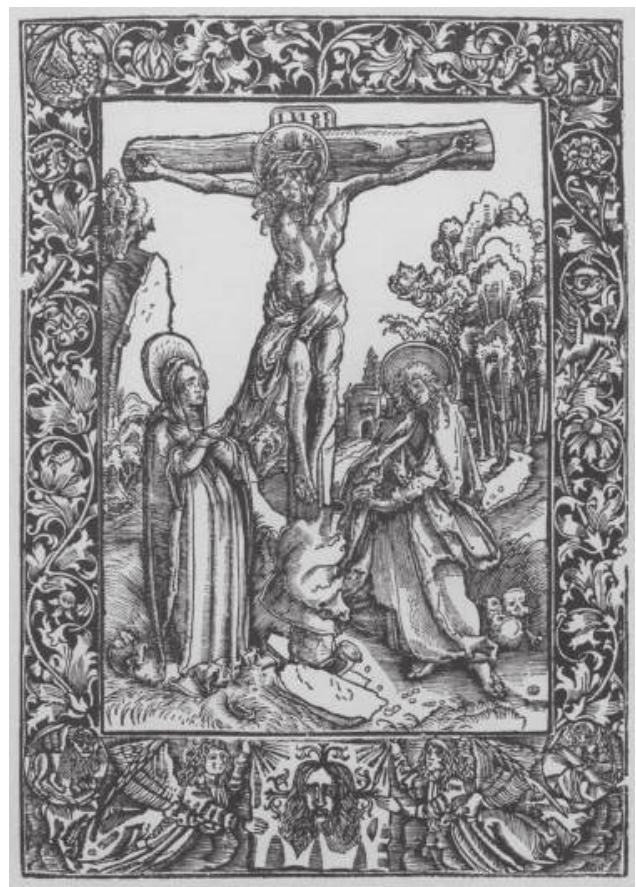

Figure 0.1 Crucifixion, woodcut in Missale Gnesnense (Cracow: Jan Haller, 1506). Unpreserved, formerly Poznań, Biblioteka Seminarium Duchownego.

Photo: Piekarski, ed., Polonia typographica, vol. 2, pl. 47.

designed to be manipulated and which are now lost or incomplete often challenges her to examine them on the basis of the flawed means of reproduction. By doing so, Karr Schmidt shows how to interpret the visual pieces of evidence of printed things that have perished.

From Karr Schmidt's lost things, Loretta Vandi examines uncut playing-card sheets discovered in a 1532 notary book that only by chance escaped destruction. They are now held in the collection of the Arcidiocesi of Urbino-UrbaniaSant'Angelo in Vado (Marche) because their interactive function never was realised and they served as wastepaper in a binder's workshop. Vandi approaches the theme of card making and the origins of tarots and minchiate from a broad cultural context, with an emphasis on Florentine sources. A detailed examination of the Urbino cards and an iconographical analysis and comparison with uncut Rosenwald card sheets held in the National Gallery of Washington, DC, inform her conclusions about both sets' origins.

In turn, James Wehn touches on various aspects of creating, multiplying and modifying Israhel van Meckenem's prints. However, this contribution's starting point is how Hartmann Schedel received ornamental patterns, as he had his manuscripts adorned with cut and coloured prints combined to conjure an imaginative response to the original designs. Wehn discusses the theory and practice of using models in designing new works, steering him toward the search for connections between artworks and 
a frequent inability to determine original designs. In his essay, Wehn consequently employs the metaphor of prints as plants that visually or materially may be harvested and used in a process of creative reproduction, either by the owner or artist, who further modifies and disseminates designs.

The section continues with two case studies that elaborate on Wehn's remarks on design's modification, which results in the creation of new artistic quality. Maureen Warren discusses the output of the Parisian atelier of Gilles and Germain Hardouyn, which specialised in producing books of hours (Horae) with woodcuts and metalcuts hand-painted to imitate illuminated manuscripts. Warren makes a clear distinction between "painted prints" and "print-assisted paintings," and she shows that woodcuts and metalcuts in Hardouyn Horae were not painted prints, but underdrawings that expedited production of a pioneering type of miniatures that became the Hardouyn house's speciality. By comparing examples of the same illustration depicting the Death of Virgin, she elaborates on significant modifications introduced by the application of opaque paint to the original metalcut composition. The analysis of various versions of over-painted print raises the question of underdrawings' role in Renaissance painting ateliers.

Olenka Horbatsch discusses another example of prayer book production and reception-a Dutch vernacular manuscript, c. 1530, with hand-painted engravings, now in the collection of the Rijksmuseum in Amsterdam. The Rijksmuseum prayer book was conceived as a coherent volume with consistently coloured prints pasted onto blank versos facing corresponding text. In her essay, Horbatsch argues that this print-manuscript hybrid is a new type of devotional object for a local audience that she situates in the vicinity of Antwerp. By analysing the selection of contemporary engravers such as Lucas van Leyden and Frans Crabbe, along with carefully applied colours and gold, she conveys how religious prints were modified and employed for devotional and aesthetic purposes.

\section{People}

Prints' devotional and aesthetic functions contribute to their universality and invite us to study the relationships among people involved in the processes of production, dissemination and reception of printed images in different milieux and cultural contexts. Two groups of human actors are particularly prominent. On one hand are people who contributed to the complex process of production-e.g. inventors, woodcutters and, above all, owners of the woodblocks or copperplates, i.e., printers and publishers. On the other hand are the recipients in several senses: beholders, readers, original owners and subsequent collectors.

According to Christophe Plantin's accounts, in 1573, Anton van Leest cut oval and round blocks to create several medallions, including ones depicting evangelists, King David and Lazarus. Given that the documents do not specify for which book Leest's medallions were intended, Plantin originally might have envisaged multiple and varied uses of the blocks. ${ }^{13}$ Indeed, in 1574, he used them twice in different ways, combining medallion borders on a few sheets of the Missale Romanum in folio and impressing two of them in the text columns of the Missale Romanum in octavo. Soon afterward, he also used them in smaller formats as almost full-page illustrations, including the 1575 Officium in $24^{\circ}$ and its subsequent editions. The thematic scope of Leest's blocks after Peeter 
van der Borcht's drawings-New Testament scenes, evangelists, praying King David, the tree of Jesse-was wide and thus suitable for various publications. ${ }^{14}$ Borcht's designs were used again for Plantin in the medallion engravings, with the woodcuts' floral frames transformed into fleuron-style ornaments in the corners, few composition details changed and new scenes from the New Testament and depictions of saints added to the original set. ${ }^{15}$ Thus, Plantin and his successors could pick and choose from the stock of medallion matrices and re-use the same illustrations easily, with the last recorded use of the woodcuts found as late as $1715 .{ }^{16}$ In the same way, a book once published by the Officina Plantiniana was a repository of images for other publishing houses.

The prints by artists working for Plantin spread across Europe due to his books' reach. Copies of medallion woodcuts can be found in the publishing house of Nikolaus Heinrich in Munich. ${ }^{17}$ They also inspired, along with Dürer's works, a woodcut by Alexander Mair used by Wilhelm Eder and Andreas Angermaier in Ingolstadt. ${ }^{18}$ A copy of King David was used in Passau by Matheus Nenninger. ${ }^{19}$ Engraved and woodcut medallions became models for illustrations of the Parisian Officium published by Toussaint du Bray. ${ }^{20}$ Among the milieux that eagerly used Plantinian medallions, both woodcut and copper-engraved, Cracow certainly has occupied an important place since the end of the sixteenth century.

One of the most influential families of Cracow printers, the Siebeneichers, had at their disposal a title woodcut cut from one block composed of ten oval compositions, including mirrored copies of Plantin's Annunciation, Adoration of the Child and-with some modifications-the evangelists. This block was used in 1584 as a title page for a collection of sermons. ${ }^{21}$ However, it was the output from the printing shop of Andrzej Piotrkowczyk I, another leading Cracow printer in the late sixteenth and early seventeenth centuries, that included illustrations in the form of small medallions with floral decorations in the corners as one of the main local types of illustrations in religious books. Woodcutters working for Piotrkowczyk copied many of Plantin's medallion woodcuts and engravings and added other scenes to the set. ${ }^{22}$ Therefore, Piotrkowczyk had a substantial stock of blocks in his publishing house with religious themes with unified formats, shapes and decorations. However, he did not adopt the copper-engraving technique, which had not yet been used on a large scale in book printing in Cracow. He probably made this choice for various reasons, including the difficulty in finding an engraver, the high cost of such a commission and the need to use another printing press adjusted to print intaglio techniques. Despite this, Piotrkowczyk used medallions in a way that resembled Plantin's practice-either as components of title pages' borders in The Saints' Lives or postils published in folio, ${ }^{23}$ or as independent illustrations in prayer books, most often in octavo and in duodecimo. ${ }^{24}$ The Piotrkowczyks used medallion woodblocks extensively throughout the entire period of the publishing house's existence, which forced Andrzej Piotrkowczyk I and his son and heir, Andrzej Piotrkowczyk II, to create duplicates. Old and new blocks were in use simultaneously, so copying the blocks in the printing house must have been, apart from their wear, due to the high demand for these designs.

Not only Andrzej I and Andrzej II but also the latter's wife, Anna Teresa, and their children kept using the medallion woodcuts. Andrzej I's second son, the brother of Andrzej II-Piotr Piotrkowczyk-borrowed six medallions to print them in a prayer book. ${ }^{25}$ Yet another Cracow printer, Wojciech Kobyliński, probably used them (Pentecost, Assumption of Mary) in several editions, among others, of A Way of Reciting the Psalter 
(Sposób mówienia psatterzyka), although he very likely owned his own copies of a few medallions. Subsequently, Marcin Horteryn, who married the wife of the late Wojciech Kobyliński and came into possession of his workshop and bookshop, also borrowed the matrices (Pentecost, Assumption of Mary, Last Supper) from Andrzej I Piotrkowczykand after 1620, from his son. Other printers who copied or used Piotrkowczyk's woodcuts or had their own versions that followed the medallions' pattern include Antoni Wosiński, Mikołaj Lob, Franciszek Cezary, Maciej Jędrzejowczyk, Wojciech Górecki, Walerian Piątkowski and Jakub Siebeneicher and his heirs (Figure 0.4). ${ }^{26}$

For example, Walerian Piątkowski used thirteen medallion woodblocks known from earlier and later use in the Piotrkowczyk family's printshop to illustrate the Delightful Garden of Divine Love (Ogród rozkoszny miłości Bożej), published in 1650 (Figures 0.2 and 0.3). ${ }^{27}$ The whole book was illustrated with twenty-two woodcuts, including a title border, a city view, two coats of arms, two printer's signets, two depictions of plants (used as a decoration), thirteen Piotrkowczyk medallions, Flagellation and Agony in the Garden. The woodblock depicting Agony in the Garden previously was used by Franciszek Cezary. Did Piątkowski borrow, receive as a gift or buy this woodblock? No clear answer can be provided yet. However, another illustration in this book, the Flagellation, also proves particularly interesting as an example of a rather complicated manner of circulating a woodcut. The research up to now has shown that the block had not been used in the Piotrkowczyks' publications before, whereas it fits their medallion set in terms of both size and border design, following the pattern of Plantin's medallions. The apple-like fruits in the corners and triple oval frame present in the Flagellation are also present in medallions used by Kobyliński, Horteryn and Cezary. So, what was the woodcut's origin?

In Cracow, at least two woodblocks depicting this very scene existed, used in works printed by the aforementioned Wojciech Kobyliński and Marcin Horteryn, and almost certainly belonging to their stocks (Figure 0.2). Horteryn was a printer and bookseller. While his bookshop's fate after his death (c. 1633-35) is known, it remains unclear what happened to the printing house. Horteryn's last known printed book is from 1630 . The posthumous bookshop inventory, dated 1635, listing various movables and the will of Horteryn's widow Anna (†1637) do not mention the press, nor typographical resources. Were they already sold by that time? After Horteryn's death, numerous printers applied to the widow for unpaid charges for their books that Horteryn had in his bookshop stock. Even though Anna Horteryn included unsold copies of books printed by the Piotrkowczyk family in her husband's posthumous inventory, Andrzej Piotrkowczyk II did not take any action against her. This is quite surprising because he used to account for his debtors meticulously. ${ }^{28}$ On this basis, Renata Żurkowa assumes that Andrzej Piotrkowczyk II bought the printing house from Horteryn and that part of this transaction entailed settling accounts for the books. ${ }^{29}$ If this holds true, it would explain how the Flagellation woodcut appeared in Piątkowski's Delightful Garden of Divine Love (Figure 0.2c). The stock of Andrzej II, probably including the Flagellation, was inherited by his wife Anna, who lent the Flagellation woodcut, along with other medallions, to Piątkowski in $1650 .{ }^{30}$ The woodblock, like many other medallions, still exists in the Museum of Jagiellonian University as part of the former university press, whose core was created by donations from Stanisław Teodor Piotrkowczyk, heir to the Piotrkowczyk family, and Marcin Waleszczyński, owner of Franciszek Cezary's printing shop. ${ }^{31}$

While the networks of producers, owners and users of the woodblocks are complex, but often traceable, the assumed and recorded recipients are much more difficult 


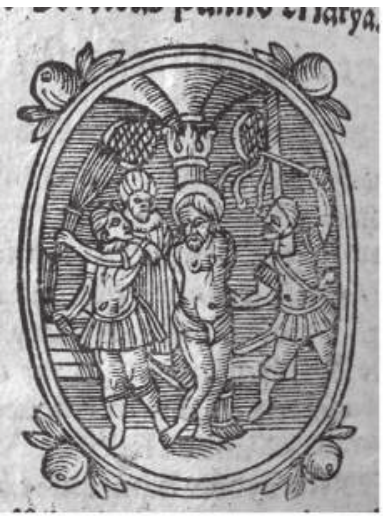

a

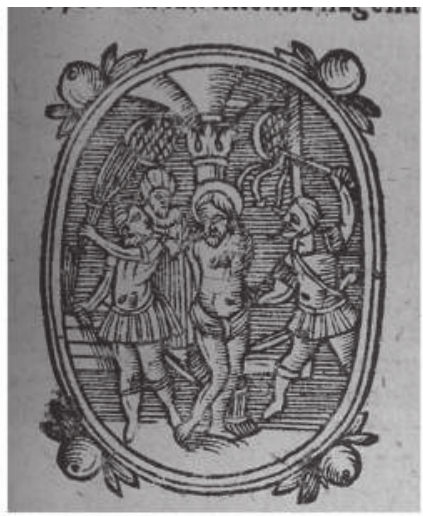

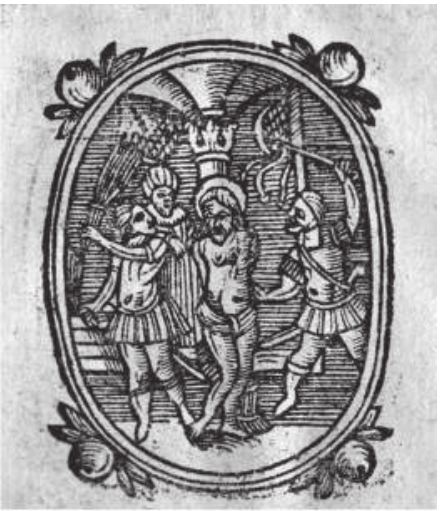

c

Figure 0.2 Flagellation, woodcuts in a) Sposób mówienia psatterzyka (Cracow: Wojciech Kobyliński, 1613), fol. 10v. Kórnik, Polska Akademia Nauk Biblioteka Kórnicka, 126722; b) Stanisław of Radymno, Fasciculus Litaniarum (Cracow: Marcin Horteryn 1622), 139. Cracow, Biblioteka Jagiellońska, 36031; c) Adrian Wieszczycki, Ogród rozkoszny miłości Bożej (Cracow: Walerian Piątkowski, 1650), fol. B4r. Cracow, Biblioteka Jagiellońska, 285484.

Photo: Magdalena Herman.

to investigate. Medallions were used in books that varied with respect to genres and dimensions, but particularly were used frequently in prayer books, often in Polish, which attracted a wide audience. Because of their popularity, which resulted in severe wear in volumes and the loss of entire editions, it is sometimes difficult to determine with total certainty the ownership of the woodblocks and who actually used them. Also, books with preserved provenance or owners' marks cannot always be traced to identifiable places or people. For instance, a prayer book now housed in Kórnik (PAN BK, 126719)—The Path of Christian Perfection (Droga doskonatości chrześcijańskiej), published in Kalisz in 1665-bears eighteenth-century ownership marks of the Cracow Order of the Visitation of Holy Mary. On the verso of the book's title page, someone pasted a woodcut medallion depicting the Crucifixion, impressed from one of the four almost-identical blocks used in Cracow at that time (Figure 0.3). Unfortunately, nothing more is known about when this could have been pasted or by whom.

Since so many printers used similar illustration types, customers who purchased a ready-made volume or combined several prayer books, often issued by different publishers, into one binding received collections of common or related graphic material. ${ }^{32}$ Readers sometimes themselves attempted to unify the books by colouring woodcuts, like that of another volume preserved in Kórnik. One of the exemplar's owners or readers had enough time or patience to add only a few colours to selected illustrations (Figure 0.4). ${ }^{33}$ As the inscriptions on free sheets indicate, the book belonged to Konstancja Kęszycka and to the library of an unspecified abbess. Manuscript fragments from the Polish translation of The Imitation of Christ, supplemented with the prayer summons "pray for the needs of the monastery" on the front pastedown, also clearly 
a
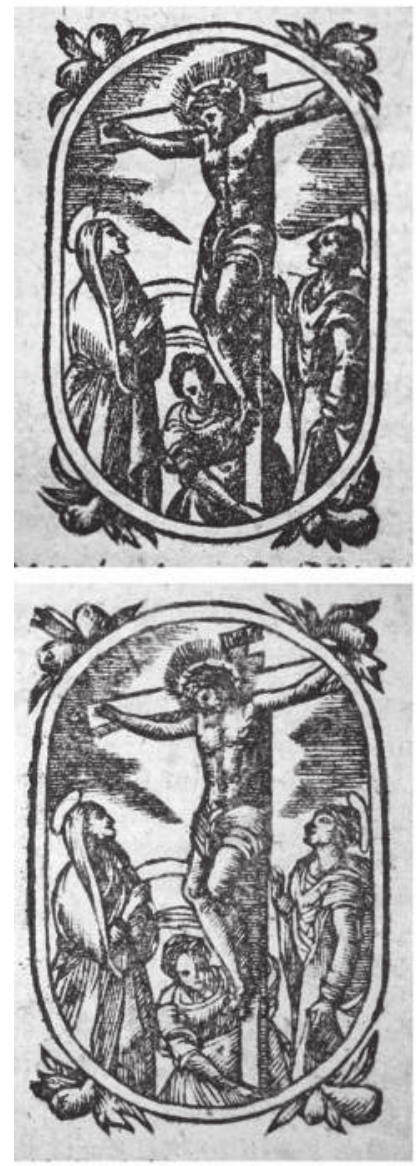

d
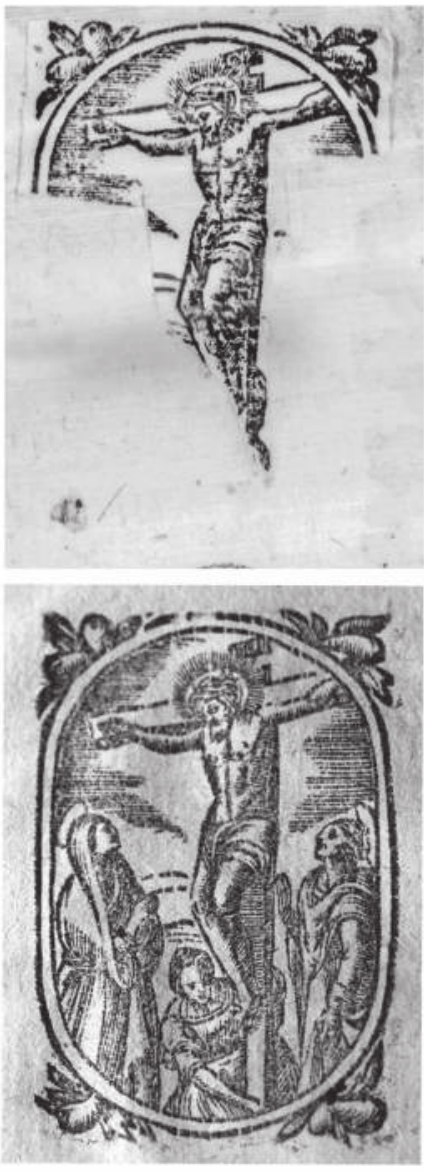

e c
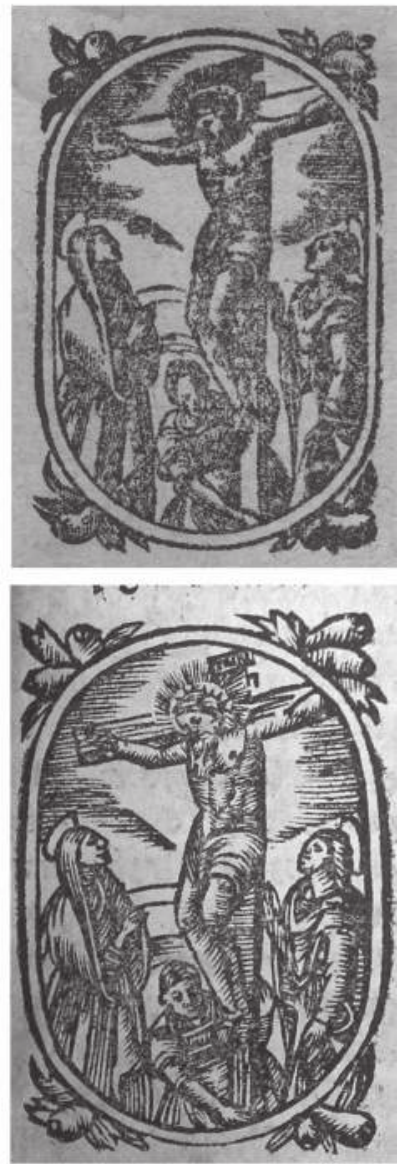

f

Figure 0.3 Crucifixion after Peeter van der Borcht and Anton van Leest. Upper row: Piotrkowczyk's block No. 1, woodcuts a) in Marcin Laterna, Harfa duchowna (Cracow: Andrzej Piotrkowczyk I, 1592), 265. Cracow, Biblioteka Jagiellońska, Cim.O.269; b) pasted into Drogi doskonałości chrześcijańskiej (Kalisz: Collegium Societatis Iesu, 1665). Kórnik, Polska Akademia Nauk Biblioteka Kórnicka 126719 (scanned from microfilm: Mf 7798); c) in Marcin Laterna, Harfa duchowna (Cracow: Andrzej Piotrkowczyk I, 1611), 384. Wrocław, Zakład Narodowy im. Ossolińskich, XVII.1175. Lower row: d) Piotrkowczyk's block No. 2 used in Adrian Wieszczycki, Modus recidandi rosarii (Cracow: Antoni Wosiński, 1629). Cracow, Biblioteka Jagiellońska, 285484; e) Piotrkowczyk's block No. 3 used in Adrian Wieszczycki, Ogród rozkoszny miłości Bożej (Cracow: Walerian Piątkowski, 1650), fol. C1v. Cracow, Biblioteka Jagiellońska, 285484; f) probably Lob's or Piotrkowczyk's block No. 4 used in unidentified prayer book, fol. K4r. Kórnik, Polska Akademia Nauk Biblioteka Kórnicka, Cim.O.611.

Photos: Magdalena Herman (a, d, e); Kórnik, Polska Akademia Nauk Biblioteka Kórnicka - Grzegorz Matz (b, f); Wrocław, Zakład Narodowy im. Ossolińskich - Andrzej Solnica (c). 
testify to the volume's provenance in the monastery. Thus, its first recorded owner would have been Konstancja Kęszycka, the Benedictine nun from the Poznań monastery who made her profession in June 1667 and who died in August 1709 during the raging plague in Poznan. ${ }^{34}$ Afterward, the prayer book may have been placed in the library of the Poznan Benedictine abbess, as was the case with other books given to the Poznań monastery by Anna Patrusówna (†1611). ${ }^{35}$ Both Kęszycka’s and Patrusówna's volumes bear similar eighteenth-century inscriptions, probably written with the same hand: Z bibliotyki P. Xieni ("From the library of abbess"). Thus, the person who attempted to colour Kęszycka's prayer book was either its original, unknown owner; the subsequent owner, Konstancja Kęszycka; or an anonymous Benedictine nun who had access to the volumes in the abbess's library in Poznań.

The Kórnik prayer book's fate has been traced to bibliophiles and book collectors who pasted their bookplates into the book, including Leon Dembowski (17891878) - a politician, regionalist and master of rituals at one of the Polish Freemasonry Lodges_and social activist Władysław Stachowski (1887-1974). For them, the copy was probably a rare example of a collectible of Cracow and Poznań origin in good condition, rather than a prayer book that they wanted to use in their devotional practices. This brings us back to diverse human actors' prominent role in the histories of thingse.g., prints, woodblocks and illustrated books-as well as images-representations. Only after finding and gathering the pieces of this delightfully complicated jigsaw puzzle, often by chance, can one proceed to solve it, still risking that the resulting image will be incomplete or hopefully diversified, depending on the elements used. In any case, producers, readers, viewers, owners and collectors aim to bind the puzzle together.

Two opening essays in Part II deal with aspects of alterations performed by readersviewers of printed books. Giuseppe Capriotti analyses the reception of woodcuts regarded as erotic that illustrate Latin and Italian editions of Ovid's Metamorphoses and Trasformationi by Lodovico Dolce. Capriotti examines five copies now held by Italian and Spanish libraries. From the very beginning, the illustrations in Metamorphoses were censored, either by local authorities or a reader's hand. Volumes analysed by author were subject to alterations written and drawn in ink, aimed at censoring illustrations or making them (more) obscene. Remarks on the types of modifications led to conclusions on those images' role and general identification of their viewers.

Karolina Mroziewicz also traces the signs of reception of illustrations in printed books, but this time in a cultural and political context. She examines various copies of the second edition of Chronica Polonorum by Maciej of Miechów to search for marginalia, notes, drawings and colouring. Adding to these other written sources, such as inventories, she provides further details on Polish nobility and foreign readers' response to the book and its visual content. She also discusses the afterlife of the Chronica series of rulers whose remarkable popularity elucidates cultural, social and political contexts on the consumption of images.

The next two chapters broaden the perspective by adding other actors: a printerpublisher and an author of prints. Although Femke Speelberg provides a minute analysis of several plates from Thomas Gemini's small booklet of moresque designs, published in London in 1548, her main interest is Gemini himself. By gathering pieces of Gemini's biography previously studied in the fields of anatomy, cartography, print 


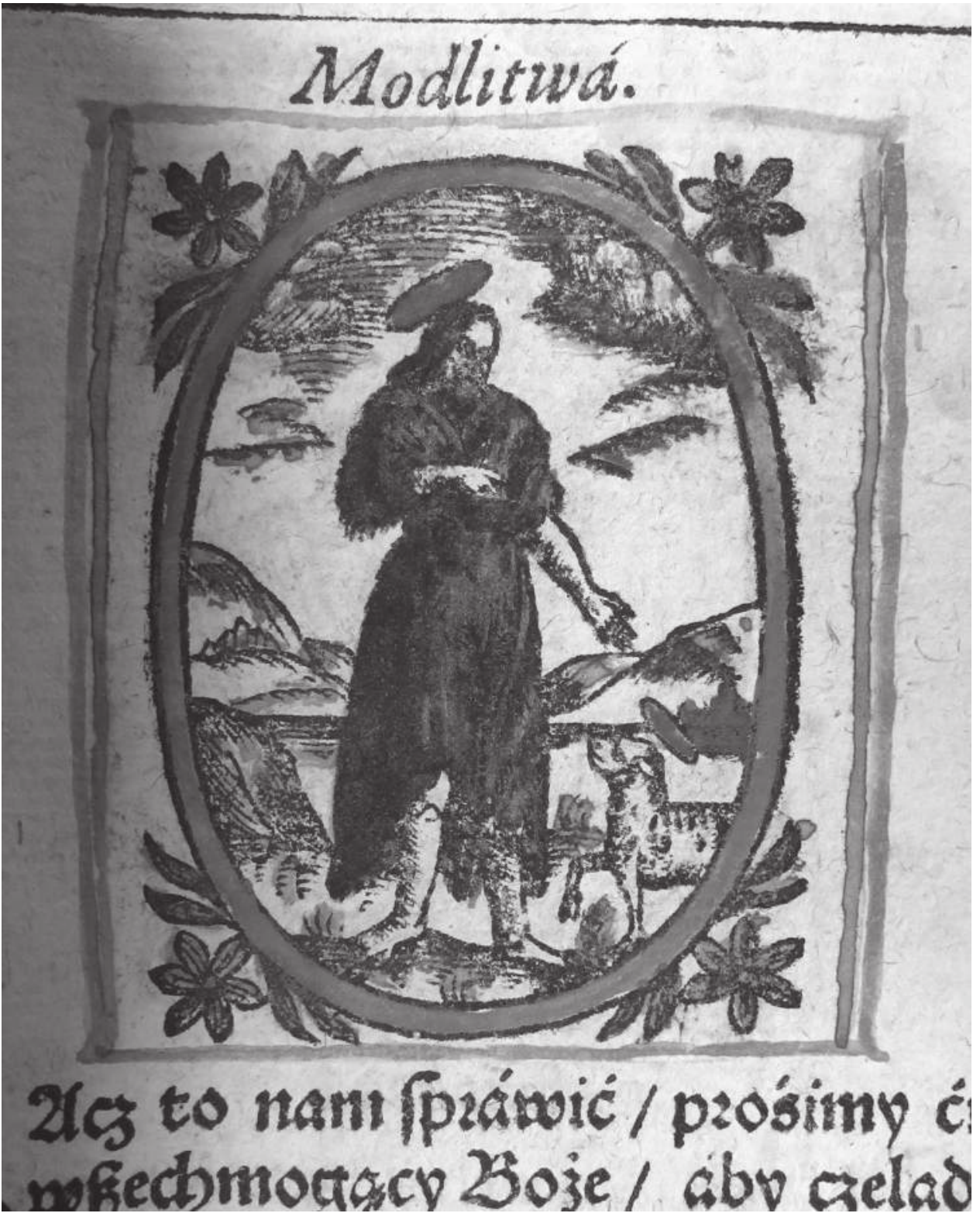

Figure 0.4 Saint John the Baptist after Peeter van der Borcht and Paulus van Wtewael, handcoloured woodcut in Marcin Laterna, Harfa Duchowna (Cracow: Andrzej Piotrkowczyk I, 1612), 575. Kórnik, Polska Akademia Nauk Biblioteka Kórnicka, 126721 adl.

Photo: Kórnik, Polska Akademia Nauk Biblioteka Kórnicka.

history and cosmography, she proves that Morysse and Damashin Renewed and Encreased [sic] occupied a vital role within his oemvre, as well as in his attempts to obtain and preserve his employment under Tudor monarchs. She argues that the model for Gemini's moresque designs-Jacques I Androuet du Cerceau's Mauresques 
de petit format-corresponded well with the decoration of astrolabes that seem to have been Gemini's métier. Thus, her contribution provides insight into rather overlooked motivations for copying prints in the early modern era.

The contribution that concludes this part brings us back to the matter of broader reception and takes up the subject of communication between the printed image and the viewer. Alexandra Kocsis analyses communicative strategies' religious prints published in Rome by Antonio Lafreri. She focuses on prints of renowned images by artists such as Raphael and Michelangelo that were subjects of artistic and devotional contemplation. Many of them had complementary texts that intensified or stimulated viewer-readers' response to the depicted subject. Kocsis analyses the inscriptions by asking whose voices are engaged in this conversation and how it is carried out. She concludes with newly discovered links between the works of Antonio Lafreri and Petrus Canisius that shed light on prints' function in the Counter-Reformation's religious culture.

\section{Images}

The role that prints play in communication is perhaps the most vital question in the discussion regarding "the printing press as an agent of change." ${ }^{36}$ Reproductive techniques facilitated dissemination of texts, but also images, or rather, impressions regarded as carriers of images, which not only provided artists with pictorial models but also enabled scholars to get some insight into phenomena that were inaccessible to them. As a consequence, the reception of one particular image varied depending on expectations, as well as a specific beholder's background. Subsequently, the same image still may have been used as a point of departure for subsequent images. This kind of multiplication also involved various modifications, intentional or not, that sometimes resulted in an original design, but occasionally in an utter misconception or ambiguity. This may be demonstrated by the confusion, still observed in the language, concerning wisent, bison and aurochs. The Merriam-Webster Dictionary of English defines wisent as "a European bison (Bison bonasus) . . . sometimes considered conspecific with the North American buffalo (B. bison) . . . called also aurochs," yet defines aurochs as "an extinct large long-horned wild ox (Bos primigenitus) of Europe that is the ancestor of domestic cattle." Where does this ambiguity come from? Roughly speaking, it stems from the early modern scholarship, and it seems that the confusion reached its peak between the mid-sixteenth and mid-seventeenth centuries, when Conrad Gessner's and Jan Jonston's treatises on quadrupeds were published in 1551 and c. 1652, respectively.

Early modern zoologists described wisent and aurochs as two separate species, as did Gessner in volume one of his History of the Animals, which focussed on livebearing, four-footed animals. ${ }^{37} \mathrm{He}$ never had seen either animal in nature and initially had no illustration for the chapter "On Wisent" (De Bisonte), while he explicitly mentioned a source for the woodcut placed in the chapter "On Aurochs" (De Uro): Anton Wied's map of Muscovy. ${ }^{38}$ Wied's map, which included a small scene that depicted an aurochs hunt, is now thought to have been created between 1537 and 1540, but the earliest engraved impressions bear the date 1555. Thus, Gessner must have had access to an earlier, possibly drawn version of the map, or at least the part that included the aurochs-hunting scene, featuring a man hidden behind a tree while piercing aurochs with a spear (Figure 0.5). Also, Jonston's Description of the Nature of Four-Footed Beasts includes two chapters: "On Aurochs" and “On Wisent." The publication is 
illustrated extensively, but the engravings, prepared by the workshop of Matthäus Merian the Elder's heirs and inserted as separate plates, neither accurately follow the argument nor are referred to in the text. One of the animals is clearly, although indirectly, modelled on the woodcut representing Gessner's aurochs, but it is unexpectedly inscribed as "Wisent" (Bison-Wilder Ochs-Wisent) (Figure 0.6). ${ }^{39}$ What else may be found in Gessner's and Jonston's works and, more importantly, what happened between the dates when these two treatises were published comprise a long and complex story that must be reduced to a few essential moments and figures here.

Both in early modern times and the present day, scholars often publish various addenda et corrigenda that prove necessary in the course of research. This also was true of Gessner, who owed much additional knowledge about wisent and aurochs, as well as two images believed to be ad vivum, to Sigismund von Herberstein. The famous Carniolan diplomat was renowned for his travels to Muscovy, as well as his interest in aurochs and wisent, particularly during the early $1540 \mathrm{~s} .{ }^{40}$ Herberstein had informants in Poland who provided him with representations of wisent and aurochs. He must have shared these images because before they were published in the third edition of his Rerum Moscovitarum Commentarii in 1556, ${ }^{41}$ the designs had been used as models for two woodcuts in Gessner's Icones animalium quadrupedum in 1553 . Subsequently, in 1554, Gessner published an Appendix to the History of the Animals, with the newly acquired images of wisent and aurochs (cf. Figure 0.7), as well as of additional Bovidae species, including one called "white Scottish bison.”42

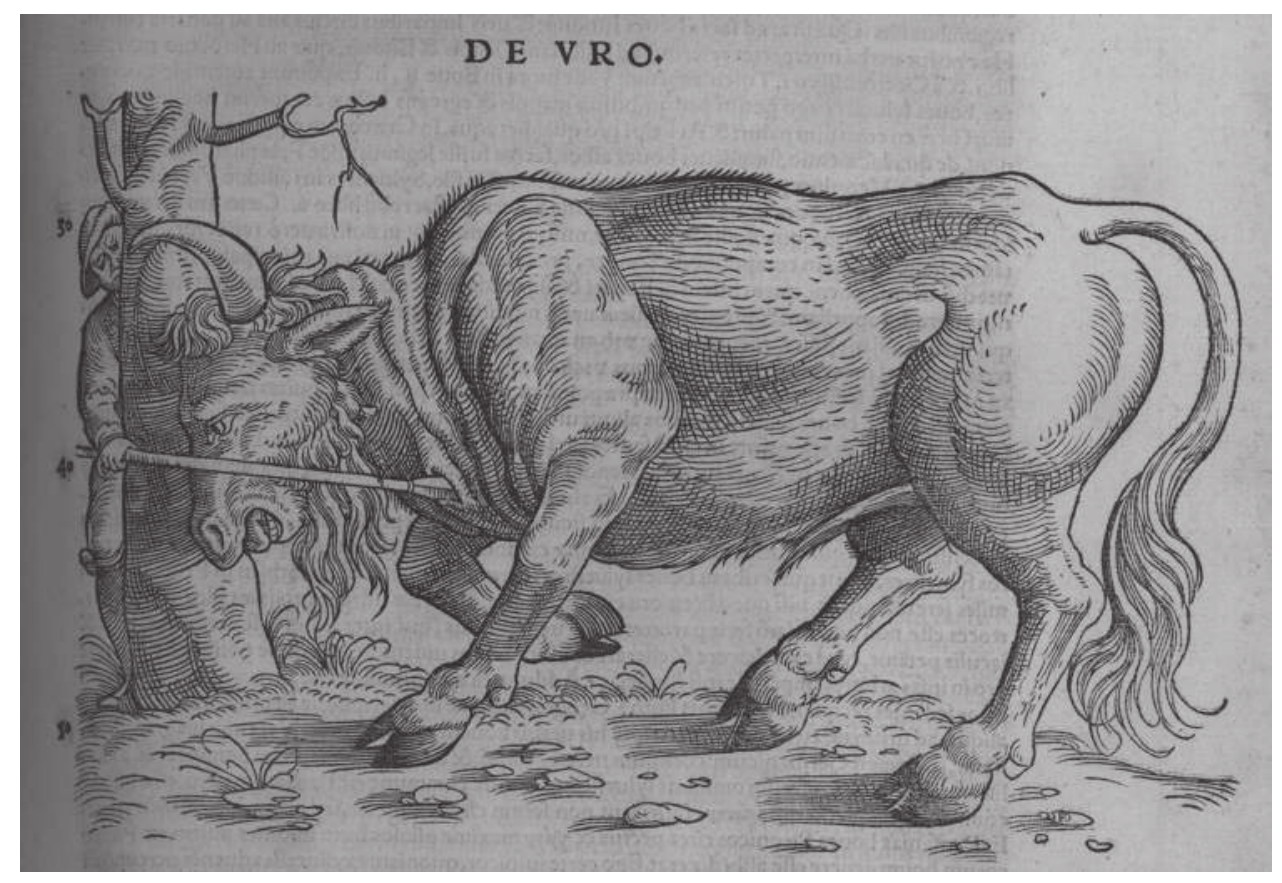

Figure 0.5 Aurochs, woodcut in Conrad Gessner, Historiae Animalium Liber I de Quadrupedibus viviparis (Zurich: Christoph Froschauer, 1551), 157. Warsaw, Biblioteka Narodowa, SD XVI.F.1429 I.

Photo: POLONA (public domain). 


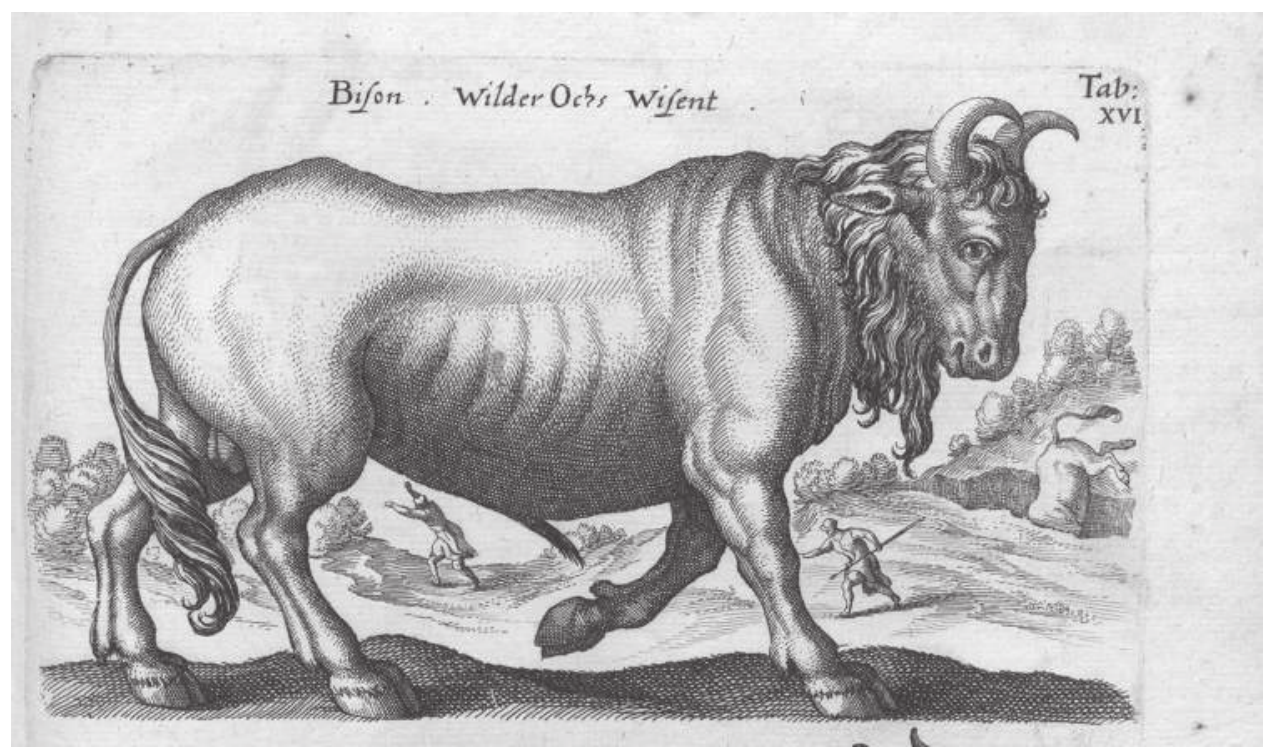

Figure 0.6 Wisent, fragment of Pl. XVI, engraving in Jan Jonston, Historiae Naturalis De Quadrupedibus Libri (Frankfurt/M: heirs of Matthäus Merian [1652?]). Warsaw, Biblioteka Narodowa, SD XVII.4.2278.

Photo: POLONA (public domain).
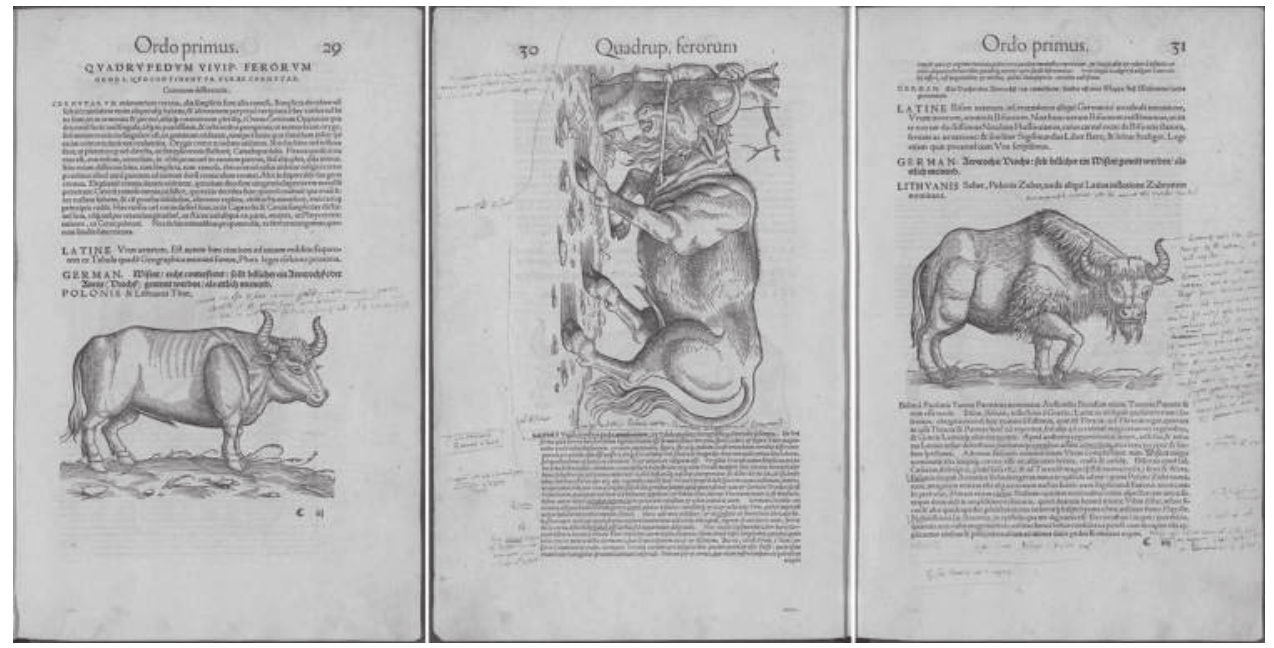

Figure 0.7 Chapters on aurochs and wisent in Gessner's personal copy of Conrad Gessner, Icones animalium quadrupedum (Zurich: Christoph Froschauer, 1560), 29-31, Zurich, Zentralbibliothek, NNN 44 I F.

Photo: https://doi.org/10.3931/e-rara-1668. 
Contemporary scholars dealing with various editions of a publication by the same author typically assume that the last version published during the author's life should be cited as the ultimate, most reliable-or at least most representative-of the author's intent. When one applies this to Gessner, who died in 1565, one should consider the second edition of Icones of 1560 as his last publication that deals with various Bovidae. The entries on aurochs and on wisent adjoin each other, which helps explain the differences between the two species. ${ }^{43}$ The reasoning is substantiated by three woodcuts: two based on designs believed to represent aurochs and wisent ad vivum and the aforementioned hunting scene (Figure 0.7). A copy of this edition including the author's handwritten notes (Zurich, Zentralbibliothek, NNN 44 | F) demonstrates that Gessner initially had some doubts regarding the latter image: "not good, as it seems to me" (non proba, ut mibi videtur), the printed text reads.

Meanwhile, mid-sixteenth-century travellers reported discovering a species of cattle that inhabited America. ${ }^{44}$ Gessner owned two copies of André Thevet's account on the New World, published in 1558, and explicitly referred to this author in the 1560 edition of the Icones. ${ }^{45}$ Although he paid attention to Thevet's description and depiction of a horned, humped wild bull inhabiting Florida, Gessner did not decide to depict this animal in the Icones, maybe because, as can be inferred from his handwritten notes, he was not sure whether the woodcut represented catoblepas, a legendary creature described by ancient and medieval authors, or a gibbous bull (Figure 0.8). Another book that made Gessner reconsider the issue of wild Bovidae was Mikołaj Hussowski's Carmen de Bisonte, a copy of which was sent to him from Cracow in October 1559. Only after reading Hussowski's poem, Gessner must have realised that the hunting scene actually represents wisent and not aurochs. Therefore, in his personal copy of the 1560 edition of Icones he crossed out "as it seems to me" and noted that the remark on the illustration from Wied's map should be referred to as wisent. ${ }^{46}$ However, Gessner's handwritten notes remained unpublished and unacknowledged in subsequent editions, translations and travesties of his works.

The champion of the next generation of scholars, Ulisse Aldrovandi, relied extensively on Gessner's published works. Printed only posthumously in Bologna in 1621, Aldrovandi's treatise on quadrupeds included woodcuts impressed from the blocks that the author had commissioned himself. ${ }^{47}$ Although it has been documented that he acquired original designs representing aurochs and wisent from Poland, he decided to copy Gessner's woodcuts, including wisent, aurochs, white Scottish bison and the hunting scene that referred to aurochs. ${ }^{48}$ Aldrovandi also mentioned humped quiuira boves, as recorded by Lopez de Gómara, and considered the "bull of Florida," or Butro, with a reference to Ambroise Paré. The latter described this animal as a great bull having "one-foot-long horns, a hump like a camel, long hair and a lion's tail."49 Aldrovandi had copied Paré's woodcut, perhaps unaware that it was, in turn, a slavish copy of Thevet's design. Aldrovandi might also not have realised that the image bears a rather vague similarity to the American bison. However, he was unable to verify that he also accepted this image as reliable, just as Gessner relied on the accuracy of the images of wisent and aurochs acquired by Herberstein.

The same set of designs can be found in two subsequent editions of Aldrovandi's treatise, first in Bologna in 1642 as woodcuts impressed from the same matrices, then in Frankfurt in 1647, in one of the engraved plates (Figure 0.9). ${ }^{50}$ Illustrating scholarly works with separate, full-sheet engravings provided with individual 


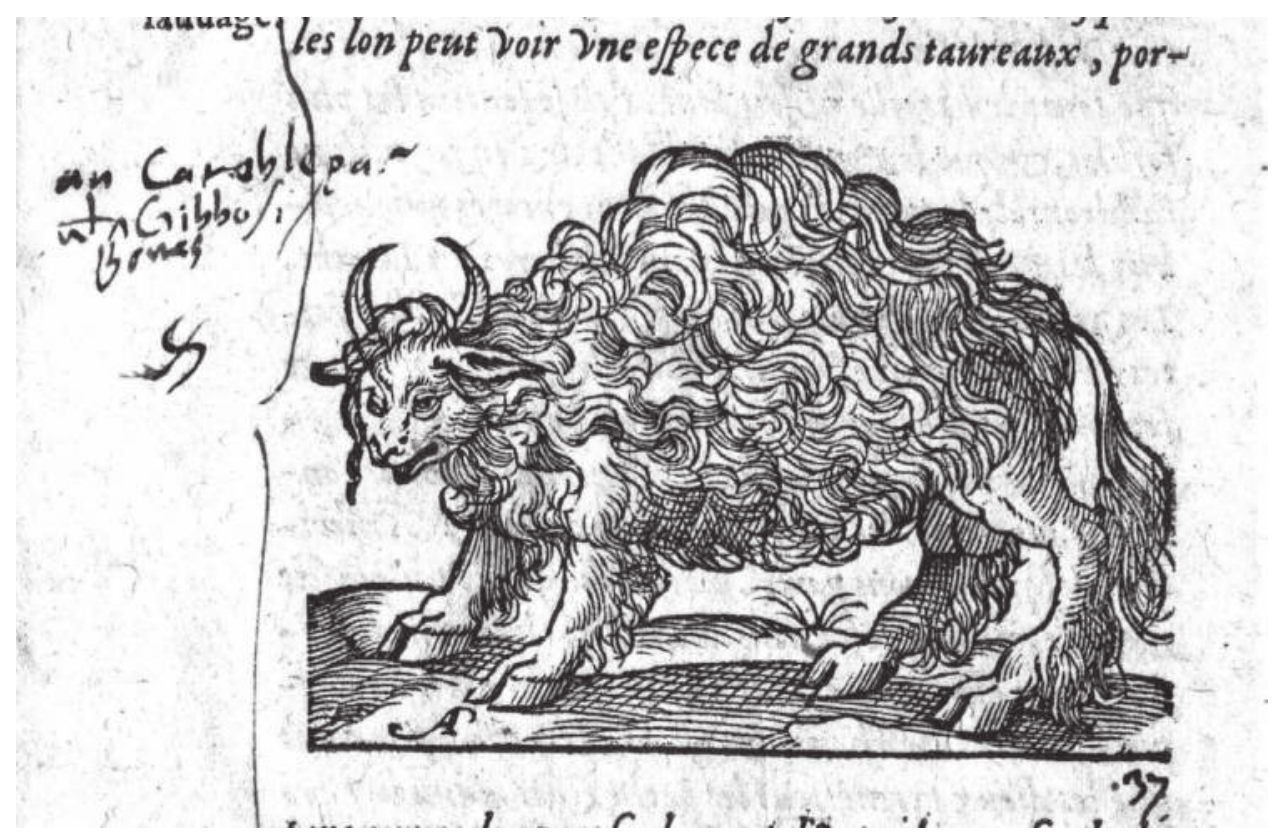

Figure 0.8 Bull of Florida, woodcut in Gessner's personal copy of André Thevet, Les singularitez de la France antarctique. . . (Antwerp: Christophe Plantin, 1558), fol. 144v. Basel, Universitätsbibliothek Basel, Hx VI 30.

Photo: https://www.ub.unibas.ch/digi/a100/diverse_projekte/pre2009pdf/BAU_1/BAU_1_003500973.pdf, public domain.

captions, instead of woodcuts inserted in the column of text, was a rather novel approach. Adopted by the Frankfurt publisher of Aldrovandi's book, it might have informed the Frankfurt printers of Jonston's treatise-Matthäus Merian's heirs-whose workshop also prepared the plates for the illustrations. Jonston's text barely mentions the "North American bulls," calling them dewlapped, gibbous animals, ${ }^{51}$ while it elaborates on, among other things, aurochs and wisent in specific chapters, collecting various authors' brief, but not always consistent, accounts. ${ }^{52}$ Such an incoherent narrative, combined with independent engravings-reprinted or copied in subsequent editions and translations of Jonston's work-resulted in an accumulation of ambiguities. The identification of the aforementioned Wisent in Jonston's work is perplexing when confronted with Gessner's and Aldrovandi's publications, while it is intriguingly, even if coincidentally, consistent with Gessner's unpublished handwritten remarks (Figure 0.6). Thus, insecure identities, interchangeable names and vague appearances by the three animals - the wisent, aurochs and North American bison-remained both a zoological and linguistic puzzle in the print era, when multiplied images contributed to both near solutions and ultimate global confusion. 


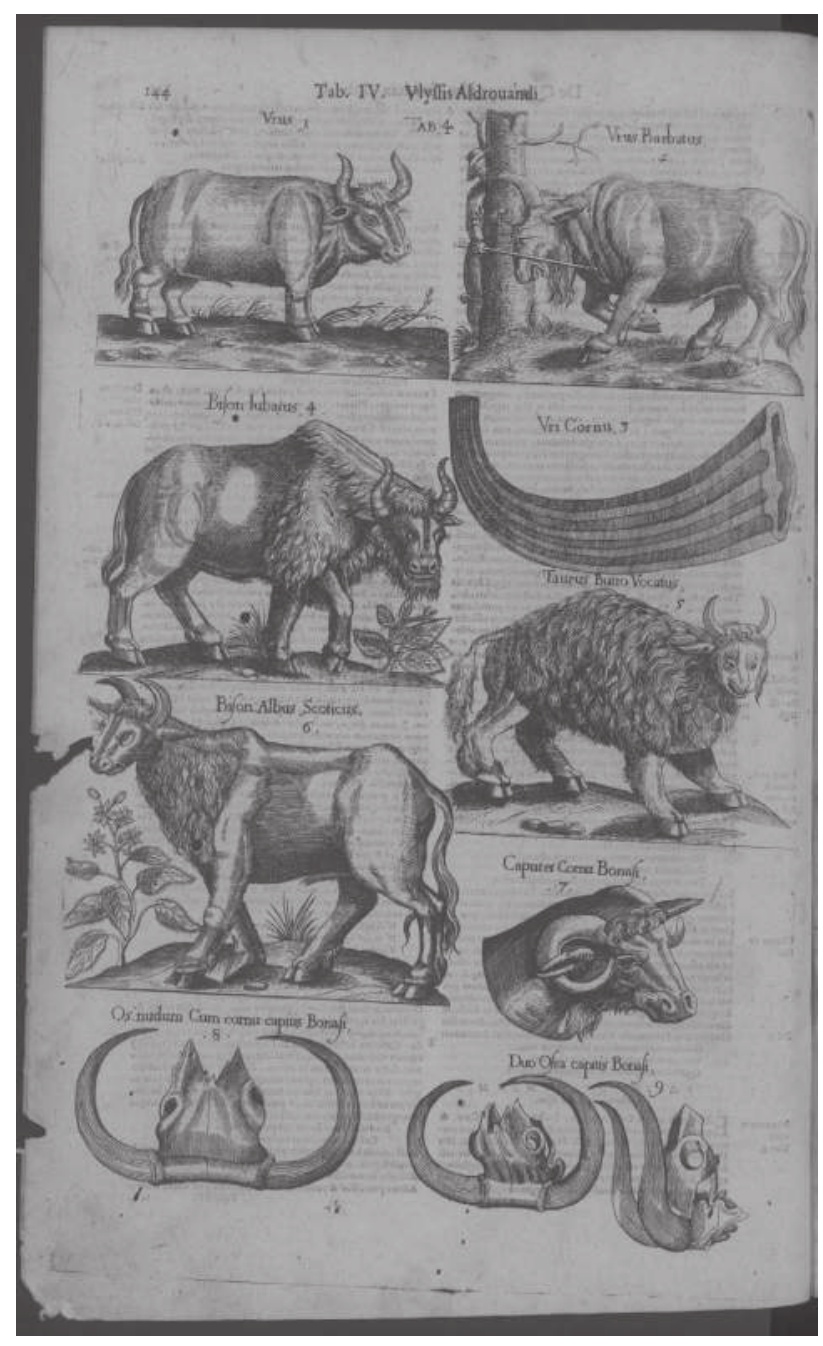

Figure $0.9 \mathrm{Pl}$. IV, engraving in Ulisse Aldrovandi, Quadrupedum omnium bisulcorum Historia (Frankfurt/M: David Johann Zunner and Peter Haubold, 1647), 144. Cracow, Biblioteka Jagiellońska, St. Dr. Zool. 539(a)III.

Photo: Cracow, Biblioteka Jagiellońska.

Admittedly, the wisent, aurochs and bison story is rather unique in its perplexity. However, multiplication of images, either by impressing them from one matrix-often reused many times - or by copying the original designs through various techniques, is vital to research on both the production and reception of printed images. Relationships among designs are sometimes simple and easy to explain, but sometimes these relationships are complex in many ways and cross genres, iconographic formulas, functions, artistic media, religions and geographic regions.

Joanna Sikorska investigates the complexities concerning the reception of Albrecht Dürer's engraving Saint George (c. 1502-1503) and analyses it in relation to other 
works by the Nuremberg master in iconographical and historical contexts. In tracing the reception of this motif, she focuses on the tomb of Ambroży Pampowski in Środa Wielkopolska. Pampowski was an important dignitary on the Jagiellonian court who paid great attention to commemoration, and one of its traditions was putting up his own tombstone during his lifetime. The reasons for selecting Dürer's print as the model became clear when Pampowski's involvement in political actions in the Polish kingdom-and more generally, Christian Europe-as well as the local cult of Saint George, are taken into consideration.

A different pattern of reception of Dürer's prints is discussed by Małgorzata Łazicka. In her essay, she examines-in terms of iconography, style and technique-the modifications to the established images of Fortune and Misfortune introduced by Sebald Beham. Despite the earlier note, her research material far exceeds Dürer's oeuvre. By describing a long tradition of depicting the personifications of human fate, she extracts the elements of tradition and innovation in Beham's etching Fortune (1520) and a pair of engravings, Fortuna and Infortunium (1541).

With the essay by Júlia Tátrai, we shift to the late sixteenth and early seventeenth centuries. The engraved set of Four Elements by Hendrick Goltzius (1586) probably was intended to target an erudite audience of collectors, but its popularity spread to English faience, French furniture and German stove tiles, among other areas. However, the set's European reputation was a result of the earlier employment of Goltzius figures for Willem Blaeu's Map of the World. Tátrai analyses how the images of elements were adopted in diverse genres, functions, materials and techniques.

In turn, András Handl's main concern is how one image, namely the Adoration of God's Lamb by Joos van Winghe and Johann Sadeler, was adopted by various media and Christian confessions. This pictorial motet (beeldmotet), with music written by Andries Pévernage, was disseminated widely and cross-confessionally in books, also by means of reuse and modifications of printing matrices, and in large-scale paintings. Handl examines the reception of Sadeler's engraving and observes how it was modified to best serve the copy's intended purpose.

The concluding essay by Jean Michel Massing broadens the European perspective on the reception of images and focuses on early knowledge of European prints in Africa, the Americas and Asia, particularly on Jerome Nadal's Evangelicae Historiae Imagines and the role that the Jesuits played in the process of dissemination. Massing examines the globalisation of European imagery through the medium of print culture and demonstrates how and why various designs were used far away from their places of origin. The question remains as to how the understanding of similar patterns differed depending on region or level of literacy-a question posed by the author as a challenge to global art history.

\section{Notes}

1 unum ex eis esse Martini Lutheri, quem se servare, dixit, non propter lecturam, sed propter imagines in eis pictas per quendam Olbricht Direr, quae artificio suo, quod exercet, sunt multum commodae, caeters vero libros dixit, esse quiusdam frenificis-Ptaśnik, Cracovia impressorum, 211.

2 Most recent contribution: Rudy, Image, Knife and Gluepot.

3 Heitz, Christus am Kreuz.

4 Hollstein, German, vol. 6, nos. 28 and 29.

5 Schade, Die Malerfamilie, 14 and note 30; Heiser, Das Frühwerk, 94-95.

6 Ameisenowa, Rękopisy i pierwodruki, cat. 190, fig. 220.

7 Kawecka-Gryczowa, ed., Drukarze, 45-47. 
8 Cracow, BJ, Inc. 2849; Ameisenowa, Rękopisy i pierwodruki, cat. 191; cf. Missale Strigoniense of 1490 cited by Schramm, Der Bilderschmuck, 9 and 20, fig. 613.

9 Hollstein, German, vol. 3, nos. 25 and 26; Anzelewsky, "Studien," 133-34.

10 Kawecka-Gryczowa et al., eds., Polonia typographica, pl. 19bis; Lewicka-Kamińska, "Na marginesie," 146. Before he came to Cracow, Hochfeder had been active in Nuremberg (and in Metz); he also had another Crucifixion block in his workshop, used in two variants of the same edition of the Missale Vratislaviense. This block is thought to be cut by Konrad Baumgarten after the anonymous Crucifixion used by Stuchs; see Piekarski, ed., Polonia typographica, pl. 55; Karłowska-Kamzowa, "Wrocławskie drzeworyty," 10, fig. 5.

11 Piekarski, ed., Polonia typographica, vol. 2, pl. 47; Chojecka, "Eukasz Cranach," 23-25. None of the three copies mentioned by Estreicher, Bibliografia polska, 432 seems to be extant now; a copy is preserved in Lublin, Biblioteka Katolickiego Uniwersytetu Lubelskiego im. Jana Pawła II, XVI.1879.

12 Instead, he commissioned another woodcut, rather a free travesty than a copy of Cranach's design, known from one unpreserved copy of the Missale Cracoviense of 1509, from the Ossoliński collection in Lwów/Lviv; Piekarski, ed., Polonia typographica, vol. 2, pl. 60; Chojecka, "Łukasz Cranach," 26, fig. 4.

13 Bowen, "Unknown examples," 13-15.

14 Mielke and Mielke, Peeter van der Borcht, nos. 522-37, 539-42, 588, 594, 638, 793-96, A 39.

15 Ibidem, nos. 810-25, 603-4, 613, 652, 654, 657, 664, 666-60, 676, 719-20, 1392-653; Bowen and Imhof, Christopher Plantin, 251-55.

16 Bowen, "Unknown examples," 13; Imhof, The Illustration of Books, cat. 10, 36, 59.

17 Full-page illustrations were also copied, Missale Romanum (Munich: Nikolaus Heinrich, 1614 and 1620$)$.

18 Missale Romanum (Ingolstadt: Wilhelm Eder, 1610, 1612 and 1629); Missale Ratisbonense (Ingolstadt: Wilhelm Eder, 1611 and 1624); Hollstein, German, vol. 23, no. 151.

19 Actus Sacerdotalis Sive Brevis Eorum Informatio (Passau: Matheus Nenninger, 1587); David Meder, Ein Andächtigs Christenlichs Gebett wider den Türcken (Passau: Matheus Nenninger, 1595); Litaniae et preces recitandae (Passau: Matheus Nenninger, 1695).

20 Officium Beatae Mariae Virginis (Paris: Toussaint du Bray, 1607).

21 Jakub Wujek, Postilla catholica (Cracow: Siebeneichers, 1584). It was reused in 1649 by Franciszek Cezary as a title page of sermons Unwithering Wreath of Most Pure Virgin Mary (Wieniec niewiędnieiacy Przeczystey P. Mariey) by Szymon Starowolski.

22 Treiderowa, "Ze studiów," 11-13; Krzak-Weiss, W ogrodzie, 180-86; Komorowska, "The Counter-Reforming," 341-44. The precise sources for added scenes are unknown, but many are rooted in compositions already popular in Cracow and in woodcuts by Lieven de Witte (particulary passion scenes) or their copies. For de Witte woodcuts, cf. Veldman, Schaik, Verbeelde boodschap; Hollstein, Duch and Flemish, vol. 53, 233-80. Many thanks to Magdalena Komorowska who shared her research prior to the publication of her essay. Special thanks are also owed for the support offered during the queries conducted so far to librarians of Biblioteka Jagiellońska, Biblioteka Kórnicka PAN and Zakład Narodowy im. Ossolińskich.

23 Piotr Skarga, Żywoty świętych (Cracow: Andrzej Piotkowczyk I, 1585, 1592-1593 and 1601); idem, Kazania na niedziele i święta (Cracow: Andrzej Piotrkowczyk I, 1595, 1597 and 1602); idem, Kazania o siedmi sakramentach (Cracow: Andrzej Piotrkowczyk I, 1600); Jakub Wujek, Postilla Katholicka Mnieysza (Cracow: Andrzej Piotrkowczyk I, 1590, 1596, 1605).

24 As epitomised by the Harfa Duchowna (Spiritual Harp) by Marcin Laterna, a popular prayer book, which had nearly twenty editions since 1585, cf. Komorowska, "The CounterReforming," 328-50.

25 Bractwo zotnierskie S. Michata Archaniola and Officium Pro Confraternitate Militari: Sub Nomine \& Patrocinio S. Michaelis Archangeli (Cracow: Piotr Piotrkowczyk, 1610).

26 Two blocks used by Mikołaj Lob, Virgin Mary and Child and Crucifixion, are also present in an unidentified prayer book (Kórnik, PAN BK, Cim.O.611). According to Komorowska, "The Counter-Reforming," 331, it was "probably printed by Andrzej Piotrkowczyk." However, further comaparative analysis on text, illustrations and typeset used in this prayer book should be undertaken. 
27 Adrian Wieszczycki, Ogród rozkoszny miłości Bożej (Cracow: Walerian Piątkowski, 1650).

28 Pirożyński, ed., Drukarze, pt. 2.1, 246.

29 Żurkowa, "Działalność," 187-88. Pirożyński, Drukarze, pt. 2.2, 549 claims that it was Krzysztof Schedel. The hypothesis that Piotrkowczyk bought Horteryn's stock is particularly interesting because there are two other medallions used by Kobyliński and Horteryn (Pentecost and another version of the Assumption of Mary) which were later, in 1642, used by Andrzej Piotrkowczyk II when he printed them in the Harfa Duchowna. Before we find their earlier use by the printing house of the Piotrkowczyk family, it cannot be excluded that they originally belonged to Kobyliński and Horteryn's stock.

30 The nature of this transaction is not known, but it can be assumed that they were lent to Piątkowski because at least one of them, Assumption of Mary, was given back to the stock and then used by Anna Teresa Piotrkowczyk in 1653 in the Office of Virgin Mary.

31 Muczkowski, Zbiór odcisków, no. 600; Socha, Typografia, 35-38.

32 The inventories of bookbinders mention volumes containing prayer books, which, as can be deduced from the titles, were dominated by medallion illustrations, Torój, Inwentarze, 76-77. As the preserved copies show, they did not always have to be publications originating from a single publishing house, Warsaw, Biblioteka Publiczna m.st. Warszawy, XVII.1.311 ADL.- XVII/1.315 ADL.

33 Marcin Laterna, Harfa Duchowna (Cracow: Andrzej Piotrkowczyk I, 1612); Sposób mówienia psałterzyka (Cracow: Wojciech Kobyliński, 1613); Koronka P. Błogosławioney Mariey, s.l. [Cracow] s.a. Kórnik, PAN BK, 126721-23.

34 Borkowska, Karkucińska and Wiesiołowski, eds Kroniki, 259; 307; Borkowska, Leksykon zakonnic, 87.

35 Kórnik, PAN BK, Cim.O.162 and Kórnik, PAN BK, 11328.

36 Eisenstein, The Printing Press.

37 Conrad Gessner, Historiae Animalium Lib. I de Quadrupedibus viviparis (Zurich: Christoph Froschauer, 1551), 143-45 and 157-59.

38 Ibidem, 1097; Nehring, "Einige Bemerkungen," 87-89.

39 Jan Jonston, Historiae Naturalis De Quadrupedibus Libri (Frankfurt/M: heirs of Matthäus Merian, 1652), 56-57, cf. pl. XVI.

40 Nehring, Über Herberstain und Hirsfogel, 87-97; Janicki and Ososiński, eds., Epistulae, 41-43.

41 Sigismund von Herberstein, Rerum Moscoviticarum Commentarii (Basel: Johann Oporinus, 1556), 111-112.

42 Conrad Gessner, Icones animalium quadrupedum (Zurich: Froschauer, 1553), 20, 60 and 63; idem, Appendix historiae quadrupedum uiuiparorum \& ouiparorum (Zurich: Christoph Froschauer, 1554), 2 and 4.

43 Conrad Gessner, Icones animalium quadrupedum (Zurich: Christoph Froschauer, 1560), 29-31.

44 Alvar Nunez Cabeza De Vaca's Relación, An Annotated Translation by Martin A. Favata and José B. Fernández (Houston, TX: Arte Publico Press, 1993), 72-73 (first published 1542).

45 André Thevet, Les singularitez de la France antarctique .. . (Antwerp: Christophe Plantin, 1558), fol. 147v, copy in Basel, UBB, Hx VI 30; the other Gessner's copy is lost, Leu, Keller and Weidmann, Conrad Gessner's Private Library, cat. 361 and 362.

46 Cf. Choptiany, "Konrad Gesner."

47 Simoni, "La natura incisa," 129-44; idem, "Dal disegno al libro," 59-70.

48 Fantuzzi, Memorie, 257-60; cf. Barycz, "Profesor krakowski," 44-49.

49 Ulisse Aldrovandi, Quadrupedum omnium bisulcorum historia (Bologna: Sebastiano Bonomi, 1621), 53 and 357 (cf. 348, 349, 355); Francisco Lopez de Gómara, Hispania victrix: Primera y secunda parte de la historia general de las Indias . . . (Medina del Campo: Guillermo de Millis, 1553), fol. CXVII; Ambroise Paré, Discours . . . asçavoir, de la mumie ... (Paris: Gabriel Buon, 1582), fol. 26; idem, Opera (Paris, 1582), 792-93.

50 Ulisse Aldrovandi, Quadrupedum omnium bisulcorum Historia (Frankfurt/M: David Johann Zunner and Peter Haubold, 1647), 144.

51 Jonston, Historiae Naturalis De Quadrupedibus Libri, 53.

52 Cf. Margócsy, “Certain Fakes," 190-225. 


\section{Grażyna Jurkowlaniec and Magdalena Herman}

\section{Bibliography}

Ameisenowa, Zofia. Rękopisy i pierwodruki iluminowane Biblioteki Jagiellońskiej. Wrocław: Zakład Narodowy im. Ossolińskich, 1958.

Anzelewsky, Fedja. "Studien zur Frühzeit Lukas Cranachs d.Ä.” Städel-Jahrbuch, 17 (1999): $125-44$.

Barycz, Henryk. "Profesor krakowski współpracownikiem wielkiego przyrodnika." In Henryk Barycz, Szkice z dziejów uniwersytetu Jagiellońskiego. Cracow: Anczyc, 1933.

Borkowska, Małgorzata. Leksykon zakonnic polskich epoki przedrozbiorowej. Vol. 1. Warsaw: DiG, 2004.

Borkowska, Małgorzata, Wanda Karkucińska, and Jacek Wiesiołowski, eds. Kroniki benedyktynek poznańskich. Poznań: Wydawnictwo Miejskie, 2001.

Bowen, Karen Lee. "Unknown Examples of Christopher Plantin's Books of Hours and New Discoveries Concerning His Working Practices.” De gulden passer, 87/2 (2009): 7-33.

Bowen, Karen Lee, and Dirk Imhof. Christopher Plantin and Engraved Book Illustrations in Sixteenth-Century Europe. Cambridge: Cambridge University Press, 2008.

Chojecka, Ewa. "Łukasz Cranach St. i krakowska grafika renesansowa." Biuletyn Historii Sztuki, 34 (1972): 23-29.

Choptiany, Michał. "Konrad Gesner jako czytelnik 'Carmen de bisonte' Mikołaja Hussowskiego: Perspektywy badawcze.” Kwartalnik Historii Nauki i Techniki, 58/2 (2013): 111-37.

Eisenstein, Elizabeth L. The Printing Press as an Agent of Change. Vols. 1-2. Cambridge: Cambridge University Press, 1979.

Estreicher, Karol. Bibliografia polska, pt. III. Vol. XI, M-My. Cracow: Czcionkami Drukarni Uniwersytetu Jagiellońskiego, 1908 (Ogólnego zbioru tom XXII).

Fantuzzi, Giacomo. Memorie della vita di Ulisse Aldrovandi. Bologna: Lelio dalla Volpe, 1774.

Heiser, Sabine. Das Frühwerk des Lucas Cranach des Älteren: Wien um 1500-Dresden um 1900. Berlin: Reimer, 2002.

Heitz, Paul. Christus am Kreuz: Kanonbilder der in Deutschland gedruckten Messbücher des fünfzehnten Jahrbunderts. Strasburg: Bekhoven, 1910.

Hollstein, Friedrich Wilhelm Heinrich. German Engravings, Etchings and Woodcuts ca. 14001700. Vols. 1-. Amsterdam: Menno Hertzberger, 1954-.

Imhof, Dirk, ed. The Illustration of Books Published by the Moretuses. Antwerp: PlantinMoretus Museum, 1996.

Janicki, Marek A., and Tomasz Ososiński. Epistulae Sigismundi de Herberstein et Ioannis Dantisci. Warsaw: Polska Akademia Umiejętności, 2008.

Karłowska-Kamzowa, Alicja. "Wrocławskie drzeworyty Konrada Baumgartena: Ze studiów nad związkami artystycznymi Wrocławia i Krakowa w początkach XVI wieku.” Roczniki Sztuki Śląskiej, 9 (1973): 7-16.

Kawecka-Gryczowa, Alodia, ed. Drukarze dawnej Polski od XV do XVIII wieku. Vol. 1: Małopolska, pt. 1: Wiek XV-XVI. Wrocław: Zakład Narodowy im. Ossolińskich, 1983.

Kawecka-Gryczowa, Alodia et al., eds. Polonia typographica saeculi sedecimi. Vol. 1: Kasper Hochfeder, Kraków 1503-1505. 2nd ed. Wrocław: Zakład Narodowy im. Ossolińskich, 1968.

Komorowska, Magdalena. "The Counter-Reforming of Polish Prayer Books: The Example of Marcin Laterna's Harfa Duchowna (1585).” Qucerendo, 47 (2017): 328-50.

Krzak-Weiss, Katarzyna. W ogrodzie duszy: Studia nad wyposażeniem ilustracyjnym polskich edycji modlitewnika 'Hortulus animae'. Poznań: Wydawnictwo Naukowe UAM, 2014.

Leu, Urs B., Raffael Keller, and Sandra Weidmann. Conrad Gessner's Private Library. Leiden: Brill, 2008.

Lewicka-Kamińska, Anna. "Na marginesie 'polskich Cranachianów'.” Biuletyn Historii Sztuki, 35 (1973): 146-49.

Margócsy, Dániel. "Certain Fakes and Uncertain Facts: Jan Jonston and the Question of Truth in Religion and Natural History." In Fakes? Hoaxes, Counterfeits, and Deception in Early 
Modern Science, eds. Marco Beretta and Maria Conforti, 190-225. Sagamore Beach, MA: Science History Publications, 2014.

Mielke, Hans, and Ursula Mielke, comp. Peeter van der Borcht, Book Illustrations, ed. Ger Luijten, pt. 4. Ouderkerk aan den Ijssel, Amsterdam: Sound \& Vision Publishers, Rijksprentenkabinet, Rijksmuseum, 2006 (NHD, Vol. 44).

Muczkowski, Józef. Zbiór odcisków drzeworytów w różnych dziełach polskich w XVI i XVII wieku. . . /Recueil de gravures sur bois imprimées dans divers ouvrages polonais au seizième et aux dix-septième siècle ... . Cracow: Drukarnia Uniwersytecka, 1849.

Nehring, Alfred. "Einige Bemerkungen über Anton Wied's Moscovia und das zugehörige Urusbild.” Globus: Illustrierte Zeitschirft für Länder- und Völkerkunde, 71/6 (1897): 87-89.

—. Über Herberstain und Hirsfogel: Beiträge zur Kenntnis ibres Lebens und ibrer Werke. Berlin: Dümmler, 1897.

Piekarski, Kazimierz, ed. Polonia typographica saeculi sedecimi: Zbiór podobizn zasobu drukarskiego tłoczni polskich XVI stulecia. Vols. 1-2. Warsaw: Szkoła Przemysłu Graficznego imienia Marszałka Józefa Piłsudskiego, 1936-1937.

Pirożyński, Jan, ed. Drukarze dawnej Polski od XV do XVIII wieku. Vol. 1: Małopolska, pt. 2. 1-2: Wiek XVII-XVIII. Cracow: Polska Akademia Umiejętności, 2000.

Ptaśnik, Jan, ed. Cracovia impressorum XV et XVI saeculorum, Lwów/Lviv: Zakład Narodowy im. Ossolińskich, 1922 (Monumenta Poloniae Typographica XV et XVI saeculorum, vol. 1).

Rudy, Kathryn M. Image, Knife and Gluepot: Early Assemblage in Manuscript and Print. Cambridge: Open Book Publishers, 2019.

Schade, Werner. Die Malerfamilie Cranach. Dresden: VEB Verlag der Kunst, 1974.

Schramm, Albert. Der Bilderschmuck der Frühdrucke. Vol. 18: Die Drucker in Nürnberg. Leipzig: Hiersemann, 1935.

Schuckman Christiaan, Ilja M. Veldman, and Jeroen de Scheemaker, comp. Frederic de Witt to Lieven de Witte, ed. D. De Hoop Scheeffer. Rotterdam: Sound \& Vision Publishers, 1999 (HD, Vol. 53).

Simoni, Fulvio. "La natura incisa nel legno: La collezione delle matrici xilografiche di Ulisse Aldrovandi conservata all'Università di Bologna.” Studi di Memofonte, 17 (2016): 129-44.

—. "Dal disegno al libro a stampa: La rappresentazione del mondo naturale nelle matrici xilografiche di Ulisse Aldrovandi." In Ulisse Aldrovandi: Libri e immagini di Storia naturale nella prima Età moderna, eds. Giuseppe Olmi and Fulvio Simoni, 59-70. Bologna: Bononia University Press, 2018.

Socha, Klaudia. Typografia publikacji pochodzacych z drukarń Uniwersytetu Jagiellońskiego 1674-1819. Cracow: Wydawnictwo UJ, 2017.

Torój, Elżbieta. Inwentarze książek lubelskich introligatorów z pierwszej połowy XVII wieku. Lublin: Wydawnictwo UMCS, 2000.

Treiderowa, Anna. "Ze studiów nad ilustracją wydawnictw krakowskich.” Rocznik Biblioteki PAN w Krakowie, 14 (1968): 5-31.

Veldman, Ilja M., and Karin van Schaik. Verbeelde boodschap: De Illustraties van Lieven de Witte bij 'Dat leven ons Heeren' (1537). Haarlem: Nederlands Bijbelgenootschap, 1989.

Żurkowa, Renata. "Działalność księgarska Marcina Horteryna (1615-1630)." Rocznik Biblioteki Polskiej Akademii Nauk w Krakowie, 33 (1988): 183-223. 


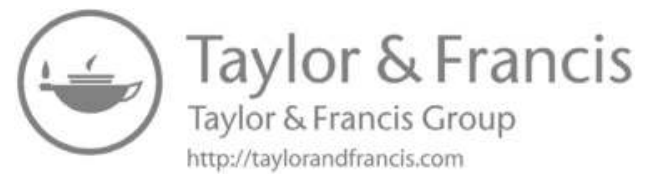


Part I

Things 


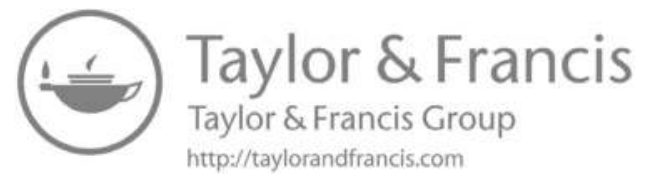




\title{
1 Multiplicity and Absence \\ The Negative Evidence of \\ Interactive Prints
}

\author{
Suzanne Karr Schmidt
}

Blank spaces, blank versos, and entirely missing pages often serve as compelling evidence for the former presence of interactive components in early modern prints. Interactive prints in particular point to a larger body of vanished specimens due to the increased fragility of pages with sewn or glued-on dials and flaps. Though attempting the first consistent documentation of pre-1800 prints, early twentieth-century reproductive technologies captured only some aspects of their functionality, when they recorded them at all. This chapter will make a case study of several interactive prints that did not survive World War II and, expanding on it, demonstrate what the lack of movable parts or instructions can tell us about the originals. Although two are known in early twentieth-century photographs, and no impressions of a third survive, all three offer particularly rich contexts: a Veronica or Vera Icon woodcut lost with most of Warsaw's printed cultural patrimony; a moralizing Memento Mori flap engraving that survives only in a copy; and a woodcut paper astrolabe fit for a Saxon Elector, formerly in Jena, Germany (Figures 1.4, 1.6, and 1.10). By looking at the clues left in related texts, physical evidence, and creative renderings of now-gone objects, one can better establish the ways the many functions of Renaissance-era prints manifested themselves. Studying these minute absences within the context of the explosion of early modern ephemera and its later reception reinforces the uniqueness of print survivals of every kind. What the buyer did with their prints and how each impression differed by the time they were finished collecting or displaying them has become an important field of study, one of the few in art history in which discoveries remain to be made. Masterful paintings or sculptures may only occasionally be rediscovered. But albums of unknown prints are frequently unearthed. Unlike the myriad iterations of workshop paintings and later copies, they are comparatively easy to assign in authorship and stand ready to be deciphered. Becoming ever more historically meaningful, early prints flourished as they were multiplied and modified, and when one looks closely enough, never truly embodied an exactly repeatable pictorial statement.

During the early modern period, handwritten and printed texts exhibited a horror vacui of sorts. Margins rarely survive without copious annotations, or alternatively, their abrupt removal. While less expensive than vellum, paper was still a commodity in relatively short supply, and its owners used it carefully. Wasted sheets, whether misprints or dangerously outdated texts, became bindings, pastedowns, and even cardboard. While single-sheet prints were used to decorate the insides of books, and even, occasionally, as printed book covers, they were more likely to be reprinted on the verso than to be pulped. Intentional blanks within prints appeared relatively frequently in heraldic contexts beginning in the fifteenth century. They were a common 
device among the secular Florentine Otto Prints, including most notably, a pair of lovers flanking a shield decorated with six Medici palle (balls) in browned ink in a unique Harvard University Art Museums impression (G2936). Late sixteenth-century Alba Amicorum by Jost Amman adapted the mode to woodcut book illustration, and Theodor de Bry and his sons engraved them into emblem books. But blank spaces were found, and filled in, in any printed object.

Some space fillers were produced precisely for this purpose, such as a possibly unique uncut sheet of decorative woodcut squares. (Figure 1.1) These little woodcuts (including the face of the moon, theatrical masks, geometric tile-like patterns, and floral motifs) are about $5 / 8$ of an inch $(1.5 \mathrm{~cm})$ per side. They were intended to be affixed to disguise blank areas in other printed objects, such as those reserved for a knotted thread to hold a volvelle dial in place. These particular examples belong to a thick astronomical text, Giovanni Paolo Gallucci's 1605 Coelestium corporum ... explicatio, in which they were found as loose sheets in the HAB in Wolfenbüttel in 2011 (A: 11.2 Astron.[3]). Initially deemed unrelated during the cataloging process, they were meant to go inside the blank squares reserved within the text on the verso pages of the book, corresponding to its fifty volvelles and similar dials requiring threads. An incomplete subset of forty-two of the covers were found in the book and never used. But this specialized printmaking technology did not start out at such an extreme scale, but instead, rather gradually.

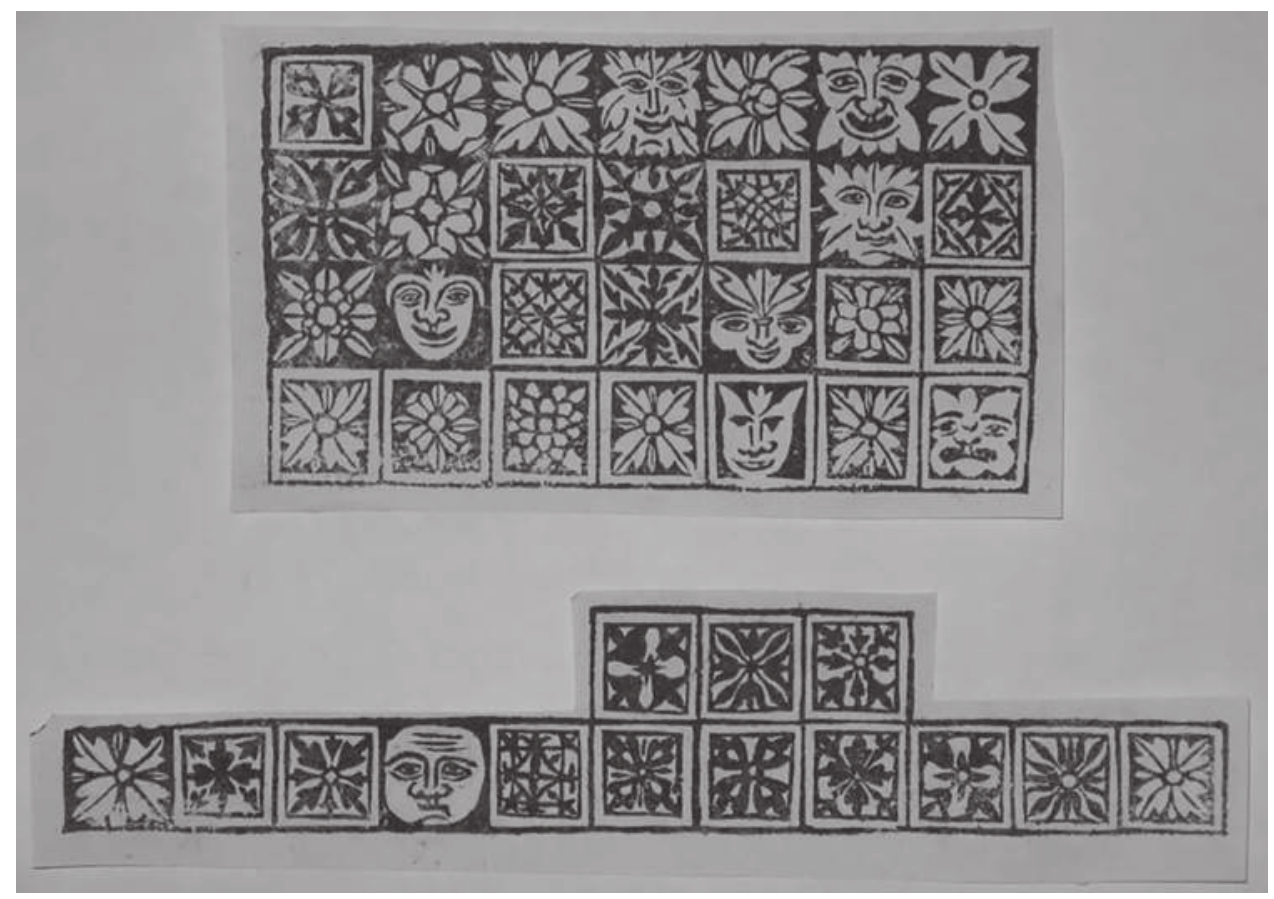

Figure 1.1 Decorative volvelle knot covers from Giovanni Paolo Gallucci, Coelestium corporum, et rerum ab ipsis pendentium accurata explicatio (Venice: Giacomo Antonio Somasco, 1605), 42 woodcut squares on two uncut sheets. Wolfenbüttel, Herzog August Bibliothek, 11.2 Astron. (3).

Photo: Christoph Boveland. 
Cutting out one of these squares and pasting it as a neat, protective cap over the knot would have made an especially attractive solution for a textbook such as Peter Apian's 1524 Cosmographicus Liber (Figure 1.2). Due to the student audience and likelihood of multiple handlers of the delicate moving diagrams, it may be the book for which the caps were in fact invented about a decade later (Figure 1.2b). Apian's popular cosmography text was published continuously with five volvelles (four with paper movable components, one thread-only) into the seventeenth century. ${ }^{1}$ Almost no space remains for the knot in the earliest editions. In Antwerp by 1533, there were imprints by Johannes Graphaeus and in 1534 by Gregorius Bontius, both with a modicum of space reserved so the knots would obscure no text. But the area was too small to install woodcut covers to keep the knots firmly in place. The verso covers proper seem to have first appeared in the 1537 Antwerp Dutch edition of Apian's Cosmographicus Liber by Arnold Berckmann, using a design in the shape of a rosette. Its roundness facilitates installation in any direction, a factor also discernable in its visual predecessor from 1524. Indeed, the rosette closely resembles the center point of the third instrument in Apian's earliest edition from Landshut (Figure 1.2a). As part of a rotating triangular component, here the rose (perhaps also a reference to a compass) is likewise conveniently multidirectional. A leering gargoyle face would soon replace the 1524 rose in a rounded cap for the recto vovelle, seen here in its most frequent form, in a later Bontius printing of 1550 (Figure 1.2b). While not every copy retained its original index string and lead plumb line weight, as does this rare Newberry Library example, the layout of the letterpress was consistent in allowing enough space to avoid any loss of text beneath the printed cap.

Once adopted in Antwerp, the design of these knot caps was employed internationally. Even in the 1551 and nearly identical 1553 Paris editions published by Vivant Gaultherot, in which the woodcut illustrations and instruments are new, there are still several decorative covers. They now include the face of a lion and a face peering through leaves, an iconography that may have influenced Gallucci half a century later. The most surprising appearance, however, may be Bontius's substitution of a tiny Veronica-like holy face of Christ woodcut for one of the volvelle rosettes in the 1553 Antwerp Latin edition at the Bayerische Staatsbibliothek in Munich (BSB) (Figure 1.2d) and for another at the John Carter Brown Library (JCB) in Providence, Rhode Island. ${ }^{2}$ The BSB woodcut is perfectly sized for the void in the text, which breaks in precisely the same location as the same page of the 1550 printing (Figure 1.2c). As they were used once per book and appear on the backs of different dials, their specific placement seems random. And yet, as the case of the lost University of Warsaw woodcut will demonstrate, these little Veronicas, or Vernicules, had long been omnipresent as badges or tokens, all used (albeit here, literally) as protective motifs.

Indeed, moving parts could be a serious risk for the publisher. Early in his career, the publisher Sebastian Münster issued a large-scale broadsheet which touted a novel combination of sundial and mapping functions in 1525, Ein new lustig und kurzweilig Instrument der Sonnen, mit eingesetzter Landtafel Teutscher nation. He reprinted it several times, though only one impression from 1528 survives, in Basel (UBB, Km XI 13:3 Tafel $)^{3}$ (Figure 1.3). This was complemented by an explanatory pamphlet emphasizing its many functional dials and circles, entitled Erklerung des newen Instruments der Sunnen, nach aller seinen Scheyben und Circkeln. ${ }^{4}$ He would later publish several sheets with moving parts and a book, Organum Uranicum, in 1536, with a separately titled suite, Organa Planetarum, composed of twenty-six astrological volvelles and instruments with index strings. ${ }^{5}$ Yet Münster was initially loath to use them at all. In his 1528 pamphlet, he described them as "unbeständig," meaning fickle or unreliable. 
a

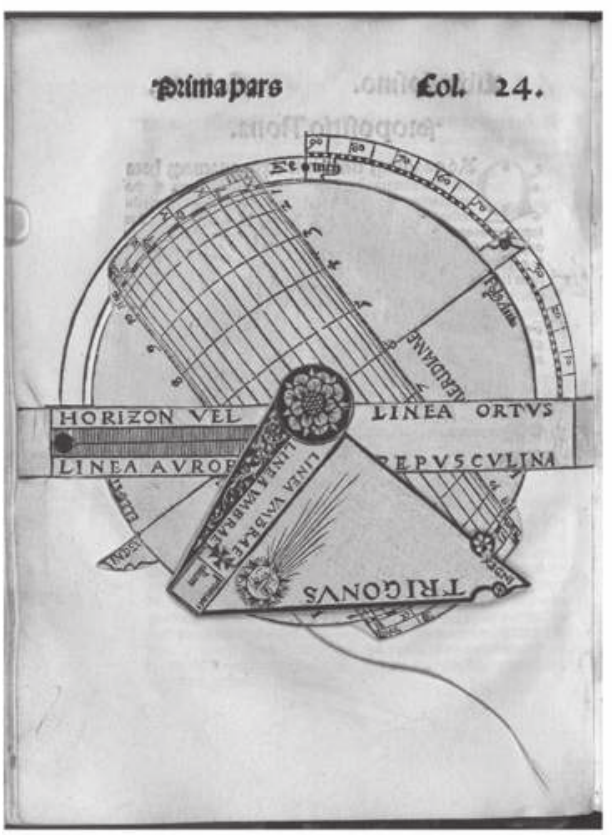

PROPOSITIO OCTAVA.

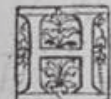

Oram initij \& finis crepufculi matutini\&vefpertini ex eodem organo, fuppolita eleuatione, indagare. Crepuiculum matutinum (quod nos aurorä nuncupamus)eft tempus, quod intercipitur inter diem clarú $k_{\text {nectem }}$ obfcuram, \&stempus in quo aèr incipit fplendefere, dicitur initium crepufculi matutini. At veró, vbi receflu Solis definit, dicitur finis

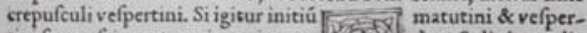
tini finem fcire optaueris, accipe gra ${ }^{2}$. dum Solis in zodia

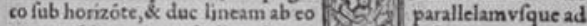
contextí linex crepufculinx, \& con 12 tactus linearú often dit(habito horarum refpectu) initium \& finem crepufculi matutini \& velpertini. Horç enim antemeridianx, initium matutini: pomeri dianx verò finem crepufculi vefpertini fupputant.

c b

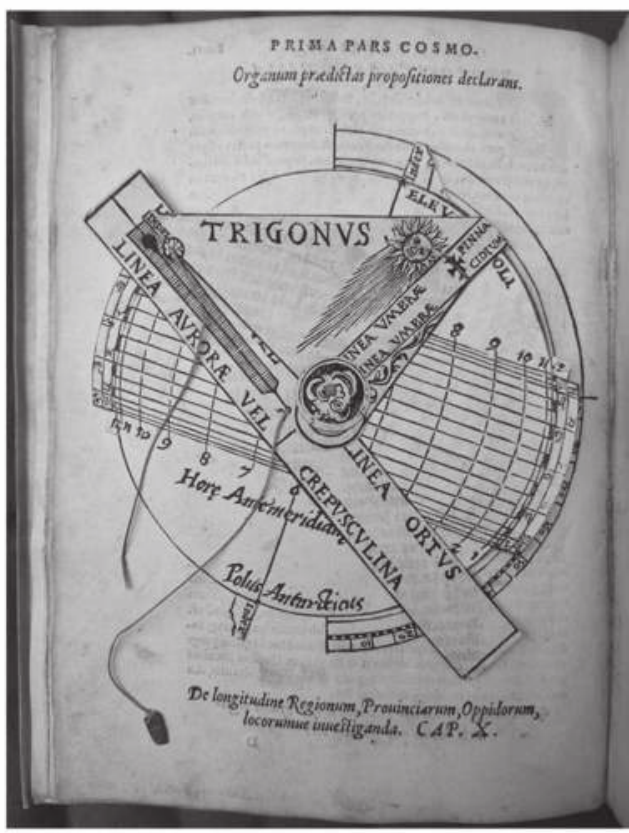

\section{PROPOSITIO OCTAVA.}

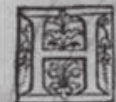

Oram initij \& finis crepufculi matutini \&vefpertini ex codem organo,fuppofita eleuatione, indagare. Crepufculum matutinum (quod nos aurorá nuncupamus) eft tempus, quod intercipitur inter diem clarú \& noctem obfcuram: \&tempus in quo aér incipit fplendeféce, dicitur initium crepufculi matutini. At verò, vbi receffu Solis definit, dicitur finis etepufculi vefpertini. Si igitur initiú ${ }^{m}$ matutini \& vefpertini finem fcire optaueris, accipe gra 4 dum Solis in zodia. co fub horizonte, \& duc lineam ab co As. 5 parallelamvfque ad contextú linex crepufculinx, \& con 1403 tactus linearú often dit(habito horarum refpeQtu) initium \& finem crepufculi matutini \&vefpertini.Horx enim antemeridianx, initium matutini:pomeridianx verò finem crepufculi velpertini fupputant.

d

Figure 1.2 a) Third volvelle in Peter Apian, Cosmographicus liber (Landshut: Johann Weyssenburger/Peter Apian, 1524), fol. 24. Munich, Bayerische Staatsbibliothek, Rar. 271, urn:nbn:de:bvb:12-bsb00064968-2; b) third volvelle from Peter Apian, Gemma Frisius, Cosmographia (Antwerp: Gregorius Bontius, 1550), fol. 11r. Chicago, Newberry Library, Ayer 7. A7 1550b); c) rosette volvelle knot cover from Peter Apian, Gemma Frisius, Cosmographia (Antwerp: Gregorius Bontius, 1550), fol. 11v, applied woodcut and letterpress. Chicago, Newberry Library, Ayer 7. A7 1550b; d) vernicule volvelle knot cover from Peter Apian, Gemma Frisius, Cosmographia (Antwerp: Gregorius Bontius, 1553), fol. 11, applied woodcut and letterpress. Munich, Bayerische Staatsbibliothek, Hbks/R 2 f., urn:nbn:de:bvb:12-bsb10806466-1.

Photos: Munich, Bayerische Staatsbibliothek, CC BY-NC-SA 4.0 (a); author (b, c); Munich, Bayerische Staatsbibliothek, CC OOC-NC (d). 


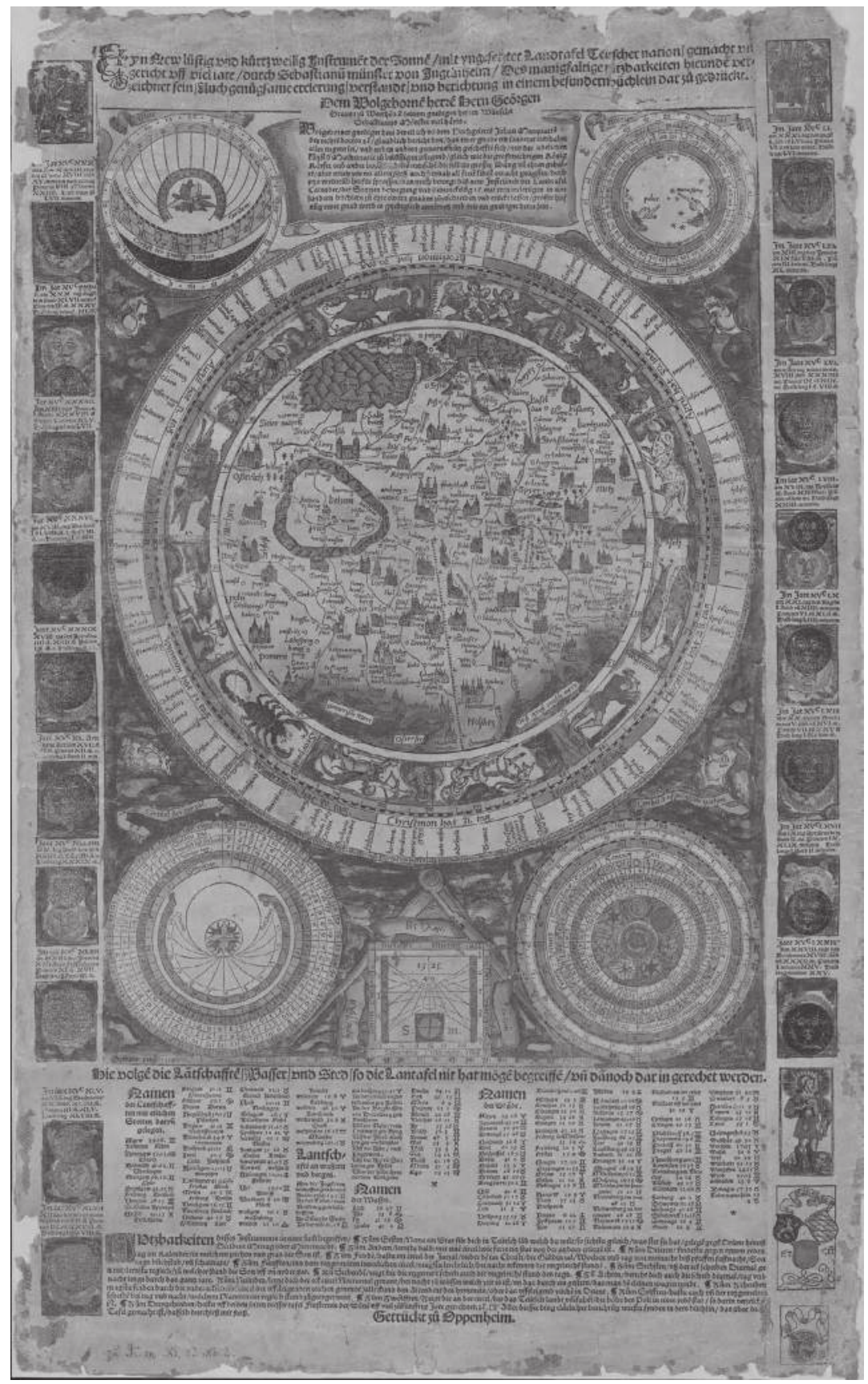

Figure 1.3 Sebastian Münster, Ein new lustig und kurzweilig Instrument der Sonnen, mit eingesetzter Landtafel Teutscher nation (Oppenheim: Sebastian Münster, 1528), handcolored woodcut and letterpress broadsheet. Basel, Universitätsbibliothek Basel, Km XI 13:3 Tafel.

Photo: Library. 
In this context, he requires the viewer to supply other movable parts for the accompanying broadsheet themselves. One can also read the word as meaning impermanent and perhaps even too fragile for the parts and the large-scale broadsheet to remain together very long. As Münster says, there were numerous requirements and extra parts to make the device, literally, the Instrument, functional:

\section{What This Instrument Needs}

First lay the instrument (saturated with glue) on a paper or a cloth ... so the circular outlines are continuous [across each sheet]. I have particularly decided that I did not want to use movable dials or wheels which one can turn around, because they are unreliable, but in their place, you must use an iron circle about a (hand) span. But if you don't have one, make do with a thread, as you please.

The map should also have a thin thread stitched into the middle by the city of Roburg, (in a tiny hole which you find near the small cross), which is the center of the larger circle. This thread should also have a small pearl or bead, which one can move up and down. Likewise, should the upper Circle called Diurnal and the lower Circle of the Year have their own threads. But the other two circles should only have the thread without the pearl. You would do well to find the center of each circle, so you should pay attention to this. ${ }^{6}$

His second paragraph further details the need for the other "dials and circles" of the title. The distinction between threads with pearl indices to mark a location and those without leaves nothing to the chance of bad installation. And yet he did not invent his own verso knot covers, even for his expansive 1536 Organa Planetarum, similar in scale as it is to Gallucci.

One of the few early modern texts to ruminate on the permanence of its applied printing technology, Münster's concerns about the Instrument der Sonnen were justified. Of his later broadsheets, two of which he produced in conjunction with Hans Holbein the Younger, only one impression has retained its volvelles. ${ }^{7}$ The lunar instrument Münster published in German in 1529 called only for a central thread, and the 1534 sheet about the sun and moon (in both Latin and German editions) had two paper volvelles at the bottom, now known only in the Latin Kunstmuseum Basel impression. This attrition is relatively consistent for most single sheets with flaps and dials, with about half of those that remain being incomplete. The survival of such elements in books is much higher than on broadsheets, though every copy is different, with some parts partially present, some entirely missing, and others never constructed.

While occasionally including didactic interactives like the Apian Cosmographicus Liber and Münster Instrument, all books for students, often handed down or resold, would benefit from marginal notation as well as the occasional affixed print as decoration to supplement internal textbook diagrams. For instance, an image of the face of Christ, now in the Yale University Art Gallery (Everett V. Meeks, B.A. 1901, Fund, 201.134.1), once resided in a Latin grammar text by Donatus, the Ars Minor, and the German owner's notes migrated ever nearer the woodcut. While the student's mind wandered, they also annotated the cloth below and behind Christ's head and doodled additional hairs into his beard. As the print represented a miraculous imprint of Christ's face on the handkerchief offered to him by Saint Veronica on his way to the Crucifixion, each woodcut or engraved version thereafter offered its viewer (or even doodler) a chance for contact and prayer over their own personal iteration of the relic. ${ }^{8}$ 


\section{Warsaw's Veronica}

This chapter's first main example of a lost interactive print deals with another annotated, so-called Veronica or Vera Icon woodcut (Figure 1.4a). Pasted inside the cover of an early fifteenth-century manuscript of sermons once at the University of Warsaw Library, and significantly before that, at Poland's Święty Krzyż, or Benedictine monastery of the Holy Cross, its owner made similar use of blank space. They inscribed several words in an apse just above the hanging cloth: de conversatione feminarum 3 et 47, which may have referenced sermons in the lost manuscript that had concealed it. Indeed, according to a recent reconstruction of the codicology of the volume, it was all written in a single hand after a text by Stanisław of Skarbimierz, the rector of the University of Cracow, around $1400 .{ }^{9}$ The volume has been tentatively described as encompassing forty-five sermons, possibly from his Sermones super symbolum Nicenum, but the 113 Sermones de Sapientia Dei included a broader range of subjects infused with divine wisdom. Inspired by Saint Augustine of Hippo, his teachings on just law became fundamental to the Polish government, though his many themes ranged from the achievement of humility to simply "bad students." ${ }^{10}$ One particular sermon, Sermo est de mulieribus magnae fidei, or its equivalent, discussed women of great faith who are wise and strong (as well as those who were decidedly not). While Mary Magdalene appeared repeatedly, the apocryphal Saint Veronica does not. She was said to have created the Vera Icon impression on her handkerchief from Christ's

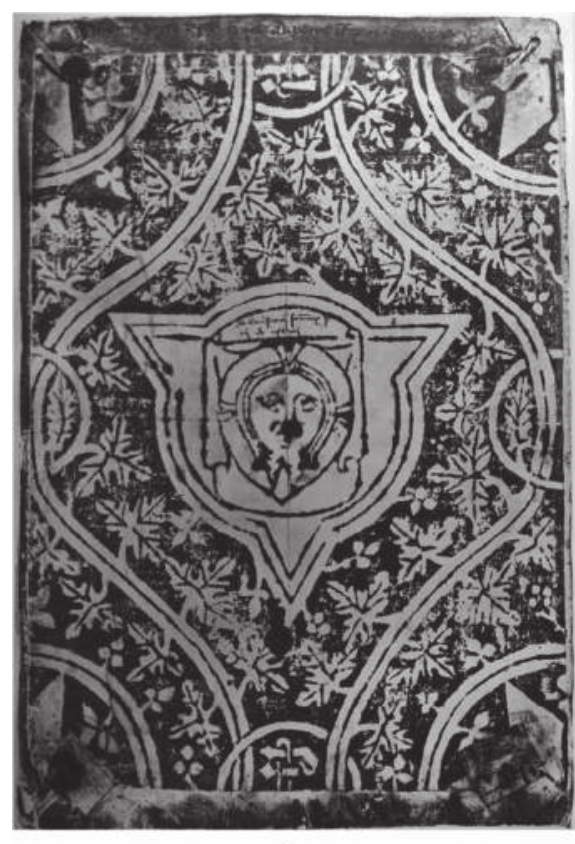

a

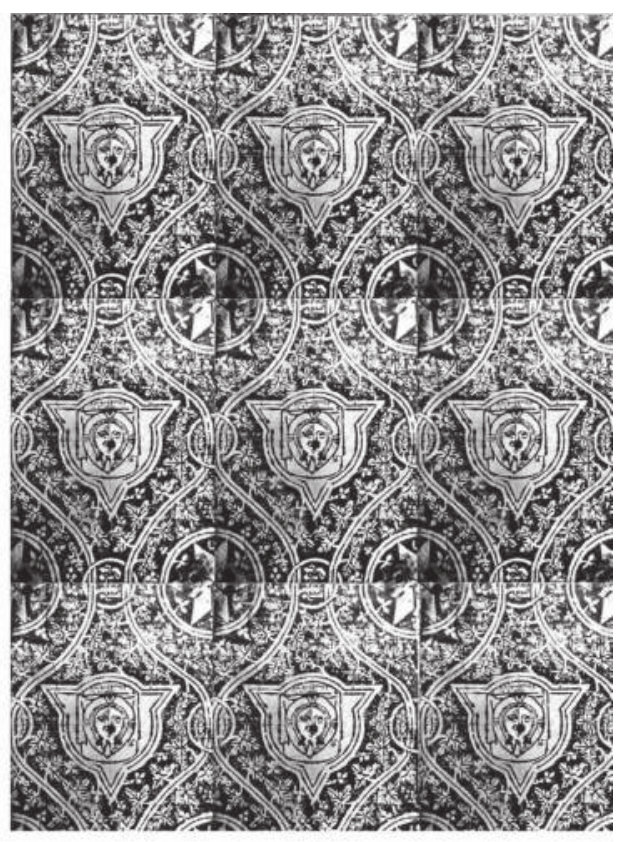

b

Figure 1.4 a) Veronica (Vera Icon) wallpaper from: Sawicka, Einblattdrucke, pl. 1, collotype of woodcut (first quarter fifteenth century). Chicago, Newberry Library, Case folio W 8014.25 v. 74, pl. 1; b) collage of multiple Veronica (Vera Icon) impressions as continuous wallpaper.

Photo: Author. 
visage by wiping his brow as he paused while carrying the cross to Calvary. Perhaps the owner of the manuscript made the connection between her act of kindness and the better-behaved examples of biblical femininity in Stanisław of Skarbimierz's sermon and inscribed the holy face on the pasted-in print accordingly.

While the annotations remain somewhat mysterious, the graphic design of the sheet has also attracted interest. Scholars, including Horst Appuhn and Conrad von Heusinger, have interpreted the geometrical borders around the holy face as a repeatable pattern that could have been used as domestic wallpaper. If so, its dating to the first quarter of the fifteenth century would make it one of the earliest examples to survive ${ }^{11}$ (Figure 1.4b). This wallpaper likely helped guarantee the sanctity of the resident, as had been the case with other devotional patterns installed on ceilings at Kloster Wienhausen and elsewhere. Perhaps this was the original "interactive print," struck as it was from Christ's own face, and miraculously able to create more impressions, even enough to cover a wall. The Salve Sancta Facies, or Hail, Holy Face prayer, seen in xylographic text below many other fifteenth-century variations, would have been universally known at the time and uttered repeatedly in hopes of indulgences for oneself or others, particularly at exam time. The reappearance of the Vernicule as a volvelle knot cover in the 1553 Latin BSB and JCB Cosmographia editions might not be as surprising in this context, especially if the two paper instruments completed with these holy prints (a sundial-volvelle hybrid that required inverting the entire book and a volvelle dealing with the phases of the moon) were among the most challenging for students to learn how to use. ${ }^{12}$

How, then, did early prints reveal their more complicated functions to early viewers? Such holy faces were recognizable and would have elicited a specific response, even without an appended prayer. Would prints with flaps or dials have been so easily understandable? Or was their attraction substantially from novelty, deception, and surprise? Conversely, have modern readers themselves correctly interpreted all the signs of prints that needed something from the viewer? This visual awareness has become an increasingly important skill when so many fifteenth-century prints are known in unique impressions.

Distinguishing the single-sheet print from book illustrations is the first taxonomic step. Later collections would infrequently make this distinction and adhere images printed with text on the verso into albums of different themes. Complicating the matter, especially with the print explosion of the sixteenth century, was the tendency to reuse wooden blocks, so easily inserted into the forme with letterpress type, to stand both alone as functional, constructible instruments and in context as diagrams.

\section{Reproducing Interactivity in the Einblattdrucke}

What then were the best known early interactive prints? At least one was reproduced in the early twentieth century in both luxury and regular editions (Plate 3). It appeared in a pioneering series called Einblattdrucke des fünfzehnten Jahrbunderts, published in 100 volumes between 1909 and 1942 with J. H. E. Heitz in Strassburg. The series was the brainchild of the publisher Paul Heitz (†1943), and his frequent contributor was the art historian Wilhelm Ludwig Schreiber, who also produced the important, multivolume Handbuch der Holz- und Metallschnitte des XV. Jahrhunderts over several decades. While the Handbuch remained unillustrated, the Einblattholzschnitte reproduced hundreds of pre-sixteenth-century prints and cross-referenced them with 
Schreiber. In many cases the collections, like the Warsaw Veronica (Schreiber 758m), did not survive World War II, so these are vitally important records of hundreds of prints and their context. ${ }^{13}$

But despite the assurance that the prints were shown as accurate, the means of reproduction was by no means straightforward or identical to the original. The general scale was maintained (with very large prints impressed on a sheet so tall it had to be folded), and some material aspects retained, as in at least one example of a woodcut on cloth reprinted on fabric and colored in an early Heitz volume (1907; pl. 10). The means of reproducing these prints was curiously work-intensive, as the publication frequently reimagined the colored woodcuts as relief prints in black and white, omitting hand coloring. In the many cases where only one impression of the original survived and it was thickly illuminated, producing the reproduction involved additional guesswork. Black and white photography was also employed, especially for metalcuts and engravings, but woodcuts tended to still be rendered in relief on textured papers in fairly accurate scale. The two techniques used-which were then apparently relatively novel, as the series treats them as selling points-are enthusiastically described as Hochätzung, or relief etching, and Lichtdruck, or collotype, the photographic technique used for the Warsaw Veronica (Figure 1.4a). The former offered a more dramatically contrasting, woodcut-like appearance, while the latter, produced on a slick surface, offered more gray mid-tones. In deluxe editions of the series, however, only the relief prints could be purchased in color. As color photography was not yet commercially available, this took the form of carefully hand-colored impressions of an approximation of the camouflaged woodcut outline.

A 1907 list of other Heitz publications issued with concurrent volumes does not distinguish the cost of relief versus collotype reproductions-only the number of reproductions overall, and another advertisement confirms that the reproductions were authorized to be sold singly as well as in the volumes. So, these new media of reproduction were considered salable additions to the cataloguing content. But what did the series do when the hand-colored original also included moving parts?

Heitz's reproductive treatment of one of the earliest woodcuts with moving parts to survive offers an interesting study. One 1913 issue included an inexpensive, black and white version of a previously unpublished Germanisches Nationalmuseum, Nuremberg (GNM, H5690) print, another a hand-colored version. His clever, but confusing, treatment of this woodcut increased the number of people to see the image, while the removal of its color in one edition simultaneously threatened to obscure its function $^{14}$ (Plates 3 and 4). Two Affen, or apes, ride an opulently appareled (and possibly purloined) steed under an archway and hold what may be a mirrored ring. Oddly, they both appear to lack part of their midsections. Was this simply an optical trick, like later roundels with conjoined figures, or Vexierbilder, that required the viewer to crane their necks to set the anamorphosis into focus?

No, this was different. In those cases, the bodies were joined, but complete. Here physical gaps appear when the moving parts are not in place. Looking closer, it appears that the Einblattdrucke team did provide the correct components: A small elongated oval band was printed with four vertical lines denoting the midsections of the apes. When the band is rotated 90 degrees, they appear to switch places, an impression that becomes much clearer in the hand-colored reproduction and its original in the GNM in Nuremberg, which are approximately the same size. Now the movable midsections snap into focus (Plates 3 and 4). The color reproduction, shown here on the left of the 
real woodcut, strikes one with the care with which it has been painted, suggesting a color image must have been produced on site for later study. The hardware used also varies. While none was present in the low-end, monochrome edition, the Newberry Library copy has a brass tack in situ. The original in Nuremberg now has a thread attachment, but other early fifteenth-century instruments did include this sort of fastener. Regiomontanus's Kalendar was the most common, appearing with a moving jointed arm as part of a woodcut sundial as early as 1474 , which each subsequent edition replicated more or less accurately. ${ }^{15}$ Hardware aside, the Einblattdrucke reproduction of the apes is surprisingly accurate in style of coloring and function.

Did the series always manage such meticulousness? A close variant to the GNM apes, from a manuscript in Saint Gallen, Switzerland, also received deluxe treatment, with color and a riveted turner in volume 50 in $1918 .{ }^{16}$ But the colorist eliminated one important component-the colored bands on the moving piece. How did this happen? Was the twentieth- or the fifteenth-century colorist in the wrong? As it turns out, the moving part is now missing in the original, so the publishers made their best guess as to how the print originally looked. The Einblattdrucke acknowledges the work's interactive format, as well as providing some context, that, like the Warsaw Veronica, these Affen appeared in a manuscript-on page 201 of a Psalter, to be precise. As a functional model for the reproduction, the producers of the 1918 volume may, however, have used the cheaper edition of the GNM-themed Heitz volume from 1913, which did not include color. Although they understood the mechanism of separating the middle of the apes with woodcut lines, still they improvised, making a differently shaped band with flared edges that more closely mirrored the empty space between the bodies in the Swiss sheet but left this band entirely white. The woodcut outline closes the gap between the two figures but makes it look as if their midsection is bandaged in white cloth, rather than becoming a continuous, if intermittent, match to the grayish-brown watercolor used on their torsos and lower halves. Thus, the Heitz team's educated guess at reconstruction failed, leaving the deluxe edition of the print interactive — and visually logical—but not optically successful to the same degree as the original.

A slightly later print with a flap that was similarly obsessed with conjoined bodies is likewise known in two impressions, one in Munich, the other in London. ${ }^{17}$ The former, which seemingly only contains a text about conjoined female twins born in Ertingen in 1512, in fact has an empty slit running down a third of it, from which the illustration was removed (Figure 1.5a). The better-known, and complete, British Museum version demonstrates that the sheet should have included a double-sided woodcut portrait of the child called Elßgret-a combination of the names Elizabet and Margareta. Composed of these two girls joined at the waist with only one pair of legs, Elßgret did not survive infancy, but the woodcut allows the viewer to flip over to see both their front and their back. No brass rivets are needed here, just additional rabbit skin glue to secure the woodcut in place. Other broadsheet versions placed the views side by side rather than including an interactive component, avoiding the temptation to remove the postcard-like portrait for separate study. Almost as an afterthought, Emperor Maximilian's ambitions to combat the Turks and other dangers are evoked at the end as a reminder of the prophetic potency of their otherness.

Misbirths like Elßgret became a standard Reformation trope, from the monk calf and the pope donkey described by Luther and Melanchthon, but multiheaded creatures often elicited a popular response, perhaps due to their resonance with the sevenheaded Beast of the Apocalypse. This conceit merged with a popular game and book combination of the lottery dial in a variety of interactive ways (Figure 1.5b). The 1620 


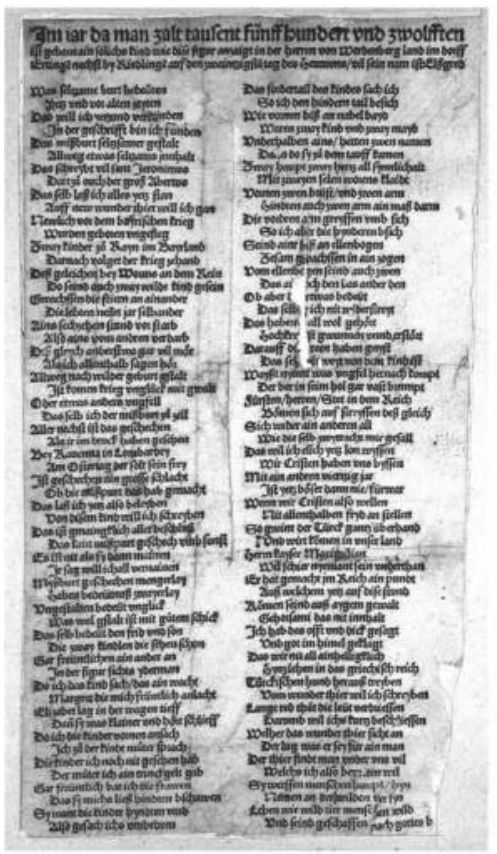

a

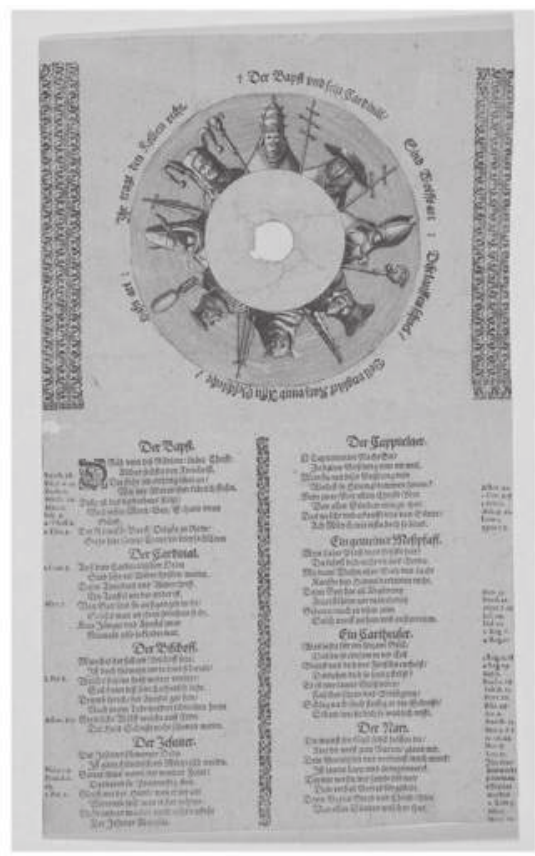

b

Figure 1.5 a) German (Augsburg), broadsheet on the conjoined twins of Ertingen, 1512, double-sided woodcut (lacking) inserted in letterpress broadsheet. Munich, Bayerische Staatsbibliothek, Einbl. I, 41, urn:nbn:de:bvb:12-bsb00098155-6; b) German, Wondrously Strange Roman Catholic Wheel of Fortune, 1620, broadsheet with engraving (missing volvelle dial) and letterpress. Nuremberg, Germanisches Nationalmuseum, HB 19894/1336.

Photo: CC BY-NC-SA 4.0 (a); CC BY-NC-ND (b).

broadsheet, entitled Römisch Cathol. Wunderseltzames GlückRad, a movable wheel of fortune with satirical Roman Catholic overtones, is now missing its dial. The bottom layer of the engraving reveals instead a hidden layout inspired by the many-headed Beast. It copies a now-unique 1556 woodcut that the author attributes elsewhere to the Swiss artist Hans Rudolph Manuel Deutsch, itself a fragmentary impression lacking the underlying broadsheet, but retaining the upper layer of the volvelle. ${ }^{18}$ Here in the GNM copy, the moving parts are gone. The ring of dubious clergy heads would have been covered by a portrait of a richly caparisoned priest with a notched void to reveal each of the heads in turn. The Pope appears at the helm atop the wheel. Rotating the dial would have moved the notch to each head in a clockwise motion, starting with the fool, with the faces helpfully numbered 1, continuing through the Pope at 6, and ending with numbers 7 and 8, Death and the Devil lifted from Dürer's Knight, Death and the Devil print made forty-three years earlier.

\section{Missing Memento Mori}

More universally applicable even than the errant clergy was the inescapability of mortality, and flap prints on this topic abounded, often commingled with sexual tension. 
The second main example of this chapter takes the form of one such deadly reminder. A macabre early sixteenth-century interactive New Year's Wish that has lost its flap at the British Museum still makes a certain amount of visual sense even though the skull of the buxom woman was all that was known to Wilhelm Ludwig Schreiber for his Handbuch. The second impression in Munich remained unknown to Schreiber, but as published by Sabine Griese in 2011 and digitized by the BSB, it does indeed retain its flap, if not the larger border. It appears that the comely model did originally have hair, a fetching hat, and even a face, all reflected in the mirror in her hand, similar to the one held by the acrobatic apes discussed earlier. ${ }^{19}$ Not all memento mori prints were so well preserved, as in a little-studied set of two flap prints with only the adhered remnants of their flaps remaining from the late sixteenth century (Figure 1.6). This unique pair of male and female allegorical prints survives only in censored form at the Kulturstiftung Sachsen-Anhalt, Kunstmuseum Moritzburg Halle (Saale). These anonymous engravings also provide evidence of another entirely lost subject. They copy one of the first liftable skirt prints, by Matthias Greuter around 1596, seen here in an impression from the Kunstsammlungen der Fürsten von Waldburg-Wolfegg (Figure 1.7). While the skirt, trousers, and offending coffin have stiffened in the copies at Halle, they offer close repetitions of Greuter's Pride, as well as the deadly scene beneath her. Their titles, in dialogue form, are likely new concoctions penned for these prints, with hers about the blindness of love and his about his appearance of desirability for young maidens.

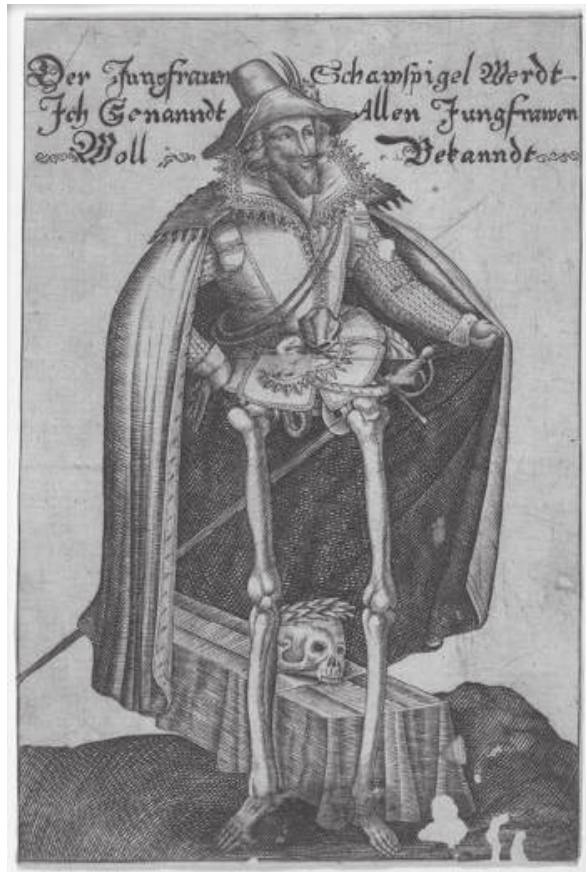

a

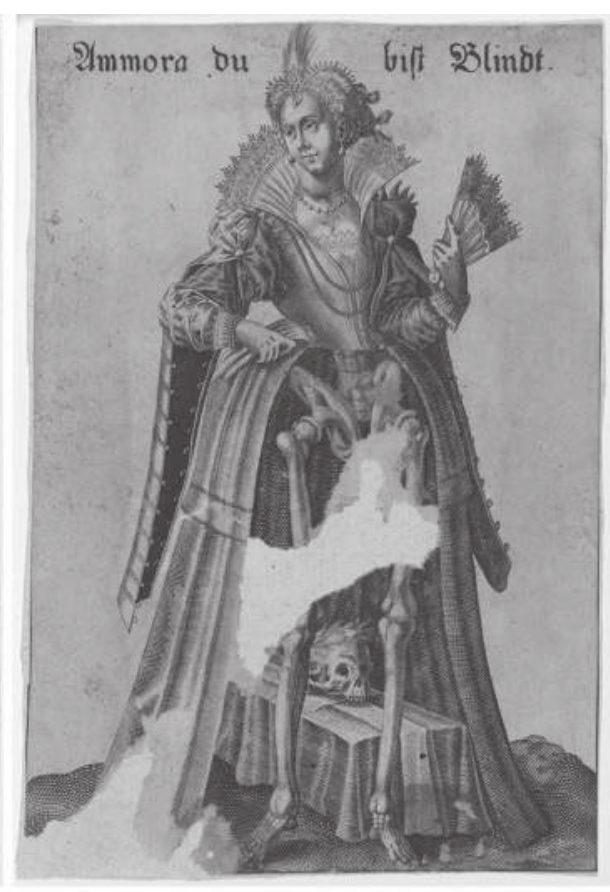

b

Figure 1.6 Anonymous after Matthäus Greuter, a) The Virgin's Mirror and b) Love, You Are Blind, after 1596, paired engravings with flaps (lacking). Halle (Saale), Kulturstiftung Sachsen-Anhalt, Staatliche Galerie Moritzburg, F 755 and F 691.

Photos: Kulturstiftung Sachsen-Anhalt. 

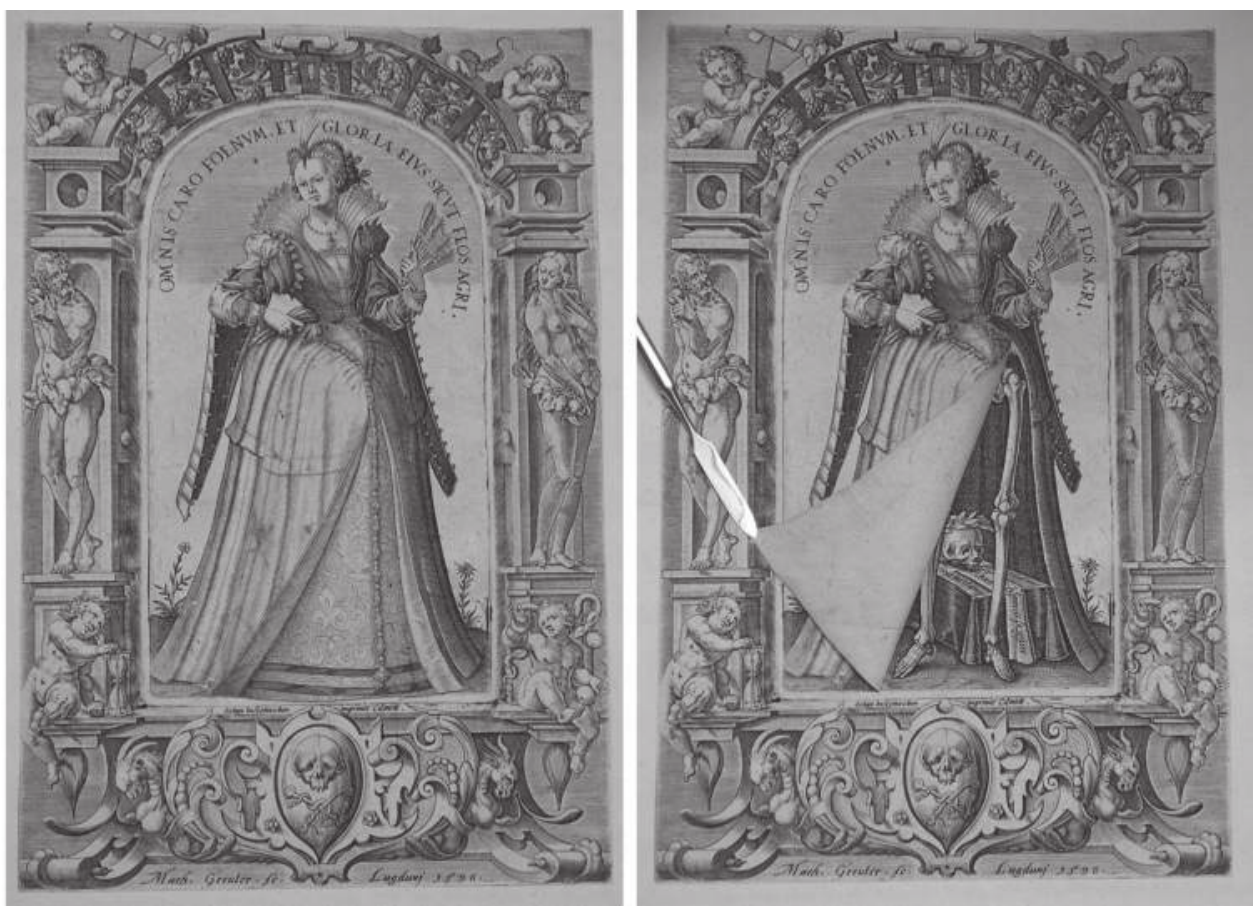

Figure 1.7 Matthäus Greuter (German, 1564-1638), Pride, 1596, engraving with skirt flap. Wolfegg, Kunstsammlungen der Fürsten zu Waldburg-Wolfegg, Album 243, no. 173.

Photo: Author.

The fact that their liftable flaps have been not just lifted but torn away reduces the surprise factor of interacting with them and makes their preening even more ridiculous. Bereft of his pant legs, the man's skinny skeleton is particularly humorous. The prints they copied were more obvious censures of pride in appearances and fine clothing. ${ }^{20}$

The Halle man and woman are simultaneously paired up as errant representatives of both genders and pared down from the rich border of the Greuter to focus only on the main figures. A number of similar flap prints, several by Hendrick Goltzius's relative Conrad, were produced by the Cologne publisher Peter Overadt in this period, while Greuter's Pride was issued by Johannes Bussemacher; perhaps the Halle pair were offered by one of these as well.

A similarly borderless Pride by Conrad Goltzius is also in Halle (Kulturstiftung Sachsen-Anhalt, Kunstmuseum Moritzburg, F 756), and it, too, was censored, this time to object to the naked embrace of Adam and Eve. This Pride, with her attribute of a peacock that turns into the Garden of Eden snake, also reappears printed within a full border, complete with vignettes of all the Deadly Sins. She is, however, not alone (Figure 1.8). Collections at Waldburg-Wolfegg, the Rijksmuseum, and the British Museum also have her accomplice, his copper plate reprinted within that very same border. His flap lifts to reveal Adam and Eve's banishment from the Garden. Looking from this pair back to the Halle prints-especially when comparing the details of the pelvises of the respective men-the Halle copies appear much closer to Greuter 


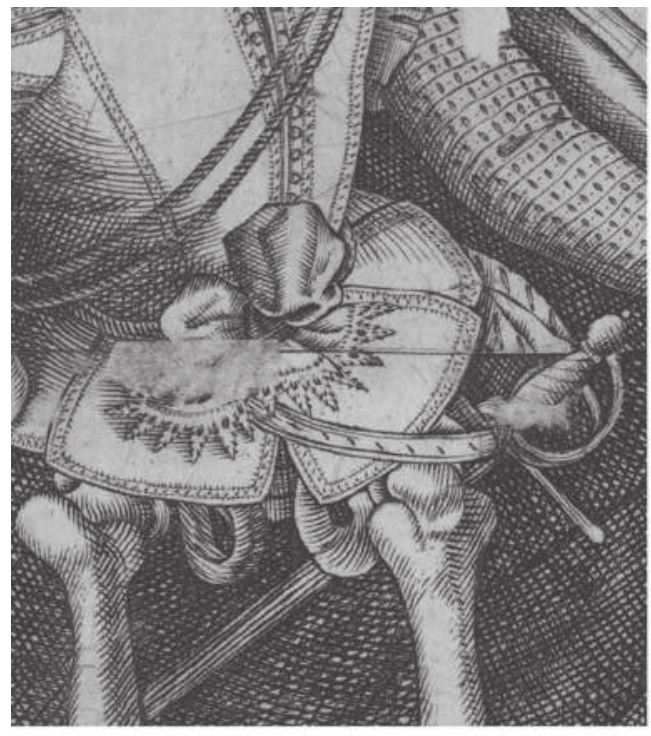

a

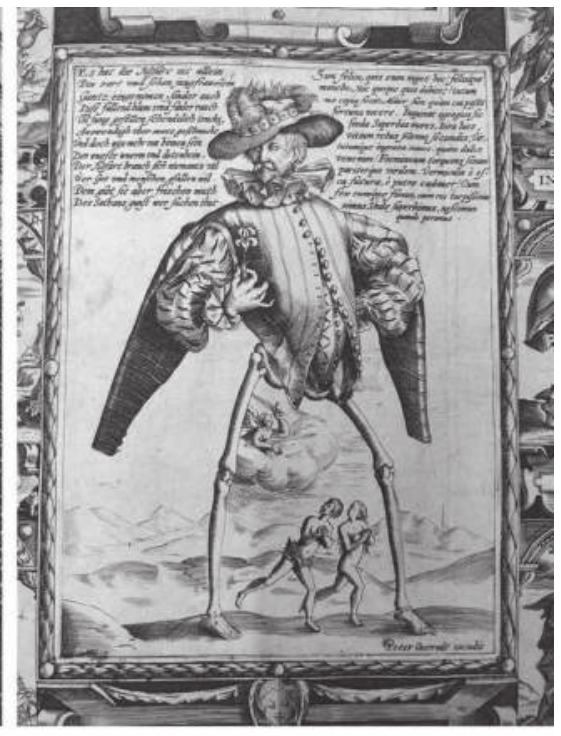

Figure 1.8 a) Detail of Figure 1.6a; b) detail of Conrad Goltzius, Male Pride, c. 1600, engraving with flap (lacking). Wolfegg, Kunstsammlungen der Fürsten zu Waldburg-Wolfegg, Album 219, no. 198.

Photo: Author.

than Conrad Goltzius. The fact that neither the details of the man's attire nor the alternative scene beneath his trousers appears in the Halle impressions strongly suggests that there was an additional flap print of a male figure of Pride by Greuter that does not survive, which also influenced the Conrad Goltzius sheets. Even in Wolfegg, where four of the Goltzius prints and one of the rare Greuter are tucked into different albums, the male flap print has not yet reemerged, but it may still be hidden away in another collection.

\section{Paper-Thin Astrolabes}

The scientific instrument print, an equally ephemeral genre that aimed to count its possessor's remaining time on earth more accurately, is this chapter's third main example of applied printmaking with significant attrition (Figures 1.9 and 1.10). By the sixteenth century, portable sundials, a form of ostentatious accessorizing in their own right, became increasingly common in printed paper form to be pasted on wooden supports, as did other navigational devices, such as astrolabes. While several examples of partially surviving prints discussed so far only retain their text, this was not always the case, particularly in instrument prints like the Sebastian Münster broadsheet with its manual discussed earlier (Figure 1.3). For instance, a woodblock for an anonymous octahedral sundial, now at the Bayerisches Nationalmuseum in Munich, does not survive in any sixteenth-century impressions (Figure 1.9). A twentieth-century Neudruck, or reprint from the original block, therefore includes a blank triangular space where the letterpress instructions text should have been inserted. Even though the 


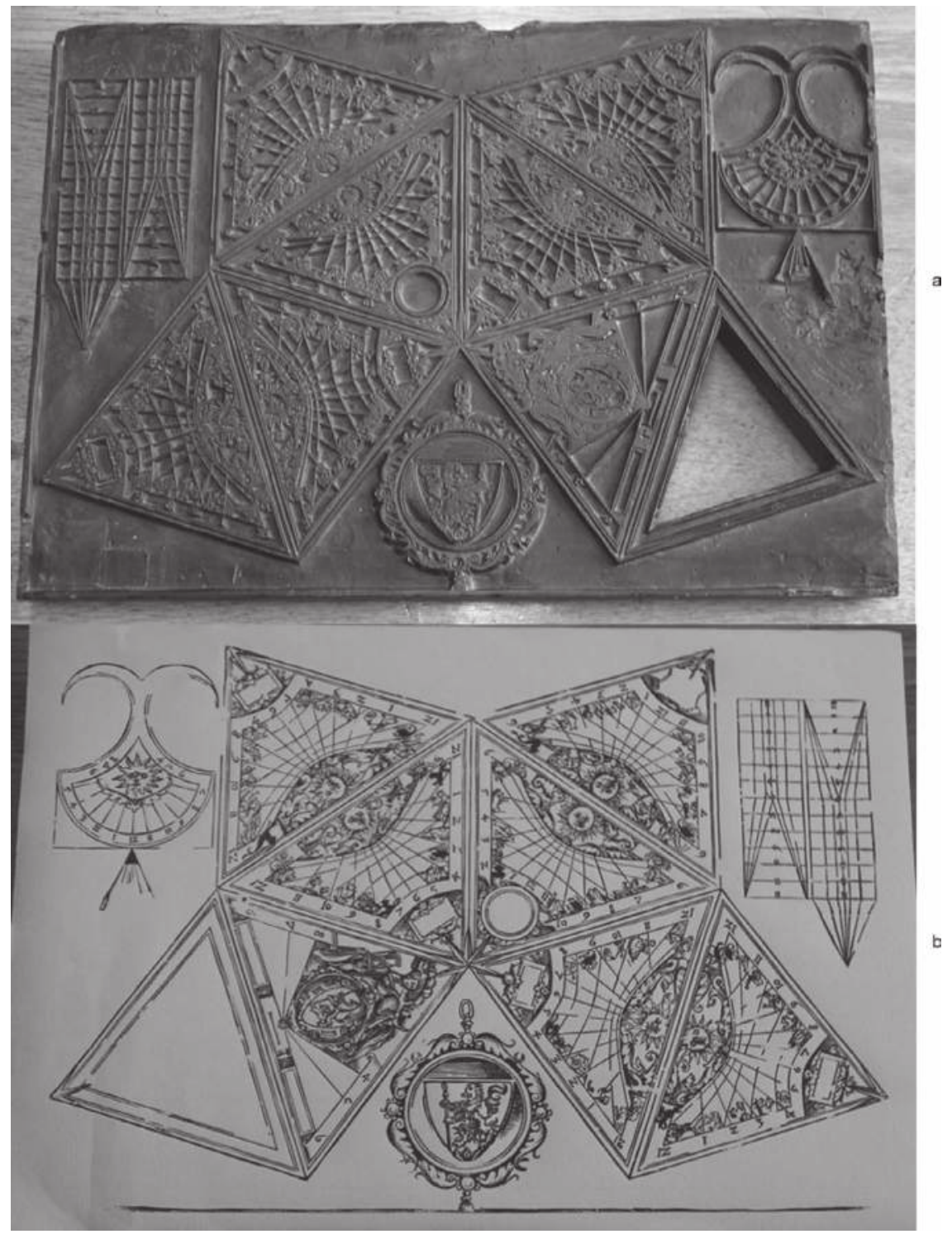

Figure 1.9 German, octahedral sundial, early sixteenth century, a) woodblock; b) modern impression. Munich, Bayerisches Nationalmuseum, Clock Department, Vitr. 27, L $72 / 130$.

Photo: Author.

main image survives, unless a pamphlet or early impression comes to light, no more may ever be known about the work's publication, designer, or intended use beyond the standard practice of cutting it out and pasting it on a wooden block.

Conversely, the Nuremberg instrument maker Georg Hartmann's printed sundials are now better known, but they were also meant to be cut out and constructed. His oeuvre included a similar engraved sundial from 1526 that suggests the woodblock 


\section{2}

\section{Suzanne Karr Schmidt}

must also date from the same period. In another case, Hartmann's woodcut was meant to be folded into a triangular prism, but was known for many years only in the text block tipped into his workshop album in Munich (BSB, Rar. 434). It had presumably been abandoned there because the sundial had already been constructed. That instrument is dated 1529 and is one of only four woodcuts Hartmann produced. A later printed woodcut astrolabe of his, complete with front, back, and removable latitude plates, shows the versatility of the medium, as well as his interest in finding a wider audience than his small intaglio press could support.

Like Hartmann, Lucas Cranach the Elder made at least two scientific instrument prints known to modernity in unique impressions, one of which is incomplete, the other lost in World War II, from 1513 and 1529, respectively. The first, now at the Albertina, was a sundial dedicated to Frederick the Wise, Elector of Saxony until his death in 1525. Although no manual or other explanatory text survives, it is printed in red and black with a central black circle that suggests it may be missing an interactive volvelle dial. This wall sundial might have included a lunar dial printed, like the title, in red to complement the solar one beneath it, a frequent pairing on horary devices at the time.

The second Cranach device is more problematic (Figure 1.10). This Charta ad Usum Studiosorum, literally, a chart for the use of studying, appears to be meant not only for royalty but also for the students of the university Frederick the Wise founded in Wittenberg in 1502. Unfortunately, all that survives is an early twentieth-century photograph of the large-scale woodcut formerly in the Jena University Library. It was taken by the scientific instrument historian Ernst Zinner. There are also some dozen copies worldwide of the accompanying astronomy handbook entitled Canones Astrolabii. The pamphlet gives a loose sense of the coloring scheme and use of the object, while from the photograph, one can discern at least eight nested parts, including movable pointers for the seven planets. The constellations bear a strong similarity to Albrecht Dürer's Northern and Southern Celestial Hemispheres of 1515, an artistic connection also made in one of the prefatory poems, despite the explicit mention of Cranach's name on the device itself. The pamphlet carefully notes that certain horary lines in the device should be either red or black, a practical consideration as well as an astrological one, as nested net systems are very difficult to distinguish without systematic color. The Jena print was evidently hand colored above and beyond the tell-tale black and red lines. But, for instance, with an added blue background for the base (or mater) of the device—which may or may not have been the hue used-one could have better distinguished the seven arms for each of the planets, including the central moon and the sun at the bottom. An additional bar spans the device and offers a conveniently placed latitude scale. In addition to these planetary pointers, the constellation map, a standard component of astrolabes, has been included using the recognizable figures of Dürer's Hemispheres, rather than by stars alone. The Northern and Southern constellations have overlapped in the Cranach device, resulting in a dense field that is difficult to read without color.

Other prints of the Zinner photo may remain, as his photo of the Charta ad Usum Studiosorum was published several times in varying quality. Yet the black and white image from Zinner's Nachlass archive at the Johann Wolfgang Goethe University of Frankfurt is the most detailed available, even considering the two binder holes on the left side (Figure 1.10). There is a sense of depth suggesting the completed object was displayed in a box, perhaps one that did not permit Zinner to inspect the verso. That 

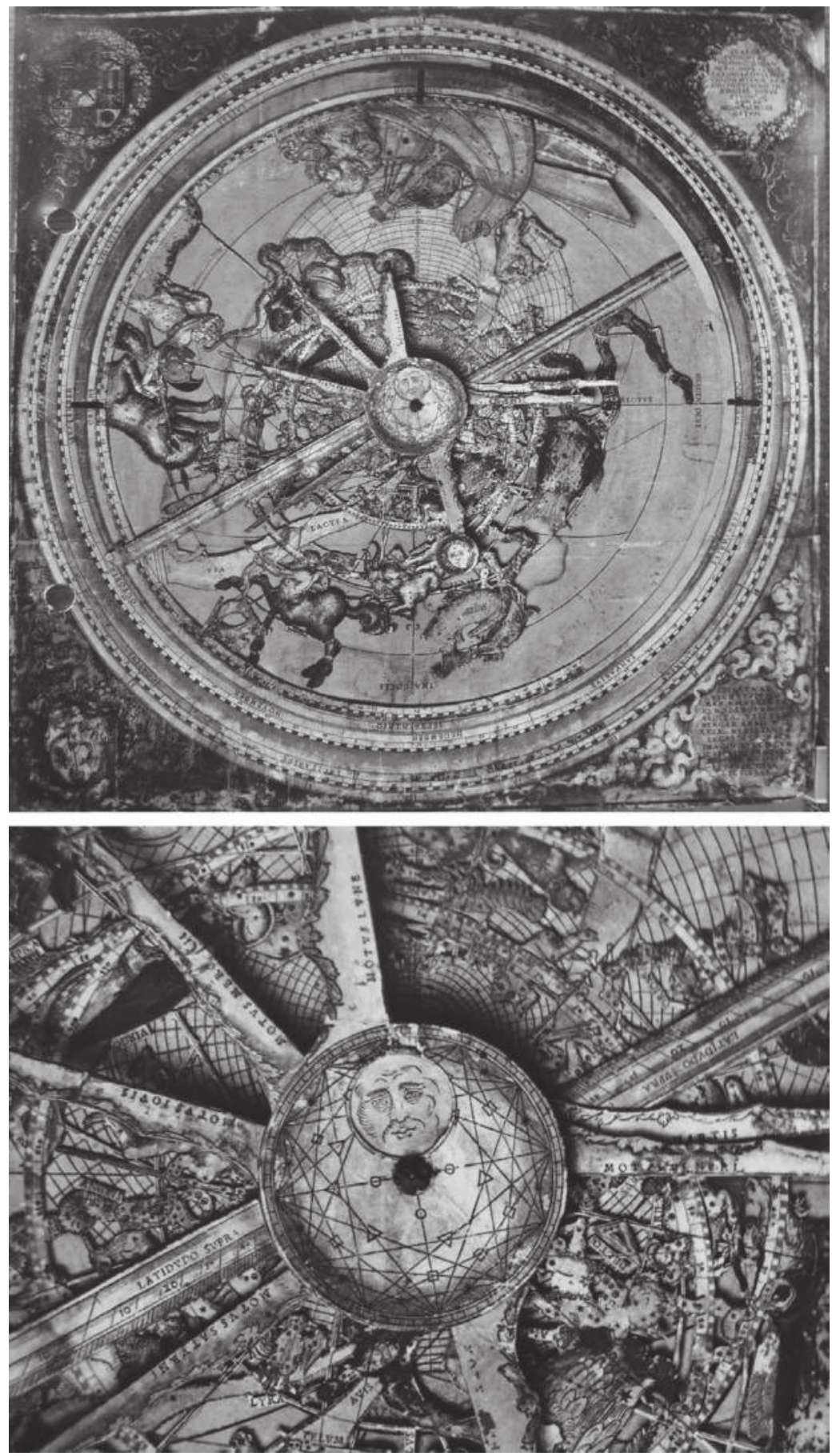

Figure 1.10 Lucas Cranach the Elder, astrolabe for students, 1529, photograph taken by Ernst Zinner before World War II of hand-colored woodcut volvelle. Formerly Jena, Universitätsbibliothek Jena.

Photo: Author. 
hidden area may in fact have included a second woodcut with inscribed measuring devices like Hartmann's printed astrolabes. The crests on the borders of the front of the device provide a variety of details, including the date; the author and artist's names; the printer, Peter Jordan; the woodblock cutter, Ludwig Schofer; and a dedication to John the Constant, Frederick the Wise's brother and recent successor to the electorate, which echoes Cranach's sundial from over a decade earlier.

This device, authored by Matthias Boemus, a professor at Wittenberg, may have boasted another reason besides World War II for its total disappearance. Philip Melanchthon, fellow Wittenberg professor and reformer, was a close friend of Boemus, and he wrote a glowing dedication for the handbook that accompanied the device. Curiously, the History of Science Museum, University of Oxford copy has had Melanchthon's name cut out, as if to avoid any connection to him and Luther. Zinner's notes about the astrolabe include a sale record for what is likely that same copy. Indeed, this act of censorship may be quite telling. Though only one other publication is known by Boemus (on the subject of plagues), he appeared posthumously on several indices of forbidden books beginning in 1546. At least one refers to him as a Hussite, a possible local benefit for a Bohemian scholar anxious to be taken seriously in the Reformation capital of Wittenberg. Given the censorship of the Oxford copy, it seems plausible that it would be the astronomical text that was found faulty, likely through association with Melanchthon, even though the work does not present a novel view of the heavens, especially not a heliocentric model. Melanchthon and Boemus were evidently close, and the reformer wrote personal letters lamenting Boemus's early demise only three years after he had dedicated his astronomical masterpiece to the Saxon elector and the university students. Unfortunately, other than the photographic evidence of the one impression that survived into modernity, it is unclear if the text was ever studied and if the print was ever used in the curriculum. Efforts over the decades since World War II to find the print in the Jena University Library have sadly proved fruitless, likely due to the campaign of Allied bombings that damaged or destroyed many buildings in central Jena in $1945 .{ }^{21}$

A return to the lost Veronica print, memorialized in Paul Heitz's Einblattdrucke in 1931, and the equally tragic events surrounding its destruction, will serve as this chapter's conclusion (Figure 1.4). Like the lost Cranach astrolabe, one can still only approximate its original appearance, even with photographic evidence. The front board of the manuscript into which the Veronica was affixed can be seen in the black and white Einblattdrucke collotype, including square fragments of manuscript waste affixed at the bottom corners, and a view of inscriptions and the binding cord at the top. The Polish writer of the Einblattdrucke series entry, the Warsaw University professor and curator, Dr. Stanisława Sawicka, offered a few more clues about it and was one of the last scholars to study and, perhaps, even see it. Her meticulous descriptions note that, like the six others from the Warsaw collection she surveys in the text, it is one of the woodcuts from a group of manuscripts that had been sent to Saint Petersburg in 1795 and 1832 and returned to the University of Warsaw in $1924 . .^{22}$

But the manuscript, and the print it contained, would not remain strangers to divided and occupied territories. The print was unfortunately not mentioned in Jerzy Kaliszuk's major 2016 catalogue and reconstruction effort to identify 1,500 of the lost manuscripts from across Warsaw, especially the National Library. ${ }^{23}$ Only some 19 remain of that library's collection, formerly totaling 4,100 manuscripts, which were destroyed during World War II during the Nazi bombing of the city targeting 
its cultural heritage after the 1944 Warsaw Uprising. ${ }^{24}$ Part of the Polish Underground State, Stanisława Sawicka edited Przeglad Spraw Kultury, a monthly government publication of the overview of cultural cases from February to November 1943. Even before the more than two-month uprising began in August 1944, Sawicka had already been arrested with three other female family members after the detection of the Government Delegate's Office Information Department. She was sent to a German concentration camp, though she would eventually return to her university post at Warsaw. ${ }^{25}$ Shortly after the failed uprising, the national special collections of rare books, manuscripts, and works on paper (which German troops had previously sequestered in a single location) were burned in retribution. This conflagration almost certainly claimed the manuscript with the Veronica woodcut.

Back in 1931 when she was writing in German for the international Einblattdrucke series, Sawicka defined the Veronica as a Reibedruck innovatively handprinted on paper from a wooden block meant for printing on fabric. Citations as early as Cennino Cennini's craftsman's handbook, Il libro dell'arte (written c. 1400), describe early fabric prints, Zeugdruck or Stoffdruck, as imitating more expensive fabric and serving for washable garments such as underclothes. However, this recognizable image was likely destined more for use as a wall hanging for private devotion, especially considering the volume's Holy Cross Benedictine monastery provenance. At about $11.7 \times 8.4$ inches $(29.8 \times 21.3 \mathrm{~cm})$, it would have made a stronger impression in multiple (Figure 1.4b). The reuse of the block on paper in a hand printing for this particular impression implies that the Veronica might have been produced in a place, like a monastery or convent, without a book press. Sawicka calls the ink "reddish" (rötlich) and suggests that the use of white space in the ornamental border would have read as predominantly white on a velvety red ground. So, given its possible secondary use as wallpaper, one must remember not that this print too is lost, but what it might have looked like in multiple. Its strikingly distinctive color and implied ability to multiply itself only added to its power as a printed contact relic from the moment of Saint Veronica's meeting with Christ onward, even in a collotype reproduction or a collaged imagining of its conquest of an entire convent wall. From the unexpected use of negative space setting off the face of Christ both in manuscripts and cosmography textbooks, to the missing flaps and dials in previous examples, this chapter has aimed to improve the understanding of the complicated survival and visual interpretation of interactive and all other forms of prints in the early modern period. Keeping a close eye on signs of absence remains key, especially unexpectedly blank pages, cut-outs, and shapes. One should not need a manual to discover many further uses that have been forgotten for prints of all eras, whether long lost or recently found.

\section{Notes}

1 For more on Apian's didactic cosmography texts, see Gingerich, "Astronomical Paper Instruments," 63-74, and more recently, Gaida, "Reading Cosmographia," 277-302.

2 Bontius appears to have been experimenting with different knot covers in 1553, following the publication of the 1551 and 1553 French editions with their more figural iconography. For instance, the JCB copy of Bontius's Dutch 1553 issue has one rosette (thread only) and one blank with a red wax residue for the third instrument, followed by two identical grotesque motifs (J553. A642cAd). The JCB Latin edition of 1553 has the grotesque, a doubleheaded eagle, and a rosette, in addition to the Vernicule (J553. A642cA). 
3 Dürst, Sebastian Münsters Sonneninstrument.

4 Sebastian Münster, Erklerung des newen Jnstruments der Sunnen, nach allen seinen Scheyben vnd Circkeln (Oppenheim: Jakob Köbel, 1528), VD16: M 6669.

5 Sebastian Münster, Organum Vranicum (Basel: Heinrich Petri, 1536), VD16 M: 6726.

6 The map portion is a close copy of a xylographic woodcut broadsheet from c. 1500 by Erhard Etzlaub. Münster, Erklerung, fol. Aiir-Aiiv.

7 Hans Holbein the Younger, Instrument of the Course of the Moon, (Instrument Uber de(n) Mondslauff), 1529, Munich, Ludwig-Maximilians-Universitāt, Universitätsbibliothek, W2 Math. 336\#2. Karr Schmidt, Interactive and Sculptural Printmaking, 298-99. Veit Rudolph Specklin after Hans Holbein the Younger, Astronomical Chart of the Sun and Moon (Instrument des himmels lauff bifs avf IXXXX iar.), 1534, Boston, Museum of Fine Arts, Maria Antoinette Evans Fund, 31.1226. Silver and Wyckoff, eds. Grand Scale, 12, 166. Hans Holbein the Younger and Sebastian Münster, Sun and Moon Instrument (Instrumentium novvum, utriufque uarios exprimens motus. . .), 1534, Kunstmuseum Basel, Kupferstichkabinett, 1923. Karr Schmidt, in Susan Dackerman, Prints and the Pursuit of Knowledge, 306-309.

8 Karr, "Marginal Devotions," 98-103.

9 Kaliszuk, Codices deperditi, 35-36.

10 Stanislaus de Scarbimiria, "Sermo," 96-112.

11 Heusinger and Appuhn, Riesenholzschnitte, 7-10.

12 Gaida, "Reading Cosmographia," 295-96.

13 Sawicka, Einblattdrucke, 7-8.

14 Stengel, Unedierte Holzschnitte, 7.

15 Karr Schmidt, Altered and Adorned, 73-77; eadem, Interactive and Sculptural Printmaking, 240-44, 301-3.

16 Major, Holz-und Metallschnitte, 11-12, pl. 6.

17 Munich, BSB, Einbl. I, 41; London, BM, 1876,0510.619 (https://www.britishmuseum.org/ collection/object/P_1876-0510-619).

18 Karr Schmidt, Interactive and Sculptural Printmaking, 168-80. Hans Rudolph Manuel Deutsch, Anti-Catholic Broadsheet: The Changing Face of the Catholic Church, 1556. Woodcut volvelle dial consisting of two circles, one notched, cut out from broadside. Dial rotates to show eight different satirical heads: $16.5 \mathrm{~cm}$ (diameter); Vienna, Albertina, DG $2002 / 209$.

19 Johannes Kurcz, Memento Mori With Death's Head, c. 1510, hand-colored xylographic woodcut, $42 \times 38 \mathrm{~cm}$ (sheet, flap closed), $44 \times 38 \mathrm{~cm}$ (sheet, flap open) (Munich, BSB, Xyl. 87, http://mdz-nbn-resolving.de/urn:nbn:de:bvb:12-bsb00100112-1). Schreiber 1893; Griese, Text-Bilder, 92-97.

20 Graul, Fran Hoeffaert, 5, 24-25.

21 Warner, The Sky Explored, 59. A recent search for the original was unsuccessful. Zinner, "Medieval and Modern Europe," 2, 60.

22 Sawicka, Einblattdrucke, 5-6.

23 Kaliszuk, Codices deperditi.

24 For more in English on the project, see: www.kasaty.pl/publications/publication-series/8-2016/ A digitized version of one of the surviving manuscripts that included early metalcut inside the back cover: https://polona.pl/item/chronica-ordinis-fratrum-minorum,ODY0MjE0OT Q/2/\#info:metadata.

2513 April 1944 is given as Sawicka's date of arrest, in Bartoszewski, Warsaw Death Ring, 320. Urén Stubbings, Blitzkrieg, 54.

\section{Bibliography}

Bartoszewski, Władysław. Warsaw Death Ring, 1939-1945, transl. Edward Rothert. Warsaw: Interpress Publishers, 1968.

Dürst, Arthur. Sebastian Münsters Sonneninstrument und die Deutschlandkarte von 1525: (Sebastian Münster: Eyn new lustig und kurtzweilig Instrumet der Sonne mit yngesetzter 
Landtafel Teutscher nation 1525): Begleittext zum Faksimiledruck des Sonneninstruments der öffentlichen Bibliothek der Universität Basel. Hochdorf: Kunst-Verlag Impuls, 1988.

Gaida, Margaret. "Reading 'Cosmographia': Peter Apian’s Book Instrument Hybrid and the Rise of the Mathematical Amateur in the Sixteenth Century." Early Science and Medicine, 21 (2016): 277-302.

Gingerich, Owen. "Astronomical Paper Instruments With Moving Parts.” In Making Instruments Count, eds. R. G. W. Anderson and J. A. Bennett. Brookfield, VT: Variorum, 1993.

Graul, Ulrike. Fran Hoeffaert \& Monsieur Alamode: Modekritik des 16. und 17. Jahrbunderts auf illustrierten Flugblättern. Halle, Sachsen-Anhalt: Staatliche Galerie Moritzburg, Landeskunstmuseum, 1998.

Griese, Sabine. Text-Bilder und ihre Kontexte: Medialität und Materialität von Einblatt-Holzund-Metallschnitten des 15. Jahrhunderts. Zurich: Chronos Verlag, 2011.

Heusinger, Christian von, and Horst Appuhn. Riesenholzschnitte und Papiertapeten der Renaissance. Unterschneidheim: Uhl, 1976.

Kaliszuk, Jerzy. Codices deperditi: średniowieczne rękopisy lacińskie Biblioteki Narodowej utracone w czasie II wojny światowej. Vol. 2. Wrocław: Wrocławskie Towarzystwo Miłośników Historii, 2016.

Karr, Suzanne. "Marginal Devotions: A Newly Acquired Veronica Woodcut.” Yale University Art Gallery Bulletin, (2002): 98-103.

Karr Schmidt, Suzanne. Altered and Adorned: Using Renaissance Prints in Daily Life. New Haven: Yale University Press, 2011.

- "Georg Hartmann and the Development of Printed Instruments in Nuremberg." In Prints and the Pursuit of Knowledge in Early Modern Europe, ed. Susan Dackerman, 268-316. New Haven: Yale University Press, 2011.

- Interactive and Sculptural Printmaking in the Renaissance. Leiden: Brill, 2017.

Major, Emil. Holz- und Metallschnitte aus Öffentlichen und Privaten Sammlungen in Aarau, Basel, Romont, St. Gallen, Zürich. Vol. 50: Einblattdrucke. Strasbourg: Heitz, 1918.

Sawicka, Stanisława. Einblattdrucke des XV Jahrhunderts in Polen: Warschau, Lemberg, Gnesen, Posen. No. 74: Einblattdrucke des fünfzehnten Jahrhunderts, ed. Paul Heitz. Strasbourg: Heitz, 1931.

Silver, Larry, and Elizabeth Wyckoff, eds. Grand Scale; Monumental Prints in the Age of Dürer and Titian. New Haven: Yale University Press, 2008.

Stanislaus, de Scarbimiria. "Sermo est de mulieribus magnae fidei, magnae sapientiae, magnae fortitudinis, plurimae fallaciae et mirae stultitiae." In idem, Sermones de Sapientia Selecti, ed. Bożena Chmielowska, 96-112. Warsaw: National Centre for Culture, 2016.

Stengel, Walter. Unedierte Holzschnitte im Nürnberger Kupferstichkabinett. Vol. 37: Einblattdrucke. Strasbourg: Heitz, 1913.

Urén Stubbings, Hilda. Blitzkrieg and Books: British and European Libraries as Casualties of World War II. Bloomington, IN: Rubena Press, 1993.

Warner, Deborah J. The Sky Explored: Celestial Cartography 1500-1800. New York: Alan R. Liss, Inc., 1979.

Zinner, Ernst. "Medieval and Modern Europe: 'Astronomy and Astrology'." In Encyclopedia of World Art, 2. New York: McGraw-Hill, 1960. 


\title{
2 Playing With Destiny \\ Three Late Fifteenth-Century Uncut Playing-Card Sheets from Florence and Urbino
}

\author{
Loretta Vandi
}

\section{Introduction}

Three recently discovered late fifteenth-century playing-card sheets from Florence and Urbino, ${ }^{1}$ seemingly belonging to the sphere of cheap production and popular use, lend themselves to a fresh investigation of a topic still much debated by art historians: the dynamics of image multiplication and modification in the fifteenth century by means of printmaking, along with the function and value of their iconography. ${ }^{2} \mathrm{I}$ am convinced that no investigation should ignore the important role of manuscripts in the development of this emerging art form, through page layout, shape of the initials, organization of the script, even the marginalia. All the elements were contrived to conjure up a new visual product. At the same time, one cannot ignore that many of those images, devised to illustrate manuscripts, were copied to fulfill different aims, such as the decoration of cheap morality tracts and popular playing cards. ${ }^{3}$ The journey from manuscript illuminator or printer to typographer and eventually playing-card producer (to list just a few) would be a chapter in the evolving function of images, with slight or no change of iconography. ${ }^{4}$ In such cases, multiplication and modification, within the field of paperwork, with its limitations as well as potentialities, were part and parcel of the same process of images' consumption for devotional, educational, or entertainment purposes.

Before proceeding, I would like to clarify why I define the iconography of these playing cards as "popular." With this adjective, I do not mean that playing cards' images were a "popular art form" or an "art for the people," two phrases that would insert me into the controversial debate on the very existence of the term "popular" itself." The debate on popular culture only moved from the periphery of the historians' interest towards the center in the course of the 1960s and 1970s thanks to the works of some scholars who decided, after some suspicions, to adopt the concept. ${ }^{6}$ Their hope was to classify materials that the category of "elite culture" could not encompass. ${ }^{7}$ However, the problem of the "popular" connected to culture may give a false impression of homogeneity as much as the adoption of the "two-tier model" (elite and popular culture) may lead astray from the true issue of interaction. ${ }^{8}$ In the present study, "popular" is used in its "material" acceptation, with the aim to distinguish playing cards mechanically derived from simple woodcut matrices printed on cheap paper from luxury playing cards, which were sometimes made of parchment and lavishly colored by hand. ${ }^{9}$

\section{Remarks on Origins of Tarots and Minchiate}

It is without a doubt extremely reductive to affirm that the printed image in Europe sprang from the three Ps-paper, piety (in the form of printed religious images), and 
playing cards. ${ }^{10}$ Although I agree with Peter Schmidt, who has convincingly argued about the inadequacy of this explanation, ${ }^{11}$ at the same time it is difficult to ignore the role playing cards seemed to have had within the cultural dynamics of fifteenthcentury Western society.

The first printed playing cards were produced in the form of woodblocks, as scholars of popular playing cards, like Michael Dummett, Timothy Husband, Franco Pratesi, Thierry Depaulis, Andrea Vitali, and Giordano Berti, have remarked. ${ }^{12}$ Rather different from the engraved playing cards, as those produced in the first half and the middle of the fifteenth century by the Master of the Playing Cards and the Master $\mathrm{ES},{ }^{13}$ the woodblock playing cards are now extremely rare, even though they were by far the most common, designed for a mass market. ${ }^{14}$ Simple in both design and production, the decks were printed on paper using large woodblocks, usually two blocks of twenty-four cards each, then the printed sheet was cut into individual cards. These cards were glued to several layers of paper to make a stiff pasteboard and then trimmed. Generally, they were not colored, but those that were had a limited range of hues (usually two colors), applied with the aid of stencils. The earlier popular playing cards were produced with little artistic pretensions but designed in such a way that the figures and suit symbols were easily distinguished and the values of pip cards readily determined. ${ }^{15}$

The newly discovered decks are of Italian origin and belong to the genre of tarot. ${ }^{16}$ Tarots are a specific kind of playing cards. Whereas the ordinary playing-card deck consists of fifty-two cards distributed through four suits, each containing numbered cards 1 (Ace) to 10 and three court cards, the standard tarot deck includes seventyeight cards: twenty-one are ordered trumps with an unnumbered Fool. There are four suits of sixteen pip cards, each containing numbered cards 1 (Ace) to 10, with the addition of four cards of Knave, Knight, King, and Queen. The suit signs are Cups, Batons, Coins, and Swords. ${ }^{17}$ The word tarot derives from the French tarau, which in turn comes from the Italian tarocco. That term, for which there is no known etymology, did not come into use until the sixteenth century. Throughout the fifteenth century, tarot cards were referred to as carte da trionfi (cards with trumps), ${ }^{18}$ with the earliest references falling within the quadrilateral field demarcated by the northern cities of Venice, Milan, Florence, and Urbino. ${ }^{19}$ One of the first mentions is to be found in I Giornali di Ser Giusto Giusti d'Anghiari (1437-82), dated 16 September 1441. ${ }^{20}$ The second one is in a toll register of 1442 in Rome, in which many mentions of Florentine merchants testify to the fact that ordinary playing cards and tarots were massively imported. ${ }^{21}$

The playing-card woodblock sheets which I employ are tarots of the specific category of minchiate or germini, a Florentine transformation of some images of the canonical tarot deck of which the trionfi, or trumps, were part. In the Florentine minchiate, a deck that became very successful also outside Italy, ${ }^{22}$ we find a female figure in the Cups and Coins instead of a Page or a Knave and Knights shown as centaurs. ${ }^{23}$ With regard to minchiate, its first mention appears in the letter of the poet Luigi Pulci (1432-84) to the young Lorenzo de' Medici, written on 23 August 1466. ${ }^{24}$ Another document comes from Cortona, rather far from Florence but which was one of the latter's possessions. ${ }^{25}$ It was also in Florence that direct actions to control the game were undertaken in the late fifteenth century. Bonfires of all the vanità [vanities], ordered by Girolamo Savonarola, in the form of an eight-sided wooden pyramid erected in the middle of the Piazza della Signoria, showed on one of its fifteen levels tavolieri, carte, tavole da stamparle, dadi e trionfi [boards for playing dice, playing cards, woodblocks, dice, and trumps], that is, some implements and the most typical 
Florentine games of the time. ${ }^{26}$ In fact, not only cards, but also woodblocks were collected and burned in those memorable nights of the last Carnival days of 1497 and 1498, around 9 p.m., con tanta festa et letitia di tutto il popolo [with great merriment and joy of the people.] Notwithstanding such radical interventions, which sought to put an end to immoral practices, the game never ceased to be played.

\section{Figurative Arts and Playing-Card Making}

Franco Pratesi, among his many contributions to the topic, has investigated the origins of the tarots and minchiate and their iconographic apparatus. ${ }^{27}$ In one of his most recent and critical articles, ${ }^{28}$ he arrives at the conclusion that for all the figures of the tarot sequence, it is possible to find antecedents in medieval imagery, particularly with regard to two kinds of figures, the angels and devils, the good and the bad. Still, along with the quality of the images, he argues, one needs quantitative elements, and it is exactly these elements that are among the most difficult to find. ${ }^{29}$

However, I am of the opinion that it would be much more rewarding, instead of searching for iconographic correspondences between wall or panel paintings and playing-card images, to look for workshop practices in Florence in the fifteenth century. Even though we will never be able to go back to the sources of those images, what really matters here is not the source but the way in which a subject is adapted to a new medium. In this respect, some instances might reveal the complexity of the situation. For example, already in 1430, Antonio di Giovanni di ser Francesco declares that his woodblocks were used for producing both naibi [playing cards] and holy pictures, ${ }^{30}$ a statement suggesting that one and the same image was printed more times on the same sheet of paper and only later was it differentiated according to market demands. If this holds true, it seems that in Florence (and I suspect elsewhere, as well), in the many small workshops, images had no specific "aura" or uniqueness. They were good to work with, thanks to their simplicity, readability, and with some added distinctive details, inner adaptability to different media and to markets looking for sacred and profane objects alike. It goes without saying that both products (not always of low quality) were generally not made to order.

Peter Schmidt, in a polemical essay published in $2005,{ }^{31}$ argues that in contrast with large altarpiece paintings, such prints were produced in large numbers for the open market, and for this reason there are no records of commission, production, receipt, or destination. He posits that in Germany, around 1450, a new impetus to copy texts coincided with a need to illustrate them, a need satisfied by printed images. Although referring to a religious cycle included in the Gulden Püchlein (Munich, BSB, Cgm 9489), Schmidt's contention may also be related to the production process of playing-card images. ${ }^{32}$ No doubt the widespread use of certain images was facilitated by a consistent reduction and standardization of iconography and composition, thereby making them appropriate for diverse texts and for playing cards. Despite formal simplification, however, what is still convincing in such images is the structure of every composition with a minimum of figures outlined within a space rendered in an uncomplicated way. It was a matter of transposition and adaptation, supported by a clear network of lines, that conveyed the basic information according to some aesthetic criteria, even in small format. Temporal and spatial mobility are important attributes of the woodcut medium that determined its availability, and even playingcard images partake of this important feature. 


\section{Urbino, Playing-Card Sheets Nos. 1, 2, and 3}

The three playing-card woodblock sheets presented in this chapter escaped destruction just by chance. In the fifteenth century, the publishers of books were also typographers and producers of playing cards. Some playing cards were never sold, since they did not fulfil the basic criteria of readability. Perhaps the images were dull for lack of ink or insufficient pressure applied to the inked woodblock. These imperfect prints were not always destroyed but employed for different purposes. One might be to reinforce a book cover, as was the case for our three uncut woodblock sheets, which were used as filler for the cover of a notary register of $1532 .{ }^{33}$

The first series of our playing-card woodblock sheets, which I call Urbino Sheet No. 1, can be compared with the Rosenwald uncut woodblock Sheet No. 2, of the late fifteenth to early sixteenth century, held in the Washington NGA (NGA, Rosenwald Collection, 1951.16.6) ${ }^{34}$ (Figure 2.1) and with the late fifteenth to first quarter of the sixteenth-century deck in the Giuliano Crippa Collection in Milan. ${ }^{35}$ All series feature four centaurs in place of knights, two maids, and two knaves instead of knaves or pages only.

There are some specific points I wish to comment on here. The first concerns dimensions. The Rosenwald sheet shape is rectangular and its dimensions are $29.1 \times$ $43.6 \mathrm{~cm}$, which corresponds to a rather common format of the time, almost identical to the dimensions of Urbino Sheets Nos. 1 and $2(28.9 \times 43.5 \mathrm{~cm})$. In all instances, one sheet is used for producing twenty-four cards.

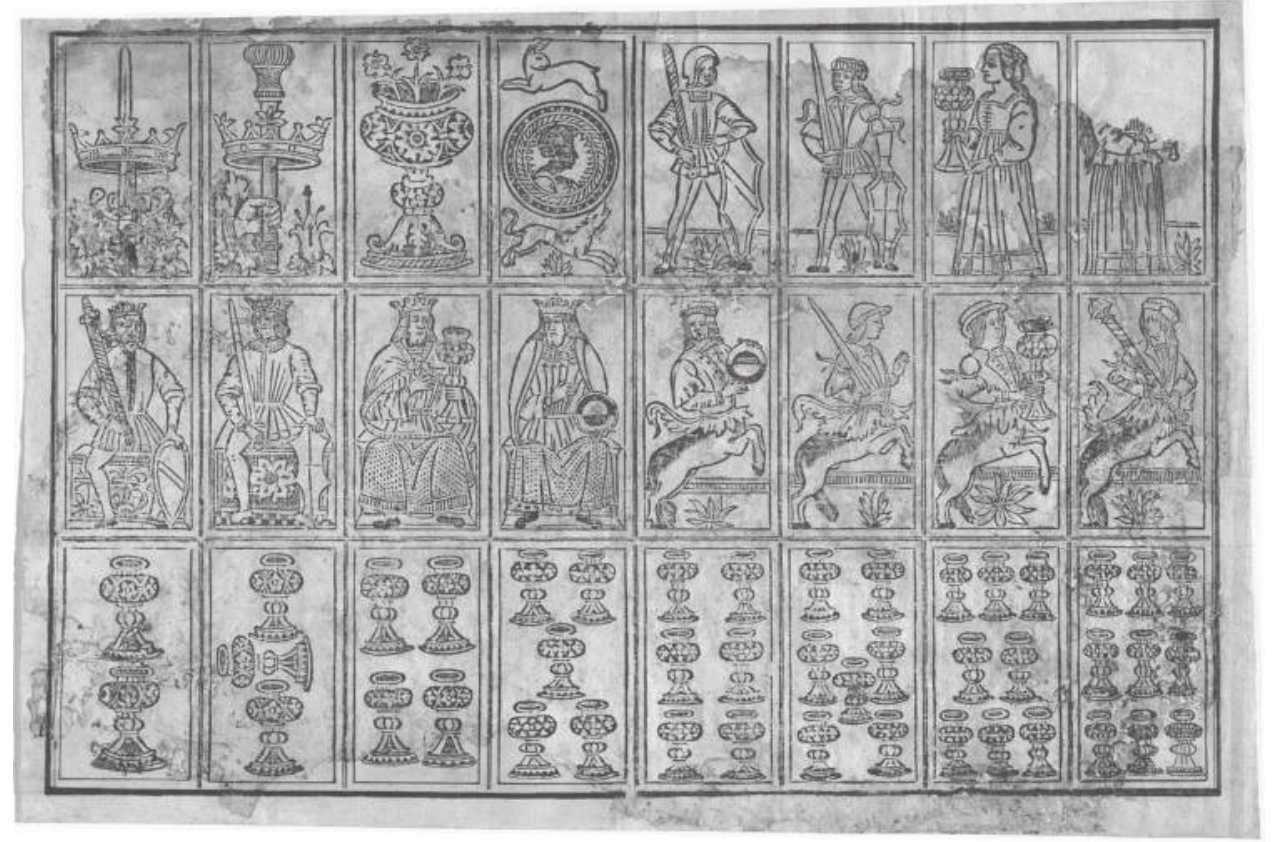

Figure 2.1 Rosenwald Playing-Card Sheet No. 2, woodcut, late fifteenth to early sixteenth century. Washington, National Gallery of Art, Lessing J. Rosenwald Collection, 1951.16.6.

Photo: Courtesy National Gallery of Art, Washington. 
The second point regards iconography. If, at first glance, similarities are immediately visible in the shapes of many characters, as in the series of kings, maids/knaves, and centaurs (in all three series, apart from the kings, who are represented in a frontal view, maids, knaves, and centaurs are generally represented with foreshortened bodies and faces in profile), with closer scrutiny one can detect many meaningful differences. They regard the forms of the faces; eyes; hands; hair; hats or helmets; and the dresses, plants, and flowers. They are not to be considered mere details but part and parcel of the expressive value of a conventional subject. Just to focus on one of these "details," I consider the rendition of the acanthus leaf, an ornamental motif used in the cards to create movement and embellish the subject. ${ }^{36}$

In the figures of the centaurs, the intersection of the upper and the lower parts of their bodies is marked by a belt made of acanthus leaves, rendered similarly in all three series. In the Rosenwald Sheet No. 2 (Figure 2.3), the four centaurs have long and rich acanthus leaves, similar to the folds of their blouses. Apart from one (the centaur of Coin), the other three show a ribbon around the right sleeve, which seems to move in parallel to the acanthus tail, while the true tail is represented between the two legs in a static position. In the Crippa centaurs, too, the acanthus motif seems to prolong the folds of the dress, with some parts enhanced by irregular spots of red color. In the Urbino Sheet No. 1, the acanthus belt is present, but in two instances (the knight-centaur of Batons and Cups), it substitutes for the hairy tail itself. Two small but important differences between the three series are the rendition of proportions and the hybrids' deportment. In the Rosenwald centaurs, proportions of the two parts forming the hybrids are respected, each part having its own specific features, while the deportment is elegant and courtly, as if the centaurs were advancing in a rhythmical pace. In the Crippa Cups series, the knight-centaur, holding a magnified cup, is well proportioned (Figure 2.2a). His deportment, however, does not express a specific attitude as much as, on the other hand, all the subjects of the Crippa Playing Cards collection. In the Urbino Sheet No. 1, by contrast, the upper human part prevails on the lower animal part, which is rendered in a more cursory manner in all four figures. The deportment is dynamic and with a stroke of ardor. This is visible, in particular, in the centaurs of Batons and Swords, who brandish their attributes as if they were true weapons. The same attitudes can be seen in two late fifteenth-century playing cards with the same subjects, both in Florence, one in a private collection and the other in the Biblioteca Nazionale Centrale. ${ }^{37}$

The third point deals with the conception of figures in space. In the Rosenwald Sheet No. 2, each figure, perfectly printed, leaving a clear, empty background around the upper part of the body, is harmoniously represented inside the rectangle that constitutes the card. Even though any question about the environment in which the figures are represented seems out of place in a context with no naturalistic purpose, what remains unclear in the Rosenwald playing cards is the spatial relation between the small plant (with eight or eleven leaves) and a long, narrow band, rather similar to a fence, both in the background. Also the printer of the Crippa Swords series (Figure 2.2b) has left no empty space around the figures, but by partially depriving the knights-centaurs of their legs and tail, it seems that he wished to enhance more the suit symbol (the Sword) and less the figure, producing, on the whole, a static visual effect. As in the Crippa Deck, in the Urbino Sheet No. 1 as well some parts of the body and other elements are cut by the cards' borders, a sign that can be interpreted as an adaptation to the smaller format of a woodcut originally intended for a larger one. At the same time, one cannot exclude 


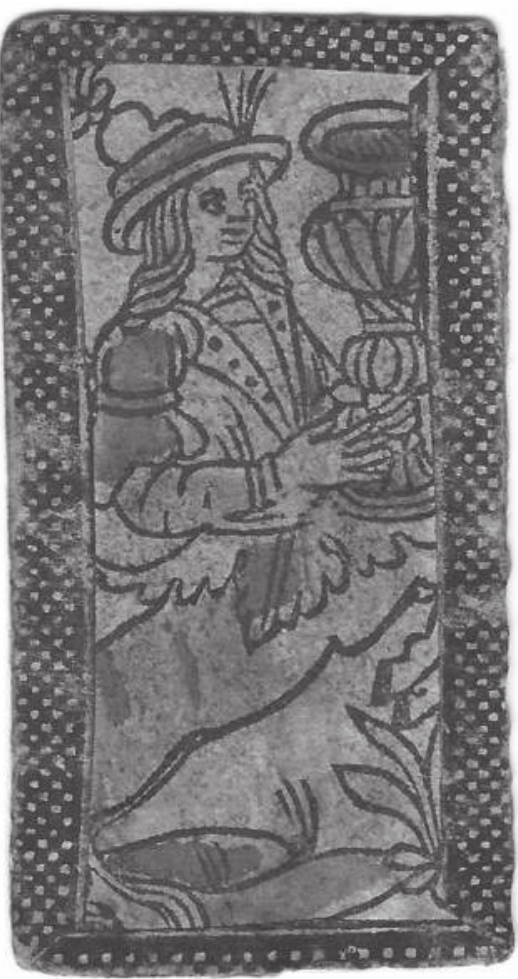

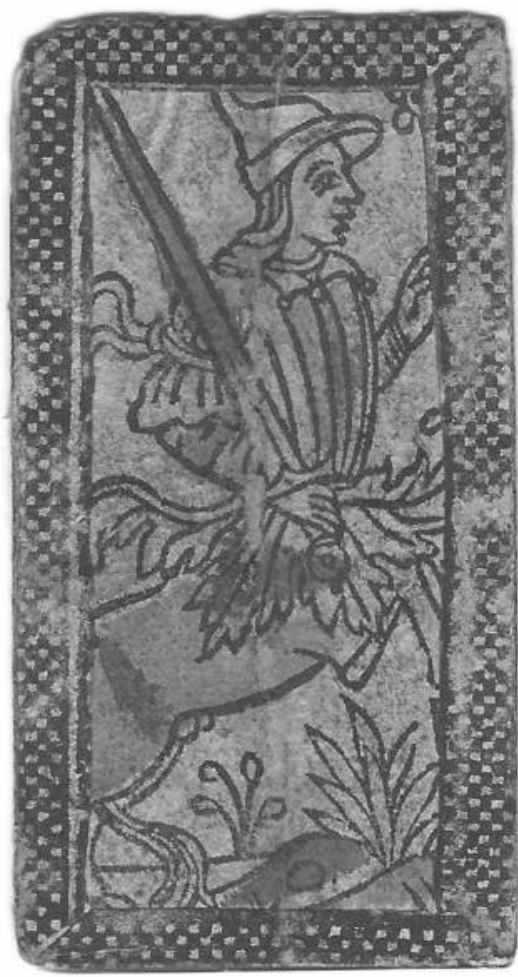

b

Figure 2.2 a) Centaur of Cups; b) Centaur of Swords, Crippa Playing-Card Deck, woodcut, late fifteenth to first quarter of the sixteenth century. Milan, Crippa Collection.

Photo: Courtesy of Dr. Giuliano Crippa.

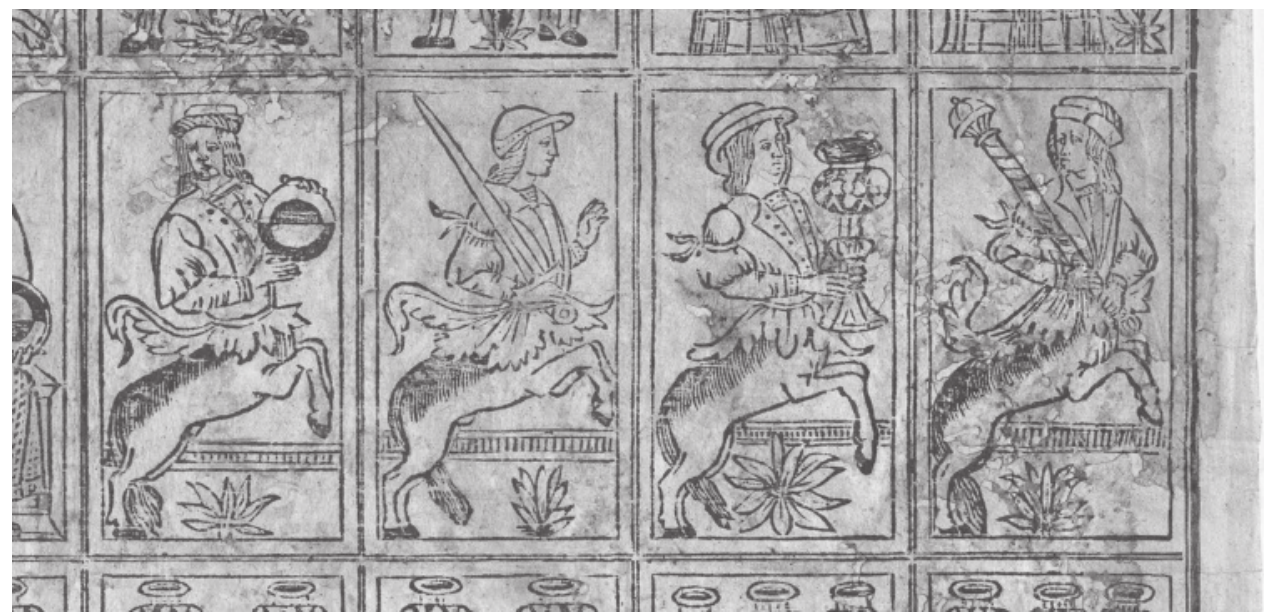

Figure 2.3 Centaurs series, detail of figure 2.1.

Photo: Courtesy National Gallery of Art, Washington. 
that this was the choice of the draftsman: big figures almost completely occupying the space were, in the end, much more impressive than smaller and simply outlined ones. In such a way, the Urbino Sheet No. 1, compared to the Crippa Deck, can be described as an exuberant rendition of conventional forms, exuberance depending on the very fact that each figure forces or surpasses the spacial limits of the card.

The fourth point regards the technique. Although the differences may initially appear unremarkable, upon closer scrutiny they betray three very different hands at work. First of all, the contour lines are thicker in Urbino Sheet No. 1, with a preference for parallel lines in the rendering of hair, folds, and decoration. The thickness of the lines makes both figures and ornamental motifs appear more solid and impressive. In the Crippa Deck, lines are both thick and thin, while some surfaces are covered by red and yellow washes applied by stencils. In the Rosenwald Sheet No. 2, instead, lines are less thick and more regular and many parts of the bodies are left empty, while the rear of the centaurs' body is rendered by means of a thick hatching, which continues in the tails, absent in the correspondent figures of both the Urbino Sheet No. 1 and the Crippa Deck.

The fifth and final point regards the cards with numerals, printed in both Urbino Sheets Nos. 1 and 2 and the Crippa Deck, compared with the same images present in the Rosenwald Sheet No. 1. Here, notwithstanding the diversity in how the rows are printed (though this distinction would have disappeared once the cards were cut), the similarities are quite striking, especially in the simplest of the pips, the Coins (Figure 2.4). These images have no pretension to decorativeness, a feature that marks instead many courtly examples, such as the Visconti-Sforza deck of $1450-55 .^{38}$

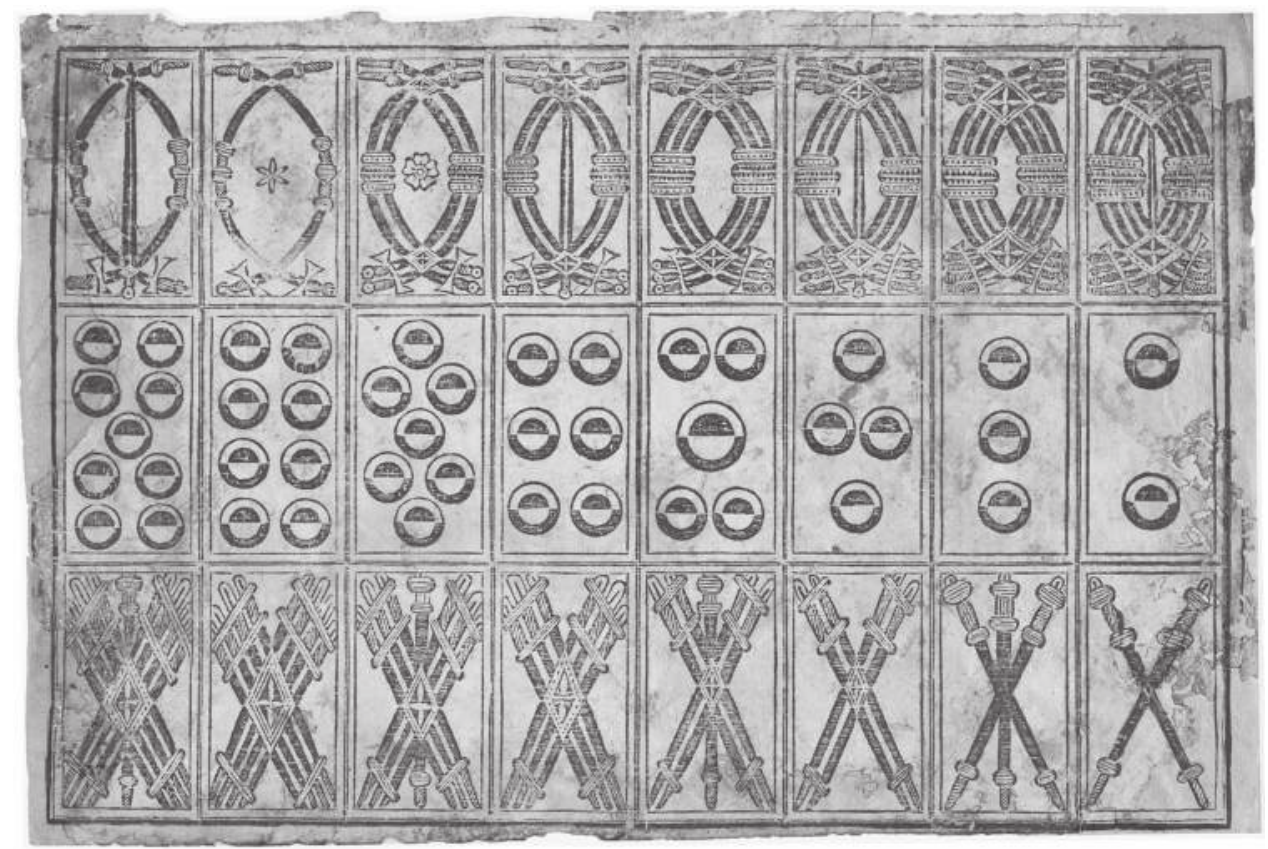

Figure 2.4 Numeral cards, Rosenwald Playing-Card Sheet No. 1, woodcut, late fifteenth to early sixteenth century. Washington, National Gallery of Art, Lessing J. Rosenwald Collection, 1951.16.5.

Photo: Courtesy National Gallery of Art, Washington. 
The Rosenwald Sheets and the Crippa Deck invite some considerations on their style and place of origins, also useful for dating and locating the Urbino Sheets. The fundamental study on the history of the fifteenth-century woodcut was published in 1905 by Paul Kristeller. ${ }^{39}$ He envisaged a three-stage development, based on technical, functional, and stylistic features. The first stage (1400 to 1440) included the first images printed on paper. The second stage (1440 to 1470$)$ encompassed a variety of images, a change in their size, and the appearance of the block book. In the third phase (1470 to 1500 ) important changes took place, as the advent of book publishing, the need for standardization, and a wider variety of subjects. Tarot was invented during the first stage, when the predominant style was the International Gothic. Printers produced both playing cards and religious images on sheets of paper with subjects characterized by heavy black lines, simple drapery, no shading, and either just essential or no background for the main image. ${ }^{40}$ The Rosenwald and the Urbino Playing-Card Sheets, produced in the late fifteenth to early sixteenth century, and the Crippa Deck, of the late fifteenth to first quarter of the sixteenth century, seem the work of woodblock carvers who copied blocks with an outdated style.

With regard to location, only the Rosenwald Sheet No. 3, with a series of trumps (Washington, NGA, Lessing J. Rosenwald Collection, 1951.17.6) may have been printed in Perugia (Umbria) around 1501-1502 under Florentine influence. ${ }^{41}$ Throughout the Middle Ages and the Renaissance, the city managed to keep its political independence, even as it reinforced strong cultural connections with Florence. ${ }^{42}$ For the Rosenwald Sheets Nos. 1 and 2, instead, the printing place may be Florence, since several details can be found in Florentine cards: the virtues' scalloped halos, centaurs for knights, and maids instead of knaves in the suits of Coins and Cups. There is also an intriguing stylistic similarity between the Rosenwald playing cards and a book printed in Florence, Fior di Virtù, often illustrated with woodcuts. This book of moral instruction for children, focusing on virtues and vices and written by an anonymous author between 1313 and 1323, was reprinted many times in several languages until the late Middle Ages. ${ }^{43}$

Florence entered rather late into block printed books. Engraving dominated the book trade, possibly because engravers belonged to the influential goldsmiths guild and monopolized the market. According to Lessing J. Rosenwald, between 1490 and 1510 , the city enjoyed a very brief flowering of block printed books in a distinct style-mostly fiction and religious texts printed on cheap paper that rarely survived for long. ${ }^{44}$ Few of those books remain, as they were generally meant for the mass market. Fior di Virtù, written in the Tuscan dialect, was one of the first books of this type in Florence, combining tight organization, lively stories, essential drawings, and a prose aiming to teach a reader how to live according to precepts of Christian morality. ${ }^{45}$ Probably a prototype for subsequent examples, the block prints of the Fiore di Virtù have a very simple style, easily designed and ready to be copied. ${ }^{46}$

The Crippa Deck was found in 1993 in Assisi (Umbria) during the demolition of an old house. The cards were kept for a while in a private museum of rural traditions, where they were discovered by Han Janssen. ${ }^{47}$ The deck, composed of forty-eight cards, which is the number of both the Rosenwald and the Urbino 1 and 2 series, and with no 10s, is evidence of a type of playing cards in use in Central Italy in the fifteenth century, differing from the cards of the Florentine minchiate, in that the hybrids are four centaurs. ${ }^{48}$ The matrices employed for the Gothic-style arches that frame the figures of the kings suggest dating the deck to the end of the fifteenth century, while the design of the back depicting a "moor" with unsheathed scimitar hints at a date 
around 1525. Even this deck may have been printed in Perugia using Florentine models. ${ }^{49}$ While the models for the Urbino Sheets Nos. 1 and 2 can be found in Florentine workshops for a number of reasons (style, detail, composition), I suspect another inspiration for the Urbino Sheet No. 3: probably they were printed in Urbino, using a model sheet possibly of Bolognese origin. ${ }^{50}$ The reason for this attribution lies in one peculiar iconographic attribute, not to be found in other playing-card decks. The Urbino Sheet No. 3 consists of two identical woodblock sheets featuring two rows of four cards each: cards with men and a boy occupy the first row, while the second one presents escutcheons, various objects, and panoplies. All are surrounded by black and white large checkered frames with thin white lines showing where the sheet had to be cut. As to demonstrate my hypothesis, I will consider the four human figures.

In one, a man totes an animal on his shoulders; In another, he is seen standing from the rear, resembling a male figure in a sixteenth-century card, now in London (BM, 1870-1008.2041.a-b). ${ }^{51}$ The latter card, featuring on the recto a gastro-cephalic Devil (his face is placed on his belly, as in the fresco of c. 1410 by Giovanni da Modena [c. 1375-1456] in the Bolognini Chapel, in San Petronio, Bologna), ${ }^{52}$ seems to be the only extant example of a tarot deck perhaps produced in Bologna by a certain M. Agnolo Ebreo (Magister Agnolo the Jew). In both London and Urbino cards, the man has his gesture described by a flowing scroll filling the upper and lateral parts of the card. In the London card, the scroll reads CHA PERSE SE GRATA EL CULLO ("The loser scratches his backside"). In the Urbino Sheet No. 3, the caption, partially effaced, is shorter: GRATA EL CUL ("He scratches his backside"). ${ }^{53} \mathrm{~A}$ third figural card in the Urbino Sheet No. 3 shows a boy riding an aged man, while the last card features a young man boldly ascending a path on his stilts. It is the latter's iconography that leads us to Urbino.

In the Middle Ages, stilts were used for practical purposes (e.g. working in swamps, fording swollen rivers or scanning the horizon for stray sheep $)^{54}$ but also for entertainment. In the small village of Schieti near Urbino, a contest with stilts still entertains visitors and inhabitants in June each year during their festival of rural traditions. Most probably, however, the youth in the Urbino Sheet No. 3 is not participating in a competition but walking to reach some destination. Considering the style of the cards, the landscape treatment, and the characters' costumes, it seems to me that the late fifteenth century is too early a date for these cards. Most probably the woodblock sheets were printed in the first quarter of the sixteenth century. ${ }^{55}$

\section{Conclusions}

The Urbino Sheets Nos. 1 and 2 are particularly important, since they confirm, along with the Rosenwald Sheets Nos. 1 and 2 and the Crippa Playing Cards, that a deck of forty-eight cards was complete even with no trumps. In addition, as it is quite likely that the Rosenwald and Crippa Playing Cards were created under the influence of Florentine block printing, the same influence would seem to hold for the Urbino Sheets Nos. 1 and 2. The Urbino Sheet No. 3, instead, though partially influenced by Bolognese models, was probably printed in Urbino, because of one card featuring a specific iconography. That said, some questions still remain on the actual place of production of Urbino Sheets Nos. 1 and 2. If they were printed in Florence by a book printer who also produced cards, how did two discarded sheets of playing cards end up in Urbino? Were the Urbino Sheets Nos. 1 and 2 designed and printed by someone 
familiar with the popular books coming out of Florence? Or had a Florentine printer set up shop in Urbino? We need more documents about the book and paper trade at the end of the fifteenth century, especially in regions such as Tuscany, Umbria, Marche, and Emilia-Romagna, to arrive at some partial explanations.

The three Urbino uncut playing-card sheets are good instances of how a discovery showcases the importance of understanding printed images as unique and modifiable multiples. However, among printed images, a playing card is an exception to the ideas of uniqueness and modifiable multiplicity as a comparison with a "classic" printed image demonstrates. A single printed image, either a woodcut, engraving, or etching, could (sometimes should) undergo both drawing transformations and technical modifications in the course of its reproduction. These transformations, due to the addition of more lines or shades to the original matrix or depending on the use of different quantities of ink or acid, produce new artistic effects. A playing card, instead, belongs to the game sphere governed by precise subject matter and color rules. These prescriptions are limiting any kind of original transformation, and so the playing card's destiny is to be multiplied with no remarkable modification, unless in some unimportant detail. Important modifications were admitted only in toto, that is when a series of playing cards were created for a new game.

As a last remark, I will now speak to problems of restoration. The three Urbino playing-card woodblock sheets have been restored according to conservative practice. Damages were serious, with many parts of paper missing. They have been reintegrated with the reversible addition of a special paper, which allowed them to look like almost contemporary to the original ones. An attempt was made to add colors, the few usually employed in the fifteenth century: blue, red, green, and yellow. But perhaps we appreciate best the naked outline and remnants of a work never completed.

\section{Notes}

1 The sheets were discovered in 2005 by Massimiliano Berretta of Urbino in the course of his restoration of a 1532 notary book, now belonging to the Arcidiocesi of Urbino-UrbaniaSant'Angelo in Vado (Marche). Nor was this discovery an exception. After the flood of Florence in November 1966, many volumes held at the Biblioteca Nazionale were restored in the laboratory of Praglia Abbey. Tucked between some of the covers appeared uncut playing-card sheets, adapted to form interior support for the covers. Cf. Omodeo, "Tarocchi fiorentini," 50-57. The images of the three uncut woodblock sheets will be published by Mons. Davide Tonti, the copyright owner, in a forthcoming article.

2 Landau and Parshall, The Renaissance Print.

3 On the relationships between playing cards and manuscripts in the fifteenth century, cf. Buren and Edmunds, "Playing Cards," 12-30; Vandi, Il Manoscritto Oliveriano.

4 Vandi, "Carte da gioco," 123-38.

5 Burke, Popular Culture, 7-15.

6 Kühn, ed., Populärkultur.

7 Muchembled, Culture populaire.

8 Burke, Popular Culture, 7. Cf. also Gurevič, The Categories of Medieval Culture, 1-24.

9 On such distinction, cf. Parshall and Schoch, "Early Woodcuts," 2. On the early use in Florence of playing cards, called najbi or naibi, cf. Franco Pratesi, "1377: Firenze," 166-73. Cf. also Singer, Researches Into the History.

10 On the three Ps, cf. Rosenfeld, "Wann und wo wurde die Holzschnittkunst erfunden?" 32742; Körner, Der Früheste deutsche Einblattholzschnitt; Hoffmann, Altdeutsche Spielkarten; Rebel, "Die Entwicklung der grafischen Techniken," 45-58.

11 Schmidt, "The Multiple Image," 39-41. As regards Florence and Lucca, cf. Vandi, "Reforming Images." 
12 Dummett, "Sulle origini dei Tarocchi popolari," 58-65; Husband, ed., The World in Play, 47-49; Pratesi, Giochi di carte; idem, Playing-Card Production; Depaulis, Le Tarot révélé; idem, "L'apparition de la xylographie," 7-19; Vitali, "La nascita dei Tarocchi," 27-33; Berti, Tarocchi.

13 The intaglio print playing cards were printed from copper plates engraved using burin and stylus. Cf. Husband, The World in Play, 41-47.

14 Pratesi, “1499-1506: Firenze," 61-71.

15 Schreiber and Heitz, Die ältesten Spielkarten; Husband, The Word in Play, 47.

16 Playing cards were not invented in Italy. The first playing-card pack appeared in Europe in the 1370 s, probably in northern Italy. They were called "najbi" or "naibi" and very rapidly spread over a large part of western Europe. Cf. Dummett and Abu-Deeb, "Some Remarks on Mamluk Playing Cards," 106-28. Cf. also Mayer, "Mamluk Playing Cards," 113-18; Ettinghausen, "Further Comments," 51-78. On Tarots, cf. Klein, "Les Tarots enluminés," 10-17 and 51-52; Dummett and McLeod, A History of Games.

17 Farley, A Cultural History of Tarots, 6-7.

18 Olsen, Carte da Trionfi, 1994.

19 Dummett, The Visconti-Sforza Tarot Cards, 1-2.

20 Giusto Giusti exported tarots which were offered to Sigismondo Pandolfo Malatesta, lord of Rimini. The original entry for 16 September 1440 reads: Venerdi a dì 16 settembre donai al magnifico signore messer Gismondo un paio di naibi a trionfi, che io avevo fatto fare a posta a Fiorenza con l'armi sua, belli, che mi costaro ducati quattro e mezzo. Cf. Newbigin, ed., "I Giornali di ser Giusto Giusti d'Anghiari," 66. The documents related to ser Giusto have been already transcribed by Ricciardi, Feste e giochi cavallereschi.

21 On Rome, cf. Esch and Esch, "Aus der Frühgeschichte," 41-53.

22 On Belgian, French, and Swiss tarots, cf. Hoffmann and Dietrich, Tarot-Tarock-Tarocchi; Depaulis, "The Tarot de Marseille," 101-20. On Spanish, German, Austrian, Bohemian, and Czechoslovakian tarots, cf. Fournier, Playing Cards.

23 De Giorgio, "I tarocchi in Italia," 51-70; Pratesi, "Florentine Card-makers," 126-35.

24 Pratesi, "Tarot in Florence," 78-83.

25 Archivio di Stato di Firenze, Sentenze dei conservatori delle leggi, no. 86, fol. 10 (20 May 1471).

26 Burlamacchi, Vita del P. F. Girolamo Savonarola. Cf. also Pratesi, "On the Introduction of Playing Cards," 107-12.

27 Pratesi, Giochi di carte.

28 Pratesi, "In Search of Tarot Sources," 95-114.

29 Ibidem, 106.

30 Ibidem; idem, "Carte da gioco," 7-17.

31 Schmidt, "The Multiple Image."

32 Ibidem, 44-47.

33 The paper of all the sheets is 100 grams per square centimeter. It is handmade, with no filigrees. The cover was in leather. The inner support was formed by the playing cards sheets and three folios of parchment, with thirteenth-century initials in blue and red ink, all stuck together with a glue made of flour and water (per the written communication of the restorer, 24 September 2016).

34 On the Rosenwald Sheets, cf. Algeri, “Tarocchi Rosenwald," 88. According to Algeri, the three Rosenwald sheets belong to different iconographic traditions. While figures and numerals share many elements with the Florentine "Minchiate," the Triumphs are closer to Ferrarese illuminated productions, such as the so-called "Tarots of Charles VI," though in a more "popular" form.

35 The playing card deck was exhibited in 2012 in Milan. On the Crippa Deck, cf. Milano, ed., Giochi da salotto.

36 For the acanthus motif in architecture, sculpture, painting, and illumination: Vandi, $\mathrm{La}$ trasformazione del motivo dell'acanto; eadem, "Sulle tracce di una tradizione della natura," 7-39.

37 For the images: Omodeo, “Tarocchi fiorentini," 52, fig. 4 (Masi collection) and 55, fig. 17.

38 Moakley, The Tarot Cards; Ortalli, “The Prince and the Playing Cards," 175-205; Zucker, "The Master of the 'Sola-Busca Tarocchi,"” 181-94. 
39 Kristeller, Kupferstich und Holzschnitt.

40 Field, "Early Woodcuts," 20.

41 On this sheet, similar to another at Leinfelden-Echterdingen, Deutsches Spielkartenmuseum, B 1006, cf. Pratesi, "Il terzo foglio Rosenwald" (27 June 2016), www.naibi.net/A/ 516-ROSEN3-Z (accessed August 2019).

42 Franco Pratesi, "Rosenwald's Fourth Sheet" (24 November 2011), www.naibi.net/A/ 103-ROSENW-Z (accessed June 2019).

43 Fersin, The Florentine Fior di Virtu; Donati, "Le vicende," 175-207.

44 Rosenwald, ed., The Florentine Fior di Virtù, foreword.

45 Grendler, "Form and Function," 451-85.

46 Bühler, "Studies in the Early Editions," 315-39.

47 On the topic, cf. www.forum.tarothistory.com/viewtopic.php? $t=1105 \& p=18343$; Franco Pratesi, "1501-1521: Carte da Perugia e città vicine" (5 January 2017), www.naibi. net/A/601-UMBRIA-Z.pdf (accessed September 2019).

48 Pratesi, "1510 ca.: Assisi-Mazzo completo di 48 carte” (22 December 2016), www.naibi. net/A/526-ASSISI-Z.pdf (accessed September 2019).

49 Crippa Playing Card Deck, Milan, Giuliano Crippa Collection, 48 cards complete, $4.9 \times 9 \mathrm{~cm}$ each card, paper. Central Italy, late fifteenth to first quarter of the sixteenth century. Cups, Coins, Batons, Swords, Ace and 2 to 9, two pages, two maids, four centaurs, and four kings.

50 Vitali and Zanetti, Il Tarocchino di Bologna.

51 Ibidem, 25, fig. 2.

52 On the Bolognini Chapel in San Petronio and Giovanni da Modena: Filippini, "Gli affreschi," 193-214; Benati and Medica, eds., Giovanni da Modena.

53 Vitali and Zanetti, Il Tarocchino di Bologna, 24.

54 Graham, The Discovery of France, chap. 12.

55 As in the Liechtenstein Playing Cards of 1440-50, now at the Louvre, with upper and under knaves of Swords, Batons, Cups, and Coins, the Batons are used in a specific naturalistic context, just as the stilt man in the Urbino Sheet No. 3. Cf. Hoffmann, Altdeutsche Spielkarten, 20, fig. 6; Also Husband, The World in Play, 47, fig. 48.

\section{Bibliography}

Algeri, Giuliana. “Tarocchi Rosenwald.” In Le carte di corte: I Tarocchi: Gioco e magia alla corte degli Estensi, eds. Giordano Berti and Andrea Vitali. Bologna: Nuova Alpha Editoriale, 1987.

Alligo, Pietro. Tarocchi dal Rinascimento a oggi. Exhibition catalogue, Turin, Museo Ettore Fico, 4 October 2017-14 January 2018. Turin: Lo Scarabeo, 2017.

Benati, Daniele, and Massimo Medica, eds. Giovanni da Modena: Un pittore all'ombra di San Petronio. Cinisello Balsamo, MI: Silvana Editoriale, 2014.

Berti, Giordano. Tarocchi: le carte del destino. Faenza: Edizioni Le Tarot, 1988.

Berti, Giordano, and Andrea Vitali, eds. Le carte di corte: I Tarocchi: Gioco e magia alla corte degli Estensi. Bologna: Nuova Alpha Editoriale, 1987.

Bühler, Curt F. "Studies in the Early Editions of the 'Fiore di Virtù'." The Papers of the Bibliographical Society of America, 49/4 (1955): 315-39.

Buren, Anne H. van, and Sheila Edmunds. "Playing Cards and Manuscripts: Some Widely Disseminated Fifteenth-Century Model Sheets.” The Art Bulletin, 56 (1974): 12-30.

Burke, Peter. Popular Culture in Early Modern Europe. Farnham: Ashgate, 2009.

Burlamacchi, Pacifico Padre. Vita del P. F. Girolamo Savonarola dell'Ordine de Predicatori scritta dal P. F. Pacifico Burlamacchi-Lucchese dello stesso ordine e famigliare del medesimo. Lucca: Jacopo Giusti, 1764.

De Giorgio, Nicola Antonio. "I tarocchi in Italia, tarocchini e minchiate." In Tarocchi dal Rinascimento a oggi, ed. Pietro Alligo, 51-70. Turin: Lo Scarabeo, 2017.

Depaulis, Thierry. "L'apparition de la xylographie et l'arrivée des cartes à jouer en Europe." Nouvelles de l'estampe, 185/186 (2003): 7-19. 
Le Tarot révélé. La Tour-de-Peilz: Musée Suisse du Jeu, 2013.

. "The Tarot de Marseille-Facts and Fallacies." The Playing-Card, 42/2 (2013): 101-20.

Donati, Lamberto. "Le vicende del 'Fior di virtù'.” La Bibliofilia, 76/3 (1974): 175-207.

Dummett, Michael, and Kemal Abu-Deeb. "Some Remarks on Mamluk Playing Cards." Journal of the Warburg and Courtauld Institutes, 36 (1973): 106-28.

Dummett, Michael, and John McLeod. The Visconti-Sforza Tarot Cards. New York: George Braziller, 1986.

—. "Sulle origini dei Tarocchi popolari." In Le carte di corte: I Tarocchi: Gioco e magia alla corte degli Estensi, eds. Giordano Berti and Andrea Vitali, 58-65. Bologna: Nuova Alpha Editoriale, 1987.

- A History of Games Played With the Tarot Pack: The Game of Triumphs. Vols. 1-2. Lewiston, NY: Edwin Mellen Press, 2004.

Esch, Arnold, and Doris Esch. "Aus der Frühgeschichte der Spielkarte: Der Import von 'carte da giocare' und 'trionfi' nach Rom 1445-1465.” Gutenberg-Jahrbuch, (2013): 41-53.

Ettinghausen, Richard. "Further Comments on Mamluk Playing Cards." In Gatherings in Honor of Dorothy E. Miner, eds. Ursula E. McCracken, Lilian M. C. Randall, and Richard H. Randall Jr., 51-78. Baltimore: The Walters Art Gallery, 1973.

Farley, Helen. A Cultural History of Tarots: From Entertainment to Esotericism. London and New York: I.B. Tauris, 2009.

Fersin, Nicholas. The Florentine Fior di Virtù of 1491: With Facsimiles of All the Original Wood Cuts. Philadelphia: Stern, 1953.

Field, Richard S. "Early Woodcuts: The Known and the Unknown." In Origins of European Printmaking: Fifteenth-Century Woodcuts and Their Public, eds. Peter Parshall and Rainer Schoch, 19-35. New Haven: Yale University Press, 2005.

Filippini, Francesco. "Gli affreschi della cappella Bolognini in San Petronio." Bollettino d'Arte del Ministero della Pubblica Istruzione, 10/7-8 (1916): 193-214.

Fournier, Felix Alfaro. Playing Cards: General History from Their Creation to the Present Day: Fournier Museum. Vitoria: Heraclio Fournier, 1982.

Graham, Robb. The Discovery of France: A Historical Geography from the Revolution to the First World War. London: Picador, 2007.

Grendler, Paul F. "Form and Function in Italian Renaissance Popular Books." Renaissance Quarterly, 46/3 (1993): 451-85.

Gurevič, Aron J. The Categories of Medieval Culture. London: Routledge, 1985.

Hoffmann, Detlef, ed. Altdeutsche Spielkarten: 1500-1650. Katalog der Holzschnittkarten mit deutschen Farben aus dem Deutschen Spielkarten-Museum Leinfelden-Echterdingen und dem Germanischen Nationalmuseum Nürnberg. Nuremberg: Germanisches Nationalmuseum, 1993.

Hoffmann, Detlef, and Margot Dietrich. Tarot-Tarock-Tarocchi: Tarocke mit italienische Farben. Marburg: Jonas Verlag, 1988.

Husband, Timothy B., ed. The World in Play: Luxury Cards 1430-1540. Exhibition catalogue, New York, The Met. New Haven: Yale University Press, 2015.

Klein, Robert. "Les Tarots enluminés du XV siècle." L'CEil, 145 (1967): 10-17.

Körner, Hans. Der Früheste deutsche Einblattholzschnitt. Mittenwald: Mäander Kunstverlag, 1979.

Kristeller, Paul Oskar. Kupferstich und Holzschnitt in vier Jahrhunderten. Berlin: Bruno Cassirer, 1911.

Kühn, Thomas, ed. Populärkultur: Perspektiven und Analysen. Bielefeld: Transcript, 2017.

Landau, David, and Peter W. Parshall, eds. The Renaissance Print, 1470-1550. New Haven: Yale University Press, 1994.

Mayer, Leo Ari. "Mamluk Playing Cards." Bulletin de l'Institut français d'archéologie orientale, 38 (1939): 113-18.

Milano, Alberto, and Giuliano Crippa. Giochi da salotto e giochi d'osteria nella vita milanese dal Cinquecento all'Ottocento. Exhibition catalogue, Milan, Palazzo Morando, December 2012-March 2013. Milan: Mazzotta, 2012. 
Moakley, Gertrude. The Tarot Cards Painted by Bonifatio Bembo for the Visconti-Sforza Family: An Iconographic and Historical Study. New York: New York Public Library, 1966.

Muchembled, Robert. Culture populaire et culture des élites dans la France moderne (XV $V^{e-}$ XVII ${ }^{e}$ siècles). Paris: Flammarion, 1977.

Newbigin, Nerida, ed. "I Giornali di ser Giusto Giusti d'Anghiari (1437-1482).” In Letteratura italiana antica, Vol. 3, 41-246. Pisa and Rome: Fabrizio Serra Editore, 2002.

Olsen, Christina. Carte da Trionfi: The Development of Tarot in Fifteenth-Century Italy. Ph.D. dissertation, University of Pennsylvania, Philadelphia, 1994.

Omodeo, Anna. "Tarocchi fiorentini." Antichità Viva, 7 (1968): 50-57.

Ortalli, Gerardo. "The Prince and the Playing Cards: The Este Family and the Role of Courts at the Time of the Kartenspiel-Invasion.” Ludica: Annali di storia e civiltà del gioco, 2 (1996): 175-205.

Pratesi, Franco. "Tarot in Florence in the XVI Century: Its Diffusion from Literary Sources." The Playing-Card, 16/3 (1988): 78-83.

- "On the Introduction of Playing Cards in Florence." The Playing-Card, 17/3 (1989): 107-12.

—. "Carte da gioco a Firenze: il primo secolo (1377-1477)." The Playing-Card, 19/1 (1990): 7-17.

— "Florentine Card-makers and Concession Holders." The Playing-Card, 21/4 (1993): $126-35$.

—. "In Search of Tarot Sources-After Fifteenth Years." The Playing-Card, 41/2 (2012): 95-114.

—. "1377: Firenze-Condanne ai giocatori di naibi." The Playing-Card, 44/3 (2015): $166-73$.

—. "1499-1506: Firenze-Nuove informazioni sulle carte fiorentine." Playing-Card, 44/1 (2015): 61-71.

- Giochi di carte nel Granducato di Toscana. Ariccia: Aracne, 2015.

- Giochi di carte nella repubblica fiorentina. Ariccia: Aracne, 2016.

- Playing-Card Production in Florence. Tricase: YouCanPrint, 2018.

Rebel, Ernst. "Die Entwicklung der grafischen Techniken im 15. Jahrhundert.” Kunsthistorische Arbeitblätter, 3 (1999): 45-58.

Ricciardi, Lucia. Feste e giochi cavallereschi nella Firenze laurenziana attraverso le memorie di Ser Giusto di Giovanni Giusti d'Angiari. Tesi di Laurea, Facoltà di Magistero, Università di Firenze, a.a. 1990-91.

Rosenfeld, Hellmut. "Wann und wo wurde die Holzschnittkunst erfunden? Papier-Zugänglichkeit, Zeugdruck-Kenntnis und Kartenspiel-Invasion als Voraussetzungen.” Archiv für Geschichte des Buchwesens, 34 (1990): 327-42.

Rosenwald, Lessing J., ed. The Florentine Fior di Virtù of 1491. Washington: Library of Congress, 1953.

Schmidt, Peter. "The Multiple Image: The Beginnings of Printmaking, Between Old Theories and New Approaches." In Origins of European Printmaking, Fifteenth-Century Woodcuts and Their Public, eds. Peter Parshall and Rainer Schoch, 37-56. New Haven: Yale University Press, 2005.

Schreiber, Wilhelm Ludwig, and Paul Heitz. Die ältesten Spielkarten und die auf das Kartenspiel bezug habenden Urkunden des 14. und 15. Jahrhunderts. Strassburg: J.H.E. Heitz, 1937.

Singer, Samuel Weller. Researches Into the History of Playing Cards; With Illustrations of the Origin of Printing and Engraving on Wood. London: R. Triphook, 1816.

Vandi, Loretta. "Carte da gioco e manoscritti: Note sul rapporto tra miniatura quattrocentesca e incisione in area romagnola." Studi Romagnoli, 49 (1998): 123-38.

—. "Sulle tracce di una tradizione della natura: Rilettura del fregio ornamentale dell'Ara Pacis Augustae." Acta ad archaeologiam et artium historiam pertinentia, XI (1999): 7-39.

- La trasformazione del motivo dell'acanto dall'antichità al XV secolo: Ricerche di teoria e storia dell'ornamento. Bern: Peter Lang, 2002. 


\section{Loretta Vandi}

Il Manoscritto Oliveriano 1: Storia di un codice boemo del XV secolo. Aletheia series, Biblioteca Oliveriana Pesaro. Urbania: STIBU, 2004.

. "Re-forming Images Through Lettering: Savonarola's Heritage in a Corpus of Sixteenth-

Century Woodcuts in the Biblioteca Statale, Lucca." In The Lettering of Prints: Forms and Functions of Writing in the Printed Image in the Sixteenth-Century Europe, eds. Marianne Grivel and Emmanuel Lurin. Bern: Peter Lang, forthcoming.

Vitali, Andrea. "La nascita dei Tarocchi." In Tarocchi dal Rinascimento a oggi. Exhibition catalogue, Turin, Museo Ettore Fico, 4 October 2017-14 January 2018, ed. Pietro Alligo, 27-33. Turin: Lo Scarabeo, 2017.

Vitali, Andrea, and Terry Zanetti. Il Tarocchino di Bologna: Storia, Iconografia, Divinazione dal XV al XX secolo. Bologna: Edizioni Martina, 2005.

Zucker, Mark J. "The Master of the 'Sola-Busca Tarocchi' and the Rediscovery of Some Ferrarese Engravings of the Fifteenth Century." Artibus et Historiae, 35 (1997): 181-94. 


\title{
3 Cultivating Designs \\ Early Ornamental Prints and \\ Creative Reproduction
}

\author{
James Wehn
}

Among the introductory pages of a manuscript recounting Polish King Władysław III's crusade against the Ottoman Empire, Hartmann Schedel (German, 1440-1514) pasted a small, hand-colored woodcut of Mary and the Christ Child sitting in a flower (Plate 5). ${ }^{1}$ Schedel, a physician and scholar, gave the image a simple blue and red frame, below which he inscribed in the same color inks a Latin prayer to the Virgin, requesting peace, protection from Turks and infectious disease, and good crops for farmers. ${ }^{2}$ The woodcut was itself a sort of harvest, cut from the stem of an ornamental Jesse Tree, a visual representation of Christ's genealogy from Jesse, the father of King David, to Mary, printed in the margin of an almanac for the year 1496 by Kaspar Hochfeder in Nuremberg. ${ }^{3}$ The iconography alludes to Isaiah 11:1, which, according to Christian belief, prophesies the coming of the Messiah using the metaphor of a tree: "A shoot will come up from the stump of Jesse; from his roots a Branch will bear fruit." ${ }^{4}$ In symbolically plucking this printed fruit to nourish his own spiritual concerns, Schedel extended the biblical metaphor in a creative act made possible by the mutability of the medium.

Yet for Schedel, the fruitfulness of the almanac's woodcut went beyond its theological meaning to include its ornamental form. Turning the page of the manuscript, one discovers two more fragments of the woodcut worked into a decorative collage pasted on an otherwise empty page (Plate 6). Schedel further trimmed the image, removing Jesse and most of David from the bottom, split the remainder in half, and pasted the two pieces side by side with another foliate woodcut from a different broadside. Having removed its main iconographic features, Schedel engaged with the Jesse Tree's formal characteristics, an aesthetic interaction reflected in his clipping and alignment of the woodcut fragments, and also in his addition of red and blue lines to frame the composition. Hartmann Schedel created a work that is decorative for the sake of decoration.

I find several aspects of Schedel's response to this woodcut remarkable: foremost that his deconstruction of the image indicates an understanding that, by definition, ornament privileges form over function and, related, that decorative design could be appreciated as an independent work of art. ${ }^{5}$ That is not to say that printed material featuring ornamental decoration were absent of meaning; Schedel's extraction and use of the Virgin and Child from the Jesse Tree ornament clearly shows they were not. Yet in the final decades of the fifteenth century, there was a market for prints featuring foliate compositions-as for example, Ornamental Engraving with the Jesse Tree (Lehrs IX.618; Figure 3.1) by the goldsmith-engraver Israhel van Meckenem (German, c. 1440/45-1503) — that functioned principally as demonstrations in the field of decoration and design. ${ }^{6}$ I assert that to this end, printmakers like Israhel used ornament as 


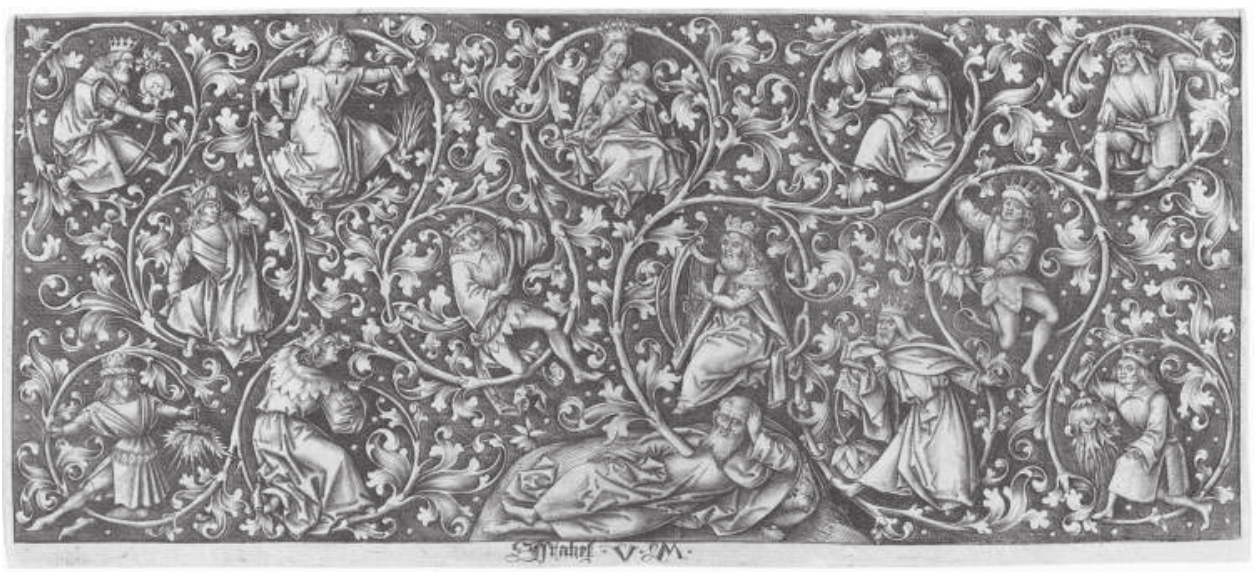

Figure 3.1 Israhel van Meckenem, Ornamental Engraving with the Jesse Tree, c. 1490, engraving. Washington, National Gallery of Art, 1943.3.169.

Photo: Courtesy National Gallery of Art, Washington.

a means to promote contemporary ideas about artistry and image making, and used subjects with generative potential like the Jesse Tree to convey that concept. Stylized branch and leaf-work combined with human figures, animals, and flowers conveyed ideas of fertility and abundance, and thus served as metaphors for artistic productivity.

To build this case, I explore the late fifteenth-century market for prints featuring vegetal designs, considering especially those by Israhel van Meckenem, active mainly in Bocholt from the 1460s until his death in 1503, as well as their reception by his contemporary, Hartmann Schedel, who lived and worked in Nuremberg. Israhel's cultivation of a market for these works, from simple pattern prints to increasingly elaborate decorative engravings, supported long-standing workshop practices involving the selection and copying of existing images in the formulation of new works. Schedel's use and modification of vegetal designs followed a similar process, thus indicating that the images prompted comparable creative responses outside the traditional workshop.

My use of the terms 'reproduction' and 'reproductive' throughout this chapter does not conform to the standard art historical definition of the 'reproductive print,' which generally denotes a category of prints that represent other objects or works of art with some promise of verisimilitude. ${ }^{7}$ Rather, I use 'reproductive' in an organic sense, with the intention of comparing artists' copying, adaptation, and hybridization of printed images with some aspects of horticulture. I do so to propose-especially within the context of this volume examining characteristics of response-a philosophical framework that portrays the copying practices of the artists discussed in this chapter while also resisting the application of a value system, as yet undeveloped in the late 1400s, that privileges a hierarchical distinction between original and copy. The extant examples of copied ornaments, many with unknown makers and uncertain dates, proves neither authorship nor the chronology of their production. What these prints do reveal, however, is a repetitive process of creation fostered by the multiplication and modification of their images throughout a network of cities within a relatively short period of time. To be clear, I am not asserting that artists or Schedel considered ornamental image-making analogous with gardening. Yet I do find plant cultivation to be a useful metaphor 
for contemplating the evidence of their work, and one that is sustained by procreative iconography featured in vegetal ornaments, Schedel's reception of this imagery, and occasionally by language used in contemporary sources to describe creativity.

Schedel is remembered foremost for authoring The Nuremberg Chronicle, published in Nuremberg in 1493, but he is also known for his extant print collection, which is the earliest known group of prints assembled by an individual in Northern Europe. ${ }^{8}$ It is not a true 'collection' of the type that later formed in the sixteenth century, whereby affluent persons amassed prints as objects of art to be appreciated, organized, and preserved in albums or drawers as part of their Kunstkammern. ${ }^{9}$ If Schedel did own an album dedicated only to prints as fine art, it has not survived. ${ }^{10}$ The extant evidence shows that Schedel was more an active consumer of prints than a collector, a reality that offers greater insight into the reception and use of prints than other early collections. ${ }^{11}$ Schedel acquired at least 300 works on paper, 43 of which are drawings and miniatures, and the rest are woodcuts, metalcuts, engravings, and a few paste prints. ${ }^{12} \mathrm{He}$ incorporated them, including fifteen engravings by Israhel, into manuscripts and books. ${ }^{13}$ Often, the prints served a devotional purpose, but Schedel sometimes embellished particular texts with thematically appropriate engravings, for example, an ornament by the monogrammist ih with vegetation and birds (Lehrs VII.1), which Schedel used for his introduction to Macer floridus, an herbal manual for apothecaries and doctors. ${ }^{14}$ Opposite the opening text of Ruralia commoda, a work about agriculture, Schedel pasted Israhel's copy of a whimsical ornament with a farmer picking fruit after the Master of the Berlin Passion (Lehrs IX.609). ${ }^{15}$ His playful adaptation of the Jesse Tree woodcut suggests that he viewed and comprehended ornamental compositions much like contemporary artists did (Plate 6).

Similar to Schedel's decorative collage, Israhel's Ornamental Engraving with the Jesse Tree, probably created several years earlier around 1490, erodes iconographic meaning in favor of design (Figure 3.1). ${ }^{16}$ Though all the main features are present, after the stout vine grows from the sleeping figure of Jesse and encircles David with his harp, the logic of the family tree swiftly breaks down. The central vine continues directly to Mary and the Christ Child in the upper center, before continuing left to wind around six generations of kings. On the right side, David's stem separately traces the lineage of five more monarchs. Rather than forebears of Mary and Christ, the sovereigns appear to be either descendants or distant cousins. Israhel's engraving, with its mesmerizing pattern of circling branches, curling leaves, and panoply of acrobatic kings, is an exercise in imaginative decorative design, a composition invented for visual delight rather than a clear articulation of Christ's ancestry.

Indeed, The Tree of Jesse is one of several ornamental engravings Israhel produced around the same time, each presenting a dazzling array of branch and leaf-work combined with a theme broadly related to human procreation. Identical in size and orientation, Israhel's Ornamental Engraving with Morris Dancers (Lehrs IX.617; Figure 3.2) forms a pendant to The Tree of Jesse. While sharing similar configurations, the two engravings contrast honorable, God-ordained procreation with the pleasures and risks of sexual desire. In the Morris Dancer ornament, flamboyantly dressed men perform a popular Shrovetide entertainment, excitedly wigwagging among thornstudded branches, as they compete for the attention of a maiden who tempts them, like Eve, with a piece of fruit.

In the history of Northern European printmaking, this line of engravings, which also includes Ornamental Engraving with Two Lovers (Lehrs IX.619) and Ornamental Flower with Eight Wild Folk (Lehrs IX.624), exemplifies a decisive effort to 


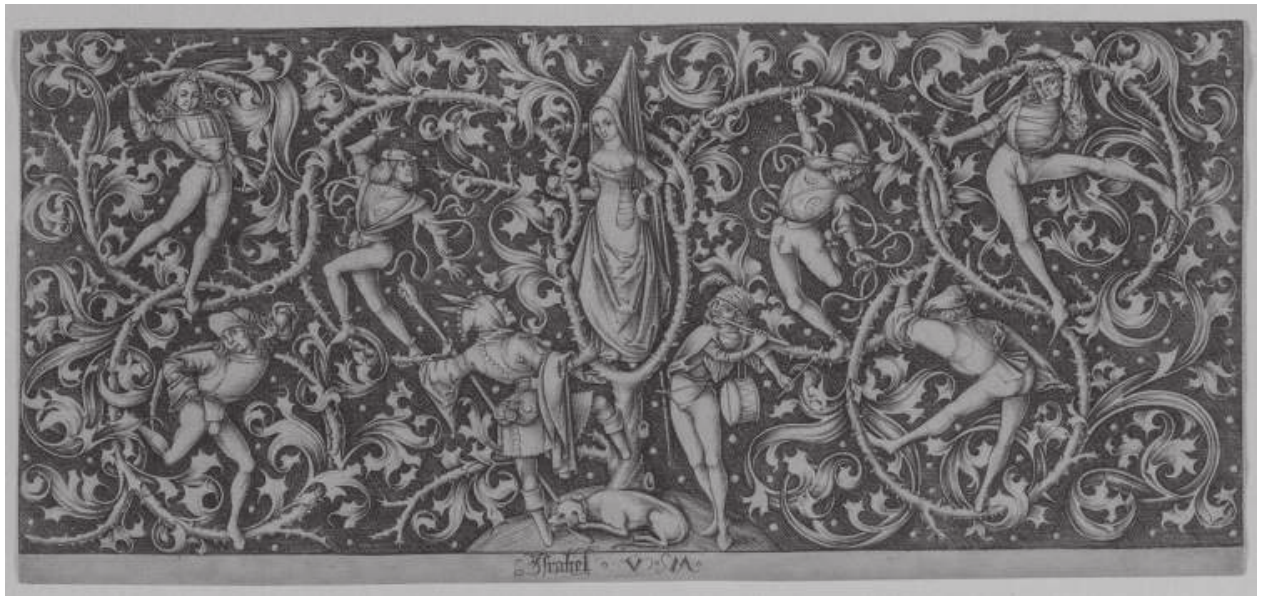

Figure 3.2 Israhel van Meckenem, Ornamental Engraving with Morris Dancers, c. 1490, engraving. Cleveland Museum of Art, 1952.532.

Photo: Cleveland Museum of Art, CC0 1.0.

produce decorative prints that served both as design templates and self-contained, pictorial compositions. ${ }^{17}$ Moreover, scholars generally agree Israhel's late ornamental engravings represent his most masterful and inventive works, a distinction especially emphasized because Israhel, while the most prolific printmaker in Europe during his lifetime, appropriated most of the images he published. ${ }^{18}$ The paradox generated by Israhel's copying habit and his often prescient development of new subject matter in printed form has led to his description as an entrepreneur with a keen awareness of popular culture and the marketability of different types of prints. ${ }^{19}$

Looking at the broader market for printed materials, it is clear Israhel's late ornaments coincide with the proliferation of similar woodcut images used to decorate broadsides and book illustrations. Ornamental leaf-work was popular on annual almanacs, which included dates for holidays, tables of new and full moons, and the best days for bloodletting according to the movements of planets and stars. ${ }^{20}$ Typically printed in anticipation of the New Year, these full-page calendars often featured depictions of Christ's nativity and New Year's greetings. Within the space of the margins, vertical and horizontal bands of decorative branches, leaves, and flowers further emphasized themes of birth and regeneration.

In semiotic terms, these ornaments' botanical forms signified nature and gardens, which were, in turn, potent signs of fecundity associated with courtly love, natural sexual desire, and, of course, the Garden of Eden. ${ }^{21}$ This archetypal paradise at the heart of God's creation was the location of the trees of Life and Knowledge, where the cataclysmic fall of Adam and Eve brought sin and death into the world. The hortus conclusus, or enclosed garden, symbolized the enduring purity of the Virgin Mary's womb, while also describing an Eden-like contemplative space in which a personal encounter with God remained a possibility. ${ }^{22}$

Israhel addressed his own relationship with God in an unusual work known today as Ornamental Engraving with the Engraver's Name (Lehrs IX.620; Figure 3.3), in which he spelled out his first name-ISRAHEL-and his last initial M, turned ninety 


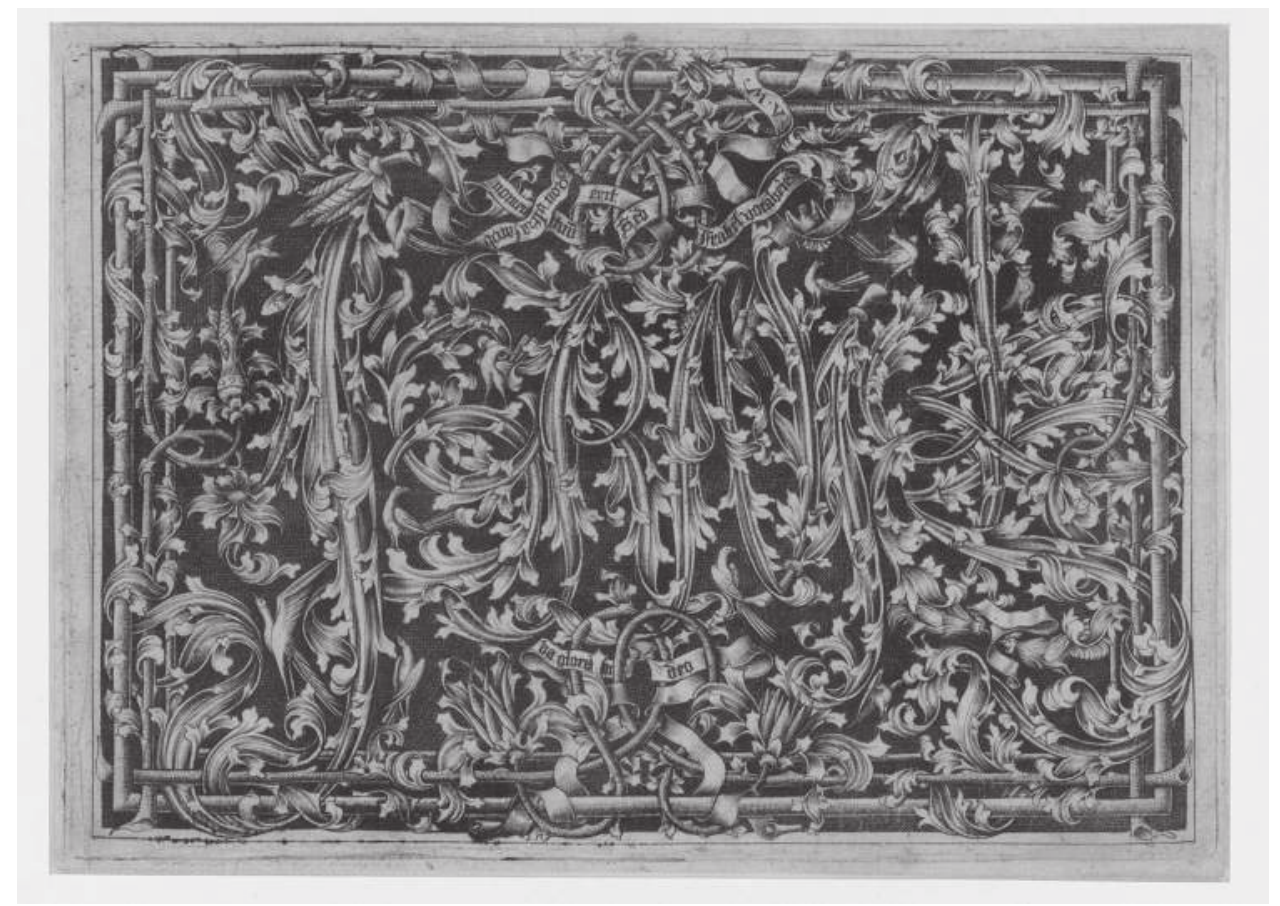

Figure 3.3 Israhel van Meckenem, Ornamental Engraving with the Engraver's Name, c. 1490, engraving. Berlin, Staatliche Museen zu Berlin, Kupferstichkabinett, 45-1884.

Photo: Dietmar Katz.

degrees, with a flourish of ornamental leaves. Around the perimeter, the foliage intertwines a frame of thinly honed and mitered wood, plaited with flower stems bent into decorative knots. At the top and bottom of the image, banderoles with Latin text ripple through the knots and surrounding leaves. The lower banderole contains the phrase da gloriam Deo, "give glory to God," while the upper one paraphrases the biblical verse Genesis 35:10, in which God speaks to Jacob saying, "no longer will your name be Jacob, but Israel." ${ }^{23}$ The meandering banderole eventually reveals the letters 'V. M.,' thereby completing an often-used version of the printmaker's signature (Israhel v. M.), in this one instance with his first name embedded in the biblical verse.

It is difficult to determine precisely what message Israhel intended to convey by referring to Genesis 35:10. The verse is part of a passage in which Jacob builds an altar and God appears to Jacob, blesses him, names him Israel, and tells him to be fruitful and multiply. This divine revelation is Jacob's third of three face-to-face encounters with God, beginning with Jacob's dream of a ladder to the Lord in heaven (Genesis 28:10-14); next, wrestling with an angel of God, who is the first to call him Israel because he 'fought' or 'struggled' with God (Genesis 32:24-32); and finally, when God appears to Jacob and speaks the words cited in the engraving. Christian theologians interpreted these episodes somewhat differently, but consistently perceived Jacob's visions of God as a prophecy of humankind's salvation through Christ. ${ }^{24}$

Considering that Israhel specifically chose to emphasize God's renaming of Jacob in the upper banderole's inscription, Augustine's well-known commentary for Genesis 
35:10, referenced in Anton Koberger's 1481 publication of the Glossa Ordinaria, offers some insight into the theological significance the names 'Jacob' and 'Israel' likely held for the engraver and his contemporaries. Augustine reasoned that that the name 'Jacob' represents a Christian's earthly, perishable body, while the name 'Israel' signifies the promise of an immortal world in which the ultimate reward is a vision of God. ${ }^{25}$

In creating the name engraving and equating himself with the Old Testament patriarch, Israhel proposed to symbolically emulate his namesake: he built an altar-the engraving itself, which faithfully praises God in the lower banderole's inscription. In so doing, the engraver strived for salvation-a vision of God like Jacob experiencedand presented himself as a successor of God's directive for Jacob: "be fruitful and multiply." Further supporting this interpretation is the commentary for this instruction (Genesis 35:11) in Koberger's Glossa Ordinaria, which prescribes the emulation of Jacob's faith and action as a means to spiritual fecundity: "the spiritual seed, that is the imitation of faith, is fertilized in good works." ${ }^{26}$ Israhel chose the formula of the ornamental print as a means to summarize his identity in name, profession, and spiritual life and to demonstrate his God-given creative potency. ${ }^{27}$ As a print, this work is the figurative multiplication of the engraver's fruitfulness. ${ }^{28}$

A hand-colored example of Israhel's Man of Sorrows in the Letter O (Lehrs IX.162) in another of Schedel's manuscripts also linked ornate foliage with the printmaker's name (Plate 7). ${ }^{29}$ The wide margin between the image and plate mark was filled with a layer of pale green pigment, carefully brushed around the engraver's ornately inscribed signature, which was tinted red and further emphasized with red vines, now heavily abraded. Although simpler than Israhel's leaf-work, these added vines echo the foliage within the $\mathrm{O}$, where leaves originate from points Schedel himself likely augmented with red: a flower below the globe, the benediction hand, and the woundbearing Christ. ${ }^{30}$ Likewise, the vines in the margin begin at Israhel's signature, climb around the image, and eventually transition to an arc of flowers that complete the frame. As Israhel's foliate decoration emphasizes the devotional icon's promise of eternal life, so, too, does the hand-applied design highlight 'Israhel' as the icon's maker.

Each work involving ornate vegetation was, in a sense, a different garden, cultivated following a basic formula within which artists might generate an infinite number of similar yet varied compositions. The main components appear in playing cards and pattern prints featuring varieties of leaves, flowers, animals, and people (Figure 3.4). Evidence shows that Israhel produced these model prints through a deliberate process of selection and reproduction, and also used those gathered specimens in the formulation of more complex ornaments. For example, his pattern sheet Ornamental Flowers and a Chimeric Animal (Lehrs IX.599; Figure 3.5) includes samples he appropriated from at least three separate sources: the border of a Mass of Saint Gregory by the Master of the Berlin Passion (Lehrs III.65), several flowers from the dense ornamental frame of Saint John by Master ES (Lehrs II.149), and the large pumpkin-like blossom from Martin Schongauer's Ornamental Engraving with Parrots and Other Birds (Lehrs V.109).. ${ }^{31}$ Israhel also incorporated several flowers from the pattern sheet in his Ornamental Engraving, Christ and Saint John as Children Accompanied by Two Angels (Lehrs IX.600) and Ornamental Engraving with Seven Birds (Lehrs IX.613).

Israhel's selection and reproduction of flowers and leaves in copper plates follows a process described by Shira Brisman in her article about pattern prints as harvestable cultivars. Brisman analyzed the verb reißen, which in modern German means 'to tear,' 'rip,' or 'crack,' but was previously used to describe the formation of an 


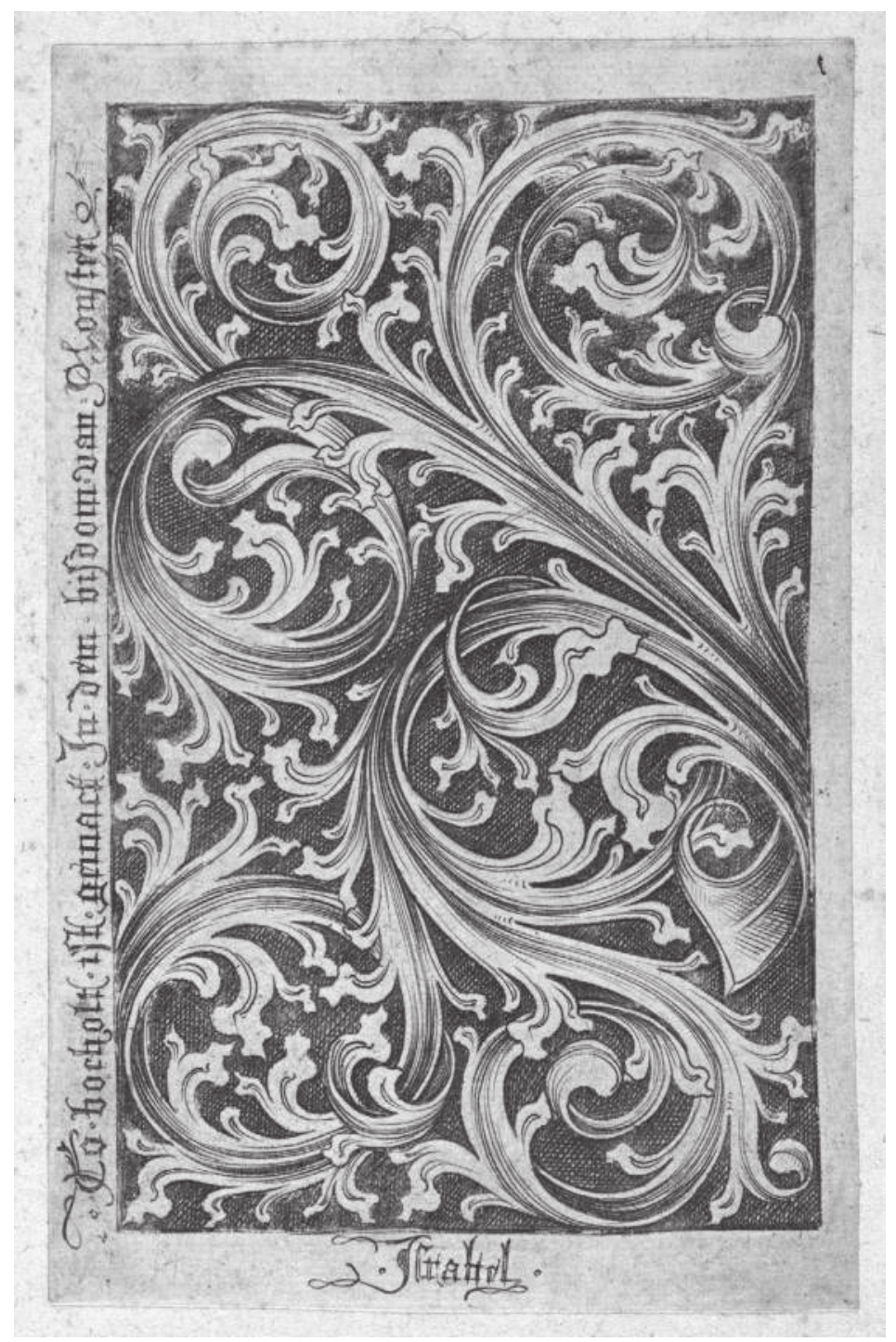

Figure 3.4 Israhel van Meckenem, after Master ES, Ornamental Engraving, Foliage on Black Ground, c. 1476, engraving. Cambridge, Fitzwilliam Museum, 22.I.2-72.

Photo: ( Cambridge, Fitzwilliam Museum.

image. ${ }^{32}$ Reißen is the verb Dürer used in the often-quoted passage about ingenuity in his Aesthetic Excursus:

something one man sketches [reyst] in a day, with a pen on a half-sheet of paper, or engraves with his graver in a little block of wood, will be more artful and excellent than another man's large work, which he makes with great diligence in a whole year. ${ }^{33}$ 
In a later passage, Dürer used reißen, perhaps wittingly, in reference to 'extracting,' or 'drawing out,' art from nature: "For truly art is embedded in nature, and he who can draw it out [herauß kan reyssenn], has it." ${ }^{34}$ Reißen thus indicated the process of selecting or harvesting something, as well as the act of visually reproducing it. ${ }^{35}$ Etymologically, the root word Riß, a 'crevice' or 'fissure,' describes the effect of the chisels and burins used to sculpt wood and metal matrixes, which in turn yielded a crop of multiplied images ready to be harvested and re-planted in a reproductive cycle of image making. ${ }^{36}$

Neither the idea that an image could be intellectual property nor the concept of plagiarism effectively applies to the widespread practice of copying and appropriation that took place during the fifteenth century. ${ }^{37}$ While in the second decade of the $1500 \mathrm{~s}$, Albrecht Dürer perceived a need to legally assert ownership of his printed compositions, just a few decades earlier, the rapid growth of the print market and the visual culture it stimulated hinged upon the swift response of printmakers who copied and reissued popular images as woodcuts and engravings. ${ }^{38}$ In turn, the multiplication of these images extended-both in whole and in part-to other media, such as metal, wood, textiles, and painting. Far from mechanical, this cyclical process of production and response was firmly anchored in the workshop tradition of the Musterbuch, or pattern book. Masters also collected drawings for the workshop to use as models, and prints served the same function.

A manuscript illuminator working in the lower Rhine region early in the sixteenth century had a cache of engravings that he used as inspiration for two pages in an antiphonary dated 1518 in the Universität- und Landesbibliothek Düsseldorf. ${ }^{39}$ The manuscript begins with the antiphon Ecce nomen Domini venit for the first Sunday of Advent (Prima dominica adventus), marking the beginning of both the annual church calendar and the season observed in anticipation of the celebration of Christ's birth (Plate 8). ${ }^{40}$ This opening page features a brightly colored ornamental Jesse Tree incorporating elements from no fewer than five engravings by Israhel. The figure of Jesse in the lower right corner and twelve of the kings arranged in the top, bottom, and right margins derive from Ornamental Engraving with the Jesse Tree (Figure 3.1). The illuminator copied the figures closely, making only a few minor changes: he reversed the king that appears in the upper left corner of the engraving, slightly altered David's mantle, and gave him a scepter rather than a harp. As in the engraving, each king poses within a circling vine that stylistically emulates, but does not precisely copy, Israhel's leaf and branch work.

A historiated letter E begins the opening Latin phrase of the antiphon, which translates, "Here the name of God comes from afar and its brightness fills the world." Within the gilded letter, an abridged Jesse Tree includes the Madonna and Child, David, and one king from Israhel's Ornamental Engraving with the Jesse Tree. However, the artist incorporated the figure of Jesse in a smaller engraving with the iconography by Israhel (Lehrs IX.602), presumably to avoid repeating the same model twice on the same page.

Lehrs noted the use of the two Jesse Tree engravings for the antiphon's decoration, but either did not observe or chose not to mention the use of additional pattern prints issued by Israhel. ${ }^{41}$ The miniaturist embellished his design by alternating the kings with large fanciful blossoms, many of which he copied from the ornamental border of Israhel's Garden of Love (Lehrs IX.511), the letter K from the Large Majuscule Alphabet (Lehrs IX.568), and four blooms from Ornamental Design with Five Flowers. ${ }^{42}$ The latter print was initially engraved by Master FVB (and catalogued by Lehrs under this monogram), but later re-published by Israhel with his own initials IVM. ${ }^{43}$ Whether the miniaturist worked from a first-state impression printed before Israhel's 
restrike of the plate is unknown, but his use of this print speaks to the close association of the two engravers within the scope of the marketplace and to the stylistic resemblance of their floral ornaments. ${ }^{44}$

Engravings published by Israhel also served as models for later pages in the antiphonary. The recto of folio 117 features a historiated letter U, which begins the song for the vigil of Saint Andrew. ${ }^{45}$ Within the letter, four blossoms from Master FVB's Ornamental Design with Five Flowers (Lehrs VII.57), possibly the edition printed by Israhel, appear around the saint's iconic X-shaped cross. Additionally, the margins of the page feature more than two dozen floral specimens extracted from the large majuscule letters D, G (reversed), H, K, L, O, Q, and V (Lehrs IX.566-69); the Garden of Love (Lehrs IX.511); Ornamental Engraving, Christ and Saint John as Children Accompanied by Two Angels (Lehrs IX.600); and, again, Master FVB's Ornamental Design with Five Flowers. ${ }^{46}$

Both the antiphonary's opening folio and folio 117 include other fantastical blossoms that do not appear in Israhel's prints but are similar in style and type. They may originate from ornaments or pattern prints by other engravers yet to be identified, from now lost sheets by Israhel or others, or could be the inventions of the illuminator himself. Several blossoms include elements that appear in flowers in the engravings already listed, and it is conceivable the artist hybridized different examples to generate variation throughout the composition. Although the miniaturist looked at existing works while decorating the antiphonary, his innovation lies in his adaptation and reconfiguration of those works, as well as in his choice and application of colors to the black and white models of the figures and imaginary flowers.

Widespread and persistent use of models to formulate new works was also embedded in contemporary literature. ${ }^{47}$ Late medieval courtly poetry followed the ancient topos that embraced the emulation of sublime literary predecessors. ${ }^{48}$ When the southGerman minstrel known by the pseudonym 'Marner' ('Seaman'; † before 1287) mused to his role model, he compared the adoption of motifs to picking flowers: "I come to your garden and read your spoken blossoms." 49 In the 1300 s, the Strassburg theologian Johannes Tauler wrote in a sermon that an artist contemplates "before a well-made picture quite simply and draws all the dots and lines on his board and thereupon forms his image afterward, so faithfully as he can." ${ }^{50}$ Not surprisingly, as artists increasingly sought to distinguish themselves and assert their ingenuity in the early sixteenth century, some attempted to link quality with originality. In 1516 when the Strasburg painters' guild was revising its statutes, one group proposed a new stipulation that a journeyman "shall make his masterpiece an independently designed one, without using any model pattern, but rather out of his own intelligence and skill." 51 Other members dissented, expressing that a masterpiece made without the use of models "is previously unheard of; for all educated men and all lovers of art, whether religious or lay, have never despised or been ashamed of taking up the art of their forebears and learning from it." ${ }^{2}$

Dürer was the first Northern European artist to write at length about the practice and theory of his profession. His thoughts on the use of existing artistic models and the development of independent inventiveness reconcile both sides of the Strasburg guild's debate. Dürer agreed that students should copy the works of older masters in order to develop a "free hand." 53 In the process of making many copies, the budding pupil becomes "fully confident" and capable of inventing their own images. ${ }^{54}$ Although Dürer emphasized nature as an artist's best model, the process of observation and amalgamation he described as a means to generate 'kunst,' Dürer's word for 
'art' as a synthesis of craft and knowledge, is also reflected in works incorporating reproductions or adaptations of elements from other artists' compositions.

Hence it follows that no one can ever make a beautiful image out of their private sense unless they have replenished their mind by painting from life. That can no longer be called private but has become 'art' acquired and gained by study, which germinates, grows and becomes fruitful of its kind. Hence it comes that the collected secret treasure of the heart is manifested by the work, and the new creature, which one creates in their heart in the shape of a thing. ${ }^{55}$

Dürer understood the ability to internalize and cogitate natural forms as a means to create something new to be a power given to artists by God. ${ }^{56}$ German theologian Nicholas of Cusa (c. 1400-64) had already expounded on this idea in the midfifteenth century as he contemplated the views of ancient philosophers, including Plato and Aristotle, and amalgamated them with his own beliefs rooted in Catholic doctrine and German mysticism. ${ }^{57}$ Dürer may have been familiar with Cusanus's writings, and it is conceivable that Israhel was as well. ${ }^{58}$ Martin Flach published Nicholas of Cusa's Opuscula theologica et mathematica in Strasbourg c. 1488, just two years before the 1490 date usually given for Israhel's late ornamental engravings. ${ }^{59}$

In Idiota de mente (The Layman on Mind), included in the Strasbourg publication, Cusanus explained that the "mind is a 'divine seed' that conceptually enfolds within its own power the exemplars of all things." ${ }^{0}$ Placed by God in a suitable earthen body, the mind, which perceives and remembers external forms, in turn "can bear fruit and can unfold from itself, conceptually, an all-encompassing unity of things." 61 With this gift of seminal power came the opportunity to actualize it. ${ }^{62}$ The creative human mind is thus able to produce, through the labor of the body, a world of concepts manifested in language, images, and objects. ${ }^{63}$ Although Dürer and Cusanus refer to different bodily sources of creativity - the 'heart' and 'mind,' respectively - their descriptions of the process are consistent conceptually, and metaphorically, both evoke images of germination and fruit.

From the perspective of contemporary science, different areas of the brain responsible for perception, evaluation, memory, and imagination facilitated the process Dürer described. According to the long-standing and often published theory of intromission, visible objects generate, or multiply, species of light and color, which are further multiplied in the viewer's eyes and impressed into the brain, like a seal in wax. ${ }^{64}$ Residing between the brain's areas of Imaginatio, a collection of received images, and Estimativa, or judgment, is Fantasia, the area that made it possible to partition and hybridize pieces of these images in the invention of something new. ${ }^{65}$ Since antiquity, hybrid creatures like centaurs and chimeras were examples of this sort of ingenuity. ${ }^{66}$ Artists who imaginatively selected and combined varieties of petals, sepals, stamens, pistils, pollen, and seeds to invent fanciful blossoms exercised the same inventiveness. Some of their flowers venture far into the realm of imagination, sporting baubles, spiraling stripes, and rows of dots. ${ }^{67}$ Perhaps the trade of prints featuring bizarre flowers, crossbred from natural forms in fertile minds, fostered a playful exchange in and among workshops. ${ }^{68}$ Might the chimera lurking among the flowers in Israhel's pattern print have been an invitation to inventively hybridize these flowers in the creation of new blossoms and compositions (Figure 3.5)?

Printed images and the culture they engendered mirrored aspects of cerebral functions in a physical form. Like visible species, prints multiplied and disseminated visible objects. As impressions, they materialized a collective memory that could be shared, 


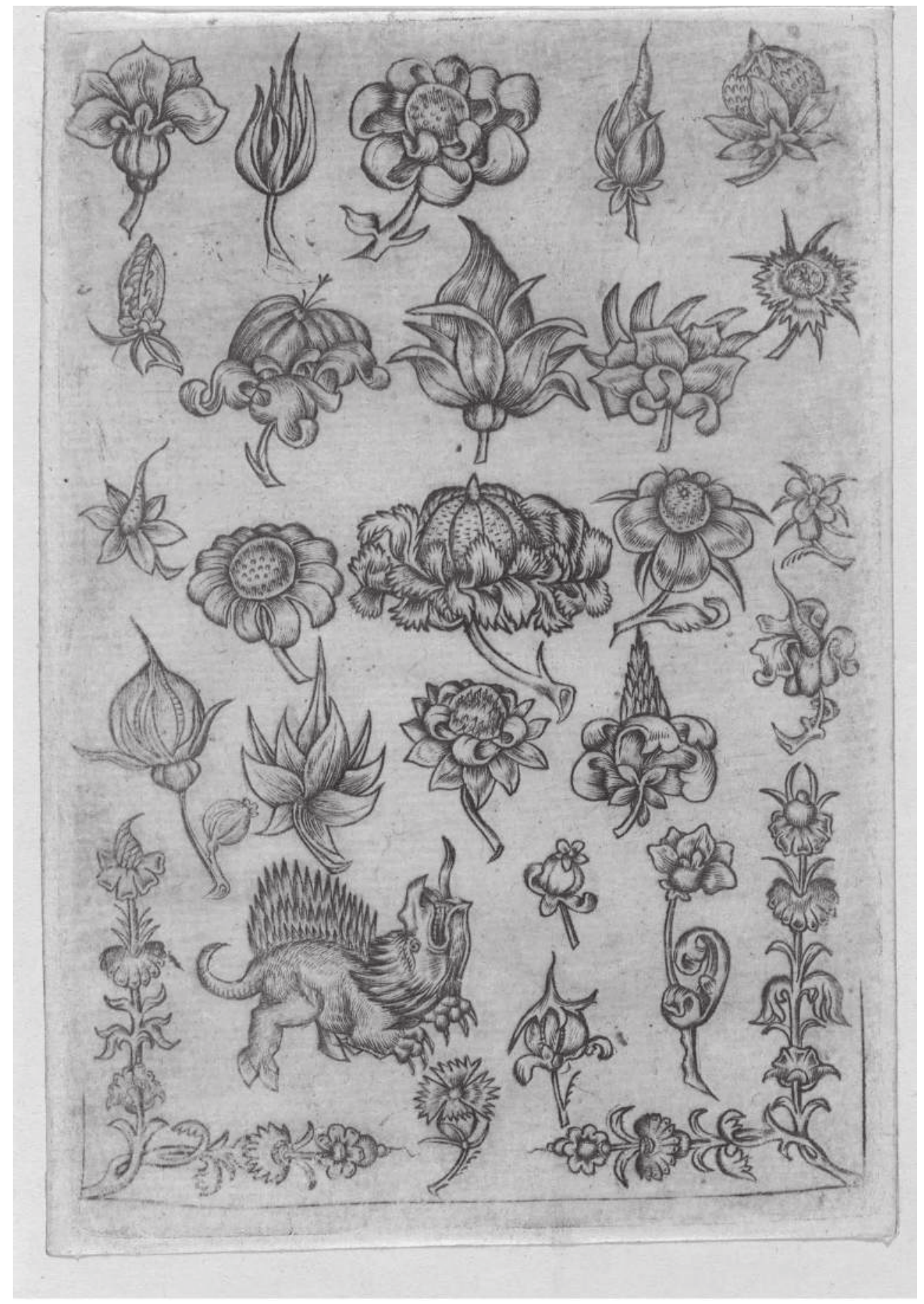

Figure 3.5 Israhel van Meckenem, Ornamental Flowers and a Chimeric Animal, c. 1485, engraving, London, The British Museum, 1925,0406.89.

Photo: () The Trustees of the British Museum. 


\section{James Wehn}

received, and, through the cogitative power of the mind, modified. Today, the vast majority of images printed in the fifteenth century do not survive, and as a result, many details of authorship and exchange have long since been forgotten. Case in point is the original designer of the Jesse Tree that Schedel clipped from Hochfeder's 1496 almanac. The design also appeared on a second almanac, printed using a separate woodblock and issued the same year by Johann Schaur in Augsburg. ${ }^{69}$ Schaur's broadside is known only in an incomplete, heavily abraded, and fragmented example, but enough of it remains to suggest the Jesse Tree woodcut decorated the full sheet's right margin. ${ }^{70}$

The two woodblocks printed separately by Hochfeder and Schaur probably stem from a now lost original that also served as the model for the back of a silver-plated Cross reliquary in Lindau, made four years earlier in 1492 (Figure 3.6). ${ }^{71}$ Incidentally, since at least the mid-twentieth century, historians have considered the reliquary a

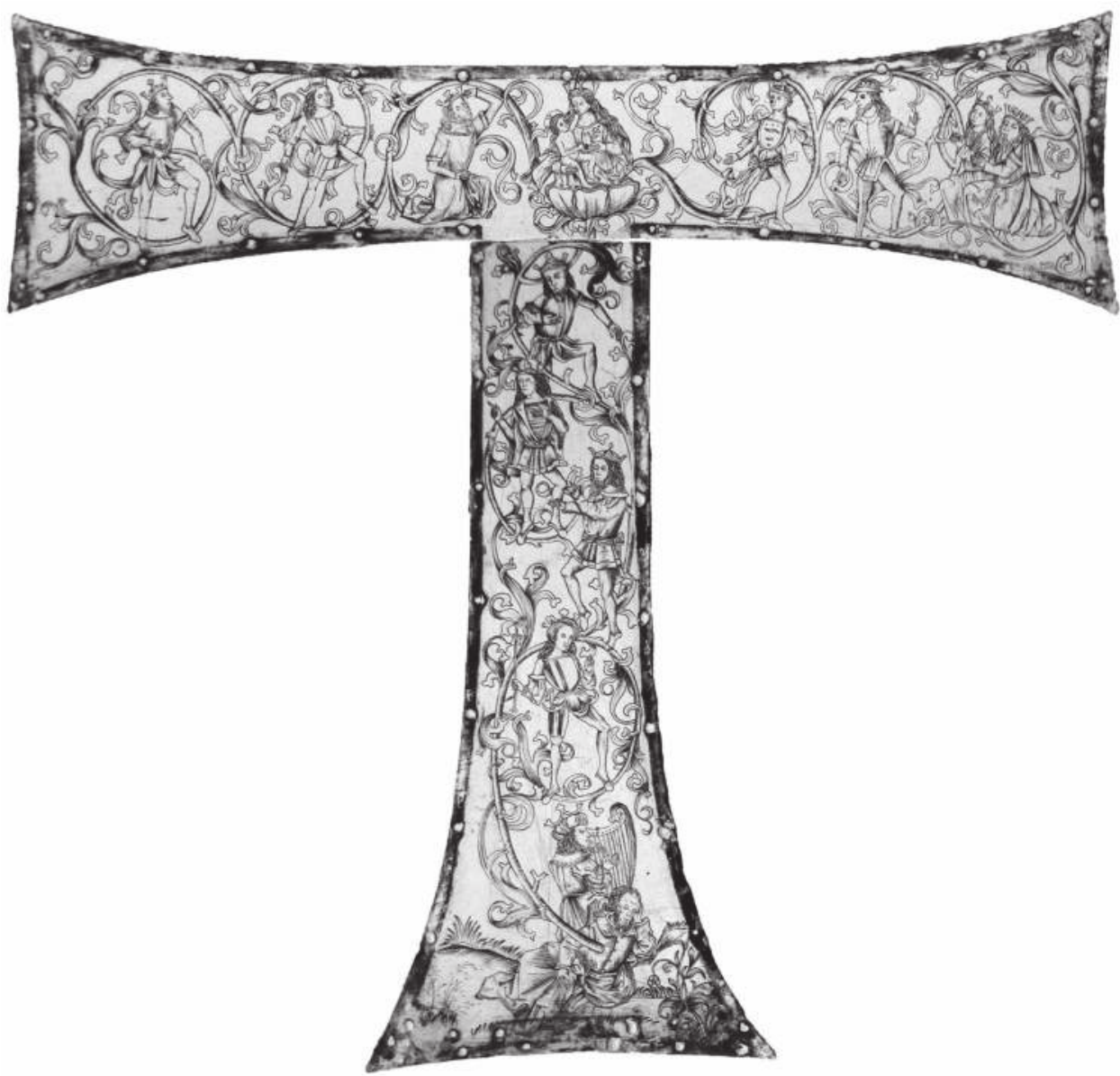

Figure 3.6 South German, backside of Cross reliquary with the Jesse Tree, 1492, Lindau, Münster Unserer Lieben Frau; digitally reconstructed using photographs of an impression of the engraved silver plate printed on wove paper, c. 1900. Munich, Staatliche Graphische Sammlung, 197000 D.

Photo: Author. 
response to Israhel's Ornamental Engraving with the Jesse Tree. ${ }^{72}$ As in Israhel's print, the leafy branches form circles around the kings, who assume a variety of full-figure stances. Jesse reclines on a grassy knoll at the tapered base of the T-shaped cross. The vine that sprouts from his chest undulates toward a blooming flower holding Mary and the Christ Child in the center of the crossbar. Like Israhel, the silversmith traded didactic intent for pattern, filling the crossbar to its ends with branches and kings that extend beyond Mary and Christ. Still, neither the figures nor the leaf-work in the reliquary correspond with Israhel's engraving. Oddly enough, however, the king standing with his back to the viewer and looking over his shoulder (nearest to the king and queen sitting together) also appears in Israhel's smaller engraving of the Jesse Tree (Lehrs IX.602). The positions of the head, legs, and arms are the same in all three works, as are the details of the king's doublet.

Lost are the details behind all these connections. How the design on a silver cross, dated 1492, came to be printed, somewhat altered, in two separate woodcuts three or so years later remains unknown. Perhaps they are all copies or adaptations of the same lost original design. ${ }^{73}$ There is little wonder why early print scholars and connoisseurs, including Max Geisberg and Max Lehrs, began observing and documenting these sorts of links; they are clearly embedded in the material record. Yet the art historical questions one might hope to answer-for example, which instance of a design is the original and who authored it-in many cases cannot be definitively answered. What these links demonstrate, on the other hand, is a great deal about the multiplication and regional distribution of printed images and the variety of ways in which artists received and used them.

As prints left these workshops and entered the marketplace, they carried with them opportunities for the public to interact with images in new and personal ways. Some of Israhel's prints indicate a deliberate effort on his part to promote collecting and to educate his audience about potential uses for his engravings. ${ }^{74}$ For example, engravings printed with four saints per sheet with lines to follow while cutting them apart (Lehrs IX.305-308). In Ornamental Engraving, Foliage on Black Ground (Lehrs IX.607; Figure 3.4), he inscribed his name and the location of production in adjacent margins, perhaps offering owners a visual indication that the decoration could function vertically or horizontally and to orient the image whichever way they preferred. ${ }^{75}$ Prints allowed Schedel to undertake the role of an amateur artist, emulating to a degree the activities taking place in workshops that illustrated and decorated manuscripts. His reformation of the Jesse Tree from the margin of Hochfeder's 1496 almanac demonstrates that he viewed images similarly to the silversmith of the Lindau cross and the miniaturist of the Düsseldorf antiphonary, who selectively extracted and reconfigured elements in new compositions (Plate 8, Figure 3.6). Similar to these artists, Schedel recognized the Jesse Tree design's versatility; he owned two copies of the woodcut, and he fractured, reassembled, and hybridized each copy differently. As described at the beginning of this chapter, Schedel harvested the flower with Mary and Christ for a devotional miniature and used other pieces in a decorative collage (Plates 5 and 6). With the second impression, Schedel removed Jesse, David, and part of the king above them; split the remaining image evenly; and pasted the two pieces side by side at the heart of a nativity-themed medley, further incorporating three woodcuts cut from another almanac. ${ }^{76}$ Schedel's consciousness of the design's variability in purpose and meaning is an important indication of the sorts of evaluative skills necessary to foster a market in which prints might be consumed for their devotional, narrative, or didactic content, but also collected, organized, and appreciated as objects of craft and artistry. 


\section{James Wehn}

During the late fifteenth century, the market for prints featuring ornamental leaves and blossoms developed out of long-standing workshop practices that depended on the selection and reproduction of existing images as a means to produce new works. Foliage and flowers conveyed ideas of creation and fecundity and therefore served as metaphors for artistic fruitfulness. Each cultivated plate or woodblock yielded a crop of images ready to be visually harvested, consumed, propagated, hybridized, and re-planted. The prints carried these ideas into the public sphere and, in the case of Hartmann Schedel, stimulated a similar imaginative response. In and out of the late fifteenth-century workshop, printed ornamental designs were viewed actively and considered changeable; their owners treated them as if they were fertile seeds in a cycle of creative reproduction.

\section{Notes}

1 Munich, BSB, Clm 464. The fifteenth-century manuscript contains Philippi Callimachi Experientis regis Poloniae secretarii de rebus in Hungaria et contra Turcos per Wladislaum Poloniae atque Hungariae regem gestis libri III, authored by Filippo Buonaccorsi, also known as Callimachus.

2 It is doubtful that Schedel hand-colored prints he collected himself; however, scholars believe that he did create the simple blue and red frames, often with simple dots or simple ornamental features on the four corners, that appear with consistency throughout his manuscripts. Schedel also regularly used red ink to selectively color small elements within printed images, including lips, flowers, and serifs of letters. For more about Schedel's coloring practices, see: Hernad, Die Graphiksammlung, 38-39.

3 GW, 1511 (for catalogue details for broadsides with GW numbers, see: http://gesamtkata logderwiegendrucke.de (accessed 21 October 2018); Eisermann, Verzeichnis, vol. 2, 220-21 (no. A-424). For an image, see: Harvard University, Francis A. Countway Library of Medicine, Ballard 106.

4 For the development of Jesse Tree iconography see Schiller, Iconography, 15-22.

5 Viljoen, "The Airs of Early Modern Ornament Prints," 117n3; Grabar, The Mediation of Ornament, 5.

6 For illustrations of engravings by Israhel that do not appear with this chapter, see: Koreny, Israhel van Meckenem, which conveniently follows Lehrs's catalogue numbers.

7 Zorach and Rodini, "On Imitation and Invention," 1-7; Landau and Parshall, The Renaissance Print, 162. Zorach and Rodini propose that the term 'reproduction' best reflects historical practices if it encompasses a range of situations, including prints that adhere to this strict definition, but also direct copies and instances of adaptation.

8 Hernad, Die Graphiksammlung, 7-8.

9 Landau and Parshall, The Renaissance Print, 64.

10 Ibidem; Parshall, "The Print Collection," 140.

11 Parshall, "Art and the Theater of Knowledge," 7-8.

12 Landau and Parshall, The Renaissance Print, 64; Hernad, Die Graphiksammlung, 39.

13 Hernad, Die Graphiksammlung, 39, 331-33.

14 Ibidem, 316 (no. 118). This page was removed from its original context and is now in Munich, Staatliche Graphische Sammlung. The engraving is a reverse copy after the Monogrammist bx8.

15 Hernad, Die Graphiksammlung, 314 (no. 117); Munich, BSB, Rar. 341, fol. 3v.

16 Freedberg and de Vries, Art in History, 217. Lyckle de Vries coined the concept of 'iconographic erosion,' in which artists privilege invention over a traditional subject's didactic meaning with the assumption that viewers will still recognize and comprehend the wellknown motif.

17 Winther, "Zu einigen Ornamentblättern," 81.

18 Riether, "Israhel van Meckenem," 21, 26. Of the approximately 516 engravings attributed to Israhel, over half are proven copies.

19 Ibidem, 26, 30-31; Gramaccini, "Meister ES," 23; Landau and Parshall, The Renaissance Print, 57-63. 
20 Amelung, "Zum Bilderschmuck," 235-36.

21 Keene, Gardens of the Renaissance, 6-7; Camille, Gothic Art, 138-42.

22 Keene, Gardens of the Renaissance, 43.

23 There are two verses that address God's renaming of Jacob as 'Israel': Genesis 32:28 and Genesis 35:10. The Latin words used by Israhel in his name engraving are identical to the latter verse (though somewhat rearranged). For comparison, see: Epistola beati Hieronimi presbiteri ad Paulinum presbite[rum] de omnibus diuin[a]e histori[a]e libris incipit [Glossa Ordinaria] (Nuremberg: Anton Koberger, 1481), Genesis 32 and 35. http://archive.thulb. uni-jena.de/ufb/receive/ufb_cbu_00000254.

24 Hayward, Interpretations, 219, 330-33.

25 Sed hoc nomen ad illam pertinet promissionem, in qua videtur Deus quomodo non est antea patribus visus, ubi non erit nomen vetus; quia nibil remanebit vel in ipso corpore vestustatis, et visio Dei summum praemium erit. Koberger (publisher), Glossa Ordinaria, Genesis 35:10. http://archive.thulb.uni-jena.de/ufb/receive/ufb_cbu_00000254.

26 de cujus semine spirituali, id est imitatione fidei, in bonis operibus fecundantur, ibidem, Genesis 35:11. http://archive.thulb.uni-jena.de/ufb/receive/ufb_cbu_00000254.

27 Pieper, "Das Namensornament," 3-4.

28 McConnell, Israhel van Meckenem, 56.

29 Hernad, Die Graphiksammlung, 169, no. 24.

30 Ibidem. It is uncertain whether Schedel painted the green frame and augmented Israhel's signature himself; however, the touches of red applied to elements within the central image, as well as the red and blue framing lines outlining the green margin, are consistent with Schedel's practice and were probably made by him.

31 For online images: Kupferstichkabinett, Dresden, A 1912-403; Cleveland Museum of Art, 1950.585; Vienna, Albertina, DG1926/1354. Other examples in which Israhel combined figures from multiple sources into new playing cards include Lehrs IX.540-42 (suit of dogs); and IX.543-45, 550 (suit of birds). That artists used playing cards as pattern prints is evident in the work of the Master of the Banderoles, e.g. the men in the engraving Der Fechtsaal und das Badehaus (Lehrs IV.99) are copied from the large playing cards by the Master E.S. (Lehrs III.242, 246-47).

32 Brisman, "A Matter of Choice," 136.

33 Ibidem, 137; Dürer, Schriftlicher Nachlass, vol. 3, 293.

34 Dan warhafftig steckt die kunst inn der natur. Wer sie herauß kan reyssenn, der hat sie. Brisman, "A Matter of Choice," 136n54; Ashcroft, Albrecht Dürer, vol. 1, 530n24; Dürer, Schriftlicher Nachlass, vol. 3, 295.

35 Brisman, "A Matter of Choice," 136-37.

36 Ibidem, 137.

37 Koerner, "Albrecht Dürer," 25-26; Landau and Parshall, The Renaissance Print, 54-55.

38 In 1512, Nuremberg authorities censured a stranger selling copies of Dürer's prints bearing his monogram AD. For the official resolution, see: Ashcroft, Albrecht Dürer, vol. 1, 346; Dürer, Schriftlicher Nachlass, vol. 1, 24.

39 Düsseldorf, Universitäts- und Landesbibliothek, MS-D-17, fol. 1r and 117r. See also: JanzWenig et al., Die mittelalterlichen Handschriften, 254.

40 Ibidem, 255.

41 Lehrs IX.401-402 (no. 511), 448 (no. 602), 458 (no. 618); Lehrs VII.162 (no. 57).

42 In place of The Large Garden, the illuminator might have referred to Eight Ornamental Flowers with a Bird (Lehrs IX.595), which includes the same flowers. However, he also adapted a section of leaf-work from The Large Garden to create a leafy flower with blue petals in the top right border. Additionally, the illuminator could have worked from Four Ornamental Flowers (Lehrs IX.597), one of two pattern sheets (along with Lehrs IX.598) attributed to Israhel with flowers that also appear in The Large Majuscule Alphabet. Yet it is more likely he used The Large Majuscule Alphabet because fol. $117 \mathrm{r}$ includes flowers from the alphabet that do not appear on these pattern sheets. It is worth noting that Koreny, Israhel van Meckenem, questioned the attribution of the three alternative pattern sheets mentioned in this note, and it remains an open question whether Israhel was indeed their creator, even though he used their flowers elsewhere. Lehrs believed that Israhel copied seven of the flowers that appear in The Large Garden and Eight Ornamental Flowers with a Bird from lost originals by the Master of the Berlin Passion. I mention this speculation as 
a reminder of the possibility that both the antiphonary's miniaturist and Israhel could have worked from the same now-lost materials, even though the extant evidence presents a different view.

43 Lehrs VII.162 (no. 57); Israhel's restrike is described and illustrated in Koreny, Israbel van Meckenem, no. 634.

44 Ornamental Design with Five Flowers is one of six engravings by Master FVB that Israel reworked and republished under his own name. The circumstances by which Israhel acquired the plates remain a mystery.

45 Janz-Wenig et al., Die mittelalterlichen Handschriften, 255. For online image: Düsseldorf, Universitäts- und Landesbibliothek, MS-D-17, fol. 117r.

46 Lehrs VII.162 (no. 57); Lehrs, “The Master FVB," 164, cat. 57. Lehrs mentions the use of Ornamental Design with Five Flowers for the historiated U, but not that the fifth flower (in the center of the engraving) appears in the page's left border.

47 Metzger, "Multiplikator des Ruhmes," 41.

48 Ibidem.

49 Ibidem.

50 Ibidem, 41-42.

51 Baxandall, The Limewood Sculptors, 123 presents the Strasburg guild's debate in a discussion of artistic personality and, more specifically, the somewhat paradoxical tension between the aim to imitate nature and the goal to develop an individual style.

52 Ibidem, 123-24; Metzger, "Multiplikator des Ruhmes," 42.

53 Metzger, "Multiplikator des Ruhmes," 46n21; Dürer, Schriftlicher Nachlass, vol. 2, 99 (lines 9-10).

54 Metzger, "Multiplikator des Ruhmes," 42.

55 Dürer, Schriftlicher Nachlass, vol. 3, 295-96 (lines 451-61).

56 Ibidem, vol. 3, 283 (lines 78-79).

57 Watts, Nicolas Cusanus, 1, 23.

58 Koerner, The Moment of Self-Portraiture, 129.

59 GW, M26367, https://gesamtkatalogderwiegendrucke.de/docs/M26367.htm (accessed 26 February 2019); Nicholas of Cusa, Opuscula theologica et mathematica (Strasbourg: Martin Flach, c. 1488), http://tudigit.ulb.tu-darmstadt.de/show/inc-iv-92/0003/image (accessed 26 February 2019).

60 Nicholas of Cusa, Complete Philosophical and Theological Treatises, vol. 1, 547.

61 Ibidem.

62 Ibidem.

63 Watts, Nicolas Cusanus, 136.

64 Lindberg, Theories of Vision, 109-16.

65 Camille, "Before the Gaze," 200.

66 For fuller discussions of the hybrid and its appearance in literature into the sixteenth century, see Parshall, "Graphic Knowledge," 395-98; Camille, "Before the Gaze," 211-14.

67 For pattern prints associated with Meckenem, see: Lehrs IX.526-29, 550-51, 555-60, 562, 565-71, 595-96 (figs. 36, 37), 597-601, 608-13, 615-18, 619-21, 624. Meckenem's frequent depiction of fantasy flowers in his signed ornamental prints may account for the large number of copies and similar images that Max Geisberg and Max Lehrs attributed to Israhel, but have been ruled out or questioned in Koreny, Israhel van Meckenem.

68 Brisman, "A Matter of Choice," 131-33.

69 Munich, Ludwig-Maximilians-Universität, Universitätsbibliothek, 2 Inc. lat. 1201a (5,1 u. 5,2; GW 1513; Eisermann, Verzeichnis, vol. 2, 216-17 (no. A-418); Hernad, Die Graphiksammlung, 151n4; Amelung, "Zum Bilderschmuck," 244.

70 Amelung, "Zum Bilderschmuck," 240-45; Lehrs IX.617a; Schreiber, Handbuch, 124 (no. 1988). The header of Schaur's almanac features a woodcut version in reverse of Israhel's Ornament with Morris Dancers. Its composition is nearly identical to another woodcut, known in a single impression in the Berlin Kupferstichkabinett (inv. 33-4). Scholars assume the woodcuts are copies after Israhel's engraving, dated on stylistic grounds to around 1490; however, the survival of these almanac fragments raise reasonable questions about the authorship of the design.

71 Horn and Meyer, Stadt und Landkreis Lindau, 57. The Staatliche Graphische Sammlung München conserves an impression printed around 1900 from the two pieces of silver plate 
with the reliquary's Jesse Tree image (inv. 197000 D). For ease of viewing, I have used a photo of this impression to digitally reproduce the reliquary.

72 Riether, "Israhel van Meckenem," 32; Fritz, Gestochene Bilder, 502. Reither describes the silverwork as a response (Nachfolgewerk) to Meckenem's Jesse Tree. Fritz notes the similarity with Meckenem's print, as well as an engraving of Mary's family tree by Master W with a Key (Lehrs VII.24). The latter print does have similar circular branch work patterns, but the figures are half-length and set in various fantastical blossoms.

73 Amelung, "Zum Bilderschmuck," 244, did not connect the Lindau cross pattern with the two woodcuts, but he did suggest that there may have been a now-lost earlier woodcut that served as the original model, thereby explaining why nearly identical Jesse Tree woodcuts appeared on almanacs published in different cities at approximately the same time.

74 Landau and Parshall, The Renaissance Print, 58-59.

75 Lehrs IX.452 (no. 607). This print has been variously described both as a Hochfüllung (vertical panel) or a Querfüllung (horizontal panel).

76 Hernad, Die Graphiksammlung, 151 (no. 10); for online image: Munich, BSB, Rar. 334, fol. $519 \mathrm{v}$.

\section{Bibliography}

Amelung, Peter. "Zum Bilderschmuck der frühen Einblattkalender: Probleme um einen Augsburger Almanach auf das Jahr 1496 (GW 1513).” Gutenberg-Jahrbuch, 55 (1980): 235-45.

Ashcroft, Jeffrey. Albrecht Dürer: Documentary Biography: Dürer's Personal and Aesthetic Writings: Words on Pictures: Family, Legal and Business Documents: The Artist in the Writings of Contempories. Vols. 1-2. New Haven: Yale University Press, 2017.

Baxandall, Michael. The Limewood Sculptors of Renaissance Germany. 7th ed. New Haven: Yale University Press, 2008.

Brisman, Shira. "A Matter of Choice: Printed Design Proposals and the Nature of Selection, 1470-1610.” Renaissance Quarterly, 71 (2018): 114-64.

Camille, Michael. Gothic Art: Glorious Visions. Upper Saddle River, NJ: Prentice Hall, 1996.

—. "Before the Gaze: The Internal Senses and Late Medieval Practices of Seeing." In Visuality Before and Beyond the Renaissance: Seeing as Others Saw, ed. Robert S. Nelson, 197223. Cambridge: Cambridge University Press, 2000.

Dürer, Albrecht. Dürer: Schriftlicher Nachlass, ed. Hans Rupprich. Vols. 1-3. Berlin: Deutscher Verein fur Kunstwissenschaft, 1956.

Eisermann, Falk. Verzeichnis der typographischen Einblattdrucke des 15. Jahrhunderts im Heiligen Römischen Reich Deutscher Nation VE 15. Vols. 1-3. Wiesbaden: Reichert, 2004.

Freedberg, David, and Jan De Vries. Art in History, History in Art: Studies in SeventeenthCentury Dutch Culture. Santa Monica: Getty Center for the History of Art and the Humanities; Chicago: Distributed by the University of Chicago Press, 1991.

Fritz, Johann Michael. Gestochene Bilder: Gravierungen auf deutschen Goldschmiedearbeiten der Spätgotik. Cologne: Böhlau, 1966.

Grabar, Oleg. The Mediation of Ornament: The A.W. Mellon Lectures in the Fine Arts, 1989. Washington: NGA, 1992.

Gramaccini, Norberto. "Meister E S und Israhel van Meckenem als Künstler-Unternehmer." In Festschrift Für Eberhard W. Kornfeld Zum 80: Geburtstag, ed. Christine E. Stauffer, 13-36. Bern: Stämpfli, 2003.

Hayward, Robert. Interpretations of the Name Israel in Ancient Judaism and Some Early Christian Writings: From Victorious Athlete to Heavenly Champion. Oxford: Oxford University Press, 2008.

Hernad, Béatrice. Die Graphiksammlung des Humanisten Hartmann Schedel. Munich: Prestel, 1990.

Horn, Adam, and Werner Meyer. Stadt und Landkreis Lindau (Bodensee), Die Kunstdenkmäler von Bayern: vom elften bis zum Ende des achtzehnten Jabrhunderts 7, Kunstdenkmaler von Schwaben, 4. Munich: Verlag der Vereinigten Kunstanstalten, 1954. 


\section{James Wehn}

Janz-Wenig, Katrin, Monika E. Müller, Gregor Patt, Irmgard Siebert, and Anne Liewert. Die mittelalterlichen Handschriften und Fragmente der Signaturengruppe D in der Universitätsund Landesbibliothek Düsseldorf. Vol. 1. Wiesbaden: Harrassowitz Verlag, 2015.

Keene, Bryan C. Gardens of the Renaissance. Los Angeles: J. Paul Getty Museum, 2013.

Koerner, Joseph Leo. The Moment of Self-Portraiture in German Renaissance Art. Chicago: University of Chicago Press, 1996.

—. "Albrecht Dürer: A Sixteenth-Century Influenza." In Albrecht Dürer and His Legacy, ed. Giulia Bartrum, 18-38. Princeton, NJ: Princeton University Press, 2003.

Koreny, Fritz, comp. Israhel van Meckenem, ed. Tilman Falk. Blaricum: A.L. van Gendt, 1986 (HG, Vols. 24 and 24A).

Landau, David, and Peter W. Parshall. The Renaissance Print, 1470-1550. New Haven: Yale University Press, 1994.

Lehrs, Max. “The Master FVB.” The Print Collector's Quarterly, 10 (1923): 149-66.

Lindberg, David C. Theories of Vision from Al-Kindi to Kepler. Chicago: University of Chicago Press, 1996.

McConnell, Joshua L. Israhel van Meckenem, the Namensornament, and the Union of Artist and Work in Late Gothic Engraving. Masters Thesis, University of Texas, Austin, 2007.

Metzger, Christof. "Multiplikator des Ruhmes: Israhel van Meckenems Kopien vor dem Hintergrund spätmittelalterlicher Traditionsgebundenheit." In Israhel van Meckenem (um 1440/45-1503): Kupferstiche der Münchner Bestand, ed. Achim Riether, 38-47. Munich: Staatliche Graphische Sammlung, 2006.

Nicholas of Cusa. Opuscula theologica et mathematica. Strasbourg: Martin Flach, c. 1488-89.

- Complete Philosophical and Theological Treatises of Nicholas of Cusa, transl. and ed. Jasper Hopkins. Vol. 1. Minneapolis: A. J. Banning Press, 2001.

Parshall, Peter. "The Print Collection of Ferdinand Archduke of Tyrol." Jabrbuch der Kunsthistorischen Sammlungen in Wien, 78 (1982): 139-84.

- "Art and the Theater of Knowledge: The Origins of Print Collecting in Northern Europe." Harvard University Art Museums Bulletin, 2 (1994) [no. 3: "Print Collecting”]: 7-36.

- "Graphic Knowledge: Albrecht Dürer and the Imagination." The Art Bulletin, 95 (2013): 393-410.

Pieper, Paul. "Das Namensornament über ein Ornamentblatt Israhel van Meckenems.” Unser Bocholt, 4 (1963): 2-4.

Riether, Achim. "Israhel van Meckenem, Kupferstecher zu Bocholt." In Israhel van Meckenem (um 1440/45-1503): Kupferstiche der Münchner Bestand, ed. Achim Riether, 8-37. Munich: Staatliche Graphische Sammlung, 2006.

Schiller, Gertrude. Iconography of Christian Art, transl. Janet Seligman. Vol. 1. Greenwich, CT: New York Graphic Society Ltd, 1971.

Schreiber, Wilhelm Ludwig. Handbuch der Holz- und Metallschnitte des XV. Jahrhunderts. Vol. 4. Leipzig: Hiersemann, 1926.

Viljoen, Madeleine C. "The Airs of Early Modern Ornament Prints." Oxford Art Journal, 37/2 (2014): 117-33.

Watts, Pauline Moffit. Nicolaus Cusanus: A Fifteenth-Century Vision of Man. Vol. 30: Studies in the History of Christian Thought, ed. Heiko A. Oberman. Leiden: E. J. Brill, 1982.

Winther, Annemarie. "Zu einigen Ornamentblättern und den Darstellungen des Moriskentanzes im Werk des lsrahel van Meckenem.” In Israhel van Meckenem und der deutsche Kupferstich des 15. Jahrbunderts, ed. Elisabeth Bröker, 81-100. Bocholt: Kunsthaus, 1972.

Zorach, Rebecca, and Elizabeth Rodini. "On Imitation and Invention: An Introduction to the Reproductive Print.” In Paper Museums: The Reproductive Print in Europe, 1500-1800, eds. Rebecca Zorach and Elizabeth Rodini, 1-29. Chicago: David and Alfred Smart Museum of Art, University of Chicago, 2005. 


\title{
4 Gillet and Germain Hardouyn's Print-Assisted Paintings
}

\author{
Prints as Underdrawings in Sixteenth- \\ Century French Books of Hours
}

\author{
Maureen Warren
}

Opening a book of hours printed by Germain Hardouyn in 1524 to Compline, the viewer comes face to face with a stirring portrayal of the Death of the Virgin (Plate 9). The most popular deathbed scene in medieval Europe, this apocryphal subject resonated with contemporaries on many levels. ${ }^{1}$ With the cult of the Virgin strong and getting stronger, it satisfied a longing for greater knowledge about Mary's life. Moreover, it represented the ideal Christian death: a painless and sanctified passing in the company of friends and family. Common in sculptural programs and panel paintings, the Death of the Virgin was a balm for the ever-present specters of sickness and suffering and a hopeful entreaty for eternal salvation.

In the Hardouyn miniature, the Virgin has just breathed her last breath. Calligraphic black strokes show her eyes closed in peaceful repose, a slight smile on her lips. If not for her soul floating overhead in a radiant mandorla, we might think that she was merely asleep. Peter, wearing an alb with a red stole, has helped administer the last rites. He holds a lit candle-symbolic of the guiding light of faith-and an aspergillum, which have been painted with the same golden pigment as the halos. Beside Peter, a tonsured apostle lifts the lid of a glimmering censor to fill the room with fragrant incense. Other apostles, clad in brightly colored garments, react with a range of emotions. Some frown deeply, grieving their loss. One man watches in open-mouthed astonishment. Others are smiling, happy that Mary and Christ will be reunited. In the front, an opening between the two apostles who are shown full-length invites the viewer to imagine entering the scene, stepping up to the foot of the bed, and closing the circle-becoming a participant in this solemn and sacred event.

Centuries of manuscript production had conditioned viewers to expect beautiful miniatures in their books of hours (or Horae, from the Latin)—and the Hardouyn brothers excelled at using print technology to better meet this desire for bright and glimmering images. The miniature in the 1524 volume is small and precious, made with brilliant pigments and shimmering gold-tone paint. It is jewel-like, enclosed within a medallion-shaped frame with fictive red, blue, and turquoise cabochon gems. The paint handling is fine, with drapery, hair, and faces articulated and softly modeled with deft brushstrokes. When Horae first began to be printed in Paris a generation earlier, the uncolored metalcuts inside them must have initially given viewers quite a shock, one not unlike the "jolt of strangeness" late fifteenth-century audiences experienced when seeing the monochrome sculpture of Tilman Riemenschneider for the first time. ${ }^{2}$ But the laity quickly developed a fondness for printed Horae with black and white prints, as well as over-painted ones like those found in this book. As such, the Hardouyns's innovation lay not in challenging expectations-neither printed 


\section{Maureen Warren}

books of hours nor miniatures were new by the time they opened shop-but in using print technology to accelerate and improve their output in a substantial way and over an extended period. The painters in their employ used printmaking technologies to expedite production, enhance the Hardouyn house style, and, ultimately, to pioneer a different kind of miniature. These miniatures have graphic foundations, but the edifices constructed upon them use the materials and techniques of manuscript illumination. Traditionally, they have been thought of as colored or painted prints-the emphasis being on the printed matrix under the pigment-but in point of fact they are miniatures, and they are so by design. When thinking of these works as miniatures or, as I argue, "print-assisted paintings," we place them first and foremost within the context of medieval and Renaissance miniature painting, rather than construing them as prints that have been supplemented with color. In other words, they are paintings that have been made with the aid of print technology, rather than prints embellished with paint. The distinction between "painted prints" and "print-assisted paintings" is no trivial matter. Using these Horae as a case study, we can see how disciplinary boundaries between art history and book history and between print studies and manuscript studies have constrained all of these fields. ${ }^{3}$ Furthermore, these Horae offer new insights into the complexities of Renaissance workshop production, and they complicate the history of printmaking as a linear trajectory of ever-increasing media specificity, especially as that history is recounted by scholars of single-sheet prints.

This chapter consists of four parts. First, I argue for the necessity of distinguishing between painted prints and print-assisted paintings. While a firm distinction between print and painting can be difficult to delineate, simply designating everything that blurs media boundaries a "hybrid" will flatten the nuances of both production and reception. Next, there is a short overview of both books of hours and the Hardouyn brothers. Afterword, the Hardouyn's octavo metalcut of the Death of the Virgin, which was commissioned from the workshop of Jean Pichore, will serve as a case study. Five overpainted impressions of this print are considered in chronological order, demonstrating some of the ways that individual painters elaborated upon the printed design to produce unique miniatures for the Hardouyns. This chapter will merely scratch the surface of this rich topic, as the Hardouyns and their atelier merit a proper book-length study. Finally, this chapter explores the theory that the metalcut was intended to function as a printed underdrawing, arguing that the prints in Hardouyn Horae offer scholars a new method of studying both reproductive printmaking (broadly defined) and the role of underdrawing in Renaissance painting ateliers.

\section{Print-Assisted Painting or Painted Print?}

Following an oft-repeated remark by Erasmus about Albrecht Dürer's technical mastery of printmaking-how if one were to "spread pigments [on the black lines] you would injure the work" - generations of scholars neglected early hand-colored prints. ${ }^{4}$ This lacuna began to close with Susan Dackerman's groundbreaking 2002 exhibition Painted Prints, which disproved a number of false assumptions. Dackerman demonstrated that color was added to many German and Netherlandish single-sheet printseven after the 1490s, when printmakers improved in their ability to suggest volume, tonality, and naturalism-not as compensation for technical deficiencies but because viewers did not see the increasing naturalism of many contemporary graphic works as being at odds with added color. ${ }^{5}$ Indeed, Dackerman rightly notes that hand-applied 
color was often integral to the conception of these prints and it could enhance their meaning and value. ${ }^{6}$

Building upon Dackerman's findings, I use "painted prints" to describe graphic works of art that have been augmented with color, which I understand to be distinct from "print-assisted paintings." The images in Hardouyn Horae are not so much "painted prints" as they are miniatures with prints underneath. Painted prints generally have transparent washes of color, which allow the printed lines beneath to show through, and occasionally areas of the paper or support are left unpainted. Colorists typically worked with inexpensive water-based paint, either freehand or more often with stencils. ${ }^{7}$ These prints were painted either at the time of their making as part of their manufacture or after having been purchased by an owner or an enterprising colorist.

Few art historians have considered the woodcuts and metalcuts made for printed books of hours to be an integral part of the history of printmaking in Renaissance Europe. Like many other book illustrations, they are often neglected, set aside for devotees of the history of the book. That said, several scholars have made inroads in the study of printed Horae. One of the first to draw attention to this fertile ground for study was Sandra Hindman, and subsequently Ina Nettekoven, Mary Beth Winn, and Caroline Zöhl, have explored the networks and output of several major French designers and publishers. ${ }^{8}$ Christina Dondi has thoroughly investigated fifteenthcentury Italian Horae. ${ }^{9}$ But few studies have fully addressed the matter of workshop overpainting. ${ }^{10}$ Inattention to these hybrid paintings has largely been due to disciplinary constraints. The Vasarian model of art history, which continues to dominate early modern European art history, privileges known artists with coherent oeuvres, which are the product of a single mind and "hand." As Lisa Pon has shown, the Vasarian notion of the artist was still new in the sixteenth century and is in large part unsuited to graphic arts of this period, which were frequently the product of collaboration. ${ }^{11}$ And as Barbara Mundy and Aaron Hyman have persuasively argued, rejecting this model enables us to reimagine the categories of artist and artwork. ${ }^{12}$ The Vasarian model would have scholars focus solely on the designer of the print matrices in Hardouyn Horae, not the painters who created the miniatures atop the metalcut impressions. With more permeable boundaries for artistic creativity and innovation, those anonymous painters in the Hardouyn atelier can be understood as creators with sophisticated graphic tools at their disposal, rather than mere assistants who embellished someone else's inventions.

\section{Book of Hours}

For those unfamiliar with Horae, it might be helpful to consider briefly the context of these images. Horae were sumptuous ritual objects that enabled lay audiences to connect with the divine. This undisputed medieval "bestseller" takes its name from the Hours of the Virgin: a set of devotional texts, usually in Latin, that in monastic practice are recited at the eight canonical hours of the day. For the laity, there was more flexibility. One fifteenth-century French theologian urged parishioners to say the first few hours before they left home in the morning and the rest in the evening. ${ }^{13} \mathrm{Or}$ as Germain Hardouyn succinctly advised, they should "be sayd or thou departe out of thy chambre at thyn uprysynge." 14 Typically, each of the canonical hours began with an image of a significant event in the life of the Virgin. Horae contain a number of 
other texts: a calendar, Office for the Dead, prayers to saints, etc., which could also incorporate images, as could the page borders. Images were especially important for owners with limited literacy (especially in Latin) as they nonetheless would have had a high degree of visual literacy, which was informed by their familiarity with theater, the visual arts, sermons, etc. ${ }^{15}$

But books of hours, even printed ones, were an extravagance. Luxury Horaehandwritten on vellum and illuminated by master painters-were the reserve of royalty and the wealthiest religious institutions. From 1485, Parisian printers greatly expanded the market, making books of hours accessible to affluent members of the professional and merchant classes. ${ }^{16}$ That is not to say that these new print volumes immediately superseded their predecessors. In fact, the advent of printing might have increased the demand for illuminators, at least for a period of time. ${ }^{17}$ Paris was the hub of production for printed Horae. By 1530, more than 1600 editions had been printed, and ninety percent of them in France. ${ }^{18}$ With editions conservatively estimated to consist of 300 copies, scholars reckon that a quarter of a million books of hours were printed between 1485 and $1530 .{ }^{19}$ They were purchased by the well-to-do all across Europe. ${ }^{20}$ Printed Horae became the main vehicle for Parisian artistic style and iconography. ${ }^{21}$ They helped create a taste for other Parisian luxury goods such as tapestries, enamel, and stained glass, which were designed by the same artists or at least originated in the same ateliers as the matrices for these books. ${ }^{22}$

All printed Horae required some manual embellishment to be considered complete. Even Horae with uncolored prints needed someone to add the rubrication, multicolored capitals, line ends, and ruling by hand. This was because it was too expensive to print both colored and black ink and because publishers wanted their volumes to resemble manuscripts. Some printed Horae do look deceptively like their manuscript counterparts. They were printed on parchment with overpainted prints, have overpainted or hand-painted borders, and some incorporate fully handmade miniatures (with no prints beneath). ${ }^{23}$ Sometimes the only indication that these books were printed was the typeface. They ran the gamut from elaborate volumes on vellum with prints overpainted in imitation of miniatures to small, simple, and crude uncolored editions on paper-thereby appealing to the broadest market possible. ${ }^{24}$

The Hardouyns (like bookseller and publisher Anthoine Verard) developed a form of illustration for their Horae that was not fully a print or a miniature as traditionally defined, because their miniaturists crafted fully fledged paintings and exercised a high degree of editorial control. As Hindman states (with regard to Verard): "Whereas previous to the appearance of the French printed Horae a clear distinction persisted between miniature and woodcut, even when pictures were painted over woodcuts as in Verard's books, in these Horae external form and internal modeling supply guidelines to illuminators." ${ }^{25}$ In other words, miniatures such as these were based on graphic models, but painterly diversification transformed the end result into something sufficiently different from the model to no longer fully be encompassed within the bounds of printmaking.

\section{Gillet and Germain Hardouyn}

While several Parisian publishers issued printed Horae, the Hardouyns made overpainted prints their house specialty. In the early years of production in Paris, until around 1490, color was not a priority for publishers; if it was applied, it was done 
somewhat carelessly. ${ }^{26}$ Verard was one of the first to understand how master painters could elevate his printed Horae to a level befitting royalty. From 1503, the Hardouyns began to corner the market for overpainted Horae. While their offerings never matched the quality of Verard's princely tomes, they did produce a number of handsome overpainted editions on parchment. The elder Hardouyn, Gillet, was born in 1455 to a Parisian bookbinder and became a university-licensed bookseller in 1491, just two decades after the first presses opened in that city. He lived and worked on the Pont Notre-Dame, one of the primary thoroughfares for elites, tourists, and others headed to Île de la Cité. ${ }^{27}$ His younger brother Germain was a frequent collaborator. The Hardouyn brothers employed an atelier of miniaturists that painted in accordance with a house style. Furthermore, both brothers were registered as illuminators as well as printers, which was uncommon. ${ }^{28}$ Two of Germain's sons also became illuminators. ${ }^{29}$ It clearly was a family vocation, as one of these sons married the sister of a master illuminator. ${ }^{30}$ When Gillet died in 1521, Germain continued his work as a printer until his own death twenty years later, in 1541.

As Katherine Baker has noted, the Hardouyn brothers seem to have been exceptional in having organized and overseen an atelier of illuminators that produced works for their printed Horae in a distinctive workshop style. ${ }^{31}$ Their workshop used materials of high quality, and some of their painters were quite skilled. Their pigments are generally vibrant, not muddy or grainy, and they typically printed on parchment, not paper. ${ }^{32}$ In one Hardouyn volume from 1505, Baker found evidence of two hands on major illustrations in one volume and one or two more working on smaller illustrations, all of which bore a certain "family resemblance" with thick outlines and a lack of gold hatching on garments. ${ }^{33}$ Workshop collaboration seems to have been common practice, at least in the volumes I have consulted, but a more systematic study of Hardouyn Horae is needed to hypothesize as to the number of artists involved and the extent of their involvement. Because their cooperative approach mimics the creation of manuscript volumes, Baker posits that the Hardouyns trained in a manuscript atelier and adapted the process to produce their luxury printed Horae on a large scale. ${ }^{34}$ It is tempting to imagine how the brothers might have worked to produce Horae to accommodate different budgets. By controlling various factors, they could have created a sliding scale of sorts. Determining the quality of pigments and materials, the amount of time illuminators spent painting each impression, and by privileging the work of the master or masters in their atelier, they could have accommodated a wider range of buyers. To use an analogy borrowed from the automotive industry, we might think of Hardouyn Horae with uncolored prints as their base model, made to the bare minimum specifications and with the least amount of hand-finishing. Overpainted prints offered buyers a higher trim-package: more or better features for a higher premium. In all likelihood this was not the only or even the most significant factor visà-vis price-the support (paper or parchment) must have been paramount-but the Hardouyns seem to have exploited overpainting more than other contemporaries, creating a lucrative niche for themselves in a competitive international market.

\section{Pichore's Death of the Virgin Metalcut for the Hardouyns}

But before delving into the overpainting of several impressions of one of these prints, which depicts the Death of the Virgin, it is worth discussing the print matrix itself. Thanks to Caroline Zöhl's excellent monograph, we know the Hardouyns relied upon 
the workshop of Jean Pichore, one of the most fashionable illuminators in Paris, for some of their print matrices. This includes the octavo series of metalcuts with the Death of the Virgin (Plate 10). ${ }^{35}$ Pichore borrowed strategically from prints by Albrecht Dürer and Martin Schongauer to create his designs, reworking their style, compositions, and figure types according to his own taste, which was informed by his work as an illuminator. ${ }^{36} \mathrm{He}$ also had a fondness for Italian architecture and ornament. Pichore transformed his sources into a new style, one with a strong Germanic flavor, which enjoyed a tremendous vogue in Paris. He rose to the top of an extremely competitive market that had been previously dominated by works with Franco-Flemish qualities, such as those produced by the Master of the Apocalypse Rose and the Master of the Très Petites Heures of Anne de Bretagne. ${ }^{37}$

Pichore might have been inspired for his design for the Hardouyn Death of the Virgin by woodcuts from Venetian books of hours printed by Johannes Hamman in the early 1490 s, which depict the last rites. ${ }^{38}$ The earliest woodcut, first used in 1490, depicts a woman lying on a bed with her hands crossed at the wrists and her head resting on a pillow with knots tied at the corners. ${ }^{39}$ Behind this woman is a tonsured cleric wearing a stole that crisscrosses his chest, who holds an aspergillum and a book. Other clergymen carry candles, an aspersorium, and a processional cross. Behind them is an apse. Doors on either side open to the outdoors. In a 1493 edition, the crowd of clerics has grown to fourteen or so, with only a few depicted full-figure and the remainder indicated only by the tops of their heads. ${ }^{40}$

\section{Comparing Hardouyn Miniatures}

Examining five miniatures painted atop impressions of the Hardouyn Death of the Virgin metalcut, it becomes clear that printed underdrawings facilitated workshop diversification by serving as the basis for painterly expression and experimentation. The five examples discussed here have much in common. In all of them, color clarifies the composition, and each painter made significant editorial decisions. Likewise, there are typological changes over time, such as a trend toward simplification, with fewer figures and less architectural detail. This case study only hints at the richness of the subject, which obviously merits much more systematic analysis. The aim of this chapter is simply to change the terms of the discussion surrounding these works as well as the role of printmaking in Renaissance painting ateliers.

The first example, from 1507, was made just one year after the matrix was produced in Pichore's workshop (Plate 11). The painting is a fairly close rendition of the metalcut. The printed lines are largely followed, using various colors of paint that also indicate shadows and highlights. The paint is opaque, covering the printed lines in most areas except for the parts of the architecture, such as the pilasters and floor tiles. The illuminator made minor editorial changes. For example, the group has grown from eighteen to twenty with the addition of a couple of halo-topped heads. In addition, the candle no longer extends into the Virgin's hand. While the iconography has largely stayed the same, the addition of color makes it easier to read the image. Peter's alb and the Virgin's lapis robe draw our eye to the center of the composition. The repetitiveness of all those brown-haired men allows us to read them as a crowda single entity in which only Peter and the apostles on the edges stand out as particularly important. The vivid red and green tiles and green fabric on the bed enhance the 
sense of depth by emphasizing the diagonals. In short, the addition of color makes everything more coherent.

More substantial changes are apparent in the miniature from 1512 (Plate 12). The overcrowded room has become an intimate gathering of nine. A blue and gold curtain covers unwanted guests and some of the architectural ornament. The remainder of it is painted in muted colors, making the space look cozier and more like a domestic setting. ${ }^{41}$ Peter has lost his stole, and the apostle on the left (Andrew?) has been given a gold processional cross, which may have been inspired by Martin Schongauer's celebrated engraving of the same subject from c. 1435 to 1491 . This is clearly the work of a different artist, whose brushstrokes are more curvilinear and abbreviated. However, as with the earlier volume, the addition of color has made the image more intelligible, as have the changes to the composition.

An edition from 1514 shows yet another approach (Plate 13). Here, there are sixteen men. The painter has omitted the three men above and to the right of Peter and added another at the far left. These changes interrupt the continuous stream of men's faces and create negative space around Peter and the candle. For this painter, it seems that the number of attendees was less significant than the overall design. The changes create a more pronounced V-shape along the tops of the men's heads, which emphasizes Peter's interactions with Mary. The Virgin's eyes might be open or closed, but the mandorla that encapsulates her soul has been enlarged with golden rays. The painter has obscured most of the busy architectural backdrop with a partially opaque wash of pink, which is outlined in red to suggest a curtain or wall that recedes to the left. Only the ornamental window remains. The landscape beyond is a verdant one, which is missing the small building found in the metalcut. This painter seems to have a more rudimentary ability to suggest three-dimensionality, as the drapery looks rather flat and angular.

Examining these first three volumes together, one is struck by numerous similarities that might suggest a shared model, although each miniature certainly has its unique qualities. All three depict the Virgin lying on green fabric, with Peter in white behind. The apostle at the left wears a lemony yellow robe either over a blue one or the robe has blue trim. The apostle on the right wears a red or rust-colored garment. The bunch of fabric over his shoulder is painted a different color in these volumes, whereas later painters often interpret this bit of cloth as a continuation of his primary garment and paint both parts the same color. Later editions with this scene seem to share fewer commonalities. ${ }^{42}$ It cannot yet be ascertained whether this is because earlier miniaturists looked to a shared model, were adhering to different prevailing conventions, or if the sample size is too small and it is merely a coincidence. Tenschert, Nettekoven, and Zöhl found that the overpainting of Hardouyn books declined around 1520, with the brothers favoring smaller formats and lower-quality painting. ${ }^{43}$ While this broad trend may hold, Germain Hardouyn did publish some impressive Horae after 1520, such as the 1524 edition discussed here.

In another 1514 edition, the crowd has shrunk from eighteen to twelve, which is more consistent with depictions in single-sheet prints (Plate 14). Several extraneous elements have been painted out, such as the candle held by Peter and Mary and the book in another apostle's hands. In addition, the landscape outside has been greatly simplified. Peter is missing his stole, and his aspergillum has been shortened and tilted. The elaborate architectural setting has been retained and painted in vivid color. To keep the Virgin's soul from being lost amidst the splendor, the mandorla around it 
has been enlarged with emphatic golden rays. Semi-transparent washes on the floor tiles permit the viewer to see the printed lines beneath, more so than with the other examples described here. Finally, in this miniature the Virgin's eyes appear to be open. This painting is the work of yet another artist, one who uses reddish-brown lines in addition to purplish-blue to articulate the folds of white drapery.

The final example, from 1524, brings us back to the beginning (Plate 9). The rectangular print has been transformed to a medallion-shaped painting. Again, only twelve men are depicted and the book has disappeared. A gray stone wall covers the elaborate architectural backdrop. It is parallel with the picture plane, which compresses the space and makes the scene feel more intimate. This illuminator-whose work appears in several Hardouyn books-is clearly one of the more talented members of the workshop, if not one of its masters. It appears to be the same efficient and confidant painter that Tenschert, Nettekoven, and Zöhl identified as a workshop manager who was active during what they deemed the highpoint of the Hardouyn brothers' career: from around 1515 to $1520 .{ }^{44}$ If so, that chronology needs to be slightly adjusted to extend to the mid-1520s. Here, draperies are deeply modeled and often have gold highlights. Calligraphic black lines swell and taper to outline forms and give emphasis, which is typical of Hardouyn works, but for this painting has been done especially well. But the best work is reserved for the expressive faces (Figure 4.1). This miniature is about the size of a four-by-six-inch index card, but it evinces a range of compelling expressions on the men's faces. There is a real sense of poignancy, which is conveyed with seemingly effortless, elegant line work. The men look like individuals, each with their own emotional response-heartache, solemnity, even happiness.

It is worth noting that artwork and vernacular plays in this period focused on the emotional state of the apostles and even Mary herself during this event, which was seen as "the prototype of the good [Christian] death." 45 The fact that the overpainting of the print makes the emotional state of the participants more legible and poignant, therefore, is not merely about augmenting the book's beauty or luxuriousness, although it certainly does that. It enhances the object's devotional use. In the context of Horae, an image of the Death of the Virgin — when included-heralds the hour of Compline: the night prayer. As Rogier Wieck has noted, night and sleep were easily associated with dormition and death. And Compline, along with the Office of the Dead, includes Psalm 129, which has this entreaty to the Virgin: "At the end of my life show me your face, and reveal to me the day and hour of my death. Please hear this humble prayer and grant me eternal life." 46 These paintings would have not only marked the beginning of Compline but also guided the faithful in prayers for a serene and sanctified death. Emotional and participatory images augmented those heartfelt appeals.

\section{Printed Underdrawings}

But how can we ascertain whether the Hardouyns had their metalcuts made primarily to facilitate the production of miniatures? In other words, are the prints underdrawings by design or by happenstance? One indication that it could be the former is that the metalcuts the Pichore workshop made for the Hardouyns are somewhat different from the ones made two years earlier for Pichore himself and Remy De Laistre (Figure 4.2). ${ }^{47} \mathrm{Zöhl}$ correctly notes that the series for Pichore and De Laistre is more detailed, does a better job of evoking the plasticity of forms and color effects in black 


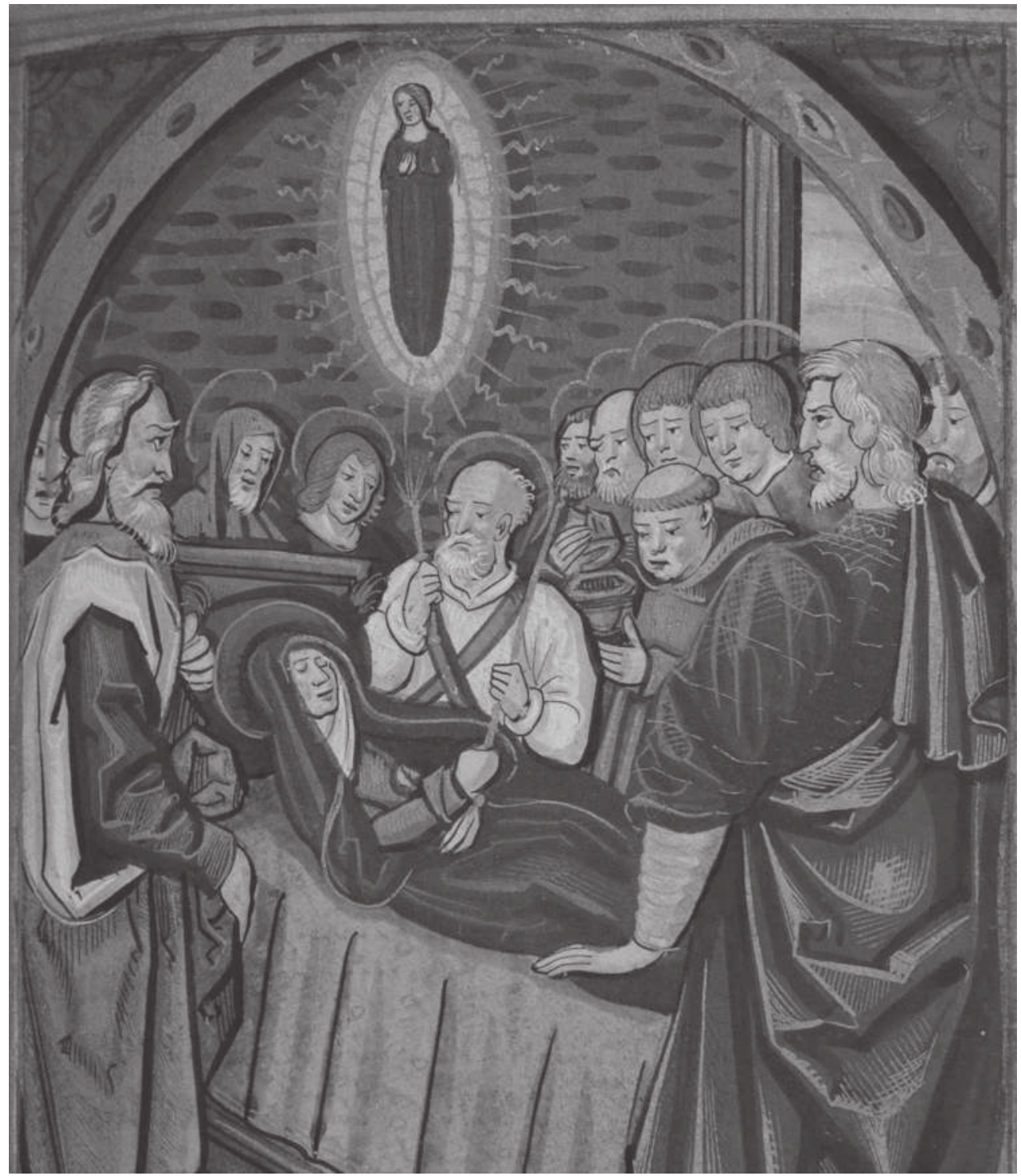

Figure 4.1 Detail of Plate 9.

and white, and were overpainted less frequently. ${ }^{48}$ These differences, I believe, are indicative of function and not quality. For the Hardouyns, it was strategic to have simpler compositions with fewer, larger figures and a reduced tonal range. Judging by extant Hardouyn volumes, inky designs did not work as well for underdrawings. Overpainted metalcuts with extensive criblé (concentrated black passages) seem to have suffered markedly greater paint loss over the centuries, with more flaking and loss. It stands to reason that dense areas of oil-based black ink would have made it harder for water-based paints to adhere to the surface. Likewise, dramatic tonal 


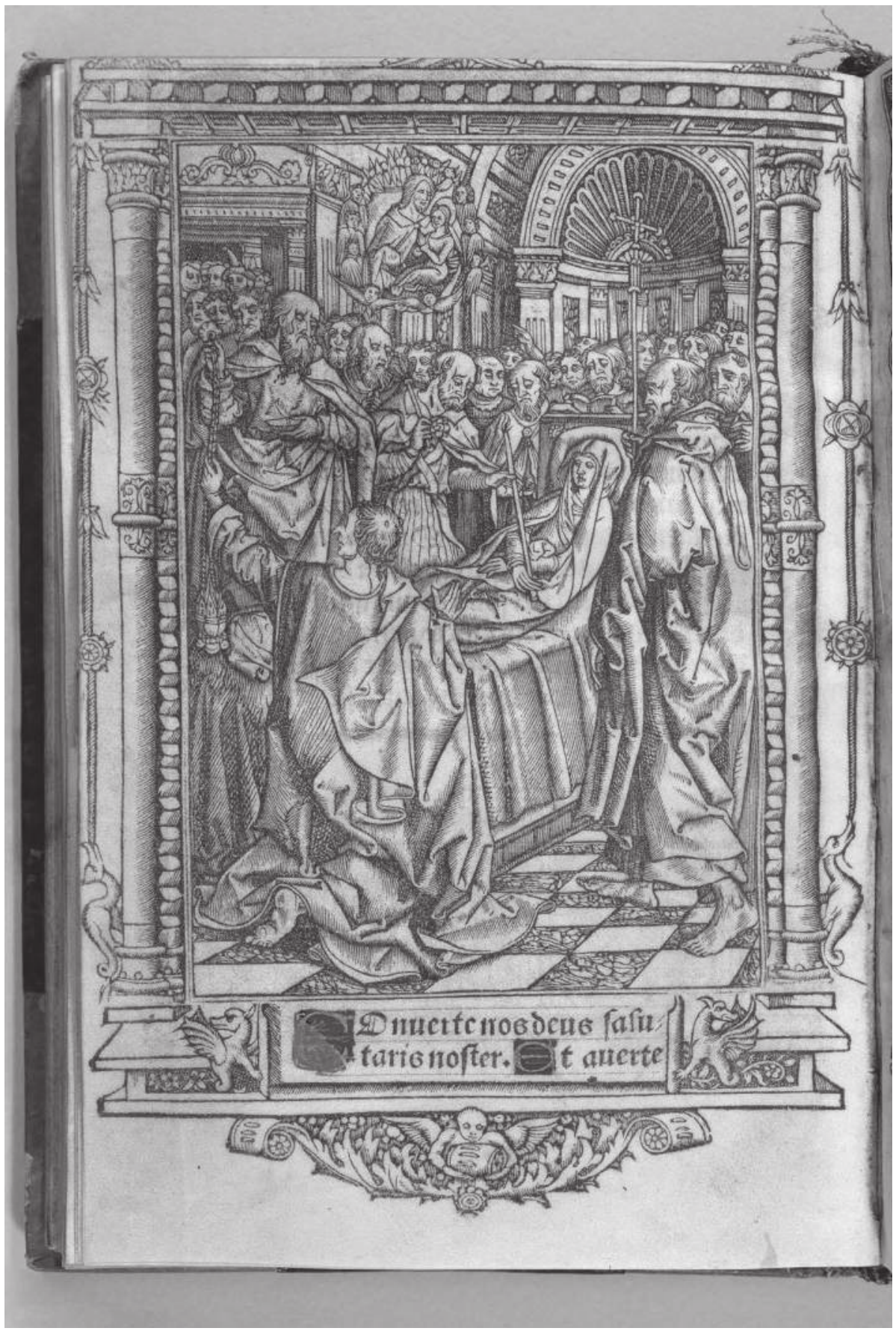

Figure 4.2 Death of the Virgin, metalcut in Hore intemerate virginis Marie secundum usum Romanum (Paris: Jean Pichore and Remy de Laistre, 24 September 1504). Berlin, Kupferstichkabinett, 796.

Photo: () Staatliche Museen zu Berlin—Kupferstichkabinett, Dietmar Katz. 
gradations and clever line work are not as important for an underdrawing, as they just disappeared beneath the paint. Because the Hardouyns did sell some Horae with uncolored metalcuts, the prints had to be legible and attractive without color, but that would not have prevented the brothers from requesting certain modifications to make the design more effective for their painters to use as underdrawings.

If the Hardouyns commissioned their metalcuts from the Pichore workshop anticipating that most impressions would ultimately function as underdrawings, they would not have been the first to capitalize on print technology this way. Indeed, as Ursula Weekes has shown, the Master of the Berlin Passion (active c. 1450-70) and others in his circle had created engravings and metalcuts expressly to serve as illustrations for para-liturgical manuscripts. For one extant book of hours, Weekes found that the engravings served as "an adaptable means to an end" that enabled the production of "replacement miniatures," which were overpainted and gilded to produce paintings that were more in keeping with the expectations of women belonging to the landed and patrician classes. ${ }^{49}$ Additionally, Weekes found evidence that the practice of using engravings to create replacement or "substitute miniatures" for manuscripts continued in the Netherlands well into the sixteenth century. ${ }^{50}$ Whereas the prints Weekes analyzed were made by enterprising artists for sale, contemporary publishers similarly made use of print technology. One publisher active in Antwerp during the 1480s and 1490s illustrated printed Horae with overpainted contour-line woodcuts, as Todor T. Petev has shown. ${ }^{51}$ But unlike the Hardouyn metalcuts, these prints could not function without the addition of color; the woodcuts were missing essential components such as facial features and inscriptions, which had to be added by a painter. The painters (or rather colorists) working on these Antwerp Horae were much less accomplished than the artists working for the Hardouyns. They followed the woodcut lines closely using simple color schemes and did not make significant editorial decisions. In other words, those prints were certainly underdrawings, and were so by design, but they were much less sophisticated than the ones commissioned by the Hardouyns, who benefited from working as (and likely being trained as) illuminators.

The fifteenth-century Venetian incunabula with overpainted woodcut borders are a more apt precedent for the Hardouyns' efforts. In those volumes, published between 1469 and 1474 , prints served as a guide for illuminators. ${ }^{52}$ This experimental method of expediting decoration, which has been much studied by Lilian Armstrong, involves hand-stamping woodblocks around the text and overpainting them. ${ }^{53}$ The woodblocks replicate white vinestem patterns (bianchi girari) that were popular in contemporary Italian manuscripts, sometimes with figural components. These prints were not merely to assist novice painters; well-known illuminators occasionally painted such woodcuts and integrated true miniature components into their design. Armstrong identifies the Putti Master as one of the woodcut designers (working for the printer Nicolaus Jenson) and asserts that his involvement supports the theory, advanced by Donati, that miniaturists and their workshops pioneered the mechanized decoration of books. ${ }^{54}$ This Venetian technique was short-lived, probably because vinestem patterns are easy enough to make and not much time was saved by printing them. ${ }^{55}$ Whether or not the Hardouyns were inspired by these incunabula, they similarly harnessed the power of print technology to expedite production, using prints as guides not only for borders but also full-page and inset miniatures. With the benefit of their larger, more detailed woodcuts and metalcuts, the Hardouyns, who-again-were unusual in that they 


\section{2}

were registered as illuminators as well as printers, realized the graphic and economic potential of partially mechanizing the miniatures in their books of hours.

This chapter proposes that the Hardouyns used metalcuts to produce printed underdrawings for their Horae, which served as the basis for painterly elaboration by their miniaturists. ${ }^{56}$ The metalcuts in Hardouyn books served as guides for overpainting, but illuminators were not entirely beholden to the designs. They could simplify or otherwise alter the design according to prevailing tastes and their own proclivities. We might think of the metalcuts as analogous to a particular kind of reproductive print, those made after the underdrawings or drawings—not the paintings—of Raphael and Jan van Scorel. Molly Faries argues that prints in Van Scorel's workshop "belong . . . to a preliminary design stage which apparently served as the basis for workshop diversification." ${ }^{57}$ Likewise, as Lisa Pon and Patricia Emison have shown, the relationship between Raimondi and Raphel was more complicated than simply an engraver-technician reproducing compositions by an overseeing artist-designer. ${ }^{58}$ The Pichore metalcuts served a similar function for the Hardouyns in that they were prompts for new works, except in this instance the print was also the support for the new work. In that respect they are similar to the "printed paintings" of the seventeenth-century Dutch artist Hercules Segers. ${ }^{59}$ Segers-who was wildly experimental-seems to have transformed nearly every one of his intaglio prints into a unique impression through a combination of prepared papers or fabric, colored inks or paint, multiplate printing, overpainting, the application of varnish, and trimming of the impression.

Because so many Hardouyn miniatures were produced using the same print, these Horae offer scholars a new way to study the role of underdrawings in Renaissance painting ateliers. Two other methods of exploring this subject have certain drawbacks. Unfinished and partially finished miniatures obviously cannot tell us as much about a painter's editorial voice, as an incomplete painting cannot reveal the extent of the changes an illuminator might have made. For this line of inquiry, scholars must use infrared spectroscopy and examine finished miniatures. This technique has other shortcomings; it is costly, and infrared cannot penetrate certain pigments or metal leaf. Limitations notwithstanding, scholars have discovered that underdrawings differed widely in terms of their complexity and the degree to which miniaturists remained faithful to them. ${ }^{60}$ Hardouyn Horae present an important way to more systematically study the role of underdrawings in French ateliers, one that is low-tech, inexpensive, and provides a ready chronology of dated works.

The Hardouyn Horae are a fascinating example of Renaissance publishers adapting print technologies to facilitate, expedite, and transform their art form. But what are we to make, ultimately, of these print-assisted paintings? In spite of all their idiosyncrasies, do they remain multiples, like any other print? Printmaker Andrew Raftery made the tantalizing declaration that "matrices, and by extension the prints they produce, have a unique and curious identity in relation to other classes of art objects. The matrix and every print pulled from it constitute the entire work of art." ${ }^{\prime 1}$ This conceit of printmaking, in which the block or plate is the archetype for all impressions, still applies to the Hardouyn Horae, but with one important caveat. What is unusual about the Hardouyn atelier is that they found a way to treat the impressions themselves like matrices. Impressions of the Death of the Virgin constitute both the ground substance for a miniature and the template for its iconography. They are generative-the matrix as in mater or mother-and produce offspring that have a family resemblance, but which are too disparate to retain the monolithic singularity that is the hallmark of printmaking. In the spirit of William Ivins, we might say that 
print-assisted paintings constitute "largely repeatable pictorial statements," but not "exactly repeatable" ones.

\section{Notes}

1 My thanks to Anna Chen for introducing me to printed books of hours when we co-curated "Making and Breaking Medieval Manuscripts" (Krannert Art Museum, 17 November 2016-11 February 2017). I would also like to extend my gratitude to Sandra Hindman, the participants and organizers of the Warsaw Multiplied and Modified conference, Lisa Rosenthal, and an anonymous reviewer for feedback on earlier drafts. Finally, thanks to Katherine Baker for graciously sharing her excellent dissertation chapter. Any mistakes or omissions are my own. Duclow, “The Virgin's 'Good Death,'” 55-84.

2 Baxandall, "The Perception of Reimenschneider," 83-98.

3 These problematic divisions have been noted by others. For example, Weekes, Early Engravers, 20.

4 Erasmus of Rotterdam, De recta Latini Graecisque sermonis pronuntiatione dialogus (Basel: Froben, 1528) cited in Dackerman, ed., Painted Prints, 2.

5 Dackerman, ed., Painted Prints, 9-10.

6 Ibidem, 11, 28.

7 Primeau, "The Materials," 48-78; idem, "Coloring Within the Lines," 11-16; idem, "BMA Voices."

8 Hindman, "Cross-Fertilization," 101-56; Nettekoven, Der Meister der Apokalypsenrose; Winn, Anthoine Vérard; eadem, "Printing and Reading," 177-204; Zöhl, Jean Pichore.

9 Dondi, Printed Books of Hours.

10 One exception is Baker, Painting and the Luxury Arts, 55-91; a broader, informative discussion can be found in Tenschert, Nettekoven, and Zöhl, eds., Horae B.M.V, vol. 1, 1379-81.

11 Pon, Raphael, Dürer, and Marcantonio Raimondi, esp. 11, 38.

12 Mundy and Hyman, "Out of the Shadow of Vasari," 283-317.

13 Quant vous serez tout appareillie, dictes en vostre hostel, si bon vous se[m]ble, matines et prime. . Quant a votre service dites iusq[u]e a tierce deva[n]t disner acheues le tout devant souper. . .- Jean Quentin, La manière de bien vivre dévotement par chascun jour (Paris: Antoine Caillaut, 1491), n.p. Quentin's advice was translated for the Prymer of Salysbury Use, one of the most popular printed Horae in England. Burger, Conduct Becoming, 51-53. Quentin also composed prayers for Anthoine Vérard's Horae. See Winn, Anthoine Vérard.

14 Enchiridi[on] preclare eccl'ie Sarisburi[en]sis ... (Paris: Germain Hardouyn, c. 1533), n.p.

15 Winn, "Printing and Reading," 183-84.

16 Vérard printed the earliest known Horae in 1485.

17 Hindman, "Cross-Fertilization," 140.

18 Winn, "Printing and Reading," 177.

19 Erler, "Devotional Literature," 496.

20 Anne Boleyn, for example, owned a Hardouyn Book of Hours (Hever Castle, c.1528). For an overview of printed books of hours for the English market: Duffy, "The Impact of Print," 121-46.

21 Baker, Painting and the Luxury Arts, 55.

22 Freeman, The Unicorn Tapestries, 196-200; Zöhl, "La Réception Précoce," 155-68.

23 Some Hardouyn volumes have true miniatures in the margins (L-shaped), the designs of which are typically derived from their larger rectangular prints.

24 This is not to say that uncolored prints were necessarily the reserve of cheap or low-quality books. Plenty of publishers created lavish printed Horae with uncolored prints.

25 Hindman, "Cross-Fertilization," 137.

26 Tenschert, Nettekoven, and Zöhl, eds., Horae B.M.V, vol. 1, 1379.

27 Gillet's earliest extant work is a 1503 Horae, for which he was a printer. He became a publisher of these books in 1509.

28 Earliest mention as illuminator is from 1500. Baker, Painting and the Luxury Arts, 84; The colophon for an August 1514 edition calls Germain "certainly libraire [publisher, not printer], and very skillful in the art of literary pictures [illuminations]" (etiam librarii et in arte litterarie picture peritissimi). Ibidem, 83, 85, 86. 


\section{Maureen Warren}

29 Jean the Elder and Thomas.

30 Thomas. Baker, Painting and the Luxury Arts, 86.

31 Ibidem.

32 On pigment quality see ibidem, 59.

33 Ibidem, 88.

34 Ibidem, 89.

35 Zöhl, Jean Pichore, 138-40.

36 Ibidem, and "La Réception Précoce," 155-68.

37 Ibidem, 157; Nettekoven, Der Meister der Apokalypsenrose.

38 Dondi, Printed Books of Hours, fig. 48, 54 and 56.

39 Ibidem, fig. 48 and 54; Officium BMV Secundum Usum Romanum (Venice: Johannes Hamman, 4 December 1490).

40 Officium BMV Secundum Usum Romanum (Venice: Johannes Hamman, 1493), London, BL, IA.23361, fol. 11v-12r (Last rites). Dondi, Printed Books of Hours, fig. 56.

41 This could be a lavish home rather than a church; Pichore painted domestic spaces that resemble this one. See Zöhl, Jean Pichore, 109.

42 For example, in a 1526 edition at Les Enluminures, eleven men surround Mary, who rests on white fabric. The apostles on the edges are dressed in red and blue. Blue and gold fabric covers all the architectural backdrop except the window. The yellows seen elsewhere are absent, with predominantly bright red, royal blue, white, and gold instead. Reference number: 60; www.medievalbooksofhours.com/inventory/boh_060.

43 Tenschert, Nettekoven, and Zöhl, eds., Horae B.M.V., vol. 1, 1380. This this change might be due to the death of Gillet in 1521.

44 Tenschert, Nettekoven, and Zöhl, Horae B.M.V., eds., vol. 4, 3291-94, book 124.2.

45 Duclow, "The Virgin's 'Good Death.'”

46 Wieck, Time Sanctified, 164; cited ibidem, 63.

47 Pichore workshop for Jean Pichore and Remy de Laistre, 1504, Berlin, Kupferstichkabinett.

48 Zöhl, Jean Pichore, 139.

49 Weekes, Early Engravers, 163-65.

50 Weekes, "The Interplay," 161-68.

51 Petev, "A Group of Hybrid Books of Hours," 469-78.

52 Donati, "I fregi xilografici" argues for a Roman point of origin, but Lilian Armstrong makes a compelling case for Venice. Armstrong, "The Decoration," 7, has documented a corpus of 135 of such books, mostly by the de Spira brothers and Nicolaus Jenson.

53 Armstrong, "The Impact of Printing," 192-200; see also eadem, "Venetian Incunables," esp. 234 and 235, footnote 19, Color Pl. XVI.

54 Armstrong, Renaissance Miniature Painters, 26-30.

55 Armstrong, Impact of Printing, 200.

56 Certainly, the Hardouyns also sold Horae with unpainted metalcuts. But even if the Hardouyns sold editions with uncolored prints, they could nevertheless have requested designs that would be more suitable for their painters to use as underdrawings.

57 Faries, "Some Remarks," 149.

58 Pon, Raphael, Dürer, and Marcantonio Raimondi; Emison, "The Forest Around the Fir Tree," 18-31.

59 Samuel van Hoogstraten said Segers "printed paintings" when he printed his copper plates on shirts and bedsheets, and scholars have made much of his turn of phrase. Inleyding tot de Hooge Schoole der Schilderkonst: anders de Zichtbaere Werelt (Rotterdam, 1678), quoted in Cornelis et al., eds., Under the Spell of Hercules Segers, 9. See also Nakamura, "On Hercules Segers's 'Printed Paintings,'” 189-95; and Leeflang and Roelofs, eds., Hercules Segers.

60 For example, three miniaturists involved with making the Hours of Isabella Stuart used underdrawings differently, some of whom made extensive changes in the painting phase. Fitzwilliam Museum, "ILLUMINATED: Manuscripts in the Making," www.fitzmuseum. cam.ac.uk/illuminated/ (accessed 10 October 2017); and Ricciardi, "Manuscripts in the Making," 60. Likewise, the Master of the Dresden Prayerbook made changes when painting. Buck, "On Relationships," 104-5.

61 Raftery, "Drawing and Its Double." 


\section{Bibliography}

Armstrong, Lilian. Renaissance Miniature Painters and Classical Imagery: The Master of the Putti and His Venetian Workshop. London: Harvey Miller Publishers, 1981.

"The Impact of Printing on Miniaturists in Venice After 1469." In Printing the Written Word: The Social History of Books, 1450-1520, ed. Sandra Hindman, 174-202. Ithaca, NY: Cornell University Press, 1991.

- "Venetian Incunables in Cambridge Collections: Modes of Hand-Illumination." In The Cambridge Illuminations: Conference Volume, ed. Stella Panayotova, 233-43. London: Harvey Miller Publishers, 2007.

- "The Decoration and Illustration of Venetian Incunabula: From Hand Illumination to the Design of Woodcuts." In Printing R-Evolution and Society 1450-1500: Fifty Years That Changed Europe, ed. Cristina Dondi. Venice: Edizioni Ca' Foscari, University of Venice, forthcoming.

Baker, Katherine Eve. Painting and the Luxury Arts in Paris, 1490-1515: Objects and Their Urban Contexts, 55-91. Ph.D. dissertation, University of Virginia, Valencia, 2013.

Baxandall, Michael. "The Perception of Reimenschneider." In Tilman Riemenschneider: Master Sculptor of the Late Middle Ages. Exhibition catalogue, Washington: NGA, 1999, 83-98. New Haven: Yale University Press.

Buck, Stephanie. "On Relationships Between Netherlandish Drawing and Manuscript Illumination in the Fifteenth Century." In Flemish Manuscript Painting in Context: Recent Research, eds. Elizabeth Morrison and Thomas Kren, 103-16. Los Angeles: J. Paul Getty Museum, 2007.

Burger, Glenn D. Conduct Becoming: Good Wives and Husbands in the Later Middle Ages. Philadelphia: University of Pennsylvania Press, 2017.

Cornelis, Mireille E. et al., eds. Under the Spell of Hercules Segers: Rembrandt and the Moderns. Zwolle: W BOOKS , 2016.

Dackerman, Susan, ed. Painted Prints: The Revelation of Color in Northern Renaissance \& Baroque Engravings, Etchings \& Woodcuts. Baltimore: Baltimore Museum of Art; University Park, PA: Pennsylvania State University Press, 2002.

Donati, Lamberto. "I fregi xilografici stampati a mano negl'incunabuli italiani." La Bibliofilia, 74 (1972): 157-64, 303-28; and La Bibliofilia, 75 (1973): 125-74.

Dondi, Cristina. Printed Books of Hours from Fifteenth-Century Italy: The Texts, the Books, and the Survival of a Long-Lasting Genre. Florence: Leo S. Olschki Editore, 2016.

Duclow, Donald F. “The Virgin's 'Good Death': The Dormition in Fifteenth-Century Drama and Art." Fifteenth-Century Studies, 21 (1994): 55-84.

Duffy, Eamon. "The Impact of Print." In Marking the Hours: English People and Their Prayers 1240-1570, 121-46. New Haven: Yale University Press, 2006.

Emison, Patricia A. “The Forest Around the Fir Tree: Looking for Marcantonio Raimondi's Art.” In Leslie A. Geddes et al., Marcantonio Raimondi, Raphael and the Image Multiplied, ed. Edward H. Wouk, 18-31. Manchester: Manchester University Press, 2016.

Erler, Mary C. “Devotional Literature." In The Cambridge History of the Book in Britain, eds. Lotte Hellinga and J. B. Trapp, 495-525. Cambridge: Cambridge University Press, 1998.

Faries, Molly. "Some Remarks on the Interrelationship of Underdrawings, Drawings and Prints." In Le Dessin Sous-Jacent Dans la Peinture: Colloque V, 29-30 Septembre-1er Octobre 1983: Dessin Sous-Jacent et Autres Techniques Graphiques, eds. Dominique HollandersFavart and Roger van Schoute. Louvain-la-Neuve: Université Catholique de Louvain, 1985. Freeman, Margaret B. The Unicorn Tapestries. New York: The Met; E. P. Dutton Inc., 1976.

Hindman, Sandra. "Cross-Fertilization." In Pen to Press: Illustrated Manuscripts and Printed Books in the First Century of Printing, 101-56. College Park, MD: University of Maryland, 1977.

Leeflang, Huigen, and Pieter Roelofs eds. Hercules Segers: Painter-Etcher. Amsterdam: Rijksmuseum, 2016. 
Mundy, Barbara E., and Aaron M. Hyman. "Out of the Shadow of Vasari: Towards a New Model of the 'Artist' in Colonial Latin America." Colonial Latin American Review, 24 (2015): 283-317.

Nakamura, Jun. “On Hercules Segers's 'Printed Paintings'.” In Printing Colour 1400-1700: History, Techniques, Functions and Receptions, eds. Ad Stijnman and Elizabeth Savage, 18995. Leiden: Brill, 2015.

Nettekoven, Ina. Der Meister der Apokalypsenrose der Sainte Chapelle und die Pariser Buchkunst um 1500. Turnhout: Brepols, 2004.

Petev, Todor T. "A Group of Hybrid Books of Hours Illustrated With Woodcuts." In Books of Hours Reconsidered, eds. Sandra Hindman and James H. Marrow, 469-78. London: Harvey Miller Publishers, 2013.

Pon, Lisa. Raphael, Dürer, and Marcantonio Raimondi: Copying and the Italian Renaissance Print. New Haven: Yale University Press, 2004.

Primeau, Thomas. "The Materials and Technology of Renaissance and Baroque Hand-Colored Prints." In Painted Prints: The Revelation of Color in Northern Renaissance \& Baroque Engravings, Etchings \& Woodcuts. Exhibition catalogue, ed. Susan Dackerman, 48-78. Baltimore: Baltimore Museum of Art; University Park, PA: Pennsylvania State University Press, 2002.

- "Coloring Within the Lines: The Use of Stencil in Early Woodcuts." Art in Print, 3/3 (2013): 11-16.

. "BMA Voices: Woodcuts, Color and the Experience of the Visual Arts I BMA Blog." (2014). http://blog.artbma.org/2014/09/bma-voices-woodcuts-color-and-the-experience-ofthe-visual-arts/ (accessed 12 October 2017).

Raftery, Andrew. "Drawing and Its Double: The Engraved Plate." Art in Print, 1/2 (2011). http://artinprint.org/article/drawing-and-its-double-the-engraved-plate/

Ricciardi, Paola. "Manuscripts in the Making: Art and Science." Heritage Science, 7 (December 2019): 60 .

Tenschert, Heribert, Ina Nettekoven, and Caroline Zöhl, eds. Horae B.M.V: 365 Gedruckte Stundenbücher Aus Der Sammlung Bibermüble, 1487-1586. Vols. 1-6. Ramsen, Switzerland: Antiquariat Bibermühle AG; Heribert Tenschert, 2014.

Weekes, Ursula. Early Engravers and the Their Public: The Master of the Berlin Passion and Manuscripts from Convents in the Rhine-Maas Region ca. 1450-1500. Turnhout: Harvey Miller, 2004.

- "The Interplay Between Prints and Illuminated Manuscripts in Brigittine Convents of the Low Countries During the Sixteenth Century." In Under the Influence: The Concept of Influence and the Study of Illuminated Manuscripts, eds. John Lowden and Alixe Bovey, 161-68. Turnhout: Brepols, 2007.

Wieck, Roger S. Time Sanctified: The Book of Hours in Medieval Art and Life. New York: G. Braziller in association with the Walters Art Gallery, Baltimore, 1988.

Winn, Mary Beth. Anthoine Vérard: Parisian Publisher 1485-1512: Prologues, Poems, and Presentations. Geneva: Librairie Droz, 1997.

- "Printing and Reading the Book of Hours: Lessons from the Borders." Bulletin of the John Rylands University Library of Manchester, 81 (1999): 177-204.

Zöhl, Caroline. Jean Pichore: Buchmaler, Graphiker und Verleger in Paris um 1500. Turnhout: Brepols, 2004.

—. "La Réception Précoce d'Albrecht Dürer Dans L'art Français.” In La France et l'Europe Autour de 1500: Croisements et Échanges Artistiques, 155-68. Paris: École du Louvre, 2015. 


\title{
5 A Passion for Prints \\ Netherlandish Engravings in an Early Sixteenth-Century Prayer Book
}

\author{
Olenka Horbatsch
}

An extraordinary manuscript prayer book with pasted-in and masterfully handcoloured engravings is a revealing example of prints modified for devotional and aesthetic purposes. Eighteen hand-coloured Netherlandish engravings from the first quarter of the sixteenth century are pasted on to the versos of parchment pages facing hand-written devotional texts. The placement of the prints within the book and the relationship between text and image make it clear that the book was conceived of as a coherent unit and the book was assembled and used as a devotional tool. Illusionistic frames of black and gold disguise the borders of the prints in the book and give the prints the appearance of miniature paintings. Through assembly and alteration, certain visual properties and devotional narratives of the engravings are emphasized and augmented. The selection of prints, furthermore, places emphasis on the role of the Virgin in salvation, which suggests that the prayer book may have held specific meaning for regional confraternities in the Low Countries. Further to the devotional function, the prayer book offers valuable evidence of the reception and function of prints. Prints by Lucas van Leyden (c. 1494-1533), the first Netherlandish printmaker of international renown, are painted to a high degree of artistic skill. His Engraved Passion (1521) is interwoven with devotional prints by his less-knower contemporaries from the southern Netherlands, which, as I will argue, reflects the growing interest in regional print production in the Low Countries. The prayer book predates documentation or coherent print-collecting criteria by several decades and can therefore be understood as a valuable marker of reception during this early period of print production.

Prints were foundational to the design and format of the prayer book, and the text is closely aligned with images. The manuscript comprises 70 parchment sheets, and the text is a collection of prayers in the vernacular Dutch and psalms in Latin about the Passion of Christ. ${ }^{1}$ The series of 14 engravings, known as the Engraved Passion by Lucas van Leyden, is pasted in the book; The Last Supper is now missing, but would have been originally included. ${ }^{2}$ Each print is facing a corresponding "meditation" (or prayer) on the respective chapter of Christ's Passion. Alongside Lucas van Leyden's series, three prints are by the south Netherlandish artist, Frans Crabbe (c. 1480-1553) who was active in Mechelen: The Mass of Saint. Gregory (fol. 24v), Christ Mocked (fol. 13v, interspersed among Lucas's Passion), and a hitherto unrecorded first state of the Adoration of the Christ Child (fol. 49v). The remaining prints are of the Seven Sorrows of the Virgin (fol. 21v) by the so-called Master S (active in Antwerp in the 1520s), and a copy after Albrecht Dürer's Virgin and Child on a wooden bench, crowned by an angel (fol. 40v) by the German artist Jacob Binck, who was active in the Low Countries in the 1520 s. $^{3}$ Binck's engraving is dated 1526, the terminus post 
quem for the manuscript, which was likely made around 1526-30 in the southern Netherlands. The prayer book is in eighteenth-century binding, and was in the Benedictine monastery library of Ampleforth Abbey, North Yorkshire, since 1801 before it was acquired by the Rijksmuseum in $2011 .^{4}$

\section{Pasting Prints Into Manuscripts}

Prints were coloured, altered, and pasted into manuscripts within the first few decades of the origins of printmaking in the fifteenth century. ${ }^{5}$ Such print-manuscript hybrids could be coloured and customized to suit a range of functions for lower markets and elite audiences alike. Studies by James Marrow and, more recently, Kathryn Rudy, have examined the cross-pollination between manuscript and print and revealed that the emerging print market influenced the format, function, and even style of manuscript illuminations. ${ }^{6}$ Illuminators engaged with prints in a variety of creative ways, depending on the social status and function of books and the interests of patrons and owners. Prints serve as models for illuminations, and prints could be pasted into manuscripts directly in lieu of illuminations. Inserted prints could be disguised through illusionistic borders and overpainting. The most elaborate examples of such manuscripts originate from the upper echelons of society in the fifteenth century. The hours of Charles d'Angoulême (c. 1480), for example, were commissioned by the French count and were passed down to his son Francis I in 1515. The dazzling visual programme was fitting for the courtly context. The manuscript combines 43 hand-painted illuminations derived from or inspired by print models, with 16 pastedin engravings by Israhel van Meckenem and 27 illuminations loosely or partly based on Netherlandish and German prints dated to the 1460s, including Master ES, the Housebook Master, and Master FVB. ${ }^{7}$ Copies of these early engravings-both printed copies by Meckenem and freehand miniatures by the illuminators-are important documents of reception and distribution during this early period. The insertion of prints is, in some cases, disguised by thick overpainting, such as Meckenem's reversed copy of Martin Schongauer's Nativity, where landscape details were added and figural details adapted and simplified. ${ }^{8}$

On the other end of the socio-economic spectrum, small devotional engravings made around the last quarter of the fifteenth century were produced and sold with the intention of being pasted into devotional manuscripts, as Ursula Weekes has argued. ${ }^{9}$ Many such prints are copies of devotional engravings by fifteenth-century printmakers working in the Maas-Rhine region. For example, 46 engravings by the Master of the Martyrdom of the Ten Thousand copied after the Master ES, Master of the Berlin Passion, and others in London (BM, 1846,0709.22-57, 1849,0210.604, and 1853,1210.1-11) survive on parchment pages of a Flemish prayer book with hand-drawn borders and originate from the same manuscript, formerly in the abbey of Saint Peter in Ghent. ${ }^{10}$ Such engravings by anonymous workshops around the Rhine-Maas region provided cost-effective alternatives for laity and clergy alike. Owners could affix and assemble the prints within their books, as the text was not dependent upon the printed images. Just as the dissemination of engravings shaped the form and function of manuscripts, so, too, the continued usage of manuscripts instigated innovations within the print market. Diminutive engravings of saints by Meckenem and others were intended to be cut and pasted into handwritten initials of manuscripts. ${ }^{11}$ Fragments of early engravings in the British Museum demonstrate that cutting, silhouetting, colouring, and 
pasting were standard practices in the fifteenth century. In many cases, intact sheets of such small engravings do not survive, and examples are only known through impressions pasted into manuscripts. ${ }^{12}$ Such engravings are customized to varying degrees of skill and often include hand-drawn borders or additions, hand-coloured and heightened with gold. Through such alterations, individual prints were adapted, modified, and customized for devotional purposes to suit a wide demographic.

\section{Colouring Prints}

Creative exchanges between print and manuscript culture continued well into the sixteenth century with heightened artistic ambitions. ${ }^{13}$ The Rijksmuseum prayer book stands between the high echelons of patronage and cheap, mass-produced images made for an open market. The prayer book comprises engravings by prominent sixteenthcentury artists as well as cheaper devotional prints painted with a high degree of artistic skill and with expensive pigments and heightened with gold. The prayer book can be interpreted to signify the positive or the negative values conferred upon prints in the early decades of the sixteenth century. Prints continued to be coloured well into the sixteenth century, and coloured prints were typically more prestigious than uncoloured impressions: coloured prints were more expensive and usually reserved for illustrious patrons or special editions. Colour played an important role in simulating other media, for example, a print could simulate a painting when hand-coloured and mounted on a secondary support. However, colour can obscure critical components of a print, such as line work, hatching, and composition, as well as crucial information for print connoisseurship, including monograms, technique, and impression quality. Colouring therefore occupies an uneasy role within the history and reception of prints and presents a hermeneutical challenge: while colour was a luxury in the early modern print market, it could also overwhelm the work of the printmaker. David Areford proposed a new model of interpreting altered prints, in which alterations and additions are considered important evidence of use, and moreover, production is understood as a continuing process. ${ }^{14}$ In other words, alterations are integral to both the production and reception of the early printed image. This broad understanding allows us to conceptualize the alterations and colouring of prints in the Rijksmuseum prayer book as integral to their function and meaning. The Rijksmuseum prayer book, with its heightened artistic ambitions, speaks to new functions and audiences for manuscriptprint hybrids in the early decades of the sixteenth century and shows how earlier practices were applied to new contexts.

The prayer book is not merely a cheaper substitute of an illuminated manuscript, but rather, I would like to suggest, it represents a new, stand-alone type of luxury devotional object for a regional audience interested in printed images. In the prayer book, the prints are selected and coloured with careful consideration of both devotional and aesthetic dimensions, and therefore not merely cheaper, mass-produced alternatives to the more costly hand-painted miniatures. Susan Dackerman's important exhibition surveyed coloured prints from northern Europe and revealed that throughout the sixteenth century, hand-coloured impression were gifted as luxury editions, often for diplomatic purposes, and likewise occupied an important place within the print market as a sought-after novelty and cost three to four times as much as uncoloured impressions. ${ }^{15}$ Dackerman convincingly argued that the prevailing negative views of coloured prints has largely been shaped by Erwin Panofsky's reading of Erasmus's 
passage that Albrecht Dürer was able to represent colouristic effects without colour in his engravings. ${ }^{16}$ Colouring prints was standard practice in Dürer's day, and with the increasing visual complexity of engravings and elevated artistic status of their makers, colour took on new significance.

Lucas van Leyden was renowned for his delicate approach to engraving, which was especially well suited to the depiction of atmospheric perspective. Early, silvery impressions of his prints demonstrate his subtle variations in tone. His prints were much sought after in his lifetime, and remained in demand throughout the seventeenth century, when it became difficult to acquire good-quality impressions. ${ }^{17}$ In the Rijksmuseum prayer book, Lucas's engravings are painted with careful consideration of the engraved lines. His monogram is emphasized by the addition of colour, in contrast to prints coloured in the fifteenth century, where monograms were obscured. ${ }^{18}$ Delicately applied transparent washes were carefully added to the prints, through which Lucas's finely engraved lines remain visible. Alternating thicknesses of paint moreover carefully cohere with Lucas's hatching. In depictions of landscape and sky, colour is added to order the pictorial field, for example, in the Agony in the Garden (Plate 15), varied shades of green and blue are used to suggest spatial recession. In the Crucifixion (Plate 19) and the Lamentation of Christ (Figure 5.1), greens and yellows in the grassy landscape are also treated with a painterly approach. Another rare survival that has recently been sold at auction shows that the practice of painting Lucas's Engraved Passion continued into the century: early impressions of Lucas's Passion were beautifully illuminated and heightened with gold and likely were originally assembled into a devotional book; the style of the colouring suggests that it was painted in the second half of the sixteenth century. ${ }^{19}$

The colourist of the Rijksmuseum prayer book made two additions to Lucas's engravings: the application of blood to Christ's body and gold halos above the holy protagonists. In Lucas's Engraved Passion, Christ's serene expression and muscular body emphasize the magnanimity with which he endured the various tortures and humiliations; his was a spiritual and meditative Passion. Lucas's rendering of Christ's heroic body could also be understood through theological commentaries that equated beauty with divinity. ${ }^{20}$ In the prayer book, however, Christ's body is covered in blood, and the materiality of the dripping paint emphasized and even embodies the physical presence of torture, as seen most prominently in the Flagellation (Plate 16), Christ Carrying the Cross (Plate 17), and the Crucifixion (Plate 19). David Areford examined the application of painted blood in fifteenth-century devotional woodcuts and argued that such depictions often held liturgical and spiritual significance. ${ }^{21}$ In this context, the application of paint transforms Lucas's spiritual rendering of the Passion into a physical rendering, in accordance with the late medieval emphasis on the bodily suffering of Christ which remained popular within confraternities well into the sixteenth century. This representation accords with the corresponding text, which recounts Christ's physical torture in detail.

Gold halos were added to Lucas's engravings in the prayer book, also following late medieval depictions of Christ across media. Lucas depicted Christ without the halo in his Engraved Passion; in the series, Christ's idealized nude body serves to represent divinity. The colourist added halos in gold to Lucas's engravings with delicate lines that resemble gold highlights in illuminated manuscripts. In two prints, gold is also used to enhance the depiction of the holy realm. In the Agony in the Garden (fol. 2v; Plate 15), gold brushstrokes are added to yellow paint in the upper left corner to 


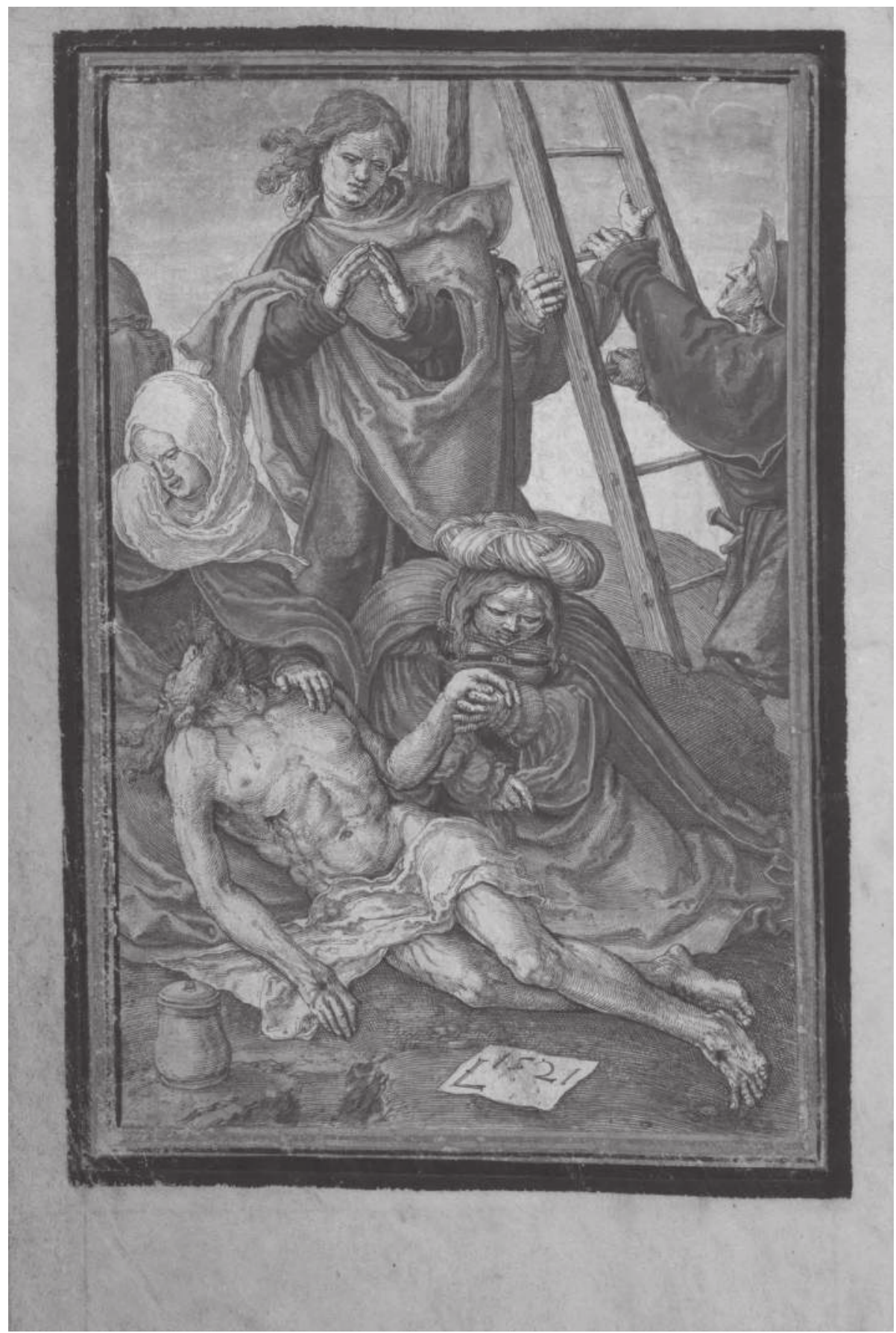

Figure 5.1 Lucas van Leyden, Lamentation of Christ, 1521, engraving, hand-coloured and pasted into prayer book manuscript c. 1530. Amsterdam, Rijksmuseum, RP-P-2011-115-11.

Photo: http://hdl.handle.net/10934/RM0001.COLLECT.505145, CC0 1.0. 
signify heaven, and this technique is also employed in the Resurrection (fol. 10v; Plate 20) to render the clouds around Christ more radiant.

The colouring of prints served the dual function of adding artistic interest, even prestige, while also emphasizing a specific understanding of the Passion narrative rooted in late medieval devotion which emphasized the physical and bodily understanding of humiliation and divinity. The colouring, together with the text, offers a contemporary gloss on how Lucas's introspective rendition of the Passion was altered and adjusted to suit contemporary devotional needs. While the more drastic alterations (especially the liberal application of blood) can be taken to mean that Lucas's artistry was not prized, I wish to emphasize that authorship and aesthetics were indeed an important consideration to the compilation of the book. The addition of blood to Christ's body follows the naturalism of Lucas's engravings: blood drips down the column and the stairs in the Flagellation (fol. 8v; Plate 16), the Crowning of Thorns (fol. 9v), and the Ecce Homo (fol. 11v). Following Areford's ideas of production as an on-going process, the contemporary colouring can be seen as a refinement or customization, not detraction, from the engraved line.

\section{Selection of Prints}

The ordering of prints in the prayer book held devotional significance. Lucas van Leyden's Passion sequence is interrupted, and Crabbe's Christ Mocked (fol. 13v, Plate 18) is inserted in between Christ Carrying the Cross (fol. 12v, Plate 17) and the Crucifixion (fol. 14v, Plate 19). In Crabbe's print, Christ is rendered even more pitiful through the generous application of painted blood and offers a meditative break from the Passion narrative in the manuscript. Christ holds the instruments of his torture, the rope and the reed, and his head hangs heavy underneath the great crown of thorns, but the wounds of crucifixion have not yet been inflicted. While the print has traditionally been described as "Man of Sorrows," it depicts a variant of the subject known as Christ Mocked. This image type originated in the fifteenth century in northern Europe, when the popularity of Passion devotion and imagery led to variations and new image types. ${ }^{22}$ Christ Mocked shares many similarities with Passion iconography, including the Man of Sorrows, Ecce Homo, and Christ in Repose, and the important distinction of this new image type is that Christ is shown removed from the Passion narrative. As Mitchell Merback observed, this image type developed in tandem with the late medieval devotional tradition to visualize moments of calm between episodes of the Passion and to use these moments to meditate on the deep significance of Christ's suffering. ${ }^{23}$ It is revealing that this particular close-up image of Christ was chosen to be interspersed among the Passion narrative in the prayer book. The meditative function of the print is emphasized and augmented by its placement in between two episodes in the Passion narrative. Crabbe's Christ offers a meditative moment in the book, further heightened by the accompanying prayer that details the extent of Christ's physical torture. Interestingly, the accompanying prayer likewise focuses on Christ's head and is titled, "to the head of the Lord Jesus." Further to the devotional function, the visual interplay between the prints is interesting: in Crabbe's print, Christ's angled head mirrors Christ's head beneath the cross in Lucas's print. Christ meets the viewer's gaze, an apt image for a contemplative moment within the narrative. Christ Mocked offered the viewer a vehicle for compassionate identification with Christ's suffering, and the 
accompanying text in the prayer book describes and venerates Christ's face in detail and ends with a plea for Christ's help to avoid temptation.

Following the Passion cycle, Crabbe's print of Mass of Saint Gregory is pasted in alongside the Paternoster prayer (fol. 24v; Figure 5.3). The story of Saint Gregory's miraculous vision, when Christ as the Man of Sorrows appeared during mass on the altar, was connected with a Byzantine icon of the Man of Sorrows in Santa Croce in Gerusalemme in Rome, ostensibly painted by Gregory himself after his vision. The episode was taken as proof of the doctrine of transubstantiation, and the Gregorian Man of Sorrows became the most popular indulgenced image in the fifteenth century. ${ }^{24}$ Prints played an important role in the development and diffusion of the subject, for example, Israhel van Meckenem's engraving from the 1480s, which bears an inscription promising 20,000 years of pardon from purgatory. ${ }^{25}$ In the Rijksmuseum prayer book, the Gregorian episode is inserted after the Passion and provides the conclusion to the narrative. In Crabbe's print, the emphasis is on Saint Gregory, who is shown in adoration of the vision. In the prayer book, the colourist has added blood dripping from Christ's side into the chalice below, shifting the focus to the Eucharistic dimension of the story. References to the ritual of mass-both in the image and in the accompanying prayer-bring the reader/viewer from the meditative journey to the physical and liturgical domain. Through image order, the book brings the Passion narrative into the experiential realm of liturgy and ritual.

\section{Marian Devotion}

The remaining prints focus on the Virgin: the Seven Sorrows of the Virgin (fol. 21v; Figure 5.2) symbolizes her compassion, the Nativity or Adoration of the Child (fol. 49v: Figure 5.4) highlights her role in the Incarnation, and the Virgin and Child Sitting on a Bench shows her in glory, crowned by an angel. The prints are accompanied by prayers to the Virgin and the seven Penitential Psalms. The role of the Virgin became greatly expanded in late medieval depictions of the Passion, as new interest in the human aspect of Christ's suffering prompted an increased role for his grieving mother. ${ }^{26}$ The Virgin became both mediator and exemplar in the Passion narrative, and veneration of the Virgin increased exponentially and led to the formation of various popular cults dedicated in her honour. ${ }^{27}$ Images of the Virgin proliferated across northern Europe in a wide range of media, including prints, illuminated books and manuscripts, panel paintings, and sculpture, that paid homage to her role in the Passion. ${ }^{28}$

In the Master S print in the Rijksmuseum prayer book (fol. 21v; Figure 5.2), a Pietà at center is surrounded by seven medallions depicting the Virgin's sorrows and the instruments of the Passion, set within an architectural frame. Such architectural features often appear in depictions of the Seven Sorrows of the Virgin across media in order to structure the narrative and serve as focal points for meditation. ${ }^{29}$ The Seven Sorrows of the Virgin was a popular subject of cult devotion among confraternities in northern Europe from the late fifteenth century onwards. ${ }^{30}$ The Confraternity of the Seven Sorrows of the Virgin was founded in three Netherlandish churches in the 1490s by Jan van Coudenberghe, secretary to Philip the Fair. ${ }^{31}$ Printed images played a critical role as instruments of devotion and for the promotion of local chapters of the cult in the Low Countries, as Dagmar Eichberger has demonstrated. ${ }^{32}$ Select confraternities, for example, Delft, even possessed printing plates and were making devotional 


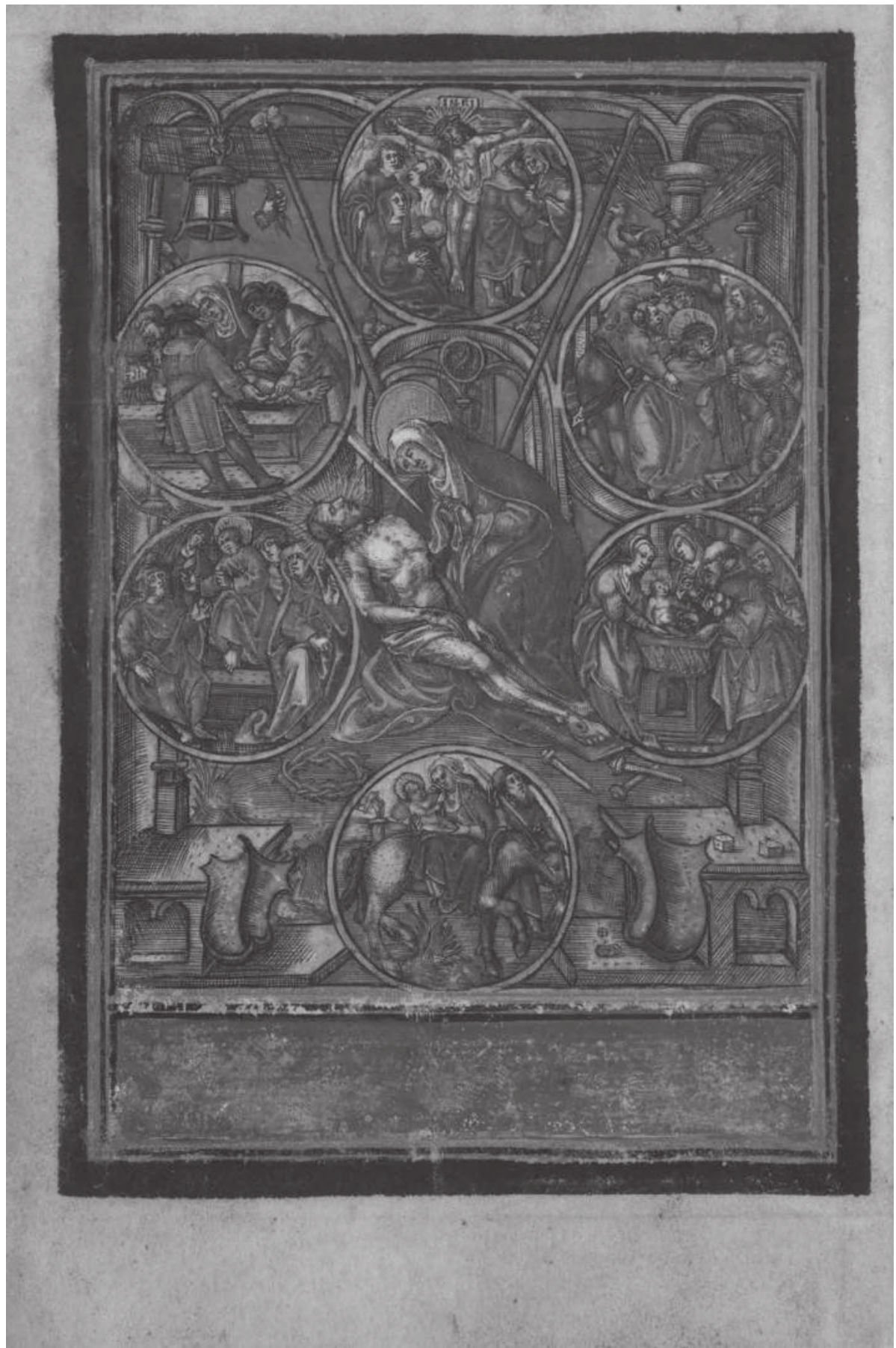

Figure 5.2 Master S, Seven Sorrows of the Virgin, c. 1520, engraving, hand-coloured and pasted into prayer book manuscript c. 1530. Amsterdam, Rijksmuseum, RP-P-2011-115-15.

Photo: http://hdl.handle.net/10934/RM0001.COLLECT.505149, CC0 1.0. 


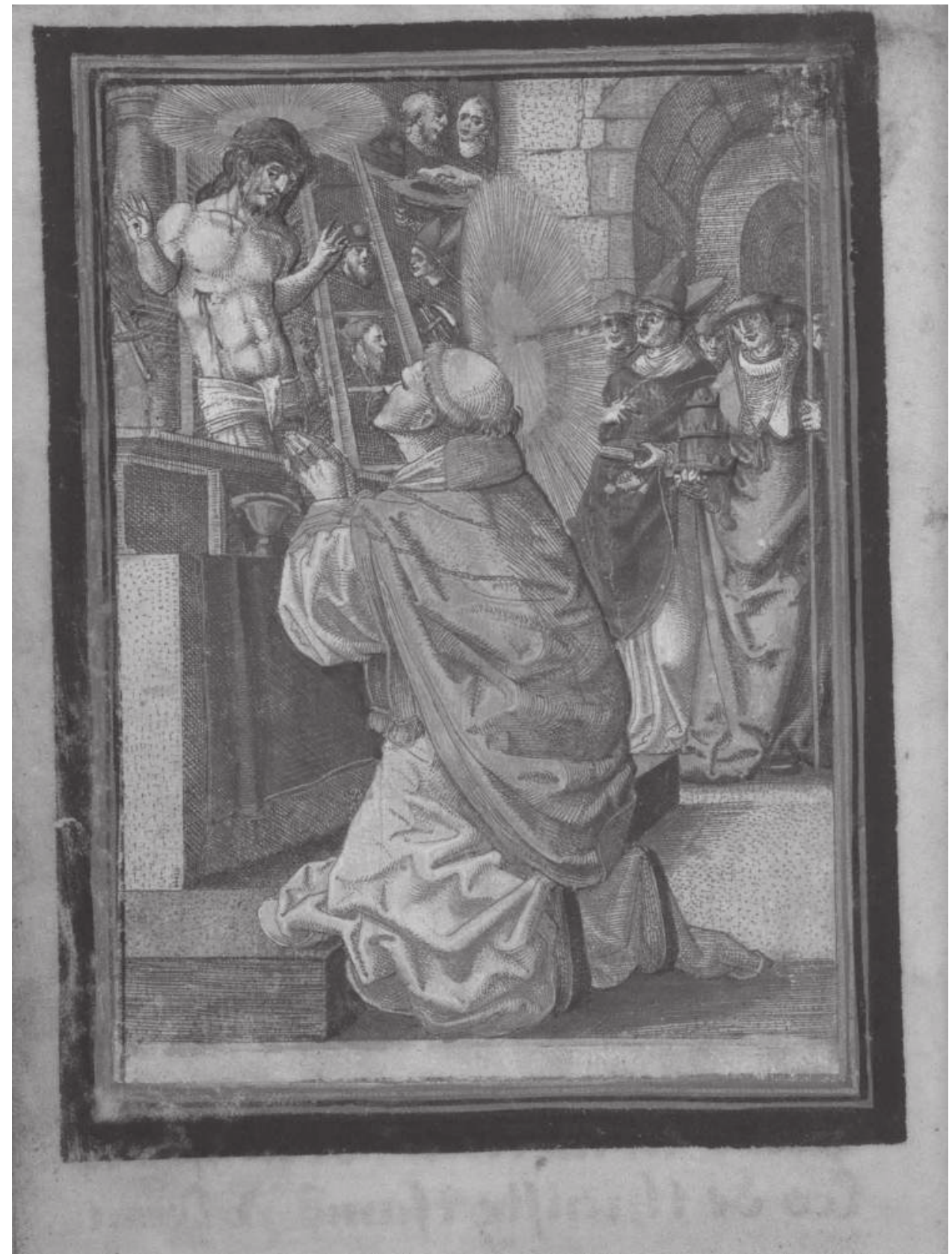

Figure 5.3 Frans Crabbe, Mass of Saint Gregory, c. 1520, engraving and etching, handcoloured and pasted into prayer book manuscript c. 1530. Amsterdam, Rijksmuseum, RP-P-2011-115-16.

Photo: http://hdl.handle.net/10934/RM0001.COLLECT.505150, CC0 1.0. 


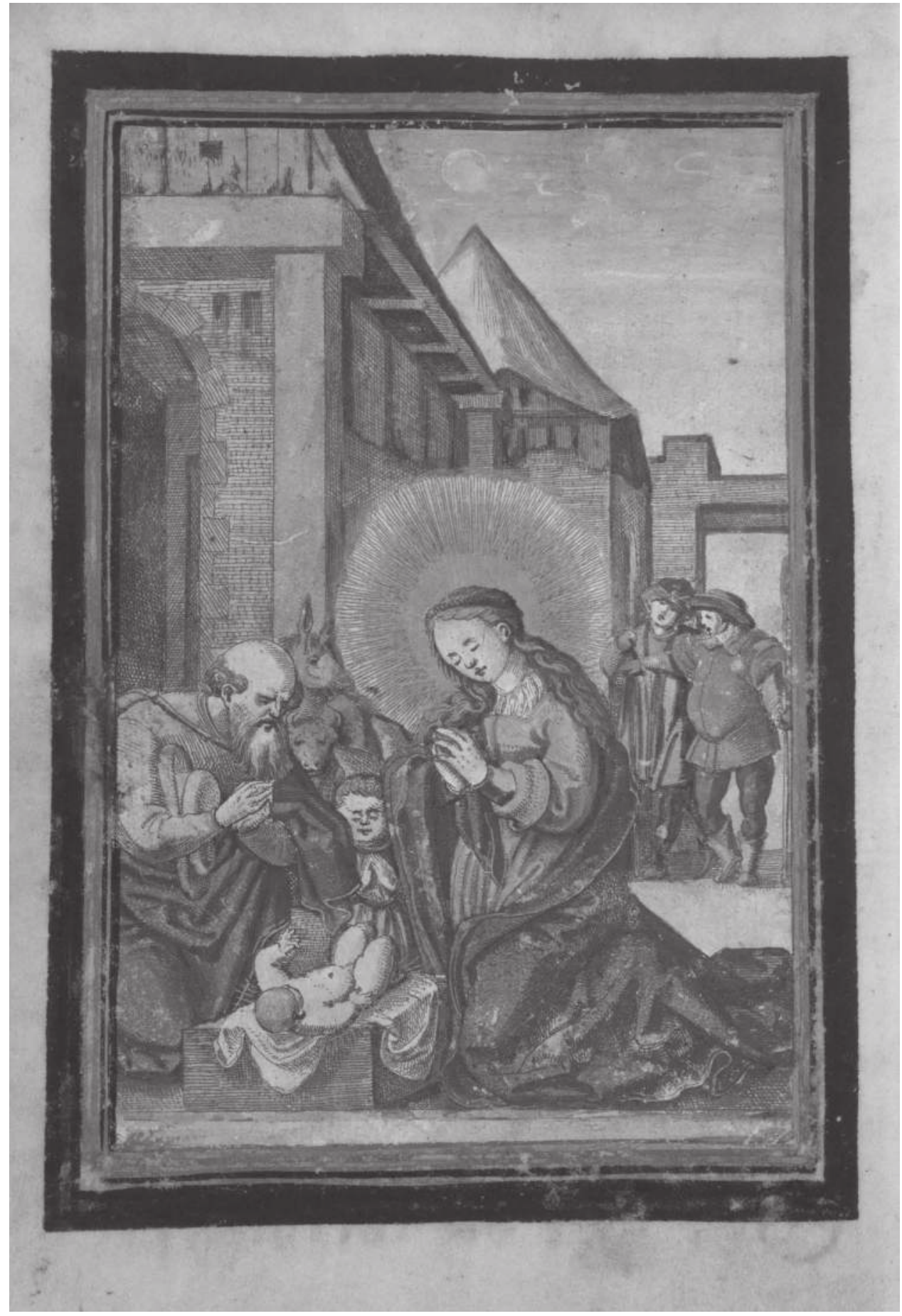

Figure 5.4 Frans Crabbe, Adoration of the Christ Child, c. 1520, engraving and etching, handcoloured and pasted into prayer book manuscript c. 1530. Amsterdam, Rijksmuseum, RP-P-2011-115-18.

Photo: http:/hdl.handle.net/10934/RM0001.COLLECT.505152, CC0 1.0. 
prints themselves, likely for participants of their annual processions. ${ }^{33}$ Several of these prints promoted civic identities and celebrated their elite patrons: an engraving by Master S in London (BM, 1848,0212.131) with a similar iconography to the one pasted in the Rijksmuseum prayer book includes the coat of arms of the city of Delft and the Duchy of Cleves in the upper corners and that of Pope Julius II and the Duke of Burgundy in the lower corners. ${ }^{34}$

Mechelen (approximately 25 kilometres south of Antwerp) was home to several important sites of devotion in the fifteenth and sixteenth centuries, including convents, confraternities, and two beguinages. The Mount Thabor Convent near the city centre was one of the earliest sites of the confraternity of the Seven Sorrows of the Virgin. The combined artistic and devotional activity in Mechelen in the first quarter of the sixteenth century makes it a highly plausible context for the production of the Rijksmuseum prayer book. Moreover, the prayer book contains early, good-quality impressions of Crabbe's prints, and this corroborates that it was assembled in or near the artist's hometown of Mechelen. ${ }^{35}$ Mechelen thrived as a court city from 1473 onwards, when it gained prominence under Burgundian-Hapsburg rule and became established as the centre for legal, political, and financial decision-making. ${ }^{36}$ Concurrently, Mechelen was a moderate-sized urban centre with local industry; the art production specialized in luxury textile and tapestry production from the thirteenth century onwards. ${ }^{37}$ For the following 60 years, it served as the central court for Burgundian princes; officials, artists, craftsmen, and financers flocked to the city to join the court retinue. ${ }^{38}$ In the first quarter of the sixteenth century, Margaret of Austria, avid collector and patron of the arts (r. 1507-15 and 1519-30) held her court in Mechelen. Margaret ruled alone after the premature death of her second husband, and the Virgin was an important figure in her cultural policy and devotional practice: she endowed confraternities of the Seven Sorrows of the Virgin and the Annunciation of the Blessed Virgin Mary in Bruges. ${ }^{39}$

\section{Function and Ownership}

The confraternity of the Seven Sorrows of the Virgin benefitted from the noble patronage of the Burgundian-Hapsburg rulers in the Low Countries, while simultaneously remaining accessible to all: there was no joining fee, and requirements of membership were easy to follow: devotees had to recite the Ave Maria and Paternoster prayers while mediating on the sorrows of the Virgin twice weekly. ${ }^{40}$ The Rijksmuseum prayer book fits directly within the devotional requirements and visual culture of the confraternity. The visual programme of the book-the colouring, alterations, and assembly of prints-is characteristic of visual images across media in the service of confraternities in the Low Countries. The assembly of meditations and prayers interwoven with engravings altered to emphasize a bodily account of Christ's Passion and to highlight the role of the Virgin suggest that the book was assembled for or by a member of the confraternity as an instrument for devotion.

The prayer book fits closely within the devotional context of pre-Reformation Europe and shows how new images were applied to existing practices in unexpected ways. How the book was conceived remains an open question: was the book made for a particular patron or was the first user indeed the assembler? Philological and paleographic research may help uncover evidence of original ownership and function. Further research into the prayers is needed to uncover if the prayers were known before 
the manuscript or if they were written in response to the prints. Before it entered the Ampleforth Abbey library, the book seems to have remained in the hands of successive female owners, whose regional names locate them within the southern Netherlands, in the vicinity of Antwerp. ${ }^{41}$

\section{Netherlandish Printmaking}

As we have seen, manuscript illuminations and printed images were considered interchangeable in the fifteenth century. ${ }^{42}$ This changed by the early sixteenth century, following the emergence of the peintre-graveur and the diffusion of artistic prints across Europe. The prints were important to the compiler and audience of the Rijksmuseum prayer book, and moreover the prayer book can offer important information about the usages of prints. Engravings were aimed at multiple markets, making it difficult to generalize or hypothesize about viewership, especially in the first half of the sixteenth century before the codification of collecting practices. As printmakers were exploring and exploiting self-aware approaches to prints, viewing publics were also becoming cognizant of prints as a collectible category that could speak to artistic, devotional, and learned ambitions. In the Rijksmuseum prayer book, prints were assembled to serve a devotional purpose; yet through careful assemblage and alteration, the artistic and aesthetic aspects of the prints equally played an important role. This prayer book can therefore be seen as a portable, preassembled collection of prints that can provide insight into the changing demands of engravings and the emerging regional markets for luxury objects at this time. The intricate visual programme of the prayer book was personalized to suit a particular audience, and both artistic and devotional significance was conveyed effectively through material means.

Print collecting was still in its nascent years in the first half of the sixteenth century, and practices and conventions were still in the process of being formed. Early audiences for prints were artists and craftsmen themselves, as prints assembled into albums took on the role of pattern books for the workshop. ${ }^{43}$ This gradually changed by the first quarter of the sixteenth century, motivated in part by increased demand for finished drawings, which were gradually finding a place on the market, and also greater interest in artistic innovation and contemporary artistic developments in other media. ${ }^{44}$ By the first quarter of the sixteenth century, the social and aesthetic dimensions of prints as collectable objects were being explored across northern Europe. International fairs in Frankfurt denote increasing production and international distribution of prints in the early years of the sixteenth century. ${ }^{45}$ While this early period pre-dates the emergence of systematic print collecting, printmakers of exceptionally high esteem, Albrecht Dürer and Lucas van Leyden, were in demand.

The inclusion of prints by Lucas van Leyden's lesser-known contemporaries, Frans Crabbe and Master S, alongside Lucas's masterful engravings is significant, and the prayer book can be regarded as an incunabule of Netherlandish printmaking. Frans Crabbe, along with Lucas van Leyden, belongs to the first generation of peintregraveur in the Low Countries, and his delicate etchings are among the most innovative prints from the first half of the sixteenth century. His name is only familiar to specialists of Netherlandish printmaking today, but he occupied a prominent place in Mechelen, serving as the dean of the local chapter of the guild of Saint Luke. Crabbe's prints are extremely rare and were likely not produced in large numbers; his etched Passion series does not survive in its entirety. Was Crabbe's Passion series used in 
similar prayer books that do not survive? His delicate linear style might be seen as well suited to the addition of translucent washes and finely wrought hand colouring. The intricate star-shaped halo in his Man of Sorrows, for example, is rendered more luminous with the application of gold and yellow paint. The shape of the halo moreover influenced the colourist of the Rijksmuseum prayer book to add similar halos to Lucas's engravings, which shows the careful consideration given to the prints in the prayer book.

It is intriguing to find a print by Master $S$ interwoven with the artistic prints of Lucas and Crabbe in the prayer book. The so-called Master S, likely a workshop rather than an individual producer, was active around 1500-25 in Antwerp and produced hundreds of small, devotional engravings for a broad market, intended to be pasted into manuscripts. ${ }^{46}$ The small prints often combine several narrative scenes in roundels with a main image, interwoven with complex framing devices akin to microarchitecture, and added colour aids in ordering these visually complex images into a coherent programme. Modern distinctions differentiate the slightly crude devotional prints of Master S from the more artistically ambitious Lucas and Crabbe; the former are typically seen to serve a lower market. This prayer book, however, suggests that such distinctions were not necessarily made in the early sixteenth century. The iconography was undoubtedly the main category for assembly and inclusion in the prayer book; however, the local context of production bespeaks a growing interest in regional print production. The assembly of prints in the book, in other words, indexes the variety of local achievements in printmaking at this time.

\section{Conclusion}

The prayer book offers a compelling example of the usage and function of prints. Prints and illustrated books were ideal for private veneration, and they occupied an important role in the daily life and devotional practices of confraternities. ${ }^{47}$ The Rijksmuseum prayer book is a rare survival that attests to the ongoing cross-fertilization between manuscripts and prints in the early decades of the sixteenth century. The book was an instrument of devotion, first and foremost, and should be understood within the context of lay devotion in the southern Low Countries. In particular, the book can probably be localized to a chapter of the Seven Sorrows of the Virgin Confraternity in or near Mechelen. In additional to the devotional function, the prints themselves were a source of interest, as I hope to have demonstrated. The Rijksmuseum prayer book offers a glimpse into the regional Netherlandish market in the first quarter of the sixteenth century, which was to become significantly expanded with the growth of the print industry a few short decades later. The increasing market for luxury goods served to incite interest in novel and artistic creations, and this was reflected in an increased artistic self-consciousness in the early sixteenth century. Attending to both the makers and the viewers of engravings at this time allows for individual objects to be rehabilitated into existing broader narratives of collection and consumption, and it enables us to consider the plurality of audiences of engravings and etchings in this early period.

\section{Notes}

1 The title reads: Een devote meditatie tot die passie on[s]e heeren Jhesu xp:isti ende eerst tot het aventmae [l] ("A devout mediation on the Passion of our Lord Jesus Christ from the 
beginning of the Last Supper"). The manuscript measures $15.7 \times 11.5 \times 2.9 \mathrm{~cm}$, and the prints are all pasted in on versos. For a description of the book, see van der Houwen-Jelles, "Net als miniature," 16-17.

2 The Last Supper is the first print in Lucas van Leyden's series, and the scene is mentioned in the title of the prayer book (see note 1). The first text in the book is a prayer on the Last Supper, and all subsequent prayers refer directly to the corresponding prints. It is therefore likely that Lucas's print of the Last Supper was the first print in the prayer book and is now lost, along with the original binding. With thanks to Huigen Leeflang for supplying this information.

3 The original print by Dürer (Meder no. 41) is dated 1520 .

4 The full provenance of the prayer book is as follows: "Anna Goedela Lefebure [. . .] Breughlen" (ex-libris in pen); "Suster Maria Lefebure" (ex-libris in pen); "Isabelle de Paddeschoet” (ex-libris in pen); “M'her de Túrnhout Chev. Seigneur D’Arcle” Arkel? (ex-libris in pen); Henry Cuwen (1783-1860), high sheriff of Cumberland (ex-libris printed in gold); Ampleforth College, MS. 278 (ex-libris printed in black); Sotheby's London 7 December 2010, lot number 28; H.B. van der Ven, The Hague; gift to the Rijksprentenkabinet, Rijksmuseum Amsterdam (RP-P-2011-115).

5 On prints pasted into manuscripts in the fifteenth century, see Schmidt, Gedruckte Bilder; Parshall, ed., The Woodcut in Fifteenth-Century Europe; Goedings, "Afsetters en meesterafsetters," 56; and Hernad, Die Graphiksammlung, $66 \mathrm{ff}$.

6 Marrow, "A Book of Hours," 590-615; Rudy, Piety in Pieces; idem, Postcards on Parchment; and most recently, eadem, The Image, the Knife, and the Gluepot.

7 Matthews, "The Use of Prints," 4-18.

8 Ibidem, 15.

9 Weekes, Early Engravers, 25-27.

10 Ibidem, $123 \mathrm{ff}$.

11 See for example, the small engraving of Saint Wolfgang by Meckenem pasted into an initial of a Flemish prayer book (a cat is drawn in ink beside the saint's feet) in London, BM, 1861,1109,680. Kathryn Rudy (The Image, the Knife, and the Gluepot, 54-59) identified and reconstructed the prints, which were cut from a Middle Dutch prayerbook, probably from Maastricht, c. 1500, now in London, BL, Add MS 24332.

12 For example, Meckenem's series of eight engravings with 48 circular scenes with religious subjects (copied after Master ES, see Lehrs IX.445-52) is not known to exist intact; a single intact sheet from the series with the Man of Sorrows and scenes from the Dance of Death, London, BM, 1848,1125.19; cf. ibidem, 2005,0429.35 for a unique, silhouetted example of Meckenem's Madonna and Child Standing on a Serpent.

13 On the continuation of this practice into the sixteenth century, see Melion, " 'Eyes Enlivened and Heart Softened," 269-312; and for three late sixteenth-century prayer books with mannerist prints and impressions of Dürer's Engraved Passion, see Illuminated Prints, 100-33.

14 Areford, "Introduction," 2.

15 Dackerman, "Painted Prints," 14.

16 Ibidem.

17 Cornelis and Filedt Kok, "The Taste," 20.

18 For example, Israhel van Meckenem's monogram was painted over in the Middle Dutch prayerbook reconstructed and analyzed by Rudy, The Image, the Knife, and the Gluepot, 89.

19 Lot 21 on 12 December 2019 at Bernaerts Auction house, Antwerp. I am grateful to Huigen Leeflang for bringing this to my attention.

20 On the spiritual significance of Lucas's late, classicizing nudes, see Silver and Smith, "Carnal Knowledge," 246.

21 Areford, The Viewer and the Printed Image, 45-46.

22 Hourihane, "Defining Terms," 38.

23 Merback, "The Man of Sorrows," 97.

24 Ringbom, Icon to Narrative, 25.

25 In the second state, the number was burnished away and changed to 45,000 years. Van Meckenem also made two engravings of the Santa Croce icon known as the Imago 
Pietatis. Landau and Parshall, The Renaissance Print, 58; see also Parshall, "Imago Contrafacta," 556.

26 Schuler "The Seven Sorrows," 7.

27 Ibidem, 13.

28 Eichberger, "Visualizing the Seven Sorrows," 114.

29 Schuler, "The Seven Sorrows," 23.

30 Ibidem, 5-28.

31 Ibidem, 1.

32 Eichberger, "Visualizing the Seven Sorrows," 114

33 Ibidem, 124.

34 Ibidem, 126 for a discussion of the print.

35 As mentioned earlier, the prayer book includes a hitherto-unknown early state of his print of the Nativity with an unfinished sky and an early impression of the so-called Man of Sorrows. In early impressions of the Man of Sorrows (as in London, BM, 1840,0627.132), the crab monogram appears on the ledge along the lower edge of the print, and the shading around Christ's halo is crisp. In later impressions (such as in Amsterdam, Rijksmuseum, RP-P-1912-334), the shading wears down, the monogram is faint, and Ecce Homo is added to the lower ledge. This later state is not described in Hollstein.

36 Prevenier "Mechelen circa 1500," 31.

37 Ibidem.

38 Ibidem.

39 Eichberger, Leben mit Kunst, 225.

40 Schuler, "The Seven Sorrows," 18.

41 For the names inscribed in the back of the prayer book in an eighteenth-century hand see note 4; cf. Van der Houwen-Jelles, "Net als miniature," 17.

42 Schmidt, "The Use of Prints," 43.

43 Luijten, "Collecting Netherlandish Prints," 197.

44 Parshall, "Art and the Theatre of Knowledge," 10.

45 Cornelis and Filedt Kok, "The Taste," 20.

46 On the Master S see Pfeifer-Helke, ed., Mit den Gezeiten, 234-35.

47 Schuler, "The Seven Sorrows," 24.

\section{Bibliography}

Areford, David. "Introduction: Towards an Archaeology of the Early Printed Image." Studies in Iconography, 24 (2003): 1-4.

- The Viewer and the Printed Image in Late Medieval Europe. Farnham: Ashgate, 2010.

Cornelis, Bart, and Jan Piet Filedt Kok. “The Taste for Lucas van Leyden Prints.” Simiolus, 26/1 (1998): 18-86.

Dackerman, Susan. "Painted Prints in Germany and the Netherlands." In Painted Prints: The Revelation of Color in Northern Renaissance \& Baroque Engravings, Etchings \& Woodcuts, ed. Susan Dackerman, 9-47. Baltimore: Baltimore Museum of Art; University Park, PA: Pennsylvania State University Press, 2002.

Eichberger, Dagmar. Leben mit Kunst, Wirkin durch Kunst: Sammelwesen und Hofkunst unter Margarete von Oesterreich, Regentin der Niederlande. Turnhout: Brepols, 2003.

- ed. Women of Distinction: Margaret of York/Margaret of Austria. Mechelen: Lamot, 2005.

- "Visualizing the Seven Sorrows of the Virgin: Early Netherlandish Woodcuts and Engravings in the Context of Netherlandish Confraternities." In The Seven Sorrows Confraternity of Brussels: Drama, Ceremony, and Art Patronage (16th-17th Centuries), ed. Emily Thelen, 113-43. Turnhout: Brepols, 2015.

Goedings, Truusje. 'Afsetters en meester-afsetters' De kunst van het kleuren 1480-1720. Amsterdam: Bijzondere Collecties Universiteit van Amsterdam, 2015.

Graham, Heather, and Lauren G. Kilroy-Ewbank, eds. Visualizing Sensuous Suffering and Affective Pain in Early Modern Europe and the Spanish Americas. Leiden: Brill, 2018. 


\section{Olenka Horbatsch}

Hernad, Béatrice. Die Graphiksammlung des Humanisten Hartmann Schedel. Munich: Bayerische Staatsbibliothek, 1990.

Hourihane, Colum. "Defining Terms: Ecce Homo, Christ of Pity, Christ Mocked, and the Man of Sorrows." In New Perspectives on the Man of Sorrows, eds. Catherine R. Puglisi and William L. Barcham, 19-47. Kalamazoo: Medieval Institute Publications, 2013.

Illuminated Prints 1480-1600. Including Three Extraordinary Manuscripts, cat. Emanuel von Baeyer, Truusje Goedings, London: Emanuel von Baeyer London, 2019.

Landau, David, and Peter W. Parshall. The Renaissance Print, 1470-1550. New Haven: Yale University Press, 1996.

Luijten, Ger. "Collecting Netherlandish Prints in the Early Sixteenth Century: The Harvest of Ferdinand Columbus." In The Print Collection of Ferdinand Columbus (1488-1539): A Renaissance Collector in Seville, ed. Mark McDonald, Vol. 1, 197-205. London: British Museum Press, 2004.

Marrow, James. "A Book of Hours from the Circle of the Master of the Berlin Passion: Notes on the Relationship Between Fifteenth-Century Manuscript Illumination and Printmaking in the Rhenish Lowlands." The Art Bulletin, 60 (1978): 590-615.

Matthews, Anne. "The Use of Prints in the Hours of Charles d'Angoulême." Print Quarterly, 3 (1986): 4-18.

Merback, Mitchell. "The Man of Sorrows in Northern Europe: Ritual Metaphor and Therapeutic Exchange." In New Perspectives on the Man of Sorrows, eds. Catherine R. Puglisi and William L. Barcham, 77-116. Kalamazoo: Medieval Institute Publications, 2013.

Parshall, Peter. “'Imago Contrafacta': Images and Facts in the Northern Renaissance.” Art History, 16 (1993): 554-79.

- "Art and the Theatre of Knowledge: The Origins of Print Collecting in Northern Europe." Harvard University Art Museums Bulletin, 2 (1994): 7-36.

- , ed. The Woodcut in Fifteenth-Century Europe. New Haven: Yale University Press, 2009.

Parshall, Peter, and Rainer Schoch, eds. Origins of European Printmaking, Fifteenth-Century Woodcuts and Their Public. Washington: National Gallery of Art, 2005.

Pfeifer-Helke, Tobias, ed. Mit den Gezeiten: Frühe Druckgraphik der Niederlande. Petersberg: Michael Imhoff Verlag, 2013.

Prevenier, Walter. "Mechelen circa 1500: Cosmopolitan Biotope for Social Elites and Nonconformists." In Women of Distinction: Margaret of York/Margaret of Austria, ed. Dagmar Eichberger, 31-41. Mechelen: Lamot, 2005.

Ringbom, Sixten. Icon to Narrative: The Rise of the Dramatic Close-Up Fifteenth-Century Devotional Painting. Turku: Åbo akademi, 1965.

Rudy, Kathryn. Postcards on Parchment: Social Lives of Medieval Books. New Haven: Yale University Press, 2015.

- Piety in Pieces: How Medieval Readers Customized Their Manuscripts. London: Open Book Publishers, 2016.

- The Image, the Knife, and the Gluepot: Early Experiments in Combining Manuscript and Print. London: Open Book Publishers, 2019.

Schmidt, Peter. Gedruckte Bilder in handgeschriebenen Buchern zum Gebrauch von Druckgraphik im 15. Jahrhundert. Cologne: Böhlau, 2003.

- "The Use of Prints in German Convents of the Fifteenth Century: The Example of Nuremberg." Studies in Iconography, 24 (2003): 43-69.

Schuler, Carol M. "The Seven Sorrows of the Virgin: Popular Culture and Cultic Imagery in Pre-Reformation Europe.” Simiolus, 21 (1992): 5-28.

Silver, Larry, and Susan Smith. "Carnal Knowledge: The Late Engravings of Lucas van Leyden." Nederlands Kunsthistorisch Jaarboek, 29 (1978): 239-98. 
Thelen, Emily, ed. The Seven Sorrows Confraternity of Brussels: Drama, Ceremony, and Art Patronage (16th-17th Centuries). Turnhout: Brepols, 2015.

Van der Houwen-Jelles, Rianneke. "Net als miniaturen: ingekleurde prenten in een ZuidNederlands gedenkenboek." Museum Catharijne Convent Magazine, 36 (2018): 16-17.

Weekes, Ursula. Early Engravers and the Their Public: The Master of the Berlin Passion and Manuscripts from Convents in the Rhine-Maas Region ca. 1450-1500. Turnhout: Harvey Miller, 2004. 


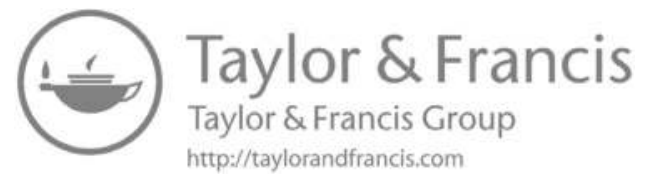


Part II

People 


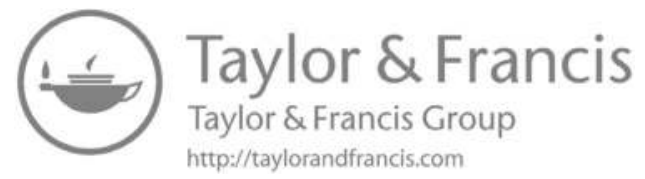




\title{
6 Eroticism Under a Watchful Eye \\ Censorship and Alteration of Woodcuts in Ovid's Metamorphoses \\ Between the Fifteenth and the \\ Sixteenth Centuries
}

\author{
Giuseppe Capriotti
}

\section{Introduction}

In a pioneering and controversial article published in 1978, Carlo Ginzburg analysed the relationship between Titian and Ovid and highlighted how in the figurative culture of the sixteenth century, the themes and forms of Greek mythology were used as a symbolic "code" to talk about eroticism. ${ }^{1}$ Other studies have shown that during the early modern period, mythological tales served as a normalising and sterilising filter that permitted artists and commissioners to portray acts of love and erotic situations. ${ }^{2}$ More than any other poem in the Western tradition, Ovid's Metamorphoses has offered artists a wealth of narrative material from which to depict all shades of love and sexual desire. Indeed, the theme of eroticism is the poem's most powerful element of continuity, running throughout the text and linking each episode. ${ }^{3}$ In his essay, Ginzburg highlights not only the importance of Ovid's text in providing material relating to love but also the role played in Western artistic culture by the woodcuts that decorated the vernacular editions of Ovid's Metamorphoses and the strong effect they triggered in the mind of the observer:

The erotic charge of these figures, often traced by inexperienced hands, is confirmed by a marginal but not negligible clues. The nudes that adorn the sixteenth century books preserved in our libraries ... often appear disfigured by the pen of distant readers. By erasing or veiling the female or male sexual attributes of the figures that occurred under their eyes, those readers gave vent to a movement of the soul (or body) perhaps ephemeral, demonstrating however that those images were not such as to leave them indifferent. ${ }^{4}$

Ginzburg explains that viewers' direct responses to these images demonstrate that the Ovidian woodcuts were viewed as erotic devices. ${ }^{5}$

This chapter aims to develop Ginsburg's remarks by analysing the ambiguous reception of the woodcuts featured in several printed editions of Ovid's Metamorphoses, published in Italy between the end of the fifteenth and sixteenth centuries. ${ }^{6}$ Some of the prints from these blocks were reused in different editions; at other times they were reproduced with slight modifications; or, in some cases, they were painted over with watercolour. In particular, I intend to examine the complex phenomenon in which prints that were regarded as erotic were altered through acts of both public and private censorship. ${ }^{7}$ 
To explore this theme, I analyse the woodcuts featured in the following five volumes published in the sixteenth century: two Latin editions of Ovid's Metamorphoses with a comment by Raffaele Regio, published in Parma by Francesco Mazali in 1505; a vernacular edition of Ovidio Metamorphoseos vulgare by Giovanni Bonsignori, published in Venice by Giorgio de' Rusconi in $1522 ;{ }^{9}$ a specimen of the translation of the Metamorphoses by Niccolò degli Agostini, published in Venice by Niccolò Zoppino in $1522 ;^{10}$ and a copy of the Trasformationi by Lodovico Dolce, published in Venice in 1553 by Gabriel Giolito de’ Ferrari. ${ }^{11}$

\section{Fortunes and Misfortunes of the 1497 Series}

The two specimens of 1505 are decorated with woodcuts that had originally been created for the first edition of Giovanni Bonsignori's Ovidio Metamorphoseos vulgare, published in Venice in 1497 by the typographer Giovanni Rosso, who worked in Venice, and the Florentine publisher Lucantonio Giunta. ${ }^{12}$ Two months before the publication of Bonsignori's volume, however, the prints were subjected to an unusual case of censorship, which was investigated by Bodo Guthmüller. ${ }^{13}$ The patriarch of Venice, Tommaso Donà, threatened to excommunicate both the publisher and the printer if they published any woodcuts portraying male and female nudes. The issue was not so much Bonsignori's text-filled with euhemeristic explanations that rendered the Latin poem harmless - as that the images were suffused with eroticism. The patriarch took particular offence to the prints illustrating the myth of Priapus and Lotis, in which Priapus was depicted with a clearly erect penis while trying to rape the sleeping Lotis and then while chasing her. In the first edition, which had already been printed, the publisher was forced to cover up the nude prints by hand with a strange dark brown colour. ${ }^{14} \mathrm{He}$ also had to modify the printing blocks for all the following editions, so that in the second edition, from 1501, the genitals were carved out. ${ }^{15}$

This event marks an important starting point towards better understanding the afterlife, the reuse and the perception of the 1497 prints. Despite the amendments required by public censorship, the woodcuts continued to be used and copied. ${ }^{16}$ In 1505, they were reused by the publisher Francesco Mazali from Parma for a Latin edition, which was published with a philological comment by the humanist Raffaele Regio $^{17}$ and the addition of seven new scenes. ${ }^{18}$ In the same year, Mazali, or another "pirate" publisher, printed a new edition of the same book, using only four new blocks and changing the positions of some images, as can be seen in a copy currently held in the Biblioteca Civica Romolo Spezioli in Fermo. ${ }^{19}$

Since most of the nudity or the erotic narratives present in the illustrations of this volume have been covered with black ink, I will only discuss a few representative examples. The woodcut with Priapus and Lotis (fol. 102v; Figure 6.1), which had so angered Tommaso Donà, has been covered with scribbles and black stains. On other pages, an unknown reader of the book has drawn undergarments on female figures and added bushes to hide the nudity. This is the case of the story of Peleus and Thetis: ${ }^{20}$ the vulva of the latter is covered by a sort of skirt, while in the background the genitals of Proteus, who is helping Peleus in his quest to have sex with Thetis, are covered by a bush (Figure 6.2). Similar cover-ups can be seen in another occurrence of the same image in the same text: Thetis's vulva is covered in scribbles, while Proteus's genitals are masked by a short tree (fol. $30 \mathrm{v}$ and $121 \mathrm{v}$ ). A skirt has also been given to the beautiful Andromeda, who is about to be released by Perseus (fol. 50v). Bushes 
appear to cover the genitals of Venus in the woodcut with Hippomenes and Atalanta (fol. 116r; Figure 6.3). On the top left Venus is helping Hippomenes, who wants to marry the virgin Atalanta, who had claimed she would only marry a man who could beat her in a race. At the bottom, Hippomenes and Atalanta make arrangements for the race, while in the centre, Venus intervenes in person, jumping on Atalanta to slow her down and allowing Hippomenes to win. ${ }^{21}$ On the left, finally, Hippomenes is marrying the girl. At the top, the newly married couple are depicted as mistakenly thanking Cybele instead of Venus. Enraged, the latter awakens in the couple a desire to have sex in Cybele's temple, who then turns them into felines as revenge. A tree is also depicted in the scene where Alcmene is giving birth (Figure 6.4). Interestingly, no genitalia are actually visible in the image; it only shows the arms of a midwife going under the skirt of the woman giving birth (fol. 101v). In this case, it appears that the mysterious owner of this volume perceives the situation of birthing itself to be embarrassing and has therefore drawn a tree.

The specimen carries the following note of ownership on the last page: Ego Fortunatus Benetellus Scribebam anno MDCLXI 18 maggio (fol. 174v). Because the ink of this signature is lighter than that used to blur the nudity in the images, it is difficult to establish whether the owner is the one who has blackened the images or if it is two individuals using two different inks. Nevertheless, since the degree of perceived

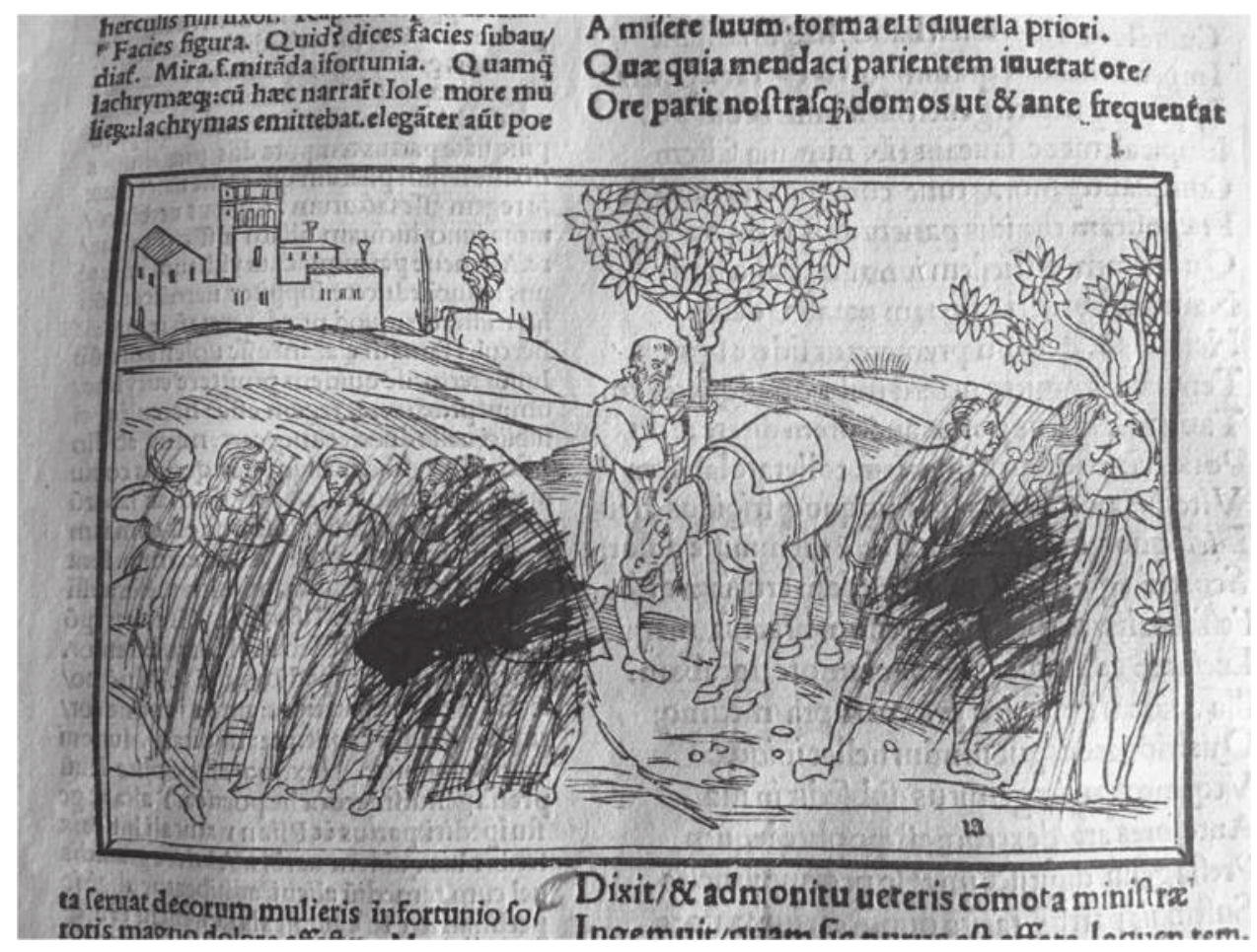

Figure 6.1 Priapus and Lotis, 1497, woodcut in Ovidius, Metamorphoses (Parma: Francesco Mazali, 1505), fol. 102v. Fermo, Biblioteca Civica Romolo Spezioli, 2V12/17241.

Photo: Author. 


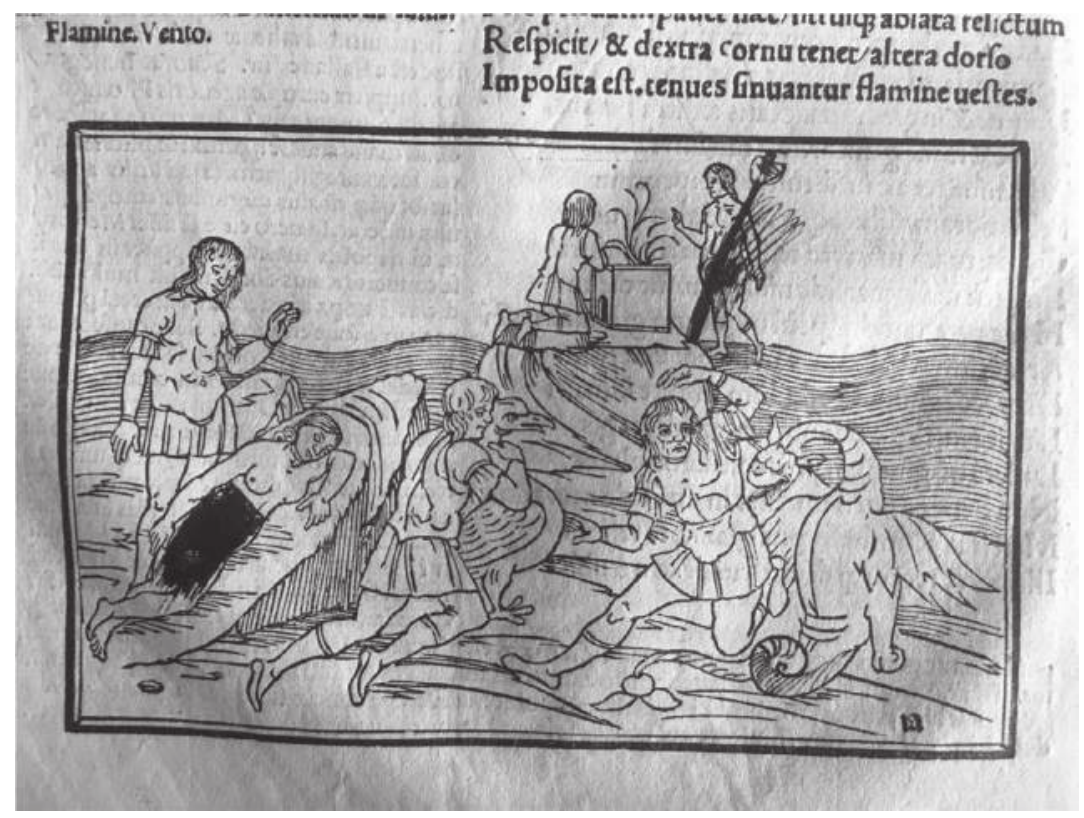

Figure 6.2 Peleus and Thetis, 1497, woodcut in Ovidius, Metamorphoses (Parma: Francesco Mazali, 1505), fol. 30v. Fermo, Biblioteca Civica Romolo Spezioli, 2V12/17241.

Photo: Author.

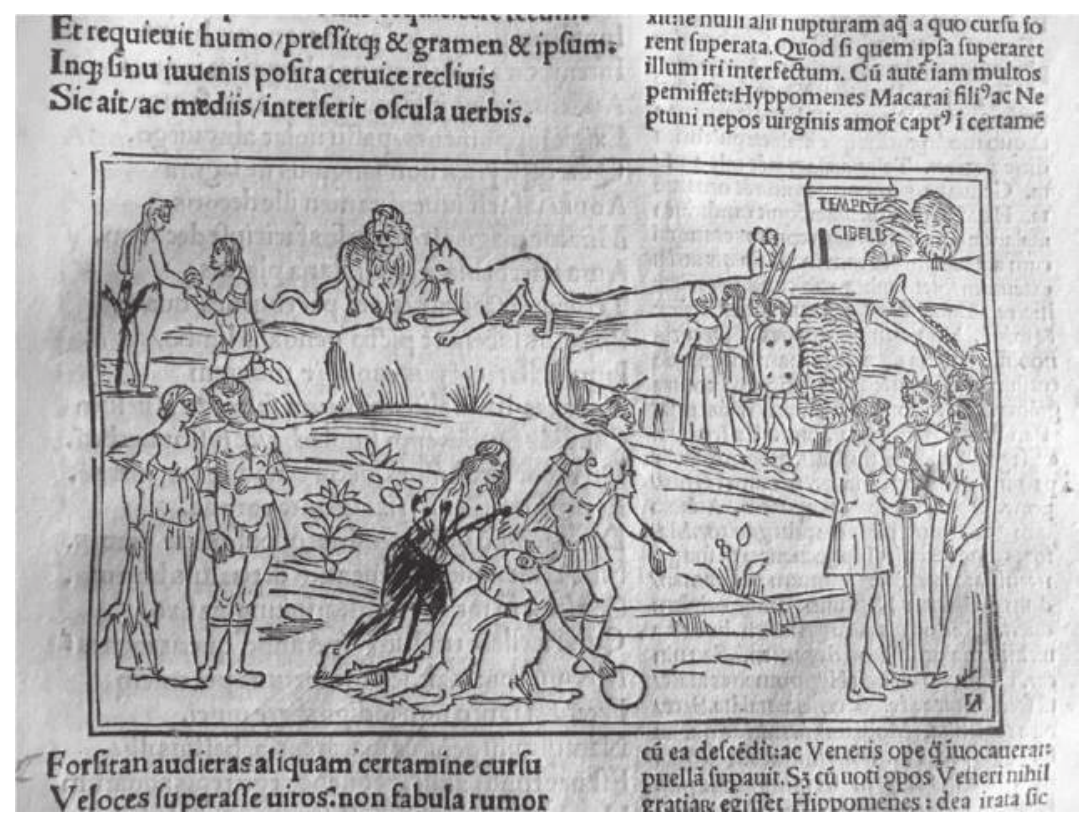

Figure 6.3 Hippomenes and Atalanta, 1497, woodcut in Ovidius, Metamorphoses (Parma: Francesco Mazali, 1505), fol. 116r. Fermo, Biblioteca Civica Romolo Spezioli, 2V12/17241.

Photo: Author. 


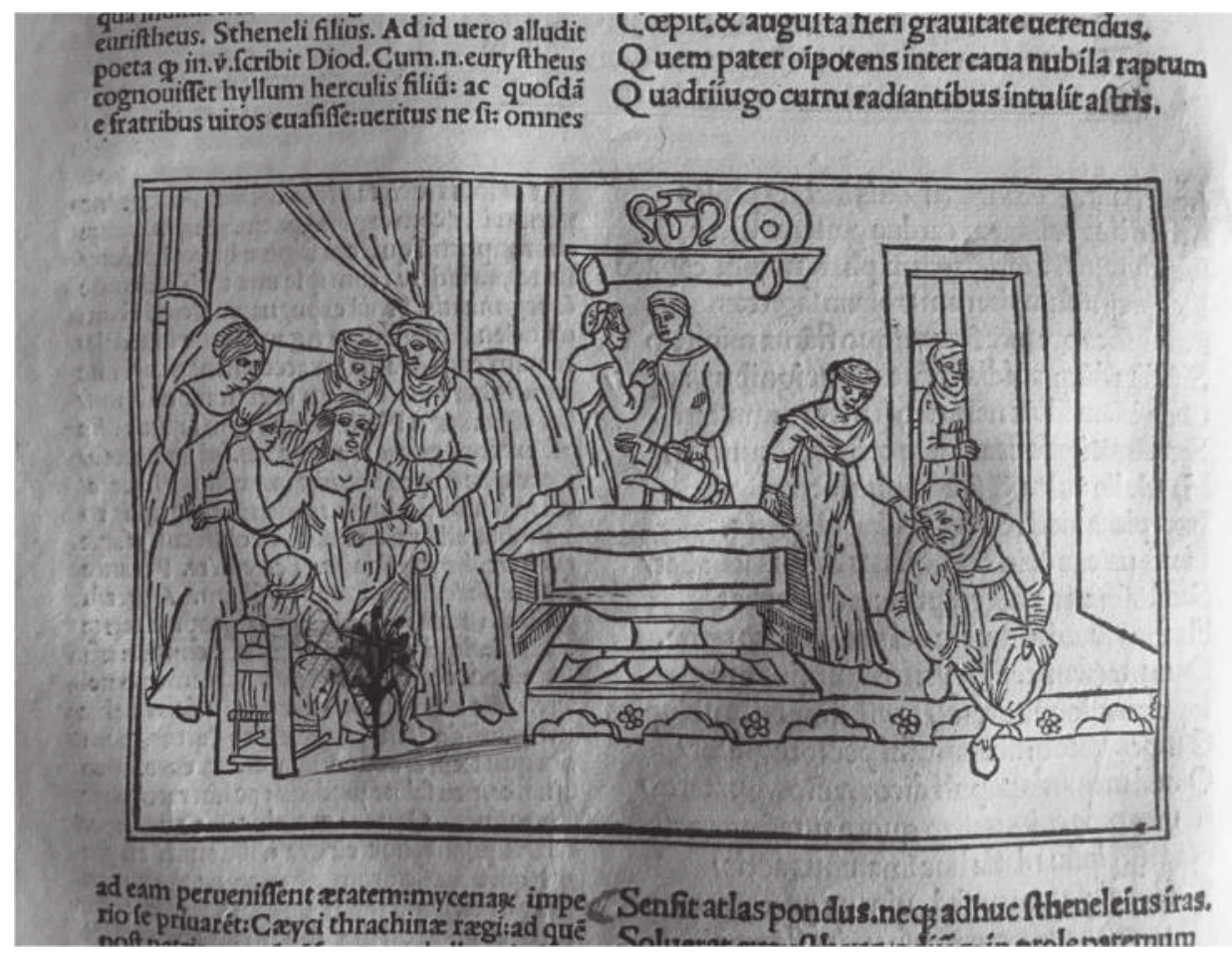

Figure 6.4 The Childbirth by Alcmene, 1497, woodcut in Ovidius, Metamorphoses (Parma: Francesco Mazali, 1505), fol. 101v. Fermo, Biblioteca Civica Romolo Spezioli, 2V12/17241.

Photo: Author.

eroticism is culturally and historically determined, ${ }^{22}$ it is highly likely that these erotic images would have stirred a greater controversy in the sixteenth century than in the second half of the seventeenth century. For this reason, I think it was a reader from the sixteenth century who altered the images of this specimen. Since the library at Fermo evolved from the libraries of religious orders that were suppressed following the unification of Italy, ${ }^{23}$ this copy of a Latin edition may have belonged to a particularly zealous cleric. In fact, unlike the censoring of the 1497 specimens, forced by the public intervention of the patriarch of Venice, the 1505 volume, preserved in Fermo, was the subject of private censorship, carried out by the owner of the volume.

The woodcuts in another copy of the same 1505 second edition of the book, preserved in the Macerata library, have met with a different fate. The volume contains no ownership note, although the last page features two written versions of a sonnet by Lorenzo the Magnificent (La ruota della fortuna or The Wheel of Fortune) with slight differences. ${ }^{24}$ The same page also bears the name of an otherwise unknown Felice Bernardo from Cingoli (a town near Macerata). Some images in the book contain additional words handwritten in brown ink, which usually provide a commentary on the episodes. The handwriting and certain orthographic occurrences allow us to 


\section{2}

estimate the temporal and geographical origins of these interventions. ${ }^{25}$ In the stories of Erysichthon, the image of Hunger is accompanied by the words cioffia forte ("blow hard"; cioffia is in fact a dialectal expression still used today in the territory of Macerata; fol. 95r). In the depiction of the Minyades, the words fila sottile ("spin tightly") have been written close to the three daughters of Minya, who are in the process of spinning wool, while the word Apignano (the name of a town near Macerata) has been inscribed close to the city shown in the background (fol. 41r). Finally, in the scene of the death of Orpheus, killed by the bacchantes, the phrase dataglie forte se lo volete amazare ("beat him hard if you want to kill him") lets us infer that the writings were made in the sixteenth century, when the absence of double letters in spellings was widely evidenced (amazare rather than ammazzare; fol. 118v). From these and other handwritten additions, which evoke a sense of irony, given the episodes depicted in the images ${ }^{26}$ one can deduce that the reader must have known the town of Appignano and may have been able to speak the local dialect of the sixteenth century. The writer was probably an inhabitant of the province of Macerata. The civic library of Macerata, like the Fermo library, contained books passed down from the noble people of the city and from the libraries of the suppressed religious orders of the province. ${ }^{27}$

Drawn in the same ink as the writings, several penises have also been strategically added to the images. ${ }^{28}$ In one print, Narcissus is shown in three positions (Figure 6.5): on the left, trying to escape the embrace of Echo; in the centre, gazing at his reflection in the pond; and on the right, a narcissus flower sprouts from his dead body, as the Dryads and Naiads stand over him weeping (fol. 36r)..$^{29}$ In Narcissus's hand, an unidentified reader has drawn a large penis that is ejaculating towards his own face; at the top, the reader has scrawled something illegible, while under him the words mena piano ("masturbate gently") are written. In Renaissance language menare meant to masturbate the penis. ${ }^{30}$ In this case, it is interesting that Narcissus, recognised since the Middle Ages mainly as a pejorative example of self-love, ${ }^{31}$ has been explicitly transformed into an onanist by the unknown reader.

Two penises are added to the scene featuring Venus with Hippomenes and Atalanta, discussed earlier (fol. 116r; Figure 6.6). While in the specimen preserved in Fermo, the nudity of the goddess was covered up, in the Macerata copy the mysterious reader has added a penis near the vulva of Venus, portrayed in the centre of the image, and a penis near the back of the goddess featured on the top left. Near the latter, the writer has added the words a trista me ("oh unhappy me"). The unhappiness of Venus, as suggested by the reader, is probably a reference to the anal penetration ${ }^{32}$ and a basic metaphor of the fact that at the end of the myth, the two ungrateful spouses, Hippomenes and Atalanta, thank Cybele and not her. However, Venus, as explained earlier, does exact her revenge.

In the scene with Peleus and Thetis, as analysed earlier, the figures of both Proteus and Thetis, which had been censored in the previous sample, now have two penises drawn near their genitals (fol. 121v). Thus, the reader heightens the eroticism of the Ovidian episode, already captured by the artist with two provocative feminine and male nudes. Furthermore, it is interesting to observe that the reader headed a drawn penis towards Proteus's male genitals, which in this image are represented in a very simplified way until to seem almost female genitals. Another penis has been added to the figure of Mercury in the woodcut with Mercury, Herse and Aglaurus (fol. 28r; Figure 6.7). Ovid (and Bonsignori as his translator) tells us that Mercury, while flying over Athens, falls hopelessly in love with Herse, who is participating in 


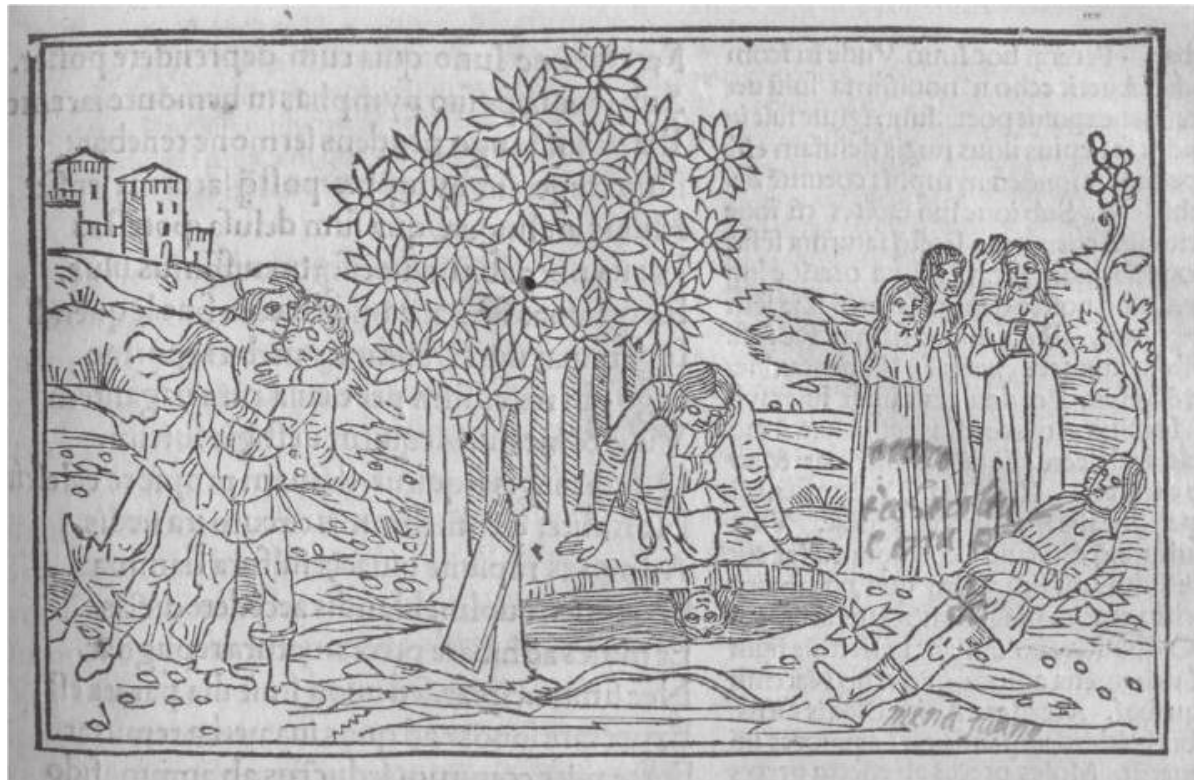

Figure 6.5 Narcissus, 1497, woodcut in Ovidius, Metamorphoses (Parma: Francesco Mazali, 1505), fol. 36r. Macerata, Biblioteca Civica Mozzi Borgetti, 9.2.A.20.

Photo: Macerata, Biblioteca Civica Mozzi Borgetti.

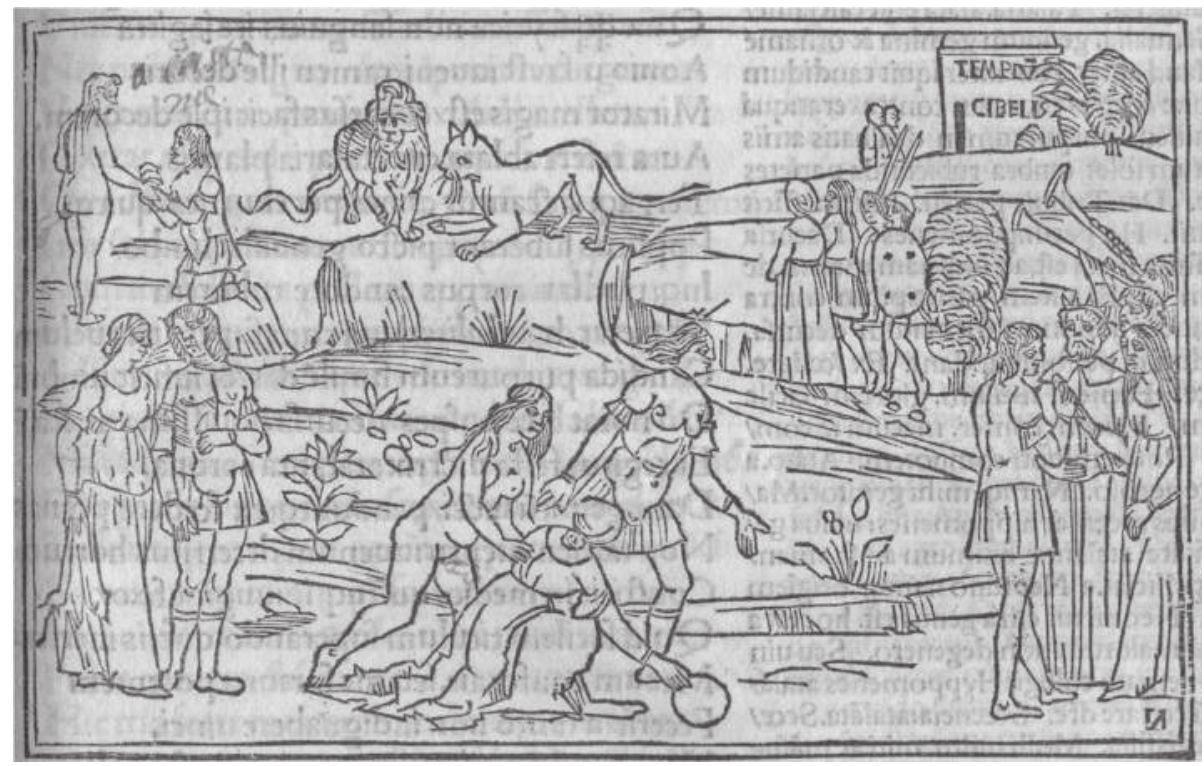

Figure 6.6 Hippomenes and Atalanta, 1497, woodcut in Ovidius, Metamorphoses (Parma: Francesco Mazali, 1505), fol. 116r. Macerata, Biblioteca Civica Mozzi Borgetti, 9.2.A.20,

Photo: Macerata, Biblioteca Civica Mozzi Borgetti. 


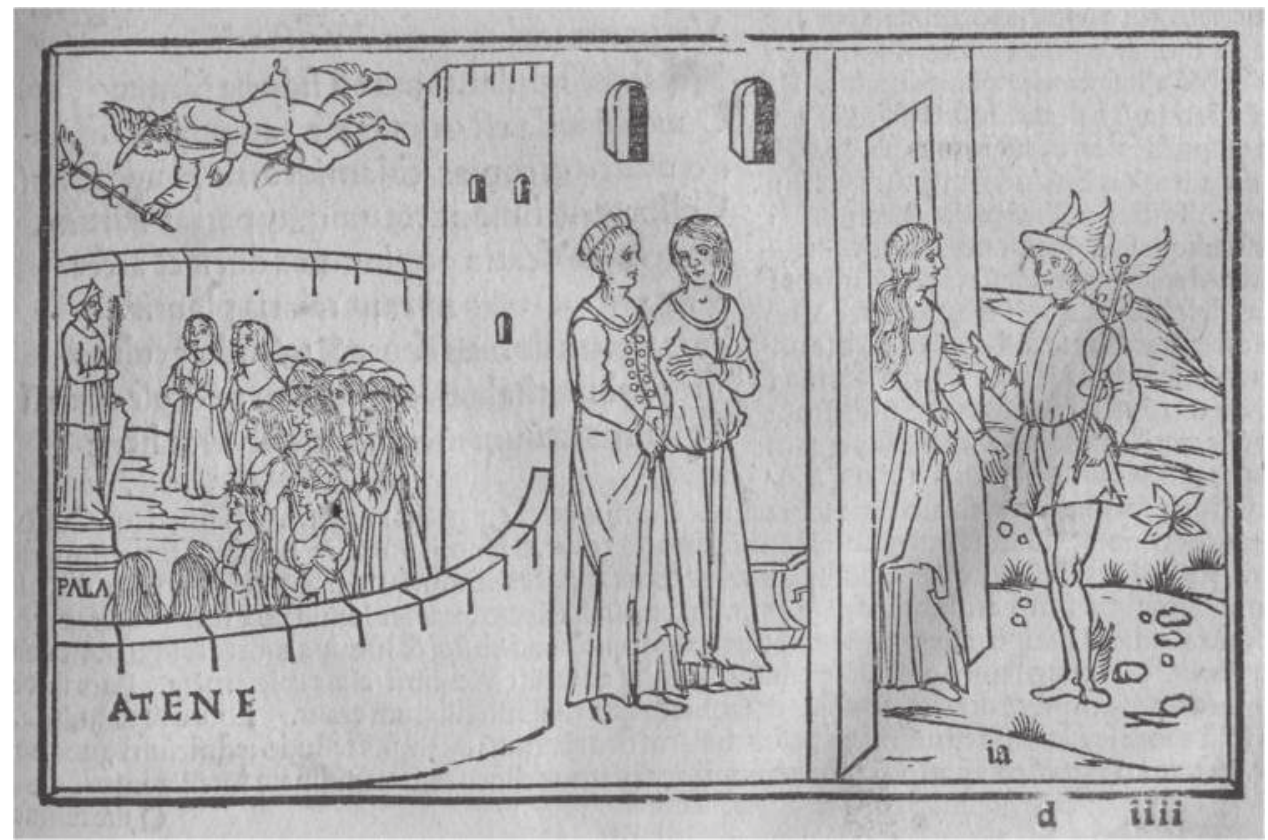

Figure 6.7 Mercury, Herse and Aglaurus, 1497, woodcut in Ovidius, Metamorphoses (Parma: Francesco Mazali, 1505), fol. 28r. Macerata, Biblioteca Civica Mozzi Borgetti, 9.2.A.20.

Photo: Macerata, Biblioteca Civica Mozzi Borgetti.

the Panathenaea (fol. XVIIIv). ${ }^{33}$ To convey Mercury's excitement, the Latin author recounts that the god flew like a kite that sighted its prey_greedy and hopeful. ${ }^{34}$ The unknown reader has added a penis to the figure of Mercury, most likely to make his erotic desire explicit. However, it is difficult to interpret the presence of a penis ejaculating in the sky near the sails of Theseus, who left Crete after successfully emerging from the maze with the help of Ariadne (fol. 87r) ${ }^{35}$ In general, the reader's use of penises could be likened to the Renaissance depiction of phalluses, which appear in the Italian maiolica, medals, manuscripts and frescos and were used to convey allusions to fertility, satirical messages, erotic innuendos and even erotic magic. ${ }^{36}$

The reactions of the two readers to the two specimens of the 1505 Latin edition indicate that in the first case, the reader was guided by a feeling of censorship, aroused at the sight of embarrassing episodes or erotic nudity. On the contrary, in the second case, the reader viewed some of the same images with a sense of profound irony and tried to convey humour through funny comments and by drawing penises in meaningful positions. ${ }^{37}$

\section{Other Ovidian Editions, Other Reactions}

In Giovanni Bonsignori's Ovidio Metamorphoseos vulgare from 1522, which is also preserved in the Fermo library, the woodcuts derived from the 1497 series 
have been painted over with watercolours. ${ }^{38}$ These also offer some surprises. In the Liberation of Andromeda (Plate 21), a small tree, similar to the bushes covering the genitals in the 1505 specimen, has been included by the woodcutter, who emended the print himself by adding a leafy branch (fol. XXIX). In the episode where Medea rejuvenates Exon, the figure of the sorceress in the centre of the image has some markings near her anus (fol. XLVIv). This time, however, the addition does not look like a penis; instead, it looks like faeces, as if the sorceress were defecating in the cauldron of her potion. It is possible that the reader's intention here was to ridicule Medea's magical practices. Similar changes have been made in the stories of Erysichthon, in which the figure of Hunger intensifies the starvation in the body of the sleeping hero, with lines emerging from her mouth (fol. LIX). As if to mock these lines, the reader has introduced perpendicular ink strokes coming out of the vagina of Hunger, as if the latter were urinating. Here, as in the Medea print, it is possible that the reader intended to mock the action of the woman. ${ }^{39}$ The scene with Priapus and Lotis, modelled on the 1505 edition, is not considered as cause for embarrassment in this book, and despite the explicit eroticism, is sumptuously watercoloured (fol. LXVI). ${ }^{40}$

In a 1522 sample of Niccolò degli Agostini's translation preserved in the Parma library, the following figures in the woodcuts have once again been given penises: ${ }^{41}$ Narcissus trying to release himself from the clutches of Echo, Alphaeus attempting to rape Arethusa while she is immersed in a cloud (Figure 6.8) and Cephalus embracing the deceased Procris (fol. 30r, 56r and 86r). ${ }^{42}$ Of these three instances,

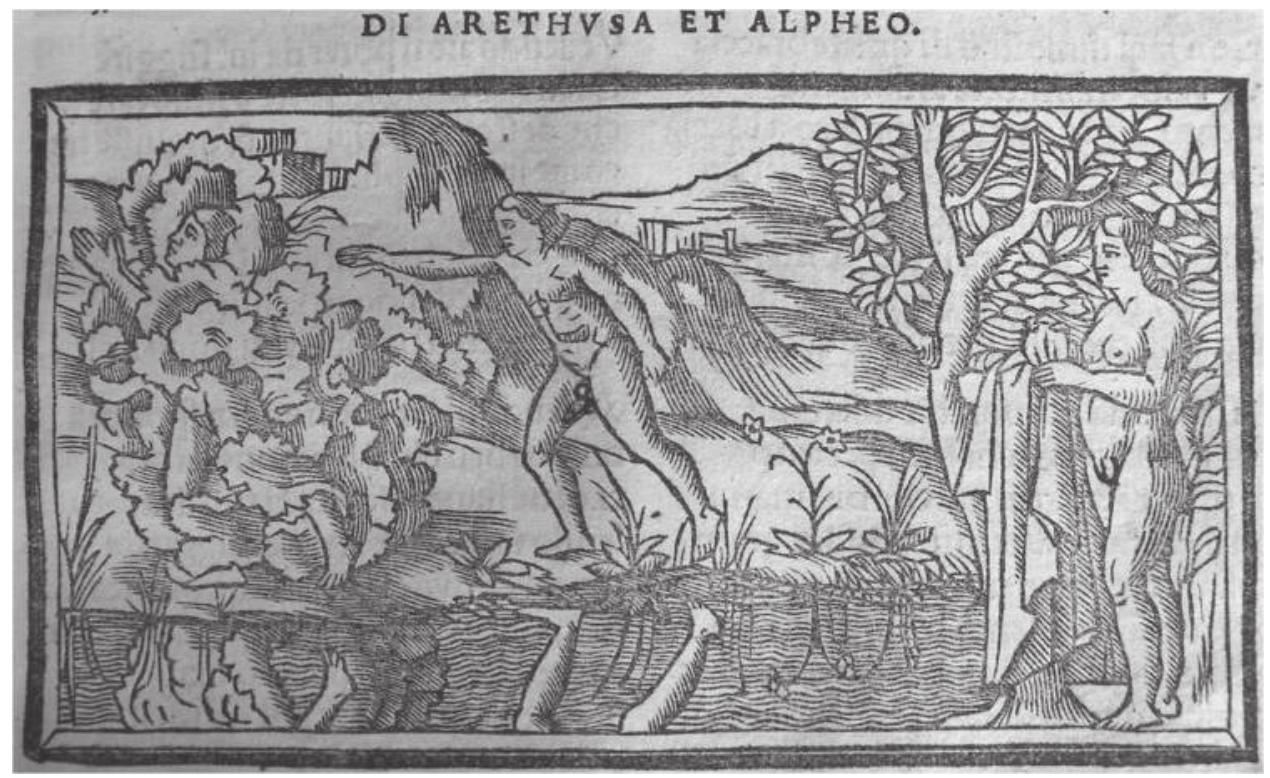

Figure 6.8 Alpheus and Arethusa, 1522, woodcut in Niccolò degli Agostini, Tutti gli libri de Ouidio Metamorphoseos (Venice: Niccolò Zoppino, 1522), fol. 56r. Parma, Biblioteca Palatina, WW VI.197.

Photo: Author; courtesy of Ministero per i Beni e le Attività Culturali. 


\section{6}

the handwritten addition serves to emphasise erotic excitement only in the case of Alphaeus and Arethusa. In the other two cases the addition is somewhat out of place: Narcissus is far from being sexually excited as he rejects Echo, and Cephalus is actually yearning for his dead wife. Nevertheless, the reader has interpreted Narcissus's attempt to free himself from Echo and the tragic embrace of Cephalus and Procris as erotic scenes. We are therefore in the presence of an unwise and uneducated reader, who inserts penises into inappropriate contexts, without considering the meaning of the myth. ${ }^{43}$

Finally I would like to present three censored woodcuts in a copy of the 1553 edition of Traformationi by Lodovico Dolce illustrated by Giovanni Antonio Rusconi, preserved in the Universidad Complutense Library of Madrid..$^{44}$ In the first two cases, the censorship is aimed at covering up embarrassing situations rather than erotic scenes. In Alcmene's birth scene, the problem is, once again, as in the first specimen from 1505, with the hands of the midwife under the skirt of the woman. In the scene with Priapus and Lotis, there is no depiction of Priapus's arousal, but the fact that the god puts his hands under the skirt is considered reprehensible (pp. 197-98). In the third print, the censor has drawn a huge black spot in the centre of the image (Figure 6.9), which only serves to heighten the observer's desire to know what is hidden underneath. As Michel Foucault noted, early modern censorship indirectly intensified the fascination for eroticism and sexuality. ${ }^{45}$ Under the black spot lies

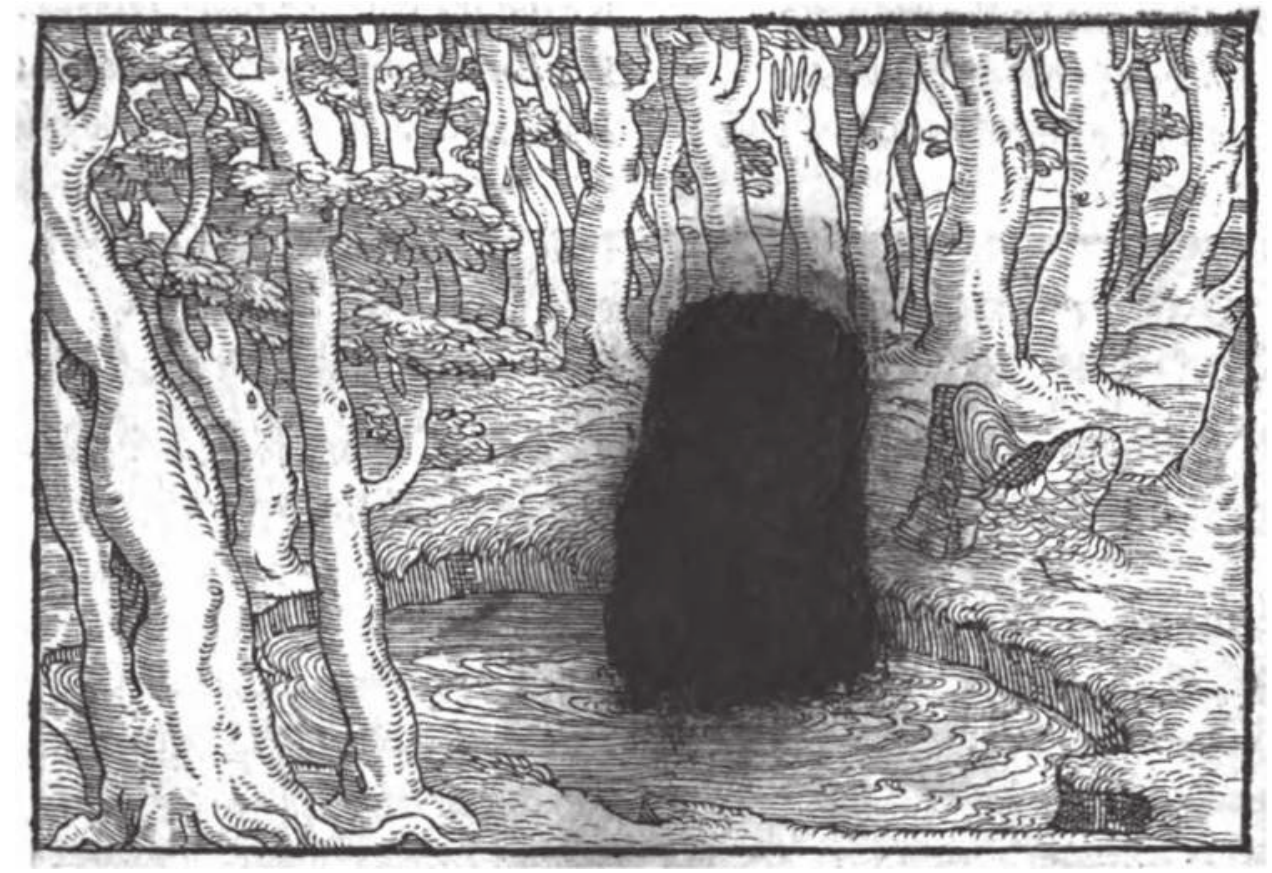

Figure 6.9 Giovanni Antonio Rusconi, Salmacis and Hermaphrodite, woodcut in Lodovico Dolce, Le Trasformationi (Venice: Gabriel Giolito de' Ferrari, 1553), 90. Madrid, Universidad Complutense, Library, BH FLL 28284.

Photo: Author. 
the embrace of Salmacis and Hermaphrodite, who are merging into one new human being (p. 90). It is the only truly erotic image present in Trasformationi by Dolce, which despite being subjected to private censorship, ${ }^{46}$ was selected in 1975 to be the opening image of the pioneering Italian volume L'incisione erotica del Rinascimento by Giorgio Lise. ${ }^{47}$

\section{Conclusions}

Some general remarks can be made on the basis of the analysis of these five specimens. First, the multiplication of the same designs in many different editions of Metamorphoses, and the modification of the impressions due to the public and private censorship and the personal use of the books, can be considered an effect of an early modern "pictorial turn," that is, the massive consumption of images, allowed and intensified by the invention of printing. ${ }^{48}$ Some modifications are particularly significant because they show us how, and how much, the images can assume new latent meanings due to the multiplication of the gazes. The user of the images projects new significances on prints, overcoming also the intentions of the artist and the commissioner who conceived them: this is the independent life of the images and, lastly, its authentic power. ${ }^{49}$

In addition, this study confirms that during the early modern era, Ovid's Metamorphoses was not only a neutral encyclopaedia of myths but an erotic device whose imagery provoked sexual arousal in the reader and the observer. The Metamorphoses was used in this way both before and after the publication of I Modi by Giulio Romano. ${ }^{50}$ Given this perspective, it is interesting to note how the 1497 prints continued to be viewed for a long time with authentic erotic interest and how the elements that aroused the greatest curiosity remained often the same (mainly Priapus and Lotis, the liberation of Andromeda, the delivery of Alcmene and Hippomenes and Atalanta). Further, one can suppose that the reader of these books and the person responsible for the drawings, scrawls and cover-ups of the images was a man. Not only does the poem express masculine desire in all its forms but the altering of the images also demonstrates a masculine ideology in which the feminine body, even that represented in images, is an object to cover and control or to injure and ridicule. ${ }^{51}$ If in the Venetian paintings of the sixteenth century, the male gaze on the female body is often implicit, ${ }^{52}$ in these specimens, we also notice an active eye that guides an attentive hand, armed with quill and ink. Moreover, it is possible to discern a dichotomy in the behaviour of the supposed masculine observer: sometimes he finds the prints excessive or too explicit and is triggered to censor them, in public or private; however, at other times, he finds that the same images are not explicit enough, and he is therefore provoked by an erotic impulse to go against censorship and react with amusement and irony.

\section{Notes}

1 Ginzburg, "Tiziano, Ovidio," 136-37. This article has been strongly criticised by Gentili, Da Tiziano a Tiziano, 173-78.

2 See in general Casazza, ed., Mytologica et Erotica; Zapperi, Eros e Controriforma. See also, with a focus on the prints: Matthews-Grieco, "Satyrs and Sausages," 26-33; Bette Talvacchia, "Il mercato dell'Eros," 193-96.

3 Labate, "Amore che trasforma," 31.

4 Ginzburg, "Tiziano, Ovidio,” 151. Translations by the author. 
5 Freedberg, The Power of Images, also emphasised how erotic prints with mythological subjects have very often been damaged by censorship (chapter "The Senses and Censorship").

6 For an exhaustive repertory of illustrated Ovidian editions, see Huber-Rebenich, Lütkemeyer, and Walter, Ikonographisches Repertorium.

7 The same phenomenon of modification and adaptation of erotic images, particularly for different markets and censorship, was also evident in individual sixteenth-century prints (which were not used as book illustrations). Cf. Matthews-Grieco, "Satyrs and Sausages," 23-25.

8 Ovidius, Habebis candide lector P. Ouidii Nasonis Metamorphosin castigatissimam, cum Raphaelis Regii commentariis emendatissimis, \& capitulis figuratis decenter appositis, \& ab aliquo calchographo hactenus non impressis (Parma: Francesco Mazali, 1505). Biblioteca Civica Romolo Spezioli, Fermo, 2V12/17241; Biblioteca Civica Mozzi Borgetti, Macerata, 9.2.A.20.

9 Giovanni Bonsignori, Ouidio Metamorphoseos vulgare (Venice: Giorgio Rusconi, 1522). Biblioteca Civica Romolo Spezioli, Fermo, 2CC13/18593.

10 Niccolò degli Agostini, Tutti gli libri de Ouidio Metamorphoseos tradutti dal litteral in uerso uulgar con le sue allegorie in prosa (Venice: Niccolò Zoppino, 1522). Biblioteca Palatina, Parma, WW VI.197.

11 Lodovico Dolce, Le Trasformationi (Venice: Gabriel Giolito, 1553). Universidad Complutense Library, Madrid, BH FLL 28284. Accessible online: https://ucm.on.worldcat.org/ oclc/1025432869.

12 Giovanni Bonsignori, Ouidio Metamorphoseos vulgare (Venice: Giovanni Rosso and Lucantonio Giunta, 1497). On this edition see: Guthmüller, Ovidio Metamorphoseos vulgare, 62-114, 185-203. On the woodcuts see: Blattner, Holzschnittfolgen; and Huber-Rebenich, Lütkemeyer, and Walter, Ikonographisches Repertorium, 32-42. Recently, the 52 woodcuts featured in this volume have been the subject of an interesting proposal of attribution by Pesavento, "Alle origini dell'illustrazione," 108, according to whom the designs were by the Paduan miniaturist Benedetto Bordon, perhaps assisted by the Second Master of the Canzoniere Grifo, while the wood carving was created by three different masters: Jacopo da Strasburgo, who signed 17 prints with initials ia (Iacobus Argentoratensis); the Master $\mathrm{N}$, who signed 5 woodcuts with this letter; and finally an anonymous Florentine master, identifiable only through their particular style.

13 Guthmüller, Mito, Poesia, Arte, 237-50. This episode of censorship has also been discussed by Andreoli, "Ovid's Meta-metamorphosis," 20-21.

14 Donati, "Edizioni quattrocentesche," 112, was the first scholar to notice that the woodcuts of the specimen preserved in the Biblioteca Casanatense in Rome had been modified to cover up the nudity with a dark brown colour that was easily erasable with a soft rubber. This dark brown colour could seem at first iron gall ink, which was the most common writing ink in Europe for many centuries, and it discolours from black to brown due to a chemical reaction. Nevertheless, since it is erasable (like Donati did), the publisher probably used another specific material.

15 Guthmüller, Mito, Poesia, Arte, 248.

16 On the extraordinary life of this series, see: Huber-Rebenich, Lütkemeyer, and Walter, Ikonographisches Repertorium, 34-73.

17 Regio, In Ovidii Metamorphosin enarrationes. On Raffaele Regio, see Pignatti, "Regio, Raffaele."

18 The seven added prints were The creation of the world (in substitution of the original one); The sending of Cadmus; Narcissus; The Minyades; Perseus and Fineus; Arachne; and Phrixus and Helle. Cf. d'Essling, Les livres à figures vénitiens, note 226, 228-29 and Mortimer, Harvard College Library, note 332, 485-86. Cf. also Pallottino, Storia dell'illustrazione italiana, 40. Like the woodcuts of 1497, those added in the 1505 edition were also produced using Giovanni Bonsignori's vernacularisation. Cf. Hubert-Rebenich, "L'iconografia della mitologia," 127, and Huber-Rebenich, Lütkemeyer, and Walter, Ikonographisches Repertorium, 41.

19 Cf. Huber-Rebenich, Lütkemeyer, and Walter, Ikonographisches Repertorium, 41-42. On the peculiar history of this 1505 second edition see: Díez-Platas, "Et Per Omnia Saecula Imagine Vivam," 115-35. 
20 On the importance of this woodcut as an iconographic model in the following series of prints Huber-Rebenich, "Kontinuität und Wandel," 63-79.

21 On this bizarre iconography see Guthmüller, Mito, Poesia, Arte, 268.

22 Freedberg, The Power of Images (chapter "Arousal by Image") observed that the threshold of shame and arousal, as well as individual perceptions of what constitutes a transgression of boundaries and limits, depends on historical and cultural context. Ruggiero, "Introduction," 5, also argued that "boundaries in the area of the erotic remained plural, defined by the period, place of production, display, artistic style, humanist packaging, social and intellectual milieu, the consumer, the censor and the age or the gender of the viewer."

23 Leonori, "La biblioteca comunale di Fermo," 20.

24 Cf. Lorenzo il Magnifico, Poesie, 169.

25 I thank Martina Mampieri for helping me read and interpret the handwriting in this book. The responsibility for any mistakes is mine alone. I also thank Marta Balzi, who first drew my attention to the handwritten comments and drawings in this volume.

26 In a print with the kidnapping of Europa, the following words are written: Quid est primus (fol. 30r); the myth of Arachne is dotted with fallo fitto, meaning, "do it tightly," referring to weaving (fol. 63r); in a print showing the hunt of the Calydonian boar, there are two instances of written text (fol. 89r): one is a cagniaccio ucicitete written close to the dog attacking the boar (cagnaccio means "cur," whereas the other word is probably an onomatopoeic description of a person calling a dog), and the other is a set of illegible words written on the left; under the figure of Hercules fighting Achelous (fol. 97r) one can find $I l$ vingi (probably il vincitore, "the winner"); in the battle of Hercules with the Amazons (fol. $100 \mathrm{r}$ ), the words ecco li sbirri ("here are the screws") have been inscribed in the upper part of the print; in the scene where Hercules throws Antaeus, the reader writes fa piano, or "be gentle" (fol. 101r); in the print with Apollo and Cyparissus (fol. 110v) the words o poverina ("oh poor girl") have been written on the trunk of the tree, with the feminine poverina being for the male lover of Apollo, Cyparissus. Given this evidence, it appears the reader who wrote these comments had a deep sense of irony towards the mythical episodes represented in the images.

27 Sfrappini, "Dalla libreria gesuitica," 146-47.

28 Something very similar occurred in some archived documents, found by Guido Guerzoni in the Modena State Archive, where "amateurs" made several erotic and pornographic sketches in the margins of Renaissance manuscripts. Cf. Guerzoni, "The Erotic Fantasies," 61-88.

29 On the fortune of this iconographic model, used by Caravaggio and Domenichino cf. Capriotti, "L'enigma d'un emblema," 595-637; idem, "Tre gigli per il cardinale," 97-128; idem, Le Trasformationi, 55-59.

30 Cf. Boggione and Casalegno, Dizionario, 341.

31 On the numerous interpretations of the myth of Narcissus from antiquity to the present day, there is plenty of literature. Cf. Vinge, The Narcissus Theme; and Bettini and Pellizer, Il mito di Narciso.

32 In Italian, to be sodomised is also a metaphor for being a victim of a fraud, as in the English phrase "to be fucked in the ass." For this meaning in Italian cf. Salvatore Battaglia, Grande dizionario della lingua italiana, vol. VII (Turin: Utet, 1972), 772 (sub voce "inculata").

33 Ovidius, Metamorphoses, II, 726-29. The creator of the 1497 images used Bonsignori's text and not the original Ovidian text as their literary source.

34 Ibidem, 716-21. Since the 1505 edition is in Latin, the producer of the handwritten text and the drawings was reading and commenting on the Latin text by Ovid.

35 Even without wings, this flying penis could contain the same erotic innuendo as the rich series studied by Grieco, "From Roosters to Cocks," 89-125.

36 Talvacchia, "Sexual Imagery," 12-13; Colantuono, "The Penis Possessed," 92-108.

37 On the connection between sex and irony in popular Italian culture see di Nola, "Riso e oscenità," 19-94; Grimaldi, ed., Il corpo e la festa; Reim, Il corpo della musa.

38 The specimen has been bound with a vulgarization of Vitruvius published in 1524 . The first page contains a drawing of a building, two profiles of faces and some brief writings. The volume does not have an ownership note. On this edition see Guthmüller, Ovidio 
Metamorphoseos vulgare, 308; and Huber-Rebenich, Lütkemeyer and Walter, Ikonographisches Repertorium, 52.

39 The ironic gaze of the reader continues in also evident in the story of Apollo and Cyparissus (fol. LXXII), where the trunk of the metamorphic tree has been given a hand-drawn vagina. Like in the specimen of 1505 (cf. note 35), in this case, the figure of the male lover of Apollo has been feminised.

40 To the print depicting the hunt of the Calydonian boar (fol. LVIv), the reader added a unique symbol derived from Christian iconography: on the shield of a hunter, the reader has drawn a scorpion, which was a traditional pejorative symbol of the Jews, often present on the shield of soldiers in scenes of the Crucifixion between the Middle Ages and the Renaissance. Cf. Capriotti, Lo scorpione sul petto.

41 The specimen without any ownership note has been a part of the heritage of the Palatina Library of Parma since its foundation in 1769 because the volume appears in the manuscript catalogue created by Paolo Maria Paciaudi. Cf. De Pasquale, "La nascita della Biblioteca Palatina," 45-46. On this edition see Guthmüller, Ovidio Metamorphoseos vulgare, 20452 and Huber-Rebenich, Lütkemeyer and Walter, Ikonographisches Repertorium, 73-81.

42 The penis of Narcissus is clearly identifiable under a spot of ink.

43 There is only one case of censorship of a female body in the book, in the print showing the Liberation of Andromeda, whose nudity has been covered with a big spot of ink (fol. 45v).

44 The second page of the specimen bears the name "Antonino Groeni," who was probably an owner of the volume. On Trasformationi by Lodovico Dolce, with the woodcuts by Giovanni Antonio Rusconi, see: Capriotti, Le Trasformationi; Capriotti, "Il tempo delle trasformazioni," 309-24; Huber-Rebenich, Lütkemeyer, and Walter, Ikonographisches Repertorium, 81-88.

45 Foucault, Histoire de la sexualité emphasises the "will of knowledge" by the confessor who exercises power and wants to repress sex, as well as prohibition and censorship against depictions of erotic scenes, which actually served to multiply the discourse on sexuality, increasing the desire to seek out and practice it.

46 Various attempts to cover up the same image may also be found in the 1561 edition of Le Trasformationi, 94. The respective woodcut in a copy preserved in Rome, Biblioteca Nazionale Centrale Vittorio Emanuele II, 6.17.D.19, was published in the entry by Stefano Benedetti in Cieri Via, ed., Immagini degli dei, 291. In the two copies preserved in the Palatina Library of Parma, the same image was censured with a black ink spot, which in one specimen (BB IV 26706) even damaged the page. The other specimen has a meaningful catalogue history (Conv. Ben. 3847), which shows that the book had been owned by a Benedictine monastery, although we do not know exactly who was responsible for this act of censorship.

47 Lise, L'incisione erotica.

48 On the concept of 'pictorial turn' see Mitchell, "Four fundamental concepts of image science," 27-32; idem, "The pictorial turn," 21-30.

49 On the intention of the work of art see: Baxandall, Patterns of intention; Mitchell, What do pictures want?

50 On this particular case, conveniently inserted into the historical context, see Talvacchia, Taking Positions.

51 For the Venetian context, see Goffen, "La donna nell'arte di Tiziano," 141-53; more in general see Tinagli, Women in Italian Renaissance Art.

52 Gentili, "Il corpo femminile," 49-56.

\section{Bibliography}

Andreoli, Ilaria. “Ovid's 'Meta-metamorphosis': Book Illustration and the Circulation of Erotic Iconographical Patterns.” In Shakespeare's Erotic Mythology and Ovidian Renaissance Culture, ed. Agnès Lafon, 19-39. Farnham: Ashgate, 2013.

Baxandall, Michael. Patterns of Intention: On the Historical Explanation of Pictures. London: Yale University Press, 1986. 
Bettini, Maurizio, and Ezio Pellizer. Il mito di Narciso: Immagini e racconti dalla Grecia a oggi. Turin: Einaudi, 2003.

Blattner, Evamarie. Holzschnittfolgen zu den Metamorphosen des Ovid: Venedig 1497 und Mainz 1545. Munich: scaneg, 1998.

Boggione, Valter, and Giovanni Casalegno. Dizionario del Lessico Erotico. Turin: Utet, 2004.

Capriotti, Giuseppe. "L'enigma d'un emblema: il Narciso di Caravaggio." Annali della Facoltà di Lettere e Filosofia dell'Università di Macerata, 34 (2001): 595-637.

-. "Tre gigli per il cardinale: Una lettura iconografica del ciclo di Domenichino nel 'Casino della Morte’ di Palazzo Farnese.” Annali della Facoltà di Lettere e Filosofia dell’Università di Macerata, 38 (2007): 97-128.

- Le Trasformationi di Lodovico Dolce: Il Rinascimento ovidiano di Giovanni Antonio Rusconi: Ristampa anastatica della prima edizione delle Trasformationi. Ancona: affinità elettive, 2013.

- Lo scorpione sul petto: Iconografia antiebraica alla periferia dello stato Pontificio tra XV e XVI secolo. Rome: Gangemi, 2014.

—. "Il tempo delle trasformazioni: Le quattro stampe di Giovanni Antonio Rusconi aggiunte alla seconda edizione del 1553 delle 'Trasformationi' di Lodovico Dolce." In Galassia Ariosto: Il modello editoriale dell'Orlando Furioso dal libro illustrato al web, ed. Lina Bolzoni, 309-24. Rome: Donzelli, 2017.

Casazza, Ornella, ed. Mytologica et Erotica: Arte e cultura dall'antichità al XVIII secolo. Livorno: Sillabe, 2005.

Cieri Via, Claudia, ed. Immagini degli dei: Mitologia e collezionismo tra '500 e '600. Milan: Leonardo Arte, 1996.

Colantuono, Anthony. "The Penis Possessed: Phallic Birds, Erotic Magic, and Sins of the Body, ca. 1470-1500." In The Body in Early Modern Italy, eds. Julia L. Hairston and Walter Stephens, 92-108. Baltimore: Johns Hopkins University Press, 2010.

De Pasquale, Andrea. "La nascita della Biblioteca Palatina." In Il Ducato in scena: Parma 1769: feste, libri, politica, eds. Andrea De Pasquale and Giovanni Godi, 41-52. Parma: Grafiche Step editrice, 2009.

d'Essling, Prince. Les livres à figures vénitiens de la fin $d u X V^{e}$ Siècle et du Commencement $d u$ XVI ${ }^{e}, I-1$. Florence: Olschki; Paris: Librairie Herri Leclerc, 1907.

Díez-Platas, Fátima. “ ‘Et Per Omnia Saecula Imagine Vivam’: The Completion of a Figurative Corpus for Ovid's 'Metamorphoses' in Fifteenth and Sixteenth Century Book Illustrations.” In The Afterlife of Ovid, eds. Peter Mack and John North, 115-35. London: Institute of Classical Studies, School of Advanced Study, University of London, 2015.

di Nola, Alfonso M. "Riso e oscenità.” In Alfonso M. di Nola, Antropologia religiosa: introduzione al problema e campioni di ricerca, 19-94. Rome: Newton, 1984.

Donati, Lamberto. "Edizioni quattrocentesche non pervenuteci delle 'Metamorfosi'." In Atti del Convegno internazionale ovidiano, Vol. 1, 111-24. Rome: Istituto di Studi Romani, 1959.

Foucault, Michel. Histoire de la sexualité: La volonté de savoir. Paris: Gallimard, 1978.

Freedberg, David. The Power of Images: Studies in the History and Theory of Response. Chicago: University of Chicago Press, 1989.

Gentili, Augusto. Da Tiziano a Tiziano: Mito e allegoria nella cultura veneziana del Cinquecento. Milan: Feltrinelli, 1980.

- "Il corpo femminile e lo sguardo maschile nella pittura veneziana del Cinquecento: Tiziano, Tintoretto, Veronese." In L'arte erotica del Rinascimento: Atti del colloquio internazionale, Tokyo 2008, ed. Michiaki Koshikawa, 49-56. Tokyo: The Yomiuri Shimbon, 2009.

Ginzburg, Carlo. "Tiziano, Ovidio e i codici della figurazione erotica nel Cinquecento." In Carlo Ginzburg, Miti Emblemi Spie. Morfologia e storia, 133-57. Turin: Einaudi, 1986.

Goffen, Rona. "La donna nell'arte di Tiziano e nella società veneta del primo Cinquecento: due mogli, due madri e alcune fantasie." In Tiziano: Amor Sacro e Amor Profano, 141-53. Milan: Electa, 1995. 


\section{Giuseppe Capriotti}

Grieco, Allen J. "From Roosters to Cocks: Italian Renaissance Fowl and Sexuality.” In Erotic Cultures of Renaissance Italy, ed. Sara F. Matthews-Grieco, 89-125. Farnham: Ashgate, 2010.

Grimaldi, Piercarlo, ed. Il corpo e la festa: Universi simbolici e pratiche della sessualità popolare. Rome: Meltemi, 1999.

Guerzoni, Guido A. "The Erotic Fantasies of a Model Clerk: Amateur Pornography at the Beginning of the Cinquecento." In Erotic Cultures of Renaissance Italy, ed. Sara F. MatthewsGrieco, 61-88. Farnham: Ashgate, 2010.

Guthmüller, Bodo. Mito, Poesia, Arte: Saggi sulla tradizione ovidiana nel Rinascimento. Rome: Bulzoni, 1997.

- Ovidio Metamorphoseos vulgare: Forme e funzioni della trasposizione in volgare della poesia classica nel Rinascimento italiano, transl. Paola Pacchioni. Fiesole: Cadmo, 2008.

Hubert-Rebenich, Gerlinde. "L'iconografia della mitologia antica tra Quattro e Cinquecento: Edizioni illustrate delle 'Metamorfosi' di Ovidio." Studi umanistici piceni, 12 (1992): 123-33.

—. "Kontinuität und Wandel in der frühen italienischen Ovid-Illustration: Die Tradition des Holzschnitte zu Giovanni dei Bonsignori: Ovidio metamorphoseos vulgare." In Metamorphosen: Wandlungen und Verwandlungen in Literatur, Sprache und Kunst von der Antike bis zur Gegenwart, eds. Heidi Marek, Anne Neuschafer, and Susanne Tichy, 63-79. Wiesbaden: Harrassowitz, 2002.

- "Sabine Lütkemeyer and Hermann Walter." In Ikonographisches Repertorium zu den Metamorphosen des Ovid: Die textbegleitende Druckgraphik, Vol. I.1, Narrative Darstellungen. Berlin: Mann, 2014.

Labate, Mario. "Amore che trasforma: dinamiche dell'eros nelle 'Metamorfosi' di Ovidio." In Mytologica et Erotica: Arte e cultura dall'antichità al XVIII secolo, ed. Ornella Casazza, 28-39. Livorno: Sillabe, 2005.

Leonori, Maria Chiara. "La biblioteca comunale di Fermo." In Biblioteca Comunale di Fermo, ed. Maria Chiara Leonori, 13-28. Fiesole: Nardini, 1996.

Lise, Giorgio. L'incisione erotica del Rinascimento. Milan: Carlo Emilio Bestetti Editore, 1975.

Lorenzo, il Magnifico. Poesie del Magnifico Lorenzo de' Medici, e di altri suoi amici e contemporanei divise in due parti. London: Nardini and Dulau, 1801.

Matthews-Grieco, Sara F. "Satyrs and Sausages: Erotic Strategies and Print Market in Cinquecento Italy." In Erotic Cultures of Renaissance Italy, ed. Sara F. Matthews-Grieco, 19-60. Farnham: Ashgate, 2010.

Mitchell, William J. T. What Do Pictures Want? The Lives and Loves of Images. Chicago: University of Chicago Press, 2005.

- "The Pictorial Turn." In Images: Critical and Primary Sources: 2: The Pictorial Turn, ed. Sunil Manghani, 21-30. London: Bloomsbury, 2013.

- "Four Fundamental Concepts of Image Science." IKON: Journal of Iconographic Studies, 7 (2014): 27-32.

Mortimer, Ruth. Harvard College Library Department of Printing and Graphic Arts Catalogue of Books and Manuscripts: II-2: Italian 16th Century Books. Cambridge, MA: Harvard University Press, 1974.

Pallottino, Paola. Storia dell'illustrazione italiana. Bologna: Zanichelli, 1988.

Pesavento, Giulio. "Alle origini dell'illustrazione xilografica delle 'Metamorfosi': l'Ovidio Metamorphoseos vulgare (Venice 1497).” In Ovidio: Amori, miti e altre storie, ed. Francesca Ghedini, 107-11. Naples: Arte'm, 2018.

Pignatti, Franco. "Regio, Raffaele." In Dizionario Biografico degli italiani, 86, ad vocem. Rome: Istituto dell'Enciclopedia Italiana, 2016.

Regio, Raffaele. In Ovidii Metamorphosin enarrationes 1: Libri 1-4, ed. Matteo Benedetti. Florence: SISMEL Edizioni del Galluzzo, 2008.

Reim, Riccardo. Il corpo della musa: Erotismo e pornografia nella letteratura italiana dal '200 al '900: storia, antologia, dizionario. Rome: Editori riuniti, 2002. 
Ruggiero, Guido. "Introduction: Hunting for Birds in the Italian Renaissance." In Erotic Cultures of Renaissance Italy, ed. Sara F. Matthews-Grieco, 1-16. Farnham: Ashgate, 2010.

Sfrappini, Alessandra. "Dalla libreria gesuitica alla 'Mozzi-Borgetti'." In La biblioteca MozziBorgetti di Macerata, ed. Alessandra Sfrappini, 101-65. Rome: Editalia, 1993.

Talvacchia, Bette. Taking Positions: On the Erotic in Renaissance Culture. Princeton, NJ: Princeton University Press, 1999.

—. "Il mercato dell'Eros: rappresentazioni della sessualità femminile nei soggetti mitologici." In Monaca, moglie, serva, cortigiana: vita e immagine delle donne tra Rinascimento $e$ Controriforma, eds. Sara F. Matthews-Grieco and Sabina Brevaglieri, 192-245. Florence: Morgana, 2001.

—. "Sexual Imagery in Renaissance Art from the Symbolic to the Obscene." In L'arte erotica del Rinascimento: Atti del colloquio internazionale, Tokyo 2008, ed. Michiaki Koshikawa, 7-17. Tokyo: The Yomiuri Shimbon, 2009.

Tinagli, Paola. Women in Italian Renaissance Art: Gender, Representation, Identity. Manchester: Manchester University Press, 1997.

Vinge, Louise. The Narcissus Theme in Western European Literature up to the Early 19 th Century. Lund: Gleerups, 1967.

Zapperi, Roberto. Eros e Controriforma: Preistoria della Galleria Farnese. Turin: Bollati Boringhieri, 1994. 


\title{
7 Limitations of the Reception and Consumption of Illustrations in Chronica Polonorum by Maciej of Miechów (Cracow, 1521) ${ }^{1}$
}

\author{
Karolina Mroziewicz
}

In the process of printing in the sixteenth century, a woodcut could be easily combined with text by placing a woodblock next to a typeset in the flatbed press. However, the pictorial and textual components of an early modern page rarely constituted a harmonious entity. The text and image had a different genealogy and used dissimilar codes of representation. ${ }^{2}$ As Ruth Luborsky observes, "The picture itself does not relate to the text; it is the reader who does the relating by attending to the fit between text and image." ${ }^{3}$ The process of relating was unsmooth in the case of the anonymous reader of Chronica Polonorum by Maciej of Miechów (c. 1457-1523). On a page featuring a figure of King Alexander Jagiellon, in the copy held today in the Early Printed Books Department of the University of Warsaw Library, a reader has left a passionate note, in which he highlights the discrepancy between the woodcut and the image of the king, presumably displayed and mutilated in the Cracow market:

Wszak ci gębę wycięto w Krakowie na rynku. A ten skurwysyn malarz szramy mu nie namalował i historyk błazen, szalbierz pochlebiał, a prawdy nie pisał [text erased]. $Z$ tego [?] znać miał sam gębę przeciętą. ${ }^{4}$

Your face was cut on the Cracow market, yet this painter, son of a bitch, did not paint the scar, and the historian clown and fraud did not write the truth [text erased]. This [?] shows that he had had his own face cut. ${ }^{5}$

The reader notes that the face of the king was cut in the Cracow market, yet his woodcut representation does not have any sign of the cut, as the Formschneider did not carve out a scar. The reader also highlights the incompetence of the historian who remained silent about the cut in the text. Annoyed at the lapses in facts, the reader has hurled invectives not only at the "painter" but also at the author of the text. To bridge the inconsistencies between the representational features of the woodcut and the extratextual reality, the reader has himself drawn a thick scar line on Alexander's figure.

Even though this reaction could be considered unusual-a prank by a shorttempered reader ${ }^{6}$ - it shows that the illustrations in Chronica Polonorum effectively stimulated the imagination and provoked the emotions of the early modern readers. The substantial impact and the numerous preserved, densely annotated copies make Chronica Polonorum by Maciej of Miechów a valuable and unique object of study for the historians of printed books, illustrations and readership in premodern Poland. An examination of the various responses to the visual content of the book offers a glimpse into how the chronicle's illustrations were used by Polish and foreign readers. ${ }^{7}$ 
Equally interesting are the problems in their interpretation and the lacunas over their reception, which characterise the limits and the cultural, social and political context of consumption and circulation of the chronicle's illustrations in the sixteenth century.

\section{Series of Illustrations}

The first edition of the chronicle with 39 illustrations, impressed from 34 woodblocks, was printed in Cracow by Hieronim Wietor (Hieronymus Vietor) in $1519 .{ }^{8}$ It was both the first printed and illustrated chronicle of Poland and the earliest documented victim of censorship in the Polish kingdom. Despite the royal printing privilege, issued on 19 August 1519, within a few months the book was banned by the senate from circulation because of passages unfavourable to the first Jagiellons and the notables of the time. ${ }^{9}$

The illustrations in Maciej of Miechów's chronicle constitute the earliest pictorial catalogue of Polish rulers-from the legendary Lech to Alexander Jagiellon. ${ }^{10}$ Apart from the images of individual rulers, each identified by a name or cognomen, depicted either full-figure standing, seated on the throne or half-figure in a decorative calyx, the chronicle also contains one group image of 12 legendary voivodes and two narrative scenes: Leszek's race for the crown and the coronation of Boleslaus I the Brave.

Much attention was paid to differentiating the figures and the symbols of power-the legendary, non-Christian rulers were shown in the so-called corona radiata, the princes wore princely hats and the kings had the corona clausa, signifying the sovereignty of their royal power. This schema was repeated in the later copies of the woodcuts. The images were modelled after German illustrated books such as the Liber Chronicarum by Hartmann Schedel of 1493 and the Chronicon Abbatis Urspergensis of 1515, as well as on the existing royal iconography-the seals of majesty. The narrative images were most likely the inventions of the masters working on the illustrations of Chronica Polonorum.

The visual and literary content of the chronicle was expanded in the second edition of Chronica Polonorum, released by the same printing press-Hieronim Wietor-in 1521. Passages that were inconvenient to the court were omitted or modified. Three new treatises by Iodocus Decius (Jost Dietz), glorifying the Jagiellons and presenting them as the main actors in the history of the Polish kingdom, were added. ${ }^{11}$ This eulogising theme was furthered by four new woodcuts: three representative likenesses of the members of the ruling family-Sigismund I; his wife Bona Sforza; and their one-year old son, Sigismund Augustus_-and a two-page genealogical tree that was an integral part of Decius's treatises. ${ }^{12}$ These new images supplemented and concluded the original series of the Polish rulers. ${ }^{13}$

\section{The Book's Price and Its Owners}

The price range of Maciej of Miechów's chronicle in the sixteenth century can be determined from inventories and provenance notes. ${ }^{14}$ The book inventory (c. 1585) of Mikołaj Bronowski, a nobleman and lawyer, lists 115 printed and handwritten books in 130 volumes. ${ }^{15}$ It includes perhaps the most expensive Polish book of the sixteenth century: a complete manuscript of Jan Długosz's Annales. The price of the book was estimated at 3000 złoties (also called Polish florins) - the equivalent of the price of a whole town house in the Cracow market. ${ }^{16}$ The most expensive printed books, the value of which was estimated between 40 and 60 złoties (approximately the annual 


\section{Karolina Mroziewicz}

salary of a town writer), included legal works, in accordance with Bronowski's profession, and foreign historical books such as Legenda aurea in folio (50 złoties) and Chronica Ioannis Carionis in octavo (also 50 złoties). Polish historical works were estimated to cost at least ten times less, between 6 and 3 złoties: Marcin Bielski's chronicle was valued at 6 złoties, Chronica Polonorum by Maciej of Miechów at 5 złoties, Marcin Kromer's chronicle at 4 złoties and Bartosz Paprocki's Herby rycerstwa polskiego at 3 złoties. This price range rendered these books expensive in the Polish market. ${ }^{17}$

Bronowski's inventory leads to three conclusions: first, foreign historical works were valued more by the Polish nobleman than domestic ones, which were easier to acquire; second, the illustrations, in contrast to the type of binding, did not influence the subjective pricing of the book; and third, Chronica Polonorum was a highly valued (and highly priced) work among Polish historical books of the time.

Additional, more divergent prices of Chronica Polonorum can be found in the notes on the pages of the chronicle. For 3 florins and 9 groszy, Balczar Engelhard bought a copy of Chronica Polonorum at some point during the turn of the sixteenth and seventeenth century. ${ }^{18}$ Andrzej Michałowski paid much more for a copy of the chronicle in 1588: 12 florins and 2 groszy. ${ }^{19}$ While a sum between 3 and 5 złoties was unaffordable for poorer readers, who could satisfy their reading needs only with cheaper leaflets and booklets, it was a fair price for a notary, a town scribe or more well-off readers. ${ }^{20}$ However, a price above 12 florins would have been high even for a nobleman.

The social reception of Chronica Polonorum has been a subject of discussion since the 1960s. Henryk Barycz traced the book's resonance to the political and historical controversies in the sixteenth century. ${ }^{21} \mathrm{He}$ acknowledged its reception among Polish townspeople and local and foreign humanists, but concluded that the book "written in a semi-medieval spirit, dry and colourless, 'not-noble,' could not satisfy the needs of a new [noble] recipient." 22 Similarly, in discussing the reception of the chronicle, Hans-Jürgen Bömelburg mainly referred to the humanists and the circles close to Sigismund I's court. Although he noted that a portion of the chronicles were rewritten by the Polish nobleman Stanisław Naropiński in his copy of Ephemerides by Johannes Stöffler, Bömelburg's conclusions echoed those of Barycz, namely, that the chronicle was not read by the Polish nobility, as its form and content did not correspond to the worldview and habits of this group of readers. ${ }^{23}$

However, the densely annotated copies of the books with provenance notes, which allow one to link them to the nobility, provide evidence to the contrary. Jan Krzysztoporski, a senior member of the Polish senate, and Jan Strzembosz, a delegate for the royal election sejm of 1587 , left numerous notes in their copies of the chronicle. ${ }^{24}$ Andrzej Michałowski, Kasper Wieruski, Mikołaj Bronowski, Stanisław Lasocki of Glewo and an anonymous noble commentator-who left a note on the page with the image of legendary Polish and Bohemian forefathers, calling for unity between the noblemen ${ }^{25}$ — serve as additional examples of noble recipients of Maciej of Miechów's chronicle. The ongoing research on the book collections of the Polish noble families and their reading habits will certainly yield more names of sixteenth-century noble readers of the chronicle and disprove the notion that the crude Latin and content of the chronicle limited its reception among the Polish nobility.

The list of foreigners who knew and valued Maciej of Miechów's chronicle starts with Philip Melanchthon, who presented his copy of Chronica Polonorum to Nicolaus 
von Klemptzen with the following recommendation: "the given history is useful and worth of reading" (utilis et digna lectu est historia donata). ${ }^{26}$ Another prominent humanist reader of Maciej of Miechów's chronicle was Christoph Scheurl, a jurist and diplomat, whose copy of the chronicle has a diligently coloured title page and an ex libris by Lucas Cranach the Elder. ${ }^{27}$ Others noted by Hans-Jürgen Bömelburg were Simon Grunau, Johannes and Olaus Magnus and Sebastian Münster. ${ }^{28}$ Pistorius's Polonicae Historiae Corpus (1582), which included the text of Chronica Polonorum, further broadened the reception of the chronicle among foreign readers in the last quarter of the sixteenth century. ${ }^{29}$

The female recipients of the book, if there were any, left no marks of their ownership, reading or viewing in the studied sample of the chronicle. There are, however, some material traces of younger readers, who may have used Chronica Polonorum as a comprehensive compendium on Polish history, in accordance with the initial intention of Maciej of Miechów.

\section{Consumption of Illustrations}

The early modern page, regardless of its visual content, functioned as a space ready to accommodate various notes, remarks, owners' signatures and other nonverbal markings. The illustrations proved useful to exuberant commentators and amateur drawers, who felt compelled to add notes and new details to the picture. ${ }^{30}$ Along with the printed page, images were often damaged by extensive reading and viewing or were removed from the book and pasted elsewhere. Yet the illustrations were rarely the sole focus of notes and drawings, as was often the case with text. In fact, the images were treated as one of several components of the book with which a reader-viewer could interact.

The majority of the interactions with the illustrations in Chronica Polonorum were unrelated to the process of reading. Two of the copies, however, carried signs of some amateur hand-colouring of a woodcut with the same ink as was used elsewhere to underline a few lines of the text or add a note. ${ }^{31}$ Reactions to images were often sparked by a deep aversion or sympathy for the depicted figure. The stronger the viewers' feelings were, the stronger the response to the image was, as exemplified by the comments on and the interventions to the woodcut depicting Queen Bona, who was generally disliked by her Polish subjects.

An anonymous reader drew on Bona Sforza a moustache and beard (Figure 7.1) besides adding the following critical comment: "She was good by name, but in fact not good in many things" (Nomine Bona fuit, sed re non omnibus bona) in the copy of the chronicle held today in the University of Warsaw Library. ${ }^{32}$ This verse fits well with a flood of popular, often obscene, puns directed at the queen's name. ${ }^{33}$ Even more harsh was the following comment left in the copy held in the Polish National Library (Figure 7.2): "Bona, even though good, nevertheless smells bad" (Bona licet / bona attamen / male olet). ${ }^{34}$ This comment was joined by an attempt to scratch off Bona's lips and obscure her nose. Another reader added the word Pięknicka ("Dainty"), which leads one to wonder if it is a sarcastic comment on the previous note.

Readers' negative attitude to the child monarch was expressed in the margin on the representation of Sigismund Augustus by a quote from Ecclesiastes 10:16 (Figure 7.3): "Woe to you, O land, / when your king is a / child, and your princes / feast in the morning!" 35 (Vae tibi, terra, / cuius Rex est / puer: Et cuius / principes mane 


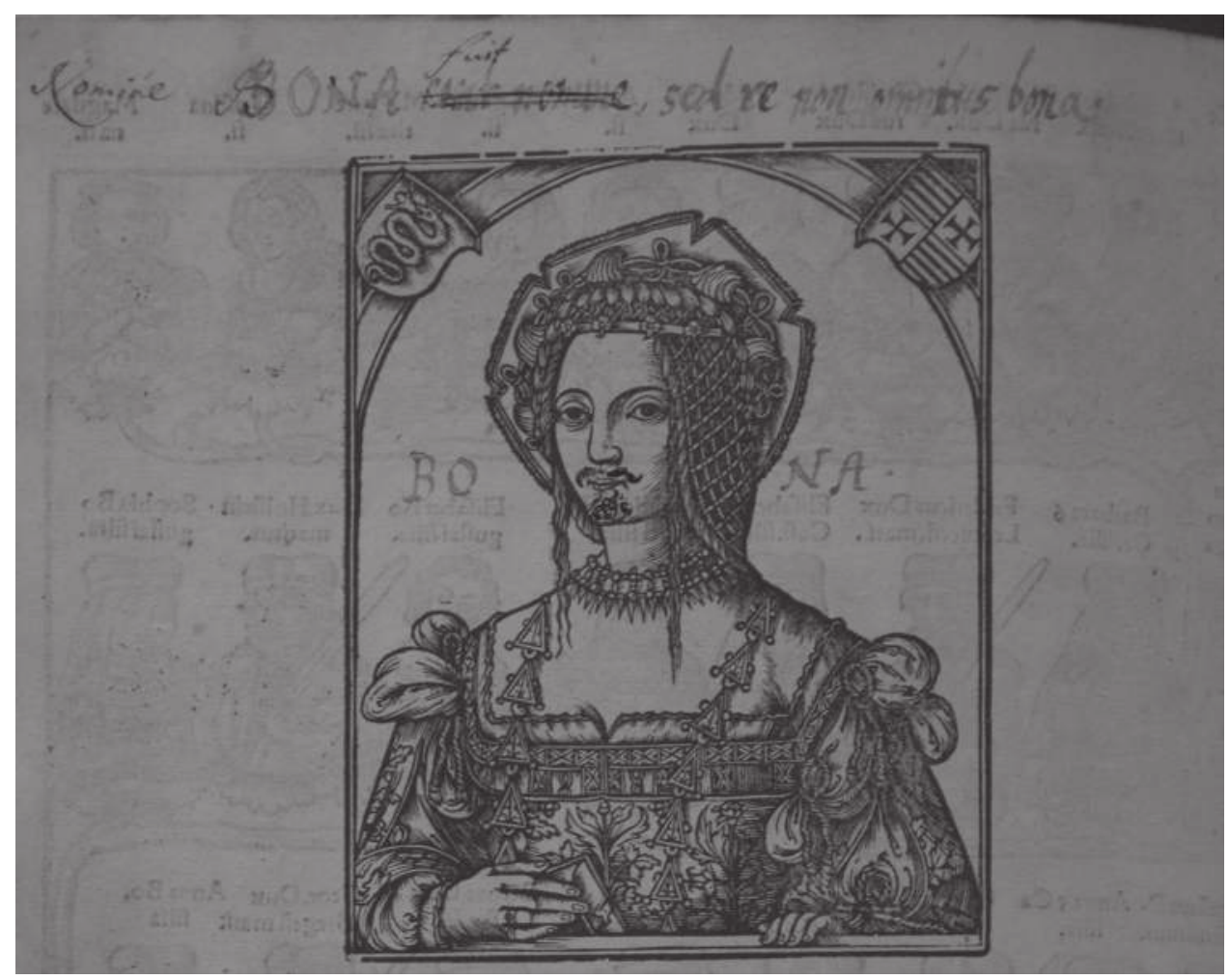

Figure 7.1 Likeness of Bona Sforza with a mustache, beard and critical comment added by a reader, in Iodocus Decius, Contenta: De vetustatibus Polonorum liber I. . . (Cracow: Hieronim Wietor, 1521), unnumbered page, woodcut, handwritten notes in ink. Warsaw, Biblioteka Uniwersytecka w Warszawie, SD 612.416.

Photo: Author.

/ comedunt). ${ }^{36}$ It appears that figures from the remote past can agitate readers. For instance, a reader has called the disliked Mieszko III a tyrant, and his figure is painted over with black ink. ${ }^{37}$

Whereas most of the responses to Bona Sforza's images were in striking contrast to the propagandistic aim of Decius's treatises and their accompanying woodcuts, some reactions seem to be in line with their initial purpose. "Glory" (Laus, chwata) read a laudatory note next to the representation of young Sigismund Augustus. Even stronger was the glorification of Sigismund I in the copy of Decius's treatises, which included a page of praise and the king's representational, medallion-like image (Figure 7.4). ${ }^{38}$ The added woodcut is diligently and skilfully hand-coloured in the same way as the title page, woodcuts and initials in the book, which belonged to the Szarfenbergs, a famous printer family based in Cracow. The careful selection and addition of colour underscores the monetary worth of the volume, the owner's prestige and the authority of the depicted figures. 


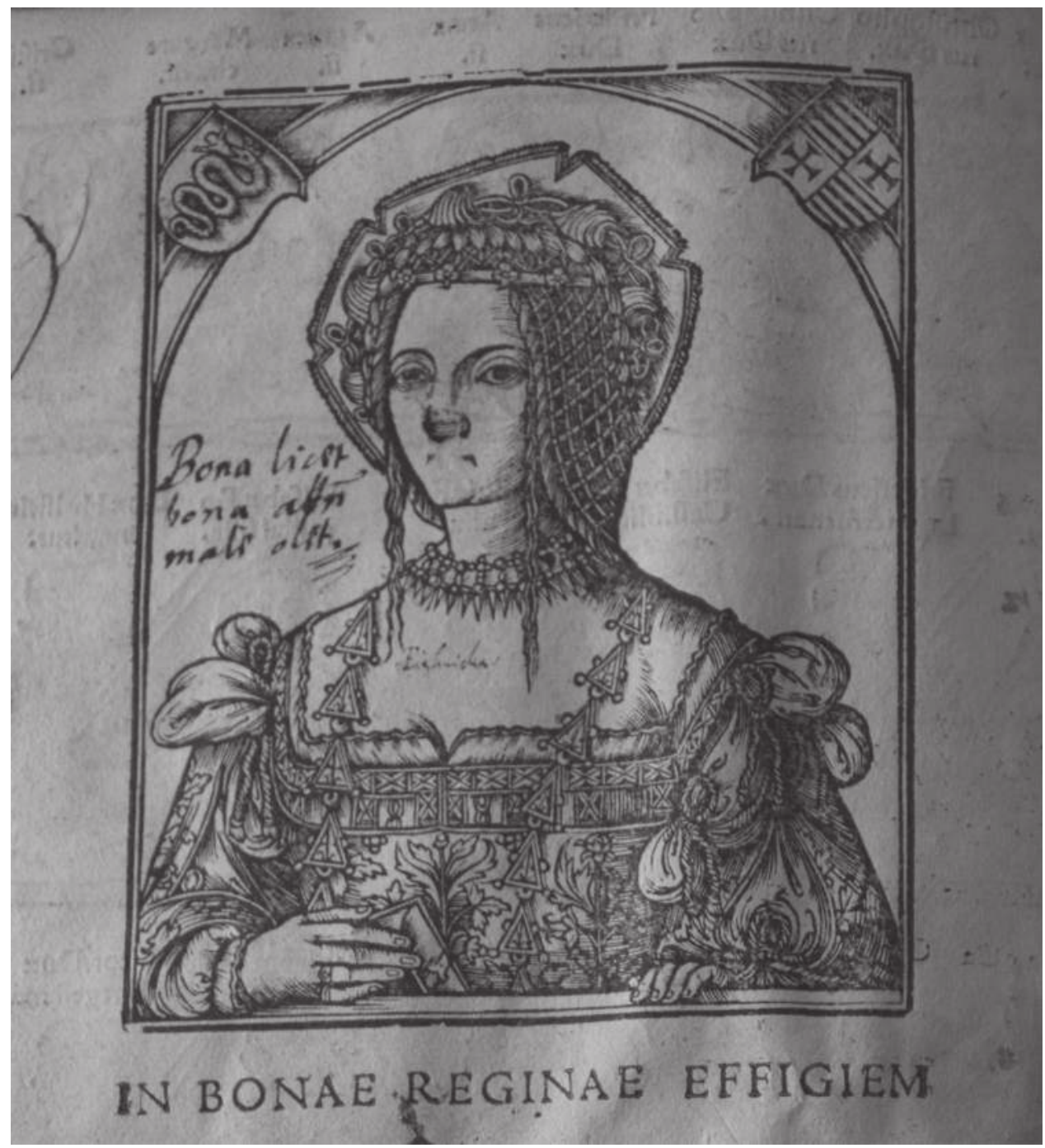

Figure 7.2 Likeness of Bona Sforza with partially scratched off lips, obscured nose and malicious note in Iodocus Decius, Contenta: De vetustatibus Polonorum liber I. . . (Cracow: Hieronim Wietor, 1521), unnumbered page, woodcut, handwritten notes in ink. Warsaw, Biblioteka Narodowa, XVI.F.44 adl.

Photo: Author.

Often, the colouring was executed by an unexperienced hand, on all the illustrations, only on selected ones or on just some parts of the woodcuts. In all cases, the colour set apart a given book and its illustrations, changing their aesthetic value. The colouring often amplified the meaning of images, as in the case of Chronica Polonorum housed in the Polish National Library, in which mainly the symbols of power, regalia and coats of arms are painted and thus highlighted in the illustrations. ${ }^{39}$ 


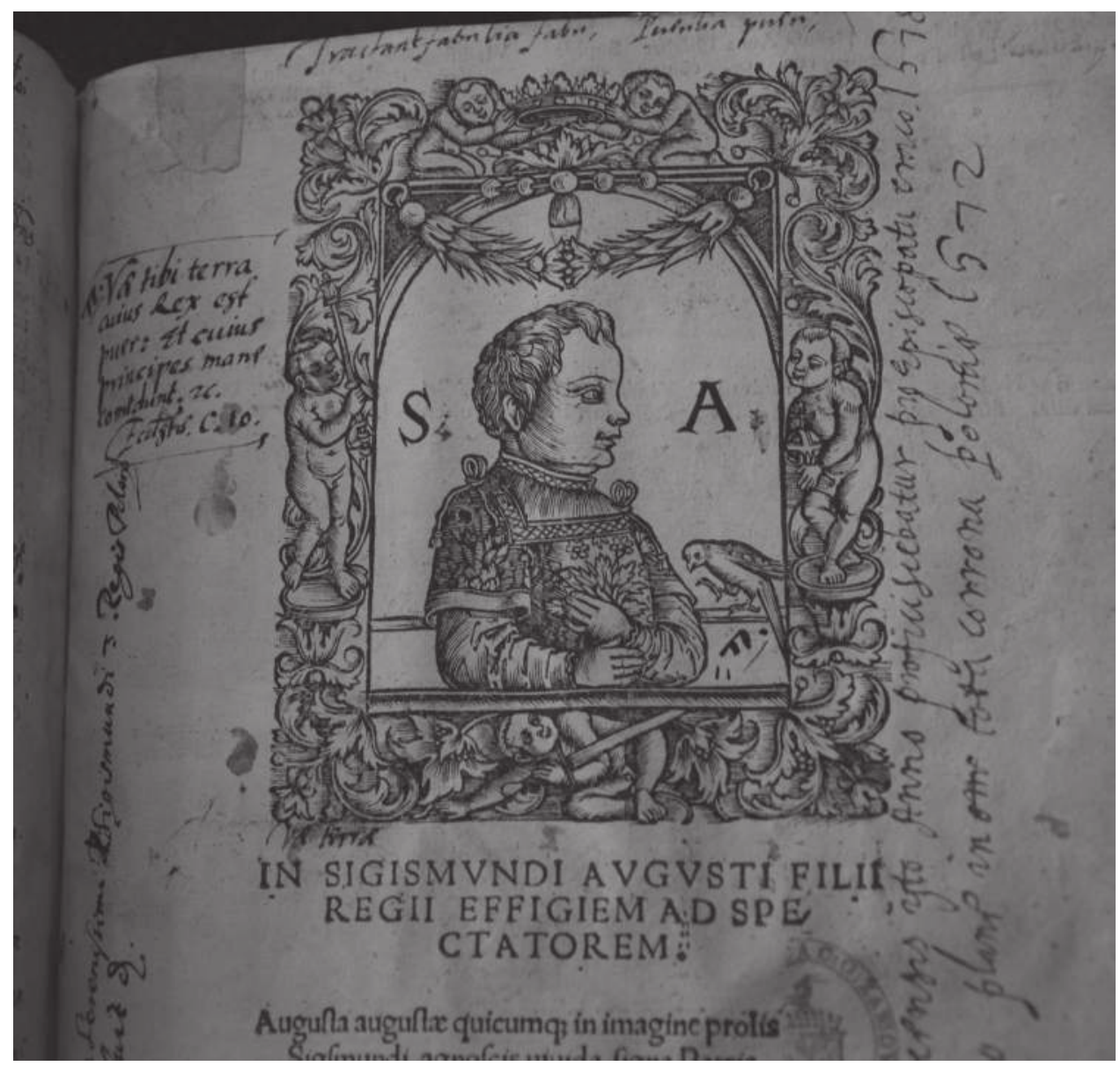

Figure 7.3 Representation of Sigismund Augustus with a quote from the Ecclesiastes (10:16) in Iodocus Decius, Contenta: De vetustatibus Polonorum liber I. . . (Cracow: Hieronim Wietor, 1521), unnumbered page, woodcut, handwritten notes in ink. Warsaw, Biblioteka Narodowa, XVI.F.44 adl.

Photo: Author.

Further differentiation of the depicted figures was achieved by the addition of dates or short notes summarising their lives and main achievements, which was a common practice in the studied copies of the chronicle. Placed on the margins, next to the images, the information helped to navigate the content of the chronicle and memorise it. The frequently occurring numbering of the kings, apart from its mnemotechnic value, stressed the sequential character of the rulers and the inherited character of royal power.

That not all the images were easy to comprehend is clear from the short explanations added to the heraldic framing of the page containing a subscribed likeness of Sigismund I. In two cases (Figure 7.5 and Plate 22), all the coats of arms were 


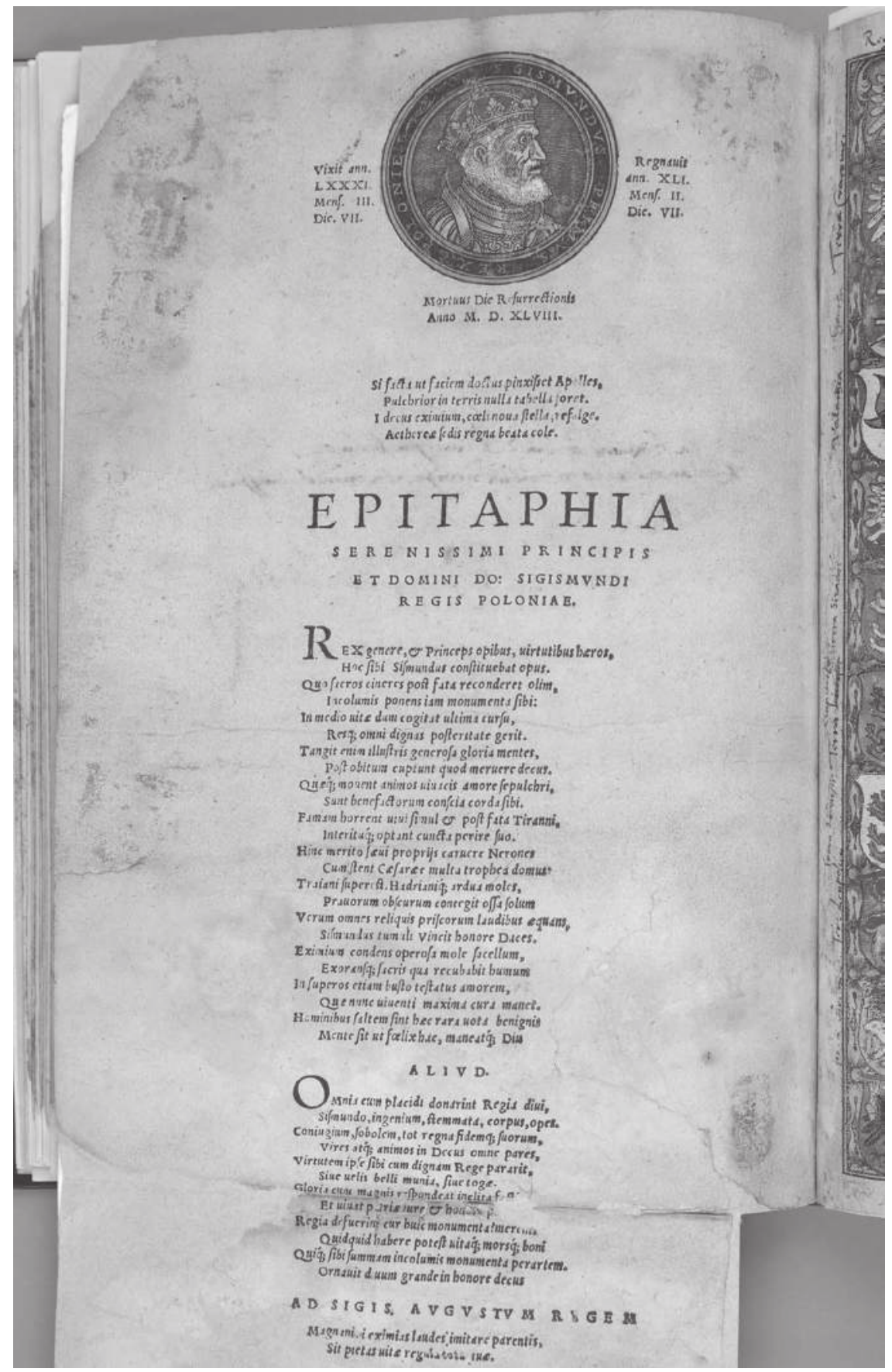

Figure 7.4 Epitaphia Serenissimi Principis et Domini Sigismundi pasted before the likeness of Sigismund I in Iodocus Decius, Contenta: De vetustatibus Polonorum liber I. . . (Cracow: Hieronim Wietor, 1521), unnumbered page, hand-coloured woodcut, letterpress. Cracow, Muzeum Narodowe w Krakowie, VIII-XVI.264.

Photo: Cracow, Muzeum Narodowe w Krakowie. 


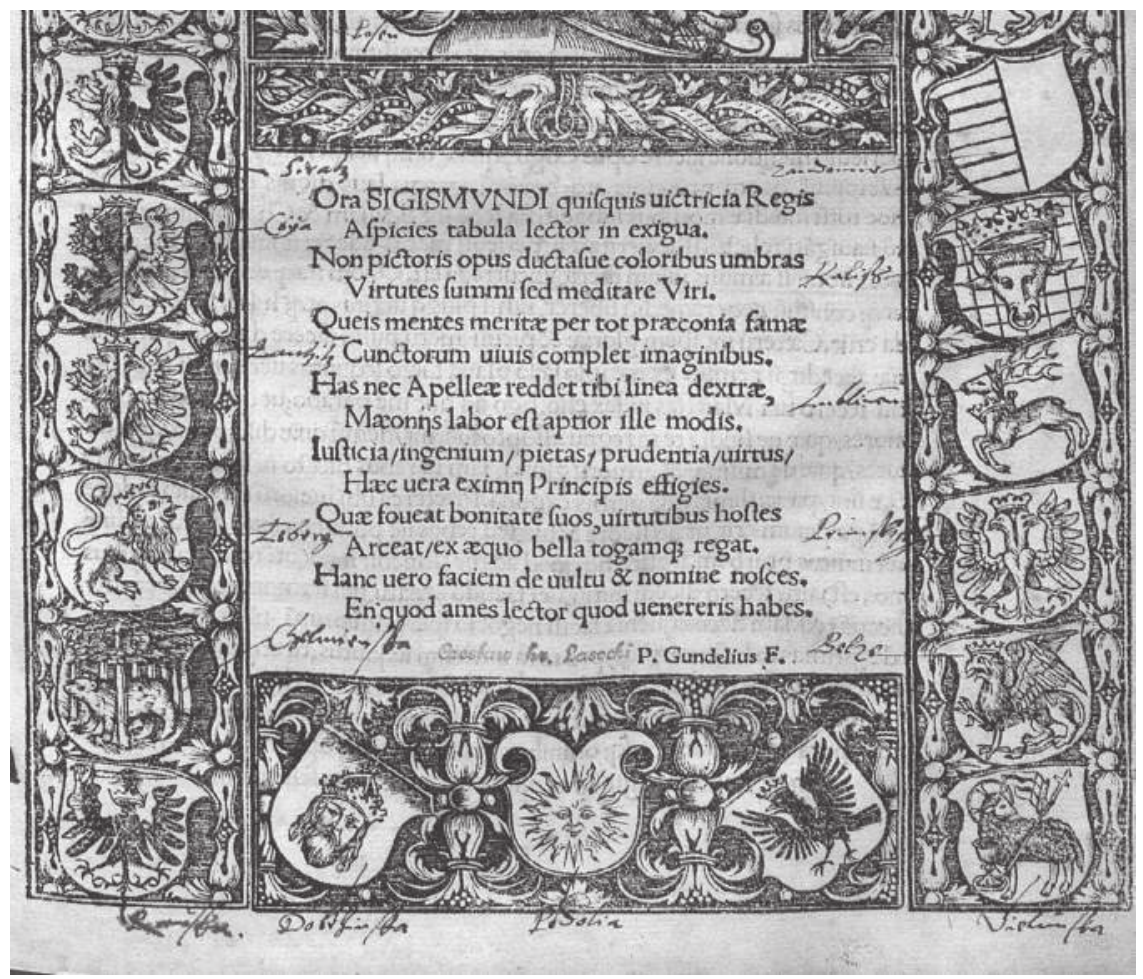

Figure 7.5 Fragment of the heraldic frame enclosing the likeness of Sigismund I with the handwritten identifications of the coats of arms of the Polish lands in Iodocus Decius, Contenta: De vetustatibus Polonorum liber I. . . (Cracow: Hieronim Wietor, 1521). Cracow, Muzeum Narodowe w Krakowie, VIII-XVI.33 adl, unnumbered page.

Photo: Cracow, Muzeum Narodowe w Krakowie.

identified by handwritten inscriptions. ${ }^{40}$ The same was done in the woodcut showing the 12 voivodes, on which an anonymous commentator superscribed the names of voivodeship allegedly represented by each of the figures. ${ }^{41}$

The complexity, obscurity and informational overload make it difficult to understand the family relations of the Jagiellons in the genealogical illustration. It is known that Sebastian Münster, confused by the genealogy, asked Polish humanists for clarifications about the male offspring of Władysław Jagiełło and the close relatives of Sigismund I. ${ }^{42}$ Similar problems with comprehending the Jagiellon family lineage seem to have troubled other readers, as is evidenced in the attempt to make sense of the print by numbering the ruling kings in the copy held today in the Polish National Library (Figure 7.6). ${ }^{43}$

\section{Reuses of Woodblocks}

The familiarity with the series of illustrations in Chronica Polonorum grew in the second half of the sixteenth century because of its copies and re-impressions in popular Polish-language historical and genealogical works. The set of Wietor's original 


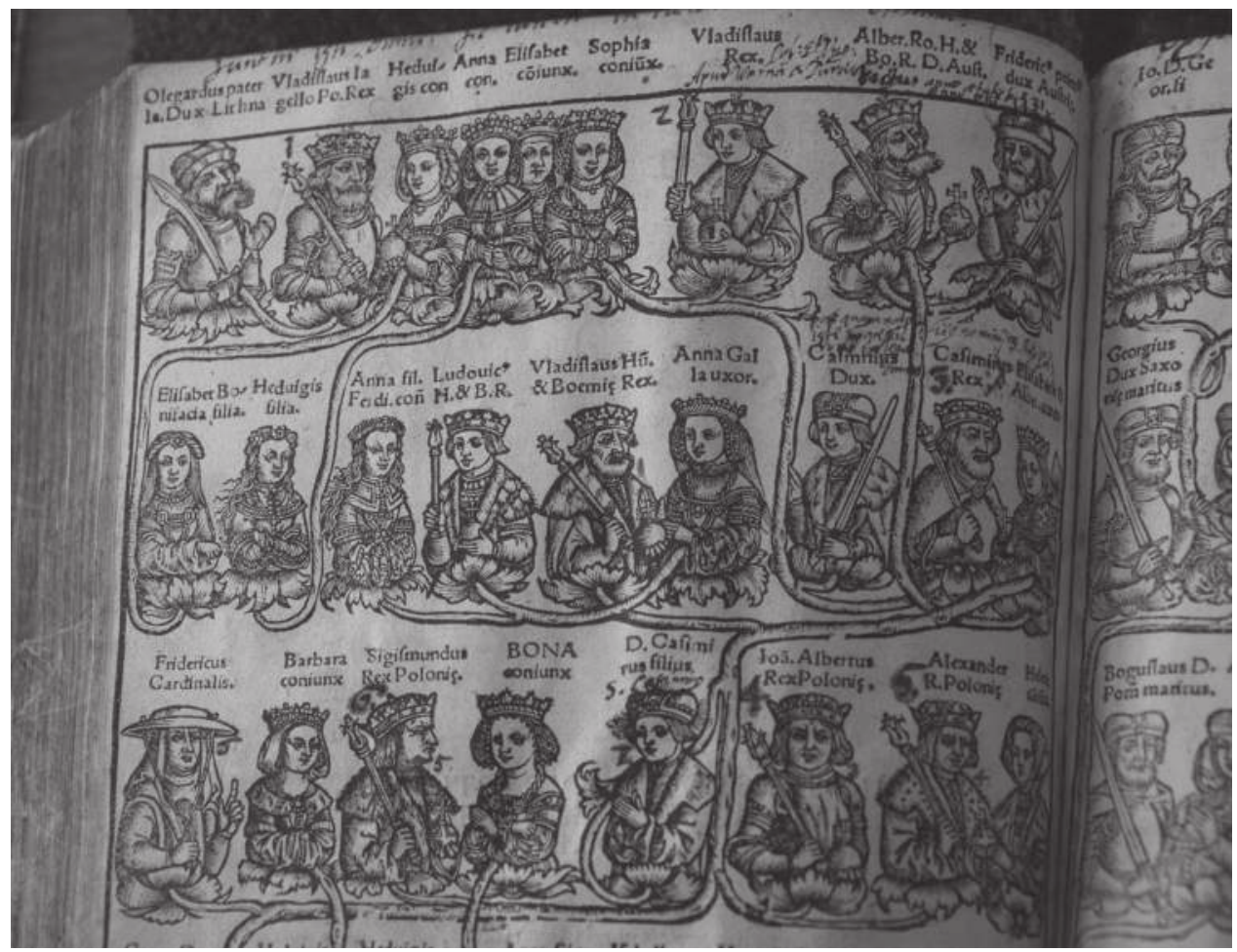

Figure 7.6 Numbering of the subsequently ruling kings of Poland in the genealogical woodcut (fragment) in Iodocus Decius, Contenta: De vetustatibus Polonorum liber I. . . (Cracow: Hieronim Wietor, 1521), unnumbered page, woodcut, letterpress, handwritten notes in ink. Warsaw, Biblioteka Narodowa, XVI.F.44 adl.

Photo: Author.

woodblocks was bought by Andrzej Piotrkowczyk I and extensively used to illustrate Bartosz Paprocki's The Nest of Virtue (Gniazdo cnoty), printed in Cracow in 1578. ${ }^{44}$ In The Nest of Virtue, the series of rulers was introduced into the narrative of the Polish nobility and was presented within the heraldic and genealogical context. The rulers were represented mostly using the same blocks and in the same order as in Chronica Polonorum. Only a few minor changes were introduced, and the most significant of them was the image of an enthroned Christian king (Mieszko II and Przemysł II in Chronica Polonorum) used to depict Mieszko I, who in Chronica Polonorum was shown as a pre-Christian ruler. The altered illustration corresponded better with Paprocki's text, which presented Mieszko as a propagator of Christianity.

Paprocki's The Nest of Virtue also serves as a rare example of the reception of the genealogical woodcut attached to the second edition of Chronica Polonorum. The images of king's spouses impressed under the representation of a particular king were modelled after the Jagiellon genealogical tree in Decius's treatises.

The use of the original woodblocks continued with the 1737 edition of Fortress of Monarchs (Forteca monarchów) by Piotr Jacek Pruszcz. Interestingly, it was 
published by the Academic Printing house, established with the equipment owned by the Piotrkowczyk family's printing press, which almost 150 years earlier had released The Nest of Virtue. Fortress of Monarchs, which merged the history of the Polish kingdom with the catalogues of rulers and the lives of national saints, was illustrated with six original blocks from Chronica Polonorum, which were used randomly. ${ }^{45}$ The enthroned likenesses of the Jagiellon rulers included the seventeenth-century monarchs: Władysław IV, John Casimir and Michał Korybut Wiśniowiecki. Only the heraldic programmes of the original images were modified to better correspond with the depicted person. For instance, the Hungarian coat of arms on the image of Władysław of Varna was replaced by the Korybut coat of arms so that the image could represent Michał Wiśniowiecki.

More often, however, the original woodblocks were used separately in other printed books. First, the likeness of Bona was reprinted in all 12 editions of the official Statuta Sigismundi Primi published by Hieronim Wietor between 1524 and 1550, to the extent that the original block was heavily worn out. ${ }^{46}$ The image of 12 voivodes was reprinted twice in The Nest of Virtue and once in Marcin Bielski's Polish Chronicle (Kronika polska) edited by Joachim Bielski in $1597 .{ }^{47}$ More distinguished was the placement of the woodcut depicting Władysław Jagiełł, which was reprinted on the title page of The King (Król) - the Polish translation of the political work by Fadrique Furió Ceriol, published in Cracow in 1578 by Maciej Garwolczyk. ${ }^{48}$ Six years later, the same printer used the heraldic frame, which was originally impressed with the likeness of Sigismund I in Chronica Polonorum, on the title page of Armorials of the Polish Knighthood (Herby rycerstwa polskiego) by Bartosz Paprocki, replacing the upper part of the frame with the coats of arms of Stephen Báthory. ${ }^{49}$ Both woodblocks, which could have been borrowed from Andrzej Piotrkowczyk, proved to be attractive and had advertising potential. ${ }^{50}$

\section{Copies of Illustrations}

As the use of the original woodblocks was limited both by their owners or borrowers and by their material durability, it was the copies of the woodcuts that established the long-lasting impact of the rulers' series.

The list of illustrations that were modelled after Chronica Polonorum is a long one but limited to the works on Polish history. The most influential of them were Polish Chronicle by Marcin and Joachim Bielski and three editions of World Chronicle (Kronika wszystkiego świata) by Marcin Bielski. ${ }^{51}$ Each of the editions referred to the illustrations in Maciej of Miechów's chronicle in its own way. While the images of rulers were mainly used as points of reference in the editions of 1551 and 1554, in the 1564 edition of the chronicle, the copies of narrative scenes were included. In fact, the richly illustrated Polish Chronicle, printed in 1597, introduced a new catalogue of Polish rulers, which would soon surpass the original series in popularity. Though stylistically different, the catalogue of 1597 also bears a resemblance to the illustrations in Chronica Polonorum.

Four faithful copies along with looser references to the originals were executed by a master working on the illustrations of Alessandro Guagnini's Sarmatiae Europeae descriptio printed by Wirzbięta in 1578, which also used illustrations from Marcin Bielski's World Chronicle as models. ${ }^{52}$ More famously, in 1588, Tomasz Treter completed his Regum Poloniae icones, a series of copper plates depicting Polish rulers 
from Lech to Sigismund III Vasa, modelled after carefully selected iconographical sources. Chronica Polonorum served Treter as a reliable source for the images of five Piast and all the legendary rulers.

Tomasz Treter's Regum Poloniae icones ensured the long-term (and mediated) reception of the series of the first rulers, which was copied and included in various catalogues of Polish rulers, printed not only in Poland but also abroad-in Cologne, Frankfurt am Main and Sulzbach, as well as reprinted in 1736 in Stockholm. ${ }^{53}$

Only a few examples can be found in which the illustrations of Chronica Polonorum influenced the iconography of a series of foreign rulers. In Diadochos by Bartosz Paprocki, printed in Prague in 1602, an attempt was made to introduce the iconography of the Polish Krak and Wanda to the series of Czech rulers. ${ }^{54}$ The legendary Krok and Libuše were modelled after the figures in Chronica Polonorum. These images, however, could not modify the canon of historical imagery, which was already established around 1540 by Martin Kuthen's Chronicle of the Founding of the Czech Lands (Kronyka o Založenij Zemie Cžeske) and Catalogus ducum regumque Boboemorum. ${ }^{55}$ Thus, no other seventeenth- or eighteenth-century catalogues of Bohemian rulers pictured Krok and Libuše like Krak and Wanda.

\section{Conclusions}

The visual content of the second edition of Chronica Polonorum by Maciej of Miechów was selectively consumed, reused and copied. The recipients of the book left numerous verbal and non-verbal marks of interest in the illustrations, which were often provoked by their uncompromising attitude to the depicted figures, especially the members of the contemporary ruling family. Skilfully hand-coloured illustrations showcased the importance and authority of the depicted figures, as well as the prestige of the volume's owners. Examples of amateurish colouring, which often augmented the meaning of images, highlighted the recipients' active interaction with the image as well as their direct involvement, which contributed to the new aesthetic of a page and the individualisation of the book's content. The most common approach to marking the illustrations, however, was the addition of numbers, dates or short notes about the reign of the depicted ruler. These notes helped identify the figure in the illustration, serving the purposes of memorisation and better orientation to the contents of a thick volume. The numbering of depicted figures or the addition of explanatory notes was also a way of managing complex and content-heavy illustrations that were difficult to understand, such as the genealogical tree of the Jagiellons or the frame with the coats of arms of the Polish lands.

The provenance notes and physical traces of reading and viewing suggest that female readers were generally excluded from the otherwise broad readership of the chronicle, which included younger and older readers, noblemen, townspeople and Polish and foreign men of letters. The high price of the book was the main hurdle to the chronicle's consumption among less well-off readers.

The steady interest in the chronicle's images, mainly its depictions of the first legendary and historical rulers, sustained by its reuses and copies, led to their absorption into the collective imagery of the Polish past from the last quarter of the sixteenth century onwards. Aspects that did not fit into the shared vision of Polish historysuch as the fictional portrait of a young king to-be and the detailed presentation of the Jagiellons' family connections-were left out. Another limitation, as in the case of 
the child portrait and the Jagiellon genealogical tree, was the provisional utility of the woodcuts. For example, the child likeness could facilitate the acceptance of the young prince as a prospective heir, but after his maturity and coronation, it would be a mere relic of the past. Furthermore, the unease of the Polish nobility with the vivente rege coronation and child monarchs could have diminished the use of this image in the political iconography of the Jagiellons and their successors. Further, the intricate genealogical woodcut, which illustrated the links of the Jagiellons with numerous neighbouring dynasties, assumed lesser importance after the death of Sigismund Augustus. The successors of the last Jagiellon were mainly concerned with finding and strengthening their links with the newly elected kings and their Jagiellon ancestors (and not their side lines), as seen in the case of the genealogical constructions of Sigismund III Vasa and his son Władysław IV. Hence, the images that served the momentary needs of Jagiellon propaganda lost their utility in the subsequent decades.

The illustrations in Chronica Polonorum circulated almost exclusively on the Polish print market, with the majority of blocks passing from one Cracow printer to another. In rare cases, when the illustrations were received abroad, the reception was mediated by late-sixteenth-century catalogues of Polish kings and limited to the popular compendia about Polish history. Their absorption into foreign historical imagery was impeded mainly by local historical and iconographic traditions.

From the mid-sixteenth century, numerous copies of the likenesses of the kings were made, illustrating the most popular works on Polish history. Thus, by the end of the sixteenth century, the majority of illustrations from Chronica Polonorum had gained the status of a visual artefact that testified to the foundation of the Polish kingdom and its political traditions. The images that did not fit with the collective vision of Polish history, on the other hand, were left out of the picture.

\section{Notes}

1 This chapter was originally written as a part of the 2015/16/S/HS2/00267 research project entitled "Icones Regum: Illustrated catalogues of rulers in the national narratives in Poland, Hungary and Bohemia," financed by the FUGA 4 programme of the National Science Centre, Poland.

2 Knapp, Illustrating the Past, 13-28.

3 Luborsky, "Connections and Disconnections," 74.

4 Maciej of Miechów, Chronica Polonorum (Cracow: Hieronim Wietor, 1521), Warsaw, BUW, SD 612.416, 361. I would like to thank Aleksander Sroczyński and Jakub Niedźwiedź for their invaluable help in deciphering the note.

5 If not stated otherwise, all the translations are by the author.

6 The copy originally belonged to Matthaeus Podgorski ex Schola Logica, as we learn from a provenance note: Mieczkowska, ed., Katalog druków, no. 6346, egz. c, 332.

7 For the purpose of this study, I examined copies of Chronica Polonorum in Cracow, BJ and MNK; Warsaw, BN, BUW and Biblioteka Publiczna m.st. Warszawy; Budapest, OSK and Library of the Hungarian Academy of Sciences, as well as selected copies of the chronicle held in Polish and foreign collections available in the digital form. The studied sample included 46 copies of the chronicle.

8 Maciej of Miechów, Chronica Polonorum (Cracow: Hieronim Wietor, 1519).

9 Graff and Wołyniec, "Maciej z Miechowa," 176-77; Bömelburg, Frühneuzeitliche Nationen, 74-75, 77-78; Buchwald-Pelcowa, Historia literatury, 604-5; eadem, Cenzura w dawnej Polsce, 16; Podlaszewska, "Pierwsze wydanie," 189-210; Bostel, Zakaz Miechowity, 438-54, 540-62, 637-52.

10 Jakimowicz, "Wizerunki władców," 68-81; eadem, Temat historyczny, 49-51; eadem, "Przeszłość i teraźniejszość," 154-204; Miodońska, “Władca i państwo,” 62-72. 
11 Iodocus Decius, Contenta: De vetustatibus Polonorum liber I; De Iagellonum familia liber II; De Sigismundi regis temporibus liber III (Cracow: Hieronim Wietor, 1521).

12 More on the representations of the members of the royal family in Chronica Polonorum: Morka, Sztuka dworu, 337-45, 396-97, 406-8; Blumówna, "O pierwszych portretach," 73-82.

13 The images accompanying Decius's treatises could also open the series, presenting the royal family as successors of a long line of Polish rulers in the cases when Decius's work was bound before Chronica Polonorum as in Warsaw, BUW, SD 612.424.

14 The use of inventories in the research on private libraries and prices of books is limited because they contain selective information about the books, which is often not sufficient for the identification of a particular book, its edition or a particular copy. This is especially true in the case of the chronicle by Maciej of Miechów, as the generic Chronica Polonorum can refer to one of the Polish- or Latin-language works on Polish history. Cf. Maleczyńska, Z dziejów księgozbiorów, 67, note 11.

15 Budka, "Bibljoteka," 209-15.

16 Bömelburg, Frühneuzeitliche Nationen, 39; Budka, "Bibljoteka," 209, 212.

17 Cf. Urban, "Ceny książek," 61-67.

18 Głombiowski, "Traktat o Dwóch Sarmacjach,” 125; Barycz, "Życie i twórczość Macieja z Miechowa," 57.

19 Provenance note in the copy of the chronicle held in the collection of the University of Warsaw Library, SD 612.560: Emptus est liber iste p[er] Andream Michalowski flo[renis] 12 et g[rossis] 2 AD 1588. The note was published in the library catalogue: Katalog druków XV i XVI wieku, vol. 5: L-O, cat. 6346, egz. h, 333.

20 Cf. Wacław Urban, "Ceny książek," 61-67; Pelc, Ceny w Krakowie.

21 Barycz, "Kilka glos”; idem, “Życie i twórczość Macieja z Miechowa,” 55-59.

22 Barycz, "Dwie syntezy," 201.

23 Bömelburg, Frühneuzeitliche Nationen, 85.

24 Jan Krzysztoporski's copy (Warsaw, BUW, the deposit of the Polish Book Institute) preserved marginalia of Jan Krzysztoporski the elder and his son. More on their book annotations: Czapnik, "Księgozbiór," 79-81. On Jan Strzembosz and his book collection: Bylinowa, "Renesansowy księgozbiór," 21-22; Budka, "Księgozbiór," 56-57.

25 Warsaw, BN, XVI.F. 43 adl., 1.

26 Barycz, "Kilka glos," 239-40. The full text of the handwritten dedication by Melanchthon is given in: Neubaur, "Ein Nachtrag zum Corpus Reformatorum," 273. Neubaur found the book in the library of Elbląg and established its history and owners in the sixteenth and seventeenth century. Today, the book is no longer registered in the library catalogue. It was likely lost between 1945 and 1947 when numerous volumes were stolen or destroyed and 18 boxes with the most precious early printed books went missing. I would like to thank Ewa Chlebus from the Special Collection of Elbląg Library for this information.

27 BJ, Cim. 8516.

28 Bömelburg, Frühneuzeitliche Nationen, 86.

29 Ibidem, 126; Puchalski, Polonika, 44-45 and 93 where he lists Pistorius's main changes.

30 In the studied sample, I came across motifs such as a bird, beads or a moustache and beard.

31 Warsaw, BUW, SD 612.424 and Biblioteka Publiczna m.st. Warszawy, XVI.F.37 adl.

32 Warsaw, BUW, SD 612.416, unnumbered page.

33 More on the unfavourable perception of the queen and various pasquills on her name in the sixteenth and seventeenth century, see Kosior, "Outlander, Baby Killer, Poisoner?" 199223; Bogucka, Bona Sforza, 254-61; idem, "Bona Sforza d'Aragona," 80-84.

34 Warsaw, BN, XVI.F. 44 adl., unnumbered page. I would like to thank Katarzyna JasińskaZdun for her indispensable philological assistance.

35 Translation after: English Standard Version.

36 Warsaw, BN, XVI.F. 44 adl., unnumbered page.

37 Warsaw, BN, XVI.F. 352 adl., 97. The same gesture had a different meaning in the case of the woodcut showing Leszek Czarny [Leszek the Black], in which the black colouring of the figure was an attempt to differentiate the ruler by colouring him in accordance to his cognomen.

38 Cracow, MNK, VIII-XVI.264. The text begins with the words Epitaphia Serenissimi Principis et Domini Sigismundi. 
39 BN, XVI.F.938.

40 Cracow, MNK, VIII-XVI.264 and VIII-XVI.33 adl., unnumbered pages.

41 BN, XVI.F.43 adl., 5.

42 Konczyńska, List Sebastjana Münstera, 15.

43 BN, XVI.F.44 adl., unnumbered pages.

44 Bartosz Paprocki, Gniazdo cnoty (Cracow: Andrzej Piotrkowczyk I, 1578). More on the ways in which Piotrkowczyk reused Wietor's woodblocks: Kawecka-Gryczowa, ed., Drukarze, 162.

45 Piotr Jacek Pruszcz, Forteca monarchow y całego Krolestwa Polskiego duchowna (Cracow: Drukarnia Akademicka, 1737). Only the image of Lech on the opening page of the first part of Forteca retained its original meaning. The rest of the woodcuts reused in the book were (1) Wyszymir, a legendary duke of Poland illustrated with the likeness of the king Casimir the Great; (2) Władysław III of Varna illustrated with the block initially used for John Albert; (3) Władysław IV, initially Alexander Jagiellon; (4) John Casimir, without the heraldic frame which originally accompanied the image of Sigismund I; and (5) Michał Korybut Wiśniowiecki, depicted by the block which in Chronica Polonorum stood for Władysław III of Varna.

46 Statuta serenissimi domini Sigismundi Primi Polonie regis (Cracow: Hieronim Wietor, [various editions between 1524 and 1550]); Piekarski, "Uwagi o chronologii," 486. NB in contrast to Chronica Polonorum, the image of Bona in the official print did not provoke the reader to interfere with it in the way the woodcut in the historical text did. In none of the copies of Statuta did I find such bitter comments about the queen's poor character and conduct as in the copies of the chronicle. The majority of annotations, mainly similia, referential notes, addenda and corrections, have a generally utilitarian character. The images were sometimes used as a writing space, as in the copy of Statuta from the collection of the BN, XVI. F. 713-714, which combines pages of two variants of the print, where the image of Sigismund I is densely covered with devotional inscriptions.

47 Paprocki, Gniazdo cnoty (see note 44), 3, 5; Bielski, Kronika polska, 34.

48 Fadrique Furió Ceriol, Krol (Cracow: Maciej Garwolczyk, 1578); Kawecka-Gryczowa, ed., Drukarze, 41.

49 Bartosz Paprocki, Herby rycerztwa polskiego (Cracow: Maciej Garwolczyk, 1584).

50 Kawecka-Gryczowa, ed., Drukarze, 41.

51 Marcin Bielski, Kronika wszytkiego swyata (Cracow: Florian Ungler, 1551); idem, Kronika wssythyego swyata (Cracow: Hieronim Szarfenberg, 1554); idem, Kronika tho iesth Historya swiata (Cracow: Mateusz Siebeneicher, 1564); Bielski, Kronika polska.

52 Alessandro Guagnini, Sarmatiae Europeae descriptio (Cracow: Maciej Wirzbięta, 1578); Kawecka-Gryczowa, ed., Polonia typographica, 36-37.

53 Tomasz Treter, Regum Poloniae icones (Rome: s.n., 1591). Treter's copperplates were reused to impress illustrations in Johan Göstaf Hallman's Polska kongars saga och skald (Stockholm: Joh. Henr. Werners enkia, 1736). The series was copied first in Principum et regum Polonorum imagines by Arnold Mylius (Cologne: Arnold Kempen, 1594). Then the copies of the illustrations in Mylius's Imagines were published inter alia in Salomon Neugebauer's Icones et vitae principium ac regum Poloniae printed in Frankfurt/M in 1620, 1626, 1644 (German translation was published in 1626, and the Swedish one in the seventeenth century), Albert Ines's Lechias (Cracow: Franciszek Cezary, 1655), Johann Melesander's Schau-Platz Polnischer Tapfferkeit (Nuremberg: Christian Sigmund Froberg, 1684, [and in] 1688; Sultzbach: Johann Holst, 1685).

54 Bartosz Paprocki, Diadochos id est successio (Prague: heirs of Jan Šuman, 1602). Reprint of Diadochos was published in Brno in 2005.

55 Martin Kuthen of Šprinsberk, Kronyka o Založenij Zemie Cžeske (Prague: Pavel Severýn, 1539); idem, Catalogus ducum regumque Bohoemorum (s.l.: s.n., 1540).

\section{Bibliography}

Barycz, Henryk. "Dwie syntezy dziejów narodowych przed sądem potomności: Losy 'Historii’ Jana Długosza i Marcina Kromera w XVI i pierwszej połowie XVII wieku.” Pamiętnik Literacki, 43 (1952): 194-251. 
_. “Życie i twórczość Macieja z Miechowa.” In Maciej z Miechowa 1457-1523: Historyk, geograf, lekarz, organizator nauki, ed. Henryk Barycz, 15-74. Wrocław: Zakład Narodowy im. Ossolińskich, 1960.

. "Kilka glos do znajomości Macieja z Miechowa w XVI i XVII w." Kwartalnik Historii Nauki i Techniki, 8/2 (1963): 237-43.

Bielski, Marcin. Kronika polska Marcina Bielskiego nowo przez Ioachima Bielskiego wydana. Cracow: Siebeneicher, 1597.

Blumówna, Helena. "O pierwszych portretach świeckich w krakowskich drukach renesansowych.” Rozprawy i Sprawozdania Muzeum Narodowego w Krakowie: Rok 1952, (1954): 73-82.

Bogucka, Maria. "Bona Sforza d'Aragona.” In Życiorysy historyczne, literackie i legendarne, eds. Zofia Stefanowska and Janusz Tazbir, 79-100. Warsaw: Państwowe Wydawnictwo Naukowe, 1989.

Bogucka, Maria. Bona Sforza. Wrocław: Zakład Narodowy im. Ossolińskich, 1998.

Bömelburg, Hans-Jürgen. Frühneuzeitliche Nationen im östlichen Europa: Das polnische Geschichtsdenken und die Reichweite einer humanistischen Nationalgeschichte (1500-1700). Wiesbaden: Harrassowitz Verlag, 2006.

Bostel, Ferdynand. Zakaz Miechowity (Odbitka z 'Przewodnika Naukowego i Literackiego' $z r$ : 1884). Lwów: Wł. Łoziński, 1884.

Buchwald-Pelcowa, Paulina. Cenzura $w$ dawnej Polsce: Między prasą drukarską a stosem. Warsaw: Wydaw SBP, 1997.

—. Historia literatury i historia książki: Studia nad książka i literaturą od średniowiecza po wiek XVIII. Cracow: TAiWPN “Universitas,” 2005.

Budka, Włodzimierz. "Bibljoteka Mikołaja Bronowskiego.” Przeglad Biblioteczny, 4 (1930): 209-15.

—. "Księgozbiór Kaspra Wieruskiego.” Przegląd Biblioteczny, 4 (1930): 54-57.

Bylinowa, Elżbieta. "Renesansowy księgozbiór rodziny Strzemboszów." In Kolekcje historyczne: Księgozbiory szlacheckie XVI-XVII wieku, 17-105. Warsaw: Wydawnictwa Uniwersytetu Warszawskiego, 2004.

Czapnik, Marianna. "Księgozbiór Krzysztoporskich: Z dziejów renesansowych bibliotek szlacheckich.” In Księgozbiory szlacheckie XVI-XVII wieku, Vol. 2, 15-152. Warsaw: Wydawnictwa Uniwersytetu Warszawskiego, 2009.

Głombiowski, Karol. “Traktat o Dwóch Sarmacjach i Kronika Polska Macieja z Miechowa na Śląsku.” Roczniki Biblioteczne, 5 (1961): 115-68.

Graff, Tomasz, and Bartłomiej M. Wołyniec. “Maciej z Miechowa: Historyk przełomu epok.” In Krakowskie środowisko historyczne XV-XX w: Ludzie-Idee-Dzieła, eds. Tomasz Gąsowski and Janusz Smołucha, 169-81. Cracow: Polska Akademia Umiejętności; Wydawnictwo Naukowe Akademii Ignatianum w Krakowie, 2018.

Jakimowicz, Teresa. "Przeszłość i teraźniejszość w sztuce wieku XVI w Polsce." In Świadomość historyczna Polaków: Problemy i metody badawcze, ed. Jerzy Topolski, 154-204. Łódź: Wydawnictwo Łódzkie, 1981.

- Temat historyczny w sztuce epoki ostatnich Jagiellonów. Warsaw: Państwowe Wydawnictwo Naukowe, 1985.

—. "Wizerunki władców Polski w 'Chronica Polonorum’ Macieja z Miechowa: Problem kreacji i funkcjonowania źródła obrazowego.” In Studia nad świadomościa historyczna Polaków, ed. Jerzy Topolski, 68-81. Poznań: Wydawnictwo Poznańskie, 1994.

Kawecka-Gryczowa, Alodia, ed. Polonia typographica saeculi sedecimi: Ttocznie polskie XVI stulecia-monografie i podobizny zasobów drukarskich: Z. 11, Maciej i Paweł Wirzbiętowie, Kraków 1555/7-1609. Wrocław: Zakład Narodowy im. Ossolińskich, 1981.

—. Drukarze dawnej Polski od XV do XVIII wieku. Vol. 1: Małopolska, pt. 1: Wiek XV-XVI. Wrocław: Zakład Narodowy im. Ossolińskich, 1983. 


\section{Karolina Mroziewicz}

Knapp, James A. Illustrating the Past in Early Modern England: The Representation of History in Printed Books. Aldershot: Ashgate, 2003.

Konczyńska, Wanda. List Sebastjana Münstera do Stanisława Łaskiego i garść szczegótów $w$ zwiazku z jego Kosmografja. Cracow: self published by the author, 1935.

Kosior, Katarzyna. "Outlander, Baby Killer, Poisoner? Rethinking Bona Sforza's Black Legend." In Virtuous or Villainess? The Image of the Royal Mother from the Early Medieval to the Early Modern Era, eds. Carey Fleiner and Elena Woodacre, 199-223. New York: Palgrave Macmillan, 2016.

Luborsky, Ruth Samson. "Connections and Disconnections Between Images and Texts: The Case of Secular Tudor Book Illustration.” Word \& Image, 3/1 (1987): 74-84.

Maleczyńska, Kazimiera. Z dziejów księgozbiorów mieszczańskich w Polsce 1506-1572. Wrocław: Wydawnictwo Uniwersytetu Wrocławskiego, 1991.

Mieczkowska, Halina, ed. Katalog druków XV i XVI wieku w zbiorach Biblioteki Uniwersyteckiej w Warszawie. Vol. 5. Warsaw: Wydawnictwa Uniwersytetu Warszawskiego, 2015.

Miodońska, Barbara. "Władca i państwo w krakowskim drzeworycie książkowym wieku XVI." In Renesans: Sztuka i ideologia: Materiaty sympozjum naukowego Komitetu Nauk o Sztuce PAN, Kraków czerwiec 1972 oraz sesji naukowej Stowarzyszenia Historyków Sztuki, Kielce listopad 1973, ed. Tadeusz S. Jaroszewski, 45-96. Warsaw: Państwowe Wydawnictwo Naukowe, 1976.

Morka, Mieczysław. Sztuka dworu Zygmunta I Starego: Treści polityczne i propagandowe. Warsaw: Argraf, 2006.

Neubaur, Leonard. "Ein Nachtrag zum Corpus Reformatorum." Altpreussische Monatsschrift, 28 (1891/1892): 246-75.

Pelc, Julian. Ceny w Krakowie w latach 1369-1600. Lwów: Skład główny, Kasa im. Mianowskiego, 1935.

Piekarski, Kazimierz. "Uwagi o chronologii wydań Statutów Sejmowych z czasów Zygmunta Starego.” Przegląd Biblioteczny, 4 (1929): 478-95.

Podlaszewska, Krystyna. "Pierwsze wydanie Kroniki Macieja z Miechowa w zbiorach Biblioteki UMK w Toruniu." In Studia o działalnosci i zbiorach Biblioteki Uniwersytetu Mikołaja Kopernika, ed. Bohdan Ryszewski, Vol. 1, 189-210. Toruń: Uniwersytet Mikołaja Kopernika, 1980.

Puchalski, Jacek. Polonika z obszaru niemieckojęzycznego-poza granicami Rzeczypospolitej-w XVI wieku. Warsaw: Wydawnictwo SBP, 1997.

Urban, Wacław. "Ceny książek w Polsce w XVI-XVII w.” Biuletyn Biblioteki Jagiellońskiej, 46 (1996): 61-67. 


\title{
8 A Foreign Affair \\ Thomas Gemini and His Booklet of Moresque Designs
}

\author{
Femke Speelberg
}

In 1548, over half a century after the ornament print genre had emerged and become popular across the European continent, a first English contribution was published in London. The series Morysse and Damashin renewed and encreased [sic] consisted of a title page with a strapwork cartouche, followed by plates with designs for moresques: a surface-covering ornament made up out of heavily stylized, interlaced vegetal tendrils sometimes combined with geometrically arranged bandwork, typically found across the Islamic world (Figures 8.1 and 8.2). ${ }^{1}$ Very few copies of this English print series have survived, and none appears to be complete. Our current knowledge about the series is principally based on the set held in the collection of the Universitätsund Landesbibliothek in Münster (formerly in the Landesmuseum Münster). It was acquired in about 1914 by the director of the museum, Dr. Max Geisberg (18751943), directly from a firm of goldsmiths in Westphalia, in whose possession it had been for a "long", yet undefined time. ${ }^{2}$

The series is extremely modest in size (the measurements of the plates do not exceed $5 \times 8.6 \mathrm{~cm}$ ), but its enigmatic author Thomas Geminus or Gemini (c. 1515-62), whose name appears in full on the title page, nevertheless dedicated it to the young, newly crowned King Edward VI (1537-53). This makes it one of the earliest-known ornament print series to carry a dedication ${ }^{3}$ and suggests that Gemini's ambition in publishing it might have gone beyond simply providing patterns "profitable for Goldsmythes and Embroiderars," as the extended title would have it. Barring the possibility of an earlier edition, which may be suggested by the inclusion of the words "renewed and increased" in the series' title, the Morysse and Damashin also proved to be the only series of ornament prints Gemini would publish in his lifetime. It therefore seems unlikely that his main intent in publishing the ornament prints was to popularize the new genre in the English print market. Instead, his motivation is more likely related to the specialized subject matter of his prints.

While originally a rather exotic form of ornament, by the 1540s moresques had long since been adopted in the English vocabulary of art and decoration. They frequently appeared as a beloved pattern in highly ornate textile decorations at the court of King Henry VIII (1491-1547). In addition, drawings and prints record designs for various pieces of metalwork decorated with the exotic ornament, including a jewelry casket and drinking vessels by court artist Hans Holbein the Younger (1497-1543). ${ }^{4}$ With his print series, Gemini thus did not introduce something completely novel to English society. Other ornaments, such as all'antica grotesques or strapwork designs, were arguably even more fashionable during this period. The latter had only recently made their debut in the designs and prints of the School of Fontainebleau and were 


\section{Femke Speelberg}

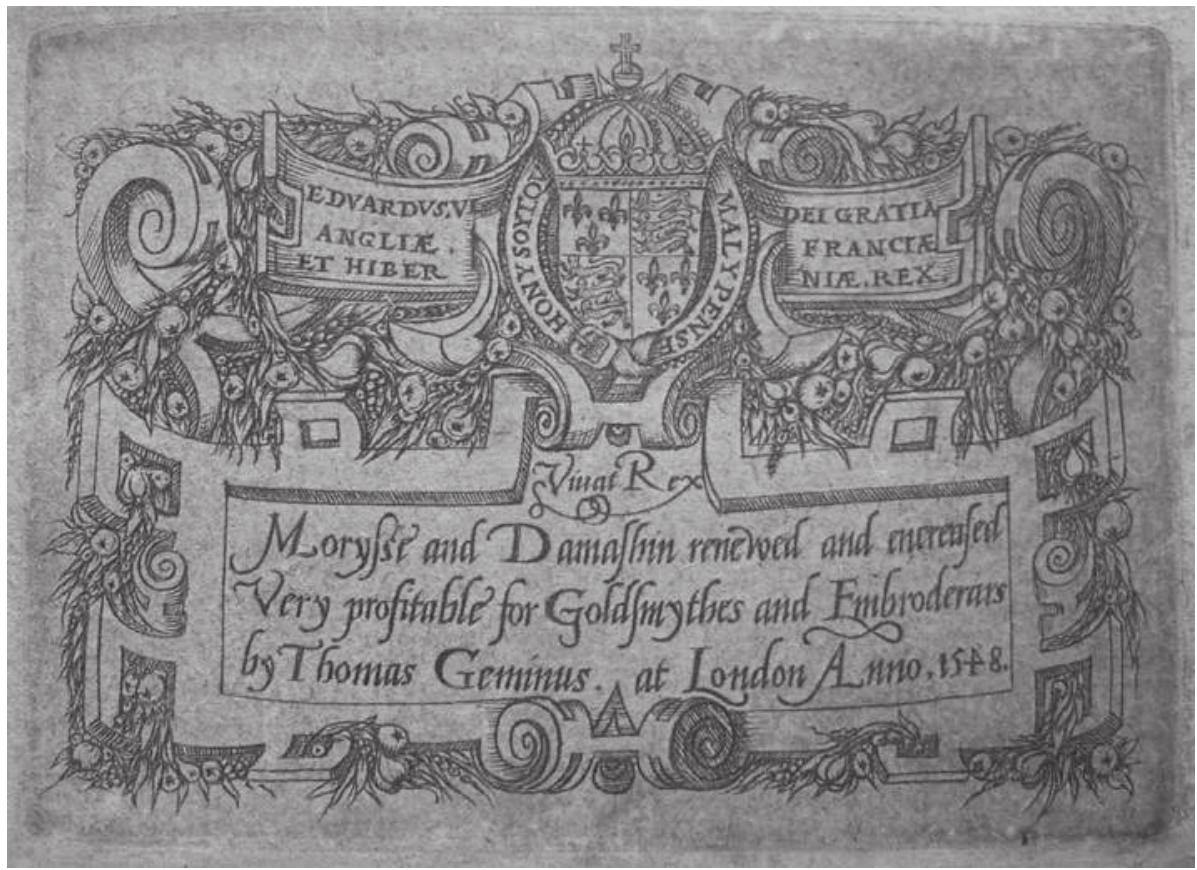

Figure 8.1 Thomas Gemini, title page for Morysse and Damashin (London 1548), engraving. Münster, Universitäts- und Landesbibliothek, 1E 8935, urn:nbn:de:hbz:6:1-33206.

Photo: Münster, Universitäts- und Landesbibliothek, CC0 1.0.

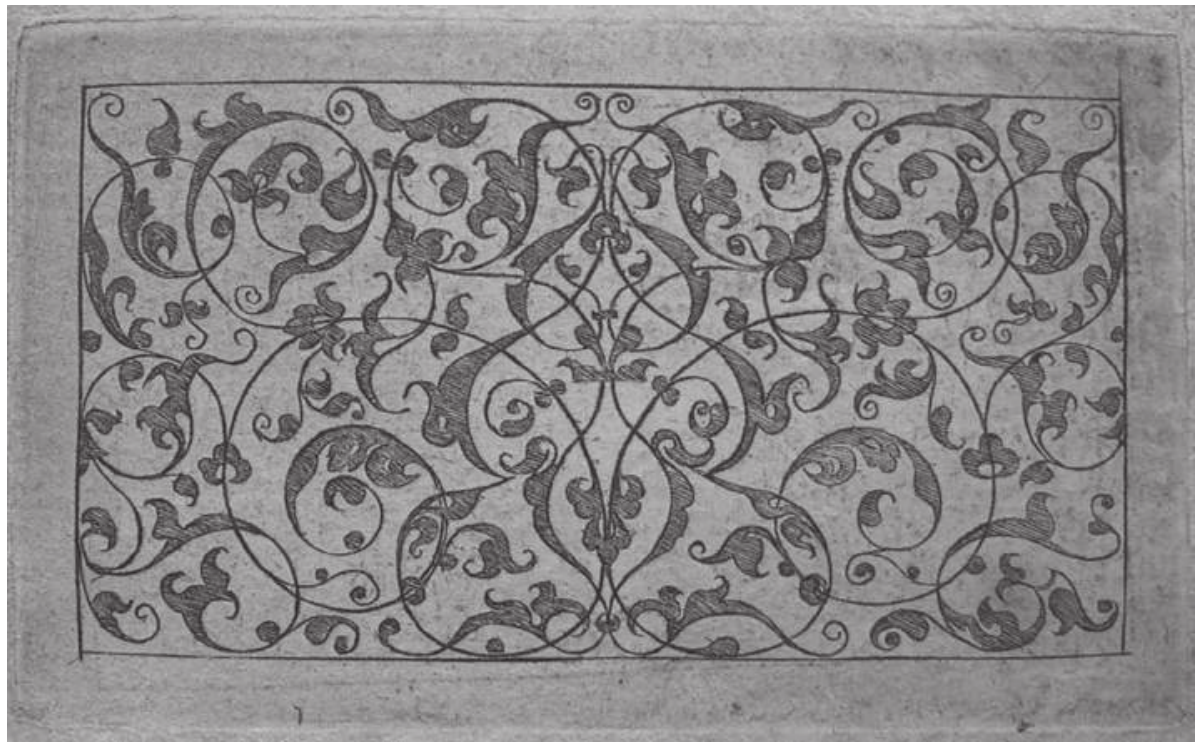

Figure 8.2 Thomas Gemini, panel with a moresque pattern, engraving in Morysse and Damashin (London 1548). Münster, Universitäts- und Landesbibliothek, 1E 8935, urn:nbn:de:hbz:6:1-33206.

Photo: Münster, Universitäts- und Landesbibliothek, CC0 1.0. 
eagerly sought after in England as well..$^{5}$ In his title page to the moresque series, as well as in an earlier, much more elaborate title page to an anatomy book illustrated and published by Gemini in 1545, he proved himself keenly aware of this new type of ornament and fully capable moreover of creating his own designs in both the French and Flemish vogue (Figure 8.3). While several motifs in the 1545 title page are based on ornament prints by Cornelis Bos (1508-55), Cornelis Massys (1510/11-56/57) and Étienne Delaune (1518-95) — providing these prints with an hitherto unexplored terminus ante quem - its overall composition appears of his own invention. Gemini does not indulge this apparent artistic inclination in the 1548 series of moresque designs, however, as the majority of the plates do not reflect his own designs. Instead, they were copied from a series of ornament prints now known under the descriptive title Mauresques de petit format (Figure 8.4), etched and published by the French artist Jacques Androuet du Cerceau (1510-84). While undated, the series is presumed to have been issued around 1545, based on a privilege requested by the artist in this year. It contained an unknown number, although at least 44 plates of moresque patterns and motifs, of which some were in turn borrowed from prints by the unidentified French Master JG. ${ }^{6}$

It is in part due to the derivative status of the London series that Gemini's ornament prints have received relatively little scholarly attention. Yet as Magdalena Adamska argues in her 2010 article on Gemini's moresque prints, there is more to learn about both Gemini and Du Cerceau by studying the interdependence between their respective series of ornament prints. ${ }^{7}$ This type of research is complicated, however, because both series are subject to a low and incomplete survival of plates. In addition, the minute detailing of the moresque patterns presents a challenge in recognizing possible state changes and copies made by yet other printmakers.

Gemini's series was first described by Campbell Dodgson (1868-1948) at a meeting of the Society of Antiquaries of London in 1917. He had been able to study the Münster series, then on loan to the British Museum, which had been part of a larger miscellany of print series and consisted of a title plate followed by 28 designs. From the manner in which the plates were bound into the album (since altered), Dodgson deduced that one plate had gone missing, which would have brought the total number of sheets in the original series to $30 .{ }^{8}$ Upon closer examination, however, the Münster series proved to contain two duplicates, which were eventually sold to the British Museum in 1920 in return for a subscription to the Burlington Magazine. 9 Since then, the set in Münster is thus composed of a title page, followed by 26 plates of moresque designs. It was photographed in this new configuration soon after, and facsimile editions were sent (amongst others) to the Kunstbibliothek in Berlin ${ }^{10}$ and the Metropolitan Museum of Art in New York. ${ }^{11}$

In her 2010 article, Adamska proposed that the Münster set was only a partial survival of the full series as published by Gemini in 1548. This suggestion was based on the discovery of prints with additional moresque patterns in the print collections of the scientific library of the Polish Academy of Arts and Sciences in Cracow and the Herzog Anton Ulrich Museum in Braunschweig (VSolis WB 3.232). In her assessment, the newly discovered prints in both collections would bring the total number of plates in Gemini's series to at least $37 .{ }^{12}$

This revised number of plates is problematic for various reasons. For one, a comparison between the Gemini prints in Münster and Du Cerceau's originals shows that while he sometimes introduced minor alterations in the details of the ornaments, 


\section{Femke Speelberg}

Gemini followed the original direction of the French patterns without fault. Among the prints in Cracow $^{13}$ and Braunschweig, there are several prints that present Du Cerceau's patterns in reverse or upside down, however. This process of reversal is evidence of a different attitude towards the process of copying and is prevalent only in those prints that do not have a corresponding plate in the Münster set. A similar inverse relationship can also be noted for prints that are incorrectly attributed to either Du Cerceau or Gemini. ${ }^{14}$ Close comparison of all these prints shows that at least several plates from Du Cerceau's Mauresques de petit format were reproduced in a minimum of four distinct copies, of which some were taken directly from the French models and others from Gemini's British publication. ${ }^{15}$ Unless the examination of paper would indicate otherwise, it appears more than likely that several of the 25 prints in Cracow described by Adamska stem from these various origins. In this light, their assemblage, aesthetically cropped and pasted together on one album page by an eighteenth-century collector, should perhaps principally be understood to represent an interest in their shared subject matter and a recognition of their familial relationship, more so than proof of their shared provenance from one single set of prints. ${ }^{16}$

That the possibility of certain additions to the number of prints in the Münster series should be allowed for is proven at least in one single case. It pertains to one of the few prints in Gemini's series that are not based on Du Cerceau's models, and in all likelihood account for the word "increased" in his title. It is unclear whether these are based on other models or are perhaps of his own design. The Münster series contains two such prints, and a very similar third design can be identified among the prints in Cracow, of which an additional copy exists in London (Figure 8.5).${ }^{17}$ It is tempting to think this print may, in fact, account for the one Dodgson found "missing" upon his first examination of the Münster series.

Further material and stylistic analysis is warranted to better classify and understand the relationship and chronology of the various copies after the Du Cerceau series. However, the remainder of this chapter will principally focus on Gemini himself in an effort to answer the question of why he chose Du Cerceau's Mauresques de petit format, in particular, as the model for his only known series of ornament prints.

$\mathrm{Du}$ Cerceau's series was part of a tradition that had originated approximately 20 years prior, when the first prints with moresque designs were published in Venice. They are often collectively attributed to one person known as the so-called "Master $f$," but should instead be considered the work of a small circle of artists. ${ }^{18}$ Theirs and other moresque designs were quickly reproduced as woodcut illustrations in textile pattern books published by Venetian printers such as Giovanni Antonio Tagliente (c. 1465-1528) and Giovanni Andrea Vavassore (active 1530-73). These booklets were avidly used and copied throughout Europe and proved instrumental in the naturalization process of the occidental moresque ornament into the arts across Western Europe. ${ }^{19}$

By 1530, the first book devoted solely to moresque ornament was published in Paris under the title La Fleur de la Science de Pourtraicture Et Patrons de Broderie. The patterns were designed by the Florentine artist Francesco Pellegrino (active c. 1525-52), who would later join the team of Italian artists working for King Francis I of France at the castle of Fontainebleau. The book of moresques preceded his other recorded work in France and may have functioned as a means to advertise his artistic abilities to prospective French patrons. Pellegrino protected the book with a six-year privilege and sold it from an address on the Rue Saint Antoine, belonging to the 


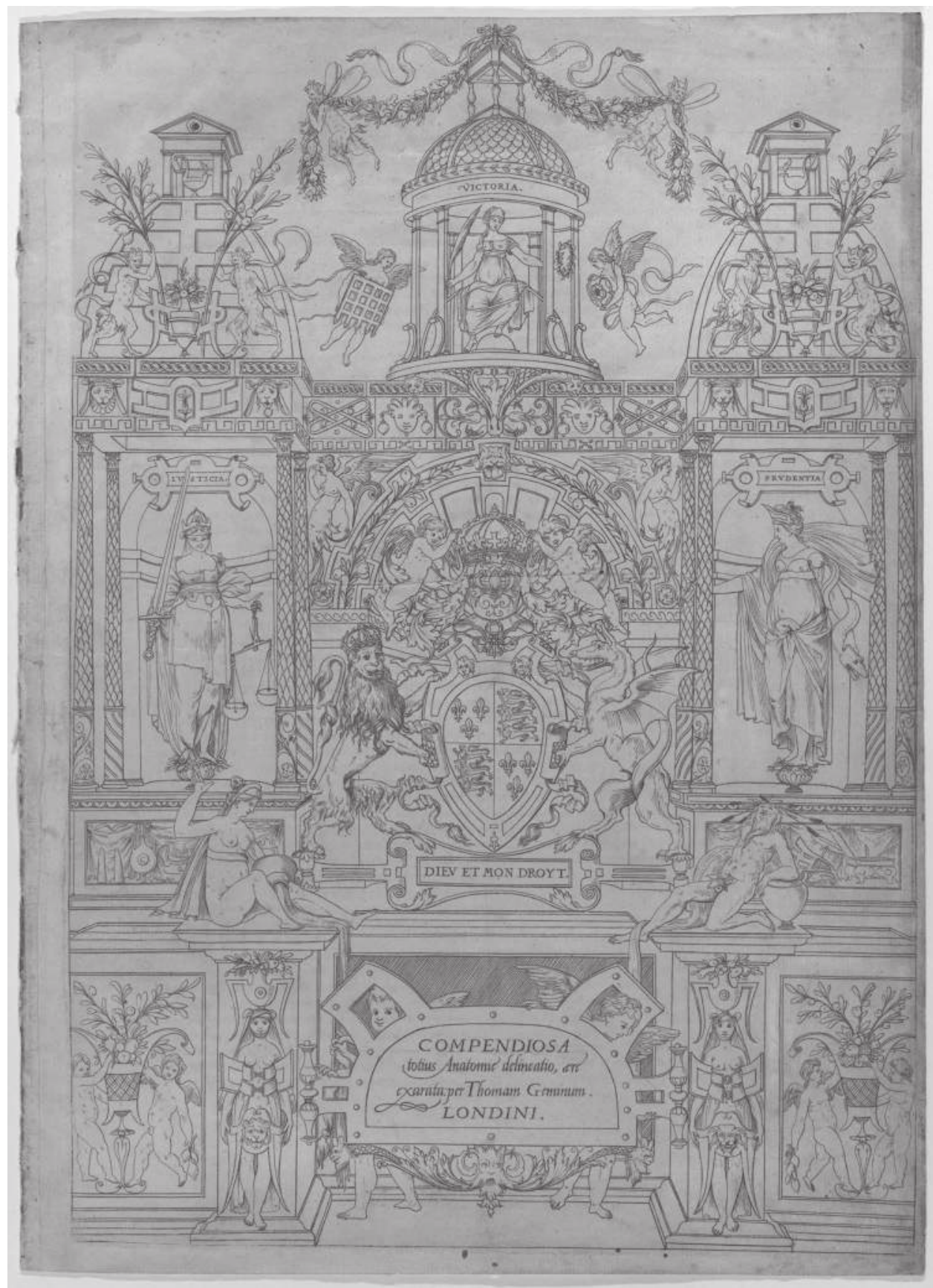

Figure 8.3 Thomas Gemini, title page for Compendiosa totius Anatomiae delineatio (London: Thomas Gemini, 1545), engraving. New York, The Metropolitan Museum of Art, Gift of Philip Hofer, 1937 (37.59a, b).

Photo: New York, The Metropolitan Museum of Art, CC0 1.0. 


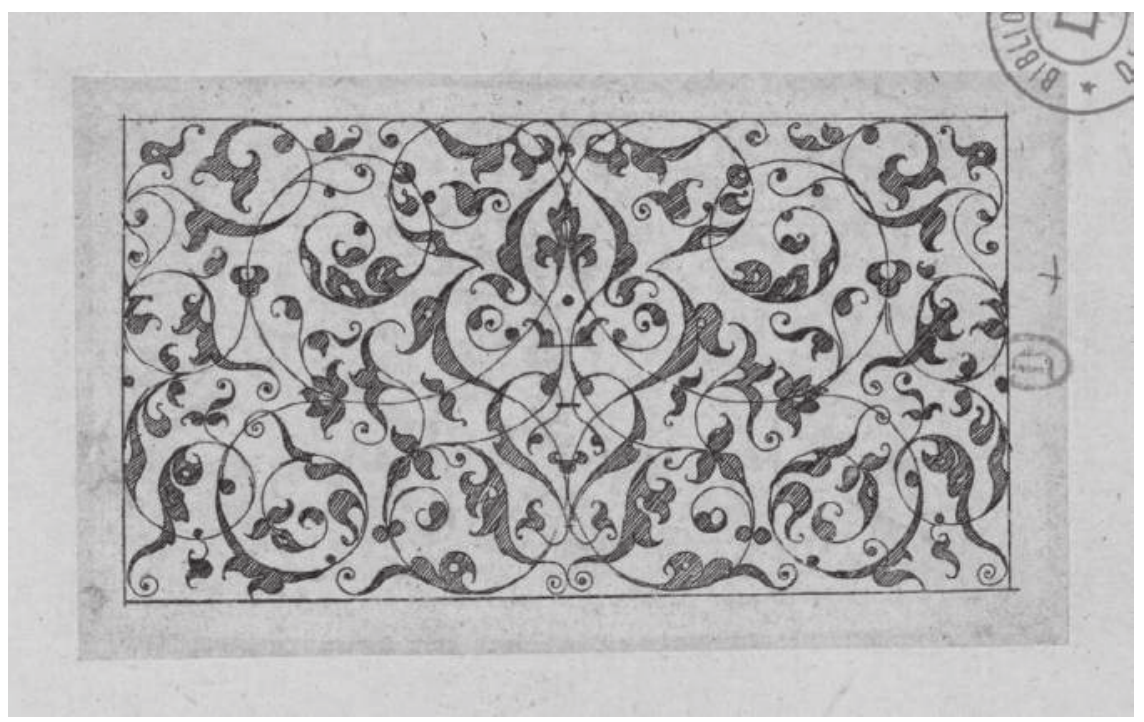

Figure 8.4 Jacques Androuet du Cerceau, panel with a moresque pattern, etching in Mauresques de petit format, 5. Paris, Bibliothèque de l'INHA, collections Jacques Doucet, NUM 8 RES 117.

Photo: Paris, Bibliothèque de l'INHA (open licence).

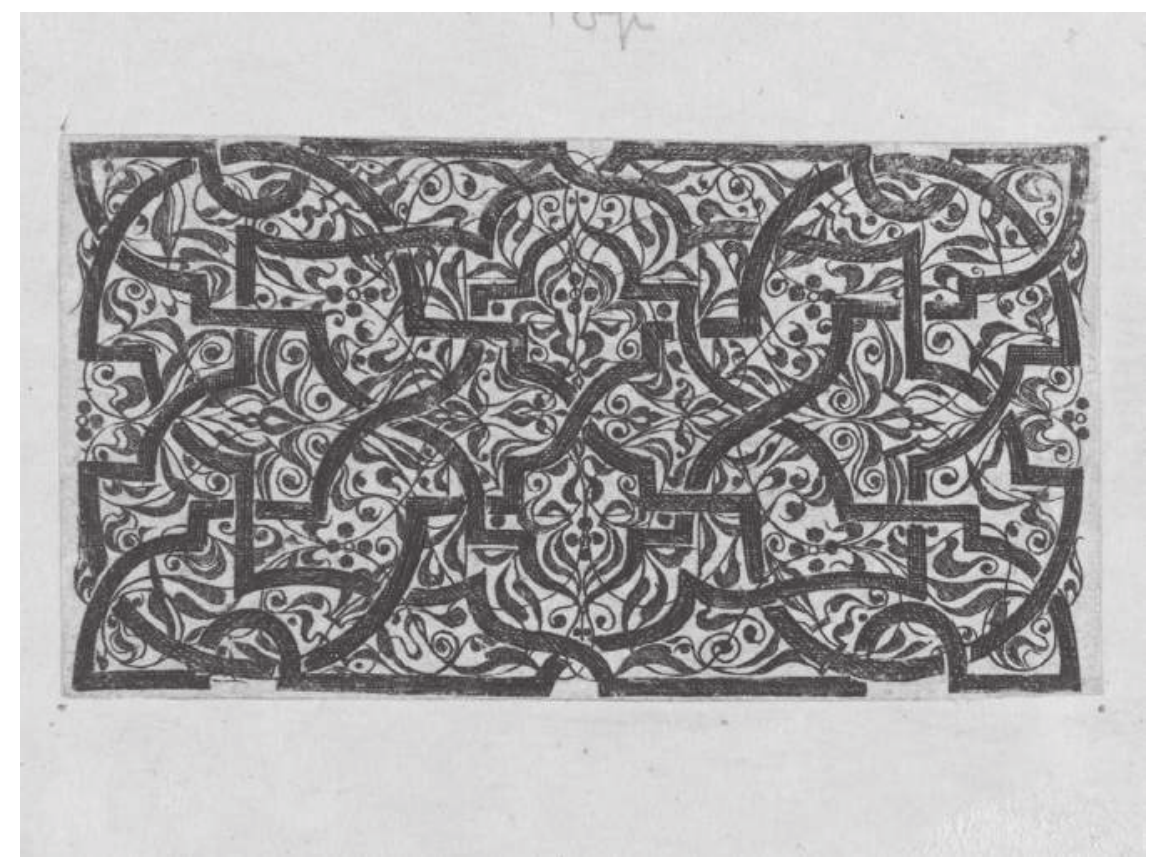

Figure 8.5 Thomas Gemini, panel with a moresque pattern, engraving in Morysse and Damashin (London, 1548). London, Victoria and Albert Museum, 19010.

Photo: () London, Victoria and Albert Museum. 
Prince of Carpi, Alberto III Pio (1475-1531). While the book was printed by Jacques Nyverd (†1548)—who appears to have operated an active press in Paris and printed many royal edicts and ordonnances-only one copy of the moresque book survives today, likely indicating a single, and limited, print run. ${ }^{20}$ Pellegrino's designs were further disseminated, however, through two copies created in the $1540 \mathrm{~s} .{ }^{21}$ In or before 1543, Cornelis Bos published a compressed version of the book in Antwerp as Een boeck van menigherleytrecken op die maniere van de Moresken, ${ }^{22}$ and in 1546 Hierosme Gormont issued a new French version in Paris under the simplified title Livre de Moresques. ${ }^{23}$ In contrast to what might be expected, Gormont's Livre was based on Bos' abridged booklet rather than Pellegrino's original. Of particular interest is the fact that in this new French edition, each illustration is accompanied by a caption that indicates possible applications for the pattern. These range from silk embroidery and tapestry weaving to gold-tooled bookbindings, damascene work, wood intarsia and gold and silversmith's work, including drinking vessels and minute decorations meant to be incised in rings. The ornament was thus most frequently associated with decoration techniques in precious materials and high-end, fine craftsmanship that was only accessible to the elite. By appropriating the ornament, even in materials and techniques of lesser refinement, some sense of this cosmopolitan luxury was transferred. This aspect, in addition to their inherent exotic qualities, greatly appealed to audiences across Western Europe.

Remarkably, this appeal seems to have outweighed any contemporary political considerations related to the Ottoman threat to the Hapsburg Empire and the Mediterranean Sea coasts. In his 1535 engraved portrait of Hayreddin Barbarossa (1475-1546), admiral in the naval fleet of Sultan Suleiman I (1494-1566), the Italian printmaker Agostino Veneziano (1490-1540) did not only depict the Ottoman with a characteristic turban but also applied a generic pattern of moresques to his costume to emphasize his near-Eastern origins (Figure 8.6). ${ }^{24}$ The ornament was thus used as an identifier for Eastern origins, and it might therefore be expected that moresques were (or should have been) favored solely by those who sympathized and sided with Ottomans, but this was not at all the case. The ornament found admiration on all sides of the political playing field and was appropriated equally by the French kings Francis I and Henry II (1519-1559), who sided with Suleiman, and by the English King Henry VIII, who found himself in constant opposition to any French cause (Figure 8.7).

The desire to maintain these particular associations with a sense of exoticism and luxury may have contributed to the fact that moresques underwent relatively little formal changes, despite being subject to considerable geographic transmission and translation into various media. Other popular and itinerant ornament types of the period, such as grotesques and the previously mentioned strapwork, inversely underwent significant local and modern adaptations. These distinctions were so clear to contemporary observers that the Spanish artist Andrés de Melgar (c. 1500-77) could note down on his sketches of grotesques exactly which ones were in the Italian style, indicated by the name "Julio," which likely referred to the Italian-trained artist Giulio Aquili (also Julio de Aquiles, $† 1556)^{25}$ and which had Flemish origins, marked with the word "Flamenco." 26 While Pellegrino, in the extended title to his Fleur de la Science de Pourtraicture, did indicate that his moresque patterns were a la façon arabicque et ytalique, seemingly suggesting that, like Andrés de Melgar, he made a distinction between the Islamic and Italian interpretation of the ornament, this distinction is no longer perceptible to the modern eye. It is therefore possible that in this case the distinction was 


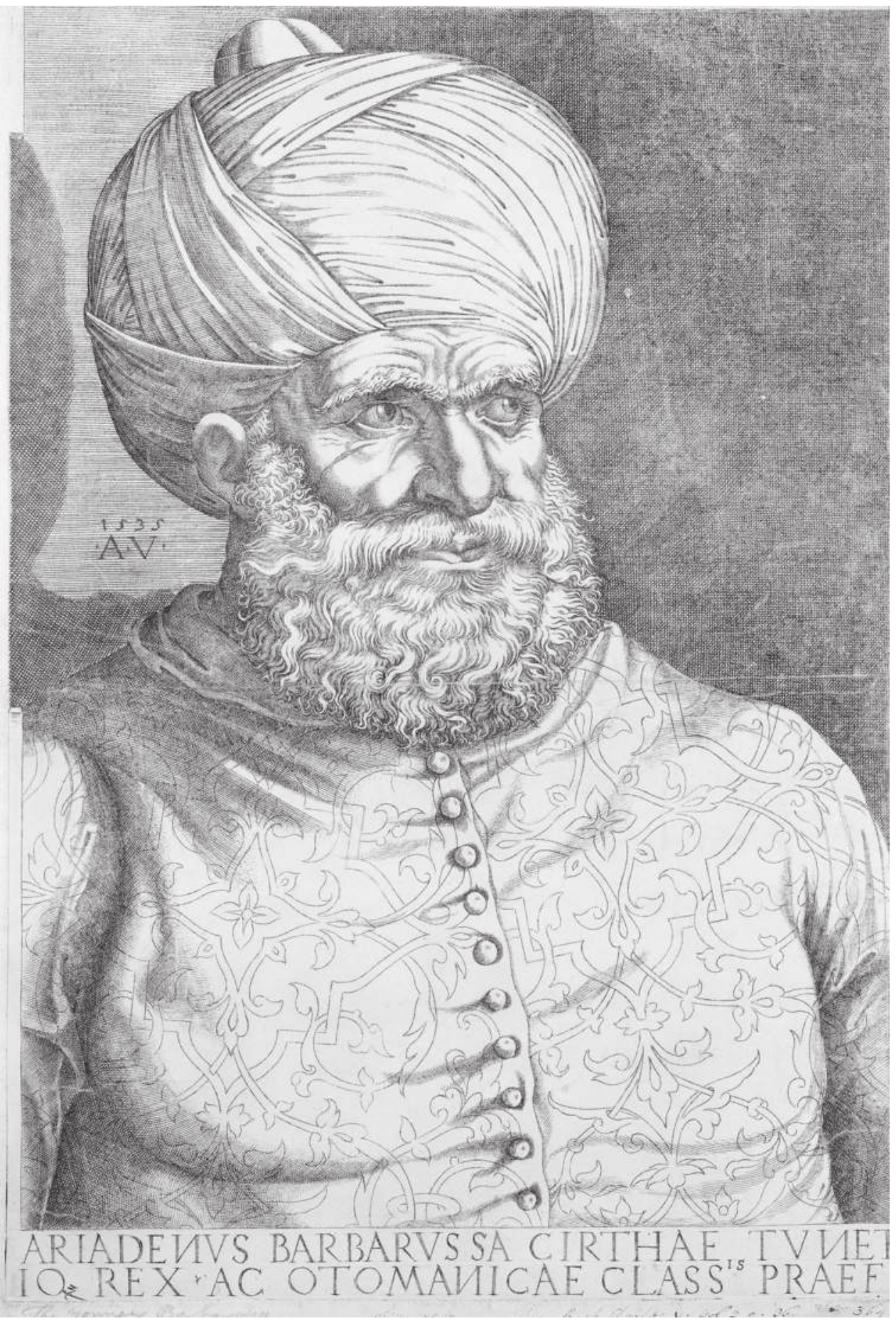

Figure 8.6 Agostino Veneziano, Portrait of Barbarossa, 1535, engraving. New York, The Metropolitan Museum of Art, The Elisha Whittelsey Collection, The Elisha Whittelsey Fund, 1949 (49.95.4).

Photo: New York, The Metropolitan Museum of Art, CC0 1.0. 


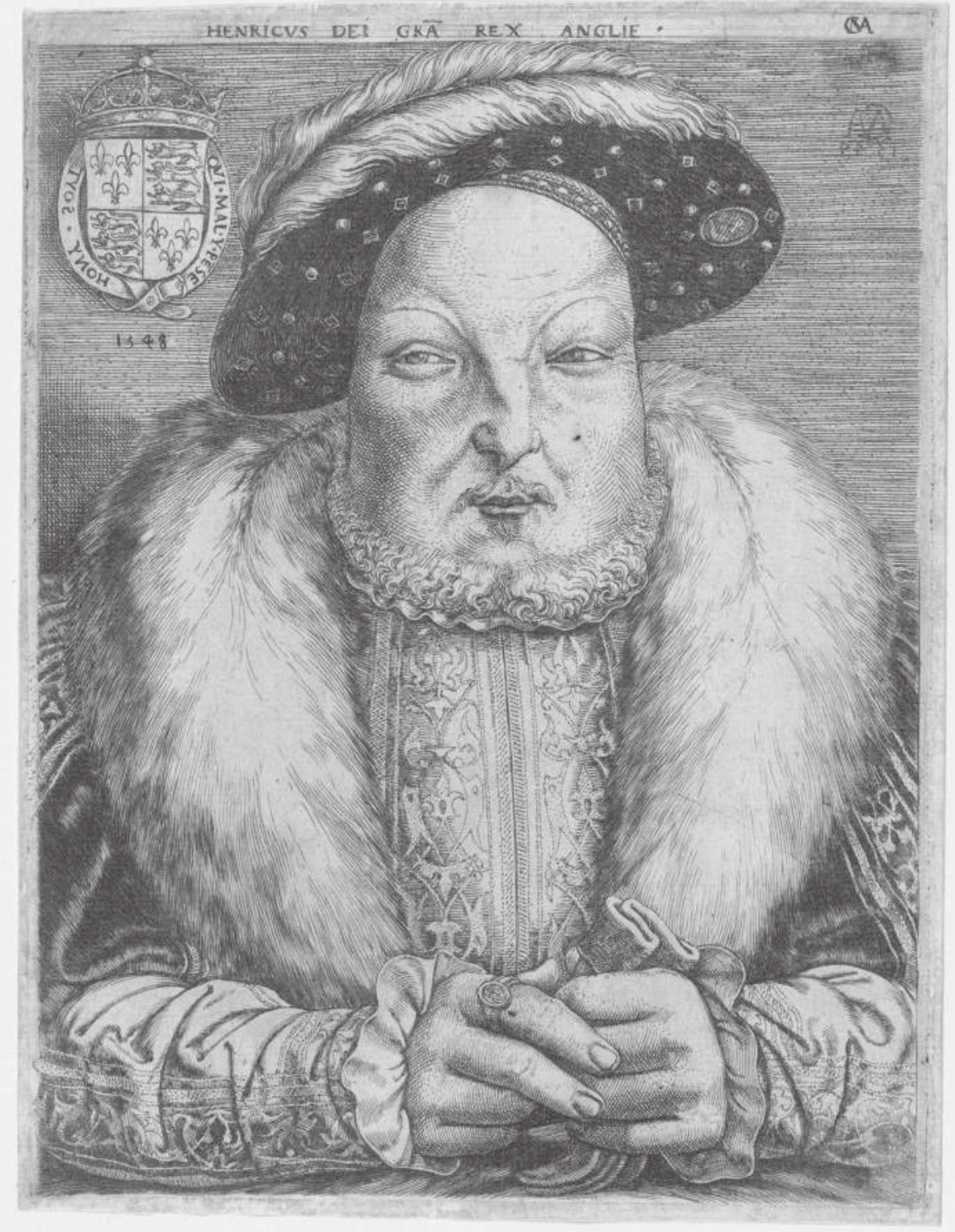

Figure 8.7 Cornelis Massys, Portrait of Henry VIII, c. 1547, engraving. New York, The Metropolitan Museum of Art, The Rogers Fund, 1922 (22.42.6).

Photo: New York, The Metropolitan Museum of Art, CC0 1.0.

not one of style at all, but instead one of origins: indicating that Pellegrino had reproduced some patterns from foreign objects, while others were designed by himself and/ or other Italian artists.

Since Thomas Gemini chose to devote his only known series of ornament prints to the subject of moresques, it is worth asking the question whether the associations 


\section{Femke Speelberg}

outlined earlier may have served a specific purpose within his biography. This in itself is not an easy matter to resolve because the facts of his life have come down to us in a fragmentary manner only and are anchored chiefly by objects rather than documents. Without new documentary evidence, much of Gemini's life remains speculative for the moment. However, for the purpose of this chapter and to stimulate future research, as many relevant details as possible have been brought together to give a general, if sometimes hypothetical, outline of his origins and career.

While Gemini's printed works firmly place him in London from at least 1545, there are multiple indications that he was not native to the city. In the dedication to the earlier-mentioned anatomy book entitled Compendiosa totius Anatomiae delineatiowhich was an abridged version of Andreas Vesalius's De humani corporis fabrica and text from the Epitome-Gemini referred to himself as Thomas Geminus Lysiensis. The latter Latin indication of place is not a common denomination for a known city and has therefore been interpreted in various ways over time. Amongst others, he has been identified as an Englishman native to Leeds and a Frenchman who hailed from the small town of Lys-les-Lannoy near Lille. ${ }^{27}$ Based on his last name and the style of his engravings, an Italian background was also put forward. ${ }^{28}$ The latter assumption also seemed to form a satisfactory explanation as to why Gemini chose the work of Vesalius, who had by then been appointed to the post of imperial physician after his professorship at the University of Padua, for his London publishing debut. Gemini's skillful translations of the original woodcut illustrations into engravings long caused him to be celebrated for introducing the art of intaglio printmaking to England. As a result, he was also associated with another anatomy book, Richard Jonas's The Birth of Mankind, otherwise named the Woman's Book, which was an English translation of Eucharius Rösslin's Der schwangern Frawwen und Hebammen Rosengarten of 1513. Jonas's English version was first published in 1540, five years before Gemini's Anatomia, and contained a few rudimentary engravings after the German model depicting babies in a womb, known as "the birth fygures." These engravings, however, had little to do with Gemini, but the confusion was further compounded by a second translation of Rösslin's text by Thomas Raynalde, which appeared in 1545 and in which the illustrations were expanded with anatomical plates that are not by Gemini, but copied from his Anatomia of the same year. ${ }^{29}$ This quick adaptation of his anatomical plates validated Gemini's intention in publishing the Anatomia, described by him in the introduction as an aid for students, physicians and surgeons to acquire knowledge of the correct arrangement of the human body. ${ }^{30}$ In doing so, he openly acknowledged his debt to Vesalius, whom he praised as the most skilled of his contemporaries in delineating the human body according to its parts. His abridged version of the Fabrica was thus not simply an act of plagiarism. Instead, his intent in publishing seems to have lain, at least partially, in distributing in England the latest anatomical knowledge available on the continent. In this endeavor, he may even have followed the direct wishes of King Henry VIII, who was heavily invested in the establishment of criteria for the practice of medicine in his country. This led, amongst others, to the Act of Unity between the Barbers and Surgeons of London (1540-1745), an event recorded in the commemorative painting by Hans Holbein the Younger, still owned by The Worshipful Company of Barbers today. In the years following, much attention was paid to the improvement of anatomical education among the company's membership. ${ }^{31}$

While an official royal commission is not documented for the Anatomia, Gemini dedicated the publication to Henry and afterwards received an annuity of $£ 10$ during 
the king's pleasure, which was continued briefly by Edward VI after his father's death in 1547. A previously noted state change pertaining to the text on the individual plates in the first edition of the book may, in fact, indicate that Gemini had purposefully sought out royal support prior to publication by preparing several loose plates for presentation. Only after receiving a positive response from his prospective patron did he set out to create the book in its entirety, which then necessitated certain changes and additions to the captions. ${ }^{32}$ This sequence of events explains why Gemini could describe in the introduction to his book that the king himself had told him that "these anatomical figures ought to be published." 33 This remark, in turn, led Jacques Grévin (1539-70), in a posthumous French translation of the book with illustrations printed from Gemini's original copperplates (Paris 1569), to make the slightly exaggerated statement that the engravings for the Anatomia were made "by order of the late Henry VIII King of England." 34

In the English translation of the Anatomia, which was first published in 1553, Gemini confirmed his foreign origins. He explained in the introduction that he had sought help in translating the book because he considered himself "not so perfeict and experte in the English tonge that I dare waraunt or trust myne owne dooynges." 35 His exact heritage, and the meaning of the term Lysiensis, were only revealed, however, with the discovery of Gemini's will, which was drawn up in 1562, a few days before his death. ${ }^{36}$ In the text, he refers to property he owned abroad in "Leighe, nighe unto Marke Wesett, within the bishopryke of Leuke, in the partes of beyonde the Sea." "Leuke" refers to the town of Liège (Luik in Flemish), and "Leighe" can more than likely be identified as the village of Lixhe, located on an island in the river Meuse, about eight miles north of Liège. ${ }^{37}$ The will also revealed Gemini's original surname through the mention of his brother "Jasper Lambrit." This surname is particularly common in the region near Liège because it refers to the local Saint Lambert, who had been bishop of the Maastricht-Liège bishopric in the late seventh century. ${ }^{38}$

Gemini's southern Netherlandish origins suggest that he likely received his training as an engraver there as well. Based on the semblance of his engraving style to that of the printmaker and cartographer Gerard Mercator, born Geert de Kremer (1512-94), the university town of Leuven has been put forward as the most likely place for his schooling. ${ }^{39}$ Mercator came to Leuven to study for his magister degree, and between 1530 and 1532 became the pupil of the polymath Gemma Frisius (1508-55), with whom he would collaborate in subsequent years to design, improve and produce globes and scientific instruments. ${ }^{40}$ Mercator's years as a student in Leuven also overlap with none other than Andreas Vesalius, born Andries van Wesel (1514-64), who studied at the university from 1528 to $1533 .{ }^{41}$ While no documentary evidence has surfaced to confirm Gemini studied at the university in Leuven as well, several indirect indications suggest that he was active in the same milieu as the other two learned men. The adoption of a Latin name, for one, indicates that he enjoyed an advanced education. Mercator and Vesalius adopted their Latinized names while attending the School of the Brethren of Common Life in 's-Hertogenbosch and Brussels, respectively. The city of Liège had its own chapter from 1496 onwards, ${ }^{42}$ although Gemini could have been educated elsewhere as well. That Gemini was personally acquainted with Vesalius, most likely while the two were both living in Leuven, appears to be confirmed by Vesalius's brother Franciscus, who in his introductory letter to Vesalius's China Root Epistle (1546) complained about the publication of the Anatomia by an "English" plagiarist who had once lived with his brother. ${ }^{43}$ A (former) personal relationship of 


\section{Femke Speelberg}

this kind with Vesalius may explain in part why Gemini felt entitled to appropriate material from the Fabrica for further distribution across the English Channel.

Placing Gemini in Leuven in the 1530 s means revisiting the idea, perpetuated in an article by Alexander Samson in 2008, that he can be identified with the "Thomas Lamberd" who was denizened on 1 July 1544 after living in England for as long as 20 years. $^{44}$ Another "Thomas Lambert," however, is mentioned on the denization role for the years $1544-45$. This person was denizened on 11 July 1544 with no prior record of residency, suggesting a more recent arrival in England. ${ }^{45}$ This new identification explains why Gemini was still slightly uncomfortable about his command of the English language in the early 1550s when the Anatomia was translated into the vernacular to service "unlatined Surgeons." If Samson is correct in suggesting that Gemini was a committed Protestant-which he bases, among other things, on the donations he left in his will to the congregation of the Dutch church in London-one of the reasons to relocate at this particular moment in time may have been the religious persecutions that took place in Leuven in from 1543 to 1544. Mercator was one of the people suspected of Lutheran convictions, and he was consequently imprisoned for a period of seven months before being released due to a lack of evidence. Many others were not so lucky. Despite his release, Mercator's arrest would have certainly served as a potent warning to Gemini and may have induced him to leave his country of origin before he, too, would be accused of and tried for heresy and would lose all rights to his property. ${ }^{46}$

That Gemini was active in a similar field as Mercator (and Frisius) is confirmed by two further books he printed in London in the 1550s. The text for both was written by the mathematician and land surveyor Leonard Digges (c. 1515 to c. 1559). The first, Prognostication of Right Good Effect, was an almanac with astronomical tables especially meant for naval navigation, which was first published in 1553 . Three years later, Digges and Gemini published a work on the art of mensuration called Boke Named Tectonicon (1556). In the introduction to the latter book, Gemini inserted an advertisement for his own business, proclaiming himself "ready exactly to make all instrumentes apperteyninge to this Booke." Like Frisius and Mercator, he thus made scientific instruments. In his survey of Gemini's prints, Hind suggested that the last plate of the Anatomia, which shows surgical instruments (Figure 8.8), had functioned as a similar advertisement and put forward the idea that alongside mathematical instruments he also made implements to service the medical profession. ${ }^{47}$ No examples of the latter kind have been identified so far, but multiple mathematical instruments by Gemini's hand survive, which all date from the 1550s. ${ }^{48}$

One of the earliest instruments by his hand is an engraved astrolabe, now in the collection of the Royal Observatory of Belgium. ${ }^{49}$ It is dated 1551 and bears the arms of King Edward VI, as well as those of John Dudley, Earl of Warwick and 1st Duke of Northumberland (1504-53), and Sir John Cheke (1514-57). In the year 1551, the king had advanced the titles of both men, and it is likely that they commissioned the astrolabe from Gemini to show their gratitude. A horary quadrant, similarly inscribed with the king's name and now at the British Museum, dates from the same year and may have belonged to the gift as well. ${ }^{50}$ Eight years later, Edward's half-sister, the newly crowned Queen Elizabeth I (1533-1603), also received an astrolabe made by Gemini (Figure 8.9). It was a gift to celebrate her ascension to the throne, presented to her by John Dudley's son, Robert, first Earl of Leicester (1532-88). ${ }^{51}$ This was not the only astrolabe in her collection, however. She came into the possession of a second 


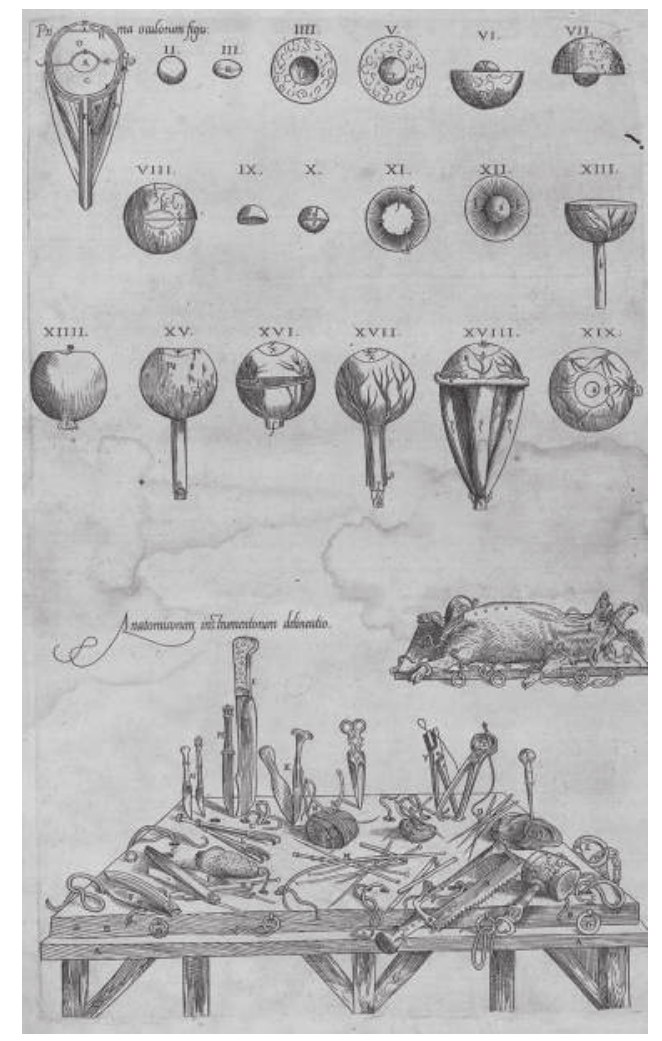

Figure 8.8 Thomas Gemini, illustration of eyes and surgical instruments, engraving in Compendiosa totius Anatomiae delineatio (London: Thomas Gemini, 1545). Wolfenbüttel, Herzog August Bibliothek, 3.3 Phys. $2^{\circ}$ (41).

Photo: () Herzog August Bibliothek Wolfenbüttel, CC BY-SA 3.0 DE.

astrolabe by Gemini, which had initially been intended for Edward. The piece was likely not yet finished when the latter died in 1553, and it was subsequently inscribed with Elizabeth's name instead.52 A significant aspect of this astrolabe is the fact that most of the information it contained was based on an astrological disc, designed by Mercator and published in print in $1551 . .^{53}$ Because a direct line of contact could hitherto not be established between Mercator and Gemini, the general assumption has been that the latter came by (information about) the disk through an intermediary. ${ }^{54}$ The name of the English polymath John Dee (1527-1608/1609) has been put forward in this context because he traveled to Leuven in 1548 and became a close friend of Mercator. ${ }^{55}$ What has never been considered, however, is the question whether, inversely, Thomas Gemini might have played a part in Dee's decision to travel to Leuven in the first place, to study there under the tutelage of his colleagues Frisius and Mercator.

In his study of Renaissance astrolabes, Gerard Turner stresses that the style of Gemini's instruments further betrays his strong connection to and training in Leuven. Not only does he incorporate the shape of a tulip in the design for the rete (a rotating 


\section{Femke Speelberg}

overlay) of his astrolabes-an element characteristic for instruments from this citybut the style of his calligraphy is also extremely close to that of Mercator. ${ }^{56}$ Based on these parallels and their similarity in age, Turner suggests that the two may have been trained together in the workshop of the goldsmith, engraver and mathematician Gaspar van der Heyden, also known as Gaspar a Myrica or Amyricius (c. 1496 to c. 1549). ${ }^{57}$ While very few of his works have survived, his professional activities and various commissions are documented for the period between 1524 and 1549. In collaboration with Franciscus Monarchus (born Frans Smunck, c. 1490-1565), Van der Heyden created the first terrestrial globe, and together with Gemma Frisius and Mercator, he would produce several other versions over the following decades. ${ }^{58}$ If Gemini indeed trained in Van der Heyden's workshop with a focus on creating instruments for math and cosmography, this would also explain the choice of his Latin surname Geminus. While sometimes thought to indicate that Thomas Lambrit may have had a twin brother (Jasper?) or sister, ${ }^{59}$ it seems more than likely that he named himself after the Greek astronomer and mathematician Geminus of Rhodes, who was active around 70 BC. He is known principally for his Isagoge, or Introduction to the Phenomena, an elementary treatise on astronomy. ${ }^{60}$ Parts of this treatise were repeated in the Mathesis or Scriptores Astronomici veteres: a compilation of astrological and astronomical texts collected and published by Aldus Manutius in Venice in 1499. This book would have undoubtedly been part of the required literature in the classes taught by Frisius at the University of Leuven ${ }^{61}$ and the name Geminus therefore known by his students and people in his immediate circle. By choosing the name of the Greek astronomer for himself, the young Thomas Lambrit marked his ambitions vis-à-vis a career in a field closely related to cosmography. The name would have certainly helped in recommending himself and his profession to new patrons upon first arriving in England.

A training in the workshop of Van der Heyden would not only explain Gemini's interest in cosmographical instruments but also why he took to making engravings to illustrate his publications, rather than the more common medium of woodcut.

In 1555 , he put his engraving skills to use once more when he produced two maps, one of British Isles and one of the Kingdom of Spain, in celebration of the union of Queen Mary and Philip II of Spain. More so than a celebration of the physical event of the marriage, the maps were intended to symbolize the unification of the two countries and the reunion of the British Crown with the Catholic faith. To this end, the map of the British Isles omitted the bishoprics created during the Henrican Reformation in the 1530 s, presenting an idealistic vision of pre- (or post-) Reformation England. Gemini did not engrave the copperplate for this map himself. Instead, it was a reprint with minor alterations of a map created by George Lily (†1559), son of the grammarian William Lily (c. 1468-1522), which was produced in Rome in 1546, but returned to England with the repatriation of Sir Reginald Pole (1500-88), to whose retinue Lily belonged. The map of Spain, on the other hand, was engraved entirely by Gemini, but using as its model a map produced by Hieronymus Cock (1518-70) in $1553 .{ }^{62}$ As revealed by the dedication text on this map, Gemini did not obscure his dependence on others for the creation of the maps, but confessed himself to be the intermediary of knowledge, supplementing and emending information only where strictly necessary, much in the same way as he had done a decade prior in his publication of Vesalius's work in the Anatomia. In both cases, the works closely related to his own expertise and professional activities. As such, they were not chosen at random, but specifically because they allowed Gemini to recommend 
himself to his new patrons by providing knowledge and objects to which he had access through his training and network, and thus build a reputation and career for himself in a country that was not his own.

While Gemini does not appear to acknowledge his debt to Du Cerceau as clearly in the Morysse and Damashin, ${ }^{63}$ the series should be understood in this same light. Rather than referring to his status as a learned man, as the other publication did, they formed an example of his ability to decorate instruments, and astrolabes in particular, in the correct and most beautiful manner. ${ }^{64}$ From the remaining instruments by his hand, we can deduce that astrolabes appear to have been Gemini's specialty, or possibly just the most popular type of instrument he made. They were avidly collected at the time, often as much for their aesthetic properties as their usefulness in determining the location of celestial bodies. While likely invented in Ancient Greece, astrolabes developed further in the Islamic world during the early Middle Ages. They

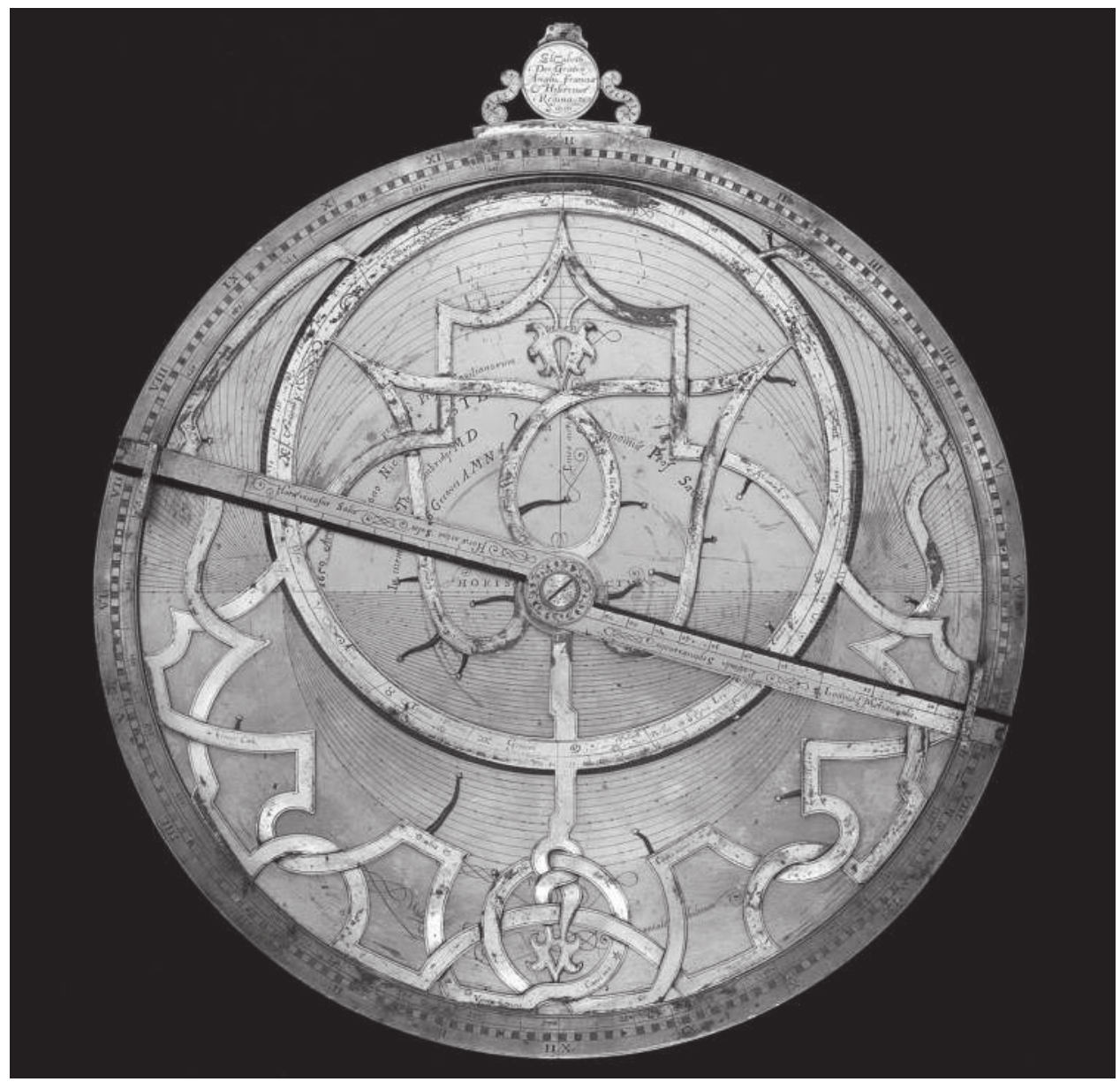

Figure 8.9 Thomas Gemini, astrolabe for Queen Elizabeth I, 1559, brass. Greenwich, History of Science Museum, 42223.

Photo: () History of Science Museum, University of Oxford. 


\section{Femke Speelberg}

were (re-)introduced to Western Europe during the conquest of Spain in the tenth century, and knowledge about them gradually spread across the continent, making its way to England, where Geoffrey Chaucer wrote his Treatise on the Astrolabe in 1391. ${ }^{65}$ Moresques feature prominently in the design of astrolabes from the Islamic world, both as part of the engraved decoration and in the functional hardware of the instrument. Western instruments adhered closely to their occidental cousins in their appearance, and particularly during the sixteenth century, when moresques became extremely fashionable, we see their application in astrolabe designs across Europe. With this purpose in mind, it becomes apparent why Gemini chose to appropriate Du Cerceau's Mauresques de petit format, rather than any of the other print series with moresque designs that had been published in the previous decades. Not only did the series contain many motifs that were directly applicable to his instruments (Figure 8.10), they were also already rendered at the appropriate (small) scale to accommodate immediate transfer. That even the largest rectangular panels of moresques in the series found their way onto astrolabes is evidenced by the piece made by the instrument maker Erasmus Habermel (c. 1550-1606) for Duke Alessandro Farnese (1545-92) between 1587 and $1592 .{ }^{66}$

Gemini's series of moresques predates all known instruments by his hand, which supports the hypothesis that the series was meant as one of the tools through which he intended to promote himself to the English court, then presided over by the young King Edward VI, as a maker of astrolabes and other related instruments. The timing of its publication, just after the coronation of the new king, was likely not coincidental. The succession provided a natural opening for the advancement of new artists,

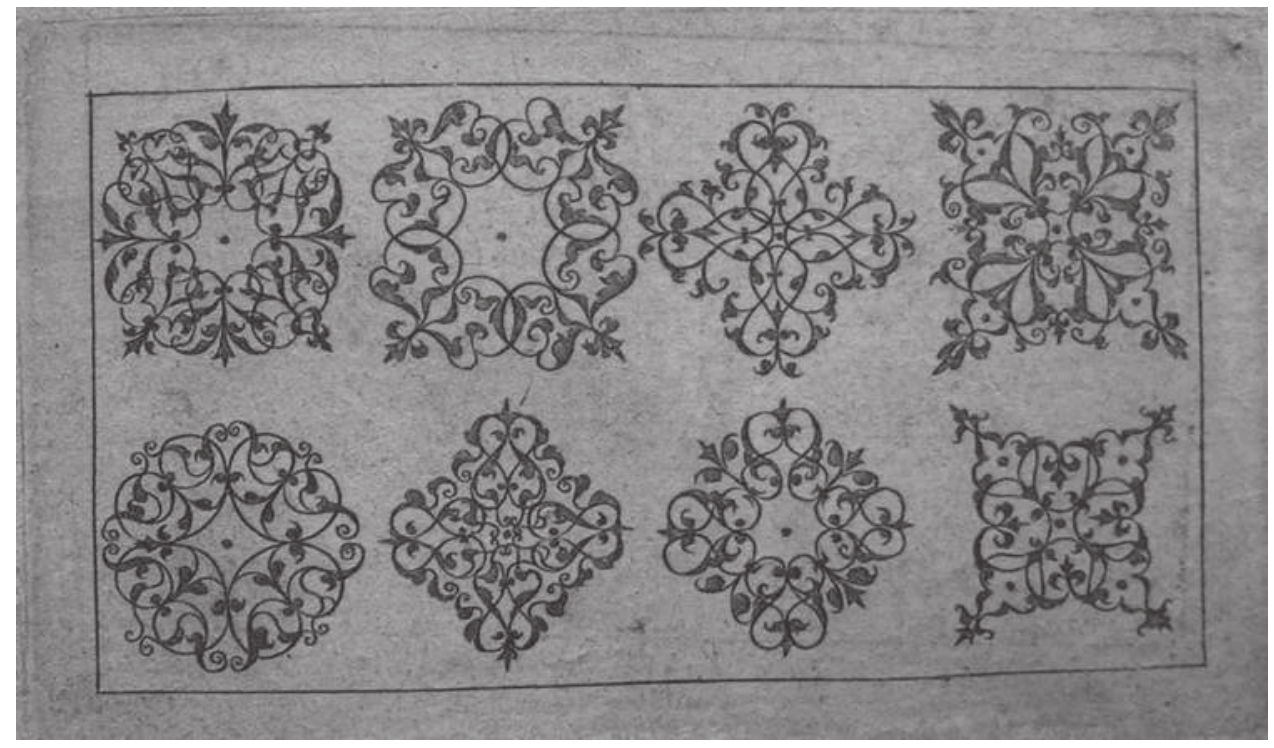

Figure 8.10 Thomas Gemini, eight small moresque motifs, engraving in Morysse and Damashin (London 1548). Münster, Universitäts- und Landesbibliothek, 1E 8935, urn:nbn:de:hbz:6:1-33206.

Photo: Münster, Universitäts- und Landesbibliothek, CC0 1.0. 
advisors and craftsmen, and Gemini may have held hope of replacing the Frenchman Bastien le Seney (fl. 1537-49), who had functioned as instrument and clockmaker to King Henry VIII. ${ }^{67}$ The only surviving instrument by his hand is an astrolabe carrying the king's coat of arms, which is now in London (BM, 1878,1101.113). Due to its unusual execution-both in its relatively small size and in the mistakes made by Le Seney in the quartering of the coat of arms-the instrument is unlikely to have impressed the Leuven-trained Gemini of the French instrument maker's qualifications.

The Morysse and Damashin is often considered an outlier in Gemini's oeuvre. By ascertaining the specific purpose of the series within his career, this chapter attempts to make an argument for the vital role prints and printmaking played in his attempt to settle and build a career in a country that was not his own. In bringing together elements of his biography, which have previously been studied separately in the fields of anatomy, cartography, cosmography and print history, it becomes clear that while printmaking was a sideline to his other professional activities, the material that he chose to publish was not selected at random. Instead, Gemini chose to (re-)produce works that tied in with his own biography and expertise. With the 1545 Anatomia he proved his impeccable pedigree in terms of artistic training, contacts and knowledge and managed to recommend himself directly to King Henry VIII. It was the first of several works which connected Gemini to the lives and politics of a succession of Tudor monarchs. This ongoing relationship suggests that he actively sought the esteem and employment of the British court by reminding them of his skills throughout his career: an aspect necessitated, in part, by the quick succession of monarchs during the two decades of his life in England. This is perhaps most clearly demonstrated by the two maps he produced for Mary and Philip in 1555; a project meant to recommend himself to the new Catholic monarchs with whom he seems to have shared few interests, other than those of cartography and navigation, but whose support he needed above all others to avoid religious persecution.

Through the multiplication and modification of prints and printed publications previously published by his peers in various professions, Thomas Gemini shaped his persona and broadened his clientele. The various stages of his career called for different types of material ranging from an anatomy book to ornament prints and mathematical treatises. The Morysse and Damashin likely represented the moment in this trajectory when he was most secure in his position in England. Having achieved success under King Henry VIII, his successor, the young and protestant King Edward VI, proved an avid student who would be interested in the kind of work Gemini had to offer. The ornament prints most closely tie in with the physical aspect of making astrolabes and other instruments that were coveted both for their functionality and as diplomatic gifts. The patronage of both John and Robert Dudley shows that by the 1550s he had recommended himself in this field with some success. Rather than forming an outlier, the series of moresques thus takes up a central role in his oeuvre and provides a compelling argument for research into the practice and purpose of copying in early modern print culture.

\section{Notes}

1 See for an elaborate description of moresque ornament: Jordan and Lachat, "Mauresques," 275-345. 


\section{Femke Speelberg}

2 Münster, Universitäts- und Landesbibliothek, 1E 8935; see: Hind, Engraving in England, $55-56$.

3 It is, in fact, even a very early example of an ornament print series with a title page. See: Fuhring, "Hieronymus Cock," 38.

4 Holbein's drawings with moresque motifs in London (BM, SL. 5308.1-.179) come from an album of jewelry and goldsmith's designs bequeathed by Sir Hans Sloane in 1753; Holbein's drinking vessels were recorded in etchings by Wenceslaus Hollar, see: Pennington, A Descriptive Catalogue, cat. 2626-37.

5 An early taste for strapwork can be gleaned from a drawing with a design for wall decorations containing the coats of arms of King Henry VIII and Catherine Parr, attributed to Nicoletto da Modena (c. 1490-1569), dated to c. 1545, now in Paris, Louvre, INV 19215.

6 As with the series by Gemini, no complete version of the series of small moresques by Androuet du Cerceau appears to have survived. The principal information about the series is based on the album in Paris, INHA, NUM 8 RES 117. See: Guillaume and Fuhring, Jacques Androuet du Cerceau, 305, M1.

7 Adamska, "Maureski," 133.

8 Dodgson's presentation was published in Proceedings of the Society of Antiquaries of London, 2nd Series, vol. 29 (28 June 1917), 210-14; Hind, Engraving in England, 55-56.

9 London, BM, 920,1116.36-.37; cf. one more sheet which is attributed to Gemini ibidem, $1875,0612.156$.

10 Described in Katalog der Ornamentstichsammlung der Staatlichen Kunstbibliothek, Berlin: Verlag für Kunstwissenschaft, 1939, 41, cat. 255, but lost during WWII.

11 While the facsimile set is not accessioned, it is kept in the drawings and prints collection together with the illustrated textile pattern books.

12 Adamska, "Maureski," 127-37, 624-30.

13 See Ibidem, Aneks. 9, 14, 15.

14 E.g. in Vienna, Museum für Angewandte Kunst, KI 2367-1, -3; KI 2238; KI 2498-1, -6, -7; London, V\&A, 19009, and even one of the duplicate prints bought by the British Museum from the museum in Münster (1920,1116.37).

15 The quality of the copies varies immensely. Further research is needed to resolve the matter of chronology and attribution for most of these prints. For want of a better alternative, most are currently still catalogued as Du Cerceau. It is known, however, that several copies were made on Italian paper (see: Guillaume and Fuhring, Jacques Androuet du Cerceau, 305, M1), possibly in the context of the Speculum Magnificentiae Romanae, while others might have been produced in the seventeenth-century workshop of Pierre I Mariette (1603-57) (Adamska, "Maureski," 132). The presence of many of these prints in German collections may point towards one or multiple German reproductions. The prints in Braunschweig were formerly given to Virgil Solis (1514-62), but have now been incorrectly attributed to Gemini himself. Several other prints in Vienna are attributed to the Antwerp printmaker Balthasar Bos (1518-80), who produced several series of moresque patterns.

16 The page is part of an album bought at the auction of the collection of Franz von SternbergManderscheidt (1764-1830), held in Dresden in 1838. For a description and image of the album page see Adamska "Maureski," 127, 624.

17 For the print in Cracow, see ibidem, aneks, 8; London, V\&A, 19010.

18 While certain prints are marked by the letter " $\mathrm{f}$," close inspection suggests that not all prints in this group appear to have been executed by the same hand. For an overview of the group of prints, see: Byrne, "Patterns by Master f.," 103-38.

19 Speelberg, "Fashion \& Virtue," 26-27.

20 See for the original: Paris, BnF, RESERVE 4-S-4544; a commercial facsimile was created in 1908, with an introduction by Gaston Migeon (1861-1930).

21 During the 1540s, other prints and print series with moresque designs were also published by artists such as Jean Gourmont, Augustin Hirschvogel, Virgil Solis and Peter Flötner, followed in the 1550s by the unidentified Master GG, Balthasar Bos and Hieronymus Cock.

22 The book is known in two editions, one undated version and one (known in a single instance at the Fürstlich zu Waldburg-Wolfegg'sche Kunstsammlungen) with the date 1543. It is unclear which of these was issued first. I thank Dr. Peter Fuhring for first alerting me to this 
previously unknown dated edition while I was working on a master's thesis dedicated to the emergence of strapwork ornament at the Radboud University in Nijmegen in 2007-2008 and for his further assistance in preparing the final draft of this chapter.

23 After Francesco di Pellegrino, Livre de Moresques (Paris: Hiérosme de Gormont, 1546). New York, The Met, Harris Brisbane Dick Fund, 1926 (26.71.8(1-34)).

24 Oberhuber, ed., The Works of Marcantonio Raimondi, 378. 520.

25 Dacos, "Giulio Aquili."

26 See for an example the recto and verso of the drawing, which is part of a group of ornament drawings attributed to Andrés de Melgar; New York, The Met, 52.570.332.

27 Hind, Engraving in England, 39.

28 Cust, "Gemini," 118-19.

29 Hind, Engraving in England, 44-45, leaves some doubt as to whether Gemini may have been involved in the role of advisor the 1545 edition by Raynalde; O'Malley, Thomas Geminus, 16-17.

30 O'Malley, Thomas Geminus, 12.

31 Ibidem, 13-14.

32 There has long been confusion about the presence of two different states of the first few plates in Gemini's book. The differences chiefly pertain to the Latin text in the accompanying captions, which in the first state is purely descriptive and does not include any indication of sequence. The later state contains a written numbering system, as well as several other textual additions. While these differences and the abnormalities in Gemini's Latin as a result of the textual changes have been teased out by Donaldson, "Two States," 89-104, no clear explanation for the change had so far been given.

33 O’Malley, Thomas Geminus, 12.

34 Ibidem, 37.

35 Taken from the dedication to King Edward VI, reproduced in: O' Malley, Thomas Geminus.

36 Discovered and published by Taylor, The Mathematical Practitioners, 165-66; published in full in: O'Malley, Thomas Geminus, 34-35.

37 This is further confirmed by the fact that the town of Visé, on the bank of the river Meuse, just southeast of Lixhe, is referenced to with the Flemish name Wesett on a map of the duchies of Brabant, Gulik and Cleves made by Gerard Mercator. It was printed in either the Tabulae Geographicae Galliae, Belgii Inferioris \& Germaniae or the Atlas sive cosmographicae meditationes de fabrica mundi et fabricati figura, both published in 1585 . See for a copy of the map in the Amsterdam, Rijksmuseum, RP-P-AO-19B-35.

38 LCI, vol. 7, 363-69.

39 Turner, Renaissance Astrolabes, 347-48.

40 Osley, Mercator, 20-21.

41 Saunders and O'Malley, Thomas Geminus, 11-12.

42 Post, The Modern Devotion, 556.

43 O'Malley, Thomas Geminus, 11.

44 Information through the England's Immigrants Database 1330-1550. Drawn from The National Archives, Thomas Lamberd [62093], WAM 12261, m. 29 (letters of denization, 1 July 1544). See also: Samson, "Mapping the Marriage," 102.

45 While missed by Samson, this information was already noted by O'Malley, who suggested the former Thomas Lamberd may have been Gemini's father. No such family connection can be positively established, however. For the original record, see: England's Immigrants Database 1330-1550. Drawn from The National Archives, Thomas Lambert [41357], C 67/73, m. 6 (letters of denization, c. 1544 to c. 1545).

46 Osley, Mercator, 21; Samson, "Mapping the Marriage," 107.

47 Hind, Engraving in England, 42.

48 In addition to the examples mentioned in this chapter, there is an astrolabe by Gemini among the instruments bequeathed to Ferdinand II de' Medici by Sir Robert Dudley (15741649). It is now in Florence, Istituto e Museo di Storia della Scienza, 1093.

49 Koninklijke Sterrenwacht van België/ Observatoire royal de Belgique. IC 450.

50 Turner, Renaissance Astrolabes, I, 241.

51 Oxford, Museum of History and Science, 42223.

52 London, National Maritime Museum, Greenwich, Caird Collection, AST0567. 
53 Turner, Renaissance Astrolabes, IX, 406. A copy mounted on board survives in Basel, Historisches Museum, 1876-20.

54 Ibidem, VIII, 347-48.

55 Ibidem, IX, 407-8.

56 Mercator developed his own Latin script, which he used for the place names on his maps and published in his Literatum Latinarum of 1540. See: Osley, Mercator.

57 Turner, Renaissance Astrolabes, VIII, 347-48.

58 De Smet, "Der Goldschmied," 32-37.

59 O’Malley, Thomas Geminus, 15.

60 "Geminos," in Der Neue Pauly, 900-2.

61 While founded in 1425, the University of Leuven only founded its official library in 1636. A catalog was compiled by its first librarian in Valerius Andreas (1636-55) in 1639, but it does not give a comprehensive account of the books in circulation at the library during the previous centuries. (Information provided in writing to the author by Dr. Tjamke Snijders, Special Collections at the Catholic University of Leuven, on 11 December 2018). Frisius's own extensive publications in this field, however, indicate that he was well aware of the literature published on the subject of astronomy, astrology and mathematics across Europe.

62 For a full overview of the project see Samson, "Mapping the Marriage," 95-115.

63 Although unlikely due to its small size, the incomplete survival of all remaining specimens of Gemini's series means we cannot fully exclude the presence of an introductory or dedicatory text containing information of this nature.

64 Mercator's Literatum Latinarum of 1540 similarly advertised his ability to provide his instruments and maps with the most beautiful, and most appropriate, script possible.

65 Turner, Renaissance Astrolabes, I, 234; Lorch, “The Literature," 23-30.

66 Reproduced in Turner, Renaissance Astrolabes, X, 1-18, figs. 1-12; See also: Auction Catalogue: Christie, Manson \& Woods, 1995.

67 I would like to thank Dr. Jennifer Nelson, assistant professor at the School of the Art Institute of Chicago, for alerting me to Bastien Le Seney during the Multiplied and Modified conference in Warsaw in 2018.

\section{Bibliography}

Adamska, Magdalena. “Maureski Thomasa Geminusa-próba rekonstrukcji wzornika.” In Amicissima: Studia Magdalenae Piwocka oblata, 127-37, 624-30. Cracow: Nomina Rosae, 2010.

An Astrolabe for Alessandro Farnese, Duke of Parma, by Erasmus Habermel: The Property of a European Family. London: Christie, Manson \& Woods, 1995.

Byrne, Janet S. "Patterns by Master f.” Metropolitan Museum Journal, 14 (1980): 103-38.

Cust, Lionel H. "Gemini, Thomas.” In Dictionary of National Biography, ed. Leslie Stephen, Vol. 21, 118-19. London: Macmillan and Co., 1890.

Dacos, Nicole. "Giulio Aquili, Andres de Melgar et leurs grotesques." Dialoghi di Storia dell'Arte, 4/5 (1997): 24-33.

Der Neue Pauly: Enzyklopädie der Antike: Altertum. Vol. 4. Stuttgart: J. B. Metzler, 1998.

De Smet, Antoine. "Der Goldschmied und Graveur Gaspar van der Heyden und die Konstruction von Globen in Löwen im ersten Drittel des XVI. Jahrhunderts.” Der Globusfreund, 13 (November 1964): 32-37.

Donaldson, Iain M. L. "Two States of the Same Plates in the 'Compendiosa' of Thomas Geminus (1545)." The Library, 11 (2010): 89-104.

Fuhring, Peter. "Hieronymus Cock and the Impact of His Published Architectural and Ornament Prints." In Hieronymus Cock: The Renaissance in Print, eds. Joris van Grieken, Ger Luijten, Jan van der Stock, 36-41. Brussels: Mercatorfonds, 2013.

Guillaume, Jean, and Peter de Fuhring. Jacques Androuet du Cerceau 'un des plus grands architectes qui se soient jamais trouvés en France'. Paris: Picard, 2010.

Hind, Arthur Mayger. Engraving in England in the Sixteenth and Seventeenth Centuries. Part 1: The Tudor Period. Cambridge: Cambridge University Press, 1952. 
Jordan, Marc-Henri, and Francisca Costantini Lachat. "Mauresques." In L'Art Décoratif en Europe: Renaissance et Maniérisme, ed. Alain Gruber, 275-345. Paris: Citadelles \& Mazenod, 1993.

Katalog der Ornamentstichsammlung der Staatlichen Kunstbibliothek Berlin. Berlin and Leipzig: Verlag für Kunstwissenschaft, 1939.

Lorch, Richard. "The Literature of the Astrolabe to 1450." In Astrolabes at Greenwich: A Catalogue of the Astrolabes in the National Maritime Museum, Greenwich, 23-30. Oxford: Oxford University Press, 2005.

Oberhuber, Konrad, ed. The Works of Marcantonio Raimondi and His School. New York: Abaris Books, 1978 (TIB, Vol. 27; formerly Vol. XIV, pt. 2).

O'Malley, Charles Donald. Thomas Geminus Compendiosa totius anatomie delineatio: A Facsimile of the First English Edition of 1553 in the Version of Nicholas Udall. London: Dawson's, 1950.

Osley, Arthur S. Mercator: A Monograph on the Lettering of Maps, etc in the 16th Century Netherlands. New York: Watson-Guptill Publications, 1969.

Pennington, Richard. A Descriptive Catalogue of the Etched Work of Wenceslaus Hollar. Cambridge: Cambridge University Press, 1982.

Post, Regnerus Richardus. The Modern Devotion: Confrontation With Reformation and Humanism. Leiden: Brill, 1968.

Samson, A. "Mapping the Marriage: Thomas Geminus's 'Britanniae Insulae Nova Descriptio' and 'Nova Descriptio Hispaniae' (1555)." In Renaissance and Reformation/Renaissance et Réforme, 31/1 (2008): 95-115.

Saunders, John B. de C. M., and Charles D. O'Malley. The Illustrations from the Works of Andreas Vesalius of Brussels. Cleveland and New York: Dover Publications, 1950.

Speelberg, Femke. "Fashion \& Virtue: Textile Patterns and the Print Revolution, 1520-1620." The Metropolitan Museum of Art Bulletin, 73 (2015).

Taylor, Eva Germaine. The Mathematical Practitioners of Tudor \& Stuart England. Cambridge: Cambridge University Press, 1954.

Turner, Gerard L'Estrane. Renaissance Astrolabes and Their Makers. Aldershot: Ashgate, 2003. 


\title{
9 Speaking Images and Speaking to the Images
}

\author{
Inscriptions in Religious Prints \\ Published by Antonio Lafreri
}

\section{Alexandra Kocsis}

Prints on religious topics account for the largest and relatively most coherent group according to subject in the works of the sixteenth-century print publisher, Antonio Lafreri (active in Rome between 1544 and 1577). Art historian Michael Bury estimated that two-fifths of Lafreri's stocklist depicted religious themes, indicating a significant change compared to single-sheet print publishing in the first decades of the sixteenth century. Bury believed that the Counter-Reformation and the great number of pilgrims visiting Rome were the main reasons for the growth in religious prints. ${ }^{1}$ In her recently published catalogue of Lafreri's prints, Birte Rubach noted that Lafreri's production of religious prints increased after his split from the heirs of his business partner, Antonio Salamanca, which incidentally coincided with the closing of the Council of Trent (1563). While Rubach pointed out that it would be difficult to interpret Lafreri's change of interest as a direct reaction to the council, she also highlighted that Lafreri had sound business sense to anticipate the demand for religious themes. ${ }^{2}$

As I briefly delineated earlier, the trend of the growing number of religious prints has been discussed; however, the characteristics of Lafreri's publications have not been examined in detail. In this chapter, I analyse selected examples from Lafreri's stock and contribute to the study of his religious prints with detailed observations of the lettering of these sheets. All the analysed prints consist of two main parts: the printed image and Latin texts inscribed on the copper plate and printed along with the image. Through the selected examples, I would like to show that the inscriptions on high-quality single-sheet prints can help us understand how these paper objects worked. The key purpose of this study is to identify innovative trends in Antonio Lafreri's religious prints and relate them to the existing traditions of devotional prints. Moreover, I discuss a newly discovered link between a Jesuit treatise and Lafreri's prints, which crystallises the connection between printmaking and the religious culture of the Counter-Reformation.

Most of the prints analysed were made after images by famous artists, like Raphael, Michelangelo, and Giulio Clovio. Consequently, they are often primarily considered collectibles representing high-quality art. In contrast, my analysis of the Latin inscriptions highlights the potential religious reception of these renowned images and offers an interpretation that considers the inscribed texts an equally important component of the prints. The superficial conflict between devotional and reproductive prints has set the tone for much of the scholarly discourse for a long time. ${ }^{3}$ This is one of the reasons why inscriptions in prints have been neglected (their transcription, translation, and interpretation did not happen) and they are only rarely analysed in detailed studies. In my opinion, the artistic and religious functions of prints can intertwine, and 
these categories cannot be considered mutually exclusive. Text and image worked in a harmonious unity in sixteenth-century prints, and the understanding and interpretation of these sheets calls for an exploration of the textual parts and the communicative strategies of the inscriptions.

Since the beginning of printmaking, religious prints often carried texts: prayers, invocations, speeches by the depicted figures, or identifying labels accompanied the printed images in many fifteenth-century woodcuts. These prints served spiritual purposes, and communication was a major issue related to them. In a way, the images spoke to their viewers, and the viewers responded with prayers dedicated to the depicted divine person. ${ }^{4}$ In his work on fifteenth-century devotional prints, David Areford highlighted how anachronistic it is to apply the conclusions of Walter Benjamin's often-referenced essay, The Work of Art in the Age of Mechanical Reproduction, to late medieval and early modern printed objects. Areford emphasised that multiplication and availability of the images did not destroy their aura, but instead enhanced their efficacy by engaging the spectator in a close and personal relationship with the depiction. ${ }^{5}$ In this chapter, I pursue the same argument by exploring how sixteenthcentury religious prints created this personal relationship between the image and its beholder. The texts and images intended for intense contemplative work encouraged the participation of the viewer, and the inscriptions were often aimed at enhancing the emotional effect of the depictions.

One of the main aspects of this study is the different voices present in the inscriptions and the relationship between the voice of the inscribed text and the depicted figures or scenes. My starting point is the tradition of speaking images, which continued in sixteenth-century prints. Inscriptions functioning as direct speeches of the depicted figures were a long-standing tradition in art, and it was an often-used device in religious prints. ${ }^{6}$ Lafreri's publications included a few relatively small sheets, similar to medieval images of devotional function, typically showing episodes from the Passion of Christ. For example, in the Carrying of the Cross that was engraved by Cherubino Alberti in 1573 (Bartsch XVII.57.20; Figure 9.1), Christ's address to the audience is captured in the Latin text below the image: Ne lachrymis, matres, me neu decorate querelis/Vosmet uos, uestra et pignora flere magis ("You shall not weep, oh mothers, and you shall not honour me with [your] lamentations, you and your beloved ones should rather weep for yourselves!" $).{ }^{7}$ In the print, Christ's speech is directed to all the mothers, which is in harmonious unity with the image that depicts the Virgin Mary behind her son. The engraving shows the figure of Christ from the knees up in front of a neutral, dark background. He is dressed in loose clothes and a cloak, wearing the crown of thorns, and carrying the massive wooden cross on his shoulder. The figure of Mary, with her hands clasped in front of her body, appears on the left, looking anxiously at her son. Christ turns his head towards her but directs his poignant gaze to the viewer outside the image. The Latin inscription refers to the concept of compassion, but at the same time delivers a rather didactic message while advising the onlookers not to weep for the suffering Christ, but for themselves and their families.

A small, anonymous Ecce Homo sheet from 1566 (Figure 9.2) offers a similarly didactic message through the illusion of a framed inscription placed below the image of Christ: Aspicite, ut caput implicitum quam plurima figat/spina, nec in nobis pars uacet ulla plagis. // Vos Homines mihi causa horum, uos serua tulisse/Supplicia et mortem post obijsse cruces ("Behold, since the head is fastened with the thorn, as much encircled as possible, none among us would be free from wounds. You, oh men, 


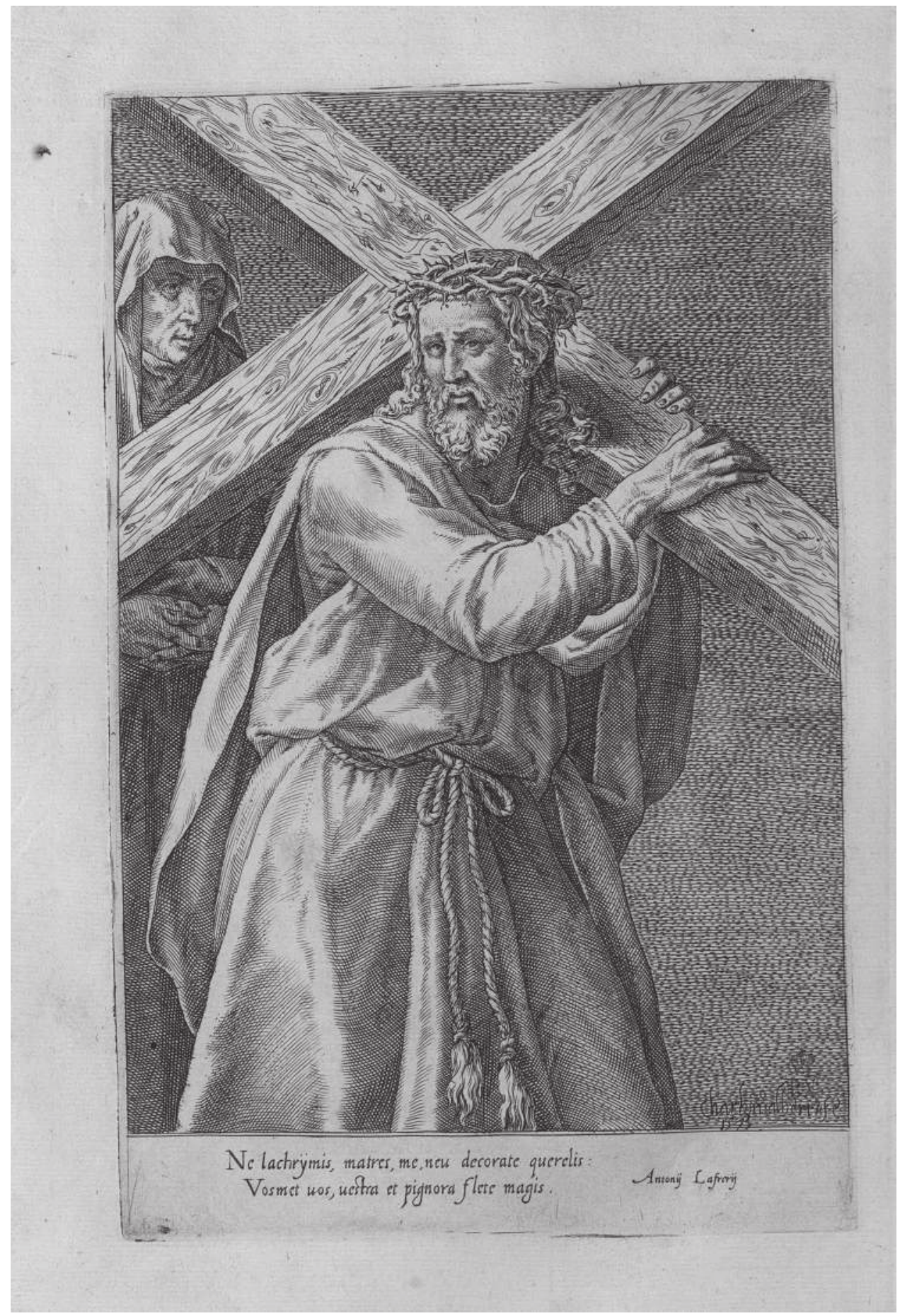

Figure 9.1 Cherubino Alberti, Carrying of the Cross, 1573, engraving. Madrid, Biblioteca Nacional de España, ER/1284 [99].

Photo: ㅇ Madrid, Biblioteca Nacional de España. 


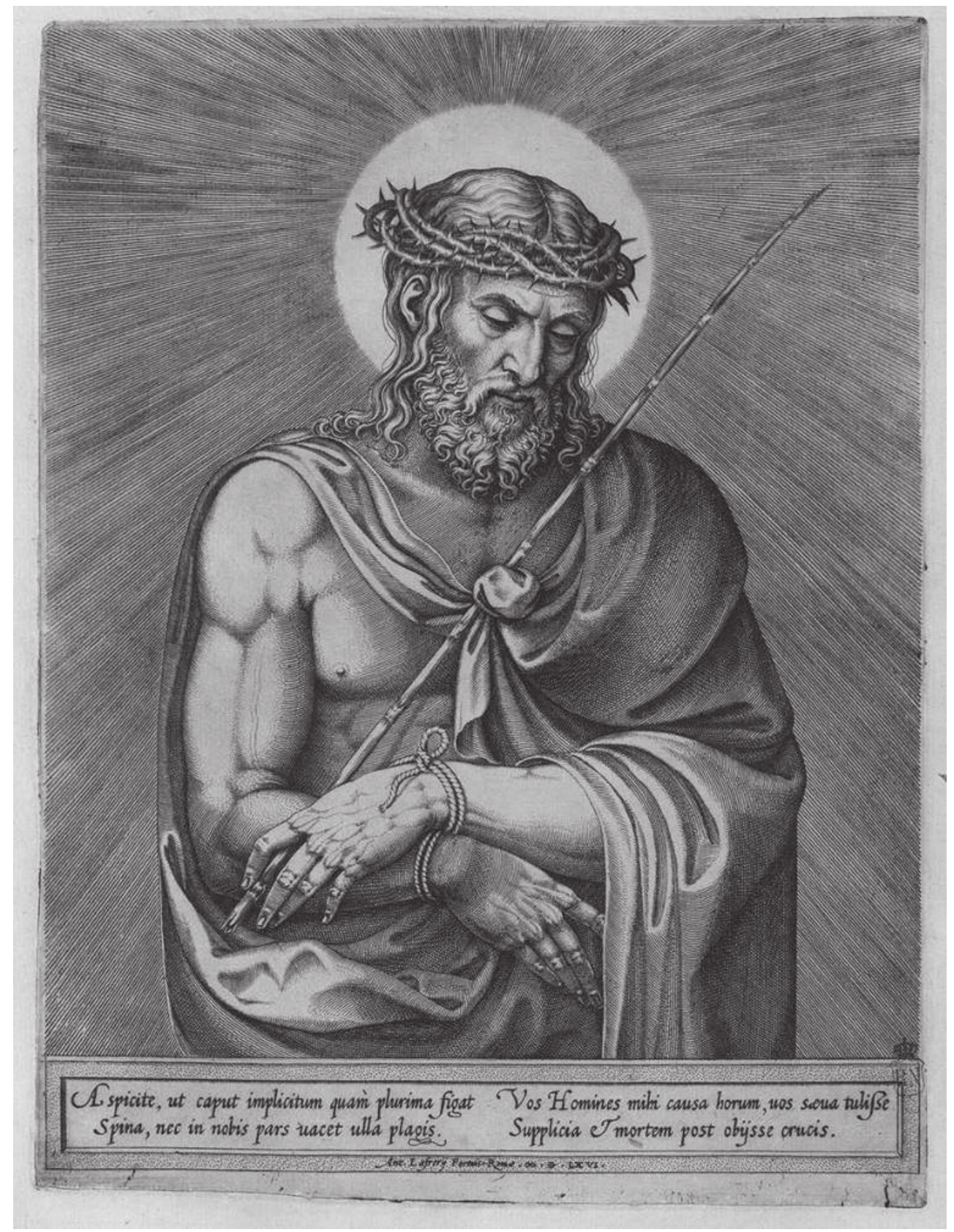

Figure 9.2 Anonymous engraver after Titian (?), Ecce Homo, 1566, engraving and etching. Madrid, Biblioteca Nacional de España, ER/1284 [172].

Photo: () Madrid, Biblioteca Nacional de España. 
[are] the reason of that, you shall keep carrying the punishment and death for me after I have died on the cross" $).{ }^{8}$ In the engraving, the athletic body of the Saviour, depicted in half-length format, is only covered with a drape tied to his chest. His hands are fastened, he wears the crown of thorns, a radiant halo appears behind his head, and dense hatchings, depicting rays, make up the background. Although Christ's figure in this sheet is closer to the viewer than it was in the Carrying of the Cross, he directs his gaze downwards. The verse below the image explains how his suffering reflects the suffering of all the faithful, addressing all the viewers in the vocative, just as in the previous example. In these two prints, the images provide the audience with a closeup depiction of Christ, displaying his tormented figure, while the additional texts highlight the beholder's sinfulness. The Latin verses urge the viewer to meditate on a certain didactic aspect of Christ's Passion.

In a bigger sheet depicting a multi-figure Crucifixion designed by Giulio Clovio and engraved by Cornelis Cort in 1568 (Figure 9.3), a longer Latin poem appears below the image, divided into three sets of two lines: Quid mundo, si nulla quies reperitur oberras?/ Huc ades: aethereum crux tibi pandit iter./Cur, age, ferre crucem cunctaris, homuncio, pro me:/Quandoquidem pro te iam Deus ipse tuli?/Nam mea uita fuit, tua mors: morte? sed obiui/Ipse tuam: uitam tu quoq[ue] uiue meam ("Where would you wander if you do not find peace? You arrive at hither: the cross unfolds the divine path for you. Why do you hesitate? You shall move, carry the cross for me, little man, since indeed, God himself has already carried it for you! For my life has been your death, but I have gone to meet your death itself: you shall live my life, too"). ${ }^{9}$ Four figures-an elderly man (presumably Nicodemus), the Virgin Mary, Saint John the Evangelist, and Longinus—are standing on either side of the cross, while Mary Magdalene is kneeling at its foot. Dark clouds and a mountainous landscape with the view of a city fill the background. In the Latin text, the crucified Christ addresses "the little man" who arrives at the cross and urges him to follow the divine path and carry the cross for him. One may consider that Christ is addressing Longinus, the Roman centurion with the lance, standing behind John and looking up towards Christ. The legend of his conversion may offer another layer of meaning to the words. However, the text can equally be interpreted as being directed to the readerviewer of the print. In fact, the two possibilities may be combined if the readers-viewers identify themselves with the figure of Longinus. In the poem, Christ rebukes his audience for hesitating to bear their own cross. Thus, the text delivers a didactic reading of the image, just like the verses on the smaller prints discussed earlier. However, in the Crucifixion, Christ talks to the viewer in a highly emotional tone, confronting them with questions and using the imperative voice. The caption builds on the emotional involvement of the reader-viewer, in addition to the didactic message.

The previous discussion shows how text and image complement each other in the three examples. If the image appeals to the emotions of the viewer, then the text is more didactic; on the other hand, if the text is paired with a multi-figure image, then it implies a more emotional message. These observations suggest that the producers of the prints constantly tried to balance the two options of emotionally involving and teaching the audience. The inscriptions served to compensate for the meaning that received less visual emphasis, and they also gave an interpretation of the image.

In the cited examples, Christ's voice in the inscriptions appears to question and exhort the audience. Thus, the communication is unidirectional, and the text is aimed at enhancing the effect of the visual part of the print. This is the traditional arrangement in religious images intended for personal use. However, the texts in Lafreri's prints do not derive from authoritative sources (like the Bible or liturgy). Although 


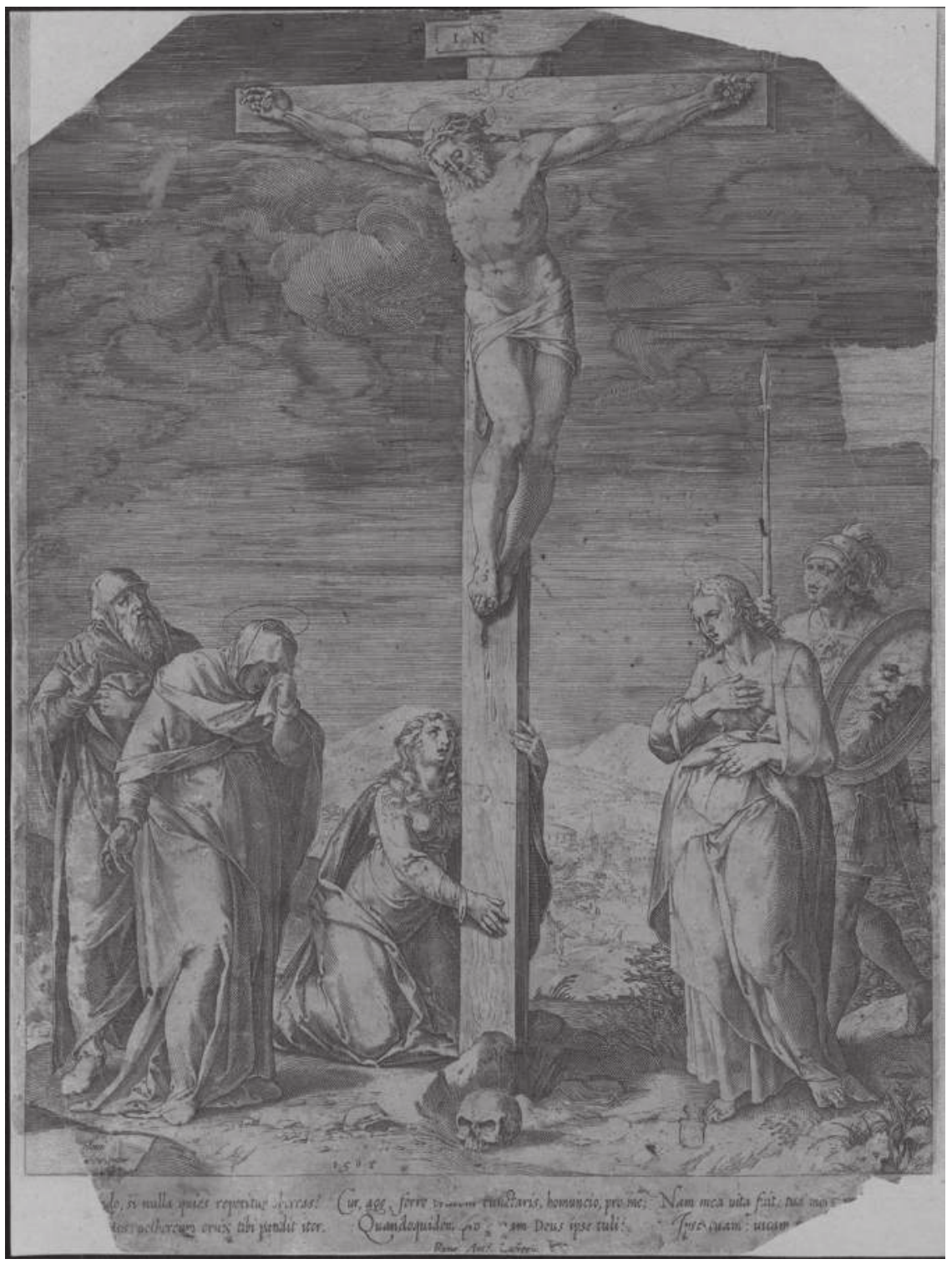

Figure 9.3 Cornelis Cort after Giulio Clovio, Crucifixion, 1568, engraving. Madrid, Biblioteca Nacional de España, INVENT/1541.

Photo: () Madrid, Biblioteca Nacional de España.

the messages are conventional, they are presented in a poetic form. Furthermore, the captions speak to specific motifs in the depictions (e.g., the figure of the mother in the Carrying of the Cross or the crown of thorns in the Ecce Homo). The close connection between image and text suggests that these verses might have been written for the prints. Although one can only assume this, the following examples include poetic texts that were most probably composed for the sheets. 


\section{Alexandra Kocsis}

In some prints published by Lafreri, the unidirectional communication was replaced with a different structure. Including the supposed response of the audience was already a strategy that many fifteenth-century religious woodcuts employed by adding a printed prayer next to the image. Thus, the beholder was provided with a ready answer to the visual challenge of the image. ${ }^{10}$ In some of Lafreri's prints, this format was altered: where the texts address the figures depicted in the image, the voice of a poetic narrator emerges as a mediator between the image and the viewer, offering a point of identification for the beholder and guiding them through the process of understanding and interpreting the depicted scene. Copies of two early prints from Raphael's workshop are fitting examples for the appearance of the narrator's voice. These sheets portray scenes of the Passion with multiple figures presented in masterly compositions, following Raphael's works.

The Christ Falling on the Way to Calvary (Figure 9.4) and the Descent from the Cross (Figure 9.5) did not include texts in their first printed versions. Neo-Latin poems were added when anonymous engravers copied the images for Lafreri. ${ }^{11}$ The size and layout of these copies are very similar, and Lafreri's address (Romae Ant. Lafrerij) and the reference to Raphael (Raphael urb in) look identical and are placed at the same positions on the sheets. Both poems end with the same Latin word (onus), and the following analysis will show that they constitute a question and an answer that belong together. The two images do not depict successive scenes of Christ's Passion. In my opinion, it is Raphael's authorship that connects them within Lafreri's stock. These two sheets are perfect examples of the intertwining of religious and artistic purposes. A customer buying the prints of Raphael's famous images received a thematically united pair of sheets at the same time. These paper objects not only celebrated artistic achievement but also offered an opportunity for a meditative exercise.

Christ Falling on the Way to Calvary (Bartsch XIV.34.28) was originally engraved by Agostino Veneziano in 1517 after Raphael's monumental painting made for the high altar of Santa Maria dello Spasimo Church in Palermo. ${ }^{12}$ The image shows Christ falling under the weight of the cross, the figure of Simon helping him, the Virgin collapsing in the arms of Magdalene and Saint John, soldiers on foot and on horses, and other accompanying figures in a detailed landscape, with the city gate on the right. The copy published by Lafreri (Figure 9.4) includes an inscription in which a firstperson narrator laments the weight of the cross by comparing Christ's suffering to a personal concern about bearing burdens: Ipse tuam bone Christe crucem portare iuberis:/Admonitus cesso cur ego ferre meam. // Ipse gemis diri tanto sub pondere ligni:/ Cur grave Christe, tuum iam videtur onus. ("You yourself are commanded to bear your cross, oh good Christ, [thus] rebuking [me] why I stop carrying mine. You yourself groan under the great weight of the tremendous cross. Why, oh Christ, does your burden seem [so] heavy now?"). The text exemplifies the reaction of an ideal viewer to the image of Christ carrying his cross: it focuses on the feeling of compassion for Christ's pains. Thus, the inscription fits the intentional meaning of Raphael's original panel. In line with the dedication of the church, the main topic of the painting was Mary's compassion. ${ }^{13}$ Visually, this remained the leitmotif in the print as well, with the slight modification of evoking in the viewer the feeling of compassion through the inscribed poem. The two choices offered in the text-bearing the burden of the cross or refusing it - turn the spotlight on another figure. Simon of Cyrene provides the viewer with an active model of compassion: he jumps to aid the falling Christ and grabs the cross to help him, while looking angrily at the soldiers. Simon represents a figure with whom the viewers can identify themselves: he takes the heavy burden from 


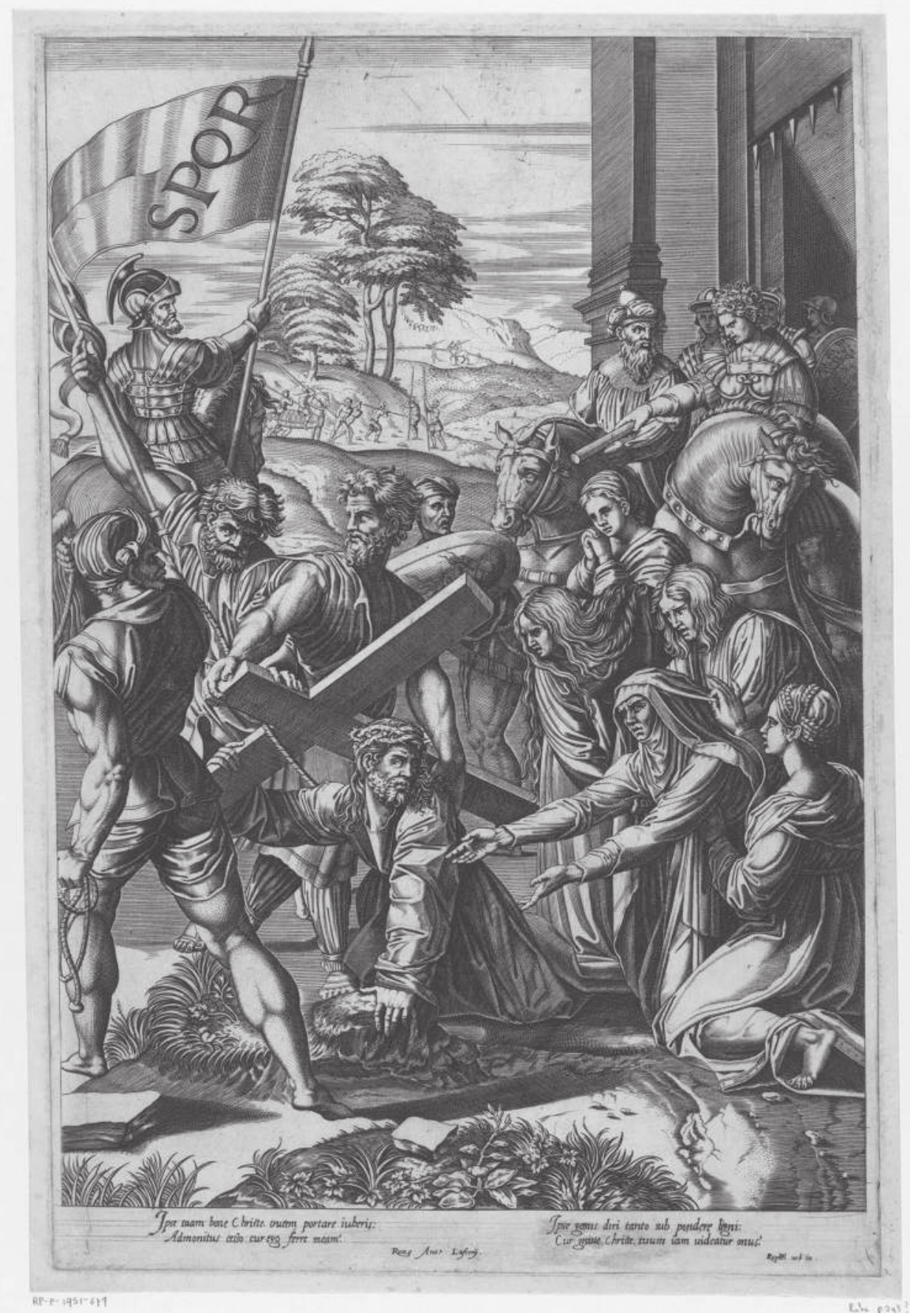

Figure 9.4 Anonymous copy of the print by Agostino Veneziano after Raphael, Christ Carrying the Cross, engraving. Amsterdam, Rijksmuseum, RP-P-1951-679.

Photo: http://hdl.handle.net/10934/RM0001.COLLECT.188560, CC0 1.0. 
Christ with confidence. His powerful figure is in stark contrast with the narrator of the inscription, who laments the weight of the cross and conveys guilt about abandoning his duty. The contrast between the ideal Simon and the hesitant, self-doubting narrator offers the audience the possibility to reflect on their own self. At the end of the text, the narrator also provides an example to the audience. Here he merges into the depicted scene when complaining about the weight of the cross: "Why, oh Christ, does your burden seem (so) heavy now?" This rhetorical question suggests that he finally chooses to follow the good example set by Simon and takes on the imaginary and allegorical burden from Christ. At this point, the inscription includes a highly emotional moment, urging the audience to respond to the image in a similar way.

The juxtaposition of Simon and the hesitant poetic narrator was not a new interpretation of the Carrying of the Cross. In 1534, the priest Cola Giacomo D'Alibrando published his poem of seventy-six stanzas, describing the production process, installation, design, and reception of Polidoro da Caravaggio's Sicilian altarpiece, the Way to Calvary. In the thirty-ninth stanza of his ekphrasis, when Alibrando describes Simon's bearing of the cross from the falling Christ, he interrupts the narration. He cries out, addressing and blaming himself for complaining about the pain and not helping the Saviour. He urges himself to follow Simon's example. In this ecstatic moment, Alibrando writes that he sees Christ himself instead of the painting, feels his pain, and wants to act instead of complain. ${ }^{14}$ The act of Simon represents an emotional peak in the description of the painting, where the narrator feels the need to reflect and respond to the painting, blurring the lines between depiction and reality. Assumedly, the producers of the print after Raphael's design wanted the image and text to have the same effect on the beholder. Alibrando's text provides us with contemporary evidence that the bimedial structure and strategy were not unknown to the educated audience of the period.

The first version of the Descent from the Cross (Bartsch XIV.37.32) was engraved by Marcantonio Raimondi, presumably based on the drawings of Raphael. ${ }^{15}$ The image shows Christ being taken down from the cross with the assistance of four male figures, including Saint John and, most probably, Nicodemus, while the fainted Virgin is supported by three women at the foot of the cross. The inscription on the copy published by Lafreri (Figure 9.5) uses the strategy of engaging the viewer in the narrative, as seen in the previously analysed example. After explaining Christ's sacrifice and his death on the cross, the narrator of this poem turns to the witnesses of the Crucifixion: Mortuus e cruce detrabitur descendere uiuus/Cum posset. nostri tantus adegit amor // Excipite exanguem dominum pia turba lacertis/Atq[u]e humeris: non uos dulce grauabit onus ("Dead, he is being taken down from the cross, although, he could descend from it alive. Such a great love for us moved him [to do this]. Oh pious crowd, receive the lifeless Lord in your arms and on your shoulders! This sweet burden will not burden you"). Symbolically speaking, an observer of the print could also become one of the witnesses receiving Christ, for example, through meditation. The call to duty in this print is not harsh or heavy: the viewer is not asked to take the cross but the body of Christa "sweet burden" as the poetic inscription describes it. The sacrifice of the Crucifixion transforms the burden of pain into salvation, and this can be denoted as the most important message of the two prints after Raphael's works. The dialogue of the two poems is also interesting from the point of view of poetic voice. In the Calvary, the first-person narrator is talking to Christ. The audience can easily embrace this text and identify themselves with the voice. In the Descent from the Cross, a much more neutral, thirdperson voice addresses the viewer, answering all the doubts raised in the previous print. 


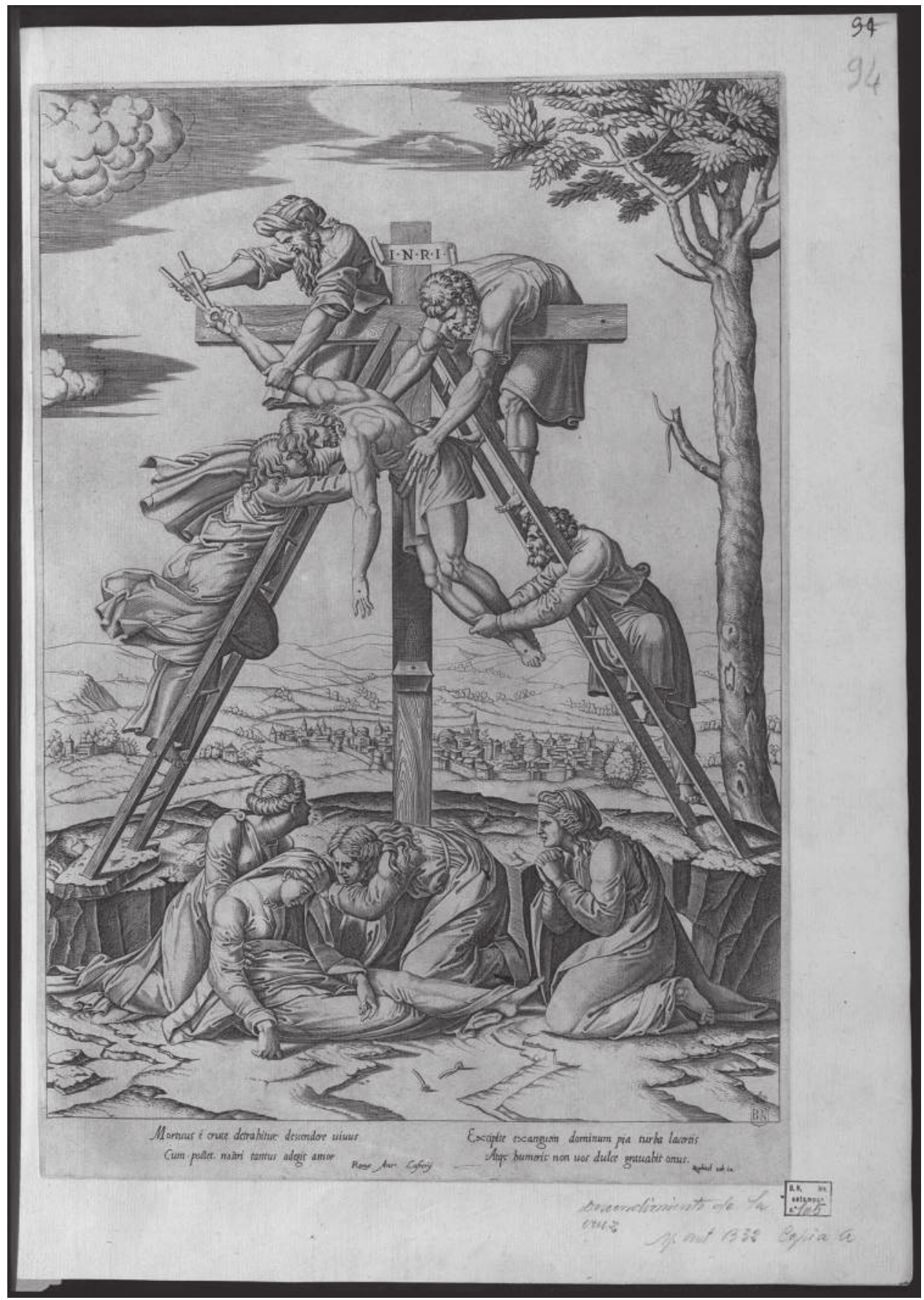

Figure 9.5 Anonymous copy of the print by Marcantonio Raimondi after Raphael, Descent from the Cross, after 1521, engraving. Madrid, Biblioteca Nacional de España, ER/1284 [105].

Photo: () Madrid, Biblioteca Nacional de España. 


\section{Alexandra Kocsis}

The analysed prints after Raphael's designs include a voice different from the traditional fifteenth-century religious woodcuts or from Lafreri's three prints mentioned at the beginning of this chapter. Instead of a depicted figure speaking to the audience, these prints feature a poetic narrator, who was an intermediary between the image and the viewer. This structure contributed to the innovative character of the prints, which is in line with literary trends of the period (the literary precedent for the poem in the Descent from the Cross has been discussed). At the same time, the producers of the prints did not refrain from emotionally involving the beholder in the scene. The analysed inscriptions serve the purpose of communicating with the viewer. The small, black-and-white images on paper are not necessarily as spectacular as the monumental paintings or sculptures. However, the texts added to the printed images help intensify the reader-viewer's (emotional) response to the depiction. The first-person voice facilitates an intimate relation between the printed image and its beholder, which could be useful in religious contemplation.

The poetic narrator is also present in one of the most innovative and complex yet the least studied prints by Lafreri-the anonymous sheet after Michelangelo's Last Judgement (Figure 9.6). This copy of Martino Rota's print (Bartsch XVI.260.28) after Michelangelo's Sistine fresco was published sometime after 1569, along with the late publications of Lafreri. ${ }^{16}$ The sheet includes a lengthy poetic inscription below the image, one of the first prints by Lafreri to combine an explanation of the subject with comments on the designer of the original work: Hoc speculo genus humanum se spectet, et ante/Discat iter, per quod uitaq[ue], morsq[ue] uenit./Discat, ut e totis surgant rediuiua sepulchris/Corpora, quidq[ue] Deo Iudice quenq[ue] manet // Arte, colore, manu Bonaroti expressa tremendi/Haec simulachra fori cerne, reuolue, paue./Et si non animus, si mens non deficit, illo,/Dic mibi quis nobis tempore sensus erit? ("The human race should look at himself through this mirror, and in front of it, he should learn the way through which life and death come. He should learn that the revived bodies would rise from all the tombs, everybody who awaits for divine judgement. You should examine, reflect upon, (and) fear this image of the dreadful court of justice exhibited through the skill, colour, and hand of Bonarotus. And if we will be left without soul and mind, (then) tell me how will we experience that time?"). The poem urges the readers-viewers to meditate on the dreadful subject of death and judgement and appreciate Michelangelo's work. The inscription even refers to the colour of the original image, which is peculiar given that the viewer is looking at the printed, monochrome version of the fresco.

Those who chose to buy this print from Lafreri's stock received a complex product that satisfied their need for effective and sophisticated religious content and artistic reproduction simultaneously. The monumental scene of the Last Judgement is reproduced together with the architectural context of the fresco, and Michelangelo's portrait placed in between the vaults further emphasises the authorship of the famous artist. Around the scene, an elaborately detailed printed frame bears the inscription that recognises the image as a mirror (speculum) of the fate of humankind-life and death on the day of divine judgement. The didactic nature of the scene is emphasised in the first stanza with the subjunctive form discat ("he shall learn") that appears two times in the text. In the second stanza, the narrator of the poem urges the readerviewer "to examine, reflect upon, and fear" the depiction that the skilled hand of Michelangelo has created. These two lines encourage the audience to respond and react to the image and to praise Michelangelo's ability at creating such an expressive picture at the same time. According to the poetic narrator, Michelangelo's "skill, colour, and hand" have produced an image that even generates the feeling of fear in 


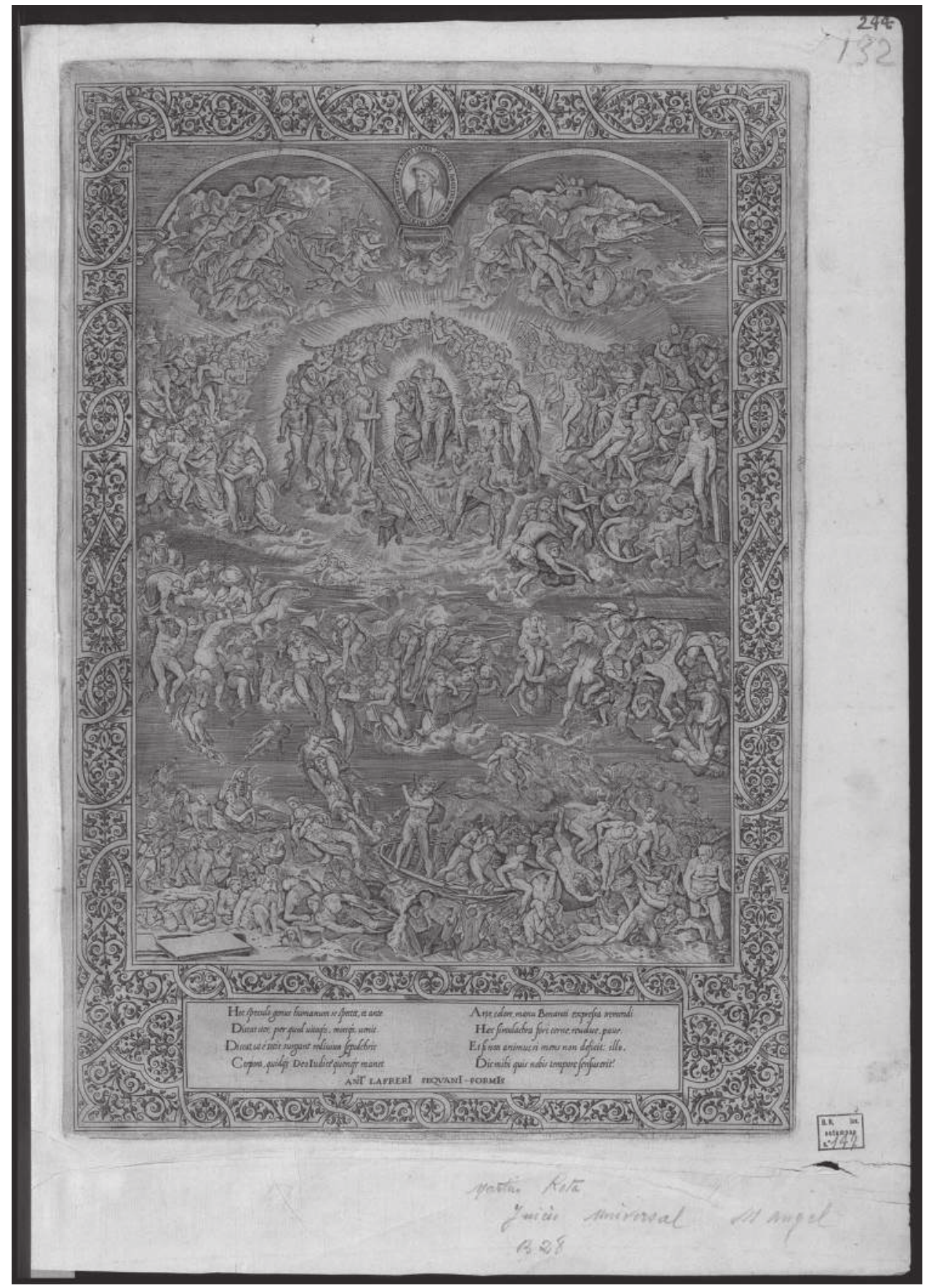

Figure 9.6 Copy of Martino Rota's print after Michelangelo, Last Judgment, after 1569, engraving. Madrid, Biblioteca Nacional de España, ER/1284 [147].

Photo: ( Madrid, Biblioteca Nacional de España. 


\section{Alexandra Kocsis}

the spectator. One of the first commentators of Michelangelo's work, Pietro Aretino, emphasised the horror that the image evoked in the viewer-he observed that the picture made the audience tremble as if they were experiencing the Last Judgement in reality. Since Aretino's letter was published several times, his thoughts on the fresco must have been popular and influential even in the 1560 s to 1570 s and thus served as an interpretative framework for Lafreri's print. ${ }^{17}$

Besides linking the print to the theoretical discourse on Michelangelo, the second stanza of the poem also aims to emotionally engage the reader-viewer, which is an important element in Lafreri's prints analysed so far. The inscribed text below the printed image ends with a question about how one will experience that dreadful time. This question offers the beholder a connecting point-it addresses the reader-viewer directly and uses the inclusive first-person plural pronoun (nobis). The poetic narrator clearly acts here as a mediator between the image — of the dogmatically important event—and the audience.

The use of the ornamental frame is somewhat unusual for Lafreri's prints, especially those of images by famous artists. However, Lafreri's stock includes two anonymous prints depicting the busts of Christ and Mary that have a surprisingly similar setting (Figure 9.7). ${ }^{18}$ The motifs and layout of the frames are very similar in all three prints: floral forms and intertwining ribbons encircle the images and the tablets bearing the captions. The three prints are also similar in size, though the Last Judgement is a little smaller than the other two sheets. All these suggest a close connection between the three prints. In my opinion, they could have been assembled as a triptych, presumably with Michelangelo's famous image in the middle.

The pairing of the Last Judgement with the bust portraits further accentuates the religious function of the print after Michelangelo's work. The close-up images of the holy figures look like printed icons, which is emphasised by the filigree-like, ornamental frame. Moreover, the texts inscribed under these images add to a prayer-like setting. The two lines underneath the picture of the Virgin praise her as unique among women, being the daughter, bride, and mother of God at the same time: Foeminei tu sola chori pulcherrima Virgo/Vna Dei pariter filia sponsa parens ("You, most beautiful Virgin, [are] unique among the choir of women, at the same time daughter, bride, and mother of God"). The inscription under Christ's image starts with a similar praise, addressing Christ as ruler of the world, saviour, and creator: Omnipotens mundi rector seruator et auctor/Laetifica uultu pectora nostra tuo ("Almighty ruler of the world, saviour and creator, let our hearts rejoice in your face!"). ${ }^{19}$ The second line evokes emotions in the viewer and forges a close bond between the viewer and the depicted figure. These inscriptions resemble the texts in traditional religious prints, which typically contained a prayer for the reader-viewer. The inscribed text allows the reader to address the holy figure, while the image provided the viewer with a visual idea of the depicted saint.

The link between the bust portraits and the print after Michelangelo built a clear religious context around the famous image of the Last Judgement. Furthermore, the reception of the "most beautiful Virgin" print provides a hint about the intended audience and the use of these images in the religious context of the second half of the sixteenth century. It has not been noted yet that the image of the Virgin was copied in a woodcut and inserted among the illustrations of the first Jesuit treatise on the Virgin Mary (Figure 9.8). Petrus Canisius's De Maria Virgine incomparabili et Dei genitrice sacrosancta libri quinque was first published in Ingolstadt in 1577, probably just a few years after Lafreri's print. Canisius's book not only contains the image of the Virgin but also the verse that appears in the print. ${ }^{20}$ The inscribed text from Lafreri's print is interpreted as the title of this specific icon of Mary, "daughter, bride, and mother of God." 


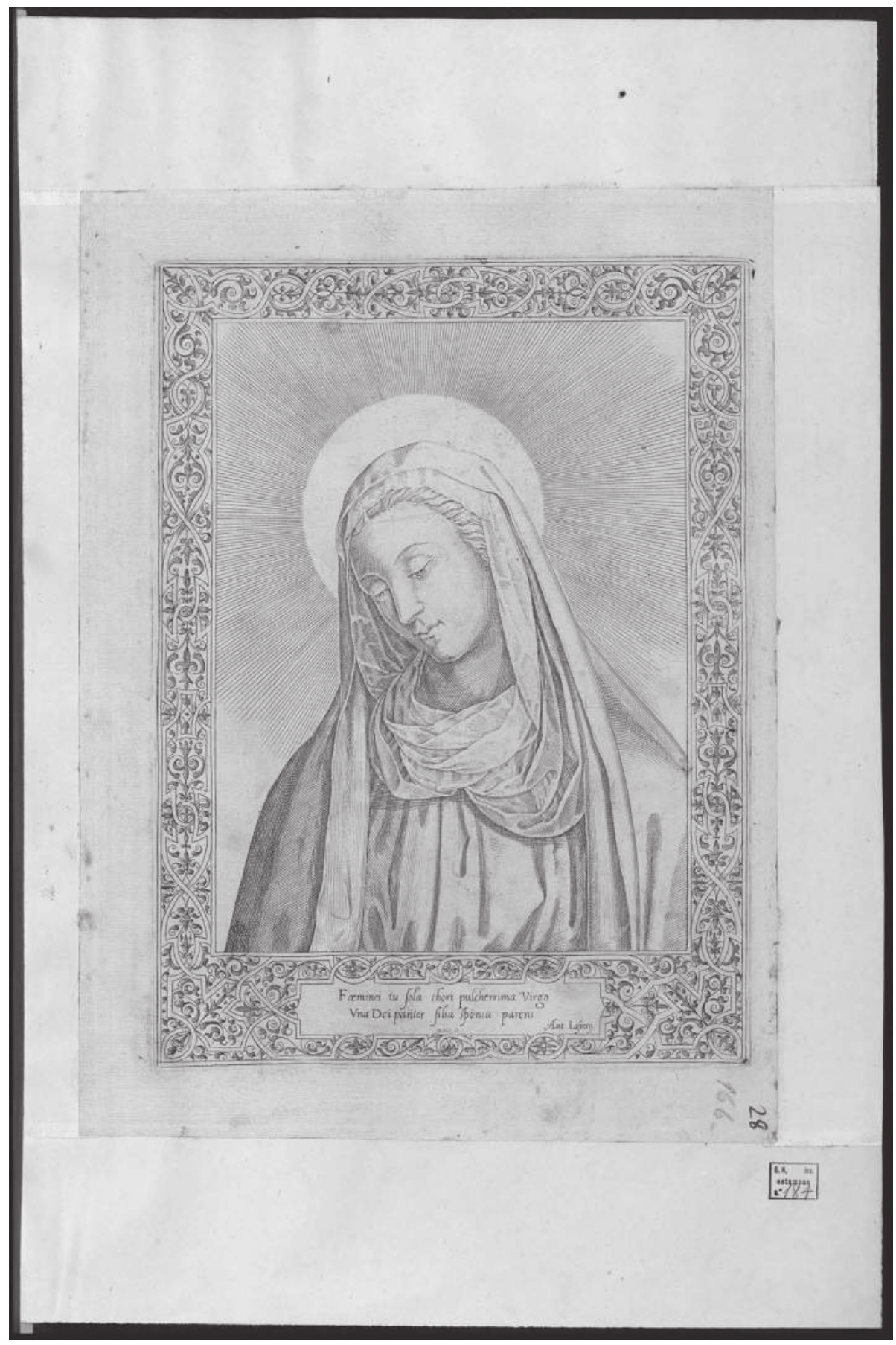

Figure 9.7 Anonymous engraver, The Most Beautiful Virgin, before 1577, engraving. Madrid, Biblioteca Nacional de España, ER/1284 [184].

Photo: () Madrid, Biblioteca Nacional de España. 


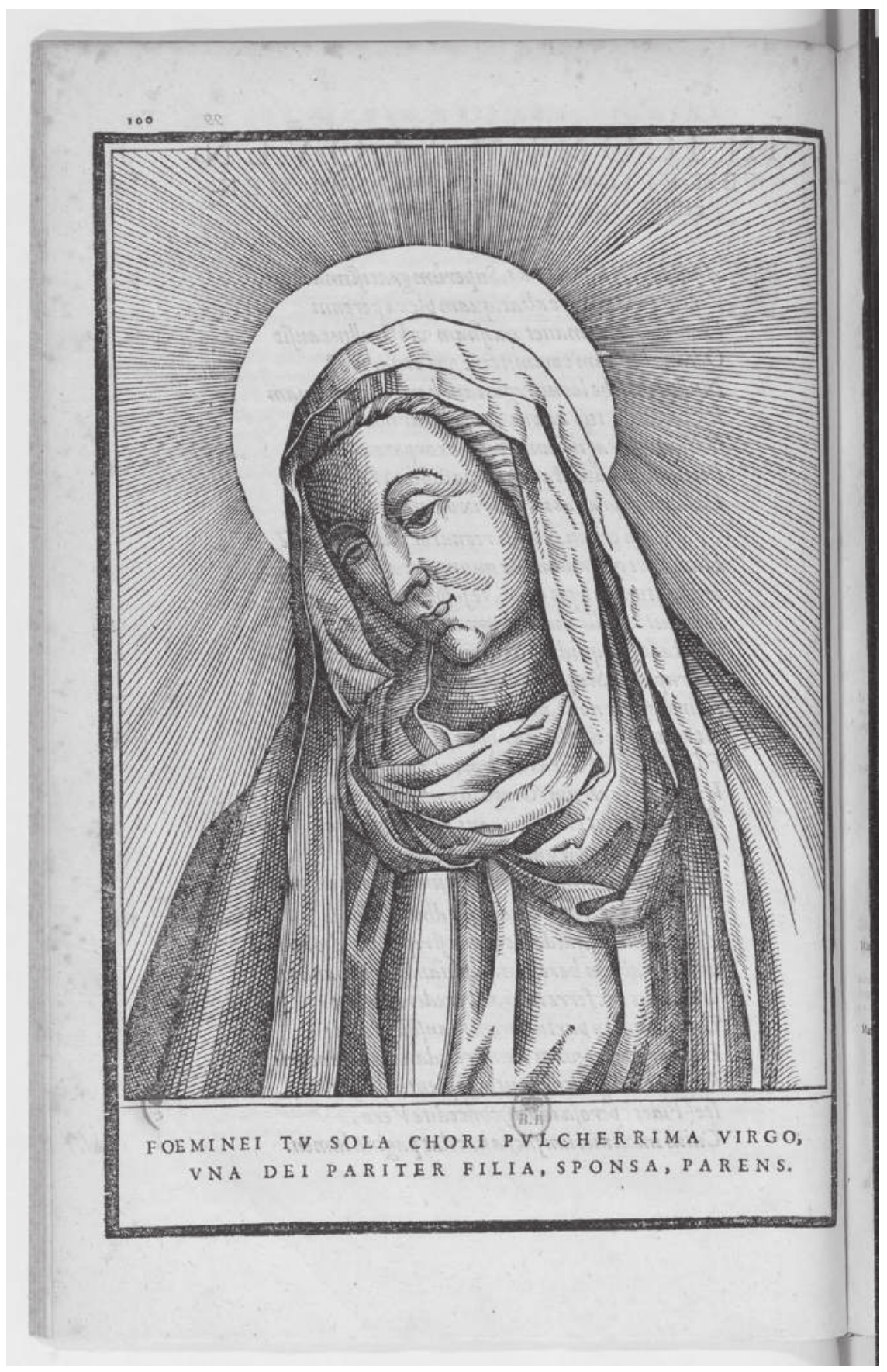

Figure 9.8 The Most Beautiful Virgin, woodcut in Petrus Canisius, De Maria Virgine incomparabili et Dei genitrice sacrosancta libri quinque (Ingolstadt: David Sartorius, 1577), 100. Paris, Bibliothèque nationale de France, FRBNF30192176.

Photo: () Paris, Bibliothèque nationale de France. 
The woodcut and Lafreri's print show the image of the Virgin Mary in the same direction. This may suggest that the woodcut was not a direct copy of the Roman engraving (in which case the copy would have been reversed), but they derive from the same source. However, the identical nature of the two images suggests otherwise. The figures resemble each other very closely—not only in their outlines (like the structure of the draperies, the features of the Virgin's face, the position of her head) but even in finer details such as the hatchings of the shadow on the Virgin's face, the folds of her drapery and veil (especially around her neck), the form of her mouth, and the structure of her halo that looks like a stylised sun with dense rays radiating from an empty circle. All these signs support the hypothesis that the two prints share a close connection. Their same direction might be explained by the iconic nature of the image. The woodcutter may have considered it important to preserve the direction of the image in the copy as well. In an attempt to produce a true copy, only those details that seemed less important were simplified, such as the fold of the drapery on the Virgin's chest.

While it is difficult to establish the date of Lafreri's print of the Virgin, and we can only ascertain a terminus ante quem based on the death of the publisher in 1577, further evidence supports that the woodcuts in Canisius's book were made later than Lafreri's single sheets. Interestingly, the image of the Virgin is not the only print by Lafreri that was used in Canisius's Marian treatise. The woodcut copy of the Virgin Immaculate with Marian Symbols, which was engraved by Cornelis Cort and published in 1567 by Lafreri (Figure 9.9), was also incorporated into the 1577 book (Figure 9.10). ${ }^{21}$ That the image was used two times as an illustration between chapters is not surprising, given that the treatise was intended to defend the Catholic cult of Mary and the doctrine of Immaculate Conception. ${ }^{22}$ In this case, the woodcutter created a reversed and simplified copy of the print, omitting the original inscription on the lower margin. In the woodcut, fewer symbols were used than in the engraving; however, the main motifs are identical. The two figures of the Virgin and Child are highly similar in the woodcut and in the engraving: Mary is standing on a crescent-shaped moon, wearing a big cloak arranged in a similar fashion, and a crown with stars above; her curly hair is flowing around her figure and she is holding a branch of lilies, while the Christ Child is embracing her neck. The radiating mandorla around the Virgin and Child is the main point of difference between the woodcut and the engraving. The figure of the hovering God the Father with the dove of the Holy Spirit, the sun and the moon on either side-all these elements are highly similar in the two depictions. The symbols of Mary are reduced and thus rearranged in the woodcut, but many of them closely resemble Cort's engraving, especially the seven-headed dragon with a curly tail that looks like it is vomiting rather than spitting fire. All the motifs appear reversed in the woodcut except for the sun and the moon, which attests to the conscious work of the woodcutter, who was copying the engraving with the symbolic content and meaning in mind.

Further evidence also supports the hypothesis that Lafreri's prints served as models for the woodcuts in Canisius's book. Personal connections can be found between Lafreri and Canisius via a high-ranking patron. In 1568, Canisius travelled to Rome from Dillingen, together with the Augsburg bishop and cardinal, Otto Truchsess von Waldburg. Canisius returned to Augsburg in 1569, but the cardinal remained in Rome until his death in 1573. ${ }^{23}$ While Canisius could have easily bought Lafreri's prints in Rome, it is likely that Waldburg may have served as the link between Lafreri and the Jesuit priest. Art historian Alessia Alberti noted that Lafreri had dedicated several prints to Waldburg from 1563 onwards, including Beatrizet's print of the Madonna of Loreto and a Crucifixion based on Giulio Clovio's design. ${ }^{24}$ Scholarly investigations on 


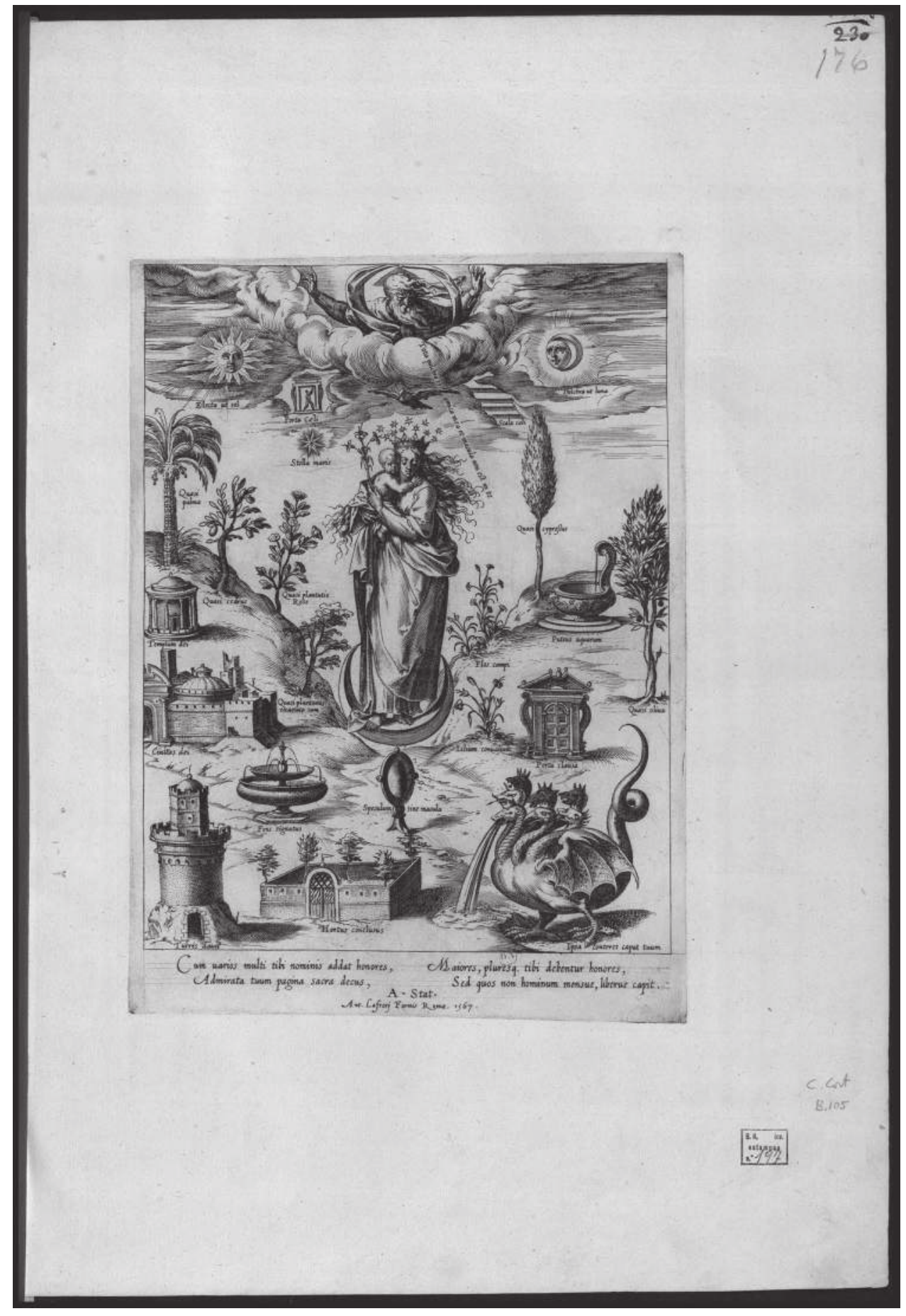

Figure 9.9 Cornelis Cort, Virgin Immaculate with Marian symbols, 1567, engraving. Madrid, Biblioteca Nacional de España, ER/1284 [197].

Photo: () Madrid, Biblioteca Nacional de España. 


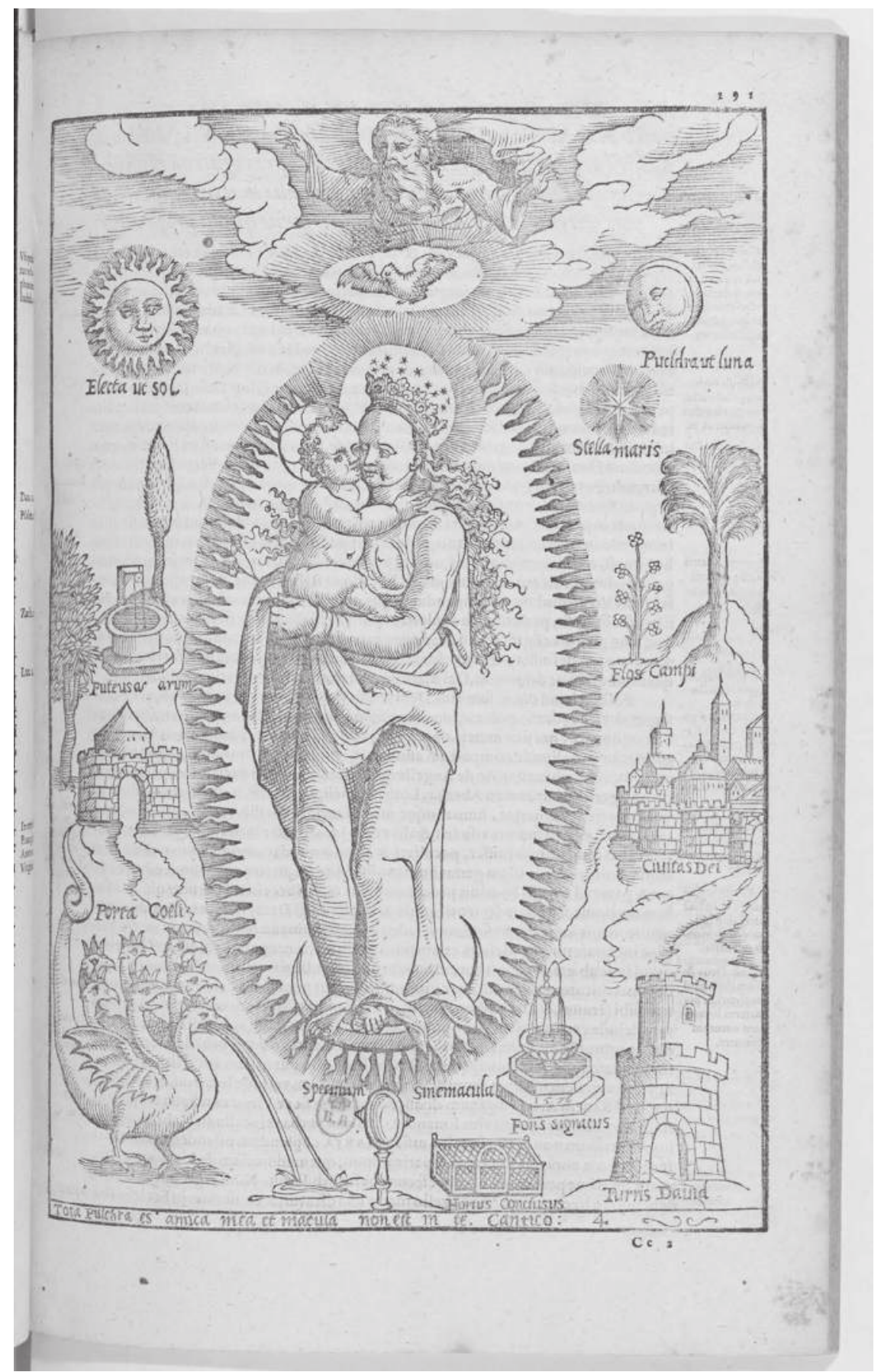

Figure 9.10 The Virgin Immaculate with Marian Symbols, woodcut in Petrus Canisius, De Maria Virgine incomparabili et Dei genitrice sacrosancta libri quinque (Ingolstadt: David Sartorius, 1577), 291. Paris, Bibliothèque nationale de France, FRBNF30192176.

Photo: ( $)$ Paris, Bibliothèque nationale de France. 
Waldburg's significant personal collection confirm that he acted as an art dealer for the Bavarian duke, Albert V..$^{25}$ Therefore, it is possible that he was also interested in prints.

Walter S. Melion examined the place and significance of the images of the Virgin in Canisius's treatise and in the context of Canisius's defence of the use of religious images and visual devotion. ${ }^{26}$ As explained in the treatise, the bust image of Mary served as a starting point for the viewer's own contemplation and provided an ideal model of prayer, visually and spiritually. Melion noted how Canisius's treatise was a perfect example of the use of images during meditation and that Canisius himself was an ardent defender of religious images in general. ${ }^{27}$ Apparently, prints played an important role in his meditation and in the practices that he described in the treatise. Thus, Canisius and his readers can be considered the ideal clients of Lafreri-the intended "users" of his text-image creations. Canisius might have known about the Last Judgement print and its potential use in meditative practice. The possible association between a Jesuit treatise and Lafreri's prints lends credence to the connection between printmaking and the religious culture of the Counter-Reformation. Inscriptions played a significant role in this context by guiding the beholder through the visual depictions. While Canisius published a whole treatise to explain and interpret the images, in the prints published by Lafreri, concise inscriptions served to evoke the appropriate response in the viewers. Captions in prints played on the liminal status of texts in between the image and the spectator by drawing on the device of the poetic narrator. The Neo-Latin poems translated the visual into verbal communication, and they were used to enhance the participation of the audience. By the means of the inscribed texts, the readers-viewers could be invited to take part in the depicted scene, thus completing and enhancing the illusionistic effect of the images.

The figure of Canisius and his treatise offer a better view of the ideal audience of Lafreri's religious prints and enable us to verify the hypothesis that was formulated on the basis of the textual frameworks in the printed images. The prints after Raphael's and Michelangelo's masterpieces must have had a meditative function. The audience represented by Canisius was educated enough to read Neo-Latin poetry and understand the visual and verbal rhetoric of the prints. Text and image complemented each other in the analysed prints in order to capture the attention of the audience through their emotions. By combining visual elements and poetic devices, these religious prints enhanced and encouraged private devotion in an elegant way. Neo-Latin poetry contributed to the innovative character of these religious prints, setting them apart from traditional examples that usually operated with authoritative texts and a "speaking figure." The voice of the poetic narrator had an important role in this shift-maintaining the emotional effect but building a sophisticated context around the printed images.

In the latter analysed prints by Lafreri, famous pictures multiplied in hundreds of copies were complemented with texts that standardised the experience of the readersviewers. Poetic inscriptions situated the images in the new visual context and engaged the audience in a personal relationship with the image. Thus multiplication and standardisation most probably did not result in the emotional detachment of the viewers but built a safe and easily understandable context for certain beholders. Lafreri's devotional prints mediated centuries-old messages with new devices and in a revolutionary medium. It is rather difficult to find out the recipients' direct responses to these prints. However, understanding and interpreting how the producers (the publisher, the authors, and the printmakers) intended their printed products to function in the eyes of the beholders brings us closer to the audience of devotional prints in the age of the Counter-Reformation. While the messages were most of the time standardised 
and included the multiplication of famous images, poetic devices made the readersviewers believe that their visual, intellectual, and emotional experience was unique and personal. Thus Lafreri's single-sheet prints of images and texts operated with the advantages of the new medium: they mediated the same content to hundreds of users but made it feel personal at the same time.

\section{Notes}

1 Bury, The Print in Italy, 127.

2 Rubach, ANT: LAFRERI FORMIS, 61.

3 In their seminal study of Renaissance prints, Landau and Parshall, The Renaissance Print, 304, also commented on the fact that many of Lafreri's religious prints depicted images by famous artists, and they considered this aspect of the prints more significant from the perspective of the audience.

4 See especially Schmidt, "The Multiple Image," 37-56.

5 Areford, The Viewer and the Printed Image, 16.

6 For further episodes of the tradition of speaking images see for example Tarr, "Visibile parlare," "223-44. As for the history of printmaking, Parshall, "Introduction," 10, pointed out that "many prints of devotional subjects quite literally 'speak' through the texts that accompany them."

7 Rubach, ANT: LAFRERI FORMIS, 174. All translations are by the author of this chapter.

8 Ibidem, 172.

9 Hollstein, Dutch and Flemish, vol. 5, no. 84; Rubach, ANT: LAFRERI FORMIS, 178.

10 See examples of fifteenth-century German prints, including prayers and indulgences, in Parshall and Schoch, eds., Origins of European Printmaking, esp. 73, 98, 157, 240, 248-50. Fifteenth-century Italian examples can be found in Zucker, "Early Italian Engravings," 366-84. For sixteenth-century prints after a painting by Raphael see Schröter, "Raffaels Madonna di Foligno," esp. 51-55.

11 For further bibliography on the copies made for Lafreri see Rubach, ANT: LAFRERI FORMIS, 174 and 178.

12 It has been suggested that Veneziano did not have time to create the print between the finishing of the panel and its transport to Sicily, so instead of the finished painting, he copied drawings and possibly the modello. Landau and Parshall, The Renaissance Print, 121.

13 Meyer zur Capellen, Raphael, vol. 2, 150.

14 D'Alibrando, Il spasmo di Maria Vergine, 18-19.

15 Shoemaker, The Engravings of Marcantonio Raimondi, 160.

16 Barnes, Michelangelo in Print, 109. Alberti, L'indice di Antonio Lafrery, 343, calls the engraver of the copy Monogrammist CBS because of the letters found in the lower right corner of the image.

17 Barnes, Michelangelo's Last Judgement, 75-78. For the Italian text of Aretino's letter see Aretino, Lettere, 236-39.

18 Rubach, ANT: LAFRERI FORMIS, 202 and 204.

19 The second line might be read as a reference to 2 Corinthians 4:6: "For God, who said, 'Let light shine out of darkness,' made his light shine in our hearts to give us the light of the knowledge of God's glory displayed in the face of Christ."

20 Petrus Canisius, De Maria Virgine incomparabili et Dei genitrice sacrosancta libri quinque (Ingolstadt: David Sartorius, 1577), 100. I worked with the copy that is in Paris, BnF, FRBNF30192176.

21 Ibidem, 291 and 589.

22 Heal, The Cult of the Virgin Mary, 150.

23 Rummel, "Der Heilige und der Kirchenfürst," 175.

24 For the list of the prints with a dedication to Waldburg see Alberti, "Contributi per Antoine Lafréry," 112-14.

25 Overbeeke, "Cardinal Otto Truchsess von Waldburg," 173-79.

26 As Melion, "Quae lecta Canisius offert et spectata Diu'," 259, put it, the woodcut served as "the contemplative image of the Virgin's self-image." Melion analysed different woodcuts of the same images from a later 1583 edition of the treatise. 


\section{Alexandra Kocsis}

27 Naturally, he also emphasised the viewers' awareness of the status of images as representations. Melion, "'Quae lecta Canisius offert et spectata Diu,” 263.

\section{Bibliography}

Alberti, Alessia. L'indice di Antonio Lafrery: origini e ricostruzione di un repertorio di immagini a stampa nell'età della controriforma. Ph.D. dissertation, Università Cattolica del Sacro Cuore, Milan, 2009.

—. "Contributi per Antoine Lafréry: Un editore francese a Roma tra Rinascimento e Controriforma." Annali di critica d'arte, 7 (2011): 75-116.

Areford, David S. The Viewer and the Printed Image in Late Medieval Europe. Farnham: Ashgate, 2010.

Aretino, Pietro. Lettere, il primo e il secondo libro, ed. Francesco Flora. Milan: Mondadori, 1960.

Barnes, Bernadine. Michelangelo in Print: Reproductions as Response in the Sixteenth Century. Farnham: Ashgate, 2010.

Bury, Michael. The Print in Italy: 1550-1620. London: The British Museum Press, 2001.

D'Alibrando, Cola Giacomo. Il spasmo di Maria Vergine: Ottave per un dipinto di Polidoro da Caravaggio a Messina, eds. Barbara Agosti, Giancarlo Alfano, and Ippolita di Majo. Naples: Paparo, 1999.

Heal, Bridget. The Cult of the Virgin Mary in Early Modern Germany: Protestant and Catholic Piety, 1500-1648. Cambridge: Cambridge University Press, 2007.

Hollstein, Friedrich Wilhelm Heinrich. Dutch and Flemish Engravings, Etchings and Woodcuts ca. 1400-1700. Vols. 1-. Amsterdam: Menno Hertzberger, 1954-.

Landau, David, and Peter W. Parshall. The Renaissance Print, 1470-1550. New Haven: Yale University Press, 1994.

Melion, Walter S. “'Quae lecta Canisius offert et spectata Diu’: The Pictorial Images in Petrus Canisius's De Maria Virgine of 1577/1583.” In Early Modern Eyes, eds. Walter S. Melion and Lee Palmer Wandel, 181-201. Leiden: Brill, 2009.

Meyer zur Capellen, Jürg. Raphael: A Critical Catalogue of His Paintings. Vol. 2: The Roman Religious Paintings, ca. 1508-1520. Landshut: Arcos, 2005.

Overbeeke, Noes M. "Cardinal Otto Truchsess von Waldburg and His Role as Art Dealer for Albrecht V of Bavaria (1568-73).” Journal of the History of Collections, 6 (1994): 173-79.

Parshall, Peter. "Introduction: The Modern Historiography of Early Printmaking." In The Woodcut in Fifteenth-Century Europe, ed. Peter Parshall, 9-15. Washington: NGA, 2009.

Parshall, Peter, and Rainer Schoch, eds. Origins of European Printmaking, Fifteenth-Century Woodcuts and Their Public. New Haven: Yale University Press, 2005.

Rubach, Birte. ANT: LAFRERI FORMIS ROMAE: Der Verleger Antonio Lafreri und seine Druckgraphikproduktion. Berlin: Lukas Verlag, 2016.

Rummel, Peter. "Der Heilige und der Kirchenfürst." Jabrbuch des Historischen Vereins Dillingen, 102 (2001): 161-79.

Schmidt, Peter. "The Multiple Image: The Beginnings of Printmaking, Between Old Theories and New Approaches." In Origins of European Printmaking, Fifteenth-Century Woodcuts and Their Public, eds. Peter Parshall and Rainer Schoch, 37-56. New Haven: Yale University Press, 2005.

Schröter, Elisabeth. "Raffaels Madonna di Foligno: Ein Pestbild?" Zeitschrift für Kunstgeschichte, 50 (1987): 46-87.

Shoemaker, Innis H. The Engravings of Marcantonio Raimondi. Lawrence, KA: Spencer Museum of Art, 1981.

Tarr, Roger. " 'Visibile parlare': The Spoken Word in Fourteenth-Century Central Italian Painting." Word \& Image, 13 (1997): 223-44.

Zucker, Mark J. "Early Italian Engravings for Religious Orders.” Zeitschrift für Kunstgeschichte, 56 (1993): 366-84. 
Part III

Images 


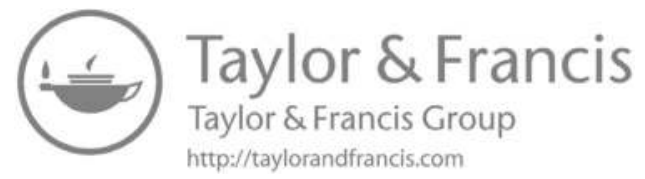




\title{
10 Saint George From Greater Poland Complexities of the Reception of Albrecht Dürer's Engraving
}

\author{
Joanna Sikorska
}

Studying the reception of Albrecht Dürer's art opens up a particular perspective on this phenomenal artist, who enjoyed a special status and truly international renown already in his lifetime. Importantly, analysing the artistic reflections of his oeuvre may sometimes reveal new aspects of the original works. Such conclusions may be drawn when one investigates the sixteenth-century resonance of Dürer's Saint George (Bartsch VII.69.53) (Figure 10.1). The main focus of this chapter is the tombstone of Ambroży Pampowski in Środa Wielkopolska (Figure 10.7), where the programme of the printed prototype interweaves with a commemoration of the dignitary from Greater Poland, an important figure at the Jagiellonian court at the turn of the sixteenth century. ${ }^{1}$

The engraving in question is currently dated to c. $1502-1503 .{ }^{2}$ At that time, Dürer already had a settled workshop in Nuremberg and his prints were distributed beyond his immediate locality. In the first decade of the sixteenth century, his printmaking activity and contacts with German humanists brought the first evidence of his transregional fame. ${ }^{3}$ The small $(11.4 \times 7.2 \mathrm{~cm})$ engraving of Saint George appears to be a typical devotional image of the popular saint. Such isolated representations of saints, apostles or Church Fathers, which constituted almost one-fourth of the graphic output of previous-generation engravers, are much rarer in Dürer's oeuvre. His three prints of Saint George place the saint third in the hagiographic "ranking," right after Saint Jerome (five prints) and Saint Christopher (four prints). Such a high position of Saint George in Dürer's iconographic hierarchy mirrored the popularity of the saint, whose veneration dates back to the fourth century in the East and the seventh century in the West. ${ }^{4}$ The heyday of his worship began in the eleventh century and was associated with the crusade movement. At that time, Saint George became the patron of knighthood, in particular crusaders and royal chivalric orders. At that time, the motif of his struggle with the dragon terrorizing the city of Silene, later popularized in his vita contained in The Golden Legend, became incorporated into his hagiography. In the fourteenth century, Saint George was listed as one of the Fourteen Holy Helpers, and in the fifteenth century-in the new political situation-his worship gained new impetus and became particularly important.

In the discussed print, Dürer did not depict Saint George as a rider in combat with the dragon-the most dramatic moment in his history-but reached for another, equally popular iconographic formula: he showed the saint post factum, as the dragon slayer standing next to the carcass of the beast. Dürer's Saint George stands on a hill against a vast waterside landscape. He is presented as a mature, bearded man in plate armour, wearing a hairnet tied with a band (Schweissband), with a two-handed 


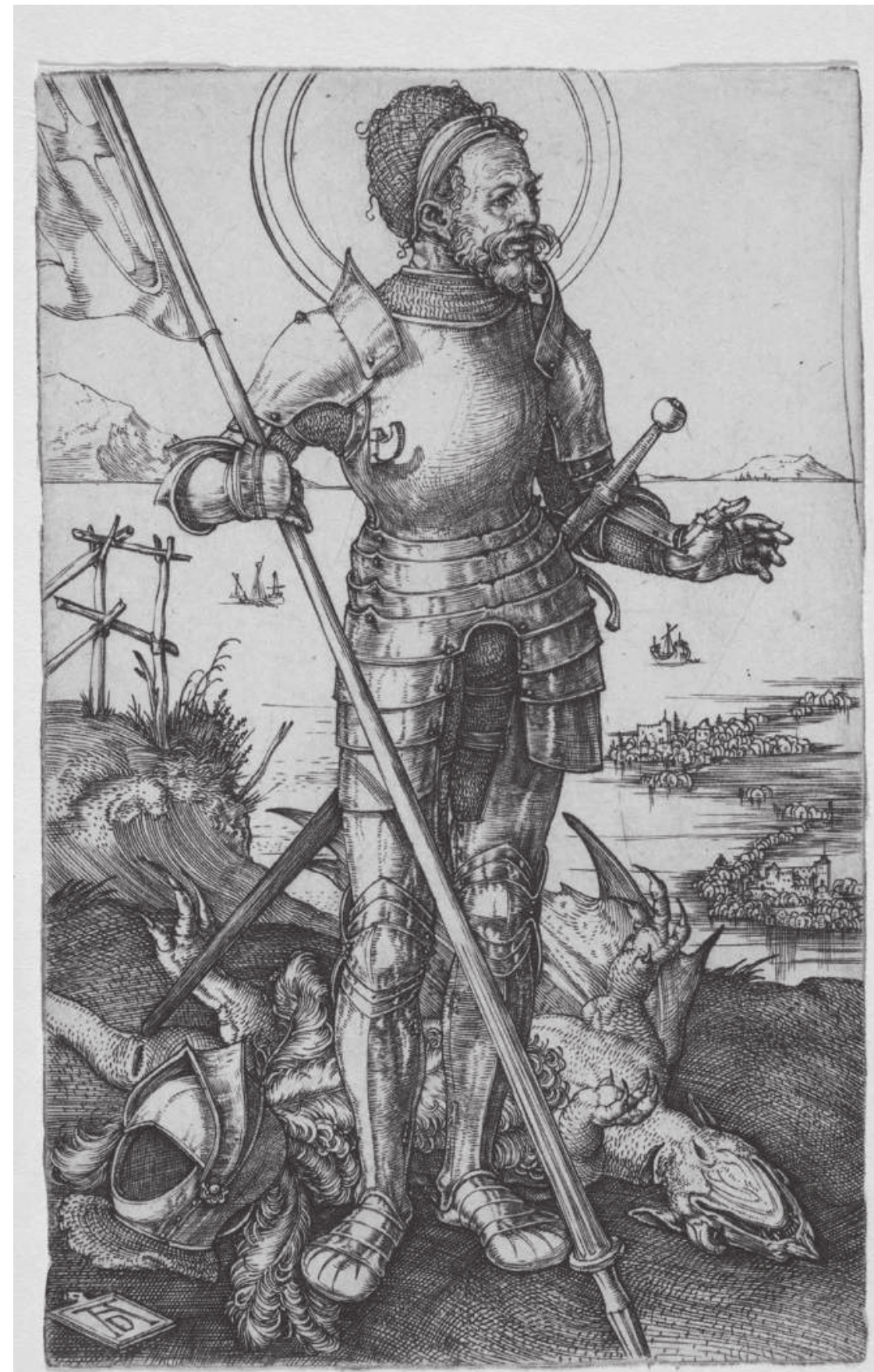

Figure 10.1 Albrecht Dürer, Saint George on foot, c. 1502-1503, engraving. London, The British Museum 1910, 0212.299.

Photo: () The Trustees of the British Museum. 
sword at his side and a lance with a banner in his right hand. The saint's head is encircled by a large halo. At his feet is a plumed helmet, and a tablet with the interlaced monogram $\mathrm{AD}$ is cast on the ground next to him. This is the earliest representation of Saint George in Dürer's oeuvre. In two later prints, the artist pictured the saint in a different manner. In the woodcut from c. 1503 to 1505 (Bartsch VII.138-139.111; Figure 10.2), he depicted the climax of the struggle with the dragon, while the engraving presumably made in 1505 but finished in 1508 (according to the corrected date on the print) employs a more statuary solution-Saint George is presented on horseback and seems engrossed in meditation after killing the dragon (Bartsch VII.70.54). While Dürer did not repeat his earlier solution in the aforementioned prints, he did refer to it in two of his drawn designs. ${ }^{5}$ And though revisiting certain motifs and employing such "self-quotations" was not a rare occurrence in his oeuvre, that does not automatically render it insignificant.

In earlier studies of the engraving in question, researchers focused on the banner atop the saint's lance. This motif has been present in the iconography of Saint George since the twelfth century, but this time the partially visible standard bears not just the usual cross but a cross within a circle. Dodgson recognized it as the emblem of the Order of Saint George, revealing the particular historical and political context of this print. ${ }^{6}$ According to his research, rather than being an ahistorical representation of the legendary dragon slayer, the engraving manifests the special dimension associated with worshipping the patron of European chivalry at the time. In the fifteenth century,

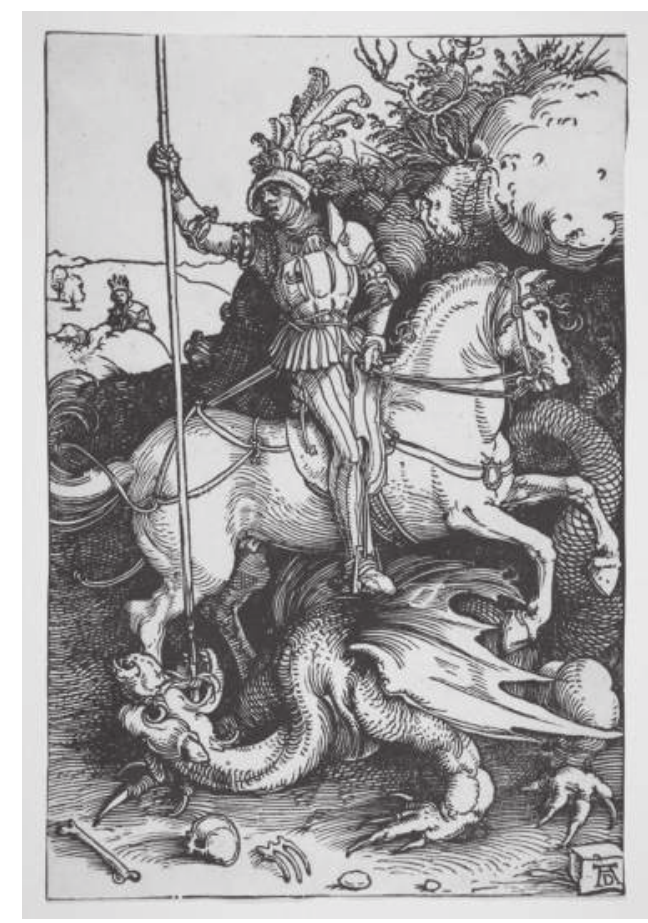

Figure 10.2 Albrecht Dürer, Saint George on horseback, c. 1504, woodcut. New York, The Metropolitan Museum of Art, 1975.653.94.

Photo: New York, The Metropolitan Museum of Art, CC0 1.0. 


\section{Joanna Sikorska}

the veneration of Saint George was renewed in the face of a new confrontation with the Ottoman Empire. The "Ottoman threat" was widely discussed all around Europe, and events such as the conquest of Constantinople, Athens and Bosnia; the siege of Rhodes; or the attack on Otranto showed just how pressing the issue was. Due to the historical rank of Saint George as the patron of crusaders and defenders of the faith, he was also referred to in the context of escalating tensions with the Ottoman Empire. This is what Emperor Frederick II Habsburg did in 1467 when he founded the Order of Saint George. The saint also became the special patron of his son, Maximilian I, who planned to call a crusade against Ottoman Turkey and consequently regain Jerusalem and the Holy Land. ${ }^{7}$ Since the 1490s, this topic had been taken up by the most eminent political figures of the day, and the new crusade seemed imminent. To this end, in 1493 Maximilian I renewed the Order of Saint George founded by his father, established the Brotherhood of Saint George and, in 1503, the Saint George Society (Georgs-Gesellschaft). According to the monarch, societas sancti Georgii was to be an important tool in the preparations to fight the Turks. Drawing both on the traditions of his own house and the court of Burgundy, Maximilian turned Saint George into an important political and artistic propaganda tool. ${ }^{8}$ Two spectacular examples of this may be found in chiaroscuro woodcuts made by Hans Burgkmair the Elder. ${ }^{9}$ In the equestrian representation of Saint George (Bartsch VII.208.23), inscribed Divus Georgius Christianorum militum propugnator, the emblem of the Order of Saint George is repetitively used as a "decorative" motif. A pendant to this work is the portrait of Maximilian I on horseback (Bartsch VII.32). ${ }^{10}$ Both demonstrate a conflation of various threads in the iconography of Saint George: idealizing the past age of chivalry, the Renaissance all'antica stylization and current political issues.

Such heterogeneity is also present in Dürer's Saint George. This comes to light if the focus of analysis is broadened to include another of his engravings: The Standard Bearer (Bartsch VII.98.87; Figure 10.3), created c. 1501 and considered to be a pendant to the print in question. One may find various parallels between the two works. To begin with, the similarities include the dimension, depiction of the figure-on an elevation above a waterside landscape-and general subject (both works rate among the earliest examples of isolated representations of figures carrying banners, a subject that would become greatly popular from the 1510s). Saint George's gesture also suggests that the two prints are related: it resembles the adlocutio gesture, thus gaining an oratorical touch, as if the saint were addressing the (invisible) person standing to his left. Finally, there are the emblems on the banners carried by both figures. In the case of The Standard Bearer, the emblazoned symbol is that of the Order of the Golden Fleece-another famous chivalric order established in $1430 .{ }^{11}$ After the House of Burgundy came to an end, Emperor Maximilian I became the Grand Master of said order as the husband of Mary of Burgundy, daughter of Charles the Bold. The emblem of the Burgundian order, founded to defend and disseminate the Catholic faith and propagate virtues, entered the group of imperial symbols, contributing to the ideological and political weapons of Maximilian I. The fact that both of Dürer's works include banners with the emblems of two chivalric orders which were of utmost importance for contemporary propaganda led Matthias Mende to assume that they may have been commissioned by Maximilian I himself. ${ }^{12}$ However, this hypothesis-not backed by any extant sources-has two flaws. First, the small format of the prints renders them rather modest. Second, the emblems of both orders were not only employed in imperial circles but treated as a universal expression of "German patriotism" at the time. One may wonder whether the presence of these symbols represents yet another 


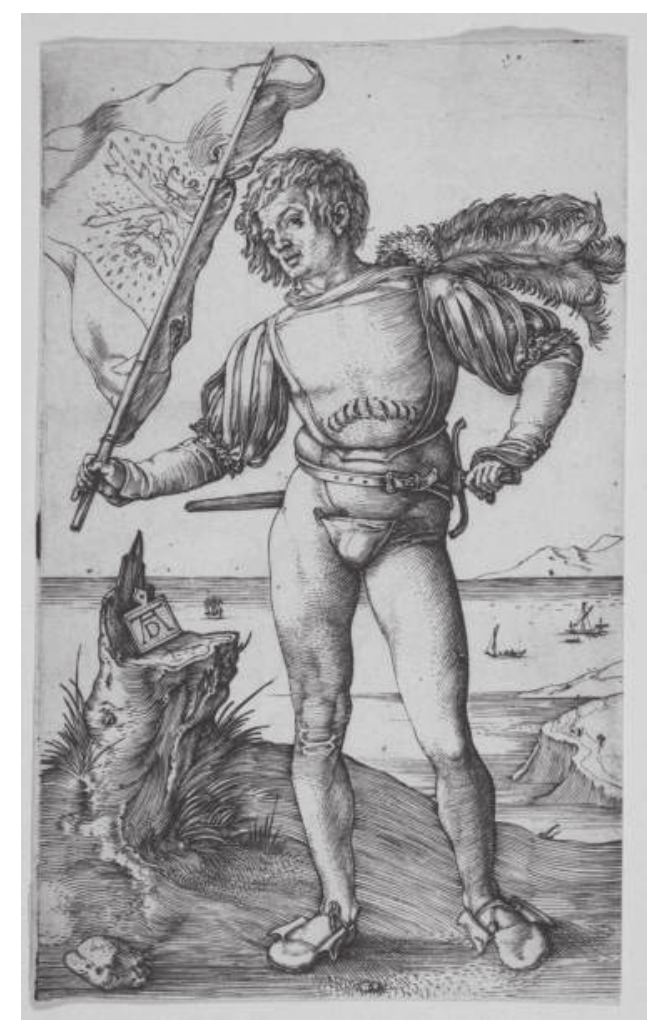

Figure 10.3 Albrecht Dürer, The Standard Bearer, c. 1501, engraving. New York, The Metropolitan Museum of Art, 19.73.99.

Photo: New York, The Metropolitan Museum of Art, CC0 1.

proof of Albrecht Dürer's amazing sense for both attractive and topical subjects. By adding the emblem of the chivalric order established in the fifteenth century to his engraving, he created a contemporary image of Saint George, who could also be interpreted as a Germanic miles Christianus.

If Saint George and The Standard Bearer are treated as a diptych of sorts, seen together, they reveal one of the main artistic questions that occupied Albrecht Dürer. Since c. 1500 , he had been fascinated by human proportion and looking for the ideal human form. The protagonists of the two prints seem to be juxtaposed as opposites. This brings to mind another pair created by the artist soon afterwards: Adam and Eve from the 1504 engraving (B.1), a work regarded as Dürer's artistic creed. The youthful figure of the standard bearer highlights his semi-nude character and swayed pose, which resembles the arrangement of Apollo Belvedere's body-the prototype of Dürer's Adam from 1504. Saint George is depicted differently: the statuary quality of his silhouette is additionally highlighted by the close-up view, giving the impression that the figure is emerging from the composition. Looking for inspiration behind this particular manner of portraying the saint, researchers pointed to Andrea Mantegna's Saint George (c. 1460; Venice, Gallerie dell'Accademia), thereby revealing in the engraving another Italianate tendency in the German master's art. ${ }^{13}$ 


\section{Joanna Sikorska}

It is through comparisons with The Standard Bearer and Mantegna's painting that the unique physiognomy of Saint George comes to light. Dürer opted for the relatively rare variant of depicting the saint as a mature, bearded man. Suggestively, researchers describing this figure have noted his apparent dishevelment, manifested, e.g., by ample and "unkempt" facial hair. ${ }^{14}$ Much more frequently, the patron of Christian chivalry was young and devoid of facial hair-like in Mantegna's representation. This original aspect of Dürer's depiction is emphasized by the large nimbus rendered with individual cuts, a reference to solutions used by the previous generation of engravers (such halos were employed by, among others, Martin Schongauer, e.g., in his prints The Baptism of Christ, Bartsch VI.123.8, and The Nativity, Bartsch VI.120.5). In his engraved images of saints, the Nuremberg artist usually either omitted halos altogether or surrounded their heads with rays of light created by dense lines contrasted with the white sheet of paper. Nimbuses made using individual lines may be found in Dürer's woodcuts (e.g. Bartsch VII.57.38), while the only engraving apart from Saint George to feature this motif is his early work The Virgin and Child with a Monkey (Bartsch VII.60.42; Figure 10.4). In this latter print-like in the case of Saint George-the halo seems to have been added in order to dispel any doubts concerning the identification of the figure and the religious character of the representation, which employed traditional, genre-like conventions of depiction. Saint George owes this genre-like feel to the "realistic" character of the figure, in contrast to the idealizing tendencies visible

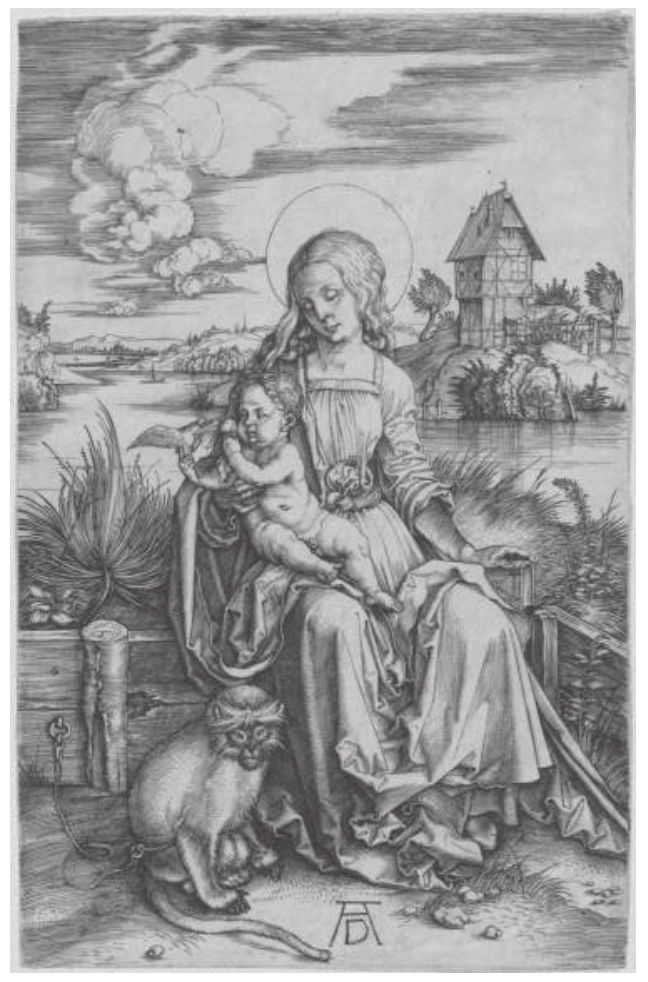

Figure 10.4 Albrecht Dürer, The Virgin and Child with a Monkey, c. 1498, engraving. Warsaw, Muzeum Narodowe w Warszawie, Gr.Ob.N.4991 MNW.

Photo: (C) Warsaw, Muzeum Narodowe w Warszawie. 
in The Standard Bearer. Showing Saint George as a mature, bearded knight could have been a case of conscious archaization (the custom of growing beards did not exist in early sixteenth-century Germany), justified by the print's subject matter. On the other hand, this realistic aspect of the representation suggests that it may have been a stylized portrait. This hypothesis seems plausible when one compares Saint George with other works created by Dürer. First, there is the surprisingly bold nude self-portrait dated to c. 1499 (Weimar, Schlossmuseum; Figure 10.5). ${ }^{15}$ In this drawing, Dürer focused on his body; the bearded face, depicted in a rather sketchy manner, and luxuriant hair pulled back in a hairnet bring to mind the discussed engraving. This observation becomes particularly meaningful given the artist's original physiognomy. His friends and acquaintances were wont to highlight it, calling him barbatus and making humorous comments on the artist's appearance and his concern for his hair and beard. ${ }^{16}$ However, the Weimar self-portrait is not cited here to imply that Saint George is in fact Dürer's crypto-portrait, but to draw attention to the conscious individualization of the saint's facial features.

This may be confirmed by another original reference to the print in question, namely Dürer's drawing dated to c. 1510 (Oxford, Christ Church Library), which contains a selection of self-quotations. ${ }^{17}$ The depicted woman is a mirror image of the figure from The Beheading of Saint John the Baptist, a woodcut from 1510 (Bartsch VII.142.125), while the man accompanying her, in plate armour and hairnet, is a clear reference to

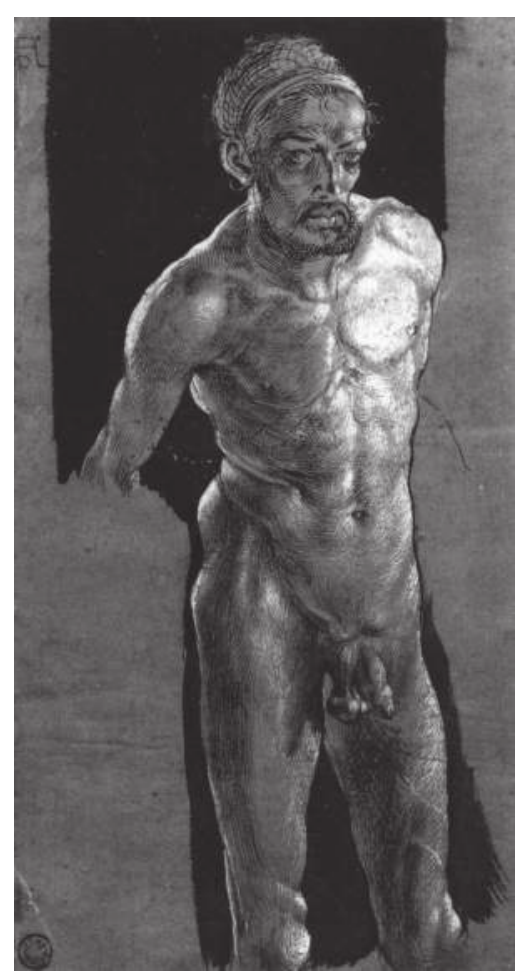

Figure 10.5 Albrecht Dürer, Self-portrait, c. 1499, pen and brush, black ink, heightened with white. Weimar Schlossmuseum, KK 106. 


\section{2}

Joanna Sikorska

the analysed image of Saint George. This drawing was made for the Vischer workshop in Nuremberg as a general design for two tombstones: those of Hermann VIII von Henneberg and his wife Elisabeta von Brandenburg in the Römhild church (c. 1510) and Eitel Friedrich II von Hohenzollern-Hechingen and his wife Magdalena von Brandenburg in the Hechingen church (c. 1512). At the same time, while both gravestones repeat the female figure from Dürer's work rather accurately, the drawn design of the male figure was followed rather freely: the motif of the bare head is omitted, among others, and new attributes are added to each of the figures.

Studying the reception of Dürer's Saint George provides reasons to assume that its "realistic" potential was frequently noticed at the time and treated as an invitation to employ portrait and quasi-portrait formulas. This was used by Lucas Cranach the Elder, who was perfectly familiar with the Nuremberg artist's painted and graphic oeuvre and liked to employ creative references to his works. ${ }^{18}$ Cranach's 1506 woodcut of Saint George (Bartsch VII.285.67; Figure 10.6) represents an early impact of Dürer's original work. The foreground of the print is filled with the monumental figure of the holy knight standing above the slain dragon, accompanied by two angels who help him take off his armour; the background includes the scene of combat with the dragon. Analogies to Dürer's design may be seen in the statuary quality of the figure, the depiction of light and dark on the armour (the engraving means of expression are beautifully translated into the language of woodcut) and the "momentary" nature of the scene, which captures the moment of the knight taking off his armour.

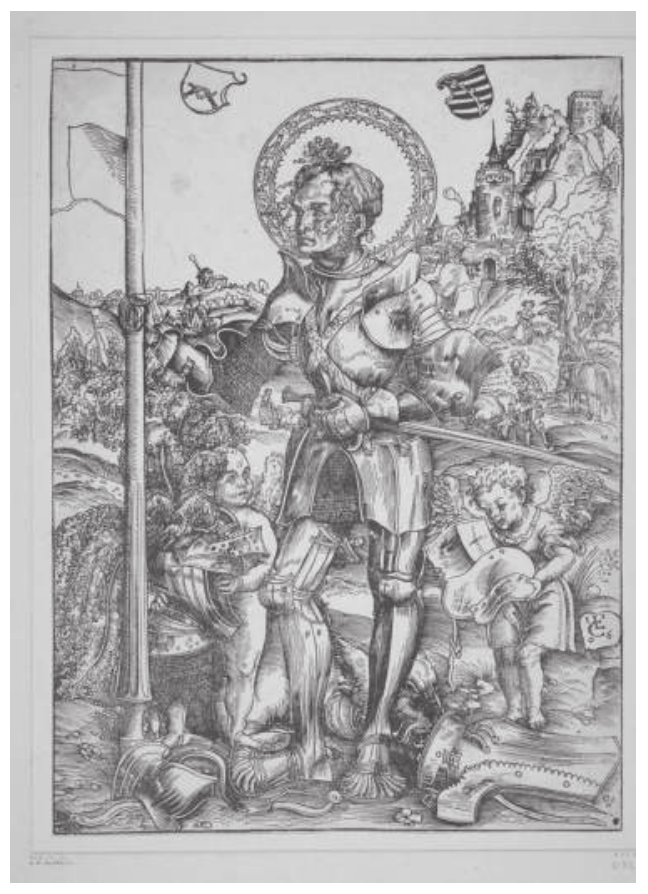

Figure 10.6 Lucas Cranach the Elder, Saint George, 1506, woodcut. London, The British Museum, 1895,0122.265.

Photo: $\odot$ The Trustees of the British Museum. 
Finally, another influence of Dürer's is the giant nimbus, which highlights the "realistic," not conventionalized or typified, manner of depicting the saint's appearance. All of these elements mean that Cranach's woodcut may be analysed as an emulation of Dürer's art.

Another example of the reception of Saint George that does not boil down to automatically copying the composition or juxtaposing its fragments ${ }^{19}$ is the tombstone of Ambroży Pampowski at the collegiate church of the Assumption of the Virgin Mary in Środa Wielkopolska (Figure 10.7). Pampowski, starosta (governor) general of Greater Poland and Prussia, was an efficient diplomat, politician and administrator under subsequent Jagiellonian monarchs, and his life exemplifies the social advance of a representative of the middle gentry and the mechanisms of obtaining high state functions in the Kingdom of Poland. ${ }^{20}$ According to Pampowski's last will, his tombstone was made when he was still alive (the nobleman died after 22 August 1510). Not only did the text outline the general form and place of burial ("near the main altar ... where communion is given"), ${ }^{21}$ but it contained additional dispositions meant to secure prayer service for the deceased's soul. ${ }^{22}$ The Pampowski family also had a chapel of their name in the Sroda church (which did not survive), and according to Bartosz Paprocki's Armorials of the Polish Knighthood, there was a votive inscription next to the starosta's tombstone. ${ }^{23}$ In light of these commemorative efforts, it is likely that Pampowski himself was responsible for the decision regarding the form of his funerary representation. Given the sepulchral character of the work, this would not have been anything out of the ordinary-at the time, tombstones were an important form of public declaration, testifying to the wealth and social status of the deceased, reiterating their lifetime achievements and expressing their hope for eternal life. Importantly, funerary sculptures created at the time, also in the Kingdom of Poland (e.g. works by Veit Stoss and bronze tombs, popular among the elites of Greater and Lesser Poland, made in the Nuremberg Vischer workshop), include eminent examples of a new approach to the portrait as an individualized image. ${ }^{24}$ Since when a tombstone was ordered, the artist could be provided with an image of the person he was to commemorate, it is also likely that the commissioner could indicate a specific formal model-in this case, a print source carrying an important and topical message.

Ambroży Pampowski's tombstone shows him in full plate armour, standing in slight contrapposto. On his head, raised and turned to the right, is a hairnet. His left arm is extended in what resembles the adlocutio gesture, and his right arm rests on the shaft of his lance. He wears a large link chain on his chest. At his left side is a twohanded sword; at his right side, a dagger. At his feet, in the lower right corner of the tombstone, is a sallet with the visor lowered. The figure is depicted against a low wall and enclosed in a profiled frame with escutcheons in the corners (Poronia, Kotwicz, Awdaniec, Three keys). Between them, an inscription in early humanist majuscule reads: HIC IACET MAGNIFICVS d[OMIN]VS AMBROSIVS PAMPOWSKY PALATINVS SIRAdIEN(SIS) QVI OBYT [] A(NNO) d[OMINI] M 510 ("Here lies the Magnificent Lord Ambroży Pampowski, Voivode of Sieradz, who died in the year of our Lord 1510"). Pampowski's pose, the arrangement of his hands and depiction of the armour reveal a general and simplified inspiration from Albrecht Dürer's print. By adopting this design, the tombstone is a relatively rare example of employing an "active" figure in Polish sepulchral sculpture (devoid of the prayer gesture of the hands). ${ }^{25}$ Although researchers have long noted the manner of figurative representation and traced it to its printed origin, ${ }^{26}$ there has so far been no in-depth analysis of whether there are any deeper ties between the chosen commemorative form and 


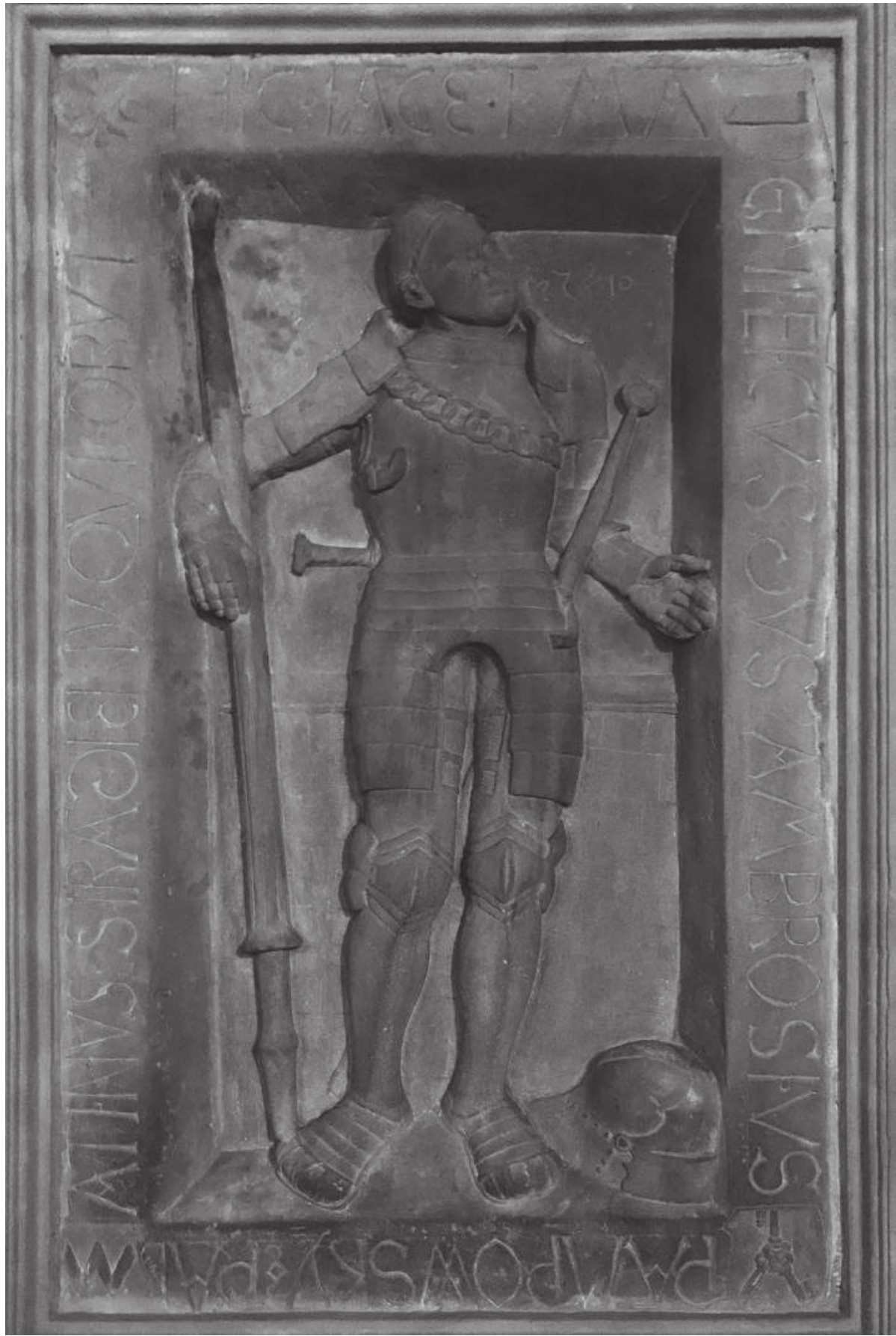

Figure 10.7 Tombstone of Ambroży Pampowski, before 1510, sandstone, Środa Wielkopolska, the collegiate church of the Assumption of the Virgin Mary.

Photo: Tadeusz Sikorski. 
Pampowski's life. However, several facts from the dignitary's biography justify the assumption that he may have deliberately modelled his tombstone on the image of Saint George, which would testify to his political consciousness. Knowledge about the Ottoman threat and crusade plans were widespread at the time (Pope Alexander VI's bull announcing a collection of funds to fight "infidels" was read out in Cracow and Greater Poland in August and September 1499, respectively), and the relevant information may have found its way to Pampowski via various channels. ${ }^{27}$ Studying his biography, one may conclude that - apart from studies at the University of Cracow, where he made contacts and friends that later helped him enter the royal court and chancellery-his political and cultural formation was greatly influenced by foreign diplomatic missions. The one from 1492 merits particular attention: it concerned the dynastic plans of the Jagiellonians, specifically the troublesome arrangements concerning the marriage of Wladislas II of Hungary to Beatrice of Naples. As an envoy, Pampowski found himself at Emperor Frederick III's court in Linz and then-via Venice and Rome-arrived at the Aragon court in Naples. ${ }^{28}$ His stay in the south of Italy coincided with rumours about the Ottoman incursion on the eastern coast of the Neapolitan state; Pampowski's reaction was to immediately leave for Bari to take part in the expected struggle with "the infidels." It is a rather telling fact that, years later, Pampowski's epitaph in the Sroda church referred to this very mission, during which the nobleman witnessed events that were to decide the future course of European politics (e.g., the funeral of Pope Innocent VIII and the election of Pope Alexander VI). ${ }^{29}$

Pampowski was also familiar with a different type of struggle against "the infidels": in the final years of Casimir IV Jagiellon's rule, Tatar raids into Polish-Lithuanian territory had already represented a pressing problem which only grew worse under his son, King John Albert. This must have influenced Jagiellonian policies towards the Ottoman Empire. ${ }^{30}$ In view of this, it is justified to assume that the tombstone design was not treated as a strictly artistic matter to be decided by the (rather mediocre) author. The idea of being commemorated as a knight of Saint George-by reaching for Dürer's design-may have come from Pampowski himself. The attractiveness of this stylization, a popular reference to the chivalric ethos in sepulchral sculpture at the time, may have been dictated not just by the current political situation of the Kingdom of Poland and Christian Europe at large but also the local dimension of the worship of Saint George. At subsequent steps of his career as an official of the crown, particularly when he served as the starosta of Malbork in Prussia, Pampowski must have had multiple contacts with the local Curia Sancti Georgii, an elite brotherhood uniting knights from rich families.

Given the lack of written sources, it is impossible to know for sure whether Pampowski chose the design for his tombstone based solely on the subject matter of representation or also its origin. At the time, the Kingdom of Poland enjoyed a particularly close relationship with Nuremberg-not just in terms of art, although the most important commissions were given to artists from this city. Nuremberg, one of Europe's major trade and artistic centres, a manufacture hub of luxurious goods and-according to the written word-a quasi centrum Europae, ${ }^{31}$ was the city of Veit Stoss, who was active in Cracow, as well as of the Vischer workshop, whose bronze output was highly acclaimed by the elites of Greater and Lesser Poland. Nuremberg was also appreciated as a printing centre. Collaboration with publishers from the city began in the late fifteenth century and gained a specific dimension through the activity of Jan Haller. In 1509, Gdańsk, Poznań, Wrocław and Cracow were among the 
twenty-nine cities where Anton Koberger's agents sold copies of Hartmann Schedel's Liber chronicarum.

It cannot be excluded that Pampowski was aware of the status enjoyed by the author of the printed composition, whose fame had already travelled beyond the borders of his native Franconia. ${ }^{32}$ Pampowski's experience, acquired during his studies at the University of Cracow as well as in the course of his work at the royal chancellery and court, must have influenced his intellectual horizons and interest in art. Consequently, his actions in that respect cannot be seen as merely building the prestige of himself and his family (this is how his donations for the Dębno and Sroda churches may be perceived). ${ }^{33}$ The dignitary was interested in poetry, astrology and astronomy; maintained his private orchestra; kept a book collection; and wrote a diary. Given his interests and historical consciousness, Pampowski could have treated his tombstone as a demonstration of his views. One may wonder, for instance, whether the choice of sandstone for a bas-relief was not a deliberate gesture meant to distance himself from the bronze tombs founded by Greater Poland's elites (a tendency often perceived as a demonstration of magnate ostentation). Pampowski may have consciously opted for a more modest material for his tombstone: as the starosta general of Greater Poland, he tried to limit the influence of magnates, facing stark opposition from representatives of the Górka, Szamotulski, Ostroróg and Bniński families. ${ }^{34}$

By modelling his image on a representation of Saint George-for it may hardly be regarded as a typical stylization as a saint-Pampowski reached for a solution found in many sixteenth-century centres. ${ }^{35}$ Neither was he the only one who used Dürer's engraving of Saint George for this purpose. The same hypothesis was put forward in the case of Imrich Czobor I's epitaph, executed around 1520 (Bratislava, Slovenská národná galéria) and originally placed in the Franciscan monastery in Skalica. The panel clearly employed two of Dürer's designs: the main design is borrowed from a 1508 print depicting the Virgin and Child on a crescent moon (Bartsch VII.52.31); reference was also made to a print from 1513 showing the sudarium held by two angels (Bartsch VII.47.25). ${ }^{36}$ So it is likely that the figure of the knight may have also come from a similar source. The armoured man and "abandoned" helmet motif may have been inspired by the engraving in question. Interestingly, Czobor came across the Ottoman issue as Wladislas II of Hungary's envoy on a diplomatic mission to Sultan Bayezid II. The second example of such a borrowing is the Falkenstein Altarpiece, created after 1530 (Stuttgart, Staatsgalerie; Figure 10.8) by the Master of Messkirch, one of the topmost artists active in the second quarter of the sixteenth century in the region of Sigmaringen. The influence of Albrecht Dürer and his pupils played a crucial role in said master's art. He relied on the discussed print to paint the altar wing with a representation of Saint George and, more precisely, the slain dragon at the saint's feet. Importantly, researchers analysing the details of Saint George's physiognomy are inclined to believe that the depicted man may be one of the counts von Zimmern. ${ }^{37}$

The creation of Pampowski's tombstone before 1510 exemplifies a fast reception of Dürer's engraving. It is striking that a few years later, the same print also inspired St Francis's altarpiece in the Franciscan church of the Holy Trinity in Gdańsk. One of the sections on the wings of the altarpiece (founded by Bartholomäus Schulte in 1515 ) shows a representation of two saints, George and Francis, and the patron saint of knighthood shows a clear influence of the discussed engraving. ${ }^{38}$ Nevertheless, this observation-even given the previous "European" reflections of Dürer's work-says 


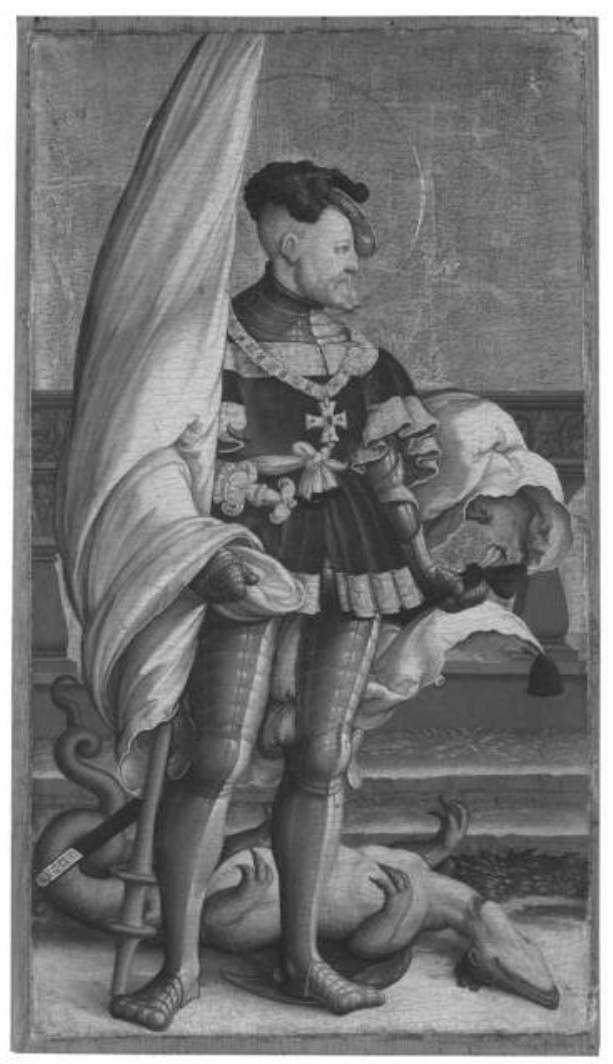

Figure 10.8 Master of Messkirch, Saint George from the Falkenstein Altarpiece. Stuttgart, Staatsgalerie, 1761.

Photo: () Staatsgalerie Stuttgart.

little about the print's circulation..$^{39}$ On the other hand, Pampowski's tombstone represents a significant contribution to our understanding of the reception of Albrecht Dürer's art in the Kingdom of Poland, a topic that still awaits in-depth research. ${ }^{40}$ Furthermore, it may also be analysed within the broader tendency of raising the status of printmaking to an important medium of art, which emerged in the early sixteenth century. A circle of people with whom Pampowski was very familiar also demonstrated a keen interest in the propaganda potential of the graphic arts (e.g. chancellor Jan Laski, one of the executors of Pampowski's will, is the assumed author of the iconographic programme of the so-called Sejm woodcut included in Łaski's Statute published in 1506 by Jan Haller). ${ }^{41}$ While Dürer's prints had already inspired illuminators in Cracow, they began to be employed more frequently around the turn of the $1510 \mathrm{~s}^{42}$ Designs that proved most influential were derived from the series published in 1511, which is also when the dynamics of reception changed and the works of the Nuremberg artist began to circulate faster. The presence in Cracow-in person or through commissioned works-of German artists whose art also drew heavily on the Nuremberg master (Michael Lancz von Kitzingen, Michael von Augsburg, Hans Süss 
von Kulmbach, Georg Pencz and finally Albrecht Dürer's brother Hans) definitely strengthened the influence of Dürer's art. Finally, this predilection for artists from Nuremberg or southern Germany could have influenced the availability and popularity of Dürer's prototypes. What may have halted the reception of his oeuvre in the coming years was associating him with the Reformation, which would imply caution or even suspicion with respect to his works, particularly as the engagement of prints and printmaking in religious disputes became commonplace. ${ }^{43}$ Nonetheless, the surviving works and the case of Michael von Augsburg demonstrate a rather pragmatic approach to confessional disputes with respect to valued artists-the sculptor, exiled from Gdańsk for propagating Lutheranism, arrived in Cracow, where his new patrons were Bishop Piotr Tomicki and Chancellor Krzysztof Szydłowiecki. ${ }^{44}$

Seen in the context of the contemporary reception of Dürer's oeuvre in the Kingdom of Poland, Pampowski's tombstone stands out as a relatively rare example of a work whose design was consciously selected by the donor. In the print in question, Albrecht Dürer expressed both topical political ideas and his own aesthetic and scientific fascinations. The artist's sense for self-promotion is also evident: the tablet with his famous monogram, which Dürer would soon have to protect from copyists and imitators, was cast on the ground like the helmet, as if forming part of Saint George's equipment. In other words, many diverse factors-topical attractiveness or political context, portrayed stylization or artist's reputation-could have had an impact on the popularity of this engraving and its appeal for sixteenth-century recipients.

\section{Notes}

1 The results of my research on the reception of Dürer's Saint George have also been published in: Sikorska, "Św. Jerzy," 5-28.

2 Schoch, Mende, and Scherbaum, eds., Albrecht Dürer, cat. 34; Michel and Sternath, eds., Emperor Maximilian I, cat. 117.

3 Cf. Białostocki, Dürer and His Critics; Bartrum, "Dürer Viewed by His Contemporaries," 9-17; Grebe, "The 'Other Apelles',” 78-89; Bubenik, Reframing Albrecht Dürer.

4 LCI, vol. 6, 365-90.

5 One is a drawing held in Oxford's Christ Church Library, analysed in the further part of this chapter. The second reference is found in Maximilian I's prayer book. The text was composed by the emperor and his advisor, Konrad Peutinger, and the decorations were to be designed by eminent artists. In his design for the page with a prayer to Saint George (Munich, BSB, MS 2 L.impr. membr. 64, fol. 9r), Dürer again depicted the saint as a bearded knight wearing a hairnet with a banner in hand. In doing so, not only did he refer to his own engraving but also to a solution employed in the Paumgartner Altarpiece (Munich, Alte Pinakothek), where one of the donors is depicted as Saint George holding a standard with a cross in one hand and in the other the dragon, which is thus transformed into the saint's "personal" attribute. Cf. Koerner, The Moment of Self-Portraiture, 227; Michel and Sternath, eds., Emperor Maximilian I, 93-94.

6 Dodgson, Albrecht Dürer, cat. 46.

7 Cf. Winkelbauer, "Kaiser Maximilian und St. Georg," 523-50; Füssel, "Die Funktionalisierung der 'Türkenfurcht'," 9-30; Silver, Marketing Maximilian; Housley, Crusading and the Ottoman Threat.

8 Some researchers even associate the growing popularity of representations of Saint George with preparations for the imperial coronation in 1508. Cf. Silver, Marketing Maximilian, 102-3; Gnann, In Farbe!, 30; Michel and Sternath, eds., Emperor Maximilian I, 325.

9 Cf. Röver-Kann, ed., Künstler und Kaiser, cat. 18, 19; Michel and Sternath, eds., Emperor Maximilian I, cat. 112; Gnann, In Farbe!, cat. 1, 2.

10 The impact of this print may already be traced in Cracow around 1520 in the form of a painting most likely made in Stanisław Samostrzelnik's studio and designated for the 
collegiate church of Saint George on Wawel Hill. Piwocka and Nowacki, Wawel 10002000 , cat. I. 39.

11 Cf. Schoch, Mende, and Scherbaum, eds., Albrecht Dürer, cat. 31; Michel and Sternath, eds., Emperor Maximilian I, cat. 117; Silver, "Civic Courtship," 134-48; Smith, "Dürer im Dienst des Kaisers und der Fürsten,” 309-13.

12 Löcher, Martin Luther, cat. 48.

13 Cf. Böckem, "The Young Dürer and Italy," 52-64; Bernard Aikema et al., eds., Dürer e il Rinascimento.

14 Michel and Sternath, eds., Emperor Maximilian I, cat. 117.

15 Dürer, focused on the aesthetic dilemmas concerning representation and idealization, elevated the self-portraits to a new dimension. Koerner, The Moment of Self-Portraiture, 35-37 and 239-42; Metzger, ed., Albrecht Dürer, cat. 1.

16 Koerner, The Moment of Self-Portraiture, 169; Grebe, "The 'Other Apelles'," 86-89.

17 Winkler, Die Zeichnungen Albrecht Dürers, no. 489.

18 Cf. Röver-Kann, ed., Künstler und Kaiser, cat. 11; Brinkmann, ed., Cranach, cat. 11, 107, 116; Grebe, Dürer, 243-46.

19 Cf. Strauss, ed., Sixteenth Century German Artists, cat. 53; Vogt, Das druckgraphische Bild, cat. 71, 233.

20 Wiesiołowski, Ambroży Pampowski; idem, “Ambroży Pampowski,” 105-7.

21 The tombstone was originally set in the floor of the chancel and may now be seen in the southern aisle. In the nineteenth century, it was moved from its original location to the right of the main altar. This is how it was noted by Raczyński, Wspomnienia, vol. 1, 291-92.

22 Cf. Ulanowski, ed., Acta capitulorum, no. 1653.

23 Bartosz Paprocki, Herby rycerztwa polskiego ... (Cracow: Maciej Garwolczyk, 1584), 225.

24 Cf. Mrozowski, Polskie nagrobki gotyckie, 95-104.

25 It is interesting to compare the tombstone in question with that of Mikołaj Tomicki in the Tomice church. Both were likely made in the same workshop, but Tomicki's figure is considerably less elaborate than Pampowski's. Ibidem, 115, cat. I.119.

26 Cf. Kohte, Verzeichnis der Kunstdenkmäler, 284. Dolczewski (“Geneza i rozwój,” 140) suggested that Pampowski's figure may have been modelled on the representation of Saint George from Albrecht Dürer's Paumgartner Altarpiece. The reference to Dürer's model is also noted by Wiesiołowski, Ambroży Pampowski, 154-55; and Mrozowski, Polskie nagrobki gotyckie, 115.

27 The information may have come from Pampowski's father Jan, commander of the Order of St John in Poznań. Wiesiołowski, Ambroży Pampowski, 68-69.

28 Pampowski made an itinerary of his diplomatic mission. Ibidem, 40-49.

29 See note 23.

30 The turning point was 1497, but even later the concept of diplomatic relations with Turkey underwent changes depending on which groups of interests were more influential. Likewise, the impact of broader European tendencies related, e.g., to the jubilee year 1500 or the diplomatic activity of Alexander VI, should not be disregarded. Cf. Wiesiołowski, Ambroży Pampowski, 68-75; Tafiłowski, Imago Turci.

31 Cf. Neuhaus, "Nürnberg in der Welt,” 20-28; Maué, ed., Quasi Centrum Europae.

32 A geographically close admirer of Dürer's art was the Cracow-born bishop of Wrocław Jan Thurzo. Cf. Grebe, Dürer, 34-36.

33 E.g., in 1496, Pampowski founded a retable for the church in Dębno, which features an image of himself and his first wife Zofia, née Kot (currently in Poznań, Muzeum Archidiecezjalne). Labuda, "Malarstwo tablicowe," 316. Cf. Wiesiołowski, Ambroży Pampowski, 146-61.

34 Ibidem, 63-65.

35 The most famous examples include the Paumgartner Altarpiece and an etching by Daniel Hopfer showing Emperor Maximilian I as Saint George. Cf. Metzger, Daniel Hopfer, cat. 55; Michel and Sternath, eds., Emperor Maximilian I, cat. 115.

36 Smith, "Albrecht Dürer," 14-15.

37 Wiemann, Der Meister von Messkirch, 126-30.

38 The painted parts of this retable are associated with the workshop of Michael of Augsburg. Also noteworthy in the aforesaid section is the wall motif in the background, echoing the one on Pampowski’s tombstone. Cf. Woziński, "Michał z Augsburga,” 26 and 75. 
39 The run of the print is unknown, but it could have been widely circulated as indicated, among other examples, by information about it being printed on various papers. When analysing known prints, Meder listed six "quality" variants, including the poorer, grey impressions, indicating subsequent editions (Meder, Dürer-Katalog, no. 55). Furthermore, the composition had already been copied in the sixteenth century-Heller lists eight and Strauss, ed., Sixteenth Century German Artists, B.53 ten copies. This implies considerable popularity of the representation-cf. there are ten known copies of Adam and Eve from 1504. Copyists were also fond of compositions from the Engraved Passion (up to twenty copies) and the Small Passion (up to seventeen copies) as well as representations of the Virgin (e.g., The Virgin and Child With a Monkeyi-fifteen copies).

40 Cf. Chojecka, "Der Einfluss," 161-72.

41 Cf. Miodońska, "Przedstawienie państwa polskiego," 19-69.

42 Chojecka, "Der Einfluss," 164-72; Olszewski, Pierwowzory, 91; Miodońska, Małopolskie malarstwo ksiażkowe, 175; Piwocka and Nowacki, eds., Wawel 1000-2000, cat. I.24.

43 See the case of woodcarver Jan before the bishop's court in Cracow in 1544. Ptaśnik, ed., Cracovia impressorum, no. 513 and 211.

44 The king interceded on his behalf, and the sentence was retracted a year later. Cf. Jakubowska, “Michel,” 503-6; Woziński, “Michał z Augsburga,” 5-91.

\section{Bibliography}

Aikema, Bernard et al., eds. Dürer e il Rinascimento tra Germania e Italia. Milan: 24 ORE Cultura, 2018.

Bartrum, Giulia. "Dürer Viewed by His Contemporaries.” In Albrecht Dürer and His Legacy: The Graphic Work of a Renaissance Artist, ed. Giulia Bartrum et al., 9-17. London: British Museum Press, 2002.

Białostocki, Jan. Dürer and His Critics, 1500-1971: Chapters in the History of Ideas Including a Collection of Texts. Baden-Baden: Koerner, 1986.

Böckem, Beate. "The Young Dürer and Italy: Contact With Italy and the Mobility of Art and Artists Around 1500." In The Early Dürer, eds. Daniel Hess and Thomas Eser, 52-64. Nuremberg: Verlag des Germanischen Nationalmuseums, 2012.

Brinkmann, Bodo, ed. Cranach. Exhibition catalogue. Frankfurt/M: Städel Museum; London: Royal Academy of Arts, 2007.

Bubenik, Andrea. Reframing Albrecht Dürer: The Appropriation of Art, 1528-1700. Farnham: Ashgate, 2013.

Chojecka, Ewa. "Der Einfluss Albrecht Dürers auf die Kunst des 16. Jahrhunderts in Polen." In Ernst Ullmann, Albrecht Dürer: Zeit und Werk: Eine Sammlung von Beiträgen zum 500: Geburtstag von Albrecht Dürer, eds. Günter Grau and Rainer Behrends, 161-72. Leipzig: Karl Marx Universität, 1971.

Dodgson, Campbell. Albrecht Dürer: Engravings and Etchings. London: Medici Society, 1926. Dolczewski, Zygmunt. "Geneza i rozwój renesansowego nagrobka z figurą stojącą w Wielkopolsce.” In Studia nad renesansem w Wielkopolsce, ed. Tadeusz Rudkowski, 131-45. Poznań: Państwowe Wydawnictwo Naukowe, 1970.

Füssel, Stephan. "Die Funktionalisierung der 'Türkenfurcht' in der Propaganda Kaiser Maximilians I." In Osmanische Expansion und europäischer Humanismus (Pirckheimer Jabrbuch für Renaissance- und Humanismusforschung: 20), ed. Franz Fuchs, 9-30. Wiesbaden: Harrassowitz, 2005.

Gnann, Achim. In Farbe! Clair-obscur-Holzschnitte der Renaissance: Meisterwerke aus der Sammlung Georg Baselitz und der Albertina in Wien. Munich: Hirmer, 2013.

Grebe, Anja. "The 'Other Apelles' and the 'Painter With the Bushy Beard': Dürer as a Subject in German Literature Around 1500." In The Early Dürer, eds. Daniel Hess and Thomas Eser, 78-89. Nuremberg: Verlag des Germanischen Nationalmuseums, 2012.

—. Dürer: Die Geschichte seines Ruhms. Petersberg: Michael Imhof Verlag, 2013. 
Housley, Norman. Crusading and the Ottoman Threat, 1453-1505. Oxford: Oxford University Press, 2013.

Jakubowska, Bogna. "Michel." In Słownik artystów polskich i obcych w Polsce działających (zmarlych przed 1966 r.), Vol. 5, 503-6. Warsaw: Instytut Sztuki PAN, 1993.

Koerner, Joseph Leo. The Moment of Self-Portraiture in German Renaissance Art. Chicago: University of Chicago Press, 1993.

Kohte, Julius. Verzeichnis der Kunstdenkmäler der Provinz Posen. Vol. 3: Die Landkreise des Regierungbezirks Posen. Berlin: Verlag von Julius Springer, 1896.

Labuda, Adam. "Malarstwo tablicowe w Wielkopolsce, na Kujawach i Mazowszu." In Malarstwo gotyckie w Polsce, eds. Adam S. Labuda and Krystyna Secomska, Vol. 1, 311-32. Warsaw: DiG, 2004.

Löcher, Kurt, ed. Martin Luther und die Reformation in Deutschland. Nuremberg: Verlag des Germanischen Nationalmuseums, 1988.

Maué, Hermann, ed. Quasi Centrum Europae. Nuremberg: Verlag des Germanischen Nationalmuseums, 2002.

Meder, Joseph. Dürer-Katalog: Ein handbuch über Albrecht Dürers Stiche.Vienna: Verlag Gilhofer \& Ranschburg, 1932.

Metzger, Christof. Daniel Hopfer: Ein Augsburger Meister der Renaissance: Eisenradierungen, Holzschnitte, Zeichnungen, Waffenätzungen. Berlin: Deutscher Kunstverlag, 2009.

- ed. Albrecht Dürer. Munich: Prestel, 2019.

Michel, Eva, and Maria Luise Sternath, eds. Emperor Maximilian I and the Age of Dürer. Munich: Prestel, 2012.

Miodońska, Barbara. "Przedstawienie państwa polskiego w 'Statucie Łaskiego' z r. 1506." Folia Historiae Artium, 5 (1968): 19-69.

- Małopolskie malarstwo ksiażkowe 1320-1540. Warsaw: Wydawnictwo Naukowe PWN, 1993.

Mrozowski, Przemysław. Polskie nagrobki gotyckie. Warsaw: Zamek Królewski w Warszawie, 1994.

Neuhaus, Helmut. "Nürnberg in der Welt: Der Blick von aussen auf die Reichsstadt an der Pegnitz in Spätmittelalter und Früher Neuzeit." Anzeiger des Germanischen Nationalmuseums, (2002): 20-28.

Olszewski, Andrzej M. Pierwowzory graficzne późnogotyckiej sztuki małopolskiej. Wrocław: Zakład Narodowy im. Ossolińskich, Wydawnictwo Polskiej Akademii Nauk, 1975.

Piwocka, Magdalena, and Dariusz Nowacki, eds. Wawel 1000-2000: Wystawa jubileuszowa. Vol. 1: Kultura artystyczna dworu królewskiego i katedry. Cracow: Zamek Królewski na Wawelu-Państwowe Zbiory Sztuki, 2000.

Ptaśnik, Jan, ed. Cracovia impressorum XV et XVI saeculorum, Lwów/Lviv: Zakład Narodowy im. Ossolińskich, 1922 (Monumenta Poloniae Typographica XV et XVI saeculorum, vol. 1).

Raczyński, Edward. Wspomnienia Wielkopolski to jest województw poznańskiego, kaliskiego i gnieźnieńskiego. Poznań: Drukarnia “Orędownika,” 1842.

Röver-Kann, Anne, ed. Künstler und Kaiser: Albrecht Dürer und Kaiser Maximilian I: Der Triumph des römisch-deutschen Kaiserhofes. Bremen: Hauschild, 2003.

Schoch, Rainer, Matthias Mende, and Anna Scherbaum, eds. Albrecht Dürer: Das druckgraphische Werk. Vol. 1: Kupferstiche, Eisenradierungen und Kaltnadelblätter. Munich: Prestel, 2001.

Sikorska, Joanna. "Św. Jerzy z Wielkopolski: Meandry recepcji miedziorytu Albrechta Dürera.” Biuletyn Historii Sztuki, 81 (2019): 5-28.

Silver, Larry. Marketing Maximilian: The Visual Ideology of a Holy Roman Emperor. Princeton, NJ: Princeton University Press, 2008.

—. "Civic Courtship: Albrecht Dürer, the Saxon Duke, and the Emperor." In The Essential Dürer, eds. Larry Silver and Jeffrey Chipps Smith, 134-48. Philadelphia: University of Pennsylvania Press, 2010. 


\section{Joanna Sikorska}

Smith, Jeffrey Chipps. "Albrecht Dürer and Eastern Europe.” Ars, 42 (2009): 5-22.

- "Dürer im Dienst des Kaisers und der Fürsten.” In Dürer: Kunst-Künstler-Kontext, eds. Jochen Sander et al., 309-13. Munich: Prestel, 2013.

Strauss, Walter L., ed. Sixteenth Century German Artists: Albrecht Dürer. New York: Abaris Books, 1981 (TIB, Vol. 10; formerly Vol. VII, pt. 1).

Tafiłowski, Piotr. Imago Turci: Studium $z$ dziejów komunikacji społecznej $w$ dawnej Polsce (1453-1572). Lublin: Wydawnictwo UMCS, 2013.

Ulanowski, Bolesław, ed. Acta capitulorum nec non iudiciorum ecclesiasticorum selecta. Vol. 2: Acta iudiciorum ecclesiasticorum dioecensum Gnezensis et Poznaniensis (1403-1530). Cracow: Akademia Umiejętności, 1902.

Vogt, Christine. Das druckgraphische Bild nach Vorlagen Albrecht Dürers (1471-1528): Zur Phänomen der graphischen Kopie (Reproduktion) zu Lebzeiten Dürers nördlich der Alpen. Munich: Deutscher Kunstverlag, 2008.

Wiemann, Elsbeth, ed. Der Meister von Messkirch: Katholische Pracht in der Reformationszeit, Staatsgalerie Stuttgart. Munich: Hirmer, 2017.

Wiesiołowski, Jacek. Ambroży Pampowski-starosta Jagiellonów: Z dziejów awansu społecznego na przełomie średniowiecza i odrodzenia. Wrocław: Zakład Narodowy im. Ossolińskich, 1976.

——. “Ambroży Pampowski.” Polski Słownik Biograficzny, 25 (1980): 105-7.

Winkelbauer, Walter. "Kaiser Maximilian und St. Georg.” Mitteilungen des Österreichischen Staatsarchivs, 7 (1954): 523-50.

Winkler, Friedrich. Die Zeichnungen Albrecht Dürers. Berlin: Deutscher Verein für Kunstwissenschaft, 1937.

Woziński, Andrzej. "Michał z Augsburga, Mistrz Paweł i epilog gotyckiej rzeźby gdańskiej.” Rocznik Historii Sztuki, 27 (2002): 5-91. 


\title{
11 Changing Fortunes \\ Dürer's Nemesis and the Beham Brothers
}

\author{
Matgorzata Łazicka
}

"Fortuna is not a substantial term, but rather a variable form which can serve various functions in different historical contexts." The notion of the goddess of fortune, its meanings and its historical representations have been widely discussed in many research disciplines, including literature, philosophy and art history. Throughout the centuries, this notion has evolved and developed in different ways. In terms of iconography, in the antique pagan tradition, Fortuna's attributes, in most cases, consisted of wings, indicating divinity; cornucopia, which was the source of happiness; a rudder that symbolised the ability to steer the course of human lives; and a small Pluto, the god of wealth. A distinctive feature of the personification was also the wheel of fortune, which first appeared in literature. Fortuna was illustrated sometimes as seated or standing on the wheel or on a sphere, which symbolised the variability and uncertainty of her gifts. Some representations showed her as the one turning the wheel, from which human fate was hanging. Fortuna's power was limited according to the Christian interpretation of the Middle Ages. ${ }^{2}$ However, the belief that the power was controlled by Divine Providence allowed the idea to survive this period.

In the early modern period, the image of fortune produced by Albrecht Dürer proved particularly prominent and became a source of inspiration for various German artists. It first appeared in an engraving called Little Fortune (Bartsch VII.92.78); ${ }^{3}$ then in a drawing that shows Fortune in profile to the left, with a separate study of a wing; and, finally, in the famous engraving dated around 1501 (Bartsch VII.91.77; Figure 11.2). The latter has been titled The Great Fortune by Adam von Bartsch, but subsequently identified as Nemesis, the goddess of justice, revenge and reward, based on Dürer's mention in his diary of his journey to the Netherlands of 1521, which probably referred to this print. ${ }^{4}$ It played a significant role in shaping the sixteenth-century iconography not only of Fortune but also of Nemesis, Venus and others. The resemblance in these various types of representations, as well as the use of several motifs in a single concept, attests to the development of such images in the graphic arts and the creativity of the artists. It seems that those who interpreted these topics always recalled the masterpiece and then developed its modifications.

Sebald Beham (1500-50), one of the so-called Nuremberg Little Masters, has interpreted this motif twice as per records: for the first time in an etching titled Fortune in 1520 (Bartsch VIII.169.139; Figure 11.1) and 21 years later in a pair of engravings Fortuna and Infortunium (Bartsch VIII.169.140 and 141; Figures 11.3 and 11.4). The earlier print is a clearly ironic and not serious interpretation of Dürer's Nemesis. A naked, corpulent woman, with her back turned and her right profile visible, is standing firmly on a globe. As Dürer's Nemesis, Beham's Fortuna has the bridle, the symbol of temperance, and a fragment of drapery, which actually does not cover any 


\section{Matgorzata Lazicka}

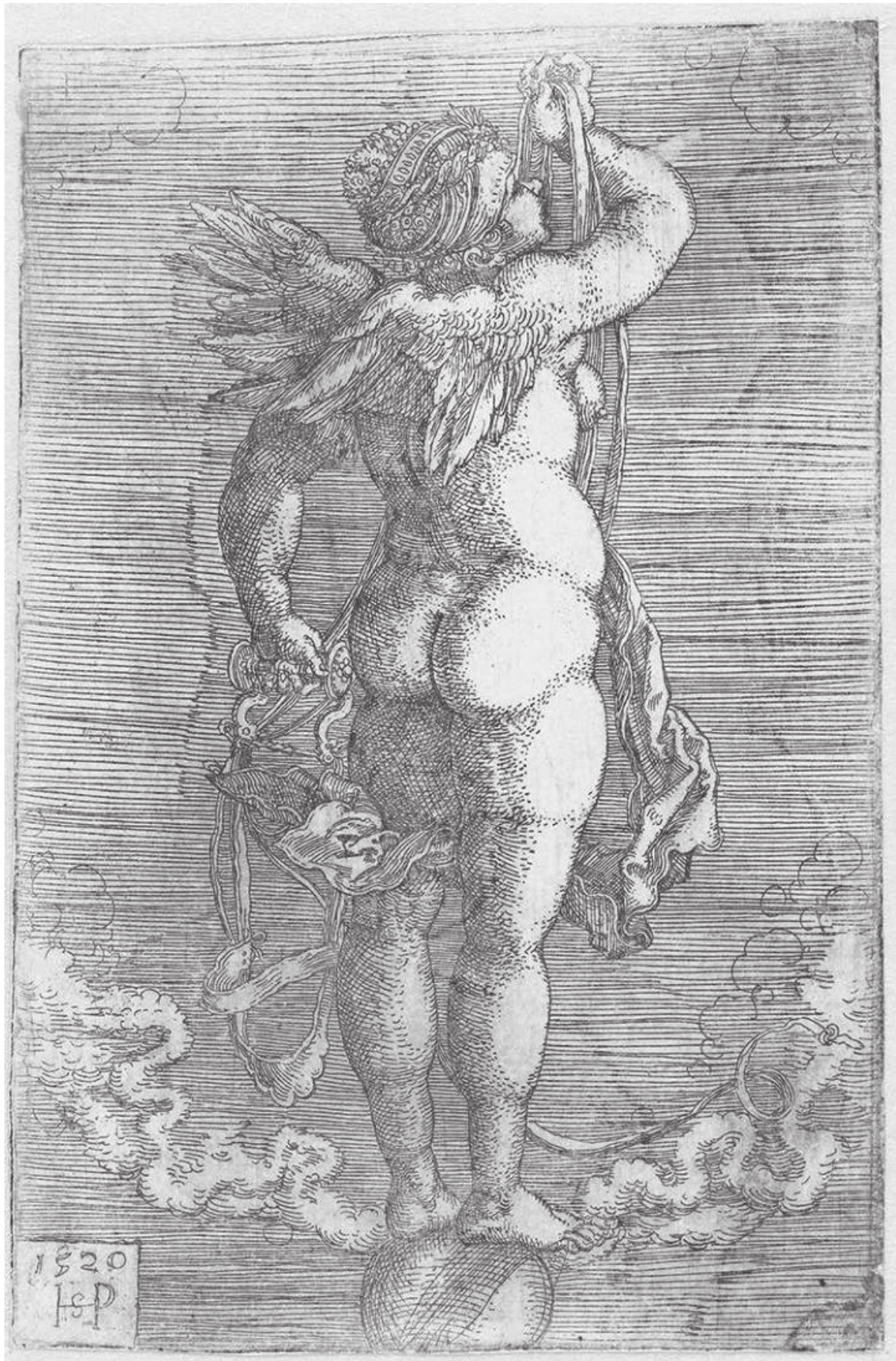

Figure 11.1 Sebald Beham, Fortuna (Fortune), 1520, etching. Amsterdam, Rijksmuseum, RP-P-OB-10.854,0.

Photo: http:/hdl.handle.net/10934/RM0001.COLLECT.31199, CC0 1.0. 


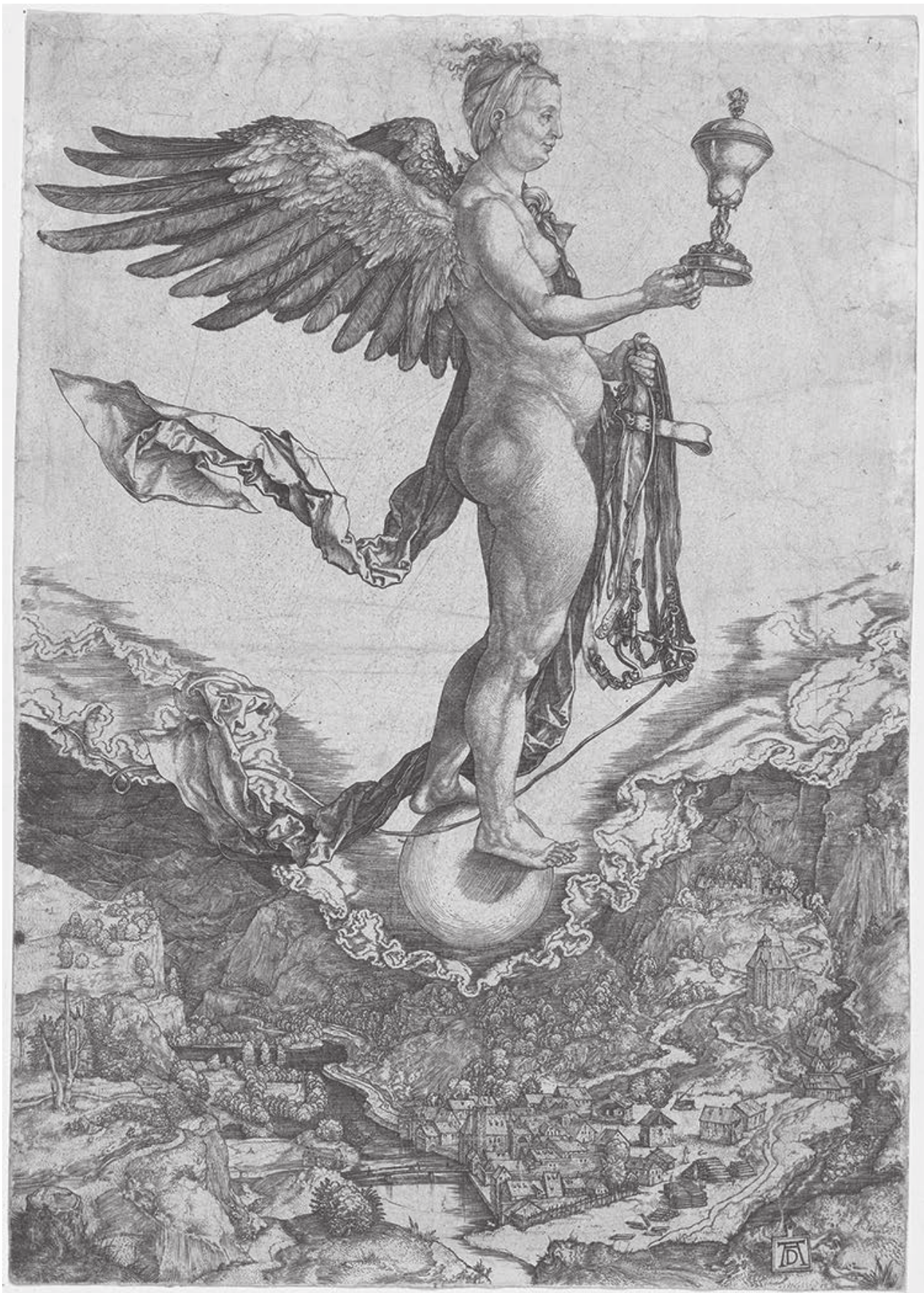

Figure 11.2 Albrecht Dürer, Nemesis or The Great Fortune, engraving. Amsterdam, Rijksmuseum, RP-P-OB-1240,1.

Photo: http://hdl.handle.net/10934/RM0001.COLLECT.33187, CC0 1.0. 


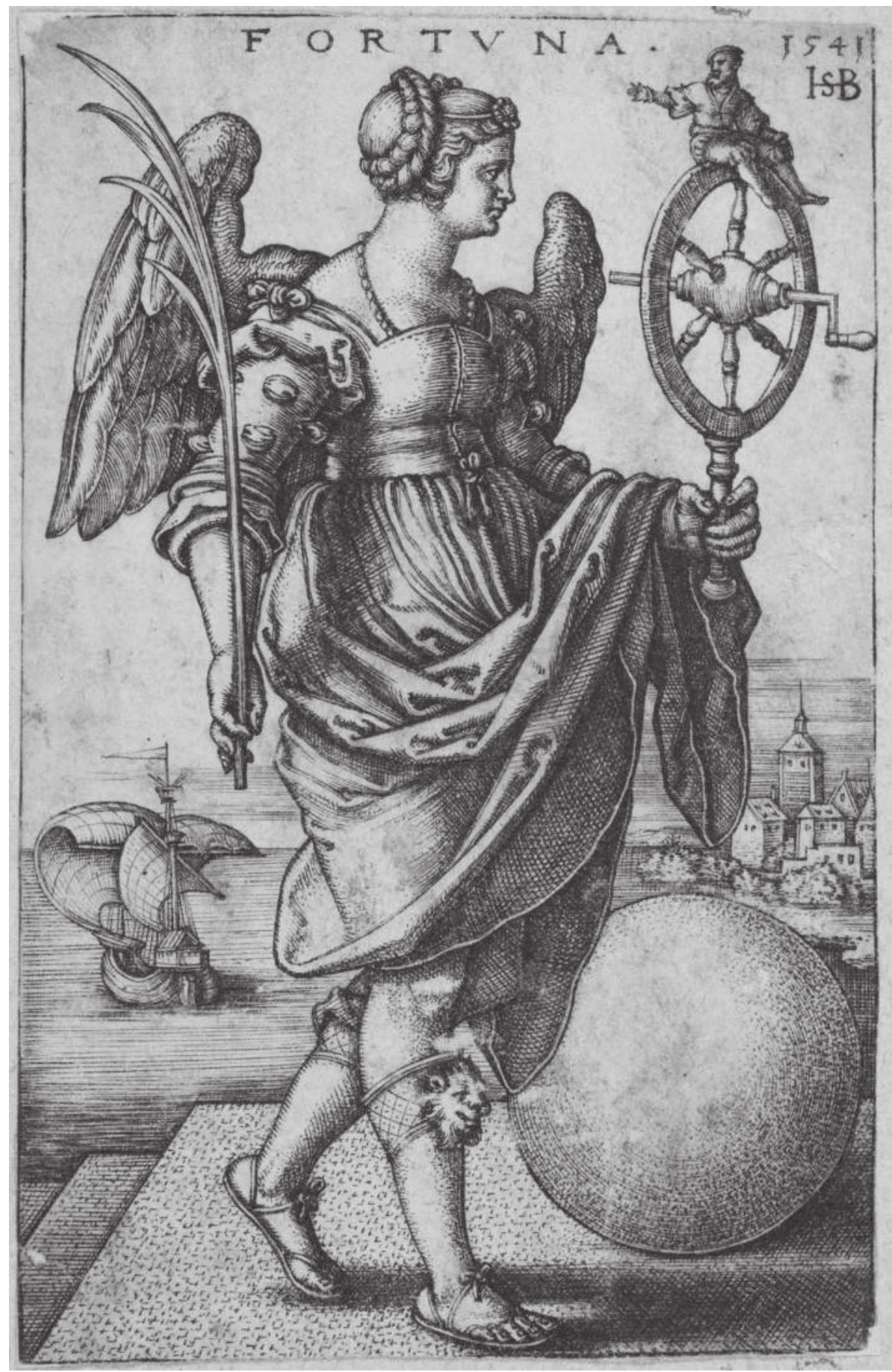

Figure 11.3 Sebald Beham, Fortuna (Fortune), 1541, state II/V, engraving. Warsaw, Biblioteka Uniwersytecka w Warszawie, Gabinet Rycin, Inw.zb.d. 3868.

Photo: Warsaw, Biblioteka Uniwersytecka w Warszawie, Gabinet Rycin. 


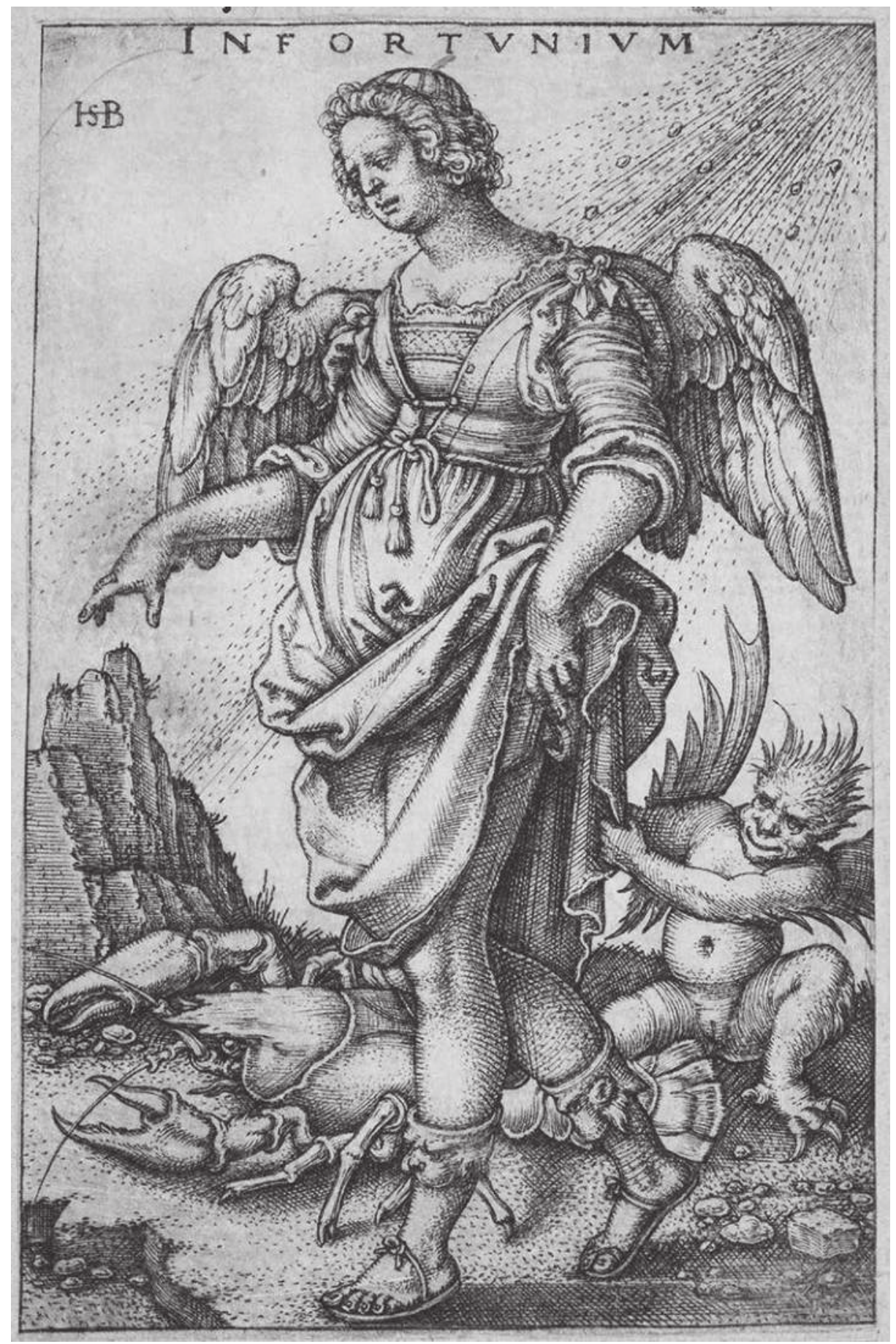

Figure 11.4 Sebald Beham, Infortunium (Misfortune), 1541, state III/IV, engraving. Warsaw, Biblioteka Uniwersytecka w Warszawie, Gabinet Rycin, Inw.zb.d. 3869.

Photo: Warsaw, Biblioteka Uniwersytecka w Warszawie, Gabinet Rycin. 
part of her body. The way of depicting the strips of clouds around the figure's feet is also similar to Dürer's image. However, she exhibits a different gesture, with one hand directed down and the other one raised high-comparable to the famous motif of holding a snake by Laocoön. ${ }^{5}$ With her muscular legs and arms and small wings, she looks like a colossal putto. ${ }^{6}$ Her stocky posture is an obvious contrast to the ideal beauty of the woman in Dürer's engraving, presented according to a Vitruvian canon, based on mathematical rules. ${ }^{7}$ The landscape has also been omitted by Sebald and replaced with regular hatching. Another important aspect of Beham's print is the technique. He used an etching, a rarity in the artist's oeuvre, to make the image more vivid through the use of the spontaneous lines, and he modelled the figure using energetic points, short lines and hatchings. Thus, the young, 20-year-old Sebald, who was not even an apprentice at that time, took part in this artistic dialogue by creating a completely different image that, at the same time, bore a direct reference to the ideal pattern. In a sense, he tried to compete with Dürer, probably his former teacher, still alive at the time, by re-formulating the subject in an ironical way. Beham's self-confidence and his challenge to the master can be inferred from a 1528 episode. That year Beham was accused by the Nuremberg council of copying Dürer's unpublished treatise on the proportions of horses and, as a consequence, was expelled from his home city. ${ }^{8}$

Modifications in terms of style and iconography, with an ironic touch, were also present in prints by Barthel Beham (1502-40), Sebald's brother. ${ }^{9}$ This specific formula is evident, for example, in an engraving entitled Genius on a Globe, Flying above a Landscape created by the young artist also in 1520 (Bartsch VIII.96.29; Figure 11.5). ${ }^{10}$ A winged genius sitting on a globe hovers in aerial space, defeating the adverse vortices and winds, marked with dynamic, twisting lines. The terrestrial zone below is separated from the upper one by a streak of clouds. The landscape consists of rural buildings at a stream and a narrow footbridge leading to them. Although it was Dürer who popularised the motif of a putto as an individual subject in works of art, Barthel Beham reformulated this image by presenting the figure as flying. Again, it was an obvious reference to the famous Nemesis. Beham's hefty and round-shouldered genius seems to be balancing on the globe, trying not to fall as he battles the resistance of the wind. The print, almost a caricature, negated the ideal proposed by the master. Beham's Genius was a contradiction of Dürer's model, mainly because of proportions of the represented figure. According to Vitruvius, the body of a figure should have the length of eight heads, while the hunched putto, as broad as high, measured no more than three heads. The chunky figure, along with the globe, filled almost the entire space of the upper part of the composition, which lent the engraving a paradoxically monumental character, despite its miniature size. ${ }^{11}$

The figure of a genius was often combined with that of Fortune, emphasising his role in the personal happiness and prosperity of a man. Two objects evoke this connection: the globe and a handle the putto holds on to, reminiscent of a walking stick, resembling, in turn, the sticks held by the geniuses in Dürer's or Albrecht Altdorfer's prints. ${ }^{12}$ Barthel Beham's Genius was interpreted in many ways. Some scholars emphasised the engraver's self-confidence as an artist. By transferring the composition of the famous Nemesis to an engraving with miniature dimensions and, at the same time, demonstrating technical excellence, Beham possibly compared himself to the young genius, boldly ascending heights available only to a chosen few. As an alleged student of Dürer, Beham probably knew the master's opinion, expressed in Treatise on Proportions, that it is not the format of the work that determines the artist's rank, but the talent given to them by God that makes them a genius. ${ }^{13}$ 


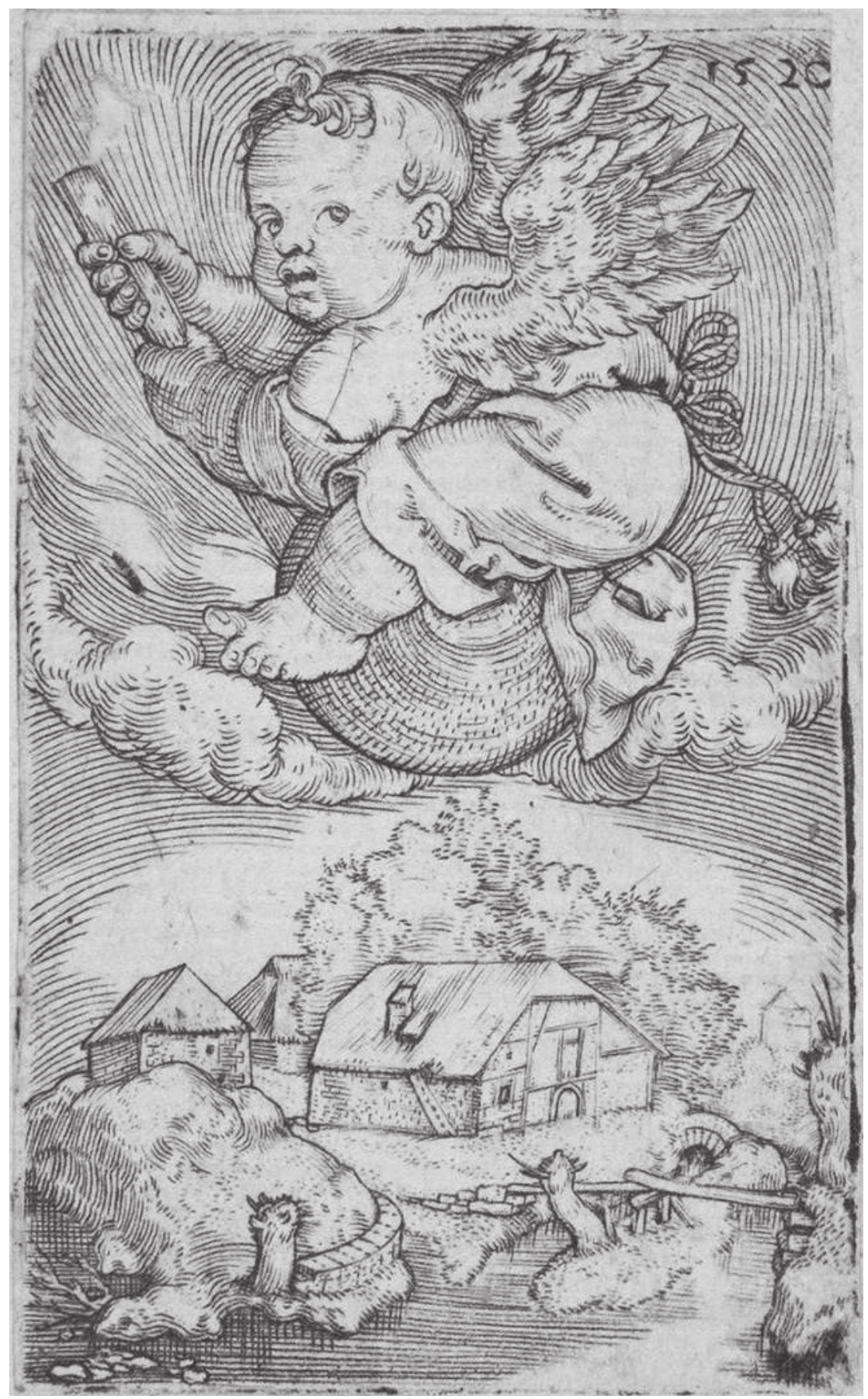

Figure 11.5 Barthel Beham, Genius on a Globe, Flying above a Landscape, 1520, state I/I, engraving. Warsaw, Biblioteka Uniwersytecka w Warszawie, Gabinet Rycin, Inw.zb.d. 3749.

Photo: Warsaw, Biblioteka Uniwersytecka w Warszawie, Gabinet Rycin. 
The idea, derived from antiquity, of a genius who transmitted messages from gods to people, was incorporated into Christian thought during the twelfth century by philosophers and poets, including Alan de Lille and Bernard Silvestris. ${ }^{14}$ The concept, proposed by the latter, influenced sixteenth-century German art and literature. The figure of a genius played a significant role in two poems, Landsknechtspiegel and Der Tod zuckt das Stüllein, both written by Hans Sachs, a Nuremberg Meistersinger, known for his cooperation with the Beham brothers. ${ }^{15}$ Sachs's works often agreed well with the topics in, and were sometimes even directly related to, the graphic productions of the Little Masters. ${ }^{16}$ It is noteworthy that in one of his poems, Sachs mentions Fortune and describes her as "changeable, unfaithful and dancing luck" (das unsthet, untrew, waltzend glück). Although there is no direct link between the stories in Sachs's literary works and Beham's engraving, the similarity in their topics is evidence that the Beham brothers' graphic oeuvre was influenced by contemporary literature, which, in turn, was based on some earlier philosophical concepts or literary tradition.

This may be epitomised by Sebald Beham's Fortuna and Infortunium of 1541 (Bartsch VIII.170.140 and 141). ${ }^{17}$ These two engravings form a sort of diptych with the main characters situated prominently in the foreground creating a sense of exceptional depth. Also, the proportions between the heads and the rest of the monumental bodies are slightly unconventional. ${ }^{18}$ The division of the notion of fortune can be traced back to late antiquity. For instance, Boethius in The Consolation of Philosophy (c. 524) not only perceived fortune, fate or destiny as being stronger than the mind-which he had valued greatly until that moment-but also described her as blind and with two faces (vultus ambigui), which served as the basis for a new type of representation: the concept of Fortuna anceps and bifrons. ${ }^{19}$ The illustrations that accompanied some later editions of Boethius's work depicted the splitting of the figure into Fortuna bona and Fortuna mala. ${ }^{20}$ The drawing in Glossarium Salomonis, dated 1165, which represents a two-headed Fortuna, is one of the earliest examples of this kind of representation. ${ }^{21}$ After 1400, the main source for developing the topos of the bipolar Fortuna was Alain de Lille's Anticlaudianus (VII, 8-VIII, 2). ${ }^{22}$ Like Boethius's depiction, de Lille's Fortuna holds the wheel on which man's fate hangs. Moreover, the author describes the place where she lives: a rock protruding from the sea, which is influenced by the tides and continual waves of change. Alain combined the simultaneous existence of happiness and unhappiness and the continuous changes to this state of mind in a complex allegory, which was incorporated into the traditions of both literature and art. ${ }^{23}$ This concept was well expressed in a woodcut illustration to Margarita philosophica by Gregor Reisch, a famous compendium for students, published for the first time in Strasbourg in $1503 .{ }^{24}$ The print depicts the wheel of fortune with four men on each side and the female personification in the middle. The woman is holding two goblets: one is full and the second one is turned down, so the contents are falling out. The first goblet symbolises material, worldly fortune, while the other one represents misfortune.

The juxtaposition of the positive and negative nature of Fortune in one image, showing a double-headed or double-faced figure, was common in the works of art before 1500 but not afterwards. ${ }^{25}$ Nevertheless, it is unlikely that any of the earlier representations could have served as a direct inspiration for Fortuna and Infortunium. The original approach to presenting this pair of prints in two separate compositions was not known in either the Middle Ages or in the sixteenth century. Therefore, such a solution was exceptional and unprecedented. It was Beham's own invention to 
juxtapose these two images and to combine both typical and atypical attributes. He broadens the visual concept by referring to the medieval idea and, at the same time, to the new model proposed by Dürer and modified by other artists.

Beham's Fortune of 1541 (Figure 11.3) is a winged, whole-length female figure in profile, stepping on to a podium to her right. Her outfit-a robe with slightly puffy, decorative sleeves_-gives an impression of being an expensive one. Her elegant appearance is complemented with a pearl necklace, a small diadem on her head and a refined hairstyle, as well as pads with lion heads on her shins. Such pads were worn by the ancient foot soldiers, and they alluded to the power of fate-sometimes it is good luck, sometimes bad luck, but it is always fate that decides people's lives. ${ }^{26}$ In her right hand, she holds a palm leaf, which symbolises victory and success, whereas in the left one, she has a wheel of fortune with the rudder, on top of which sits a male figure. A palm leaf is Beham's addition to the typical repertoire of Fame's attributes. A sphere lying on the ground is an element developed in the early modern iconography. It symbolises perfection and volatility but, at the same time, instability and uncertainty. The main character is positioned in a unique manner: not on the sphere as usual, but next to it. ${ }^{27}$ Moreover, in the majority of the sixteenth-century images, the sphere replaced the wheel, whereas Beham portrayed both items, one above another.

The background of the engraving shows a seascape, with a ship to the left and a few buildings on the right. The juxtaposition of the sea and the pedestal emphasises the lability of water and the stability of the ground. Interestingly, the motif of a ship with unfurled sails, which symbolised favourable wind conditions, was not common either in the medieval or in the early modern representations of Fortuna. Many of the aforedescribed elements-water, the sphere and the rudder-may be found in works of contemporary Italian artists, including Fortuna by Nicoletto da Modena. ${ }^{28}$ Instead of flying above the landscape, the frontally depicted figure in Nicoletto's version is drifting on water, surrounded by rocks, buildings and mountains. Given the sailing accessories, the rudder and the robe in the shape of a sail, the personification was associated with Venus searching for her male partner. ${ }^{29}$ The connection between Fortune and water can be traced back to the ancient figure of Tyche, who was associated with the ebb and flow of the sea. She was one of the Oceanids mentioned by Hesiod in the hymn of Demeter as one of Persephone's companions. The goddess, among others, began to be assimilated in the personification of Fortuna because she did not appear in any myth. Moreover, the Greek word tyche, which means "fate," "chance" or "opportunity," was a synonym of the Latin fortuna. ${ }^{30}$ Tyche was also compared to the sea in Boethius's Consolation of Philosophy.

Beham also referred back to the traditional model of the wheel of fortune with people placed around it, which was still present in the sixteenth-century prints, such as in Georg Pencz's woodcut Wheel of Fortune (1534) ${ }^{31}$ or Hans Weiditz's drawing inscribed Als Midt der Zeydt ("in the course of time") (1519). ${ }^{32}$ The latter showed the wheel with four figures and a hand in the clouds holding a rope that controlled the rotation. The drawing was clearly connected to two woodcuts by the same artist completed by 1520 that illustrated Petrarch's dialogues about good and bad luck in human life, De remediis utriusque fortunae, translated into German and published in Augsburg in 1532 (one repeated on title pages of both parts and the second one on fol. SIIIv [first part]). ${ }^{33}$ Weiditz's woodcut used on title pages depicts the wheel of fortune driven by four winds. The motif of God's hand appearing in the clouds, present in Weiditz's drawing, occurred also in the aforementioned Pencz's woodcut in which a blindfolded 


\section{2}

\section{Matgorzata Łazicka}

Fortune is turning the wheel with six people who are controlled by the invisible power in the sky. This idea was deeply rooted in the medieval tradition, which emphasised the control of the Divine Providence over Fortune. In contrast, the man sitting on the rudder in Beham's Fortuna (1541) is not dependent on God, but solely on Fortunahe keeps his head and hand turned in the woman's direction as if asking her to stop turning the wheel exactly at the moment when he is at its top.

Another Fortune's feature that appeared in medieval literature was its erotic character. However, also in images created after 1500 "the relation of man and Fortuna gained increasingly erotic and blatant sexual aspects." ${ }^{34}$ Interpretations which accentuated this aspect were proposed, for example, by two Swiss artists, Niklaus Manuel Deutsch and Urs Graf. ${ }^{35}$ Deutsch's Venus was inspired by Dürer's Nemesis with regard to the pose and the attributes; however, the Cupid standing on her shoulders signified her as the goddess of love. Thus, the sexual meaning was more in focus. Sebald Beham could have learned of the erotic aspect from both the medieval literature and from the Swiss artists' works or the copies made after their compositions. He introduced it to some extent in his Infortunium, a pendant engraving to Fortuna.

Beham's representation of bad luck, or Infortunium (Figure 11.4), is a winged woman stepping to the left and wearing a rather casual dress. Her wings are smaller than Fortuna's and seem to be lowered. One of Misfortune's hands is pointing probably to the rocks at the left, and the other is holding the robe. The sexual connotations are expressed in the rolling up of Infortunium's dress by a clearly female devil. A similar motif of the devilkin occurred earlier in Graf's drawing, Fortune as a prostitute (1520) that depicts a woman standing on the globe, holding her dress blown by the wind so that her legs and private parts are exposed. ${ }^{36}$ The emphasis here is on Fortuna's promiscuity. Although inspired by Nemesis, the unclassical appearance, the goblet from which dark smoke is rising and the presence of a little imp changed the meaning of Graf's composition. This drawing was also interpreted in the context of Pandora's box, which emphasises the negative aspects of Fortuna. ${ }^{37}$

Sebald's Infortunium can also refer to the personification specific only to the Germanspeaking countries, Fran Welt-a woman equivalent of Fürst der Welt ("the prince of the world"), another term for the devil. Her front side was attractive, but the back showed vermin, snakes and toads. The image personified the deceitfulness of the world and the transience of human life. The connotation between Misfortune and Frau Welt is even more emphasised by the presence of the small devil-like creature, an original element in Beham's work..$^{38}$ According to the Christian interpretation, Fortune was an instrument of God and a special executive of the Creator. Thus, one may conclude that the juxtaposition of Fortuna, a long-standing symbol of providence, with Infortunium, accompanied by the devil, was a well-thought-out combination invented by Sebald Beham.

The personification of bad luck is accompanied not only by the small devil but also by a huge crayfish which was perceived in folklore as unhappy because of its tendency to walk backwards; therefore, it came to allude to failure and misfortune. ${ }^{39}$ All the figures are surrounded by a barren landscape with stones, while brimstone is raining down from the upper right corner, also symbolising bad luck. Rocks and crayfish were symbols typical of earlier images of Fortuna.

The fact that Beham's personifications of Fortune and Misfortune are dressed is a distinctive feature of both images, which is reflective of medieval imagery rather than Beham's contemporary style. Nudity, which was introduced by Dürer's Nemesis, is a typical attribute of the majority of the sixteenth-century personifications of good 
and bad luck. One of the exceptions was Heinrich Aldegrever's engraving Fortuna from the series Virtues and Vices (1549, Figure 11.6). The drapery of her robe is reminiscent of the medieval pictorial tradition. Further, a blend of the early and modern iconography is visible in the depiction of both the wheel and the sphere, as in Beham's engraving. Interestingly, Fortuna and Infortunium, as well as Aldegrever's print, were created in 1540s, so they were more distanced in time from the Middle Ages than the majority of the earlier representations of Fortuna. Thus, this may indicate a conscious return to the medieval tradition by the two artists.

Interpreting the subject in such an original form resulted in later repetitions of the two compositions. Gustav Pauli mentioned four printed copies of Fortuna, including Christoffel van Sichem's woodcuts and two made after Infortunium, one of them again by van Sichem. ${ }^{40}$ Moreover, the compositions of both engravings served as a pattern for the figures on a stove tile from the third quarter of the sixteenth century, made in Rhineland. ${ }^{41}$ Interestingly, the personification of Misfortune was chosen to be part of the decoration of a silver goblet from the sixteenth century, which is stored in the Museum of Applied Arts in Budapest. ${ }^{42}$

Sebald Beham might have been familiar with both the literary and iconographic traditions of depicting Fortuna, including the idea of her double nature. His images of Fortune show approaches of an artist to a well-known theme that he realised in the different stages of his career. Beham's etching of 1520 serves as an example of a witty dialogue with the serious topic and a great piece of art made by Albrecht Dürer, who was already well renowned at that time. The simplification achieved by the grotesque appearance of the woman, which contrasts to the ideal of beauty, as well as the omission of the landscape, surely changed the way the image of the goddess was perceived by making it more "common." Additionally, using a more difficult technique could also be a way of emphasising Beham's self-consciousness as an independent artist, who moved a step further than his master.

Whereas both Sebald and Barthel Beham prints of 1520 might be regarded as ironic responses to Dürer's Nemesis by two young engravers, the 1541 Fortuna and Infortunium must be considered a more sophisticated concept elaborated by a mature artist. The division of one notion into two figures-good and bad luck-was not borrowed from Dürer's works. Instead, it had its roots in various sources: first, in the writings of the ancient and medieval philosophers and humanists, German translations of these texts and contemporary poems; second, in the earlier medieval imagery, including book miniatures and prints; and finally, in the sixteenth-century prints and drawings made in Italian- and German-speaking countries, which served as a source of various motifs and attributes. In fact, it appears that the traditions rooted in literature influenced this pair of prints more than those in illustrations. By returning to a subject at the height of his career and presenting significant familiarity with both early and modern literature and iconography, Beham strengthened his own position as a conscious and talented engraver. It appears that he succeeded in dissociating himself from the great Nuremberg master and proved his abilities as an independent artist, capable of modifying well-known motifs in an unconventional and original fashion by combining tradition with innovation. Last but not least, one should not neglect the economic aspect of producing these two prints. As in many other cases of Beham's works, they were expected to be bought together. For the artist, it was more lucrative to sell two prints to a buyer. Further, as a pair, these engravings, depicting a popular motif but in an interesting form, were more attractive to the audience. 


\section{Matgorzata Eazicka}

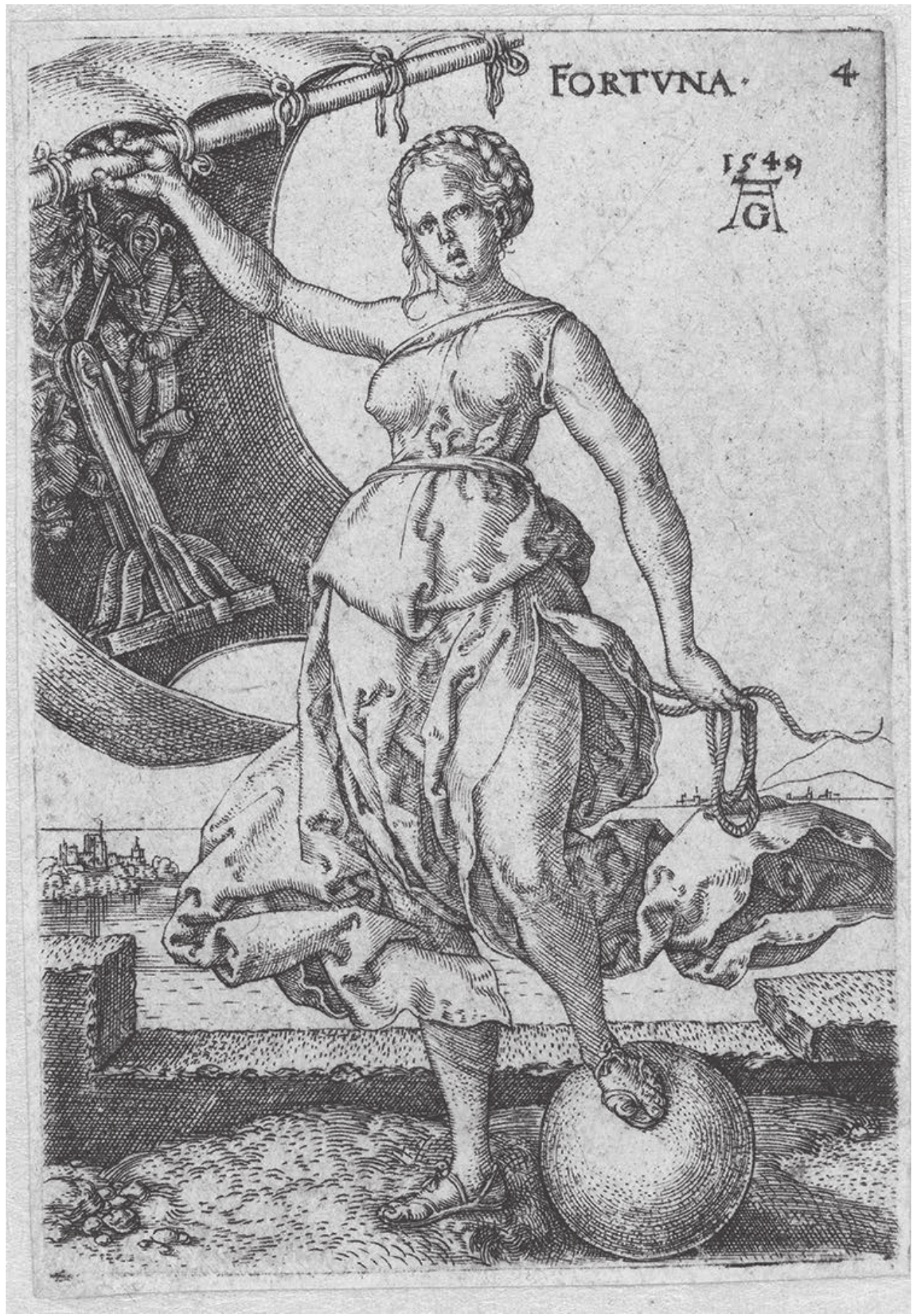

Figure 11.6 Heinrich Aldegrever after Cornelis Anthonisz, Fortuna (from the series Virtues and Vices), 1549, engraving. Amsterdam, Rijksmuseum, RP-P-OB-2723,2.

Photo: http://hdl.handle.net/10934/RM0001.COLLECT.30546, CC0 1.0. 


\section{Notes}

1 Buttay, "La Fortune victime des Lumières?" 207-8.

2 Holländer, "Die Kugel der Fortuna," 150-51; Brendecke and Vogt, "Introduction," 1-4.

3 Cf. Russell and Barnes, Eva/Ave, 211, cat. 138; Schoch, Mende, and Scherbaum, Albrecht Dürer, 36-37, cat. 5.

4 Cf. Albrecht Dürer, "Tagebuch der Reise in die Niederlande." In idem, Schriftlicher Nachlass, vol. 1, ad indicem. The print was interpreted repeatedly; recently: Russell and Barnes, Eva/Ave, 212, cat. 139; Schoch, Mende, and Scherbaum, Albrecht Dürer, 95-99, cat. 33; Roth, Ullrich, Anzelewsky, et al., Dürers Mutter, 79, cat. 38. About the title, see Appuhn-Radtke, "Fortuna Bifrons," 138-39.

5 Kaschek, "Kühnes Kinderspiel," 143.

6 Emison, "The Little Masters," 35.

7 Panofsky, Hercules am Scheidewege, 347.

8 Despite the prohibition, Beham's treatise was issued in Nuremberg by Hieronymus Andreae in 1528. More about this episode cf. Kurthen, "Zum Problem der Dürerschen"; Smith, Nuremberg, 96, cat. 95 and 176; Stewart "Sebald Beham," 17.

9 Such an ironic interpretation created even earlier included Albrecht Altdorfer's Allegorical winged female figure (1510, engraving); Goddard, The World in Miniature, cat. 2; Russell and Barnes, EvalAve, 214, cat. 140; Kaschek, "Kühnes Kinderspiel,” 148, fig. 7.

10 Giulia Bartrum emphasised that the technical aspects and originality of the composition were unusual for such a young age; Bartrum, German Renaissance Prints, 123. Cf. Łazicka, The Print Room, 36-39, cat. 10.

11 Emil Waldmann highlighted this feature, describing the theme of the engraving as A Genius Sitting on a Cannonball; this identification, however, seems to be erroneous, Waldmann, Die Nürnberger Kleinmeister, 79.

12 Strauss, ed., Sixteenth Century German Artists, 58, cat. 67 (82), 70, cat. 78 (92), 68, cat. 76 (91); Hollstein, German, vol. 1, no. 78; Goddard, ed., The World in Miniature, 67-68.

13 Ibidem, 68; Müller, “Albrecht Dürer's," 183; Kaschek, "Kühnes Kinderspiel,” 150.

14 Knowlton, "The Allegorical Figure," 380-84; Goddard, ed., The World in Miniature, 67, refers to Nitzsche, The Genius Figure, 80, 115.

15 Hans Sachs, "Landsknechtspiegel," in Zeitgedichte und Schwänke, ed. Karl Martin Schiller, 25-34. Several woodcuts and engravings by the Beham brothers bear texts by Hans Sachs; it was a two-way cooperation-sometimes the prints were adapted to the content of the poems, and sometimes the poems were created as comments to the Little Masters' works.

16 About these relations, see: Freitag-Stadler, Die Welt des Hans Sachs; and Lazicka, "Tańce chłopskie," 196-97.

17 The etching was analysed in the context of other representations of Fortune in: Kaschek, "Kühnes Kinderspiel," 142-44. For some basic literature on the pair of prints, see: Pauli, "Hans Sebald Beham," 149, cat. 143; Hollstein, German, vol. 3, no. 83; Koch, ed., Early German Masters: Barthel Beham, Hans Sebald Beham, 171, cat. 83 (232); Unverfehrt, Gerissen und gestochen, 138-39, cat. 59-60; Russell and Barnes, EvalAve, 209-10, cat. 137; Müller and Schauerte, "Die gottlosen," 237, cat. 60; Łazicka, The Print Room, 225-29, cat. 153-54.

18 Such solutions are also evident in Beham's other works, for example The Four Evangelists; Hollstein, German, vol. 3, no. 36; Koch, ed., Early German Masters: Barthel Beham, Hans Sebald Beham, 58, cat. 55 (138)-58 (138).

19 Appuhn-Radtke, "Fortuna Bifrons," 130.

20 E.g. a manuscript of 1497, Paris, BnF, ms. lat. 6643, fol. 76r.

21 Munich, BSB, clm 13002, fol. 3v; see: Appuhn-Radtke, "Fortuna Bifrons," 131, fig. 1.

22 Ibidem, 134.

23 Ibidem, 135.

24 G. Reisch, Margarita philosophica (Freiburg im Breisgau: Johann Schott, 1503), Lib. VIII, cap. 16.

25 The time around this date is sometimes called a "saddle period," which means a period of transition. More about "saddle period" and the representations of Fortuna from that time see: Müller and Gruber, "Fortuna Revalued," 84f. 
26 Cf. Müller and Schauerte, "Die gottlosen,” 237, cat. 60A.

27 The famous Dürer's engravings, as well as the works by other contemporary artists, show Fortuna standing on the sphere or at least resting a leg on it, cf. Albrecht Altdorfer: 1511, Koch, ed., Early German Masters: Albrecht Altdorfer, 67, cat. 59 (62); Hollstein, German, vol. 1, no. 78, 208, or Heinrich Aldegrever 1555: Koch, ed., Early German Masters: Jacob Bink, Georg Pencz, Heinrich Aldegrever, 202, cat. 143 (407); Mielke, Heinrich Aldegrever, 67, no. 143.

28 C. 1500. Zucker, ed., Early Italian Masters, 111, cat. 38 (277).

29 The motif of these two goddesses' voyage was established in Northern Europe; Müller and Gruber, "Fortuna Revalued," 91-93.

30 For a definition and further literature see: LCI, vol. 2, 54.

31 Landau, Catalogo completo, 167, cat. 146; Soellner, "King Lear," 286.

32 London, BM, 1997,0712.22; Rowlands, German Drawings, 39, cat. 34.

33 Francesco Petrarca, Von der Artzney bayder Glück (Augsburg: Heinrich Steyner, 1532).

34 Müller and Gruber, "Fortuna Revalued," 84.

35 Cf. Andersson, "Jungfrau, Dirne, Fortuna," 32-35; Müller and Gruber, "Fortuna Revalued," 96-107; Müller, Urs Graf, 170, cat. 077, 172, cat. 079; Kaschek, "Kühnes Kinderspiel," 145-47.

36 Urs Graf, Fortune as a Prostitute, pen and black ink drawing, c. 1520, Nuremberg, GNM, HZ 160/561; Müller, Urs Graf, 268, cat. 266-68; Kaschek, "Kühnes Kinderspiel," 145-46. This is not the only case representing Fortune or a similar personification as a prostitute in Graf's oeuvre; e.g.: Foolish Virgin, 1513, drawing, Kupferstichkabinett, Basel (U.X.46) or Swiss Mercenary and Prostitute, c. 1516, drawing, Frankfurt/M, Städel Museum, no. 15673.

37 Müller and Gruber, "Fortuna Revalued," 37-40.

38 On the relation between Fortuna and Frau Welt cf. Skowronek, "Fortuna und Frau Welt"; and Schüürmann, "Morte Cateana," 100-1.

39 In this context, the crayfish appeared as early as in Brant's Ship of Fools; Brant, Das Narrenschiff, 95 (chapter: Am Narrenheit Anstoss nehmen), as well as in the cycles of planets by Sebald Beham and also by Heinrich Aldegrever as an attribute of the Moon-Luna; cf. Müller and Schauerte, "Die gottlosen," 238, cat. 60B and Unverfehrt, Gerissen und gestochen, 138 , cat. 59.

40 Pauli, Hans Sebald Beham, 150-52, cat. 143a-d, 144a-b.

41 Heppe, Heinrich Aldegrever, 211, cat. 343; 259, cat. 133a-b.

42 Budapst, Iparművészeti Múzeum, 53-1191; Szilágyi, “Ein Silberbecher,” 38-40.

\section{Bibliography}

Andersson, Christiane. "Jungfrau, Dirne, Fortuna: Das Bild der Frau in den Zeichnungen von Urs Graf.” Kritische Beichte, 16 (1988): 26-35.

Appuhn-Radtke, Sybille. "Fortuna Bifrons: Zu einem mittelalterlichen Bildtyp und dessen Nachleben in der Ikonographie Albrecht Dürers." Das Mittelalter, 1 (1996): 29-148.

Bartrum, Giulia. German Renaissance Prints 1490-1550. Exhibition catalogue. London: British Museum, 1995.

Brant, Sebastian. Das Narrenschiff, ed. and transl. Margot Richter. Leipzig: Rütten \& Loening, 1958.

Brendecke, Arndt, and Peter Vogt. "Introduction: The Late Fortuna and the Rise of Modernity." In The End of Fortuna and the Rise of Modernity, eds. Arndt Brendecke and Peter Vogt, 1-14. Berlin: De Gruyter, 2017.

Buttay, Florence. "La Fortune victime des Lumières? Remarques sur les transformations de Fortune aux XVIIe et XVIIIe siècles." In The End of Fortuna and the Rise of Modernity, eds. Arndt Brendecke and Peter Vogt, 192-210. Berlin: De Gruyter, 2017.

Dürer, Albrecht. Dürer: Schriftlicher Nachlass, ed. Hans Rupprich. Vols. 1-3. Berlin: Deutscher Verein fur Kunstwissenschaft, 1956.

Emison, Patricia. "The Little Masters, Italy, and Rome." In The World in Miniature: Engravings by the German Little Masters 1500-1550: Exhibition Catalogue, ed. Stephen H. Goddard, 30-39. Lawrence, KS: Spencer Museum of Art, University of Kansas, 1988. 
Freitag-Stadler, Renate. Die Welt des Hans Sachs: 400 Holzschnitte des 16. Jahrhunderts: Ausstellung im Kemenatenbau der Kaiserburg vom 30.07-3.10.1976: Exhibition catalogue, ed. Renate Freitag-Stadler. Nuemberg: Hans Carl, 1976.

Goddard, Stephen H., ed. The World in Miniature: Engravings by the German Little Masters 1500-1550. Exhibition catalogue. Lawrence, KS: Spencer Museum of Art, University of Kansas, 1988.

Heppe, Karl Bernd. Heinrich Aldegrever, die Kleinmeister und das Kunsthandwerk der Renaissance. Exhibition catalogue, ed. Karl Bernd Heppe. Unna: Kreis Unna, Kulturamt, 1986.

Holländer, Hans. "Die Kugel der Fortuna.” Das Mittelalter, 1 (1996): 149-67.

Hollstein, Friedrich Wilhelm Heinrich. German Engravings, Etchings and Woodcuts ca. 14001700. Vols. 1-. Amsterdam: Menno Hertzberger, 1954-.

Kaschek, Bertram. "Kühnes Kinderspiel: Zum Motivkreis der infantia im druckgraphischen Frühwerk der Gebrüder Beham." In Von der Freiheit der Bilder: Spott, Kritik und Subversion in der Kunst der Dürerzeit, eds. Thomas Schauerte, Jürgen Müller, and Bertram Kaschek, 136-56. Petersberg: Michael Imhof Verlag, 2013.

Knowlton, Edgar C. “The Allegorical Figure Genius.” Classical Philology, 15 (1920-1924): 380-84.

Koch, Robert A., ed. Early German Masters: Albrecht Altdorfer, Monogrammists. New York: Abaris Books, 1980 (TIB, Vol. 14, formerly Vol. VIII, pt. 1).

- Early German Masters: Barthel Beham, Hans Sebald Beham. New York: Abaris Books, 1978 (TIB, Vol. 15, formerly Vol. VIII, pt. 2).

- Early German Masters: Jacob Bink, Georg Pencz, Heinrich Aldegrever. New York: Abaris Books, 1980 (TIB, Vol. 16, formerly Vol. VIII, pt. 3).

Kurthen, Josef. "Zum Problem der Dürerschen Pferde-Konstruktion: Ein Beitrag zur Dürer- und Behamforschung." Repertorium für Kunstwissenschaft, 44 (1924): 77-106.

Landau, David. Catalogo completo dell'opera grafica di Georg Pencz, English transl. Anthony Paul. Milan: Salamon e Agustoni, 1978.

Łazicka, Małgorzata. “Tańce chłopskie w twórczości graficznej Sebalda Behama w kontekście historycznym, społecznym i kulturowym.” Rocznik Historii Sztuki, 39 (2014): 191-222.

- The Print Room of the University of Warsaw Library: Catalogue of the Collection: Old Master Prints: 15th Century to the 1820s: German School: Barthel Beham and Sebald Beham. Warsaw: University of Warsaw, 2019.

Mielke, Ursula. Heinrich Aldegrever, eds. Holm Bevers and Christiane Wiebel. Vol. 3. Rotterdam: Sound \& Vision Publishers, 1998 (NHG).

Müller, Christian. Urs Graf: Die Zeichnungen im Kupferkabinett Basel: Beschreibende Katalog der Zeichnungen: Die Zeichnungen des 15. und 16. Jahrhunderts. Vol. 3, part 2B. Basel: Schwabe \& Co. AG Verlag, 2001.

Müller, Jürgen. “Albrecht Dürer's Peasant Engravings: A Different Laocoön, or the Birth of Aesthetic Subversion in the Spirit of the Reformation." Journal of Historians of Netherlandish Art, 3 (2011-2011). DOI:10.5092/jhna.2011.3.1.2

Müller, Jürgen, and Bettina Gruber. "Fortuna Revalued: On the Goddess's Sexualisation in the Renaissance." In The End of Fortuna and the Rise of Modernity, eds. Arndt Brendecke and Peter Vogt, 82-107. Berlin: De Gruyter, 2017.

Müller, Jürgen, and Thomas Schauerte. Die gottlosen Maler von Nürnberg: Konvention und Subversion in der Druckgrafik der Beham-Brüder. Exhibition catalogue. Emsdetten: Edition Imorde, 2011.

Nitzsche, Jane Chance. The Genius Figure in Antiquity and the Middle Ages. New York: Columbia University Press, 1975.

Panofsky, Erwin. Hercules am Scheidewege und andere Antike Bildstoffe in der neueren Kunst. Leipzig: Teubner, 1930.

Pauli, Gustav. Hans Sebald Beham: Ein kritisches Verzeichnis seiner Kupferstiche, Radi[e]rungen und Holzschnitte. Strassburg: J. H. Ed. Heitz (Heitz \& Mündel), 1901. 


\section{Matgorzata Lazicka}

Rościszewska, Danuta. Grafika niemiecka XV i XVI wieku: Katalog Zbiorów Muzeum Narodowego $w$ Poznaniu/German Prints of the 15th and 16th Centuries. Collection catalogue. Poznań: Muzeum Narodowe w Poznaniu, 2014.

Roth, Michael, Uta Barbara Ullrich, Fedja Anzelewsky, et al. Dürers Mutter: Schönheit, Alter und Tod im Bild der Renaissance. Berlin: Kupferstichkabinett Staatliche Museen, Nicolai, 2006.

Rowlands, John. German Drawings from a Private Collection. Exhibition catalogue. London: British Museum; Nuremberg: Germanisches Nationalmuseum, 1984.

Russell, H. Diane, and Bernadine Barnes. EvalAve: Woman in Renaissance and Baroque Prints. Exhibition catalogue. Washington: NGA; New York: Feminist Press at the City University of New York, 1990.

Sachs, Hans. Zeitgedichte und Schwänke: Ausgewählte Werke, ed. Karl Martin Schiller, afterword by Christa Gobrisch. Leipzig: Verlag Philipp Reclam Jun., 1960.

Scheidig, Walther. Die Holzschnitte des Petrarca-Meisters zu Petrarcas Werk: Von der Artzney bayder Glück des guten und widerwärtigen. Berlin: Henschelverlag, 1955.

Schoch, Rainer, Matthias Mende, and Anna Scherbaum. Albrecht Dürer: Das druckgraphische Werk: Kupferstiche, Eisenradierungen und Kaltnadelblätter. Vol. 1. Munich: Prestel, 2001.

Schüürmann, Dania. "Morte Cateana, Fortuna und Frau Welt: Ariano Suassunas 'Romance d'a Pedra do Reino'." Graphos, 13 (2011): 99-107.

Schwerhoff, Gerd. "Wie gottlos waren die 'gottlosen Maler'? Zur Rekonstruktion des Nürnberger Verfahrens von 1525 und seiner Hintergründe.” In Die gottlosen Maler von Nürnberg: Konvention und Subversion in der Druckgrafik der Beham-Brüder: Exhibition Catalogue, eds. Jürgen Müller and Thomas Schauerte, 33-48. Emsdetten: Edition Imorde, 2011.

Skowronek, Marianne. Fortuna und Frau Welt: Zwei allegorische Doppelgängerinnen des Mittelalters. Ph.D. dissertation, Freie Universität, Berlin, 1964.

Smith, Jeffrey Chipps. Nuremberg: A Renaissance City, 1500-1618. Exhibition catalogue, ed. Jeffrey Chipps Smith. Austin, TX: University of Texas Press, 1983.

Soellner, Rolf. "King Lear and the Magic of the Wheel." Shakespeare Quarterly, 35 (1984): 274-89.

Stewart, Alison G. "Sebald Beham." In Die gottlosen Maler von Nürnberg: Konvention und Subversion in der Druckgrafik der Beham-Brüder: Exhibition Catalogue, eds. Jürgen Müller and Thomas Schauerte, 13-19. Emsdetten: Edition Imorde, 2011.

Strauss, Walter L., ed. Sixteenth Century German Artists: Albrecht Dürer. New York: Abaris Books, 1981 (TIB, Vol. 10, formerly Vol. VII).

Szilágyi, András. "Ein Silberbecher mit Gravierungen nach Georg Pencz und H. S. Beham." Ars Decorativa (Annuaire du Musée des Arts Décoratifs et du Musée d'Art d'Extreme Orient Ferenc Hopp), 4 (1976): 33-50.

Unverfehrt, Gerd. Gerissen und gestochen: Graphik der Dürer-Zeit aus der Kunstsammlung der Universität Göttingen. Göttingen: Vandenhoeck \& Ruprecht, 2001.

Waldmann, Emil. Die Nürnberger Kleinmeister: mit 223 Abbildungen auf 55 Tafeln, 13 Textillustrationen. Leipzig: Klinkhardt \& Biermann, 1910.

Zucker, Mark J., ed. Early Italian Masters: Da Brescia, Campagnola, Mantegna, Mocetto, Montagna, Nicoletto, Pollainolo, Roberta, Zoan Andrea; Monogrammists, ed. Mark J. Zucker. New York: Abaris Books, 1980 (TIB, Vol. 25, formerly Vol. XIII, pt. 2). 


\title{
12 The Set of the Four Elements by Hendrick Goltzius and the Use of Engravings in the Seventeenth Century
}

\author{
Júlia Tátrai
}

The spread of print reproductions resulted in the significant growth of the pool of visual elements that could be used as models and broadened the possibilities of the artists and craftsmen of modern Europe. The compositions of northern artists such as Master E.S., Albrecht Dürer, Lucas van Leyden and Hendrick Goltzius resonates throughout artworks of various genres. These range from copies borrowing details and compilations to depictions completely departed from the original context and can date several hundred years later than the original model. Goltzius's engravings were popular almost immediately after their completion and are a testimony to the artist's virtuoso technical skills and inventive composing abilities. This chapter does not intend to examine the general use of Goltzius's engravings, nor does it aim to compare one particular artwork with the original model. This chapter instead analyses the four-element series of 1586 and attempts to paint a picture of their sixteenth- and seventeenth-century afterlife. I will examine artworks from different locations in various mediums, focusing on how the allegorical depictions ended up in a partially or completely different iconographical context, what kind of objects were used to decorate and, throughout the process, how the Mannerist style of Goltzius transformed with each specific medium.

The engravings made after the drawings by Hendrick Goltzius in 1586 depict the four elements as strong and imposing nude figures. ${ }^{1}$ Surrounding the large figures, represented as godly creatures, are only a few attributes associated with the given element. Fire appears as a naked young man holding a flame in his right hand and a flaming fireball in his left; the locks of his hair also remind us of flames. Behind this figure there is flowing drapery, and by his foot between the flames sits a salamander, the animal traditionally believed not to be burnt by fire (cf. Pliny's Natural History, 10: 86). On the left side of the background during Elijah's Miracle of Fire a flame erupts from the altar towards the sky. The inscriptions on the print read Ignis and HGoltzius excudebat $A(n n)_{0} 1586$ (Figure 12.1). The personification of Air is also a naked young man who is standing on clouds. He, too, is placed before flowing drapery, and on his left arm sits an eagle, while in his right hand he holds a chameleon. The latter creature, according to Pliny, does not eat or drink; it sustains itself with air (Natural History, 28: 8). By the head of the figure a spider crawls in his web, in the background birds are flying and putti heads are blowing wind towards the four cardinal points. The young man's hair is also blowing in the wind. On the bottom right of the sheet the Miracle of Pentecost appears (Figure 12.2). The print with the Aqua inscription depicts Water as a naked young woman whose hair is adorned with a large shell, and drapery falls on her shoulders, which she holds up with her left hand. She rests her right hand on a large stone vessel, out of which water pours to the ground. In the 


\section{0}

water small animals are visible. In the background the scene of the Baptism completes the composition (Figure 12.3). In the fourth print the personification of Earth is also a naked young woman with drapery-covered shoulders. She wears a flower coronet and a mural crown, which she inherited from the Phrygian Earth Mother, Cybele. She is holding a large cornucopia filled with fruits and other harvested goods with both her hands, the attribute of the Roman goddess, Ceres. On the ground by her feet lies more fruits. In the background the scene of the Creation of Man in Paradise is visible (Figure 12.4). The Latin inscriptions on the bottom of the prints indicate mainly each element's place in the cosmos, not their earthly effects. ${ }^{2}$ Therefore, the representation of the elements moves away from the material world, which is further emphasised by the biblical scenes in the background of the compositions, as each scene is in close relation to the given element. Through these means, Goltzius correlates the elements to the religious sphere: the elements are the vessels of redemption, immanently godly. Parallels of this typically alchemist approach are present in contemporary literature.

The Flemish alchemist and Paracelsian Gerard Dornaeus, for example, associates the four elements' alchemist metamorphosis with phases of spiritual cleansing: the cleansing of man derives from dust, therefore his creation from the earth, through the purifying effect of the baptism (water), then the illumination of the spirit (air), leads to the sacrifice of fire, resulting in his communication with God. ${ }^{3}$

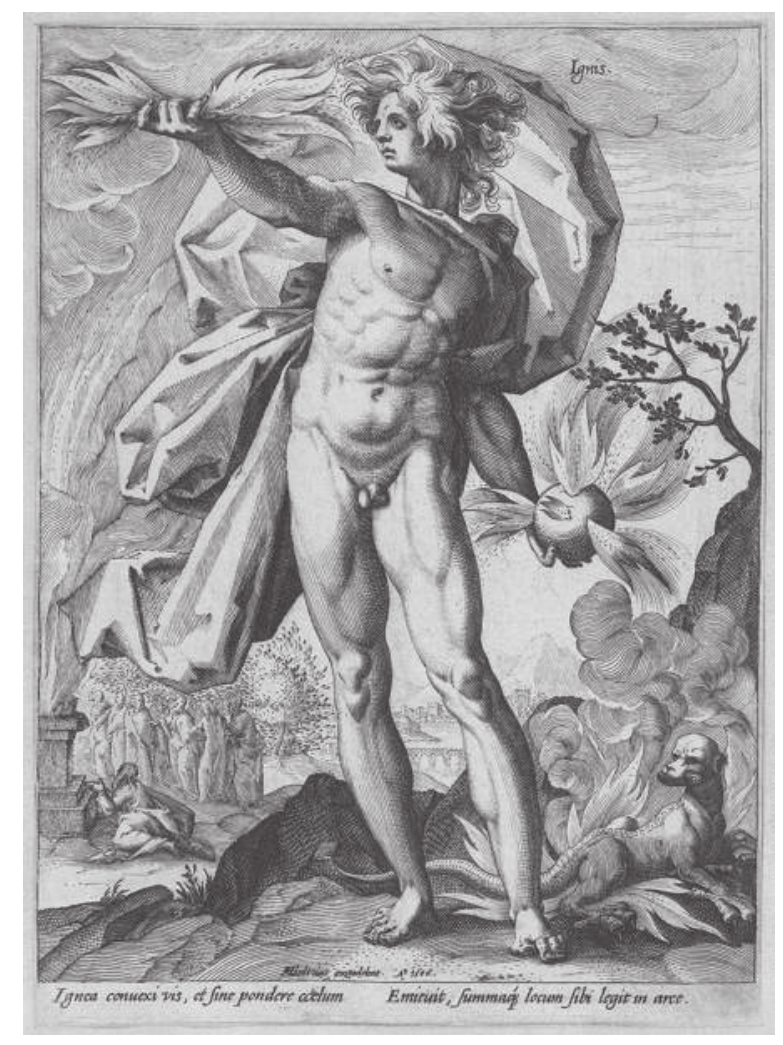

Figure 12.1 Anonymous engraver after Hendrick Goltzius, Fire, 1586, engraving. Amsterdam, Rijksmuseum, RP-P-OB-10.231. 


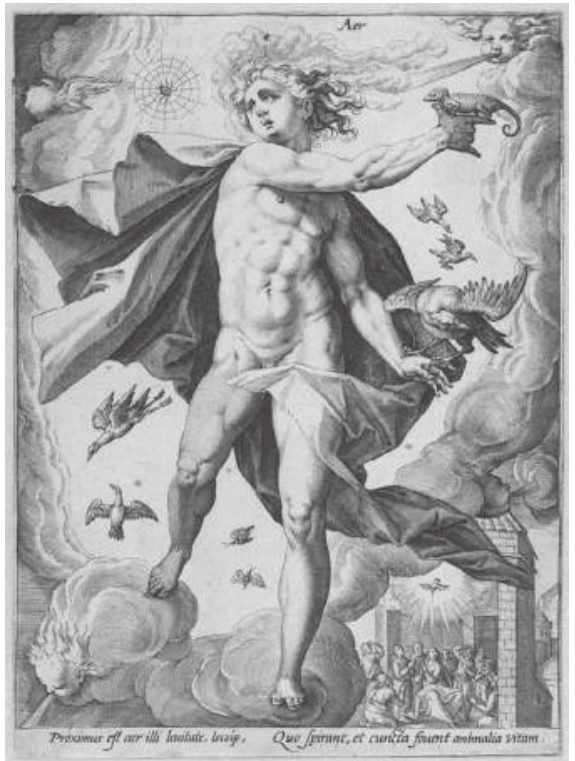

Figure 12.2 Anonymous engraver after Hendrick Goltzius, Air, 1586, engraving. Amsterdam, Rijksmuseum, RP-P-OB-10.229.

Photo: http://hdl.handle.net/10934/RM0001.COLLECT.448241, CC0 1.0.

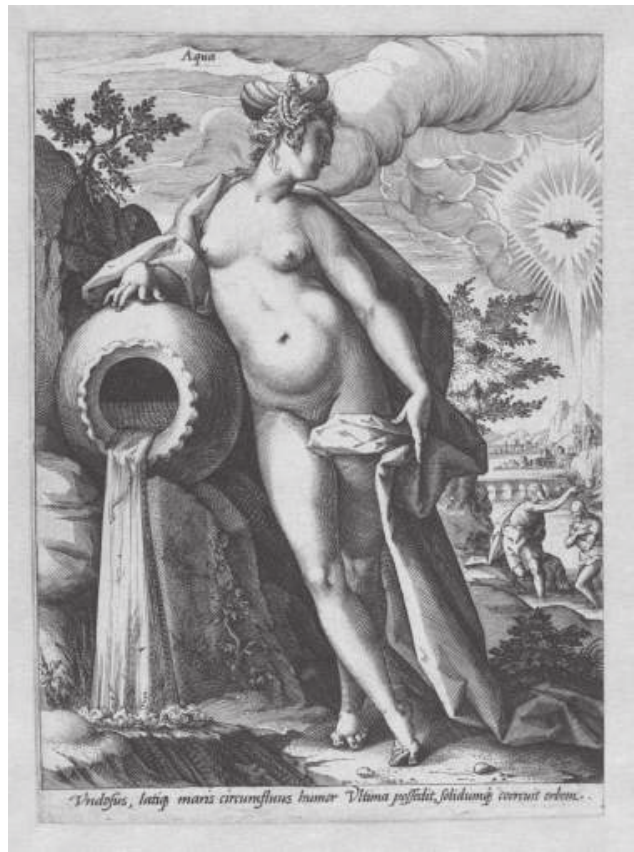

Figure 12.3 Anonymous engraver after Hendrick Goltzius, Water, 1586, engraving. Amsterdam, Rijksmuseum, RP-P-OB-10.232.

Photo: http://hdl.handle.net/10934/RM0001.COLLECT.448243, CC0 1.0. 


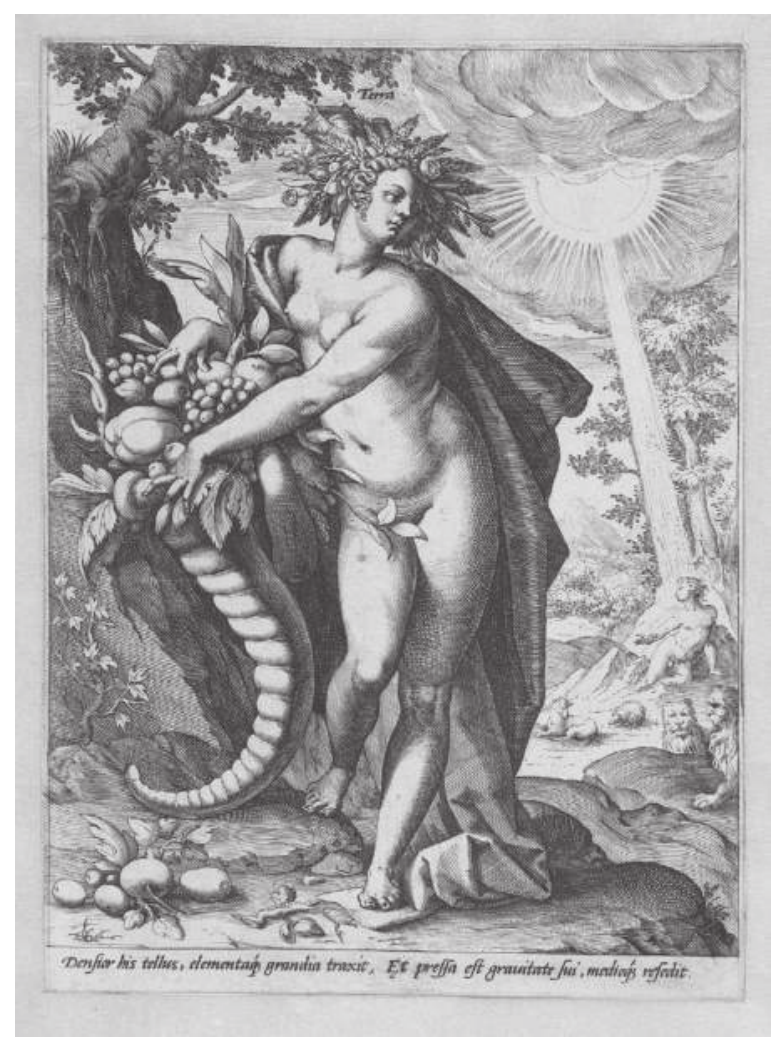

Figure 12.4 Anonymous engraver after Hendrick Goltzius, Earth, 1586, engraving. Amsterdam, Rijksmuseum, RP-P-OB-10.230.

Photo: http://hdl.handle.net/10934/RM0001.COLLECT.448242, CC0 1.0.

Karel van Mander recounts that Goltzius himself was actively engaged in alchemy. ${ }^{4}$ This is evident in a number of his works, for example, on the 1581 engraved portrait of Charlotte de Bourbon, the third wife of William of Orange. ${ }^{5}$ As was popular in art in Antwerp at the time, the rectangular cartouches around the portrait contain the four elements as female figures. It was Goltzius's iconographic innovation that the allegorical compositions are completed with biblical scenes in their backgrounds. ${ }^{6}$

The four-sheet series, five years later, is characterised by the same compositional principles and alchemist views. ${ }^{7}$ The target audience of these engravings with their Latin inscriptions was most likely a small circle of collectors from the contemporary Humanist elite, ${ }^{8}$ whose members understood the fine art manifestation of Neoplatonist and Paracelsian ideas.

Nonetheless, the engravings depicting the four elements became well known and popular throughout Europe, though removed from their original context. The popularity was most likely due to the figures being illustrations in Willem Jansz Blaeu's (1571-1638) world map entitled Nova Totius Terrarum orbis Geographica ac Hydrographica Tabula (Plate 23). This most renowned piece of seventeenth-century cartography has been published on several occasions since 1606, both individually and as part of an atlas. A 1648 copy, for example, made it into the exclusive fifty-volume Atlas 
Blaeu-Van der Hem, or, by another name, Der Atlas des Prinzen Eugen (Vienna, Österreichischer Nationalbibliothek). The world map first published in 1606, engraved by Joshua van den Ende, showed the newly discovered expedition routes and territories of the time. Due to its small, intricate engravings and the innovative, richly decorated borders, Blaeu's work became the most significant product of modern cartography. ${ }^{9}$

Blaeu combines different types of representations on the map: while Earth is depicted objectively and the seven wonders of the world in the lower part of the framing are also represented as realistically as the knowledge of the time allowed, on the two sides of the border the four elements, the four seasons and the seven planets known at the time (Sun, Moon, Mercury, Venus, Mars, Jupiter and Saturn) on the top portion of the border are depicted as allegorical figures. The figures on the left and right borders are taken from the 1586 and 1589 print series of the elements and seasons by Goltzius, and the wonderful manmade creations-the Pyramids of Giza, the Hanging Gardens of Babylon, the Temple of Artemis at Ephesus, the Statue of Zeus, the Mausoleum at Halicarnassus, the Colossus of Rhodes and the Lighthouse of Alexandriaare the 1572 engravings from Octo Mundi Miracula by Philips Galle, after Maarten van Heemskerck's drawings. The personifications of the planets seated in carts flying above the clouds are also taken from the drawings by Heemskerck, engraved by Jan Hermansz Muller. The border decorations of the map are the simplified versions of the complex planet allegories.

The four elements decorating Blaeu's map were modified from Goltzius's original compositions, as neither the inscriptions nor the biblical scenes are present. The figures are undoubtedly after the originals, but they are less intricate, probably due to their smaller size. The map was last published in 1662 by the son of Johan Blaeu, Willem, as part of the twelve-volume Le Grand Atlas. Goltzius's figures reappear on John Overton's 1670 smaller-scale world map, published in London, though they are the oversimplified copies of the more than hundred-year-old originals. The draughtsman of this map most likely only indirectly knew Goltzius's compositions. The well-known nature of the aforementioned maps, and due to the fact that Goltzius's engravings were so widespread in the seventeenth century, the figures of the four elements were used in many genres and iconographic contexts, with a merely decorative purpose. Without need for a complete list, let us examine a few of these.

The first example is a tin-glazed earthenware with blue, green and yellow on white ground in the shape of the figure of Fire from 1679 (Plate 24). ${ }^{10}$ It is interesting to note that the potter, who presumably also used the border decorations of the Le Grand Atlas published a few years earlier as inspiration, combined the gestures of Goltzius's Fire and Air to create his own Fire figure. Therefore, the contrapposto posture, which leans on the right leg, and the globe in his left hand can be traced back to the engraving of Fire, while the execution of the drapery, the way the head is held and the left arm in front of the body are more reminiscent of Air. For this, and for the flaming globe that resembles the sun, the ceramic in the Allen Gallery was thought to be Apollo and not the personification of Fire. ${ }^{11}$ Goltzius's Fire figure can be traced back to the third- and fourth-century depictions of the sun god on Roman coins, which were available to the artist through his Flemish namesake Hubertus Goltzius's (1526-83) books dealing with numismatics.

The small earthenware figurine from the Allen Gallery in Hampshire bears the same inscription (16 EC 79) as the delftware bust of King Charles I in London (BM, 1935,1016.1.CR). ${ }^{12}$ The latter was without a doubt made in London (Southwark); therefore, it is safe to assume that the Fire figurine was as well. It is possible that this 


\section{Júlia Tátrai}

fragile ceramic figure was once part of a four-element series, and the EC monogram in the inscription refers to its former owner. ${ }^{13}$

The objects used in everyday life in the sixteenth and seventeenth centuries, now categorised as European Decorative Arts, were commissioned by the nobility, urban patricians and the richest merchants. The objects in the houses and residences of the time were created and decorated following the latest fashions, so subject matter and decorative motifs were often inspired by popular and widely known prints. ${ }^{14}$ For example, the prints of sixteenth-century Netherlandish masters such as Goltzius, Dirck Volkertsz Coornhert or Philips Galle were often used in the early Baroque German centres of ceramic tile production. These cities included Nuremberg, which was home to many craftsmen who fled their native Netherlands, along with Winterthur, Frankfurt and Karlsruhe-Durlach. ${ }^{15}$ Many tiles based on Goltzius's prints can be associated with the ceramics workshop of the Vest family, originally from Creussen, but its members were also active in the earlier-mentioned Nuremberg and later in Frankfurt. Often all sheets of the print series were used for large rectangular tiles decorating stoves (Blattkacheln). Such a complete tile series is now housed in the Universitätsmuseum für Kunst und Kulturgeschichte in Marburg; the glazed ceramic tiles were made between 1605 and 1611 in the Frankfurt workshop of Johannes Vest (1575-1611), after the models of Georg Vest the Elder (Figure 12.5) ${ }^{16}$. The personifications of the elements stand in semi-circular niches in the middle of the rectangular tiles. Two knights in armour stand on both sides of the niches, and above them lions hold grotesque masks. Above and below the niches four female figures, the personifications of the cardinal virtues, are depicted. The element figures are in high relief; the folds of their draperies sculptural. Of the attributes depicted on the prints, only a few remain here: for example, the figure of Air is only accompanied by the chameleon and the eagle, and only two of the four putti blowing in the direction of the cardinal points are depicted, while the biblical scenes are completely left out. It is evident that the material of the tile and the nature of the clay highly influenced the intricacy of the details. It is still open to discussion whether the figures on the tile were selected with a particular iconographic programme in mind, such as in relation to the cardinal and chivalric virtues, or if they were simply chosen from the given decorative moulds. ${ }^{17}$ It is very likely that the early seventeenth-century, richly decorated, two-part stove originally from the Stiftungshaus in Sankenberg (today in Goethe Haus, Frankfurt am Main) is also from the Frankfurt workshop of Vest. Goltzius's element figures appear on the top part, along with the personifications of the four seasons, the five senses, the cardinal virtues and the Last Judgement, which are all part of the decoration's iconographic programme. ${ }^{18}$

It is important to note that the gesture of the Fire figure on the tile series in Marburg-similar to the figure of Ignis on other German stove tile series-does not follow Goltzius's engravings, but rather the gesture on the ceramic in the Allen Gallery. This leads us to believe that there is a print variation made after the original composition, and throughout Europe the Fire figure from the 1586 series was not used as a model, but rather the male figure combined the gestures of Goltzius's Fire and Air. This presumed print is currently unknown.

Goltzius's element figures also appear in a series dating c. 1660 from the region of Karlsruhe-Durlach, though their execution is much more simplistic and less intricate than the Marburg tiles. The personifications of the elements are also in semi-circular niches in the rectangular field, and above the niches are winged angel heads, while on the two sides there are putti holding bunches of grapes. The naked figures holding drapery and standing next to the element figures are unidentified. In terms of 


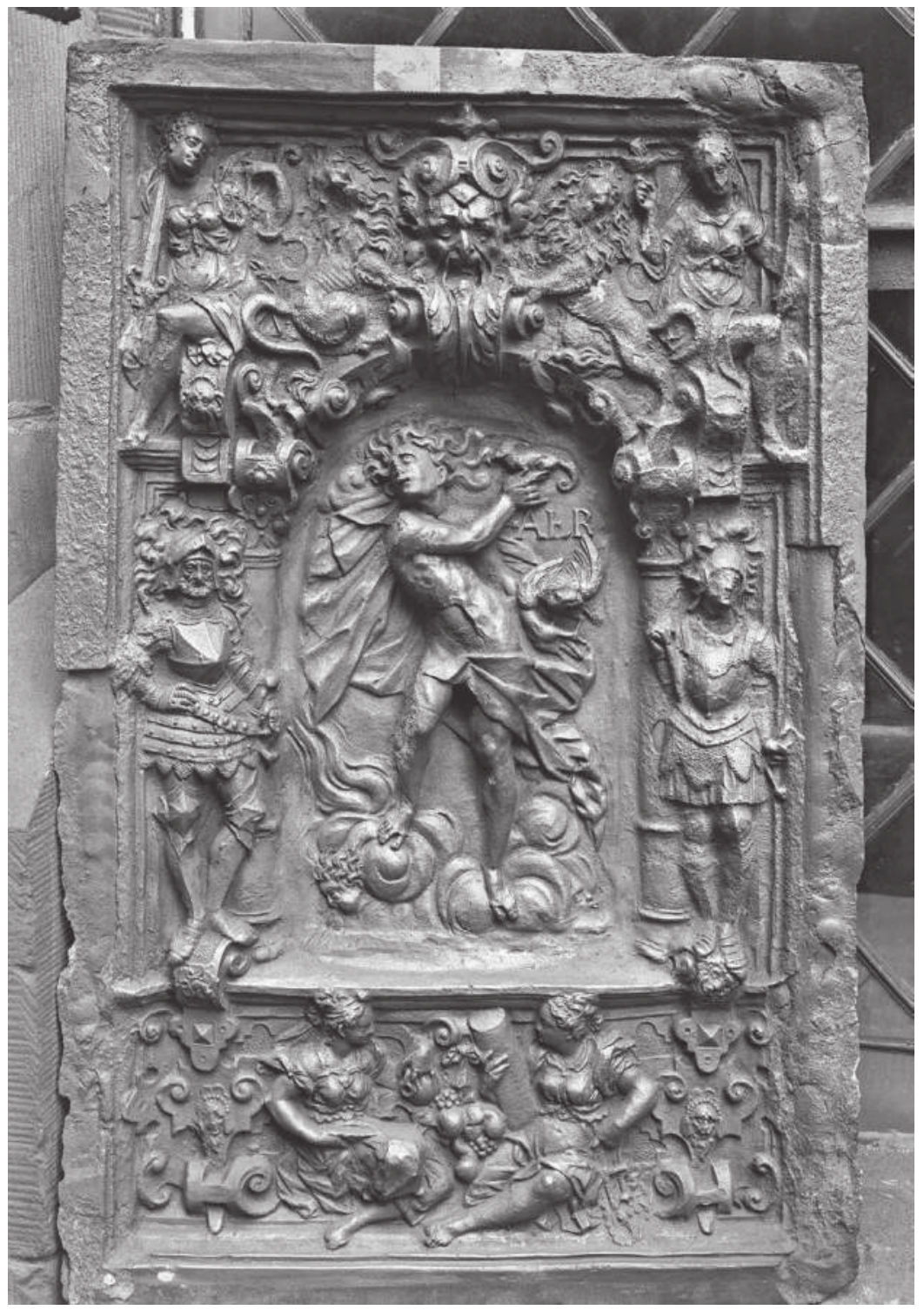

Figure 12.5 Workshop of Johannes Vest after the models of Georg Vest the Elder, stove stile with the figure of Air, 1605-11, glazed clay. Marburg, Universitätsmuseum für Kunst und Kulturgeschichte.

Photo: ( Bildarchiv Foto Marburg.

iconography these tiles have nothing in common with the alchemist and Paracelsian spirit of the engravings. Their makers probably knew the Vest family's almost halfcentury-old products, and they most likely picked popular designs from the workshop to decorate the tiles, without any attention to the subject matter. Ceramics by the Vest family had a wide impact among many in the southern part of the territory of Hessen and the region of Rhine-Main. ${ }^{19}$ 


\section{Júlia Tátrai}

Perhaps it is not a coincidence that at the Vest family's place of origin in Creussen on a tin-glazed tankard that one of Goltzius's element figures appears. Two dated examples are known from 1684, and the figure of Earth from the print series was used to decorate the pear-shaped vessels. ${ }^{20}$ One of them is housed in the Hetjens Museum in Düsseldorf, while the other recently surfaced on the art market. ${ }^{21}$

A naked, loosely veiled female figure holding a cornucopia appears in a tondo on the two sides of the metal mount in front of a homogenous blue background. Not the basic format nor other elements and details were used from the original composition when making the tankard. The female figure appears not as Earth, but as Abundance, the personification of plenty, with her attribute, the cornucopia. Showing the figure as Abundance and not as Earth suits the function of the vessel well, which is drinking (most likely beer). The twenty-five-centimetre-tall tankard from a Munich private collection not only features the two figures of Abundance but also in a medallion a pelican feeding its nestlings with its own blood, along with some rosettes, a combination of motifs that is quite alien to Goltzius's perception. The tankards do not just lack the original context of the depiction of the elements but also the high quality in their execution. The modelling of the figure of Abundance is simplified in both cases, with the decorative use of colour being a more important factor.

Goltzius's elements series was popular shortly after the appearance of the engravings in French furniture making. This is apparent in the typical creations of the socalled second French Renaissance on two-part cabinets (armoire à deux corps), where the four figures were placed on the four large doors. The piece, housed in the Bowes Museum, ${ }^{22}$ is made of walnut and has a marble inlay (Plate 26). The furniture maker could only partially follow Goltzius's typical Mannerist foreshortening of the muscular, twisted bodies, which resulted in more elongated and flatter figures. The strong folds that end in sharp turns on the engravings are transformed into soft and arched forms. Beside the figures of the four elements, the cabinet is embellished with other decorative motifs. The figures can be positioned on the doors in various ways. In this instance, on the Bowes Museum cabinet the two female figures of Water and Earth are placed on the lower doors of the lower stage, while the male figures of Air and Fire are on the ones above. Goltzius's figures are also positioned like this on the doors of a cabinet in Cracow in the Wawel Museum made at the end of the sixteenth century in the Île-de-France region. ${ }^{23}$

The cabinet from the collection of the Petit Palais ${ }^{24}$ also consists of two stages, but unlike the previous examples, it is "crowned" with a broken pediment complete with three figures, which results in an even more impressive and overall powerful effect. The elements carved on its doors are contrasts of one another: the male figure of Air with the female figure of Earth, while the male figure of Fire is paired with the female figure of Water. ${ }^{25}$ Here the scale of the figures and their attributes follow the engravings quite closely, though the motifs in the background are vague; the clouds have been carved without precision or attention to detail, and the biblical scenes are missing completely. It is possible that Air and Earth were made by a different hand, as they are of higher quality than Water and Fire.

A muff glass decorated en grisaille, with details etched with a needle, entered the collection of the Fitzwilliam Museum in Cambridge in $1991^{26}$ (Plate 25). The master, who was perhaps active in Flanders, modified the square composition into an oval. Fire, who is originally naked, is clothed here in a garment taken from another Goltzius series, The Roman Heroes. ${ }^{27}$ He wears sandals and a cuirass-like tunic with short sleeves and short breeches with the right leg rolled up. During the late 1400s glass 
windows in domestic interiors became ubiquitous, and small painted roundels-a single piece of clear glass with vitreous paint and golden silver stain-became so popular that their production reached nearly industrial proportions by the 1520s. Purchased in large cycles or as single images, they were intended to amuse and instruct, with subjects like zodiac signs, religious imagery, portraits and heraldry. It was fashionable around 1600 to arrange the ethereal and earthly world, or nature's and mankind's achievements, into groups of four, sometimes into groups of five or seven. The seasons, stages of life, elements, cardinal points, temperaments, states of physical conditions and bodily fluids make up groups of four; the senses are in a group of five; and the planets and the wonders of the world are in groups of seven (see Blaeu's world map).$^{28}$ It is plausible that this piece of glass, decorated with the figure of Fire, was once part of a series and served as decoration in a wealthy family's home, alongside another series. Perhaps the naked figure was draped to comply with the morality of the proud Flemish bourgeois.

Among the examples of decorative art objects Goltzius's print series was used for, there is a particularly nice cutlery set in Rijksmuseum, Amsterdam (Figure 12.6). Meant as a wedding gift in 1597, the groom commissioned a knife and fork, their gold hilts decorated with niello, together with an ornate leather case for his future wife. It is interesting to note that their decoration, apart from the personifications of the elements, consists only of profane motifs such as sphinxes, satyr-like winged creatures, birds, butterflies and grotesque figures, while the main decorating motifs of the leather case are the personifications of two Christian virtues, Charity and Justice. The elements were combined with personified figures of virtues in other instances, such as in the case of the German stove tiles. The original designs decorating the niello of the cutlery are not directly taken from Goltzius's engravings, but rather from Johann Theodor de Bry's (1561-1623) scaled-down copies (Figure 12.7). These element depictions are present on the ornament prints of the cutlery hilts and, as opposed to the original design, mirrored and a quarter of the size. Compared to the original rectangular composition, here the figures are placed in a much narrower architectural framework, though when modelling the figures De Bry follows the originals very closely. ${ }^{29}$ The personifications are identified by Latin inscriptions in the centre of the hilt, and the rest of the composition is completed with a rich floral ornament sprouting from candelabra. In a medallion above the female figures we see a pelican feeding its blood to its nestlings, while above Fire and Air there are two hands holding one another and a heart, motifs representing the Christian values of love and sacrifice. Combining the depiction of the four elements with Christian symbols-just like in the case of the engagement gifts_clearly deviates from the Paracelsian ideas behind Goltzius's sheets. The prints and drawings collection of the Art Institute of Chicago houses not only the aforementioned ornament prints but also their variants. In these the element figures face the same way as in Goltzius's engravings, though their style differs a lot more from the originals than De Bry's version. The other motifs decorating the knife hilts include male and female portraits in medallions, along with the personifications of Prudence, Patience, Justice and Temperance; therefore, the four elements are paired with virtues as well, in this case. ${ }^{30}$

At this point, it is also interesting to mention that among the many techniques that used Goltzius's print series, one of the most common purposes these prints served was as models for the composition of paintings. Fifteen years ago, a $99 \times 80 \mathrm{~cm}$ oil on canvas dating c. 1600 surfaced in a Hungarian private collection. The painting follows the depiction of Water in the 1586 print relatively closely. When compared to the 


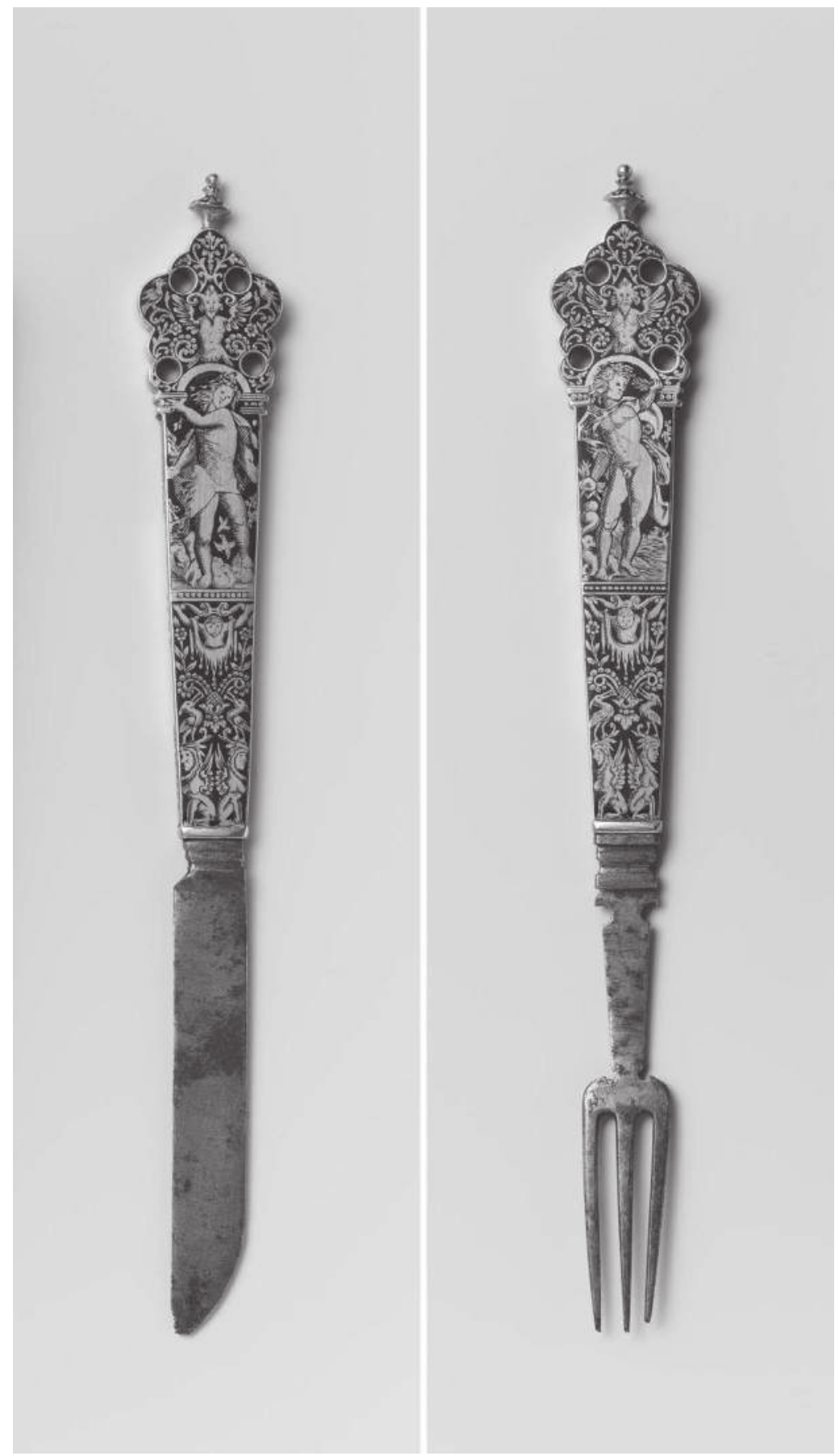

Figure 12.6 Northern Netherlandish, fork and knife from a wedding cutlery, 1597, gold, iron, niello. Amsterdam, Rijksmuseum, BK-1975-79-A, BK-1975-79-B.

Photos: http://hdl.handle.net/10934/RM0001.COLLECT.17182 and http://hdl.handle.net/10934/RM0001. COLLECT.17183, CC0 1.0. 


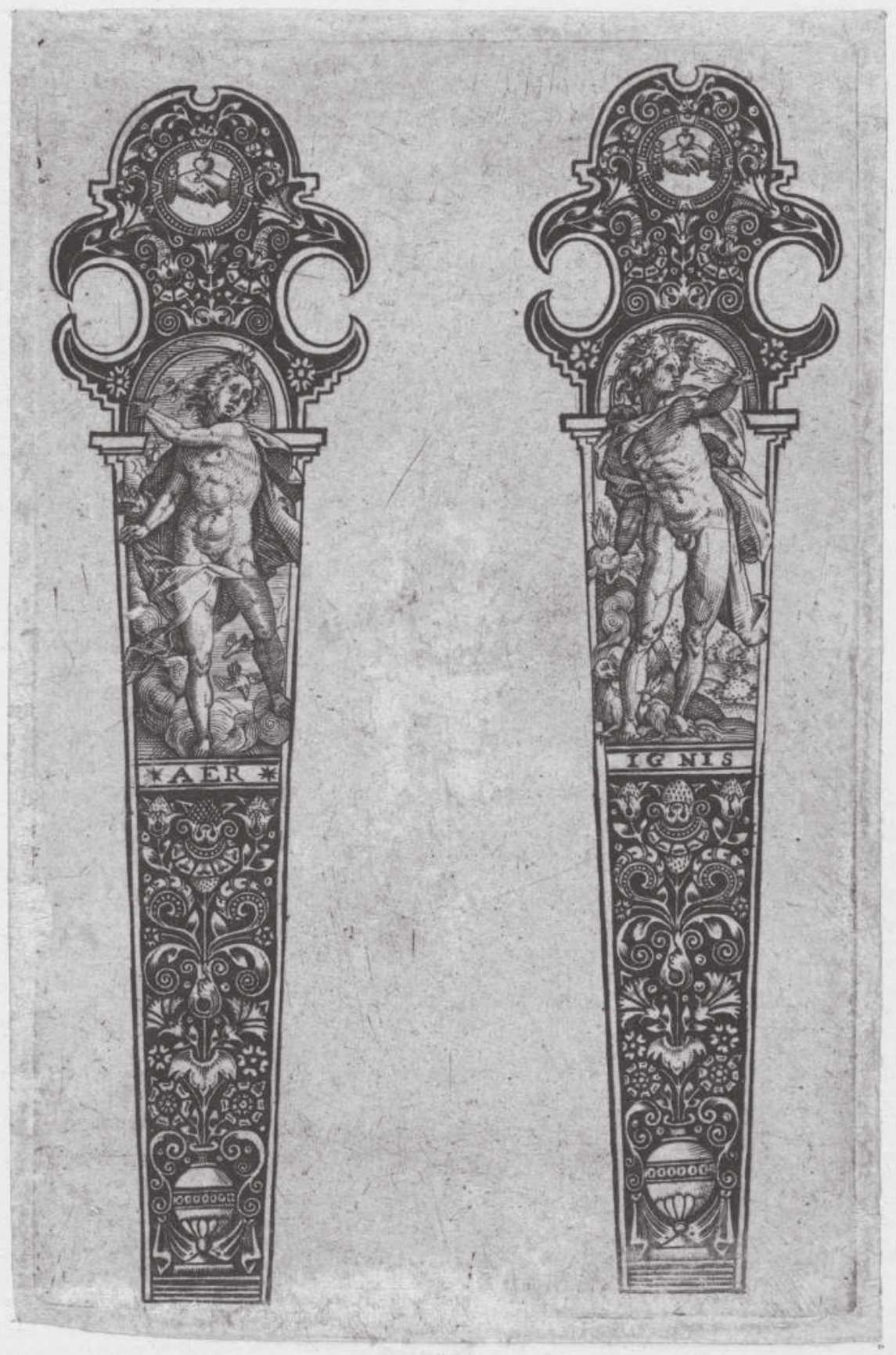

Figure 12.7 Theodor de Bry (?), design for knife handles with Personifications of the Elements, c. 1598, engraving. Amsterdam, Rijksmuseum, RP-P-1964-4642.

Photo: http://hdl.handle.net/10934/RM0001.COLLECT.415618, CC0 1.0. 
original composition, only the dove of the Holy Ghost and the clouds are missing. ${ }^{31}$ This, along with the lack of signature, make it difficult to determine whether it was made north or south of the Alps, let alone attribute it to an artist. It is also unclear whether it was part of a complete elements series. It is also Goltzius's Water figure that appears on an Antwerp cabinet's doors, though it only loosely follows the original. ${ }^{32}$ The ebony cabinet, decorated with different-sized mythological paintings, was made c. 1640, its two doors showcasing the allegorical figures of the four elements. Interestingly, the artist only used Goltzius's composition for the figure of Water, while the other personifications follow different sources, e.g. Jan Brueghel's in the case of Air.

Rubens also used Goltzius's compositions in a unique compilation in his allegoric painting of the union of Scheldt and Antwerp (Hermitage Museum). The figure of Cybele holding a cornucopia leaning on Neptune's vessel clearly recalls Goltzius's Water. The union symbolises fertility, wealth and prosperity, specifically for the city of Antwerp and the river Schelde, whose mouth in Rubens's time was blocked by the Dutch, depriving Flanders of access to the sea. ${ }^{33}$ Although the Saint Petersburg painting clearly recalls the original Goltzius model, the Flemish master endows the figure with a completely different iconographical content, and the nude female character is revived in a full-blooded Baroque style. Nevertheless, as Rubens was affected by Goltzius's compositions, he, too, was inspired by antiquity, such as Roman statues and coins, along with the Renaissance, when he created the figures of the elements. Renaissance models, such as Agostino Veneziano's engravings (e.g. Standing Woman with a Vase), are a testimony to the cycle of forms and content that derives from the Renaissance and is continued in the following centuries, ever changing.

The oeuvre of Goltzius is an area of art history that has been much researched and well written on in terms of style, iconography and the techniques used by the artist. The extensive reuse of his prints is also known, though to my knowledge there is no comprehensive study to date. In my chapter I have chosen a point of view that is different from previous works on the subject. My goal was to choose one series and map out where, when and how it was applied throughout Europe. How many, in what context and what kinds of stylistic elements were reused? To what level of artistry were these ichnographically complex engravings that combine motifs inherited from antiquity with contemporary religious and alchemist views altered? I have tried to illustrate my findings with the artworks discussed earlier, most of which had a utilitarian function in the seventeenth century. The world map, the ceramic tiles, the tin-glazed tankard, the cabinets and the tableware were all important accessories of contemporary life, the execution of which very much depended on the needs of the customer, the fashion of the time and the skills of the craftsmen creating them. Among the various mentioned artworks in different mediums, the common denominator is that they all feature the allegorical figures removed from their original context, and the once-complicated iconographical depictions are simplified to a great extent. In some instances, they are combined with other figures or motifs, which places them in a new framework, while in other cases even the most basic allegorical meaning of the elements is stripped, restricting them to a mere decorative function. The seventeenthcentury afterlife of Goltzius's 1586 four-element series is a fine example demonstrating how the important compositions in prints became an integral part of European visual culture from the highest degree of artistry down to folk art. 


\section{Notes}

1 Leesberg, Hendrick Goltzius, pt. 4, no. 650; Strauss, ed., Netherlendish Artists, 300-3, cat. 018-021; Popitz, Die Darstellung, 40.

2 The inscription of the sheets: Water: Undosus, latique maris circumfluus humor / Ultima possedit, solidumque coercuit orbem. ("The streaming water took the last place of all, and held the solid land confined in its embrace"); Fire: Ignea convexi vis, et sine pondere coelum / Emicuit, summaque locum sibi legit in arce. ("The fiery weightless element that forms heaven's vault leaped up and made place for itself upon the topmost height"); Air: Proximus est aer illi levitate, locoque / Quo spirant, et cuncta fovent animalia Vitam. ("Next came the air in lightness and in place. By which all animals [beings with a spirit, including men] breath and enjoy life"); Earth: Densior his tellus, elementaque grandia traxit, / Et pressa est gravitate sui, medioque resedit " "The earth was heavier than these, and, drawing with it the grosser elements, sank to the bottom by its own weight"). The inscriptions on the sheets depicting Water, Fire and Earth are all from Ovid's Metamorphoses; interestingly, however, the inscription on the print depicting Air is only partially taken from Ovid's text. I would like to thank Janos Jarecsni for the identification of the inscriptions.

3 Gerard Dornaeus, Clavis totius phylosophiae chymistiae (Lyon, 1567), Frankfurt/M 1583, quoted by Popitz, Die Darstellung, 41.

4 Karel van Mander, Het Schilder-boeck (Haarlem: Passchier Wesbusch, 1604), fol. 286v. More than anecdotic is van Mander's account of Goltzius's alchemical activities, related to the "purification of pigments," that is corroborated by other sources. See Weststeijn, "Painting's Enchanting Poison," 141-78, especially 149, note 35 with further bibliography.

5 Leesberg, Hendrick Goltzius, pt. 2, 138, no. 262 I. For further information on the pendant portraits of William of Orange and his wife, read Eyffinger, "De portretten van Prins Willem van Oranje en Charlotte de Bourbon," 53-46. For more on the intellectual content of the members of the Haarlem Academy, see McGee, Cornelis Corneliszoon van Haarlem.

6 For more on the depictions of the four elements and on Goltzius's mentioned works, see Frey, Beer, and Wirth, "Elemente," 1256-87, especially 1271-76 and figs. 6 a-d and 9. For Goltzius's element depictions, see Veldman, “Goltzius' Zintuigen,” 307-36.

7 On Goltzius's interest in alchemy and on its appearance in his works, see Göttler, "Allegories of Fire," 134-45, especially 143-45, cat. 61.

8 On the social network of the Humanist circles, see Burke, "Humanism and Friendship," 262-74.

9 Cf. Koeman, Joan Blaeu; Donkersloot-de Vrij, Drie generaties Blaeu: Amsterdamse cartografie en boekdrukkunst, 16-22; Fölsing, "Das Bild der Erde," 30-33.

10 Hampshire Cultural Trust, Allen Gallery, HCCMS DA1987.29.

11 For a detailed technical and iconographic analysis, see Macfarlane, Apollo Reconsidered, 257-68.

12 Ibidem, 261-62; Lipski and Archer, Dated English Delftware, 416-17, fig. 1744.

13 See Macfarlane, Apollo Reconsidered, 261 and 267.

14 Plötz, "Die Goltzius-Stiche," 36.

15 On the topic of stove tiles made in German territories, this is a must-read: Franz, Der Kachelofen, esp. 121-34, and fig. 427-32.

16 Marburg, Universitätsmuseum für Kunst und Kulturgeschichte, 10.404 (Earth), 10.407 (Fire) 10.405 (Air) and 10.406 (Water). Also for the use of Goltzius's engravings on stove tiles, see Plötz, "Die Goltzius-Stiche," 35-48, esp. 36-39, where he notes a tile inscribed Aer also from Vest's workshop, now in the Kunstgewerbemuseum in Dresden. See also Lauffer, "Der Kachelofen in Frankfurt," 103 ff.

17 The Landesmuseum in Mainz also houses glazed stove tiles depicting Goltzius's elements, similar to the Marburg ones. Next to the figure of Earth, however, instead of the armoured knights, other figures stand (angels, saints?), and on the lower part of the tile, instead of the two female figures personifying two cardinal virtues, the bust of a collared man (ruler) is visible in a medallion. See Bildarchiv Foto Marburg, No. 1.169. 704; www.bildindex.de/document/ obj20749051 (Earth); and no. 1.169.699; www.bildindex.de/document/obj20749052 (Fire).

18 Franz, Der Kachelofen, 130, figs. 427 and 428. 


\section{Júlia Tátrai}

19 Rosmanitz, "Vom Gott," esp. 251-54. For the Karlsruhe-Durlach tiles, and for the prints used for decorating the tiles, see also http://furnologia.de/galerie/die-ofenkeramik-der-spaetgotikder-renaissance-und-des-fruehbarocks-und-ihre-graphischen-vorlagen/

20 For the Creussen earthenware, see Kröll, Creussener Steinzeug.

21 Munich, Kunstauktionshaus Neumeister, 5 July 2017, lot 5.

22 Barnard Castle, Teesdale, County Durham, The Bowes Museum, FW.107.

23 Cracow, Wawel Royal Castle, see Link-Lenczowska, Meble francuskie.

24 Paris, Petit Palais, ODUT01756.

25 For the characteristics paired with the genders and the elements, see Filipczak, "A Little World," 14-29. On Golzius's 1586 element prints, and their connection to Blaeu's map, ibidem, 10-13, cat. 1-3.

26 Cambridge, Fitzwilliam Museum, C.341-1991.

27 For an example of the Goltzius engraving Titus Manlius Torquatus, from the series The Roman Heroes, see Leesberg, Hendrick Goltzius, vol. 2, 168. II.

28 For more on the subject, see Bodnár, Csillagsorsok.

29 The aforementioned prints belong to the following series: Theodor de Bry, title plate to a series of four designs for knife handles with grotesque ornament entitled Mansches de coutiaus aveques les feremens de la gaine, Frankfurt, 1575-85. Illustrated: Tafelzier und Klingenkunst, Bestandskatalog Graphik, 18, cat. 15-16. Both the prints depicting the decoration for the four sides of the cutlery can also be found in the collection of the Rijksprentenkabinet. They are not attributed to Theodor de Bry but are believed to be the work of an unknown Dutch artist; see Fuhring, Ornament Prints in the Rijksmuseum II: The Seventeenth Century, 217, cat. 1241-42.

30 Special thanks to Dr Suzanne Karr Schmidt (The Newberry, Chicago, George Amos Poole III Curator of Rare Books and Manuscripts), who, following my lecture at the Warsaw conference, brought to my attention the two-ornament print series in their collection.

31 Unpublished, currently in an unknown location.

32 Sold: London, Christie's, Important Old Master Pictures, sale 7290, 8 December 2006, lot. 101.

33 Saint Petersburg, Hermitage Museum, GE 464. On the iconography of the painting with previous bibliography, see Gritsay, in Peter Paul Rubens, 36-37, cat. 2.

\section{Bibliography}

Becks, Leonie et al., ed. Tafelzier und Klingenkunst: Bestandskatalog Graphik. Solingen: Deutsches Klingenmuseum, 1994.

Burke, Peter. "Humanism and Friendship in the Sixteenth Century Europe." In Friendship in Medieval Europe, ed. Julian Haseldine, 262-74. Stroud: Sutton, 1999.

Donkersloot-de Vrij, Marijke. Drie generaties Blaeu: Amsterdamse cartografie en boekdrukkunst in de zeventiende eeuw. Exhibition catalogue. Amsterdam: Rijksmuseum Nederlands Scheepvaartsmuseum, 1992.

Eyffinger, Arthur. "De portretten van Prins Willem van Oranje en Charlotte de Bourbon door Hendrick Goltzius.” Vereniging Oranje-Nassau, Jaarboek, (1982): 35-46.

Filipczak, Zirka Z. "A Little World Made Cunningly of Elements.” In Hot Dry Men, Cold Wet Women: The Theory of Humors in Western European Art 1575-1700. Exhibiton catalogue, ed. Zirka Z. Filipczak. New York: The American Federation of Arts, 1997.

Fölsing, Ulla. "Das Bild der Erde.” In Weltkunst, 74 (2004): 30-33.

Franz, Rosemarie. Der Kachelofen: Entstehung und kunstgeschichtliche Entwicklung vom Mittelalter bis zum Ausgang des Klassizismus, Forschungen und Berichte des Kunsthistorischen Institutes des Universität Graz, 1. Graz: Akademische Druck- und Verlagsanstalt, 1969.

Frey, Gerhard, Ellen J. Beer, and Karl-August Wirth. "Elemente." In Reallexikon zur deutschen Kunstgeschichte, Vol. 4, 1256-88. Stuttgart: Druckenmüller, 1958.

Fuhring, Gerhard. Ornament Prints in the Rijksmuseum II: The Seventeenth Century, pt. 1. Amsterdam: Rijksmuseum, Rotterdam: Sound \& Vision Publishers, 2004. 
Göttler, Christine. "Allegories of Fire and of the Arts." In Art and Alchemy: The Mystery of Transformation: Exhibition Catalogue, eds. Sven Dupré, Dedo von Kerssenbrock-Krosig, and Beat Wiesmer. Düsseldorf: Museum Kunstpalast, 2014.

Gritsay, Natalia. Peter Paul Rubens: Gemälde aus der Ermitage. Exhibition catalogue, ed. Wilfried Seipel. Vienna: Kunsthistorisches Museum, 2004.

Koeman, Cornelis. Joan Blaeu and His Grand Atlas. Amsterdam: Theatrum Orbis Terrarum, 1970.

Kröll, Joachim. Creussener Steinzeug. Braunschweig: Klinkhardt und Biermann, 1980.

Lauffer, Otto. "Der Kachelofen in Frankfurt." In Festschrift zur Feier des 25 jährigen Bestehens des Städtischen Historischen Museums in Frankfurt am Main. Frankfurt/M: Knauer, 1903.

Leesberg, Marjolein, comp. Hendrick Goltzius, ed. Huigen Leeflang, pt. 4. Amsterdam: Sound \& Vision Publishers, 2012 (NHD, Vol. 22).

Link-Lenczowska, Stanisława. Meble francuskie w zbiorach Zamku Królewskiego na Wawelu. Cracow: Zamek Królewski na Wawelu, 2016.

Lipski, Louis L., and Michael Archer. Dated English Delftware. London: Sotheby Publications, 1984.

Macfarlane, Margaret. Apollo Reconsidered, a paper read at the Linnean Society Rooms on 20 October 1996, ed. the Committee of the English Ceramic Circle, 1998.

McGee, Julie L. Cornelis Corneliszoon van Haarlem, 1562-1638: Patrons, Friends, and Dutch Humanists. Nieuwkoop: De Graaf, 1991.

Plötz, Robert. "Die Goltzius-Stiche als Vorlage.” In Der Kupferstecher Hendrick Goltzius, 1558-1617: Exhibition Catalogue, ed. Robert Plötz. Kevelaer: Niederrheinisches Museum für Volkskunde und Kulturgeschichte; Bergisch Gladbach: Städtische Galerie-Villa Zanders; Kempen, Kleve: Städtisches Kramer-Museum, 1982.

Popitz, Klaus. Die Darstellung der vier Elemente in der niederländischen Graphik von 1565 bis 1630. Ph.D. dissertation, Ludwig-Maximilians-Universität, Munich, 1965.

Rosmanitz, Harald. "Vom Gott des Handels und der Diebe: ein frühbarockes Kachelmodel mit Merkur aus dem Museum im Ritterhaus in Offenburg.” Die Ortenau, 77 (1997): 235-56.

Strauss, Walter, ed. Netherlandish Artists (Hendrick Goltzius), Commentary. New York: Abaris Books, 1982 (TIB, Vol. 3).

Szilvia, Bodnár. Csillagsorsok-embersorsok/Sternenschicksale und Menschenschicksale. Exhibition catalogue. Budapest: Szépmüvészeti Múzeum, 1990.

Veldman, Ilja. "Goltzius' Zintuigen, Seizoenen, Elementen, Planeten en Vier tijden van de dag: van allegorie naar genre-voorstelling." Nederlands Kunsthistorisch Jaarboek, 42-43 (199192): 307-36.

Weststeijn, Thijs. "Painting's Enchanting Poison: Artistic Efficacy and the Transfer of Spirits." In Spirits Unseen: The Representation of Subtle Bodies in Early Modern European Culture, eds. Christine Göttler and Wolfgang Neuber, 141-78. Leiden: Brill, 2008. 


\title{
13 Different Confessions, Different Visions of Heaven?
}

\author{
Visual Eschatology, Cross- \\ Confessional Conformity and \\ Confessional Identity Marking in the \\ Picture Motet The Adoration of the \\ Lamb and in Its Reception*
}

\author{
András Hándl
}

\section{Introduction}

It is in difficult times, when war is fought for decades, when mighty empires fall and new ones rise, when settled beliefs are challenged by strange new notions, when injustice, military terror and epidemics devour an endless stream of fresh victims-it is in such times when apocalyptic visions boom. In 1587, at the peak of the Dutch struggle for independence from the Spanish Netherlands, a year and a half after Antwerp had fallen in summer 1585 and thousands of its citizens had fled, two Flemish refugees arrived in Frankfurt am Main. A year later, in 1588, both of them, Joos van Winghe (c. 1544-1603), a painter and draftsman for engravings, and Jan Sadeler (1550 to c. 1600), an engraver and publisher, met to draft the engraving The Adoration of the Lamb of God (Figure 13.1). They used a newly invented genre, the picture motet (beeldmotet or Bildmotette), to sketch out a vivid and complex composition based on several passages of the Apocalypse. Unique to this genre is the skilful arrangement of a short polyphonic vocal composition, usually displayed in a choral part book or on a panel with a complete score and text within an image that sets the context of the music and visually corresponds to it. ${ }^{1}$

\section{The Picture Motet The Adoration of the Lamb of God}

The visual programme ${ }^{2}$ of The Adoration of the Lamb of God is composed of two parts separated by a blanket of clouds at the middle. The upper part is a consequent, but not entirely faithful, visualisation of the so-called "throne room vision" as described in Revelation 4 and 5. Depicted is a throne positioned over the clouds and placed on a rainbow; on the throne is seated a bearded man dressed in a long robe (Rev. 4:2). ${ }^{3}$ In his right hand he holds an open book that had been previously sealed with seven seals (Rev. 5:1). A radial halo surrounds his head, and above him are placed seven flaming torches (Rev. 4:5-6). Twenty-four thrones and twenty-four elders surround the throne, the elders kneeling and clad in white robes, holding harps, wearing golden crowns and holding bowls filled with smoking incense (Rev. 4:4 and 10). Their musical instruments are the first visual reference to music; several others will follow. Four six-winged apocalyptic creatures are placed in the corners of the upper half of the 


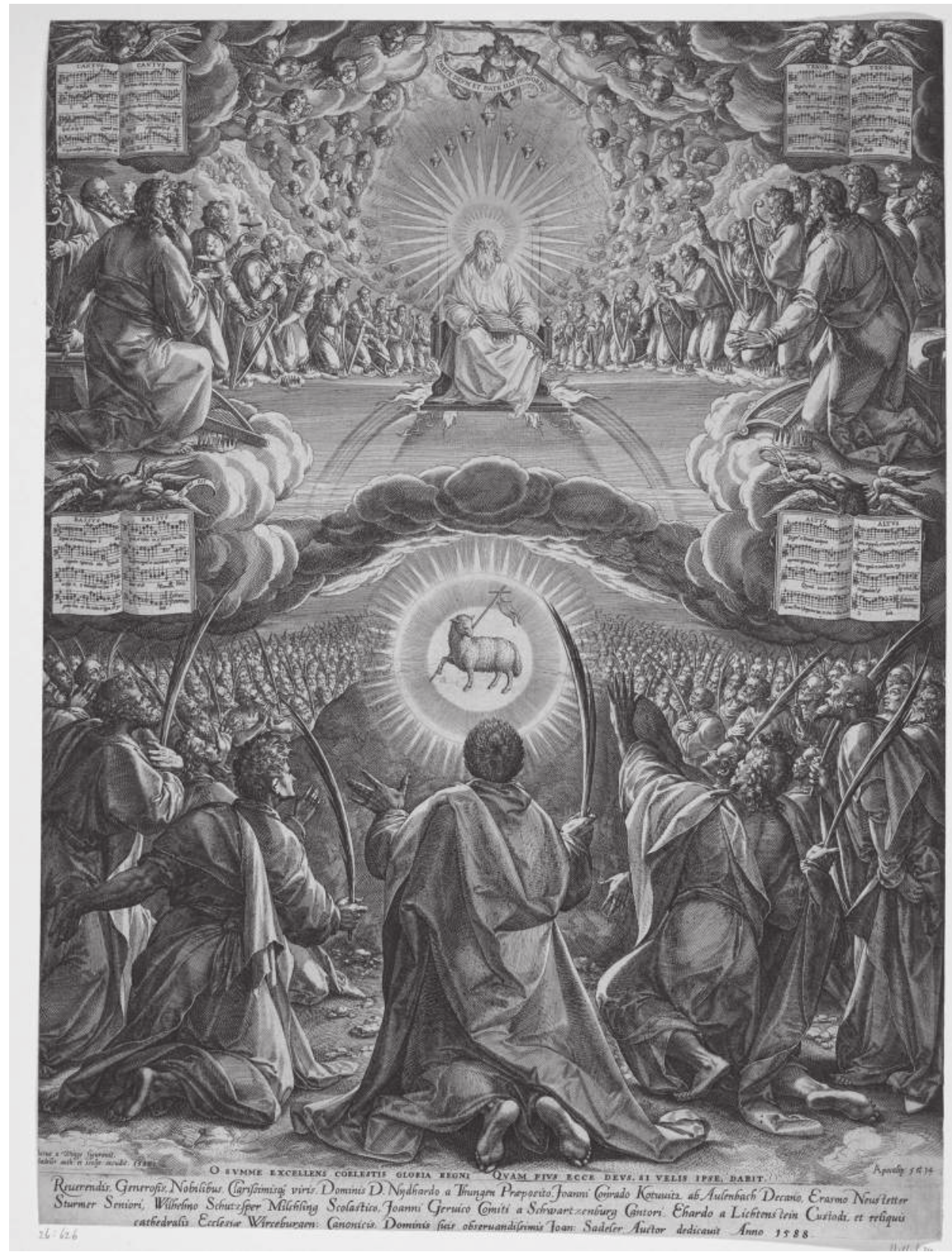

Figure 13.1 Joos van Winghe, Jan Sadeler and Andries Pévernage, Adoration of God's Lamb, 1588, engraving. Amsterdam, Rijksmuseum, RP-P-1926-626.

Photo: http://hdl.handle.net/10934/RM0001.COLLECT.168516, CC0 1.0. 


\section{András Hándl}

composition, yet in Revelation they are surrounding the throne. This is not the only difference between the visual rendering and the text of Revelation, as the sequence of the creatures (human, lion, ox, eagle) also changes. In the presented form, it reflects the order of the Gospels, as the creatures were identified with the four Evangelists already in the early church, ${ }^{4}$ and not the biblical account (lion, ox, human and eagle [Rev. 4:6-8]). The praise of the apocalyptic creatures-the second reference-with the so-called Trisagion, "Holy, holy, holy, the Lord God the Almighty, who was and is and is to come" (Rev. 4:8), is split between the four creatures and printed in Latin on small banderols attached to each creature's mouth or beak. Each of the creatures holds a book, which is, against all expectations, not a Gospel book but a choral part book. These display the text and the score of an eight-part motet with two parts each for "CANTVS", "TENOR", "BASSVS" and "ALTVS". A postscript at the end of the voices "BASSVS" and "ALTVS" names Andries Pévernage (1542/3-91) as the composer of the motet, a musician who had worked as choirmaster at the Cathedral in Antwerp from 1585 onward. ${ }^{5}$ The text of the chant, Dignus es Domine, is a literary quotation of the "new song" that was sung by the twenty-four elders (Rev. 5:9-10) as a reaction to the appearance of the Lamb that was slaughtered, that is, the Lamb who had seven eyes and seven horns (Rev. 5:6-8). The "new song" is the third musical reference and serves also as a musical link between the upper and lower parts of the composition. The visual link is the Lamb himself, a symbol of the resurrected and victorious Christ situated on Mount Zion (Rev. 14:1). He is the one worthy to open the book of seven seals (Rev. 5:6-8) held by God the Father, who is depicted as seated on the throne. The Lamb is also the subject of the heavenly worship by the elders, creatures, all the angels (Rev. 5:11-13) and the 144,000, all of whom gathered at the foot of Mount Zion to adore the Lamb (Rev. 14:1-5). Thus, the appearance of the Lamb is the culmination of the vision, the very essence and centre point of every praise, of the entire heavenly gathering and of the composition itself.

While the visual combination of non-consecutive chapters of the Scripture in a single scene is a rather common feature of many religious images of this period, the depiction of the heavenly worship with the imagery of musical scores is an original invention. An inscription at the bottom right listing the visualised scriptural sources puts the emphasis once again on the musical motif, as it records only chapters 5 and 14 , although the "throne room vision", which depicts the space in which the heavenly worship takes place, is described in chapter $4 .{ }^{6}$ The combination of indirectly related chapters with the accentuated presence of musical elements results in a complex and intriguing rendering with several creative and individual solutions. Thus, the composition is to a high degree original and bears witness to an intensive encounter with the biblical account beyond recapitulating well-known iconographical models. Despite following the Revelation text closely, the engraving offers more than simple visual exegesis to various passages of Revelation. By singing the true and only heavenly tones and by sneaking a peek into "eternity", the person viewing the image and performing the music is transformed for this time to one of the 144,000. The viewer-performer is privileged enough to have learned the new song, therefore having the sensation of having joined, if only for a moment, the ranks of the redeemed. The overwhelming illustration of the promised future, combined with the true musica mundana, induces a unique multi-sensory impression and thus an extraordinary spiritual experience far beyond what often-circulated devotional prints offered, which were characteristic for the Catholic confessionalisation. ${ }^{7}$ This effect, as well as the devotional use of the engraving, was doubtless intended by the artists, who include the following 
subscription at the bottom of the sheet: "O SVMME EXCELLENS COELESTIS GLORIA REGNI QVAM PIVS ECCE DEVS, SI VELIS IPSE, DABIT"

Despite the engraving's spiritual aspects, some of its rather subtle elements, or more precisely a combination of them, imply a confessional orientation. One of these is the exclusive use of Latin instead of vernacular. Another element is recorded in the choral part books: the angels and the elders worship God and the Lamb with polyphonic and instrumental ${ }^{9}$ music. For some, such flamboyant music would have been an unbearable sacrilege, particularly in a liturgical context, for, as Calvin himself had noted, "the venom and the corruption is distilled [...] by the melody" ${ }^{10}$ For others, instrumental music and polyphony reproduce purely the celestial tones of the heavenly liturgy. ${ }^{11}$ The latter group certainly includes the Catholic emigrants Sadeler and Winghe, and particularly Pévernage, whose livelihood and, indeed, his existence were endangered by the radical refusal of polyphonic music by the Calvinists who ruled Flanders and Antwerp for several years. Even if the point was only implied, it was clear to anyone: heaven is Roman Catholic, not Protestant and most certainly not Calvinist. The confessional character and the initially envisaged market segment are further highlighted by the dedication on an early impression located at the bottom of the sheet. ${ }^{12}$ Named are various representatives of the higher Roman Catholic hierarchy, among many others, ${ }^{13}$ for instance, Neithart von Thüngen (1545-98), provost and rector of the university at Würzburg, from 1591 prince-bishop of Bamberg and an active promoter of the Catholic Revival. ${ }^{14}$ Based upon these observations, one may say with relative certainty that the initial target market for this print was not the local (and overwhelmingly Lutheran) citizens of the free imperial city of Frankfurt, ${ }^{15}$ but rather well-educated and musically disposed Roman Catholic intellectuals and the Roman Catholic Church's ecclesiastic elite. ${ }^{16}$ Even so, the use of a separate second plate to impress the dedication implies that Sadeler might have intended to distribute the print to a larger, not necessarily Catholic audience as well.

Neither the initial market positioning nor the clear, if subtle, confessional orientation prevented the eventual cross-confessional dissemination and reception of the composition. On the contrary, it was diligently reproduced, modified and disseminated all over Europe - certainly as an illustration in several German, Dutch and even Armenian Bible editions-as Vorlage for large-scale oil paintings at least in two cases, and, it would seem, in Italy as well.

\section{Second-State Prints}

After the death of Sadeler, the original printing plate was used for second-state impressions. ${ }^{17}$ Some small yet significant modifications had been made to the plate. The signature "Jodocus a Winge figurauit, I. Sadeler auth: et scalpt: excudit. 1588." was eliminated from the bottom left and replaced with "Ago. Caracci in. f. 1542", and the initials "AF" were added at the bottom right. The new signature reattributes the print to the renowned Italian painter and printmaker Agostino Carracci (1557-1602). The re-engraver, however, appears to have made a glaring mistake when he antedated the engraving to 1542 -the date fifteen years prior to the birth of Agostiono Carracci. ${ }^{18}$ The identity of "AF" must remain obscure-by no means can it be attributed to Carracci ${ }^{19}$-it is not unlikely that the re-engraver here used his own monogram.

Curators of Carracci collections have considered the second-state impressions to have been made relatively early, not long after the death of Sadeler, and somewhere in Italy. ${ }^{20}$ The fact that Sadeler spent the last five years of his life-from 1595 to 1600 in Italy, first in Verona and then from 1597 in Venice, made such considerations 
plausible. However, the altered plate was still in use probably as late as the nineteenth century when the impression from the Biblioteca di San Giorgio collection might have been printed. This is attested to by its support-the industrially produced paper of comparably rather "hairy" haptic, without laid and chain lines and missing a watermark. ${ }^{21}$ What is more, the Carracci signature bears a resemblance to nineteenth-century Italian cursive handwriting, and this may suggest a substantially later date of the second state. ${ }^{22}$

Despite the fact that the engraving's date of " 1542 " belies its status as an original Carracci, the impression was apparently convincing enough to be considered an original Carracci; indeed, it has entered at least two Carracci collections. ${ }^{23}$ As the prints likely gained higher profit using the new pseudonym, the reattribution literarily paid off. The modifications the re-engraver-or maybe closer to reality, probably the forger-made betray economic interests above all. Importantly, the engraving provides no indicators that would suggest a confessional, devotional or other religious motivation for the alterations or for the reprint.

\section{Reproduction in Bible Editions}

The close visual rendering of the biblical text and the high artistic quality destined the print to serve as an illustration for the Book of Revelation, though it is not until now that this has been noted in scholarship.

The engraver and publisher Matthäus Merian the Elder (1593-1650) was probably the first to customise Sadeler and Winghe's design and use it for his own purposes. $\mathrm{He}$ did this in his first independent project as a publisher, the Icones biblicae. ${ }^{24}$ This album, a Bilderbibel, which is to say, a collection featuring illustrations to all the books of the Bible yet without text, was printed in four volumes between 1625 and 1627 in the print shop of his late father-in-law, Johann Theodor de Bry (1561-1623). Three volumes are dedicated to the Old Testament and one to the New Testament. The altogether 233 plates are accompanied only by short subscriptiones in Latin, German and French, which were written by the Calvinist theologian Johann Ludwig Gottfried (1584-1633). ${ }^{25}$ The presentation of the illustrations in the style of the popular emblem books was a savvy and indeed low-risk endeavour. Being confessionally and thus also politically neutral, it was bound to sell well. ${ }^{26}$

Merian engraved twelve illustrations of scenes from Revelation, one of them of the throne room vision described in chapter 4 (Figure 13.2). Even a quick glance reveals the extraordinary similarities in composition and design between the beeldmotet and Merian's illustration: the latter has its visual roots in the upper part of the former. The reprint of the entire monumental scene, one in which several chapters were mingled, was evidently not an option for a religion-aware and well-educated engraver. ${ }^{27}$ Consequently, he re-used the upper part only. Moreover, he altered the original design for a more text-tailored fit: he added the figure of John of Patmos beneath the clouds and placed the Lamb with seven horns above them in the front of the throne (Rev. 5:6). In addition, he removed a few elements that are not mentioned in the text. These include the angel holding a banderol above the seven lampstands, as well as the choral part books being held by the four apocalyptic creatures. Merian also reduced the width of the print by cropping narrow strips from both sides. Due to the strict symmetrical composition, it is difficult to notice that the scene is mirror inverted. This typical effect of the copy process resulted in a peculiar sequence of the apocalyptic creatures: they correspond neither to the descriptions of the biblical passage nor to the sequence of the Gospels. 


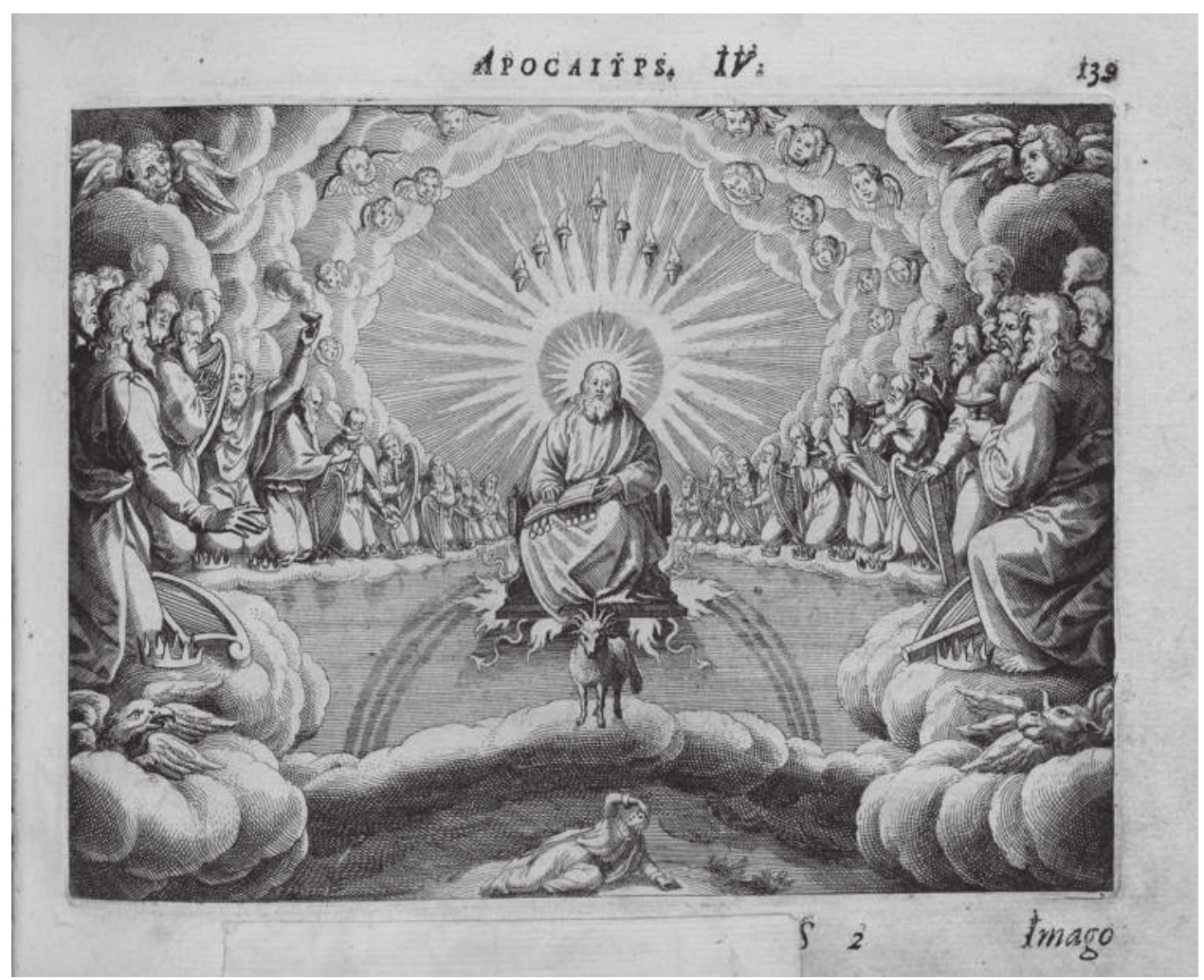

Figure 13.2 Matthäus Merian, APOCAIY்PS. IV. in Icones Biblicae, vol. 4: Novi Testamenti . . historiae (Frankfurt/M: Matthäus Merian, 1627), 139, engraving and letterpress. Bamberg, Staatsbibliothek Bamberg, A.symb.q.23\#4, urn:nbn:de:bvb:22-dtl-0000003700\#0139.

Photo: Gerald Raab, Staatsbibliothek Bamberg, CC-BY-SA 4.0.

Due to financial difficulties or as a political precaution, Merian sold the printing plates to the publishing house Lazarus Zetzners Erben in Strasbourg. ${ }^{28}$ After printing two editions of the Icones biblicae (1629/30), the publishers incorporated the illustration into the famous "Merian Bible" (1630), a folio-format Bible based on the translation of Martin Luther. ${ }^{29}$ In order to fit a text column, a further reduction of the width of the engraving was necessary. Not surprisingly, the editors chose to trim rather than to re-engrave the image. Their approach meant that one of the elders on the left-hand side was cropped out, resulting in the depiction not of the twenty-four elders, but of twenty-three.

As the thorough study of L. H. Wüthrich makes quite clear, Merian used the rich tradition of illustrated Bibles and the works of a number of artists as sources of inspiration for his selection of topics, figures, landscapes and battle scenes. Yet Wüthrich also claims that Merian's compositions are original. ${ }^{30}$ Clearly, the illustration of the throne room vision is an exception to this general observation, as Merian does not simply render several characteristic features of an archetype, but rather reproduces 


\section{András Hándl}

nearly in its entirety the upper part of the picture motet. Although Merian's prints have been celebrated as "extraordinarily beautiful and complex renderings of the biblical stories (...) capturing the grandeur of large-scale historical painting in the small dimensions of the engraving", ${ }^{31}$ the credit should be given to Sadeler and Winghe in this particular case. Ironically, the very "grandeur" of the composition led scholars to believe it was Merian's genuine invention. Importantly, this observation also makes another of Wüthrich's claims obsolete, namely that Merian had used a composition from his father-in-law's 1609 Vulgata edition as the inspiration for his throne room engraving. ${ }^{32}$ All this notwithstanding, De Bry still plays an important role. The Flemish print artist, goldsmith and publisher arrived at Frankfurt in the same year as Winghe (1586) and just a year prior to Sadeler (1587). He was an associate of the Sadelers in Antwerp prior to their departure ${ }^{33}$ and even printed some of their engravings in Frankfurt. Thus, it is more than likely that Merian discovered the picture motet when he took over the late De Bry's print shop in 1623.

The Wirkungsgeschichte of Merian's illustrations, and thus that of the beeldmotet, is immense. Although the Icones biblicae series quickly became popular and was frequently copied from soon after its completion, it was the Kupferbibel that most profoundly shaped generations of illustrated Bible editions, as it was reproduced across confessional $^{34}$ and state $^{35}$ borders in the seventeenth and eighteenth centuries no fewer than nine times. Moreover, the images it contained-including the throne room vision-were used as a model for painted decorations in various churches, mainly Lutheran, across the Holy Roman Empire. ${ }^{36}$

Christoffel van Sichem II (c. 1581-1658), the Basel-born, Amsterdam-based Protestant woodcutter, print artist and publisher, employed a different approach when he made extensive use of the picture motet's design. He adopted it (Figure 13.3) for a Dutch Catholic New Testament edition. The text is based on the 1622 translation by Henricus van den Leemputte (1587-1657) and was printed in Amsterdam in 1646 by the Catholic publisher Pieter Jacobsz Paets (1587-after 1657). ${ }^{37}$ In contrast to Merian, van Sichem was not bothered by the fact that the composition combined several nonconsecutive chapters of Revelation in a single scene. He simply made use of the entire composition and cut it into a wooden block. Although the technique and the reduced dimensions of the column illustration forced him to simplify the design, he made efforts to keep all the characteristic features of the original. Apart from adding his initials ("CVS") in the angel's part book, the woodcutter made no further alterations to the composition. This approach is characteristic of van Sichem's work, who relied heavily on the oeuvre of renowned artists such as Albrecht Dürer, Lucas van Leyden and Hendrik Goltzius as a source of inspiration and beyond. Indeed, he often modified his models marginally but still signed them with his monogram. ${ }^{38}$

Paets used the same wooden blocks two years later in ' $t$ Schat der zielen ("The Treasure of Souls"), a Catholic devotional anthology on the life of Christ. The work was based on the New Testament and executed in the style of religious emblem books. ${ }^{39}$ Since both this work and that of the Dutch New Testament were richly illustratedvan Sichem cut twenty images for Revelation, whereas Merian had etched only twelve, and Paets used almost seven hundred for the 't Schat der zielen-they might offer not only intellectual value to their readers but a high degree of visual delight as well. Somewhat later, Paets sold the complete set of biblically themed wooden blocks to the Amsterdam-based Armenian scholar and publisher Oskan Yrevantsi (or Voskan of Yerevan, 1614-74), who founded and ran the first Armenian publishing house in 


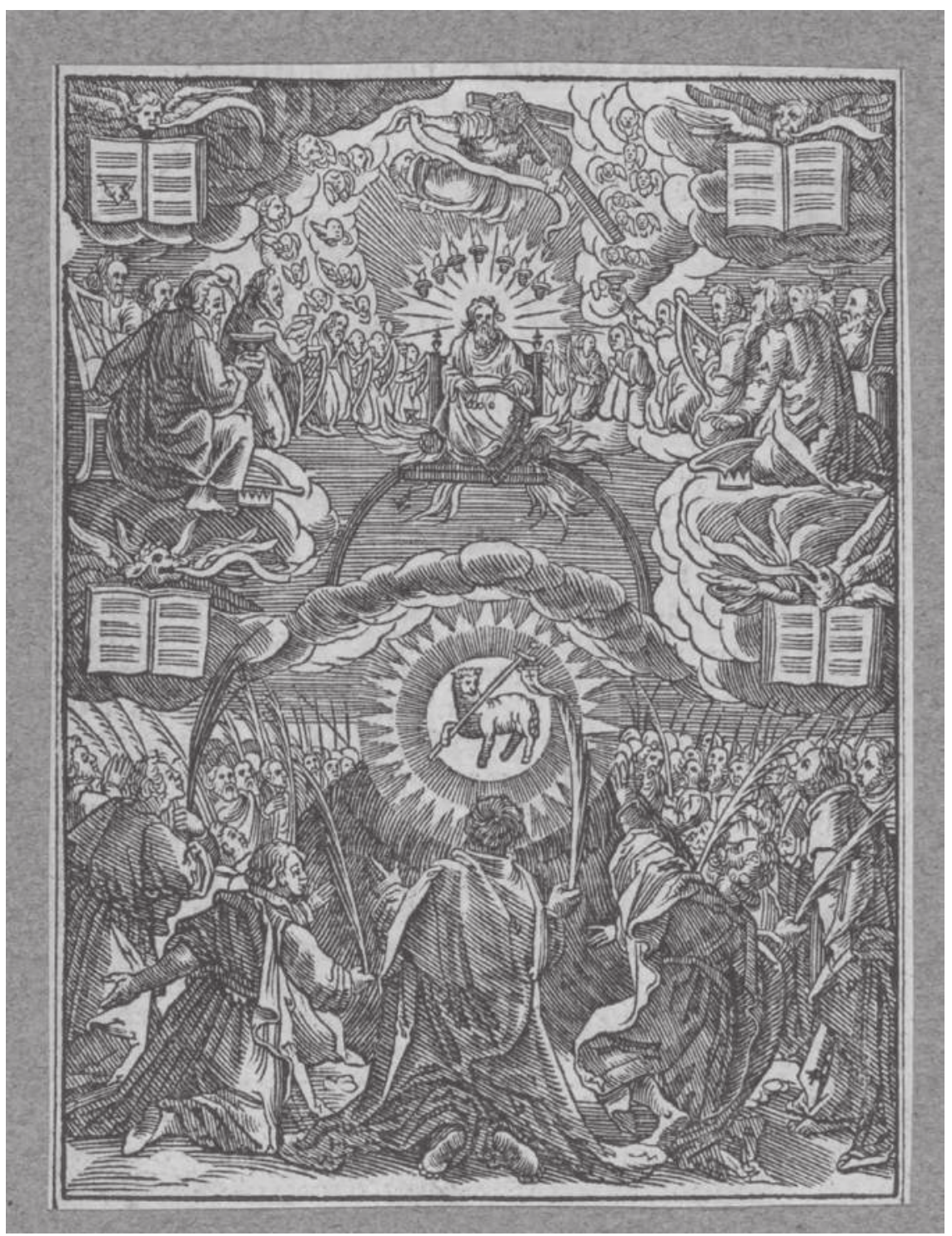

Figure 13.3 Christoffel van Sichem II, Adoration of God's Lamb, 1646. Amsterdam, Rijksmuseum, RP-P-2015-17-38-2.

Photo: http://hdl.handle.net/10934/RM0001.COLLECT.590024, CC0 1.0.

history. ${ }^{40}$ Thus, Oskan used van Sichem's simplified composition of the picture motet alongside 158 other of van Sichem's woodcuts to illustrate the first-ever complete printed Bible in Armenian (Amsterdam, 1666, Figure 13.4). ${ }^{41}$ As the printed copies of the Bible were intended for export, Oskan's edition, with the design of the beeldmotet, reached Armenian communities throughout the Ottoman Empire and Iran. The "Oskan Bible" quickly gained authority and was established as normative for 


\section{András Hándl}

centuries: not only was its text deemed authoritative, ${ }^{42}$ but more importantly, its iconography influenced the illustrative canon of Armenian Bible prints and beyond. ${ }^{43}$ For instance, the 1733 Bible edition (the so-called "Mekhitar Bible") of the priest Mekhitar Sebastatsi (or Sebastia, 1676-1749), printed in Venice, reproduced many of van Sichem's illustrations as etchings, among them The Adoration of the Lamb. ${ }^{44}$

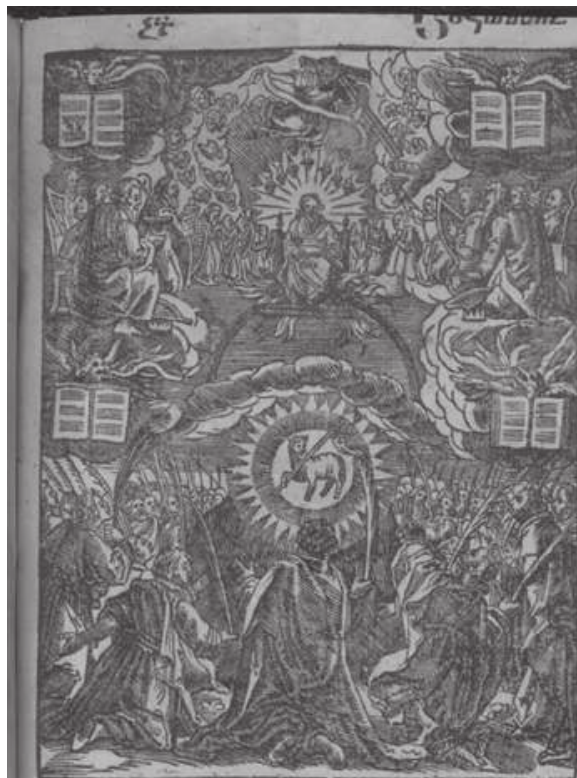

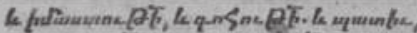

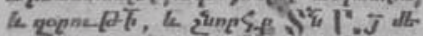

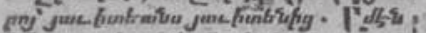

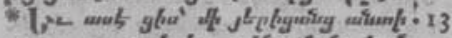

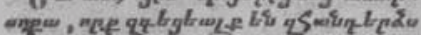

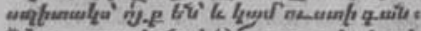

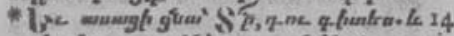

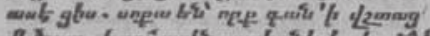

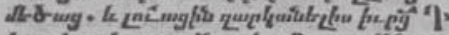

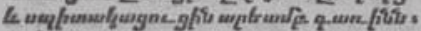

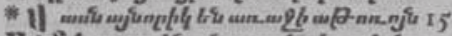

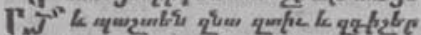

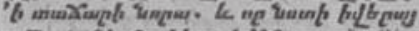

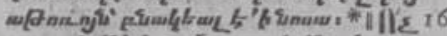

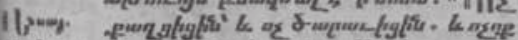

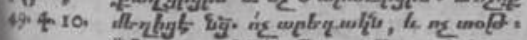

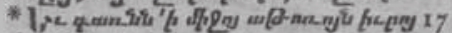

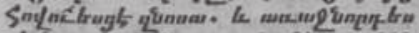

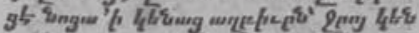

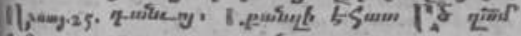
4.8. mpuroong jugiug singus: तो $=2 \cdot 2 x$ 0,4

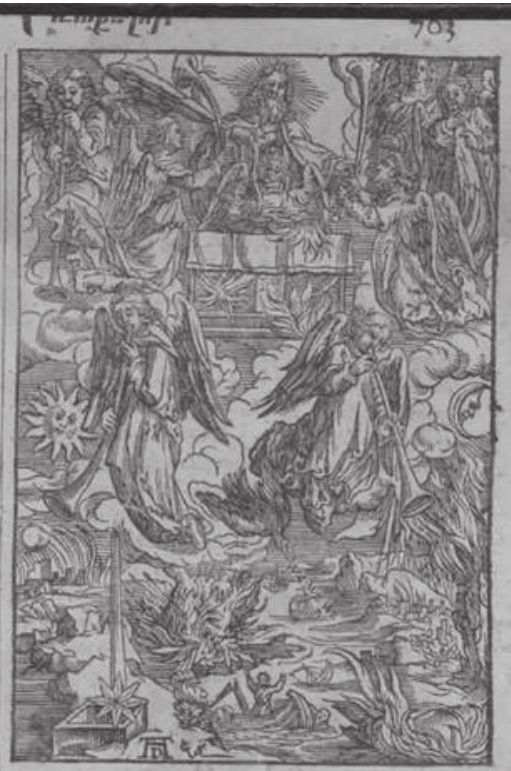

$9 \cdot \mathrm{I}: \mathrm{P}:$

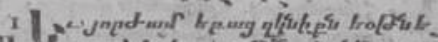

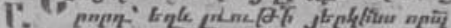

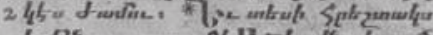

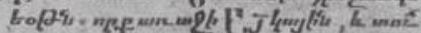

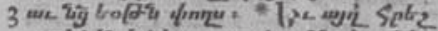

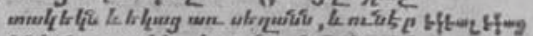

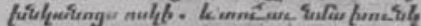

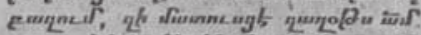

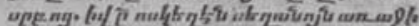

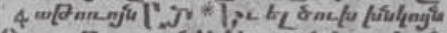

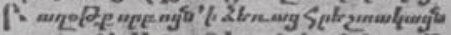

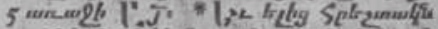

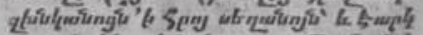

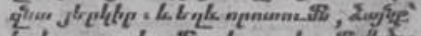

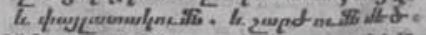

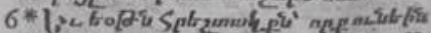

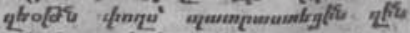

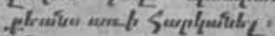

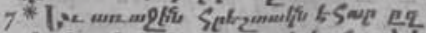

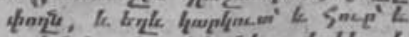

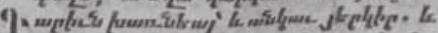

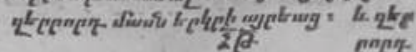

Figure 13.4 Christoffel van Sichem II, Adoration of God's Lamb (left) in "Oskan Bible" (Uuunnumdu2nı\{々) (Amsterdam: Tparan St. Ejmiatsin and St. Sargis the General, 1666), 703, woodcut and letterpess. Washington, Library of Congress, BS95 1666.

Photo: https://www.wdl.org/en/item/18400/view/1/1344/. 
The reception of this picture motet in Bible editions remains an ambivalent matter. On the one hand, it pays tribute to Sadeler and Winghe's extraordinary designimitation reportedly being the highest form of flattery. On the other hand, the use and reuse of the image represents a reduction of what was originally a novel, and indeed revolutionary, piece of multimedia art into little more than a "simple" illustration depicting a rather obscure passage from the Scriptures. The reception process, as demonstrated earlier, is often anything but creative; by and large, it is characterised by the reduction of complexity and the loss of its original devotional function. And yet the rise of illustrated Bibles containing remodellings or renditions of the original piece facilitated a wide distribution of Sadeler and Winghe's design, or at least parts of it, and thus influenced visual culture far beyond the confessional and state borders that originally confined it.

\section{Reproduction in Large-Scale Paintings}

One of the most praised qualities of the engraving - that it has the grandeur of largescale painting - made the composition a suitable basis for adaptation as actual largescale oil paintings. One of them (Plate 27) is today in the possession of the German St Gertrude's parish in the Old Town (gamla stan) of Stockholm. It is situated in the parish hall and has apparently thus far escaped the attention of a larger and international audience. ${ }^{45}$ According to an inscription located on the top and bottom parts of the heavy and heavily decorated picture frame, the painting was donated to the German church in Stockholm by Friderich Jürgens in the year $1614 .{ }^{46}$ The Jürgens are depicted in the painting, where Friderich is accompanied by his wife and several children. This figurative addition to the original design follows the canon of sixteenthcentury Protestant epitaphs: on the left-hand, or "male", side, the donor and his son are depicted on their knees in an attitude of prayer; on the right-hand, or "female", side, one finds his wife and three daughters. The gold jewellery and pearl-decorated garments worn by the donor and his wife emphasise the wealth of the family. The coat of arms-Saint George and the Dragon on the one hand and Justitia on the other hand-suggests that the members of the Jürgens family were citizens of Stockholm rather than members of the nobility. As the majority of the German population in Stockholm was involved in trade in one way or another, we may infer that they were a family of merchants. ${ }^{47}$ The painting was probably made in the Holy Roman Empire, since a painting of such high quality was still quite exceptional in early seventeenthcentury Stockholm.

Beside the depiction of the donor and his family, another notable modification is the change of the picture's format from horizontal to vertical. The re-orientation was necessary to gain the space needed to accommodate the donor's family. In order to keep the proportions, some elements had to be rearranged. In the upper part, the apocalyptic creatures were simply redistributed from the periphery so that they now frame the elders from the side. Reconfiguring the lower section must have presented a greater challenge. Apart from extending the space on both sides of the central kneeling figure, three additional figures were inserted to fill the gap behind the donor and his family. Two of them are turning their faces towards the viewer, but only the man on the right establishes eye contact. The anticipation and the elaborate facial features suggest that they might be portraits of contemporaries. The painter otherwise implements the Sadeler and Winghe's composition quite faithfully. For instance, the text on the banderols and 


\section{András Hándl}

the motto at the bottom remain in Latin. Likewise, the choral part books still refer to polyphonic music, even if, apart from the first couple of syllables, the text is largely unreadable. The scores follow to some extent the visual pattern of the original, but result in cacophony rather than euphony, as any attempted performance would reveal.

Far less obvious, but much more characteristic, is a further modification. One of the elders in the upper right corner, next to the part book "TENOR", is altered to represent none other than Martin Luther. His well-shaved face, black academic gown, red collar and a book in his hand-most likely the Bible-is in obvious contrast to the other twenty-three heavily bearded elders, wrapped as they are in colourful garments and holding harps and golden bowls. Picturing Luther as one of the elders, as a member of the most elite of the heavenly hierarchy and most intimate with God, might be read/is a visual expression of the new faith's divine approval. What is more, God does not simply acknowledge Luther's quest for the truth, but by being the only identifiable person among the elders, the Reformer is represented, it would seem, as the one true teacher of the one true faith. The consequences and implications cannot be more straightforward: there is not only a place for the Lutherans in heaven, but heaven favours Lutherans (and, it may be implied, not Catholics). Yet it is difficult to pin down the motivation behind Luther's demonstrative presence in heaven to one single reason. On the one hand, it could easily have been rooted in the growing conflict between Catholics and Protestants as they rushed towards the outbreak of the Thirty Years' War. On the other hand, representing Luther in this way might simply have been the easiest way to confessionalise a largely neutral, slightly Catholic design and render it unmistakably Protestant. Or perhaps the answer lies somewhere in between.

\section{The Toruń Panel}

The origins of the painting today known as "Adoracja Baranka" (Adoration of the Lamb, Plate 28) and exhibited in the St Stephen Church (kościół św. Szczepana) in Torun (Thorn) are mysterious. A drawing of the whittawer and amateur illustrator Georg Friedrich Steiner (1704-66) substantiates for the first time its existence and confirms that the painting was placed in an altarpiece in the Holy Trinity Church (kościół św. Trójcy) at the New Town market. ${ }^{48}$ This church was used by the Protestant $^{49}$ citizens of Torun from 1667 onwards until its replacement with the current building, which was erected in $1824 .{ }^{50}$ According to the records, the altarpiece depicted on Steiner's drawing was not commissioned until 1679-twelve years after the conversion of the formal New Town city hall into a church. ${ }^{51}$ It is possible that the painting has a longer history and was painted before 1679; due to the lack of records, however, a more precise dating is not currently possible. ${ }^{52}$

The large-scale painting renders Sadeler's engraving accurately; only a small number of additions to and deletions from the original design can be observed. The choral part books and the apocalyptic creatures' banderols displaying the Trisagion are eliminated, as are all the additional references to music. In this way, the celestial choir had been "muted", as it were, and the composition is reduced-similar to the biblical illustrations - to a bare visualisation of Revelation. A rather notable addition is a good number of eyes covering the wings of the apocalyptic creatures, as described in Rev. 4:8. Still another subtle but meaningful change is an amendment of the reference list located in the painting's lower right corner. The insertion of Revelation 4 into the list is long overdue because, as has been pointed out earlier, the upper part of 
the composition features the "throne room vision" as it is elaborated in Revelation 4. ${ }^{53}$ One should not, however, underestimate the insertion's significance because it substantiates that the iconographic programme of the composition was evaluated, or at least reflected, in light of the biblical account. In other words, the one who commissioned or executed the conjecture must have been, or become, familiar with the Book of Revelation. Moreover, he had an eye for detail and an evident interest in the accuracy of the visualisation. Thus, the alterations to the original design are not necessarily and exclusively reflections of the visual or iconographical tradition, but in this case, they also indicate theological concerns.

Further alterations to the original design are secondary; that is to say, they were added to the painting at a later stage. ${ }^{54}$ One of them is the discreet masking of God's portrayal with a golden aureole and the enlargement of the aureole with oversized golden beams that replace a smaller-scale radial halo that was painted with pastel colours. The aureole was marked with the theonym יִּיה (YHWH), or the Tetragrammaton (the biblical name of the God of Israel), which is rendered in red and back paint and with the vocalisation for "Adonai" ("my Lords"). The effect of the Hebrew label is to identify the obscured presence as God the Father. The golden paint that was used for the aureole was also used to remodel and slightly enlarge the pastel-coloured radial halo of the Lamb, an integral part of Sadeler and Winghe's design. The latter intervention was likely a practical necessity that was undertaken first to highlight the Lamb's glory and second to shift the visual focus from the now-overpowering presence of God the Father back to the actual centre and essence of the composition-the Lamb. In contrast, the formal alteration reflects sturdy theological (re)considerations and a shift of religious sentiments. With the successive consolidation of Calvinism among the rather wealthy Protestant citizens of Toruń, an explicit anthropomorphic rendering of God was no longer welcomed, ${ }^{55}$ especially in light of the Second Commandment of the Decalogue (Ex. 20:4) and its strict Calvinistic interpretation. ${ }^{56}$ In order for the altarpiece to conform to the Calvinist theological sentiment and meet with the expectation of the church's "conservative laity", 57 these rather rudimentary alterations were both necessary and sufficient. ${ }^{58}$

\section{Conclusions}

The most important observation to be made at the conclusion of this chapter might, to a certain degree, appear unsatisfying: the reception of The Adoration of the Lamb, a beeldmotet by Winghe and Sadeler, is in its individual expressions so diverse that it is challenging to outline its universally characteristic features. Certainly, the choice of the subject and the extraordinary composition were important keys to its success. The intellectually appealing combination of several non-consecutive scenes in a single image, to say nothing of the overwhelming spectacle, in a strict symmetrical yet dynamic design must have attracted particular attention from the Bible illustrators who saw it. Merian's radically reduced redesign was printed several times from 1627 onwards. Van Sichem's slightly simplified iconographic adoption in a woodcut nearly twenty years later was also successful. Almost eighty years after the creation of the original motet picture, the wooden block was sold and used in Oskan's Armenian Bible in 1666. The implementations of the composition in Bible editions fostered its dissemination across Western and Eastern Europe, eventually reaching even 


\section{András Hándl}

Armenia and Iran. Yet other artists, mainly local, used it as a model for the decoration of numerous church furnishings, from panels in Lutheran churches to silverware in Armenia.

Nevertheless, its subject and composition were not the only keys to the beeldmotet's success. The lack of insuperable confessional features and connotations, together with the otherwise confessionally neutral design, played an essential role as well. The few elements that do in fact reflect some kind of confessional attribution were in contrast to the obvious dedication of the first impression and were rather subdued, such as the exclusive use of Latin or the representation of polyphonic music in the part books. Hence, any deconfessionalisation, if it were considered necessary at all, was easily implemented by the replacement or removal of the objectionable elements. Occasionally, these features were not even seen as definite expressions of confessional sentiments, as the decision to keep the Latin language (Stockholm and Toruń) or the choral part books (Stockholm) demonstrates. The local political and religious contexts in which the individual receptions took place seem to have had significant bearing on whether elements would be interpreted as confessional markers: the more the confessionally diverse and competitive the environment was, the more these elements were perceived as expressions of a specific confessional sentiment. In any case, it was the "neutral" iconography-that is, the iconography that had its source in the biblical account itself-that facilitated the reproduction or implementation of the design beyond the borders of the established confessional visual canon. After all, it appears that the Catholic imagination of heaven differs, if only in minor detail, from that of that of the Calvinists, Lutherans or Armenians.

The spiritual-devotional dimensions appear likewise to be an important factor of the picture motet's broad reception. The commissioners of both large-scale paintings valued the devotional character of the original: The Stockholm painting demonstrably retains this aspect by recapitulating the invocation "IN SVMMA," though without any effort to render it in German-this is in contrast to the inscriptions that are placed on the frame. At the same time, the large-scale reproduction of the print and its public exhibition-one that was intended originally for private use only-goes well beyond Sadeler's initial intentions. Represented as partakers of divine action, the donor, together with his family, put their piety on display for the assembled congregation and for anyone who might visit the church. What is more, members of the congregation personally benefited from the donor's piety: the donor's pious intentions now made it possible for other members of the community to use the painting for contemplation and personal edification, and in so doing, catch a glimpse of eternity-well in line with Sadeler's exhortation and original intentions.

Even so, the framing of the Torun panel in a baroque altarpiece elevated the composition's spiritual-devotional dimension to an entirely new level. It was before this altar that the faithful assembled to receive the (symbolic) body and blood of Christthe tangible proof of God's mercy and the only materialised expression of salvation besides baptism. For the community, then, the altar represented not only the majesty and glory of the celestial worship but also the promised salvation as brought to them through Communion. Moreover, the communicants joined, if only for a moment, the circle of the 144,000 and became participants in the heavenly worship. Hence, the altarpiece acted not only as a visual-illustrative backdrop to the liturgical performance but, together with the materialised sanctity of the Communion bread and wine, actually created a multi-sensory preview of the heavenly worship within God's very throne room, which, for this brief moment, extends to the earth itself. 


\section{Notes}

* I would like to express my appreciation and thanks to Dr Alexandra Mütel (Bonn) for her essential support at the early stage of the research. Parts of this research received funding from the European Union's Horizon 2020 research and innovation programme under the Marie Skłodowska-Curie grant agreement No. 665501 in form of a FWO [PEGASUS]2 Marie Skłodowska-Curie fellowships no. $12 \mathrm{~T} 3717 \mathrm{~N}$ to the author.

1 See Seiffert, "Bildzeugnisse," 49-67; Hammerstein, "Imaginäres Gesamtkunstwerk," 165204; Vignau-Wilberg, "Pictorial Motets," 166-86; idem, Niederländische Bildmotetten; idem, "Bildmotetten," 219-28.

2 The engraving had received appreciation, if only generic, mainly from musicologists. Cf. note 1 . The few art historical accounts are limited almost exclusively to exhibition catalogues: Bartrum, "The Vision," 117; 201, cat. 104; Vignau-Wilberg, "Pictorial Motets," 178. The most substantial contribution has been made by Vignau-Wilberg, Niederländische Bildmotetten, 26.

3 The description offered in Revelation is less anthropomorphic than the engraver's visual rendering. Though he made considerable efforts to avoid such descriptions of the divine, John of Patmos, the author of Revelation, is forced by the lack of alternatives to apply anthropomorphic terminology throughout his text, for instance, in Rev. 4:2: “one [is] seated on the throne" (emphasis is mine). Cf. Vignau-Wilberg, Niederländische Bildmotetten, 26.

4 While the identification goes back to Irenaeus of Lyon (†c. 202), Jerome's (347-420) interpretation ultimately prevailed. He associated the human with Matthew (not with John), the lion with Mark, the ox with Luke and the eagle with John (and not with Matthew, as suggested in Vignau-Wilberg, "Pictorial Motets," 179).

5 Stellfeld, Andries Pevernage, 7-34; Bossuyt, Van Deun, and Cooremans, eds., Beeldmotetten, 2-4; Forney, "Pevernage."

6 Apocalip: 5 et 14. Kruszelnicki, "Obraz," 114, expresses his astonishment about the inclusion of chapter 14, citing a lack of visual reflection of the chapter in the painting. Yet several elements, such as Mount Zion and the palm leaves, are mentioned only in Rev. 14. Moreover, while chapter 14 does not provide any further descriptions of the Lamb, the "slaughtered Lamb" of chapter 5 has seven horns and seven eyes. Cf. Merian's engraving, Figure 13.2.

7 See the contribution of Alexandra Kocsis in this volume.

8 "O highest, excellent glory of the kingdom of heaven, which God the pious will grant to you if you desire."

9 Whether the instrumental aspect of the music has an intended confessional edge is debatable at least. On the one hand, Rev. 4:4 mentions harps as being held by the twenty-four elders. On the other hand, the vision does not specify that the elders actually provide musical accompaniment on their harps as they intone the "new song" (Rev. 5:9-10).

10 Preface to La forme des prières et chants ecclésiastiques (1543) in Calvin, Opera Selecta, vol. 2, 17. Among other things, he strictly opposed polyphony and musical instruments in the liturgy. Even so, polyphonic settings of the Genevan Psalter had been made by Pevernage and others, though it must be added that such settings were not intended for liturgical use. Cf. Bertoglio, Reforming Music, 219-24 and 318-27. See also: Weeda, Le Psautier de Calvin and the contributions in Grunewald, Jürgens, and Luth, eds., Der Genfer Psalter.

11 Since the Catholic musical repertoires and practices are largely heterogeneous across early modern Europe, it is challenging to briefly summarise their characteristics. First, the primary role of polyphonic music was never questioned in liturgy, religious ceremonies, and public and private life. Composers of sacred music were merely urged to refrain from "lascivious or impure" compositions. Although vernacular was gaining popularity over time, it had rather little influence on liturgical compositions, as the language of the Tridentine mass was Latin. In this respect, the Council of Trent strongly influences discussions of music within the Catholic Church. Even so, Trent's role has been overemphasised. Postconciliar spiritual renewal also shaped sacred repertories significantly and supported the rise of new musical forms, particularly in connection with (popular) devotion. An instructive overview with references to further readings: Fisher, "Music and Religious Change," 397-404. 


\section{András Hándl}

12 Other surviving examples witness that impressions were also made without the dedication: Lisbon, Biblioteca Nacional de Portugal, 5340; 272-312(084.1) and London, BM, $1868,0612.505$. The sheet with the dedication is slightly taller $(42.2 \mathrm{~cm})$ than the prints without it (they vary between 40 and $40.5 \mathrm{~cm}$ ). In addition, a fine black line runs between the dedication and the main motif, which is absent from the prints without. For these reasons, it can be safely deduced that Sadeler likely used an additional plate for the dedication.

13 A good number of further names on the dedication list suggests that Sadeler intended to reach a larger group of potential wealthy patrons, such as Johann Conrad Kottwitz von Aulenbach (†1611), who was also a rector of the university (1585-86) and a cathedral dean at Würzburg and Mainz. Cf. Romberg, Das Bistum Würzburg, 60. Likewise, Erasmus Neustetter genannt Stürmer (1523-94) was rector of Würzburg University (1589-90) and provost. See Wendehorst, Das Bistum Würzburg, 253-54. The listed ecclesiastical authorities were active in the prince-bishopric of Würzburg around 1588, which was, next to Mainz, the closest Catholic territory to Frankfurt.

14 Weiß, Die Bistümer der Kirchenprovinz Mainz, 258-304; Brommer, Rekatholisierung, 475-78.

15 A first publication in Munich, as Vignau-Wilberg, Niederländische Bildmotetten, 26, suggests, is in my opinion less likely, particularly in light of the dedication. An exclusive orientation towards the bishopric of Würzburg makes more sense in the Lutheran free-imperial city of Frankfurt than in Munich, the centre of the Catholic revival, with the bishopric of Freising in the immediate vicinity. Cf. note 11.

16 The confessional character of the picture motet becomes even more evident if one considers the subjects of further examples designed and published by Sadeler: Mary and Child with Saint Anna, Mary surrounded by music playing angels and St Cecilia and an organ-playing angel, NHD, nos. 294, 304-5.

17 AF, Adoration of the Lamb (Adorazione dell'Agnello), Dutch? sixteenth- to seventeenthcentury, engraving, $40.3 \times 32.3 \mathrm{~cm}$, Gabinetto delle Stampe, “A. Davoli” (F 1542, cat. no. 282) and AF, Triumph of the Lamb (Il trionfo dell'agnello), engraving, $40.5 \times 32.3 \mathrm{~cm}$, Bologna, Biblioteca d'Arte e di Storia di San Giorgio in Poggiale, stampe, 4872. Given the fact that both prints feature the "AF" monogram and the alleged Carracci signature, it is rather likely that they belong to the same state of the print. Yet, only an autopsy of the Davoli print can provide a more definite answer. I would like to express my gratitude to the staff of the print collection of the library for granting access to the print and for the illuminating discussion. Yet, only an autopsy of the Davoli print can provide a more definite answer.

18 Cf. Emiliani, Baldassari, and De Liberali, I Carracci, 7-19 and 66-67.

19 Cf. Davoli, ed., La raccolta, 26.

20 Ibidem and the description on the Biblioteca di San Giorgio in Poggiale website: https:// collezioni.genusbononiae.it/products/dettaglio/389 (accessed 17 January 2019). For the actual state of the description see note 17.

21 Green, "Paper," 81-94; Hunter, Papermaking, 114-33.

22 The description on the Biblioteca di San Giorgio in Poggiale website was updated at some point after the consultation of the print on 5 July 2019 to include the following remark: Recenti indagini sul supporto cartaceo portano a ritenere l'esemplare in esame una tiratura tardo ottocentesca. https://collezioni.genusbononiae.it/products/dettaglio/389 (accessed 26 November 2019).

23 Both Italian prints were formally parts of larger Carracci collections. While the Davoli collection holds 127 prints of Agostino Carracci and 179 of Annibalo Davoli, the Biblioteca di San Giorgio in Poggiale provides a short note as to the provenance of the print. https:// collezioni.genusbononiae.it/products/dettaglio/389 (accessed 17 January 2019).

24 Geyrhalter, "Icones biblicae"; Drescher, "Icones biblicae," 80-91; Keuchen, Bild-Konzeptionen, 93-115.

25 Wüthrich, "Der Chronist, ” 188-216.

26 Wüthrich, Das druckgraphische Werk, XIII; Keuchen, Bild-Konzeptionen, 1:97.

27 Merian favoured illustrations that merged several moments of a story or parable, but not elements from various stories. Cf. Keuchen, Bild-Konzeptionen, 1:105-11. The importance of faith, religion and piety for Merian is demonstratively expressed by the motto of his 
publishing house: Pietas contenta lucratur (“zealous piety pays”). See Wüthrich, Matthaeus Merian der Ältere, 161-79.

28 Wüthrich, "Nachwort," 7.

29 Wüthrich, Merianbibel; Keuchen, Bild-Konzeptionen, 1: 98-99.

30 Wüthrich, Merianbibel, 45.

31 Price, "The Bible and the Visual Arts," 744-45.

32 Biblia Sacra Vulgatae Editionis Sixti V. Pont. Max. Iussu recognita Et Clementis VIII auctoritate edita (Frankfurt/M: Schon Wetterus, 1609), 192; Wuthrich, Merianbibel, 55.

33 Cf. Groesen, "De Bry and Antwerp," 36.

34 E.g., a French L'Histoire du Vieux et du Nouveau Testament, représentée avec des figures et des explications édifiantes (Paris: Pierre le Petit, 1670); or German Catholische Mayntzische Bibel (Frankfurt/M: Hutter, 1740).

35 Schmidt, Die Illustration der Lutherbibel, 304-29; Wüthrich, Merianbibel, 21-28.

36 For instance, the throne room vision based on Merian's design is depicted in the Friedenskirche of Świdnica/Schweidnitz in Silesia (present-day Poland). It is located on the ceiling over the west wing, situated among three further motifs from Revelation that also follow illustrations of the Kupferbibel. Cf. Seidel-Grzesińska, "Das 'sichtbare Wort Gottes'," 912-13.

37 Het Nieuwe Testament ons Salichmaeckers Iesv Christi, mitsgaders d'Epistelen ..., Amsterdam: Pieter Iacobsz Paets, 1646. Accessible online: https://archive.org/details/hetnieuwetestame00leem/page/418 (accessed 4 December 2018).

38 Cf. Funck, ed., Le livre Belge à gravures, 394.

39 't Schat der zielen, Dat Is: Het geheele leven ons Heeren Iesu Christi (Amsterdam: Pieter Iacobsz Paets, 1648), 666 [558], fig. 530. To the work, see Dietz, "Dark Images, Clear Words," 302-4. The print is accessible online: http://objects.library.uu.nl/reader/index.php?obj= 1874-32195\&lan=en\#page//10/73/22/107322450775815387409498162151163593979. jpg/mode/1up (accessed 4 December 2018).

40 Merian, "Illuminating the Apocalypse," 622-26.

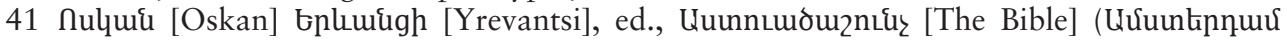
[Amsterdam]: กuluu bplumugnı, unu. U. Equhuớh l. U. Uunquh [Oskan Yrevantsi, Tparan St. Ejmiatsin and St. Sargis the General], 1666), 703 (fist pagination), fig. 1. Concerning the use of van Sichem's woodcuts in the Oskanian press: Nersessian, Catalogue of Early Armenian Books, 28.

42 Cowe, "The Armenian Version," 254-55.

43 Regarding van Sichem's influence on the Armenian iconography, for instance, on silverwork see: Merian, "Armenian Metalwork," 241-45. Against a larger influence on the iconography of the All Saviour's Cathedral in New Julfa see Landau, "Adaptation of Religious Iconography," 425-46.

44 Uhuppup [Mekhitar] Uthuuunugnt [Sebastatsi], ed., Uuunnumouznıu々 [The Bible]

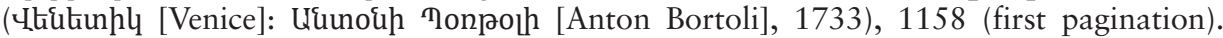
Accessible online: www.wdl.org/en/item/15542/view/1/1170/ (accessed 14 December 2018).

45 For the first time, Emil Ohly (1885-1944), pastor of the parish, published a description of the painting on the occasion of its successful restoration: Ohly, "Ein wertvoller Fund," 30-31. It had been badly damaged by a fire in 1878 and had laid forgotten in the attic of the church until its rediscovery in 1936. The visual model of the epitaph was not identified, and a reproduction was not published there. Once I identified the painting, I found a single but forgotten study that touches upon it. It was written by the musicologist Norlind, Fran tyska kyrkans glansdagar, 111-12, figs. on 114-15.

46 "Glory to God. To decorate this church. / Friderich Jürgens worshipped in the same location" and "This board and the lustres / In the year 1614" (In Gottes Ehrre. Diser Kyrchen Züraett. / Friderich Jürgens Alhir vorehret hatt. and Deise Taffell unnd Die Leüchter Dar I Im Thüsent Seyhündert unnd veirzenden Jaer:).

47 The German presence and influence had been strong in Stockholm since the Middle Ages. See e.g. Wubs-Mrozewicz, "Interplay of Identities," 53-67.

48 Arszyński and Biskup, eds., Toruń i miasta, 95, fig. 47.

49 The precise determination of Torun's Protestant citizens' confessional affiliation is challenging, see: Müller, Zweite Reformation, esp. 99, note 296 and 101, note 299. 
50 Birecki, Sztuka Luterańska, 117-20.

51 Ibidem, 171; Archiwum Państwowe Toruń, Ewangelicka Gmina Wyznaniowa Nowomiejska, sign. 204.

52 Kruszelnicki, “Obraz," 115, suggests a late dating-around 1700—-though he remarks that dating is challenging due to the lack of comparative pieces. Birecki, Sztuka Luterańska, 117-18 considers it as part of the altarpiece commissioned in 1679. The exhibition catalogue: Arszyńska, Lewandowska, and Mierzejewska, Reformacja w Toruniu, 249, dates it to the 1620 s, though without providing substantiation.

53 Sadeler's reference "Apocalip: 5 et 14" is extended to "APOCALIP: IV.V.ET.Xiiii".

54 The secondary character of the intervention is substantiated by the following observations. First, there is the exclusive use of golden paint: it also replaces all elements that were originally painted yellow to symbolise gold or light, like the chalices, crowns or flashes around the throne. Second, note the remains of the original design's pastelcoloured halo, which is still traceable around God the Father; even so, it remains most obviously around the Lamb. Finally, there is the rather dilettantish manner of the execution: the paint runs often without respect to figures (the rays cover, for instance, the eyes of some angels) or their contours (the flames of the seven torches are only partly covered).

55 While Muller, "Les premières apparitions," 327-46 postulates a non-confessional use of the Tetragrammaton, recent research produced a more nuanced picture: Davis, Seeing Faith, 179-212; Wilkinson, Tetragrammaton, 351-81.

56 For Calvin, any depiction of God, whether anthropomorphic or not, was in itself an outrageous attack on the glory and majesty of God. Calvin, Institutes of the Christian Religion, I, 11, 1 -4; II, 8, 12; published in idem, Opera Selecta, vol. 3, 88-93 and 345-46 Cf. Van Asselt, "The Prohibition of Images," 297-312.

57 Cf. note 30.

58 Cf. note 3.

\section{Bibliography}

Arszyńska, Joanna, Liliana Lewandowska, and Aleksandra Mierzejewska. Reformacja w Toruniu: wplyw kultury ewangelickiej na rozwój miasta. Exhibition catalogue. Toruń, Muzeum Okręgowe, 9 June-15 October 2017. Toruń: Biblioteka Uniwersytecka w Toruniu; Uniwersytet Mikołaja Kopernika, 2017.

Arszyński, Marian, and Marian Biskup, eds. Toruń i miasta ziemi chetmińskiej na rysunkach Jerzego Fryderyka Steinera z pierwszej połowy XVIII wieku: (tzw. Album Steinera). Toruń: TN, 1998.

Bartrum, Giulia. "The Vision of the Apocalypse in the Sixteenth and Seventeenth Centuries: Catalogue." In The Apocalypse and the Shape of Things to Come, ed. Frances Carey, 125207. London: British Museum, 1999.

Bertoglio, Chiara. Reforming Music: Music and the Religious Reformations of the Sixteenth Century. Berlin: De Gruyter, 2017.

Birecki, Piotr. Sztuka Luterańska na ziemi chetmińskiej: od drugiej połowy XVI do pierwszej ćwierci XVIII wieku. Warsaw: DiG, 2007.

Bossuyt, Ignace, Jacques Van Deun, and Camiel Cooremans, eds. Beeldmotetten Andreas Pevernage. Brugge: Uitgeverij Marc Van de Wiele, 1985.

Brommer, Hanna. Rekatholisierung mit und ohne System: die Hochstifte Würzburg und Bamberg im Vergleich (ca. 1555-1700). Göttingen: V\&R Unipress, 2014.

Calvin, Jean. Joannis Calvini Opera Selecta, eds. Peter Barth and Wilhelm Niesel. 2nd ed. Vol. 2: Tractatus theologicos minores ab anno 1542 usque ad annum 1564 editos continens. Munich: Kaiser, 1952.

—. Joannis Calvini Opera Selecta, eds. Peter Barth and Wilhelm Niesel. 2nd ed. Vol. 3: Institutionis Christianae religionis 1559 libros I et II continens. Munich: Kaiser, 1957. 
Cowe, S. Peter. "The Armenian Version of the New Testament." In The Text of the New Testament in Contemporary Research: Essays on the Status Quaestionis, ed. Bart D. Ehrman, 2nd ed., 253-92. Leiden: Brill, 2013.

Davis, David J. Seeing Faith, Printing Pictures: Religious Identity During the English Reformation. Leiden: Brill, 2013.

Davoli, Zeno, ed. La Raccolta di Stampe Angelo Davoli. Vol. 1: A-Bio. Reggio Emilia: Diabasis, 1995.

Dietz, Feike. "Dark Images, Clear Words: Pieter Paet's Illustrated Devotional Literature from the Missio Hollandica.” In Meditatio-Refashioning the Self, eds. Karl A. E. Enenkel and Walter Melion, 291-320. Leiden: Brill, 2010.

Drescher, Georg. "Icones biblicae.” In Matthäus Merian der Ältere: Ätzkünstler und Verleger: Ausstellung der Bibliothek Otto Schäfer und des Stadtarchives Schweinfurt vom 27. April 2003-31. Oktober 2004, eds. Uwe Müller and Georg Drescher, 80-91. Schweinfurt: Bibliothek Otto Schäfer, 2003.

Emiliani, Andrea, Marco Baldassari, and Gloria De Liberali. I Carracci: capolavori giovanili di Ludovico, Agostino e Annibale nel passaggio dal Manierismo al Barocco. Rimini: Agenzia NFC di Amedeo Bartolini, 2015. http://foundation.stefanozanasi.it/assets/Uploads/Carracci DEF-ITA-per-web.pdf.

Fisher, Alexander J. "Music and Religious Change." In Cambridge History of Christianity: Reform and Expansion, 1500-1660, ed. R. Po-chia Hsia, 386-405. Cambridge: Cambridge University Press, 2007.

Forney, Kristine. "Pevernage [Bevernage, Beveringen], Andreas." In Grove Oxford Music Online. Oxford: Oxford University Press, 2001.

Funck, M., ed. Le livre belge à gravures: guide de l'amateur de livres illustrés imprimés en Belgique avant le XVIIIe siècle. Paris: van Oest, 1925.

Geyrhalter, Johanna. 'Icones biblicae' Matthaeus Merians der Älteren: die künstlerischen Quellen zum Neuen Testament; ein Beitrag zur Merian-Forschung. Ph.D. dissertation, Universität Graz, Graz, 1971.

Green, Maureen. "Paper." In A Companion to the History of the Book, eds. Simon Eliot and Jonathan Rose, 2nd ed., 81-94. Hoboken, NJ: Wiley-Blackwell, 2019.

Groesen, M. van. "De Bry and Antwerp: A Formative Period, 1577-1585." In Inszenierte Welten: die west- und ostindischen Reisen der Verleger de Bry, Staging New Worlds: De Bry's Illustrated Travel Reports, 1590-1630, ed. Susanna Burghartz, 19-45. Basel: Schwabe, 2004.

Grunewald, Eckhard, Henning P. Jürgens, and Jan R. Luth, eds. Der Genfer Psalter und seine Rezeption in Deutschland, der Schweiz und den Niederlanden: 16. - 18. Jahrhundert. Tübingen: Niemeyer, 2004.

Hammerstein, Reinhold. "Imaginäres Gesamtkunstwerk: Die niederländischen Bildmotetten des 16. Jahrhunderts." In Die Motette: Beiträge zu ihrer Gattungsgeschichte, ed. Herbert Schneider, 165-204. Mainz: Schott, 1992.

Hunter, Dard. Papermaking: The History and Technique of an Ancient Craft. New York: Dover Publications, 1978.

Keuchen, Marion. Bild-Konzeptionen in Bilder- und Kinderbibeln: die historischen Anfänge und ibre Wiederentdeckung in der Gegenwart. Vol. 1. Göttingen: V\&R unipress, 2016.

Kruszelnicki, Zygmunt. "Obraz ‘Adoracja Baranka Apokaliptycznego’ z dawnego kościoła św. Trójcy w Toruniu.” In Ars una: prace z historii sztuki, ed. Eugeniusz Iwanoyko, 113-20. Poznań: Wydawnictwa Naukowe Uniwersytetu im. Adama Mickiewicza, 1976.

Landau, Amy. "Adaptation of Religious Iconography in Seventeenth-Century Iran: The Case of Bethlehem Church." In Iran and the World in the Safavid Age, ed. Willem Floor, 425-46. London: Tauris, 2012.

Merian, Sylvie L. "Illuminating the Apocalypse in Seventeenth-Century Armenian Manuscripts: The Transition from Printed Book to Manuscript." In The Armenian Apocalyptic Tradition, eds. Kevork Bardakjian and Sergio La Porta, 603-39. Leiden: Brill, 2014. 


\section{András Hándl}

"Armenian Metalwork in Kayseri." In Armenia: Art, Religion, and Trade in the Middle Ages, ed. Helen C. Evans, 241-45. New York: The Met, 2018.

Muller, Frank. "Les premières apparitions du tétragramme dans l'art allemand et néerlandais des débuts de la Réforme." Bibliothèque d'Humanisme et Renaissance, 56/2 (1994): 327-46.

Müller, Michael G. Zweite Reformation und städtische Autonomie im königlichen Preußen: Danzig, Elbing und Thorn in der Epoche der Konfessionalisierung (1557-1660). Berlin: Akademie Verlag, 1997.

Nersessian, Vrej. Catalogue of Early Armenian Books: 1512-1850. London: British Library, 1980.

Norlind, Tobias. Frän tyska kyrkans glansdagar. Vol. 1: Reformationstidevarvet, 1523-1600. Stockholm: Musikhistoriska Museet, 1944; reprinted as "Svensk musikodling under reformationstidevarvet." Svensk tidskrift för musikforskning, 5 (1944): 15-118.

Ohly, Emil. "Ein wertvoller Fund." Deutsches Gemeindeblatt: Organ der deutschen S:ta Gertruds Gemeinde in Stockholm, 14/5-8 (1939): 30-31.

Price, David H. "The Bible and the Visual Arts in Early Modern Europe." In The New Cambridge History of the Bible, ed. Euan Cameron, 3: From 1450 to 1750: 718-61. New York: Cambridge University Press, 2016.

Romberg, Winfried. Das Bistum Würzburg. Vol. 7: Die Würzburger Bischöfe von 1617 bis 1684. Berlin: De Gruyter, 2011.

Schmidt, Philipp. Die Illustration der Lutherbibel: 1522-1700; ein Stück abendländische Kultur- und Kirchengeschichte; mit Verzeichnissen der Bibeln, Bilder und Künstler. Basel: Reinhardt, 1962.

Seidel-Grzesińska, Agnieszka. "Das 'sichtbare Wort Gottes' an der Decke der evangelischen Friedenskirche zu Schweidnitz." In Kulturgeschichte Schlesiens in der Frühen Neuzeit, ed. Klaus Garber, 912-24. Berlin: De Gruyter, 2005.

Seiffert, Max. "Bildzeugnisse des 16. Jahrhunderts: Für die instrumentale Begleitung des Gesanges und den Ursprung des Musikkupferstiches." Archiv für Musikwissenschaft, 1/1 (1918): 49-67.

Stellfeld, Jean Auguste. Andries Pevernage: zijn leven, zijne werken. Leuven: De Vlaamsche drukkerij, 1943.

Van Asselt, Willem. "The Prohibition of Images and Protestant Identity." In Iconoclasm and Iconoclash: Struggle for Religious Identity, eds. Willem Asselt, Daniela Müller, Paul Geest, and Theo Salemink, 297-312. Leiden: Brill, 2007.

Vignau-Wilberg, Thea. "Pictorial Motets and Motet Pictures." In O Musica du edle Kunst: Musik und Tanz im 16. Jabrbundert, ed. Thea Vignau-Wilberg, 166-86. Munich: Staatliche Graphische Sammlung, 1999.

- Niederländische Bildmotetten: Multimediale Kunst um 1600. Altenburg: Kamprad, 2013.

. "Bildmotetten-Motettenbilder." In Die Kirchenmusik in Kunst und Architektur, ed. Ulrich Fürst, 219-28. Laaber: Laaber-Verlag, 2015.

Weeda, Robert. Le Psautier de Calvin: l'histoire d'un livre populaire au XVIe siècle (15511598). Turnhout: Brepols, 2002.

Weiß, Dieter J. Die Bistümer der Kirchenprovinz Mainz: Das exemte Bistum Bamberg. Vol. 3: Die Bischofsreihe von 1522 bis 1693. Berlin: De Gruyter, 2000.

Wendehorst, Alfred. Das Bistum Würzburg. Vol. 6: Die Benediktinerabtei und das Adelige Säkularkanonikerstift St. Burkard in Würzburg. Berlin: De Gruyter, 2001.

Wilkinson, Robert J. Tetragrammaton: Western Christians and the Hebrew Name of God; from the Beginnings to the Seventeenth Century. Leiden: Brill, 2015.

Witetschek, Stephan. "Den unsichtbaren Gott sehen? Die Darstellung des nicht Darstellbaren in der Thronsaalvision der Johannesapokalypse (Apk 4).” In Bilder von dem Einen Gott, eds. Nicola Hömke, Gian Franco Chiai, and Antonia Jenik, 161-74. Berlin: De Gruyter, 2016. 
Wubs-Mrozewicz, Justyna. "Interplay of Identities: German Settlers in Late Medieval Stockholm." Scandinavian Journal of History, 29 (2004): 53-67.

Wüthrich, Lucas Heinrich. "Der Chronist Johann Ludwig Gottfried (ca. 1584-1633).” Archiv für Kulturgeschichte, 43 (1961): 188-216.

—. "Nachwort." In Matthaeus Merian Bilderbibel: Originalgetreuer Faksimiledruck der Erstausgabe mit einem Nachwort herausgegeben von Lucas Heinrich Wüthrich, 1-19. Kassel: Bärenreiter, 1965.

. Das druckgraphische Werk von Matthaeus Merian der Ältere. Vol. 3: Die grossen Buchpublikationen: 1: Die Merianbibel. Hamburg: Hoffmann und Campe, 1993.

. Matthaeus Merian der Ältere: eine Biographie. Darmstadt: Wissenschaftliche Buchgesellschaft, 2007. 


\title{
14 Prints and the Beginnings of Global Imagery
}

\author{
Jean Michel Massing
}

It may be surprising to many today to realise how much of the scholarly interest in prints in the Anglo-Saxon world is linked to the publication of Print Quarterly. As David Landau rightly wrote in a recent article "Print Quarterly Turns 35", referring to the period when the periodical was launched,

scholars of printmaking like me suffered the humiliation of being always last in the queue when they submitted their contributions to the leading art history magazines. Prints were, to a much greater extent than they are now, the Cinderella of art history, and little space was available for one's articles, however laboured over, well-researched and original. ${ }^{1}$

The need to show that the field was as scholarly as others explains that the first article of the first issue was "A Checklist of Catalogues of British Print Publishers circa 16501830 ”, by Antony Griffiths. If the first issue was Eurocentric, the most recent one on my desk (2018) commemorating thirty-five years of scholarship includes articles by Daan van Heesch on "The Graphic Source of Rajput Images of Fools" and John Tyson's “Cy Twombly's Cardboard Prints: Impressions, Inversions and Decomposition", but also notes and book reviews encompassing early seventeenth-century Chinese and Japanese woodcuts from the seventeenth to the nineteenth centuries, while a review article covers recent publications on Mexican prints in the United States. The scope of Print Quarterly has become global.

\section{Prints and the West European Diffusion of Images}

As one of the eight original members of the editorial board of Print Quarterly, I can only agree with David Landau's remarks. In 1984, I was delighted to contribute to volume 1 an article, which was then considered slightly eccentric, on "Schongauer's Tribulations of St Anthony. Its Iconography and Influence on German Art”, in which my aim was not just to study the iconography (then my main interest) but also the influence of the print (Figure 14.1). ${ }^{2}$ Michelangelo was interested in the print, as was the anonymous designer of The Fall of Antichrist woodcut in the Nuremberg Chronicle of 1493 and Albrecht Dürer's Fall of the Rebel Angels in his Apocalypse series of c. 1497-98; but also others, such as two works by the Master of the Kaufbeurer Sakristeischrank, a painting by Nikolaus Manuel Deutsch and a drawing by Jörg Schweiger, among others; to this was added a new group centred around Hans Springinklee's woodcut of the Tribulations of Saint Anthony in Johann Koberger's Hortulus animae printed by Friedrich Peypus in Nuremberg in 1518. Ten years after my first 
article, I added a few more works, including Hans von Köln's Saint Anthony attacked by Devils (Kloster Salem) and an anonymous Flemish painting from the wider circle of the Breughel. ${ }^{3}$ The two articles confirmed my contention that a number of early prints were widely used by artists and artisans, but, for Schongauer's print, this diffusion was still geographically limited and linked to trade connections.

The Renaissance in the arts, which started in Florence at the end of the fourteenth and the beginning of the fifteenth century, slowly influenced the art of other regions

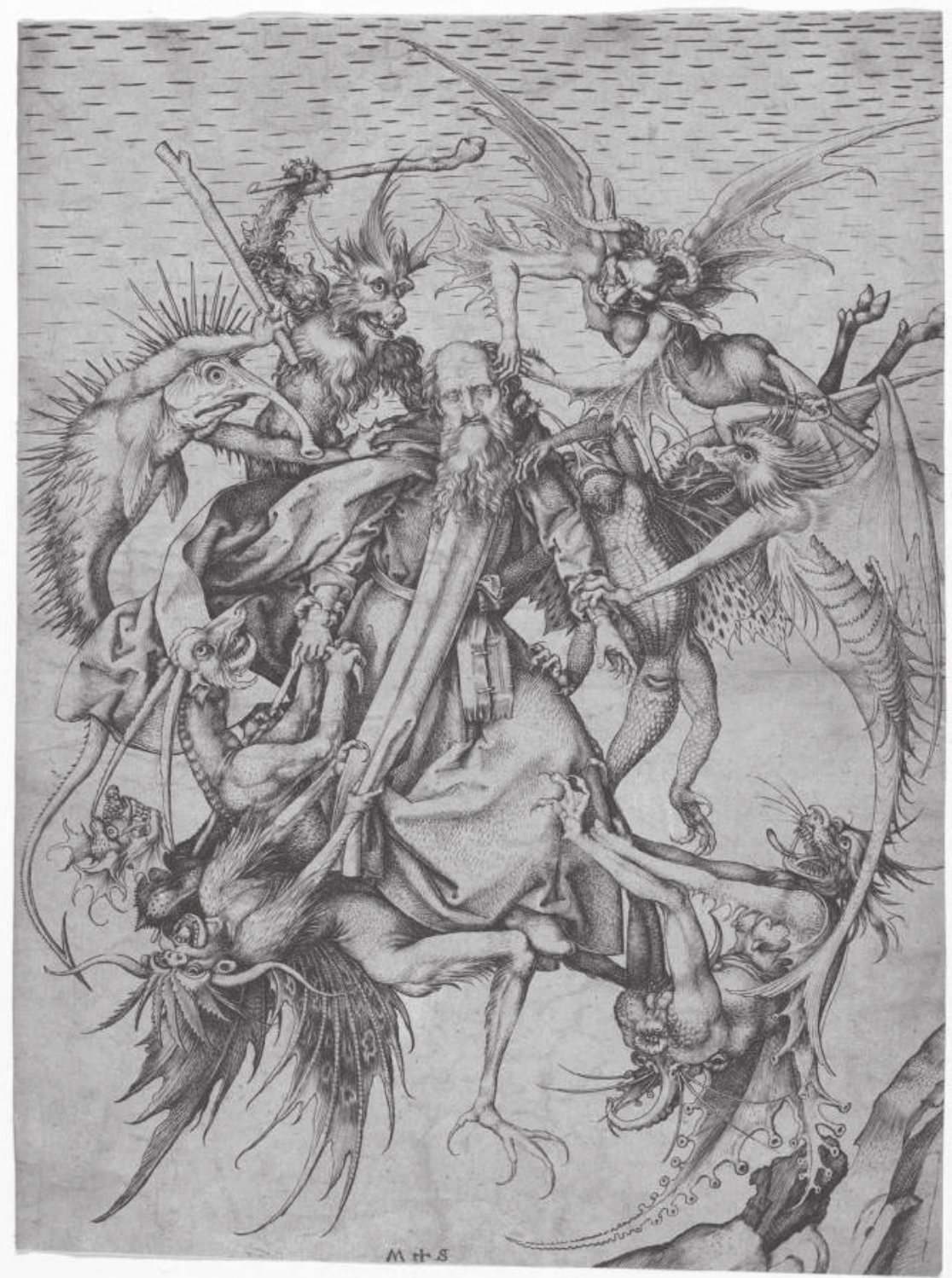

Figure 14.1 Martin Schongauer, Tribulations of Saint Anthony, c. 1470-75, engraving. New York, The Metropolitan Museum of Art, Rogers Fund, 1920, 20.5.2.

Photo: New York, The Metropolitan Museum of Art, CC0 1.0. 
of Italy and then the rest of European art; prints which combined classical subject matter with classical forms became a privileged medium, their graphic language being especially appropriate for this transmission. Andrew Martindale's book on The Triumphs of Caesar by Andrea Mantegna at Hampton Court led me to look more carefully at the influence of the artist's painted cycle. ${ }^{4}$ Andrea Mantegna was painting the Triumphs in 1486, but they were never on public display, probably left the ducal collection of Mantua before the imperial siege of 1629 and were shipped from Venice in 1630. Because of the private character of the commission, and later the damage and restoration work on the canvases, they did not have much influence; early copies, painted, drawn and engraved (of the Elephants, the Trophy Bearers and the Senators) were made, but these, too, had a limited influence. ${ }^{5}$ Martindale had rightly concluded that "On the whole, the art-historian who searches for precise evidence of stylistic 'influence' will be disappointed. The works directly and obviously inspired by the Triumphs [in the sixteenth century] are, by and large, trivial". ${ }^{6}$

One of the more interesting influences of Mantegna's engraved compositions (and possibly some drawings after the cycle) already mentioned by Martindale became for me a good test case to look at the wider influence of a printed cycle: it is the set of twelve woodcuts designed by Benedetto Bordone and cut by Jacobus Argentoratensis, a woodcutter from Strasbourg working in Venice in the late fifteenth and early sixteenth century. On 30 March 1504, Benedetto received a ten-year privilege for this Triumph of Caesar which he had designed and published. ${ }^{7}$ Benedetto probably never saw

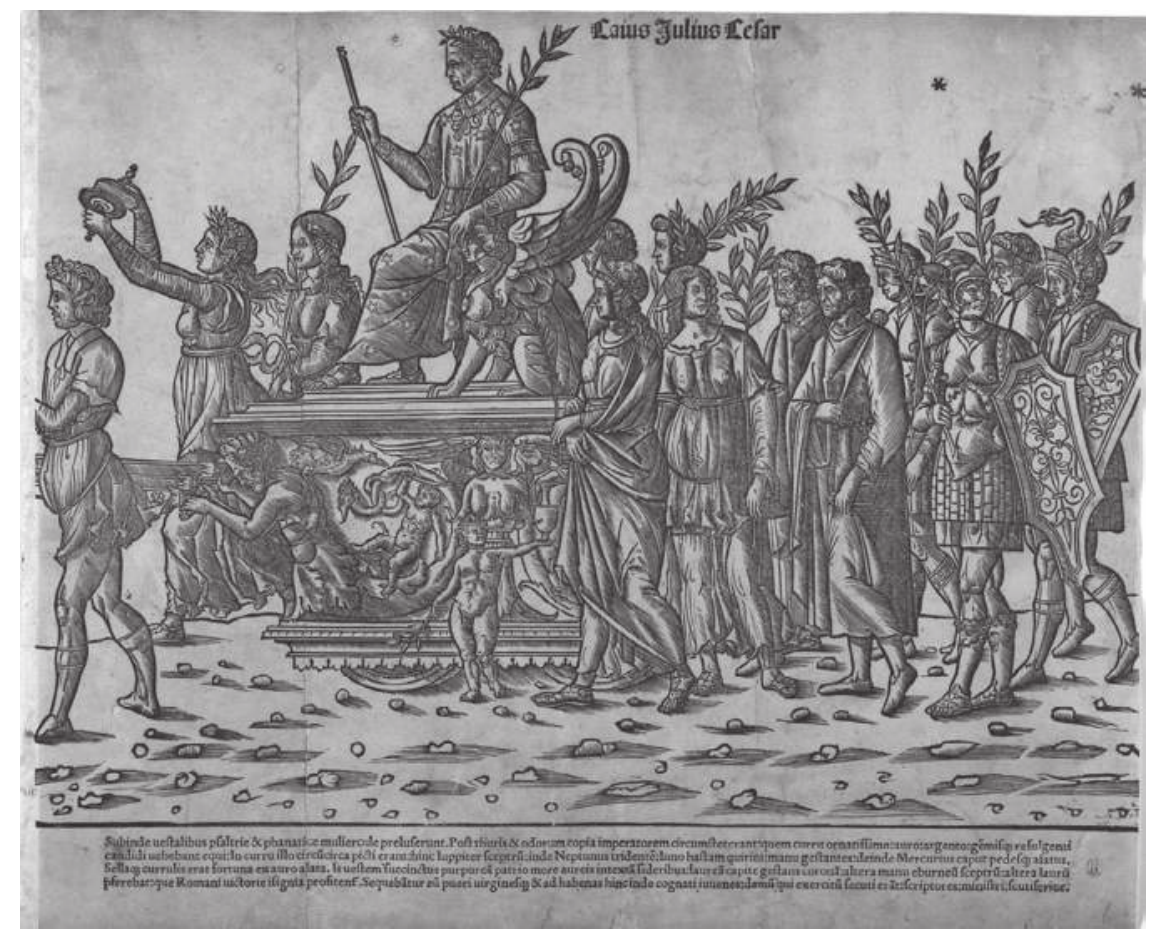

Figure 14.2 Jacob of Strasbourg, after Benedetto Bordone, Triumph of Caesar (single sheet), 1504, woodcut. New York, The Metropolitan Museum of Art, Harris Brisbane Dick Fund, 1927, 27.54.124.

Photo: New York, The Metropolitan Museum of Art, CC0 1.0. 
Mantegna's large canvasses, but he used the prints after some of Mantegna's compositions (the Trophy Bearers, the Elephants and possibly even an odd drawing after one of the scenes); he was also influenced by the woodcuts in Francesco Colonna's Hypnerotomachia Poliphili first published in Venice in 1499, especially the four chariots of the Triumph of Love. ${ }^{8}$ There are, however, major differences between the two Triumphs:

Mantegna's cycle contains a great density of figures, with soldiers marching in tight rows; he reconstructed Caesar's Triumph as an antiquarian might, studying Latin inscriptions and classical monuments. Benedetto was more interested in simple narrative; the order of the procession and the depiction of identifiable groups are often repetitive but the figures are linked pictorially. He varied the attitudes and the expressions of his figures; for example, the soldiers bearing the image of a town in the third woodcut anticipate the group in the next, and often a figure turns back towards the next group. The woodcuts have a frieze-like character, without much spatial depth, a result of Jacobus's linear style which accentuates outlines and defines forms with uninterrupted contours, the shading being added in parallel hatching. ${ }^{9}$

Such characteristics made it a perfect model for representations of triumphs.

The influence of the 1504 Triumph was unprecedented. The large Riesenholzschnitt, $28.5 \mathrm{~cm}$ in height and $449 \mathrm{~cm}$ in length, had no fewer than three editions. Because of its clarity and its simplicity, the woodcuts were used for large renderings of classical triumphs in the first half of the sixteenth century. The earliest adaptation was a wooden frieze formerly in the Salòn del Triumfo of the castle of the Fajardos at Vélez Blanco near Granada built between 1506 and 1515 (now Paris, Musée des Arts Décoratifs; Figures. 14.2 and 14.3). The six sections of the Triumph (each $73 \mathrm{~cm}$ high and $530 \mathrm{~cm}$ long), of which five are based on the Venetian woodcuts, can be dated more precisely between 1508 and 1515, as they carry the coats of arms of Don Pedro and his second

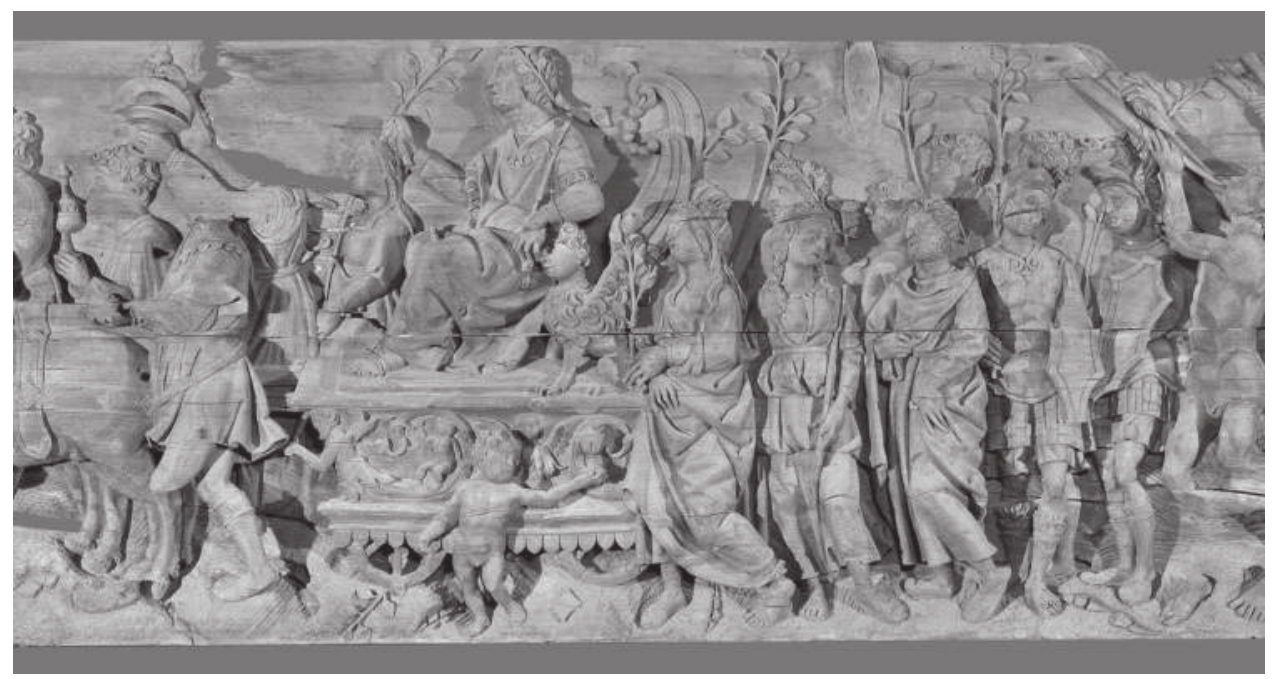

Figure 14.3 Anonymous Spanish sculptor, Triumph of Caesar from the castle of the Fajardos at Vélez Blanco near Granada (detail of Cesar's chariot), 1506-15, bas-relief, wood. Paris, Musée des Arts décoratifs, D 2007-1-4.

Photo: () Ville de Castres-Musée Goya, musée d'art hispanique, F. Pons. 
wife, Doña Mencia de la Cueva y Toledo. ${ }^{10}$ This was followed by many monumental painted and sculpted examples, also numerous sets of tapestries, of which today only a few survive. The set of prints also influenced manuscript and book illustrations, including borders of books of hours and frontispieces; also majolica dishes, such as two large dishes by Jacopo de Cafaggiolo, one of them dated 1514; Renaissance enamels; white lead pastiglia caskets; and bronze plaquettes. Its influence reached as far as the Greek island of Corfu, then under Venetian rule: a Veneto-Saracen brass dish made by Nicolo Rugina, c. 1540-60 is engraved with concentric circles of which the first band shows the siege of Corfu and the second the Triumph of Caesar (London, $\mathrm{BM})$, two appropriate subject matters, as the Ottomans besieged the fortress of Corfu for thirteen years without managing to conquer it. ${ }^{11}$

\section{Prints and the Worldwide Diffusion of Images}

\section{Ottoman Turkey}

Prints also travelled, although more slowly, outside Western Europe. This is the case of a group of sixteen sheets in the collection of the Topkapi Saray Museum in Istanbul that seem to have been acquired either by or for Mehmed II (1431-1481), the Ottoman Sultan. The prints cover a wide scope, including religious subjects (Dead Christ in the Tomb, between the Virgin and Saint John, with Signs of the Passion; Mass of Saint Gregory; Scenes from the Life of Saint Jerome; Saint Sebastian, with Eleven Scenes from His Life; Martyrdom of Saint Sebastian, within a scroll border); there are also mythological scenes (Hercules and the Hydra, after Pollaiuolo; Urania, from the so-called Tarocchi; two different engravings of Cupids at the Vintage; Round Dance in the Antique Manner and Roundel with a Triton, between a Gallant and His Mistress), as well as allegories (The Triumph of Fame, from the Triumphs of Petrarch, Fight between Women and Devils and Monkeys and the Pedlar). There is also an engraving, quite fanciful, of an Ottoman Sultan (El Gran Turco), but the rarest of them, at least according to the survival rates of this kind of imagery, is a pornographic Ornamental Scroll showing a jug from which grows a rich foliage in which the flowers are either phallic or with children-shall we call them amorini-holding masculine sexes. ${ }^{12}$ The collection is a homogenous group, as eleven prints are Florentine, in the Fine Manner, and from the same workshop, probably that of the Master of the Vienna Passion; five are from Ferrara (of which one of them is probably copying a Florentine print). They have been linked, quite convincingly, to Benedetto Dei, a Florentine resident in Pera (Istanbul) from 1460 to 1467, close to the sultan, but also a member of one of the most distinguished families of goldsmiths and niello engravers in fifteenth-century Florence. When A.M. Hind published the group-except for the Ornamental Scroll, which he did not even mention-he noticed that ten (so eleven) of them were newly discovered engravings, two were undescribed states of known prints and only the remaining three were known from other impressions. This has not changed much since, as today nine prints are still unique, while another five are known from only one single impression. ${ }^{13}$

\section{Africa: Sierra Leone}

The first use of European prints by Africans happened in the first quarter of the sixteenth century. ${ }^{14}$ In the sixteenth-century Portuguese sources, the inhabitants of Sierra 
Leone were called Sapi, a denomination covering various sub-groups such as the Kissi, Bullom, Temne, Baga, Landoman and other coastal inhabitants. ${ }^{15}$ According to the Portuguese Valentim Fernandes (1506-10), in Sierra Leone, "the people of this land are blacks very skilled in manual work, they produce salt-cellars in ivory and spoons and whatever task one sketches for them, they carve it in ivory". ${ }^{16}$ The link between the earliest surviving works in ivory and Sierra Leone stone sculptures (nomolisia) cannot be doubted. Both nomolisia (sing. nomoli) and pomta (sing. pomdo) are small stone figures found over more than the southeastern half of Sierra Leone, as well as in neighbouring areas of Guinea and Liberia. ${ }^{17}$ Found on agricultural and mining sites, they were not done by the local populations now living in this area, but by unidentified predecessors who then migrated elsewhere-stylistic relationships made it evident that they were also responsible for the so-called Sapi-Portuguese ivories.

The ivories which can be linked to Sierra Leone form a homogenous group of at least sixty-six saltcellars more or less complete, forty-one oliphants, three pyxes, three daggers, eight spoon and three forks. ${ }^{18}$ Quite a number of these works bear Portuguese coat-of-arms, such as those of the House of Aviz ruling Portugal from 1385 to 1580, the cross of Beja and the device of Manuel I, king of Portugal, from 1495 to 1521; their models, of course, were Portuguese and mostly printed. The early dating of this group cannot be challenged, as a substantial part of the Sapi-Portuguese ivories are recorded in sixteenth-, seventeenth- and eighteenth-century collections, including that of the Medici. A number of saltcellars have Marian subjects, but the most extensive Christian cycles are found on three pyxes (containers for the host); they are circular, like the elephant tusks out of which they were carved, and are, respectively, in Viseu (Museu de Grão Vasco), ${ }^{19}$ in a Portuguese private collection ${ }^{20}$ and in the Walters Art Museum in Baltimore. ${ }^{21}$ All their scenes, without exception, are based on one printed source, a book of hours published by Thielman Kerver in Paris sometime between 1509 and $1511 .^{22}$ Kerver produced devotional books of this type between 1497 and his death in 1522, and his editions show the gradual transition from late gothic to more classical compositions. His books of hours published before 1509 do not yet include all the models used by the ivory carvers, while those after 1511 include new compositions no longer linked to the decoration of the pyxes. Of course the carver has simplified his models and did not always fully understand the detail of the iconography, but the relationships can be followed scene by scene. This conclusion is fully supported, for example, by the seven scenes on the pyx in Baltimore: Arrest of Christ (Figure 14.4), Crowning of Thorns, Carrying of the Cross, Nailing to the Cross, Crucifixion, Deposition and Lamentation-all based on the woodcuts in the books of hours. This is confirmed, for example, by comparing the full-page illustration of the Arrest of Christ in the Garden of Gethsemane (Figure 14.5) with the corresponding scene on the pyx. In both compositions, Christ is kissed by Judas; at the same time, he is stopping Saint Peter, who has just cut Malchus's ear, from doing further harm. The main figures, including Malchus lying on the ground with his outstretched left hand holding his lantern, are shown in the same position. The identification of the model used by the ivory carvers confirms the early date of the whole group while providing a terminus post quem for most of them and testifying to the fruitful complexity of the interaction between Portuguese and African traditions-with influences and appropriations. It also provides the source for the numerous European motives found on the Sapi oliphants (or horns) which sometimes bear the device (flanked unicorns) of Thielman Kerver, the Parisian printer mentioned earlier, who called his shop "At the Sign of the Unicorn", another proof of the use of one of his books of hours in the Sapi carving 


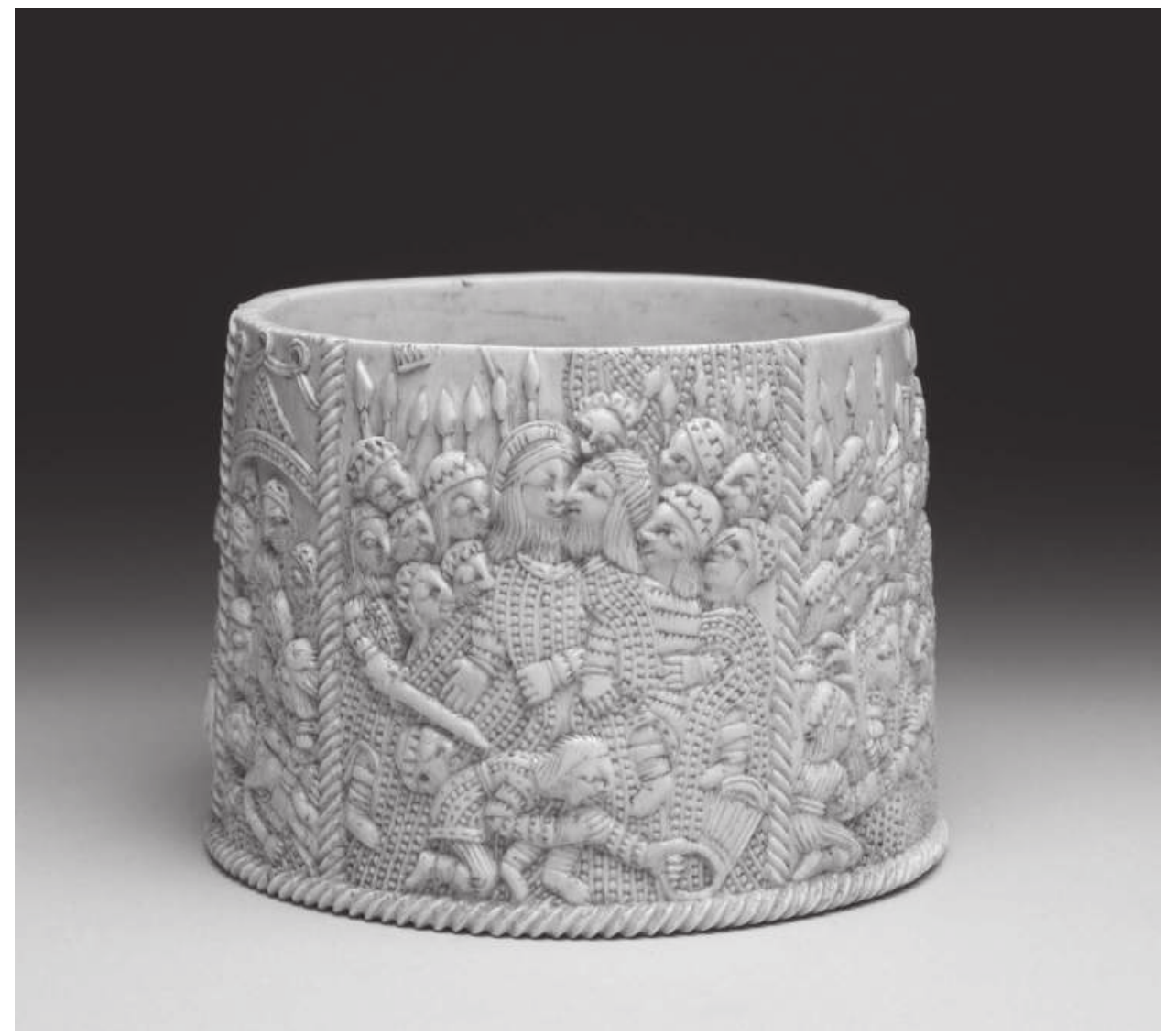

Figure 14.4 Sierra Leone sculptor, ivory pyx, 1490-1530, carved ivory. Baltimore, Walters Art Museum, 71.108.

Photo: Baltimore, Walters Art Museum, CC0 1.0.

centre. ${ }^{23}$ The relationship provided by this group of ivories is a rare survival of an extra European influence at the beginning of the sixteenth century.

\section{Goa, India and Sri Lanka}

On the Indian subcontinent, which already had a rich artistic tradition and crafts not very different from European traditions, the appropriation of European forms was easier than elsewhere. The earliest example of a use of European printed sources is found on two ivory caskets dating from the 1540s, respectively, the Robinson casket in the Victoria and Albert Museum and another in a private collection. ${ }^{24}$ They are part of a homogenous group of twelve caskets, rectangular in shape and with a pitched lid, done in Kotte (Sri Lanka). The earliest instance of a Singhalese ivory casket recorded in the Portuguese royal collection is 1546-48, in the inventory of Queen Catherine (1507-78), the wife of Dom João III (r. 1521-57)..$^{25}$ The Victoria and Albert Museum casket and the exemplar in a private collection are slightly later and seem to be the 


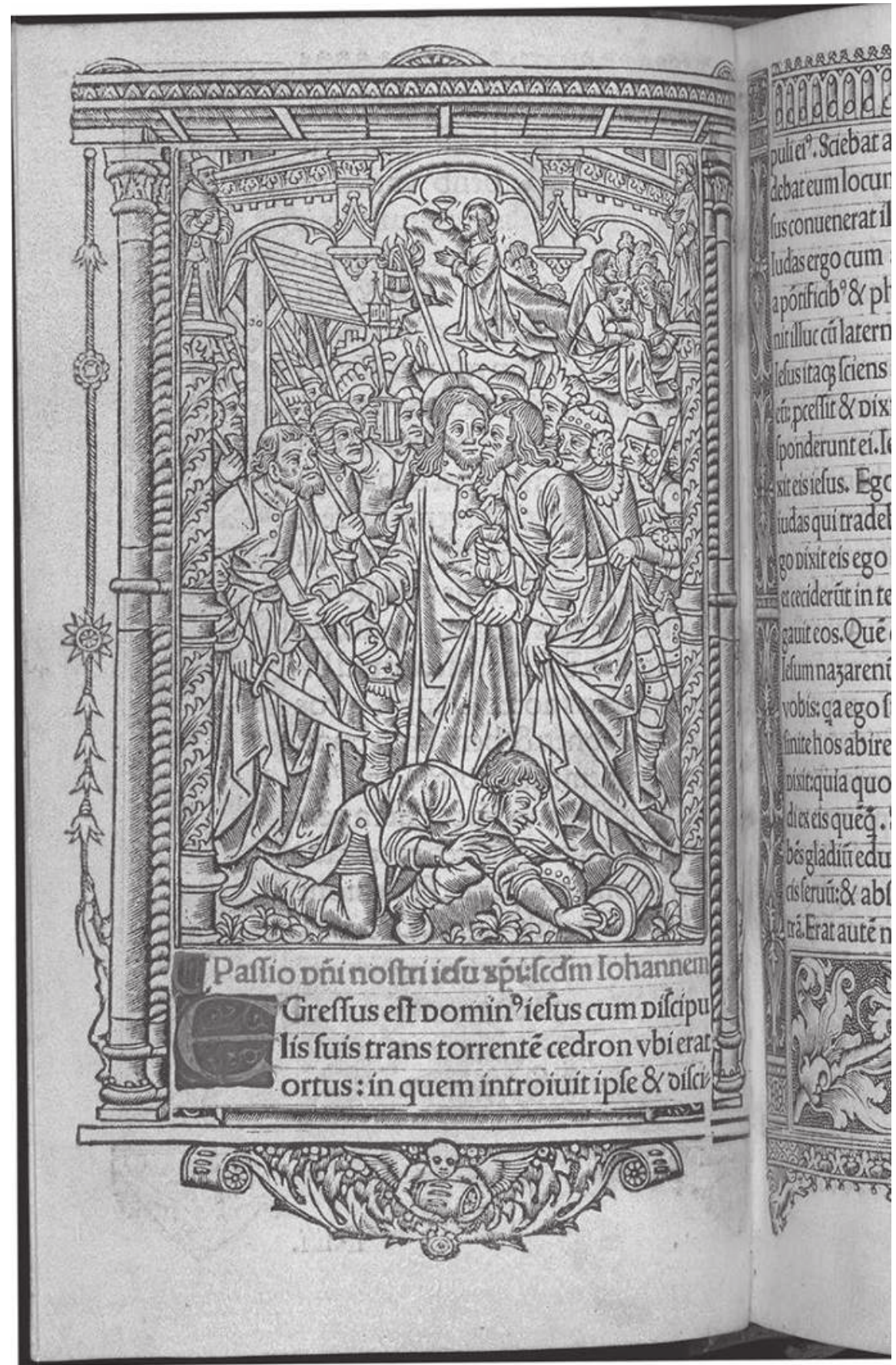

Figure 14.5 Arrest of Christ, woodcut in Hore dive virginis Marie secundum verum usum Romanum (Paris: Thielman Kerver, 1511), fol. B4v. Cambridge University Library, SSS.17.14.

Photo: Cambridge University Library. 
earliest surviving works from the Indian subcontinent directly influenced by European prints. They have been tentatively dated to c. 1557 , when Dharmapala converted to Christianity, but I would date them earlier (c. 1540), as the imagery is eclectic rather than reflecting an overall Christian theme. Albrecht Dürer's Bagpipe Player of 1514 is shown twice on the front, both on the left and the right panels of the Robinson casket, where a unicorn recalls Thielman Kerver's printer's device. The back of the casket includes on the left the Betrothal of the Virgin, in which both Mary and Joseph trample dragons, and on the right the Flight to Egypt. On the right side of the casket is shown the Tree of Jesse, in a rendering based on the Horae Beatae Mariae published by Thielman Kerver from 1499 onwards; the carving follows closely the details of the printed page. The Singhalese carver has filled his composition with a horror vacui using details, such as hunting scenes, often linked to the rich decoration of books of hours. These seem to have been the main source for the knowledge of Christian images outside Europe in the first half of the sixteenth century. ${ }^{26}$ The second casket with European scenes, in a private collection (Figure 14.6), has a bagpipe player after Dürer's engraving of 1514, surrounded by animals on the right front lid panel and below four fabulous figures riding animals straight out of a book of hours. On the back can be found the unicorns from Thielman Kerver's device and various scenes related to vignettes in books of hours. The two side panels of the casket show, respectively, Saint Lucas and the Harrowing to Hell after two prints by Lucas van Leyden of 1508 and 1521, the latter part of his Passion series. ${ }^{27}$

\title{
America: The Mass of Saint Gregory
}

In the Americas, the first surviving dated Christian composition was done exactly twenty years after Hernán Cortés's first march to Central Mexico, entering Tenochtitlan on 8 November 1519, an event which led ultimately to the death of Moctezuma on 1 July 1520 and to the fall of the Aztec empire. The work in question is a Mass of Saint Gregory (Auch, Musée des Jacobins; Figure 14.8), an iconography going back to a Eucharistic miracle referring to Gregory the Great in the Late Middle Ages. ${ }^{28}$ The inscription around the scene confirms that the feather panel was "Made in Mexico, the great city of the Indies, for Pope Paul III, under the government of Don Diego [de Alvarado] Huanitzín (Didacus), for Pope Paul III in the year 1539, through the care of Pieter van Gent (Pedro de Gante) of the Order of the Friars Minor":

\author{
PAULO III PONTIFICE MAXIMALE \\ IN MAGNA INDIARUM URBE MEXICO \\ COMPOSITA DOMINO DIDACO GUBERNA \\ TORI CURA FRATRIS PETRI A GANTE \\ MINORITAE A.D. 1539
}

The work was made for Pope Paul III and sent to him by the Dominicans, who were protecting the Indians, to thank him for the Papal Bull Sublimis Deus which forbids the enslavement of the Indians. The composition shows Saint Gregory in front of the altar, while Christ, shown as Man of Sorrows and surrounded by the symbols of the Passion, appears in front of him. The composition is conventional but for a few important details, such as the pineapple on the edge of the sarcophagus. ${ }^{29}$ It is also remarkable in that it is a feather work combining both the technique of the Amantecas, the 


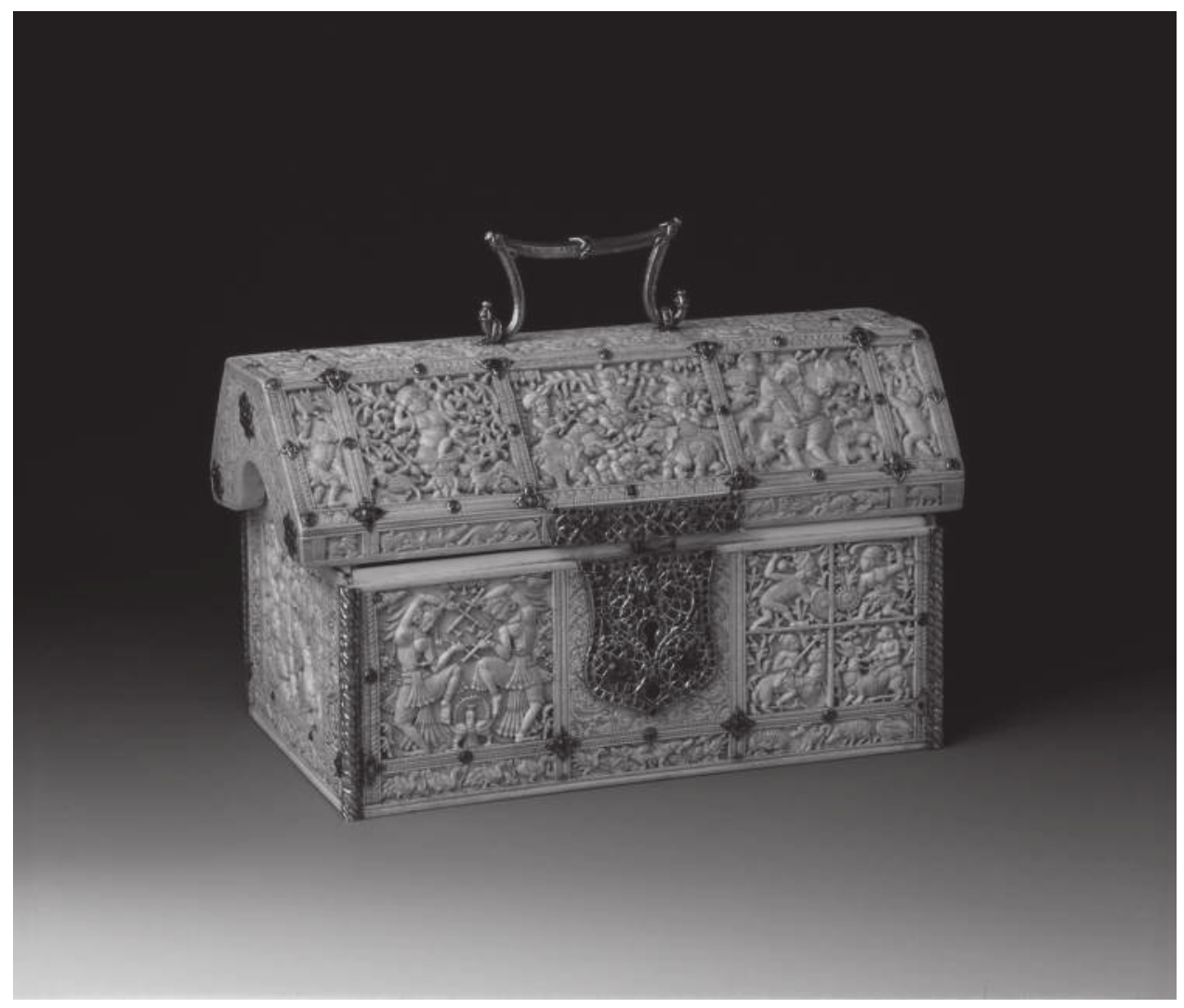

Figure 14.6 Sri Lanka artist, ivory casket with figurative scenes, 1540-50, carved ivory, gold, rubies, sapphires. Private collection.

Photo: Private collection.

Aztec feather workers, and European iconography. This creolisation produced an interesting production, in this case, the first dated (and possibly surviving) Christian work, but also one of the last testimonies of traditional Aztec art. ${ }^{30}$ The composition recalls the traditional late medieval representations of the vision of the saint, where the altar is either shown frontally or on the side. The iconography was popular, and W. L. Schreiber recorded some forty prints, although none of these is the exact model. ${ }^{31}$ It is not really surprising, however, that the exact model has not been identified. Is there thus a graphic source? When he catalogued the print collection known today from a manuscript describing 3,204 prints purchased by Ferdinand Columbus (1488-1539), Mark McDonald concluded that around half of the works do not seem to have survived, not even in a single impression. ${ }^{32}$ The model of the Auch Mass of Saint Gregory too seems to be lost today, but it is difficult, when looking at the feather work, not to see a print as model, as there is a clarity and a linearity in the composition recalling an engraving probably not very different in composition from Israhel van Meckenem's Mass of Saint Gregory of c. 1480-85 (Figure 14.7). ${ }^{33}$ 


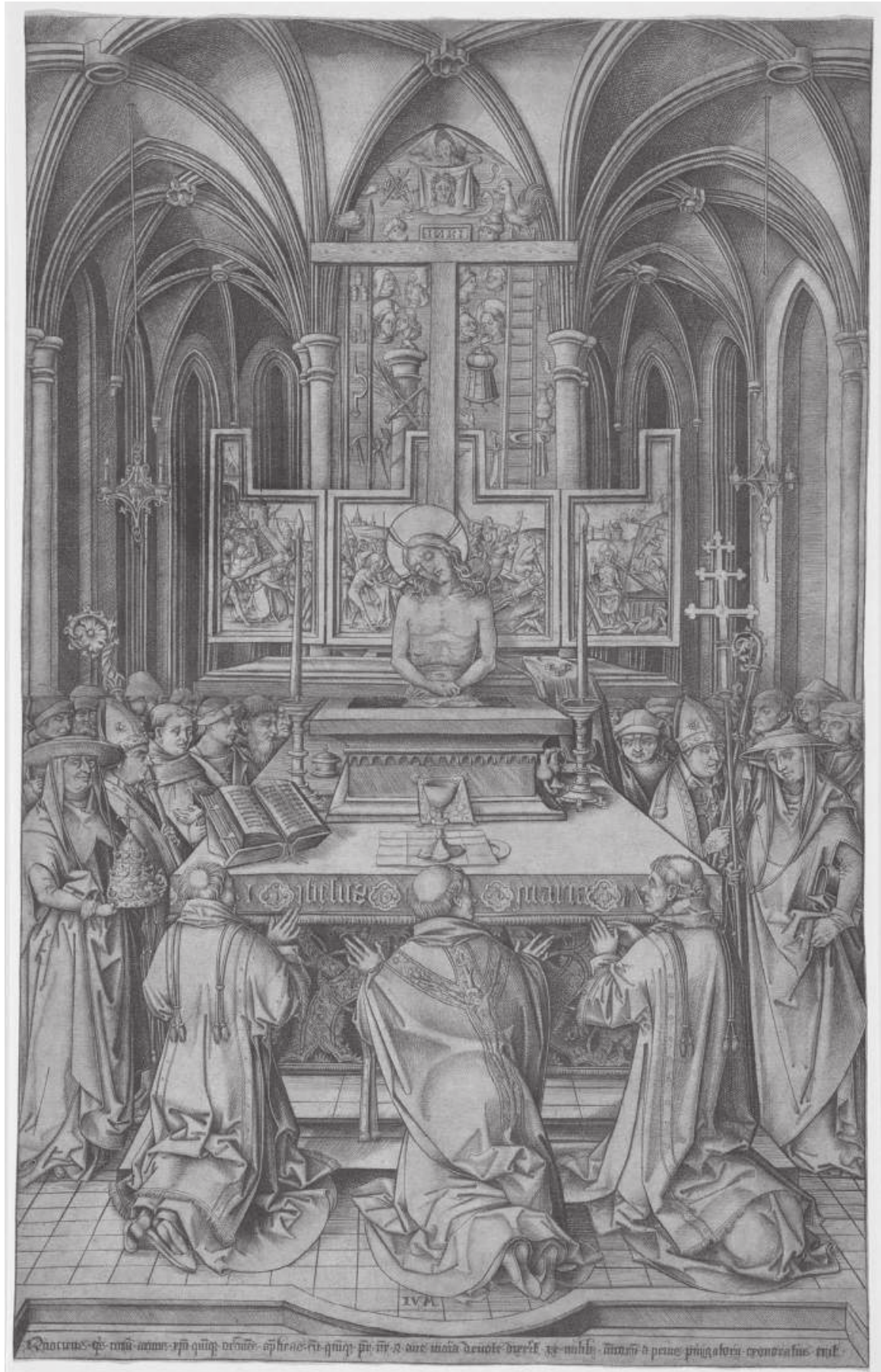

Figure 14.7 Israhel van Meckenem, Mass of Saint Gregory, c. 1490-1500, engraving, Washington, National Gallery of Art, Rosenwald Collection, 1954.12.91.

Photo: Courtesy of the National Gallery of Art. 


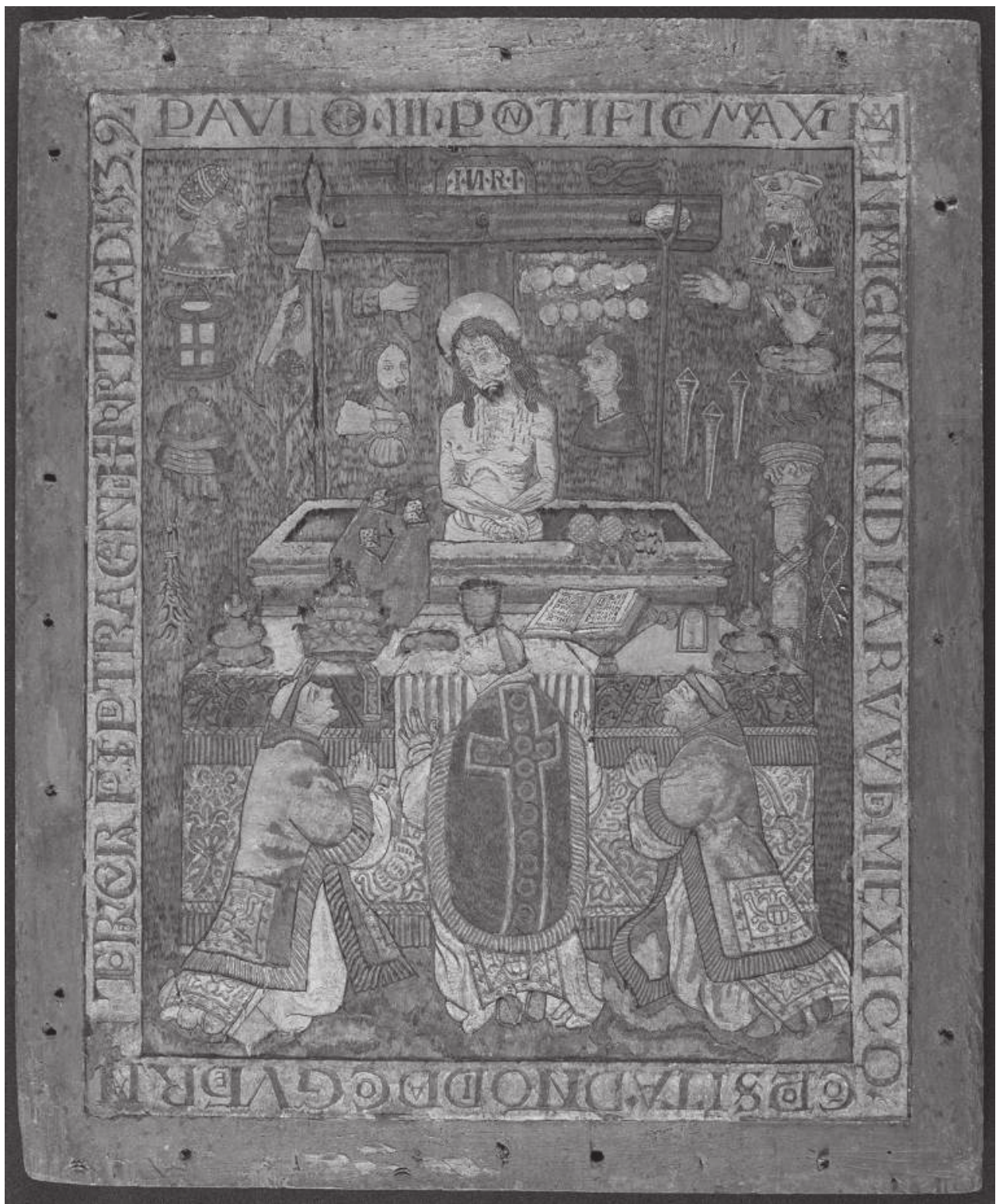

Figure 14.8 Aztec artist, Mass of Saint Gregory, 1539, feathers on wood. Auch, Musée des Jacobins.

Photo: (C) RMN-Grand Palais / Benoît Touchard.

\section{Antwerp Printers and the Globalisation of European Imagery}

The globalisation of the print culture and its dissemination worldwide happened in the second half, in fact, in the last quarter of the sixteenth century. When looking at the influence of the engraving of Saint Michael by Hieronymus Wierix after Maerten de 
Vos of 1584, Stephanie Porras sees it as "perhaps the first print design to circumnavigate the globe" by showing its rich influence in Europe, Mexico, Peru and, she claims, Goa and the Philippines. ${ }^{34}$ In regard to the 1584 print, however, she certainly showed the wide diffusion of the print in Spain, Mexico and Peru, but other examples claimed to be based on its composition are more generic, such as its influence on Guarani sculpture (Paraguay) or on the various ivory figures of Saint Michael, done from the sixteenth century onwards in Asia under Portuguese and Spanish influence. The position of the hands of the anonymous Hispano-Philippine Saint Michel studied by Porras does not conform to the iconography of the 1584 engraving; the Archangel was probably originally holding a sword or a lance in his right hand and scales or chains to fetter Satan in the other. ${ }^{35}$ The cult and the imagery of Saint Michael are now certainly global, but perhaps not the influence of the 1584 print.

I would claim that the globalisation of visual culture came initially through the influence of the Jesuits, especially the prints in Jerome Nadal's books. Born in Mallorca, the Catalan Jesuit Jerome Nadal (1507-80) became one of the ten original members of the Society of Jesus, which he joined on 23 November $1545 .{ }^{36}$ Nadal's Adnotationes et Meditationes in Evangelia quae in sacrosanto missae sacrificio toto anno leguntur had been written by the autumn of 1574, six years before Nadal's death (on 3 April 1580), at the request of Ignatius of Loyola, the founder of the Jesuit Order, and in the tradition of Ignatian meditations. ${ }^{37}$ The book, 595 pages, was first published in Antwerp in 1594 as a complement and a commentary to the 153 large engravings which had previously appeared in Antwerp in 1593 as Nadal's Evangelicae historiae imagines. ${ }^{38}$ The commission for the prints was given to the Wierix brothers, the principal engravers being Hieronymus, Johan and Antoon, but also Adrian and Jan Collaert, as well as Karel van Mallery. ${ }^{39}$

The Adnotationes was produced for the community of Jesuit scholars, but we know from the letter written by Paul Hoffaeus, Assistant of Everard Mercurian, to Pope Clement VIII, that this book was meant to be "useful and profitable to all classes of persons who know Latin, especially to candidates for the priesthood" and that it

is not only much desired by contemplatives in Europe, but also coveted in both the Indies by the Company's workers who, using the images, could more easily imprint new Christians with all the mysteries of human redemption, which they retain without difficulty through preaching and catechism. ${ }^{40}$

The didactic character of the dogmatic content of the Adnotationes is exemplified by the structure of the book focussing on the 153 illustrations of the Imagines. Each engraving has on top the basic information relative to its place in the liturgical calendar, the scene depicted, the text it illustrates, the year of Christ's life and finally, as we have seen, its order in the life of Christ and in the liturgical calendar. The engravings show the narratives divided into specific moments identified by capital letters added on the image (A, B, C, D, etc.) referring to the captions found below (Figure 14.9). Their fixed order leads the beholder's mind from scene to scene, tracing and retracing the peregrinationes of Christ, of the Virgin and of their followers. For each image, the text volume starts by quoting the relevant biblical passages, before the Annotations develop the approach by focussing on them one by one, and furthering the message of the scenes depicted and identified by capital letters; the Meditations follow, crowning the religious experience. 


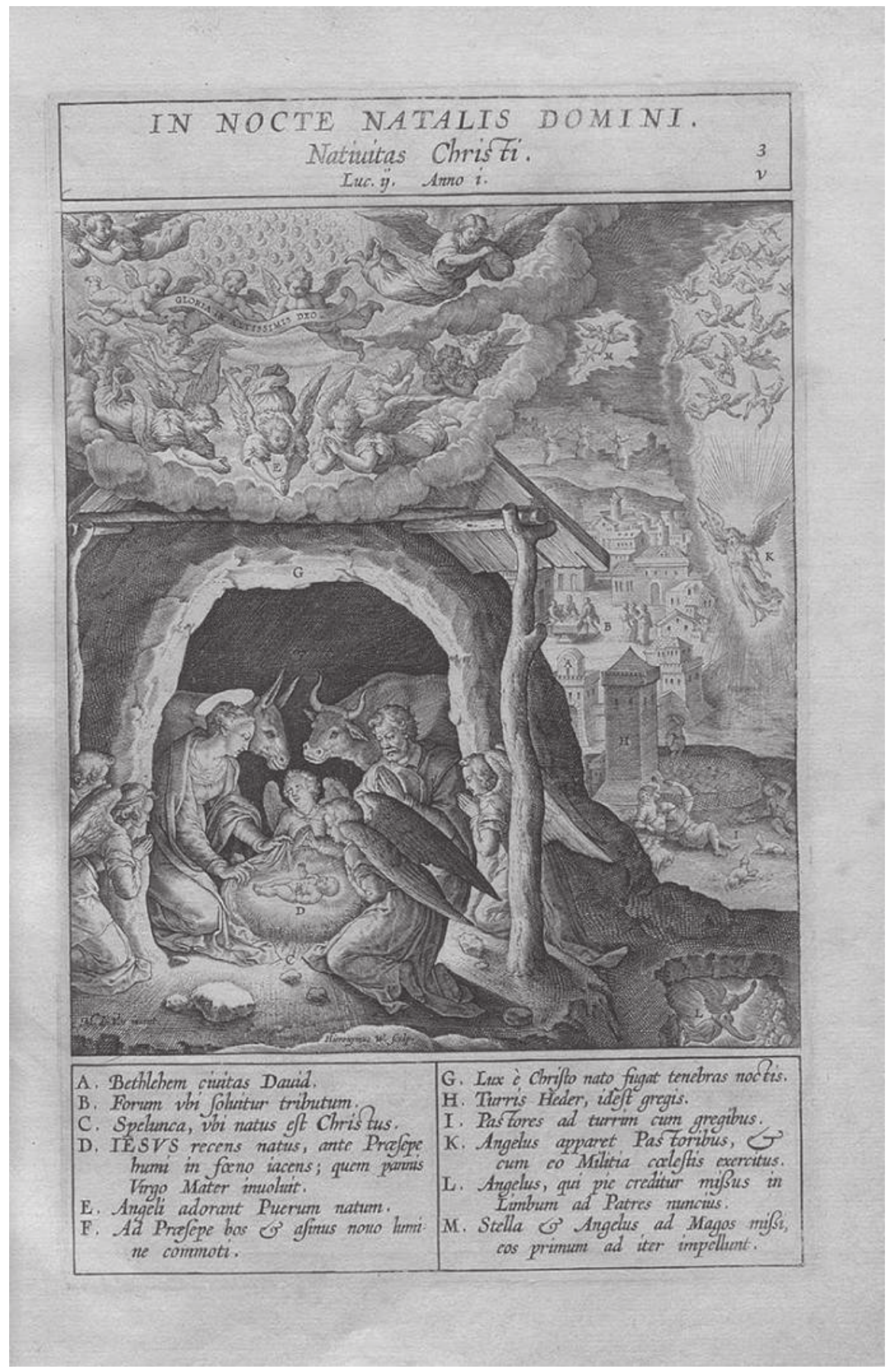

Figure 14.9 Nativity, engraving in Jerome Nadal, Evangelicae historiae imagines (Antwerp, 1593), pl. 3. Los Angeles, Getty Research Institute, 3009-135.

Photo: Los Angeles, Getty Research Institute (public domain). 


\section{The European Zones of Influence}

In the seventeenth century Nadal became, and for 200 years remained, a basic source for post-Tridentine iconography, as his book and its illustration not only defined the key moments in the Christian narrative but also analysed it and commented on it. This is why its attraction was global; the book was republished, translated into numerous languages and illustrated with engravings or woodcuts. ${ }^{41}$ Shortly after Nadal's volume first appeared, twenty-five plates from his book were copied between 1594 and 1596 by the sculptors Giovanni Giacomo and Gianpaolo Taurino on nine or ten confessionals, of which eight survive, in the Jesuit Church of San Fedele in Milan, a building by Pelegrino Tibaldi commissioned by Carlo Borromeo in 1569.42 The prints were copied all over Europe. A most interesting use of Nadal's book is found in various paintings by Philippe de Champaigne showing, respectively, Christ and the Canaanite Woman, the Entry of Christ to Jerusalem (both c. 1628, Paris, église du Val-de-Grâce) and his Resurrection of Lazarus. ${ }^{43}$ Other famous artists who used some of the prints from the book include Rubens, in the modello of his painting showing the Assumption and Coronation of the Virgin in the Hermitage (Saint Petersburg) and presented to the chapter of Antwerp cathedral on 22 April 1611, and even his famous Descent from the Cross in Antwerp Cathedral. ${ }^{44}$ In Spain, the engravings of Nadal's Imagines were mentioned at least twenty times by Francisco Pacheco in his Arte de la Pintura (1649), which has been called the "Catholic painter's guide to Orthodox iconography". ${ }^{45}$ They had a direct and indirect influence, perhaps, even on Pacheco's pupil and future son-in-law, Diego Velázquez, and, more specifically, on the Spanish picturewithin-the-picture tradition. ${ }^{46} \mathrm{~A}$ direct borrowing from Hieronymus Wierix's plate of the Circumcision of Christ (5/VII: Circuncisio Christi) is found in a painting by Francisco de Zurbarán done for the high altar of the Charterhouse of Our Lady of the Defence (Cartuja de Santa María de la Defensión) outside Jerez de la Frontera in 1639 , now in Grenoble. ${ }^{47}$

In Poland, Nadal's influence was seminal: compositions after Nadal are found in Cracow cathedral, in the monasteries of the Norbertine canonesses, the Clarisses, and the Dominicans in Cracow, but also in the ex-Cistercian church of Oliwa (Gdańsk) and in the Camaldolese monastery at Bielany (Cracow). In the Bernardine church of Kalwaria Zebrzydowska, six reliefs in the stalls, dating from the second third of the seventeenth century, copy aspects of Nadal's engravings, while paintings on copper in the monastery are based, sometimes directly, in other cases in a free way, on the engraved sources. There, some of the wall paintings in the Chapel of the House of Our Lady dating from the seventeenth century, showing the Adoration of the Magi, Christ's entry to Jerusalem, Christ appearing to the Virgin, the Virgin's Dormition and her Assumption (shown again on the predella of the altarpiece) are all based on the prints; they were also used for various paintings done at the beginning of the nineteenth century by the painter Jan Jerzyczek, among others. ${ }^{48}$ Finally, a series of icons by Mikołaj Morochowski Petrarchnowicz in the churches of the Dormition and of St Paraskeva in Lviv (Lwów) are based once again, directly or probably indirectly, on the engravings in Nadal's book. ${ }^{49}$ The engravings were even copied, with legends in Russian, by unidentified engravers of the Polish-Lithuanian Commonwealth for the local Greek Catholic and Orthodox Churches. ${ }^{50}$ 


\section{The Americas}

As a summa of Catholic dogma and because of its rich iconography, Jerome Nadal's opus magnum had a wide resonance outside Europe, in Asia, America and even Africa. ${ }^{51}$ It was in Central and South America that its influence was strongest; not only in Mexico and Peru but also in Colombia, Ecuador, Bolivia and Paraguay. ${ }^{52}$ In Peru, the influence of the prints was enormous. In their Historia de la pintura Cuzqueña (1982), José de Mesa and Teresa Gisbert identified twenty-six mainly seventeenthcentury borrowings from 1625 onwards. These are mainly found in Cuzco, including in the cathedral, and were painted by artists like D. Puente, Quispe Tito, Salvador Sandoval, F. Galindo and B. Pacheco. ${ }^{53}$ Quite astonishing is also a group of c. fifty paintings from a mid-eighteenth-century workshop in Ayacucho, the capital city of the Peruvian Huamanga province west of Cuzco, famous for its thirty-three churches (one for each year of Christ's life). These paintings, the best of them attributed to an unknown but talented master working with a less skilled assistant, are based on the engravings in Jerome Nadal's publication. ${ }^{54}$ In convents, Nadal's commentaries clearly provided the basic explanation of the compositions, but also probably the source for the spiritual exercises and the meditations of the monks and the nuns in front of the paintings, as a summa of Catholic knowledge. More borrowings have been identified in Peru, in Arequipa and elsewhere, but also in Bolivia and Ecuador. From Bolivia comes a large painting of the Antichrist in the Iglesia de Caquiaviri in La Paz based on plate 97/CXLVIII (De Antichristo. The Antichrist) of Nadal's plates. ${ }^{55}$

Another important appropriation of the prints in Nadal's book can be seen in Central Mexico, not far from San Miguel de Allende, on the vaults of the sanctuary of Jesus of Nazareth at Atotonilco, Guanajuato. There, a Creole Oratorian priest and poet, Luis Felipe Neri de Alfaro, founded the sanctuary and recruited a local artist, Miguel Antonio Martinez de Pocasangre, to paint the walls and the ceilings with thirteen cycles of paintings and sculpture focussing on meditations on the via crucis of Jesus, His Sacred Heart (1740-76) and the Virgin. ${ }^{56}$ The decoration is not without repetitions, but the most interesting aspect of the iconography is the fact that the majority of the representations of the Passion are based, thematically and often compositionally, on engravings of Nadal's books, among others in the seven vaults of the nave, each one decorated by four radial scenes. ${ }^{57}$ This influence is not isolated, as numerous works of art in Mexico can be linked to Nadal's plates. ${ }^{58}$

\section{The Eastwards Influence}

Through the Treaty of Tordesillas in 1494, the world was divided into two commercial zones of influence: the western part, with the exception of Brazil, went to Spain, while the Portuguese obtained control over the eastern shores as far as Japan. Nadal's book was as popular there as elsewhere. From Antwerp and Lisbon, Nadal's books were exported to the east, as a summa of post-Tridentine beliefs and for missionary work.

\section{Safavid Persia and India}

Nadal's book was known in Safavid Persia and used as model for wall paintings in the Armenian cathedral at New Julfa, built between 1606 and 1654, in a suburb of Isfahan. There the defeated Armenians were allowed, in the words of the seventeenth-century 
historian Arakcel of Tabriz, "to decorate them [their churches] with the paintings of the divine mysteries and images of the Saints". ${ }^{59}$ Wall paintings based on the Antwerp engravings are also found in another Armenian sanctuary in New Julfa, the church of Bethlehem; there, no fewer than thirteen compositions can be traced to those in Nadal's book. Later, images after Nadal are found in the first Armenian printed Bible, which was started in Antwerp in 1666 and completed two years later. ${ }^{60}$

In India, most recorded interest comes from the Mugal court. Velha Goa became a major administrative centre of Portuguese influence. At the third official visit to meet Emperor Akbar in Lahore (1595-1605), they brought to the emperor a newly published book, a copy of Jerome Nadal's Imagines, which had appeared shortly before. ${ }^{61}$ The copy made by the Jesuits, however, did not satisfy Salim, the emperor's son, so he had a deluxe copy made with a much richer illustration:

he ordered it transcribed in very fine letters on extremely costly paper and ordered paintings made of every scene that could possibly be depicted.... He was not content with the scenes that were engraved by Father Nadal: he [had] these painted, and many others. It was an extremely lavish book, and in Rome one would make an effort to see it. ${ }^{62}$

The manuscript does not survive, but the Persian text was published in 1639 describing in great detail the New Testament stories. A few Mughal miniatures too undeniably show the influence of engravings in Nadal's book (Figure 14.10). ${ }^{63}$

\section{China}

The most obvious evidence of Nadal's popularity, however, is found in China. ${ }^{64}$ There, too, Nadal's book was central to Jesuit religiosity and missionary expansion and led to three major illustrations of the life of Christ in book form:

- The Song Nianzhu guicheng (Rules for Reciting the Rosary), translated by the Portuguese Jesuit, João da Rocha—or sometimes given to another Jesuit, Gaspar Ferreira, published in Nanjing c. 1619, with twenty-five woodcuts, as well as short texts, based on Nadal's book. ${ }^{65}$

- The Tianzhu jiangsheng chuxiang jingje (Explanation of the Images of the Lord of Heaven's Incarnation) published by another Jesuit, Giulio Aleni, in 1637 in Quanzhou, with fifty-six woodcuts mostly based on Nadal (Figure 14.11).66

- The Jincheng shuxian (Images in a Booklet Presented to His Majesty), composed by the Jesuit Johann Adam Schall von Bell and published in Beijing in 1640 (the preface is dated 14 November 1640), includes 160 illustrations of which half are based on Nadal. ${ }^{67}$

In China, incidentally, the first four European copied prints are found in the Chengshi moyuan (the "Ink Garden of Mr Cheng"), published by Cheng Dayue after 1605, at the suggestion of Matteo Ricci. ${ }^{68}$

\section{The Ethiopian Connection}

Jerome Nadal was also influential in Japan ${ }^{69}$ and, even more surprisingly, in Ethiopia. ${ }^{70}$ His name appears in the Ethiopian account found in the annual letter from the Jesuit 


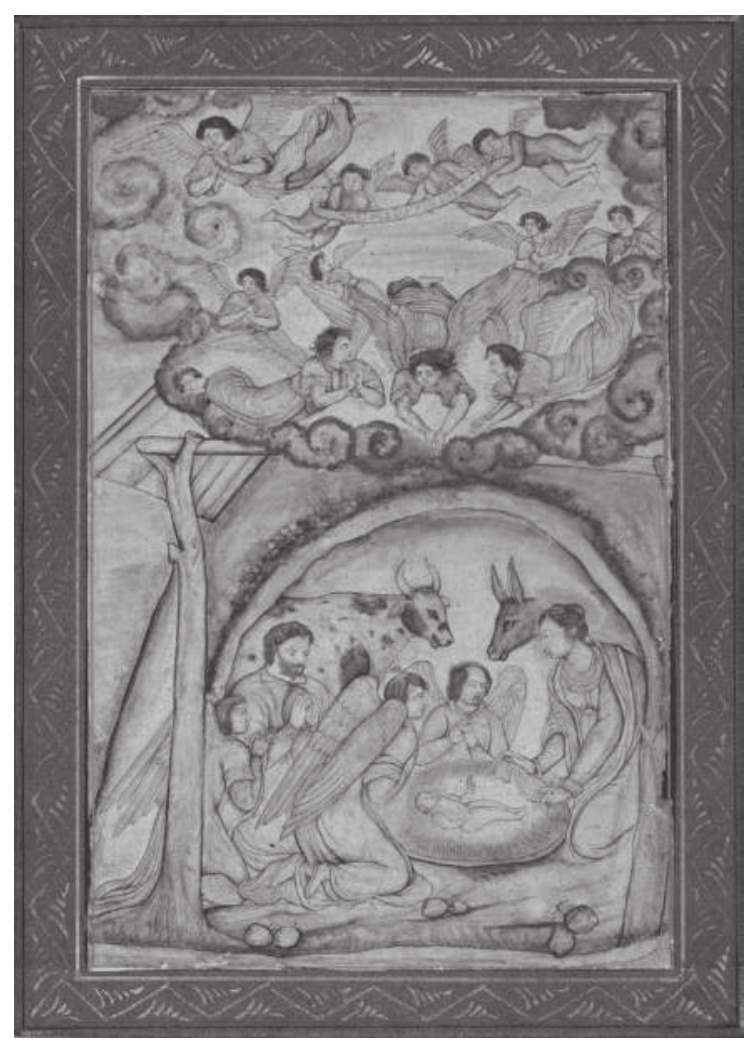

Figure 14.10 Anonymous Moghul artist, Nativity, 1605-10, painted and drawn in ink, watercolour and gold on paper. London, Victoria and Albert Museum, D.402-1885.

Photo: () London, Victoria and Albert Museum.

Province of Goa in 1611. There we learn that a close relative of Emperor Susenyos I (1607-32) had all the engravings in Nadal's book painted and that the emperor liked them so much that he asked the Jesuits to explain them to him and that he would have given much money to have them painted. ${ }^{71}$ It is difficult to see if this early encounter had much influence on Ethiopian art, as borrowings from the compositions in Nadal's book only date from the eighteenth century. The Jesuits were expelled from Ethiopia in 1633, but it may be that one of them, Charles François Xavier de Brévédent, who came back in 1698, introduced a French version of Nadal's book, which shows some of the compositions reversed, perhaps together with Nadal's original contribution. This had a major influence, directly and indirectly, on Ethiopian painting in the eighteenth and nineteenth centuries. ${ }^{72}$ The prints were used for the murals of the church of Nārgā Śillasse ordered by Queen Mentewāb (Wälätä Giyorgis), mother of King Iyasu II (r. 1730-55). There the Transfiguration painted between 1737 and 1750 on the north side of the drum of the church and the Ascension of Christ, on the east side of the drum, are clearly modelled on the engravings in Nadal's book. Numerous Ethiopian eighteenth-century manuscripts and panel paintings have compositions or just figures based on the imagery of the French versions. ${ }^{73}$ 


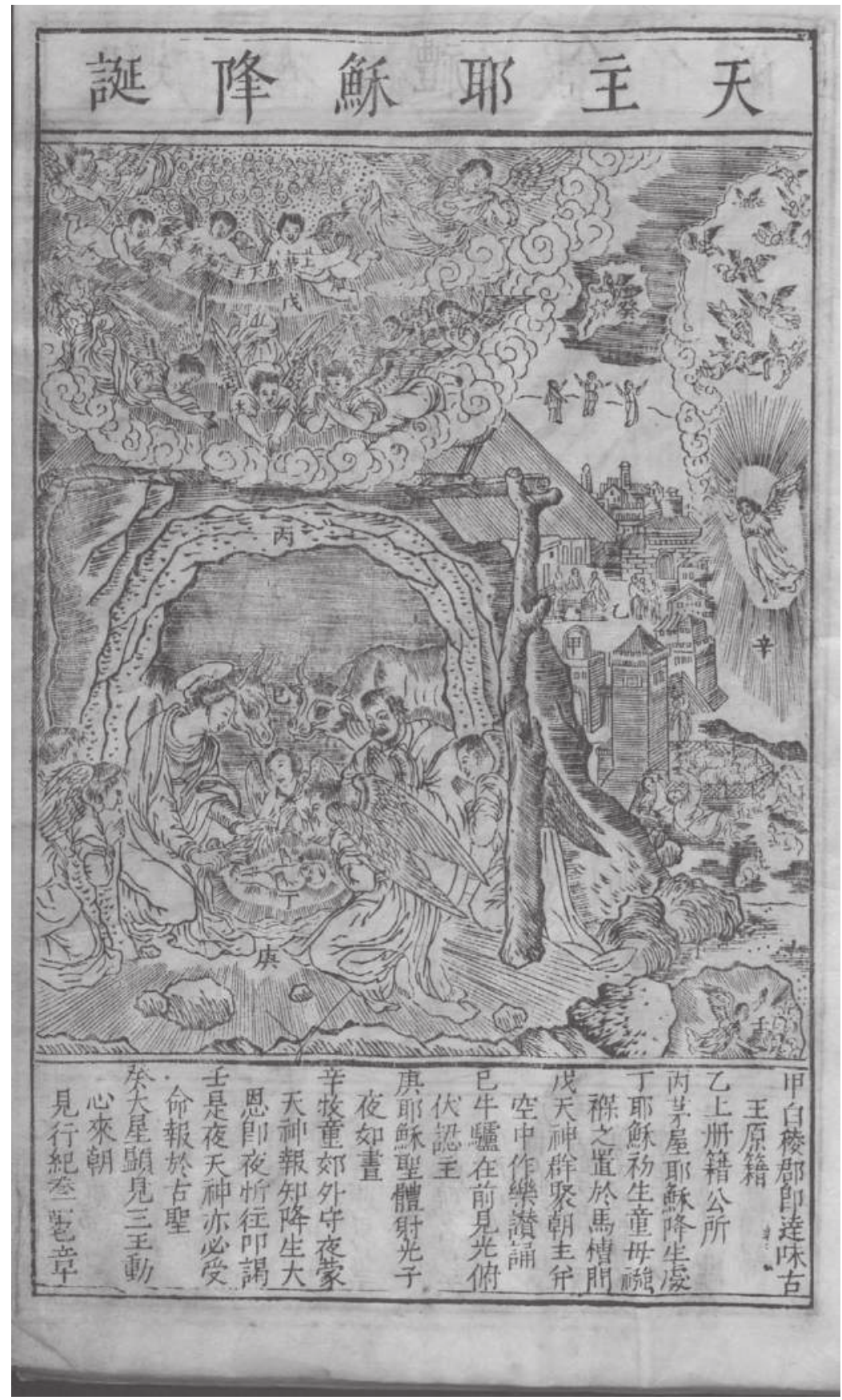

Figure 14.11 Nativity in Giulio Aleni, Explanation of the Images of the Lord of Heaven's Incarnation (Tianzhu jiangsheng chuxiang jingje) (Quanzhou 1637), unnumbered pages, woodblock printing. Munich, Bayerische Staatsbibliothek, Cod.sin. 4 23, urn:nbn:de:bvb:12-bsb00080038-2.

Photo: Munich, Bayerische Staatsbibliothek, CC BY-NC-SA 4.0. 


\section{Towards a Global Art History}

The influence of the prints of the Imagines on four continents visualises the attempt of the Jesuits to Christianise but also to provide a clear theological and visual coverage both of Christian history and of the liturgical year, providing not only the images but also various levels of analysis and meditation for the learned, or those whose aim was simply to teach the Christian doctrine. The whole picture is overwhelming, showing an extremely successful attempt to promote Christianity, which became one of the basic sources not only for the Jesuits but for numerous other Catholic religious orders, if not for all. It is, of course, difficult to define here all the specific local implications, as the levels of learning and understanding of images differed-from full theological implications and helping the learned in their meditations to providing models for images to visualise the basic religious message for the illiterate. How people from all over the world, from such divergent backgrounds, understood the images is a challenge to global art history.

\section{Notes}

1 In this chapter I have used, sometimes verbatim, the text of my own publications. I would like to thank David Landau and all my colleagues, past and present, from the editorial board of Print Quarterly with whom I have discussed prints at our stimulating trimestrial editorial meetings. I would also like to thank Elizabeth McGrath and Ann Massing for their assistance. Without the extraordinary resources of the Warburg Institute, both in its library and photographic collection, I would never have been able to trace all the examples. Landau, "Print Quarterly Turns 35," 3.

2 Massing, "Schongauer's 'Tribulations of St Anthony'," 220-36. For me, the question was raised by my research and my article Massing, "Étude iconographique," 105-26, in which I noted that this masterpiece hardly had any influence until the twentieth century (in this case because of its geographical location).

3 Massing, "Schongauer, Bosch, Grünewald et les autres," 141-55.

4 Martindale, The Triumphs of Caesar, reviewed by Jean Michel Massing in The Burlington Magazine, CXXIII (1981): 360 and 363; Lightbown, Mantegna, esp. 140-53 and 424-33, no. 28 , pls. $101-19$.

5 Martindale, The Triumphs of Caesar, passim; for the engravings, 167-68, figs. 58-65; Lightbown, Mantegna, esp. 432-33. For the earliest direct borrowings, Martindale, The Triumphs of Caesar, 99-101.

6 Ibidem, 101; for the wider influence in the sixteenth century, 97-108.

7 Massing, "Jacobus Argentoratensis: Étude préliminaire," 42-52; idem, "The "Triumph of Caesar'," 2-21; idem, "Jacobus Argentoratensis," 297-98, figs. 217-18. For the privilege, Witcombe, Copyright, 90-95.

8 Massing, "The 'Triumph of Caesar'," 5-7.

9 Ibidem, 6-7 for the quote.

10 Ibidem, 8-9 for the identification. More recently Blanc, Les frises oubliées; and Massing, "The Triumph of Caesar from Vélez Blanco," 288-89.

11 Almost all the examples here are discussed at length by Massing, "Arnould Poissonier," 69-74; idem, "The 'Triumph of Caesar'," 8-21.

12 Hind, "Fifteenth-Century Italian Engravings," 279-96; Raby, "Mehmed II Fatih," 42-49; Landau and Parshall, The Renaissance Print, 91-95.

13 See, respectively, Hind, "Fifteenth-Century Italian Engravings," 279; and Landau and Parshall, The Renaissance Print, 94.

14 Hart, Continuity and Discontinuity. For the most recent accounts, with a rich bibliography, see Massing, "Stone Carving," 64-75 and 266-71; idem, "Os marfins africanos," 10-35. These ivories were first catalogued by Curnow, The Afro-Portuguese Ivories, then by Bassani and Fagg, Africa and the Renaissance, passim and, for the catalogue, 225-38, cat. and 
figs. 1-108 (a few of these may not belong to the group) and then by Bassani, African Art, who listed (on p. 285) the ivories which were brought to his attention after 1988.

15 Person, "Les Kissi," 1-59.

16 Fernandes, Description de la Côte Occidentale d'Afrique, 76-77, 96-97 and 104-5. For Portuguese texts and documents relative to Sierra Leone ivories, Bassani, African Art, 17982; a good assessment of the literary sources is found in Hart, Continuity and Discontinuity, 41-44.

17 On stone carvings, see Massing, "Stone Carving," 65-72; and idem, "Os marfins africanos," 17-20, figs. 1 and 2; also Lamp, "House of Stones," 219-37.

18 Massing, "Os marfins africanos," 13-35.

19 Bassani and Fagg, Africa and the Renaissance, 83-84, 138 and 232, no. and fig. 57; Bassani, African Art, 246, no. and fig. 758.

20 Bassani and Fagg, Africa and the Renaissance, 83-84, 114-15, 138 and 232, no. and fig. 58; Bassani, African Art, 246-47, no. and fig. 759; Massing, in Levenson, ed., Encompassing the Globe, 2: Reference catalogue, 72, no. and fig. A-13.

21 Randall, Masterpieces of Ivory, 310-11, no. and fig. 467; Bassani and Fagg, Africa and the Renaissance, 83, 113, 115, 138, and 232, no. and fig. 59; Bassani, African Art, 247, no. and fig. 760.

22 See for example, in London, BL, the Hore dive virginis Marie secundum usum Romanum cum verum aliis multis folio sequenti notatis una cum figuris apocalipsis post figuras biblie recenter insertis (Paris: Thielman Kerver, 1509 [die vero. XIX. mensis Septembris], fols. B8v, $\mathrm{C1}^{\mathrm{r}}, \mathrm{C} 8^{\mathrm{v}}, \mathrm{D} 5^{\mathrm{v}}, \mathrm{D} 7^{\mathrm{v}}, \mathrm{E} 1^{\mathrm{v}}, \mathrm{E} 3^{\mathrm{v}}$ and E5 ${ }^{\mathrm{v}}$, respectively. Other books of hours published by Kerver between 1509 and 1511 have the same illustration; some could probably be a few months earlier, the others slightly later.

23 For example Bassani and Fagg, Africa and the Renaissance, 114-15, figs. 139-40. For the mark of the printer, see Davies, Devices of the Early Printers, 448-51, cat. 130-130a, with ills.

24 Jaffer and Schwabe, "A Group of Sixteenth-Century Ivory Caskets," 8-9; Vassallo e Silva, "Export Art from Portuguese India," 208-9, figs. 12-13; idem, "'Engenho e primor,," 90-96, figs. 1 and 3; Biedermann, "Diplomatic Ivories," 88-118.

25 Jordan Gschwend, "Ivory Caskets," 103.

26 Jaffer and Schwabe, "A Group of Sixteenth-Century Ivory Caskets," 8-9 and 14, cat. 5, with bibl., figs. 16-19; Vassallo e Silva, "Engenho e primor'," 93-94. Jordan Gschwend and Beltz, Elfenbeine aus Ceylon, 60-69, with the identication of some of the printed sources; For Dürer's Bagpipe Player and its influence, Schoch, Mende, and Scherbaum, eds., Albrecht Dürer, 53-54, no. 12, with ill.

27 Vassallo e Silva, "Export Art from Portuguese India," 134-35, no. and fig. 1-44; idem, "Engenho e primor'," 93-94 and 96, fig. 3.

28 Mongne, "La Messe de saint Grégoire," 38-47; Pierce, Ruiz Gomar, and Bargellini, Painting a New World, 94-102; Courcelles, Louis-Combet, and Malgouyres, 'Messe de saint Grégoire'.

29 Wolf, “Ananas und Tiara," 333-47.

30 Castelló Ituribe and Cortina Portilla, El arte plumaria; Haag et al., eds., Der Altmexikanische Federkopfschmuck.

31 Schreiber, Handbuch der Holz und Metallschnitte, 103-17, cat. 1455-93.

32 McDonald, The Print Collection; see also Massing, "Gathering the Wisdom," 38.

33 Shestack, Fifteenth Century Engravings, cat. and fig. 214.

34 Porras, "'St Michael the Archangel'," 183-202; see also idem, "Going Viral?" 54-79.

35 Porras, "'St Michael the Archangel'," 196-98, fig. 10.7; and eadem, "Going Viral?” 59 and 61, fig. 4 (detail, p. 79).

36 Nicolau, Jerónimo Nadal; for his biography, see also Bangert, Jerome Nadal. Most of the following part of the present chapter, except for the section on Poland, is based on my article, Massing, "Jerome Nadal's 'Evangelicae historiae imagines'," 161-220, which first inserted a wealth of local identification in a global frame.

37 Jerome Nadal, Adnotationes et Meditationes in Evangelia quae in sacrosanto missae sacrificio toto anno leguntur (Antwerp: Marcus Nutius, 1593). For a partial English translation and edition of some of the images, see Nadal, Annotations and Meditations. For the influence of the book, Gutiérrez, "Los grabadores flamencos," 89-119. 
38 Jerome Nadal, Evangelicae historiae imagines ex ordine Evangeliorum, quae toto anno in missae sacrificio recitantur (Antwerp: Society of Jesus, 1593).

39 The engravings have been systematically studied by Mauquoy-Hendrickx, "Les Wierix," 28-63. For the individual engravings, idem, Les estampes des Wierix, 400-29 and pls 30621, no. and fig. 1989-2121.

40 For this letter, see the Nadal, Epistolae, 727-28, esp. 72; for the translation, Nadal, Annotations and Meditaions, vol. 1, 1. See also Dekoninck, "A Graphic 'koiné'," 277.

41 Massing, "Jerome Nadal's 'Evangelicae historiae imagines'," 161-220.

42 Pirri, "Intagliatori Gesuiti," 35-39, pls. V-VI, figs. 7-11.

43 Massing, "Jerome Nadal's 'Evangelicae historiae imagines'," 170 and 172-77, for the whole study.

44 Ibidem, 175 and $178-80$.

45 Brown, Images and Ideas, 51. See also Gutiérrez, "Los grabadores flamencos," 96-99. Pacheco, Arte de la pintura, s.v. Nadal; For Nadal's influence in Spain, see also Delgado, "El padre Jerónimo Nadal," 354-63.

46 Moffitt, "Francisco Pacheco," 631-38. See also Freedberg, Steinberg and Moffitt, "Pacheco, Nadal and Velázquez," 503-7.

47 For this painting and its relation to Nadal, Cunnar, "Jerome Nadal and Francisco Pacheco," 105-12; Navarette Prieto, La pintura andaluza, 50-51, figs. 33-34; Gerard-Powell, Autour de Zurbarán, 70-75, cat. 6, ills.

48 Ponińska, "Wpływ rycin," 101-15, figs. 76-101; Deluga, "Printed Sources," 229-32, figs. 204-7 (see also 229-30, figs. 202-3, for a relief of the Presentation of the Virgin to the temple, of 1636-1637, from the Holy Virgin Church in Cracow).

49 Ałeksandrowycz, "Cykl pasyjny," 791-816; Deluga, "Printed Sources," 229.

50 Ermakova and Khromov, Русская Гравюра, 13-15, cat. and figs. 4-5; Deluga, "Printed Sources," 229.

51 An interesting preliminary account is by Gutiérrez, "Los grabadores flamencos," 89-119. Also Massing, "Jerome Nadal's 'Evangelicae historiae imagines'."

52 Ibidem, 184-202.

53 Mesa and Gisbert, Historia de la pintura, 105-6 and the index, s.v. Nadal; see also Bernales Ballesteros, "La pintura en Lima," 103.

54 Garcia Saiz, "Las 'Imágenes de la historia evangélica'," 43-66; Dekoninck, "A Graphic 'koiné," 286 and 288, fig. 10, reproduces and studies a painting of The Canaanite Women and the Plights of the Centurion, in the Monasterio de Santa Teresa in Ayacucho, based on the engraving from Nadal's book.

55 Mujica Pinilla, "Hell in the Andes," 192-93, fig. 144.

56 Santiago, Atotonilco; Pérez Gavilán, The 'Via Crucis'.

57 Santiago, Atotonilco, 159-258, for the correspondences between the Exercises of Saint Ignatius, the prints by Nadal and the paintings in the nave.

58 Massing, "Jerome Nadal's 'Evangelicae historiae imagines'," 184-90.

59 Arakel of Tabriz, Collection d'histoires arméniennes, 302. For the cathedral and its wall paintings, Boase, "A Seventeenth-Century Typological Cycle," 323-27; Amenaperkitch, "All Saviour's Cathedral," 30-34, fig. 10, pls. III; on 22-25, Carswell links them to the Armenian bible of 1666, which is, incidentally, indirectly related to Nadal. Bailey, Counter Reformation Symbolism, 188, note 20, mentioned the book of Nadal as a source for the paintings; more recently, Laporte-Eftekharian, "Diffusion et exploitation des gravures religieuses," 51-67, figs. 3-9, and "Transmission et métamorphose de modèles iconographiques," esp. 64-69, 72-75 and 79, figs. 1-2 and 7-8. More recently Massing, "Jerome Nadal's 'Evangelicae historiae imagines'," 212-13.

60 For the Armenian Bible, see Boase, "A Seventeenth-Century Typological Cycle," 326-27; Massing, "Jerome Nadal's 'Evangelicae historiae imagines'," 168.

61 Bailey, "The Truth-Showing Mirror'," 392; idem, Art on the Jesuit Missions, 123 and 129. For Nadal in India, Massing, "Jerome Nadal's 'Evangelicae historiae imagines'," 202-4.

62 Mentioned by Bailey, Art on the Jesuit Missions, 129.

63 Stronge, Painting for the Mughal Emperor, 111-13, pls. 78-79. Pl. 33/CXXX of Nadal's book is found in a Mughal album in Istanbul, Topkapi Sarayi Museum: Bailey, " 'The TruthShowing Mirror'," 385-86, and 387, fig. 18.5. 
64 For China, Massing, “Jerome Nadal's 'Evangelicae historiae imagines',” 205-12.

65 For a rich bibliography, see Standaert, An Illustrated 'Life of Christ', 12-13, notes 6-7. For this book, see most recently Reed and Demattè, China on Paper, 168-71, no. 16.

66 Standaert, An Illustrated 'Life of Christ', 13-14, note 10, for the basic bibliography; this book, too, has other editions; Dehergne, "Une vie illustrée de Notre-Seigneur," 103-15. For a nineteenth-century version, after a version of Brispot, La vie de N. S. Jésus-Christ, see Sun, "Cultural Translatability," 484.

67 Standaert, An Illustrated 'Life of Christ', esp. 14-15; also 57 and 91-96, Table 4.

68 Ibidem, 12-13; esp. note 3 for the bibliography of the work.

69 Massing, "Jerome Nadal's 'Evangelicae historiae imagines'," 212.

70 Ibidem, 214-20.

71 Beccari, Relationes et epistolae variorum, 209 (Ex litteris annuis Provinciae Goanae an. 1611). See Caraman, The Lost Empire, 82; Bosc-Tiessé, Les îles de la mémoire, 99-102. For Nadal's influence in Ethiopia, Massing, "Jerome Nadal's 'Evangelicae historiae imagines,," 214-20.

72 Mercier, "Les sources iconographiques," esp. 379-85; he mentioned the use of fifty-seven prints after Nadal. Bosc-Tiessé, "The Use of Occidental Engravings," esp. 314-26.

73 See Massing, "Jerome Nadal's 'Evangelicae historiae imagines'," 214 and 216. For the tryptich, Bosc-Tiessé and Wion, Peintures sacrées d'Ethiopie, 50-53.

\section{Bibliography}

Ałeksandrowycz, Wołodymyr. "Cykl pasyjny Mikołaja Morochowskiego Petrachnowicza z ikonostasu cerkwi Zaśnięcia Matki Boskiej we Lwowie: Źródła inspiracji oraz osobliwości ich wykorzystania." Przeglad Wschodni, 7 (2001): 791-816.

Amenaperkitch, Surb. “All Saviour's Cathedral.” In John Carswell, New Julfa: The Armenian Churches and Other Buildings. Oxford: Clarendon Press, 1968.

Arakel of Tabriz. Collection d'histoires arméniennes, transl. Marie-Félicité Broset, 1. St Petersburg: n. p., 1874.

Bailey, Gauvin Alexander. Counter Reformation Symbolism and Allegory in Mughal Painting. Ph.D. dissertation, Harvard University, Cambridge, MA, 1996.

- Art on the Jesuit Missions in Asia and Latin America, 1542-1773. Toronto: University of Toronto Press, 1999.

—. "The Truth-Showing Mirror': Jesuit Catechism and the Arts in Mughal India." In The Jesuits: Cultures, Sciences and the Arts 1540-1773, eds. John W. O’Malley et al., 380-401. Toronto: University of Toronto Press, 1999.

Bangert, William V. Jerome Nadal, S.J., 1507-1580: Tracking the First Generation of Jesuits, edited and completed by Thomas M. McCoog, S. J. Chicago: Loyola University Press, 1992.

Bassani, Ezio. African Art and Artefacts in European Collections 1400-1800. London: British Museum Press, 2000.

Bassani, Ezio, and William B. Fagg. Africa and the Renaissance: Art in Ivory. New York: Center for African Art and Prestel, 1988.

Beccari, Camillo. Relationes et epistolae variorum, 1.2 (Rerum Aethiopicarum scriptores occidentales, XI). Rome: Luigi, 1911.

Bernales Ballesteros, Jorge. "La pintura en Lima durante el Virreinato." In Pintura en el Virreinato del Perú. Lima: Banco de Crédito del Peru, 1989.

Biedermann, Zoltán. "Diplomatic Ivories: Sri Lankan Caskets and the Portuguese-Asian Exchange in the Sixteenth Century." In Global Gifts: The Material Culture of Diplomacy in Early Modern Eurasia, eds. Zoltán Biedermann, Anne Gerritsen, and Giorgio Riello, 88-118. Cambridge: Cambridge University Press, 2018.

Blanc, Monique. Les frises oubliées de Vélez Blanco. Exhibition catalogue, Paris, Musée des Arts décoratifs, 7 December 1999-13 March 2000. Paris: Musée des Arts Décoratifs, 1999. 
Boase, Thomas Sherrer Ross. "A Seventeenth-Century Typological Cycle of Paintings in the Armenian Cathedral at Julfa." Journal of the Warburg and Courtauld Institutes, 13 (1950): 323-27.

Bosc-Tiessé, Claire. "The Use of Occidental Engravings in Ethiopian Painting in the 17th and 18th Centuries." In The Indigenous and the Foreign in Christian Ethiopian Art: On Portuguese-Ethiopian Contacts in the 16th-17th Centuries, eds. Manuel João Ramos and Isabel Boavida, 83-102. Aldershot: Ashgate, 2004.

—. Les îles de la mémoire: Fabrique des images et écriture de l'histoire dans les églises du lac Tānā, Éthiopie, XVII ${ }^{e-X V I I I^{e}}$ siècle. Paris: Publications de la Sorbonne, 2008.

Bosc-Tiessé, Claire, and Anaïs Wion. Peintures sacrées d'Ethiopie: Collection de la Mission Dakar-Djibouti. St-Maur-des-Fossés: Sépia, 2005.

Brispot, Pierre. La vie de N. S. Jésus-Christ écrite par les quatre Evangélistes. 2nd ed. Paris: Abel Pilon, 1853.

Brown, Jonathan. Images and Ideas in Seventeenth-Century Spanish Painting. Princeton, NJ: Princeton University Press, 1978.

Caraman, Philip. The Lost Empire: The Story of the Jesuits in Ethiopia, 1555-1634. London: Sidgwick \& Jackson, 1985.

Castelló Ituribe, Teresa, and Manuel Cortina Portilla. El arte plumaria en México. Mexico: Fomento Cultural Bamanex, 1993.

Courcelles, Dominique de, Claude Louis-Combet, and Philippe Malgouyres. 'Messe de saint Grégoire', œeuvre anonyme, Mexique, XVIe siècle. Paris: Ophrys, 2011.

Cunnar, Eugene R. "Jerome Nadal and Francisco Pacheco: A Print and a Verbal Source for Zurbaran's 'Circumcision' (1639).” Boletín del Museo e Instituto «Camón Aznar〉, 33 (1988): 105-12.

Curnow, Kathy. The Afro-Portuguese Ivories: Classification and Stylistic Analysis of a Hybrid Art Form. Ph.D. dissertation, Indiana University, Indianapolis, 1983.

Davies, Hugh William. Devices of the Early Printers 1457-1560: Their History and Development. London: Grafton \& Co., 1935.

Dehergne, Joseph. "Une vie illustrée de Notre-Seigneur au temps des Ming." Neue Zeitschrift für Missionswissenschaft: Nouvelle revue d'histoire missionaire, XIV (1958): 103-15.

Dekoninck, Ralph. "A Graphic 'koiné' for a New Religious Value: The Visual Translatability of the 'Evangelicae Historiae Imagines'." Netherlands Yearbook for History of Art/Netherlands Kunsthistorisch Jaarboek, 64 (2014): 272-97.

Delgado, Feliciano. "El padre Jerónimo Nadal y la pintura sevillana del siglo XVII." Archivum Historicum Societatis Iesu, 28 (1959): 354-63.

Deluga, Waldemar. "Printed Sources of Seventeenth- and Eighteenth-Century Polish Art." Print Quarterly, 31 (2014): 229-32.

Ermakova, M. E., and O. R. Khromov [M. Е. Ермакова, О. Р. Хромов]. Русская Гравюра на меди. Moscow: Индрик, 2004.

Fernandes, Valentim. Description de la Côte Occidentale d'Afrique (Sénégal au Cap de Monte, Archipels), eds. Théodore Monod, Avelino Teixeira da Mota, and Raymond Mauny. Bissau: Centro de Estudos da Guiné Portuguesa, 1951.

Freedberg, David, Leo Steinberg, and John F. Moffitt. "Pacheco, Nadal and Velázquez." The Art Bulletin, 73 (1991): 503-7.

Garcia Saiz, María Concepción. “Las 'Imágenes de la historia evangélica’ del P. Jerónimo Nadal y la pintura en Ayacucho (Perú).” Quadernos de arte colonial, 4 (1988): 43-66.

Gerard-Powell, Véronique. Autour de Zurbarán: Catalogue raisonné des peintures espagnoles $d u X V^{e}$ au XIXe siècles du Musée de Grenoble. Paris: Réunion des Musées Nationaux, 2000.

Gutiérrez, Fernando García. "Los grabadores flamencos de los siglos XVI y XVII y la Compañía de Jesús.” Archivum historicum Societatis lesu, 73 (2004): 89-119.

Haag, Sabine et al., eds. Der Altmexikanische Federkopfschmuck. Vienna: ZKF Publishers, 2012. 


\section{8}

Jean Michel Massing

Hart, William A. Continuity and Discontinuity in the Art History of Sierra Leone (Quaderni Poro, 9). Milan: Carlo Monzino, 1995.

Hind, Arthur M. "Fifteenth-Century Italian Engravings at Constantinople." The Print Collector's Quarterly, 20 (1933): 279-96.

Jaffer, Amin, and Mélanie Anne Schwabe. “A Group of Sixteenth-Century Ivory Caskets from Ceylon.” Apollo, 149/445 (1999): 3-14.

Jordan Gschwend, Annemarie. "Ivory Caskets, Combs and Fans from Ceylon." In A Herança de Rauluchantim-The Heritage of Rauluchantim, ed. Roque Nuno Vassallo e Silva. Exhibition catalogue, Lisbon, Museu de São. Lisbon: Museu de São Roque, 1996.

Jordan Gschwend, Annemarie, and Johannes Beltz. Elfenbeine aus Ceylon: Luxusgüter für Katharina von Habsburg (1507-1578). Exhibition catalogue, Zurich, Museum Rietberg, 28 November 2010-13 March 2011. Zurich: Museum Rietberg, 2010.

Lamp, Frederick John. "House of Stones: Memorial Art of Fifteenth-Century Sierra Leone." The Art Bulletin, 65 (1983): 219-37.

Landau, David. “Print Quarterly Turns 35.” Print Quarterly, 35 (2018): 3-5.

Landau, David, and Peter W. Parshall. The Renaissance Print, 1470-1550. New Haven: Yale University Press, 1994.

Laporte-Eftekharian, Sâyeh. "Diffusion et exploitation des gravures religieuses dans la Perse Safavide: L'exemple de la Nouvelle Djoulfa." Annales d'histoire de l'art et d'archéologie, 25 (2003): 51-67.

—. "Transmission et métamorphose de modèles iconographiques occidentaux, principalement flamands, dans les églises de la Nouvelle-Djoulfa (Ispahan)." Revue belge d'archéologie et d'histoire de l'art, 73 (2004): 63-80.

Levenson, Jay A., ed. Encompassing the Globe: Portugal and the World in the 16th of 17th Centuries. Exhibition catalogue, Washington, D.C., Arthur M. Sackler Gallery in partnership with the National Museum of African Art, 24 June-16 September 2007. Washington, DC: Arthur M. Sackler Gallery, Smithsonian Institution, 2007.

Levenson, Jay A., and Ana de Castro Henriques, eds. Encompassing the globe: Portugal e o mundo nos séculos XVI e XVII. Exhibition catalogue, Lisbon, Museu Nacional de Arte Antiga, 15 July-11 October 2009. Lisbon: Museu Nacional de Arte Antiga, 2009; Ministério da Cultura; Inst. dos Museos e da Conservação, 2009.

Lightbown, Ronald. Mantegna, With a Complete Catalogue of the Paintings, Drawings and Prints. Oxford: Phaidon-Christie's, 1986.

Martindale, Andrew. The Triumphs of Caesar by Andrea Mantegna in the Collection of Her Majesty the Queen at Hampton Court. London: Harvey Miller, 1979.

Massing, Jean Michel. "Étude iconographique de l'agression de saint Antoine de Grünewald." In Grünewald et son oeuvre, 105-26. Strasbourg, 1976 (republished from the Cabiers alsaciens d' archéologie, d'art et d'histoire, 19 (1975-1976): 105-26 and then in Massing, Studies in Imagery, Vol. 1, 363-91).

—. "Jacobus Argentoratensis. Étude préliminaire.” Arte Veneta, 31 (1977): 42-52 (republished in Massing, Studies in Imagery, Vol. 1, 69-97).

- "Schongauer's 'Tribulations of St Anthony': Its Iconography and Influence on German Art.” Print Quarterly, I (1984): 220-36 (republished in Massing, Studies in Imagery, Vol. 1, 327-62).

—. "Arnould Poissonier of Tournai and His ' . . . huit pièces du Triomphe de César' for Margaret of Austria." Artes textiles: Bijdragen tot de geschiedenis van de tapijt-en textielkunst, 11 (1986): 69-74 (republished in Massing, Studies in Imagery, Vol. 1, 98-107).

—. "Jacobus Argentoratensis." Print Quarterly, 4 (1987): 297-98.

—. "The 'Triumph of Caesar' by Benedetto Bordon and Jacobus Argentoratensis: Its Iconography and Influence." Print Quarterly, 7 (1990): 2-21 (republished in Massing, Studies in Imagery, Vol. 1, 108-40).

- "Schongauer, Bosch, Grünewald et les autres: De quelques 'Tribulations de saint Antoine' et de leurs influences.” In Le Beau Martin: Etudes et mises au point: Actes du 
colloque organisé par le musée d'Unterlinden à Colmar les 30 septembre, $1^{\text {er }}$ et 2 octobre 1991, 141-55. Strasbourg: Musée d'Unterlinden, 1994 (republished in Massing, Studies in Imagery, Vol. 1, 392-420).

—. "The Triumph of Caesar from Vélez Blanco." Print Quarterly, 17 (2000): 288-89.

Studies in Imagery. Vols. 1-2. London: Pindar Press, 2004-2007. 38.

. "Gathering the Wisdom of the Whole Universe." The Art Newspaper, (March 2005): 38.

. "Os marfins africanos e os Portugueses.” In Marfins no Império Português, eds. Gauvin Alexander Bailey, Jean Michel Massing, and Nuno Vassallo e Silva, 10-35. Lisbon: Scribe, 2013.

- "Jerome Nadal's 'Evangelicae Historiae Imagines' and the Birth of Global Imagery." Journal of the Warburg and Courtauld Institutes, 80 (2017): 161-220.

—. "Stone Carving and Ivory Sculpture in Sierra Leone." In Levenson, ed., Encompassing the Globe, 64-75 and 266-71 (republished in Levenson and Henriques, eds., Encompassing the Globe, 115-30, and in Massing, Studies in Imagery, Vol. 2, 199-241).

Mauquoy-Hendrickx, Marie. "Les Wierix illustrateurs de la Bible dite de Natalis." Qucerendo, 6 (1976): 28-63.

- Les estampes des Wierix conservées au Cabinet des Estampes de la Bibliothèque Royale Albert $1^{\text {er }}$. Brussels: Bibliothèque Royale Albert $1^{\text {er }}, 1982$.

McDonald, Mark P. The Print Collection of Ferdinand Columbus (1488-1539): A Renaissance Collector in Seville. London: British Museum Press, 2004.

Mercier, Jacques. "Les sources iconographiques occidentales du cycle de la vie du Christ dans la peinture éthiopienne du dix-huitième siècle.” Journal asiatique, 287 (1999): 375-94.

Mesa, José de, and Teresa Gisbert. Historia de la pintura Cuzqueña, I. Lima: Fundación Augusto N. Wiese, 1982.

Moffitt, John Francis. "Francisco Pacheco and Jerome Nadal: New Light on the Flemish Sources of the Spanish 'Picture-Within-the-Picture'.” The Art Bulletin, 72 (1990): 631-38.

Mongne, Pascal. "La Messe de saint Grégoire du musée des Jacobins d’Auch: Une mosaïque de plumes mexicaine du XVIe siècle." La Revue du Louvre: La revue des musées de France, 5/6 (1994): 38-47.

Mujica Pinilla, Ramón. "Hell in the Andes: The Last Judgment in the Art of Viceregal Peru." In Contested Visions in the Spanish Colonial World. Exhibition catalogue, ed. Ilona Katzew, Los Angeles, Los Angeles County Museum of Art, 6 November 2011-29 January 2012 and Mexico City, Museo Nacional de Historia, 6 July-7 October 2012. New Haven: Yale University Press, 2011.

Nadal, Jerome. Epistolae P. Hieronymi Nadal Societatis Jesu ab anno 1546 ad 1577. Vol. 4. Madrid: Augustino Avrial, 1905.

- Annotations and Meditations on the Gospels, transl. and ed. Frederick A. Homann, with an introduction by Walter S. Melion. Vols. 1-4. Philadelphia: Saint Joseph's University Press, resp. 2003, 2007, 2005 and 2014.

Navarette Prieto, Benito. La pintura andaluza del siglo XVII y sus fuentes grabadas. Madrid: Fundación de Apoyo, 1998.

Nicolau, Miguel. Jerónimo Nadal, S.I. (1507-1580): Sus obras y doctrinas espirituales. Madrid: Instituto Francisco Suárez, 1949.

Pacheco, Francisco. Arte de la pintura, ed. Bonaventura Bassegoda i Hugas. Madrid: ADD, 2001. Pérez, Gavilán, and Ana Isabel. The 'Via Crucis' in Eighteenth-Century New Spain: Innovative Practices in the Sanctuary of Jesus of Nazareth at Atotonilco, Guanajuato. Ph.D. dissertation, Binghampton University, State University of New York, 2010.

Person, Yves. "Les Kissi et leurs statuettes de pierre dans le cadre de l'histoire ouest-africaine." Bulletin de l'Institut français d'Afrique Noire XXIII, sér. B: Sciences humaines, (1961): 1-59.

Pierce, Donna, Rogelio Ruiz Gomar, and Clara Bargellini. Painting a New World: Mexican Art and Life, 1521-1821. Exhibition catalogue, Denver, Denver Art Museum, 3 April-25 July 2004. Austin, TX: University of Texas Press, 2004. 
Pirri, Pietro. "Intagliatori Gesuiti italiani dei secoli XVI e XVII.” Archivum Historicum Societatis Iesu, 21 (1952): 35-39.

Ponińska, Katarzyna. “Wpływ rycin z dzieła 'Evangelicae Historiae Imagines’ Hieronymusa Natalisa na przedstawienia plastyczne w Kalwarii Zebrzydowskiej.” In Inspiracje grafika europejska $w$ sztuce polskiej: Czasy nowożytne, eds. Krystyna Moisan-Jabłońska and Katarzyna Ponińska, 101-15. Warsaw: Wydawnictwo Uniwersytetu Kardynała Stefana Wyszyńskiego, 2010.

Porras, Stephanie. “Going Viral? Maerten de Vos's 'St Michael the Archangel'.” Netherlands Yearbook for History of Art/Nederlands Kunsthistorisch Jaarboek, 66 (2016): 54-79.

_. " 'St Michael the Archangel': Spiritual, Visual and Material Translations from Antwerp to Lima.” In Prints in Translation, 1450-1750: Image, Materiality, Space, eds. Suzanne Karr Schmidt and Edward H. Wouk, 183-202. Abingdon: Routledge, 2017.

Raby, Julian. "Mehmed II Fatih and the Fatih Album." Islamic Art, 1 (1981): 42-49.

Randall, Richard H. Jr. et al. Masterpieces of Ivory from the Walters Art Gallery. London: Sotheby's Publications, 1985.

Reed, Marcia, and Paola Demattè. China on Paper: European and Chinese Works from the Late Sixteenth to the Early Nineteenth Century. Malibu: Getty Research Institute Publications, 2007.

Santiago, José de. Atotonilco: Alfaro y Pocasangre. Guanajato: Ediciones La Rana, 2004.

Schoch, Rainer, Matthias Mende, and Anna Scherbaum, eds. Albrecht Dürer: Das druckgraphische Werk. Vol. I: Kupferstiche, Eisenradierungen und Kaltnadelblätter. Munich: Prestel, 2001.

Schreiber, Wilhelm Ludwig. Handbuch der Holz und Metallschnitte des XV. Jahrhunderts. Vol. 3. Leipzig: Hierseman, 1927.

Shestack, Alan. Fifteenth Century Engravings of Northern Europe from the National Gallery of Art, Washington, D.C. Exhibition catalogue, Washington, NGA, 3 December 1967-7 January 1968. Washington: NGA, 1967.

Standaert, Nicolas. An Illustrated 'Life of Christ' Presented to the Chinese Emperor: The History of Jincheng Shuxiang (1640). Sankt Augustin-Nettetal: Steyler Verlag, 2007.

Stronge, Susan. Painting for the Mughal Emperor: The Art of the Book 1560-1660. London: V\&A Publications, 2002.

Sun, Yuming. "Cultural Translatability and the Presentation of Christ as Portrayed in Visual Images from Ricci to Aleni.” In The Chinese Face of Jesus Christ, ed. Roman Malek. Sankt Augustin-Nettetal: Steyler Verlag, 2003.

Vassallo e Silva, Nuno. "Export Art from Portuguese India.” In Levenson, ed., Encompassing the Globe, Vol. 3, 208-9 (republished in Levenson and Henriques, Encompassing the Globe).

_. " 'Engenho e primor': A arte do marfim no Ceilão.” In Marfins no Império Português, eds. Gauvin Alexander Bailey, Jean Michel Massing, and Nuno Vassallo e Silva, 90-96. Lisbon: Scribe, 2013.

Witcombe, Christopher L. C. E. Copyright in the Renaissance: Prints and the 'Privilegio' in Sixteenth-Century Venice and Rome. Leiden: Brill, 2004.

Wolf, Gerhard. "Ananas und Tiara: Zur Gregormesse von Auch.” In Was aus dem Bild fällt: Figuren des Details in Kunst und Literatur, eds. Edith Futscher et al., 333-47. Munich: Wilhelm Fink Verlag, 2007. 


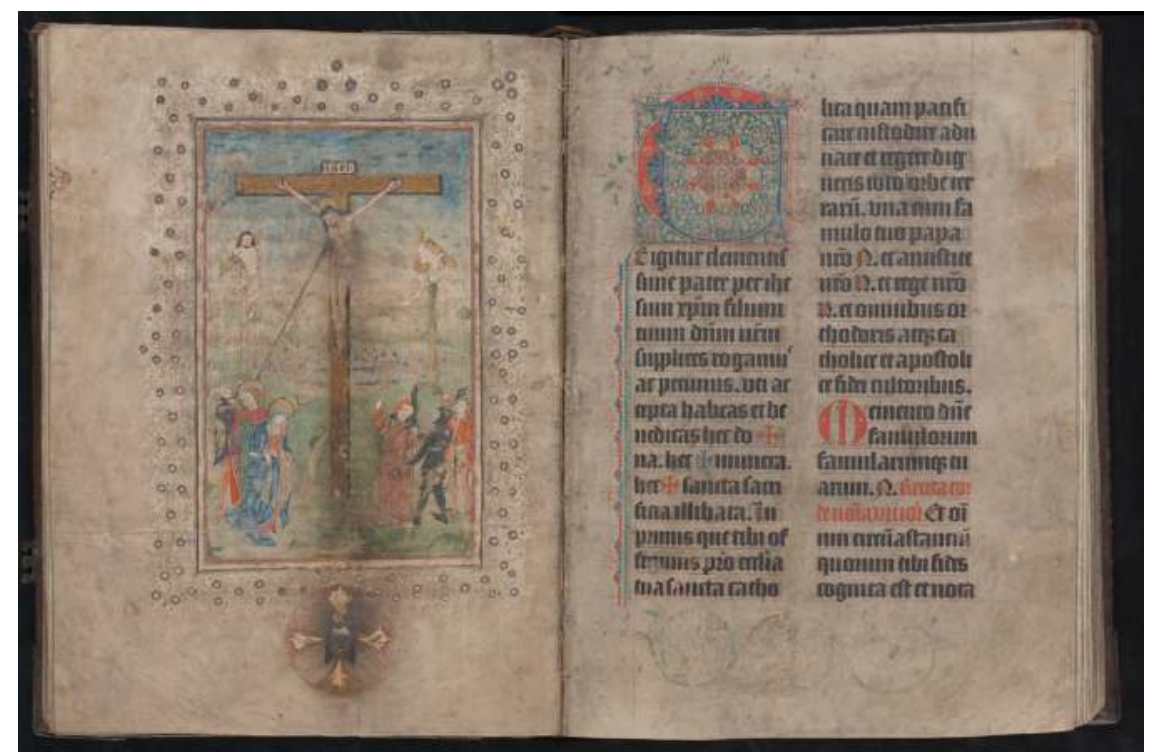

Plate 1 Crucifixion and T(e igitur) prayer in the Missal from St. Servatius in Maastricht (use of Liège), miniature on parchment. The Hague, Koninklijke Bibliotheek I Nationale Bibliotheek van Nederland, ms 78 D 44, fol. 133v-134r.

Photo: The Hague, Koninklijke Bibliotheek.

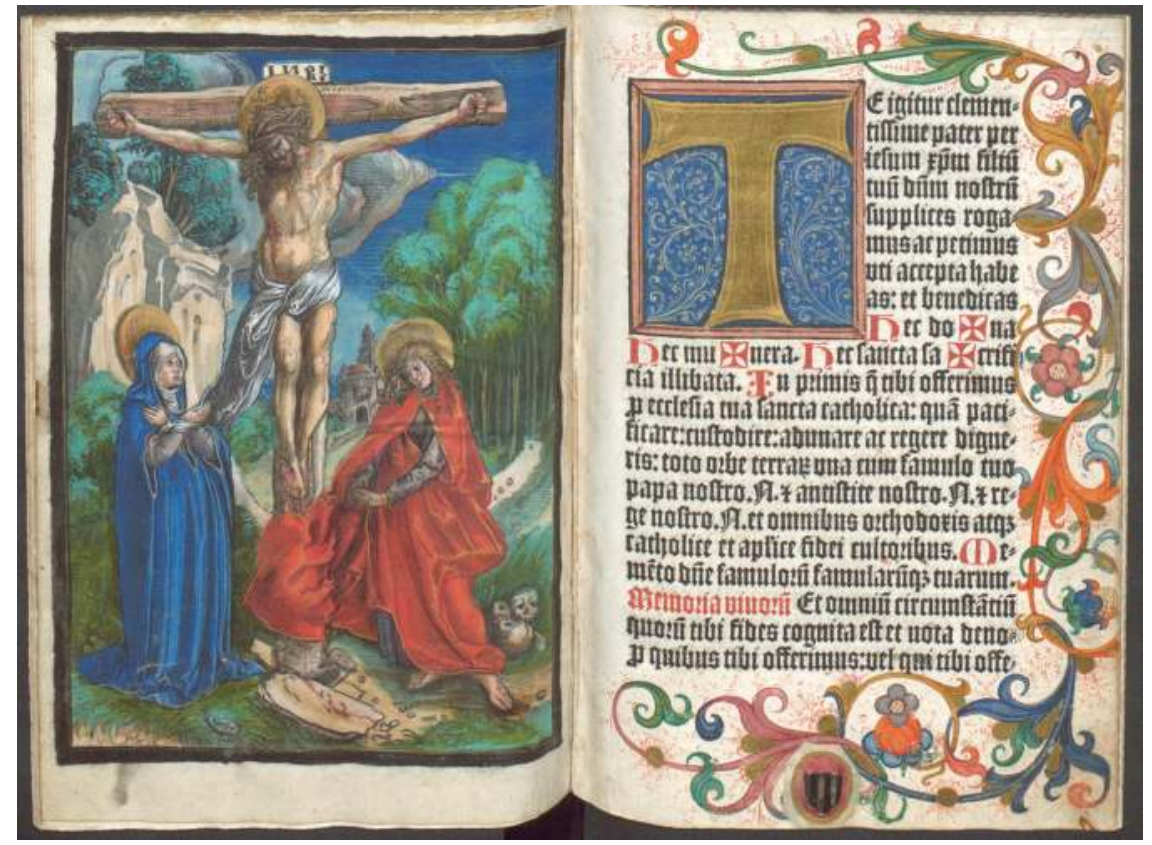

Plate 2 Lucas Cranach the Elder, Crucifixion [H 28], coloured woodcut on parchment in Missale Cracoviense. Cracow, Biblioteka Jagiellońska, Inc. 2850, fol. 180v.

Photo: Cracow, Biblioteka Jagiellońska. 


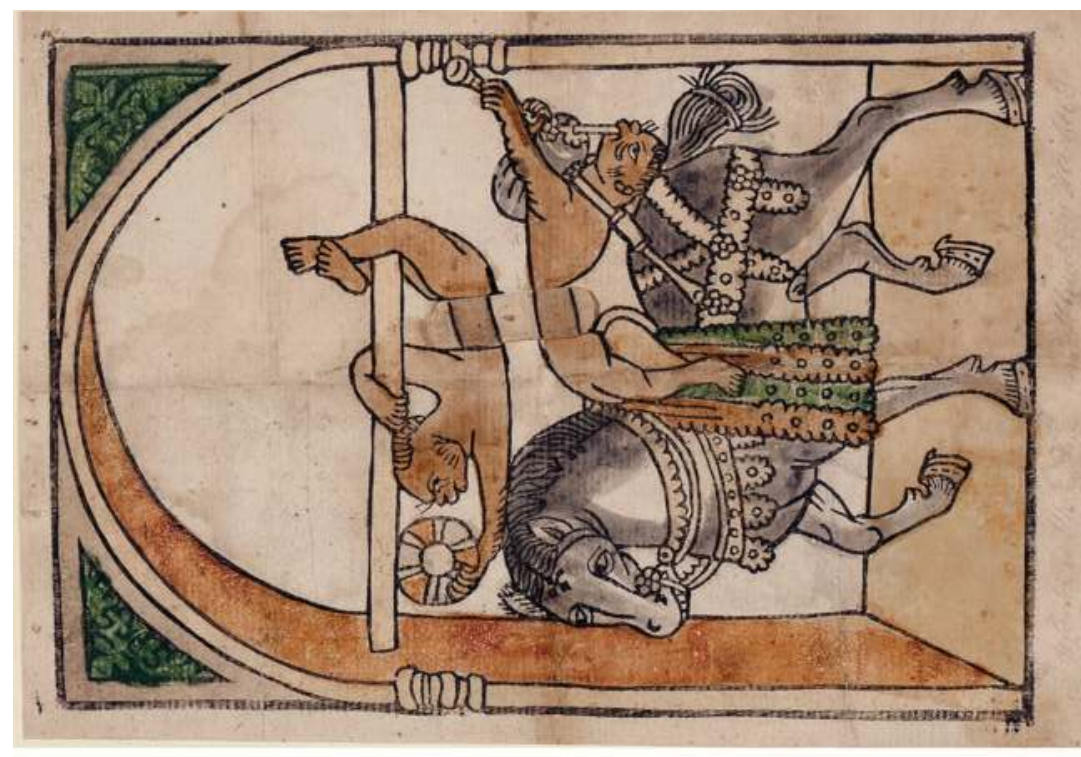

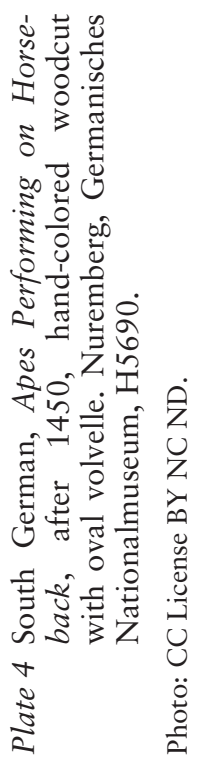

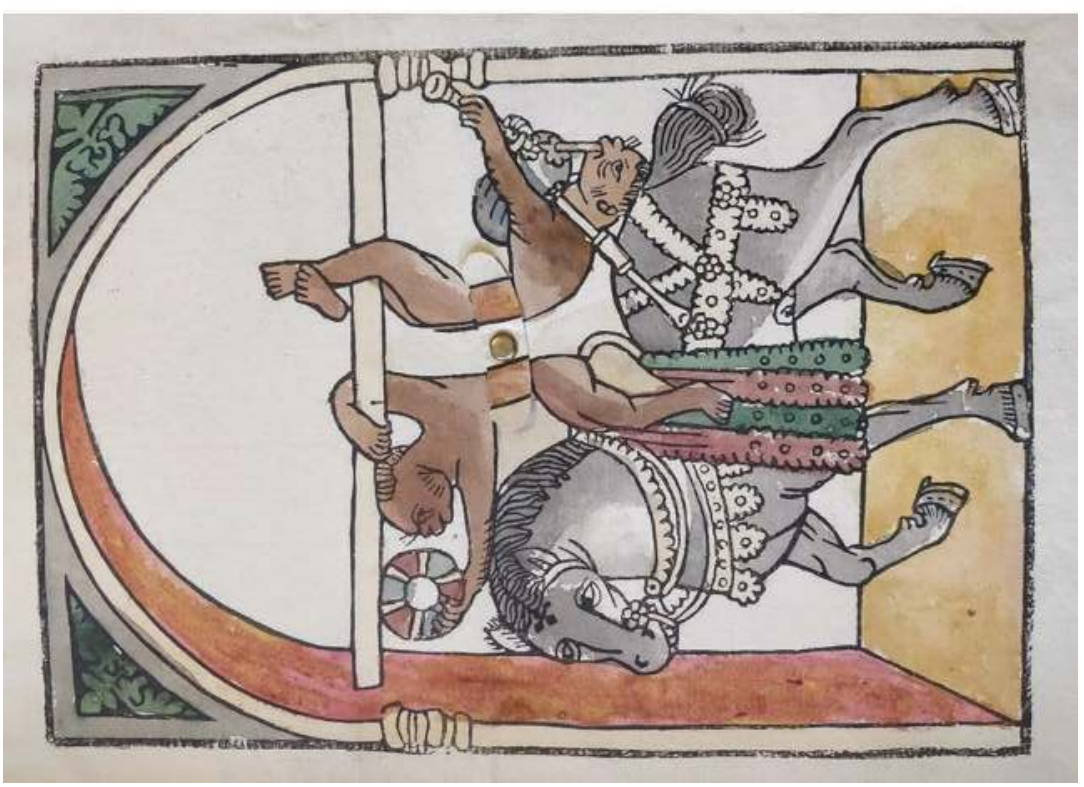

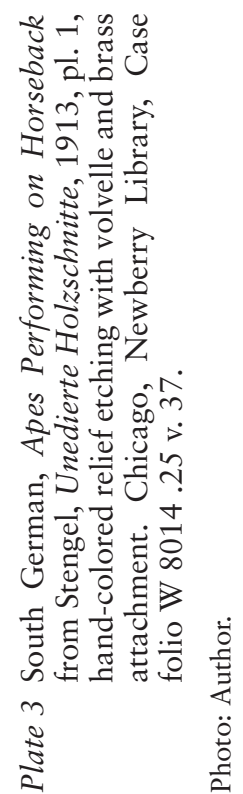




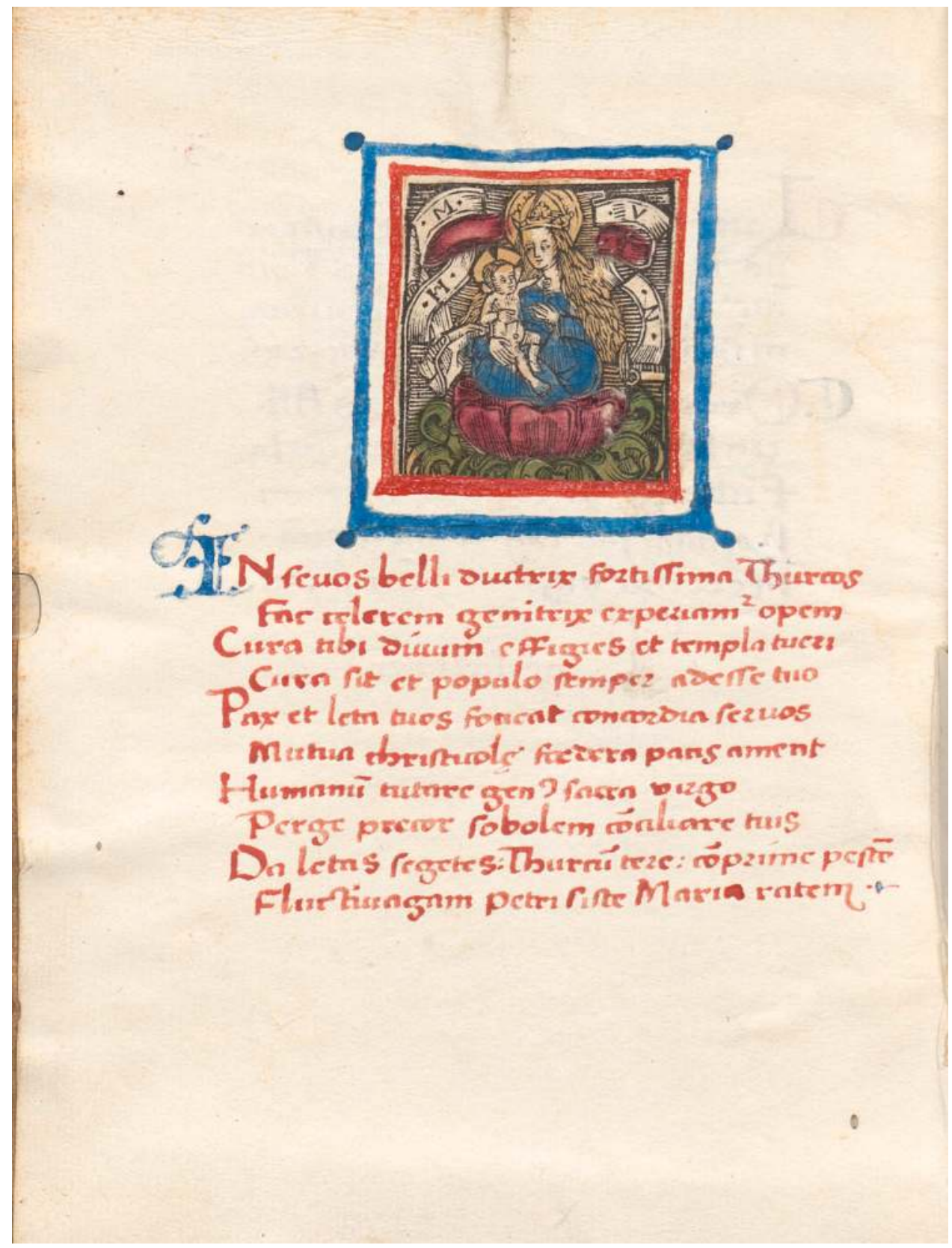

Plate 5 German, Madonna and Child, fragment from The Jesse Tree, Almanac for Austria in the Year 1496, c. 1495-96, hand-coloured woodcut. Munich, Bayerische Staatsbibliothek, Clm 464, fol. 3v.

Photo: Munich, Bayerische Staatsbibliothek. 


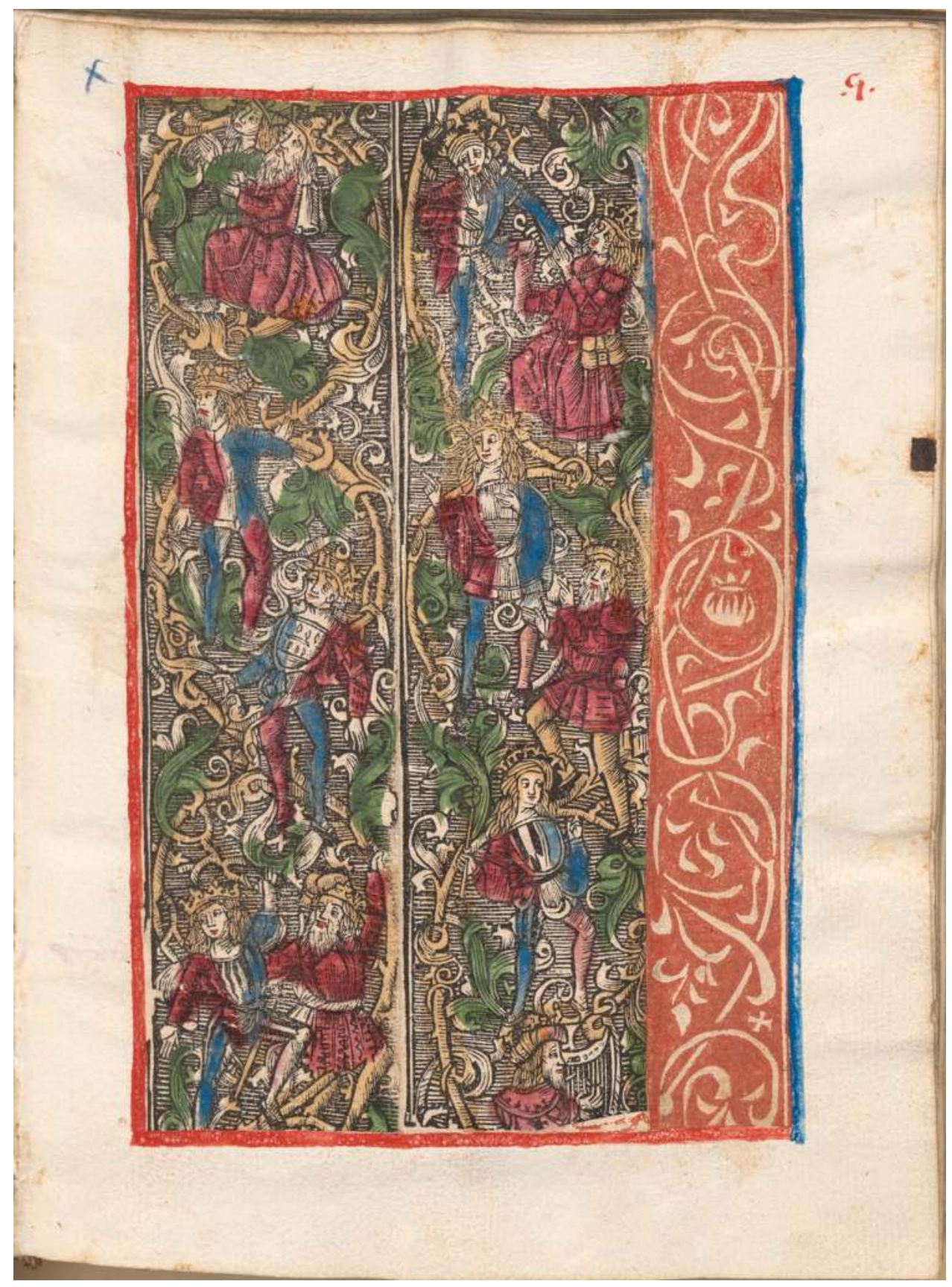

Plate 6 Hartmann Schedel, decorative collage, 1506, hand-coloured woodcut fragments and fragment of woodcut printed in red ink, with red and blue ink border. Munich, Bayerische Staatsbibliothek, Clm 464, fol. 5r.

Photo: Munich, Bayerische Staatsbibliothek. 


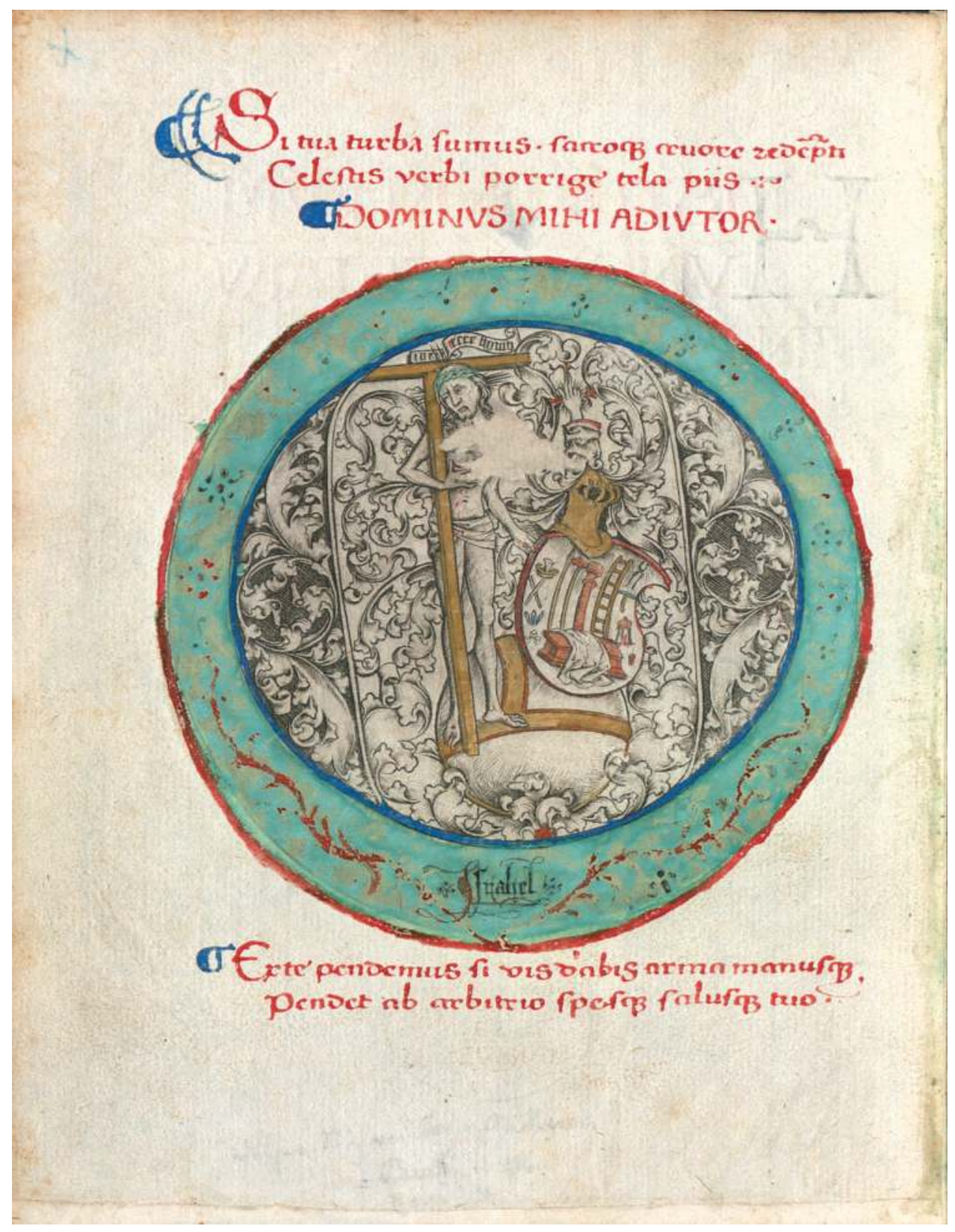

Plate 7 Israhel van Meckenem, Man of Sorrows in the Letter O, c. 1475-90, hand-colored engraving. Munich, Bayerische Staatsbibliothek, Clm 386, fol. 1v.

Photo: Munich, Bayerische Staatsbibliothek. 


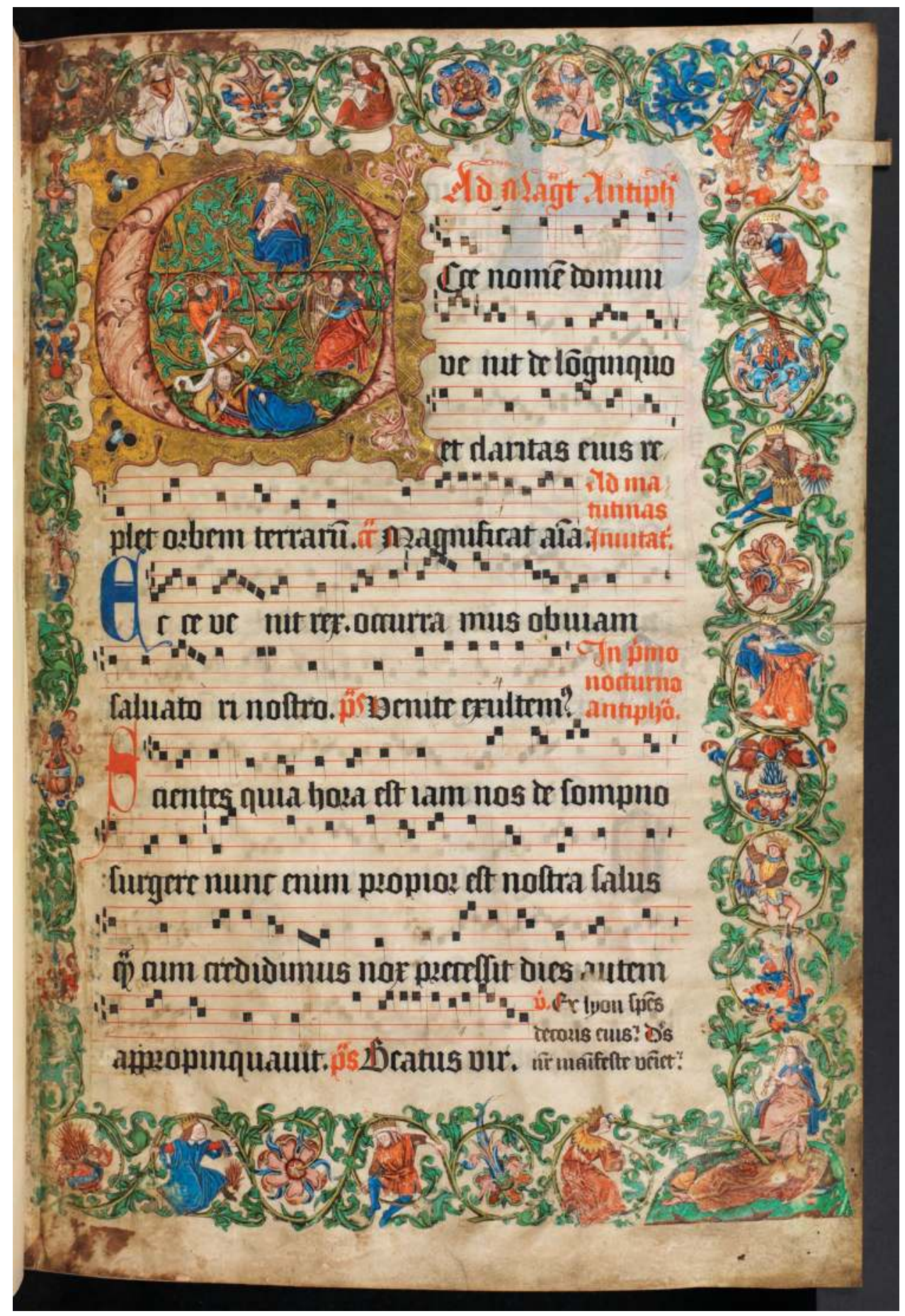

Plate 8 German, sixteenth century, Antiphonale Officii, Proprium de Tempore, ink, tempera, and gold on parchment. Düsseldorf, Universitäts- und Landesbibliothek, MS-D-17, fol. $1 \mathrm{r}$.

Photo: Düsseldorf, Universitäts- und Landesbibliothek. 


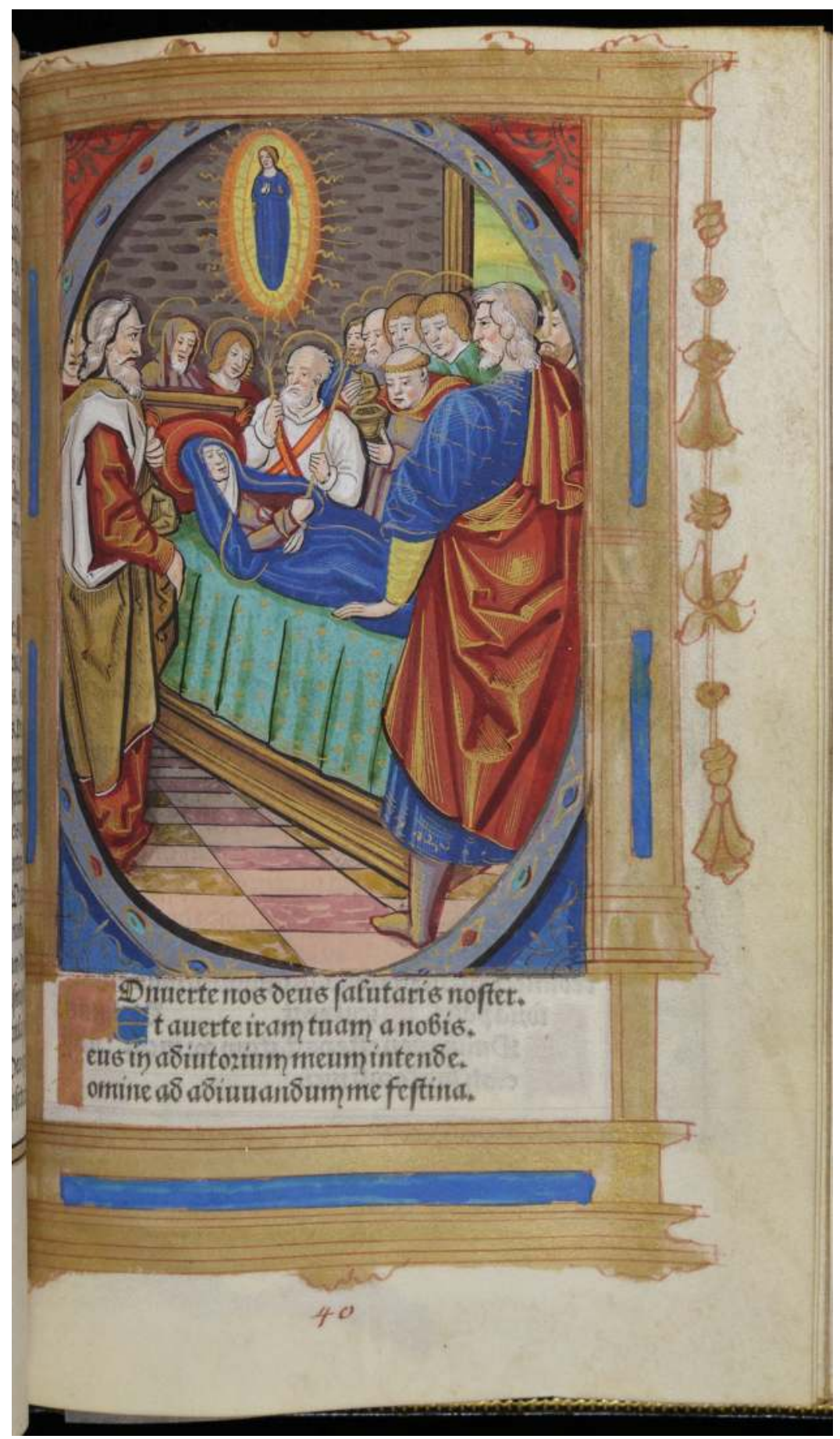

Plate 9 Death of the Virgin, metalcut in Heures a l'usaige de Romme (Paris: Germain Hardouyn, 1524). Chicago, Newberry Library, Wing ZP 539. H224 1524.

Photo: Courtesy of the Newberry Library. 


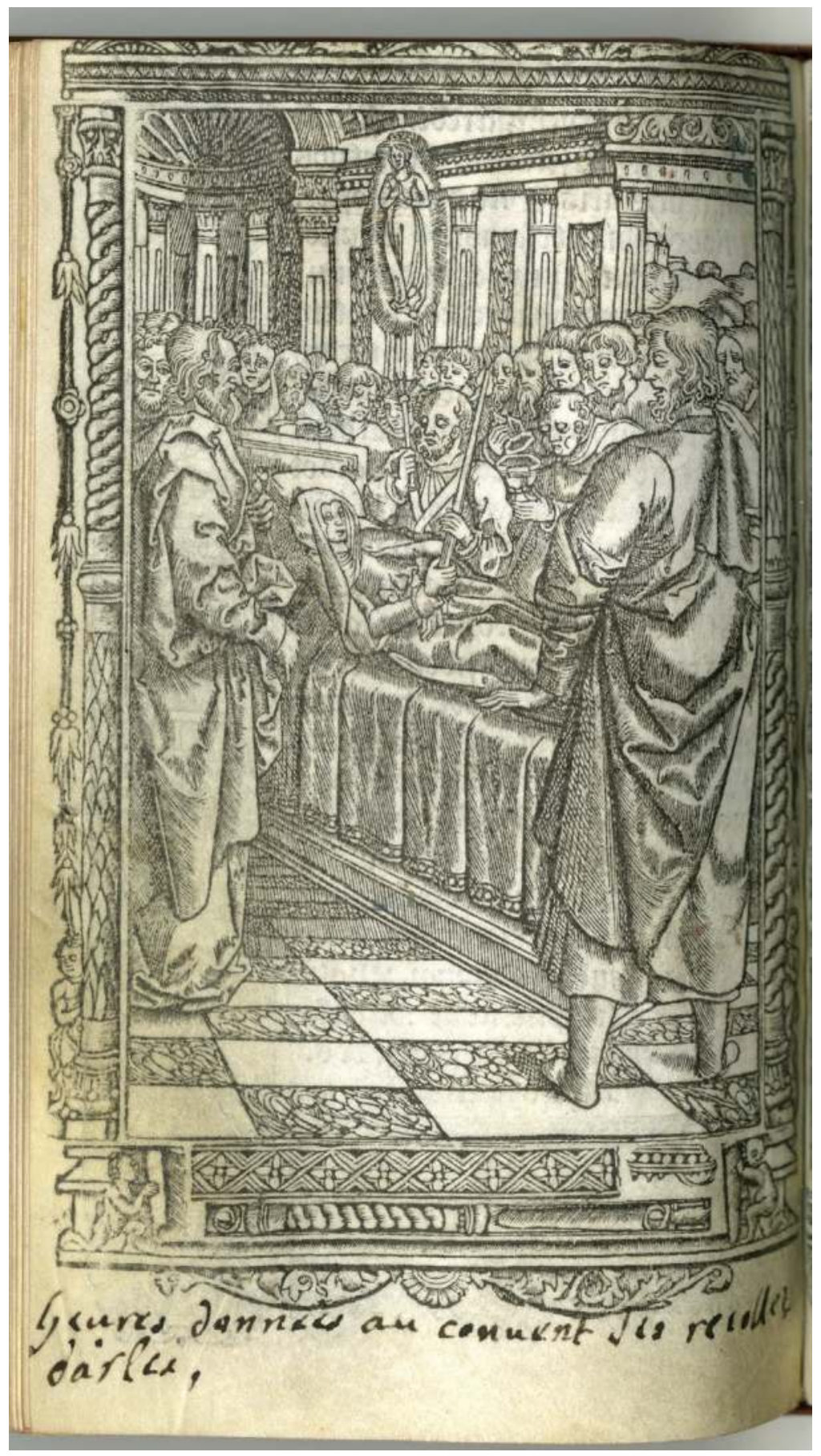

Plate 10 Death of the Virgin, metalcut in Heures a l'usaige de Romme (Paris: Gillet Hardouyn, c. 1515). Bridwell Library Special Collections, Perkins School of Theology, Southern Methodist University, BRA0841.

Photo: Courtesy of the Newberry Library. 


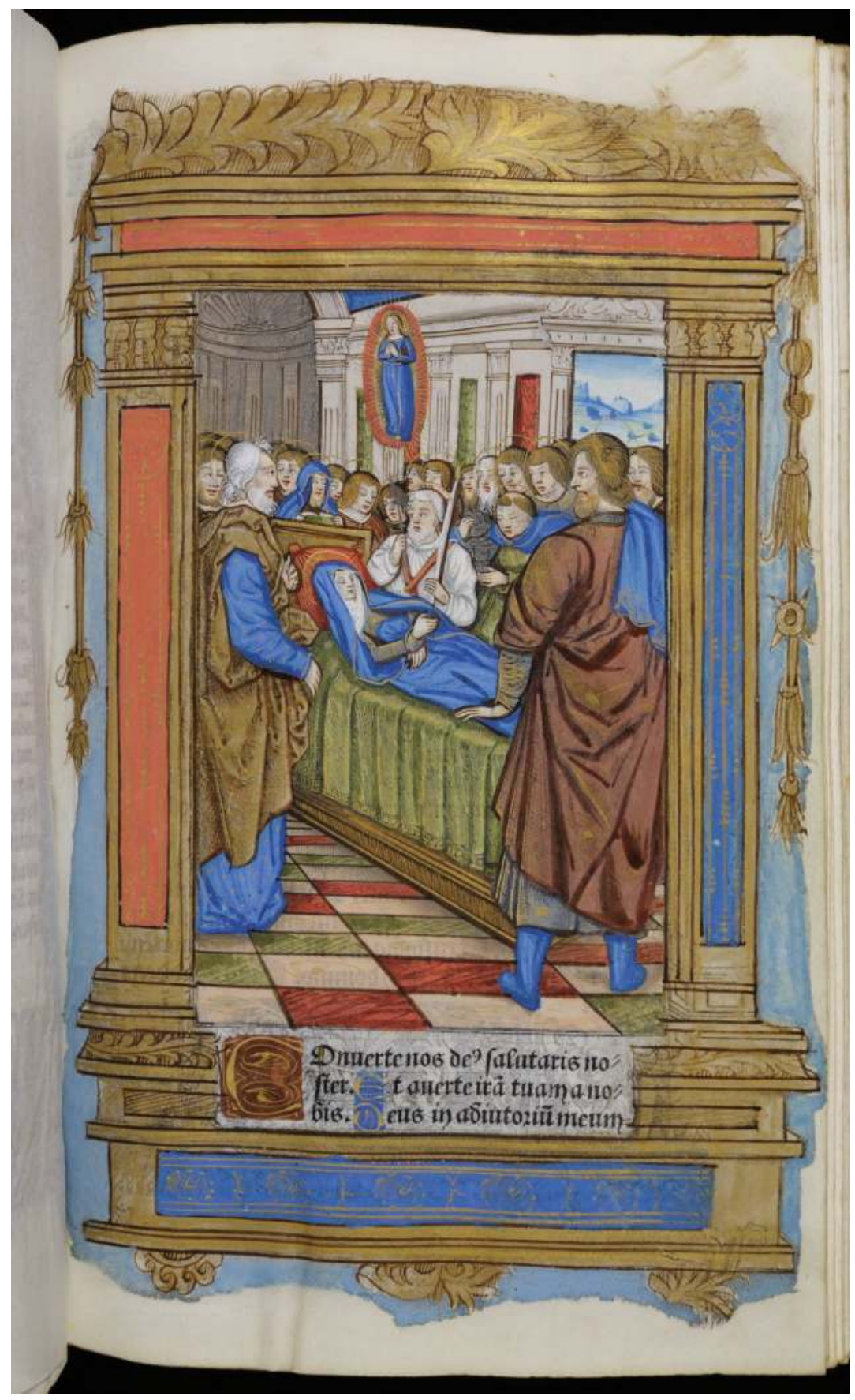

Plate 11 Death of the Virgin, metalcut in Heures a l'usaige de Romme (Paris: Guillaume Anabat, Gilles Hardouyn, Germain Hardouyn, 1507). Chicago, Newberry Library, VAULT Wing ZP 539. A54.

Photo: Courtesy of the Newberry Library. 


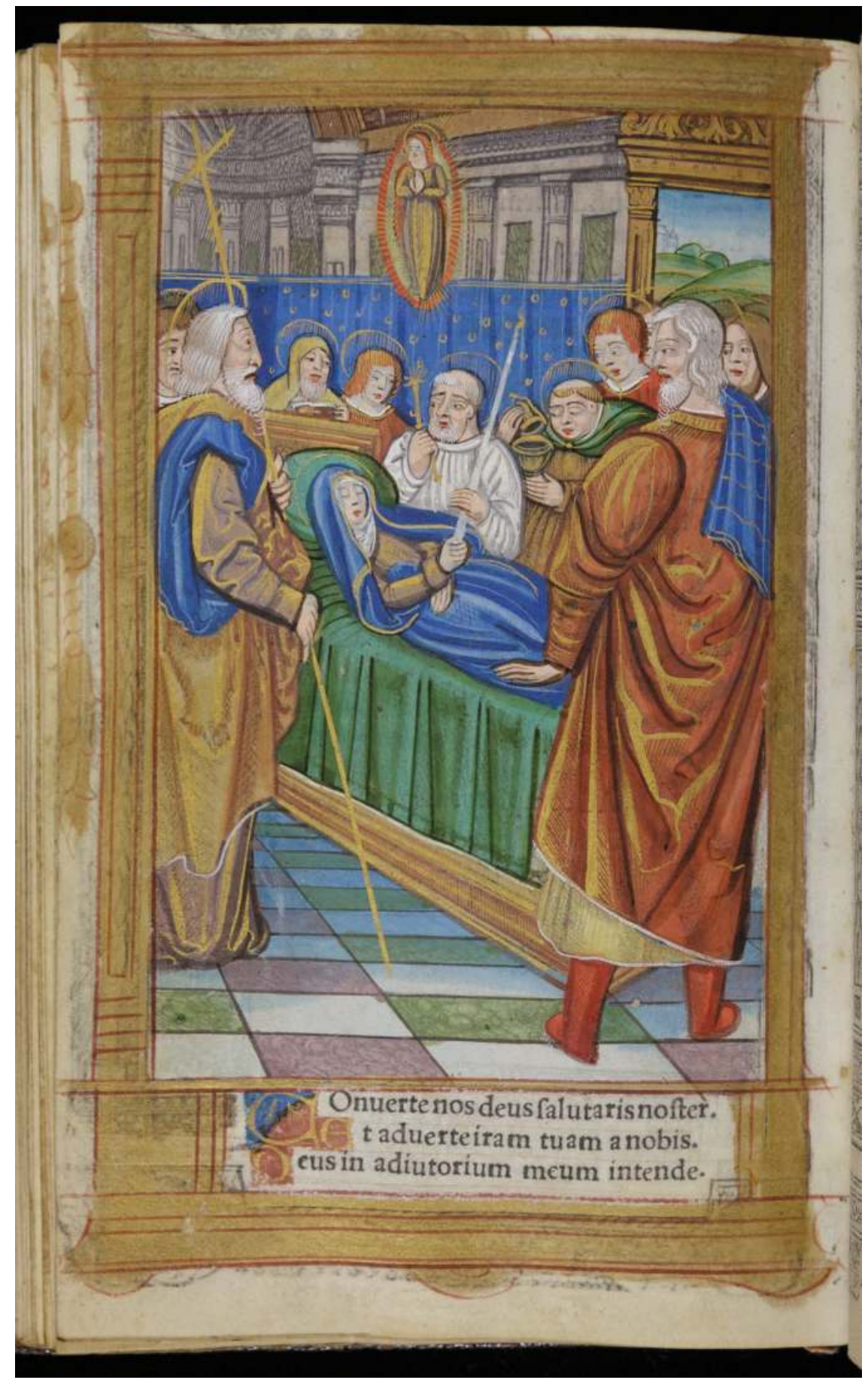

Plate 12 Death of the Virgin, metalcut in Hore divine virginis Marie secundum usum Romanum (Paris: Gilles Hardouyn [printer], Germain Hardouyn [publisher], c. 1512). Chicago, Newberry Library, Wing ZP 539. H2212.

Photo: Courtesy of the Newberry Library. 


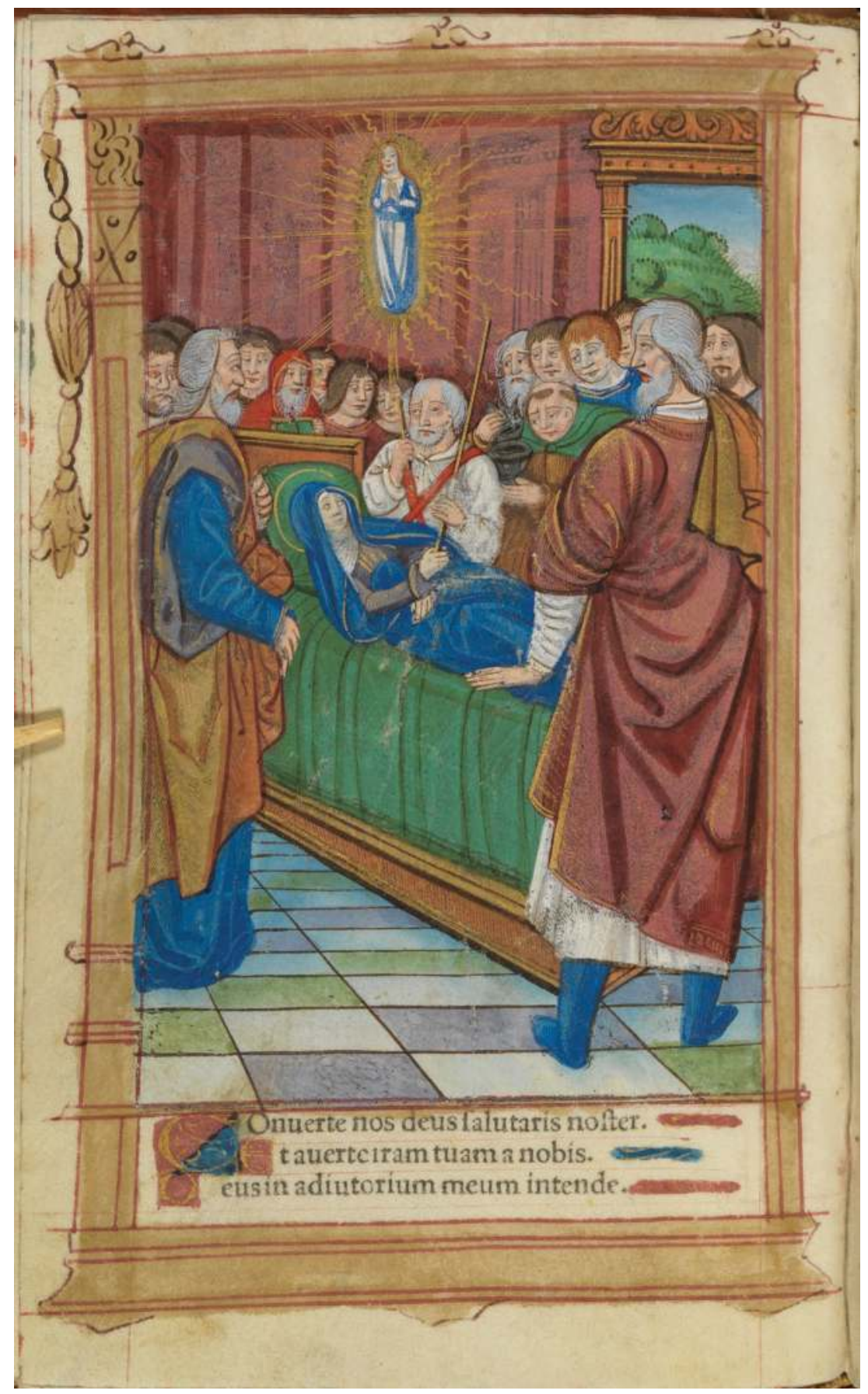

Plate 13 Death of the Virgin, metalcut in Hore Dive Virginis Marie secundum usum Romanum (Paris: Gilles Hardouyn and Germain Hardouyn, 9 August 1514), fol. FIv. Warsaw, Biblioteka Narodowa, SD XVI.O.4101.

Photo: POLONA (public domain). 


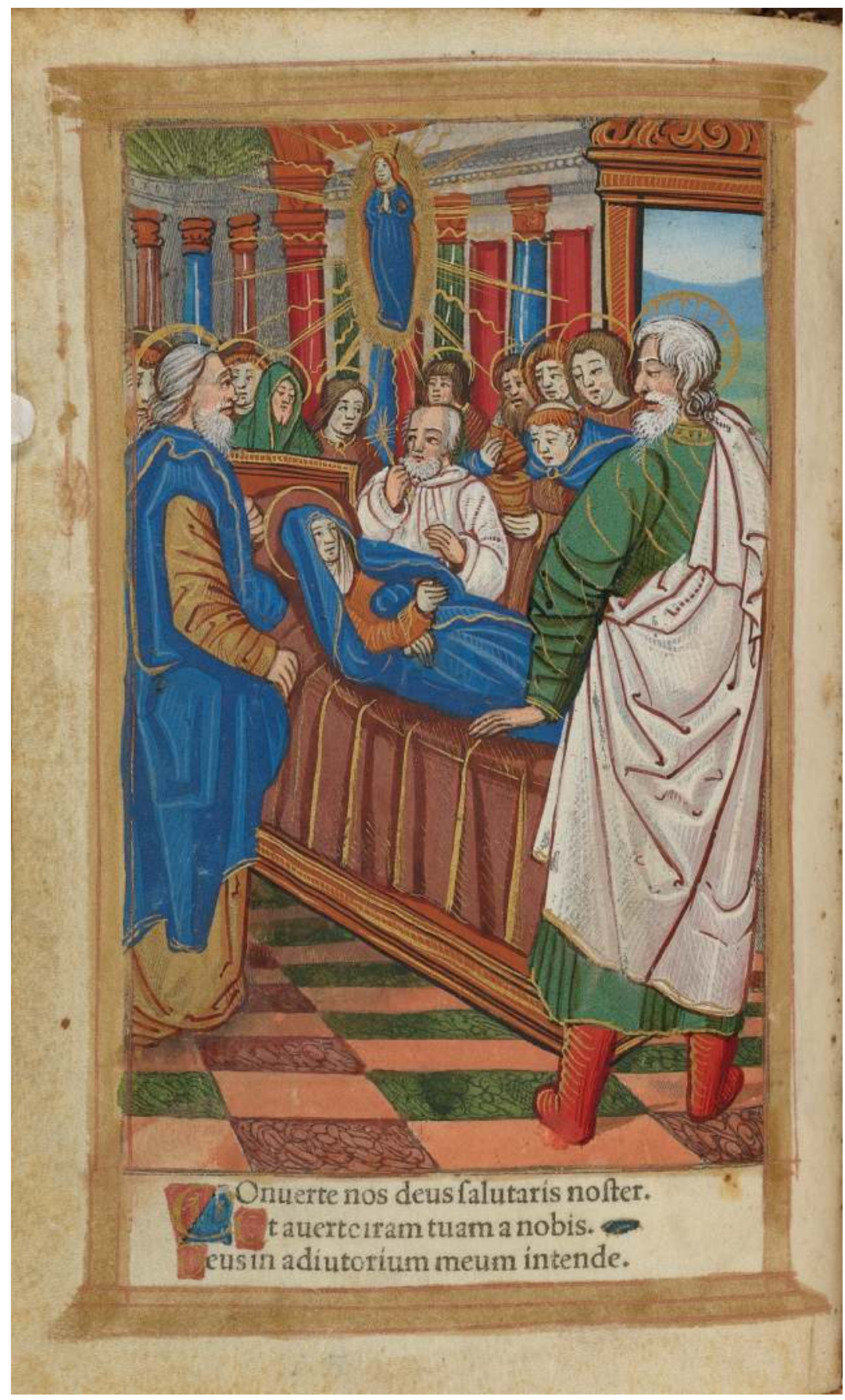

Plate 14 Death of the Virgin, metalcut in Officium beate Marie virginis secundum verum usum Romanum (Paris: Gilles Hardouyn and Germain Hardouyn, 9 August 1514. University of Illinois at Urbana-Champaign, Rare Book and Manuscript Library, IUA02546.

Photo: Courtesy of the University of Illinois at Urbana-Champaign. 


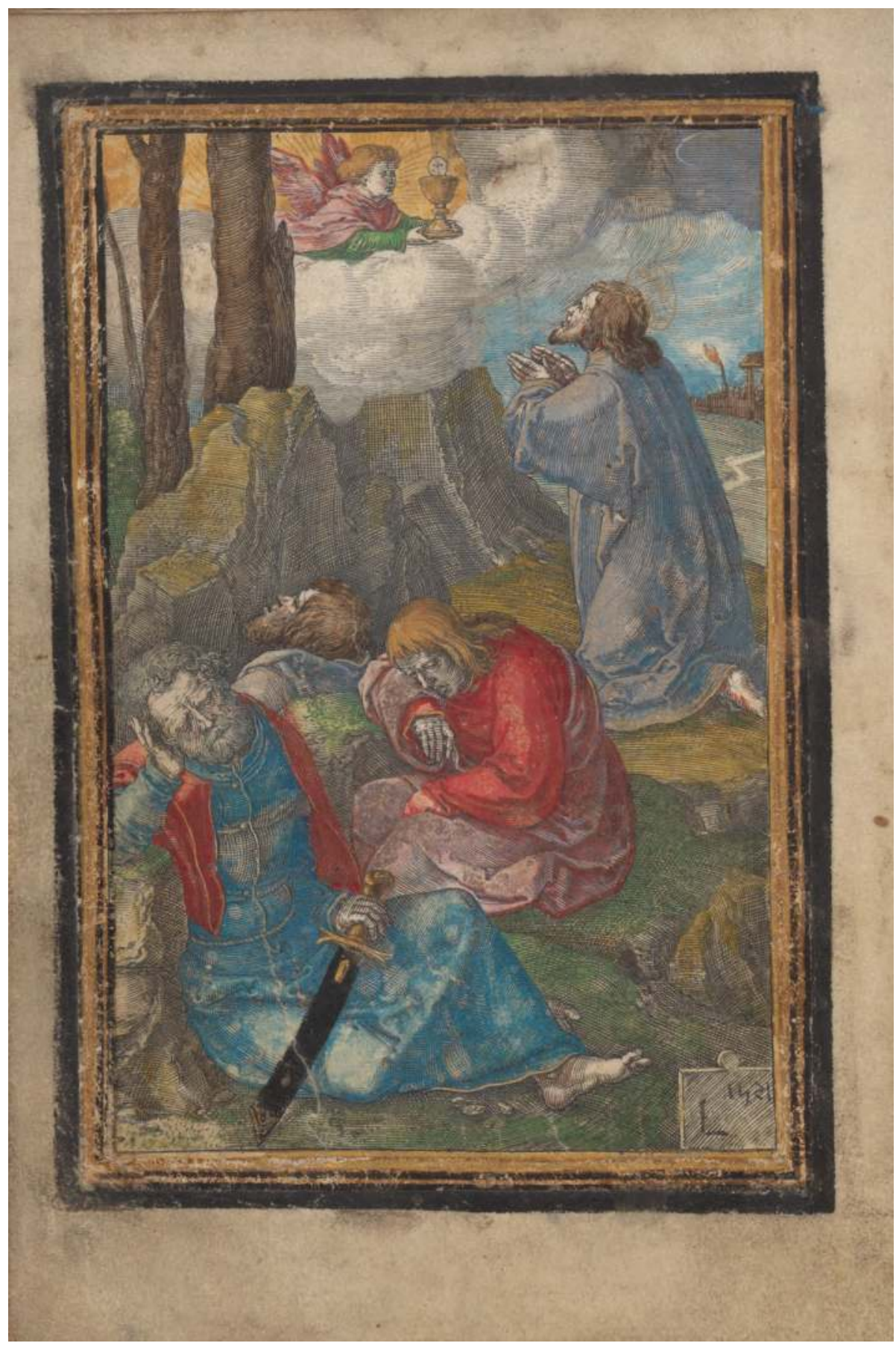

Plate 15 Lucas van Leyden, Agony in the Garden, 1521, engraving, hand-coloured and pasted into prayer book manuscript c. 1530. Amsterdam, Rijksmuseum, RP-P-2011-115-1.

Photo: http://hdl.handle.net/10934/RM0001.COLLECT.504601, CC0 1.0. 


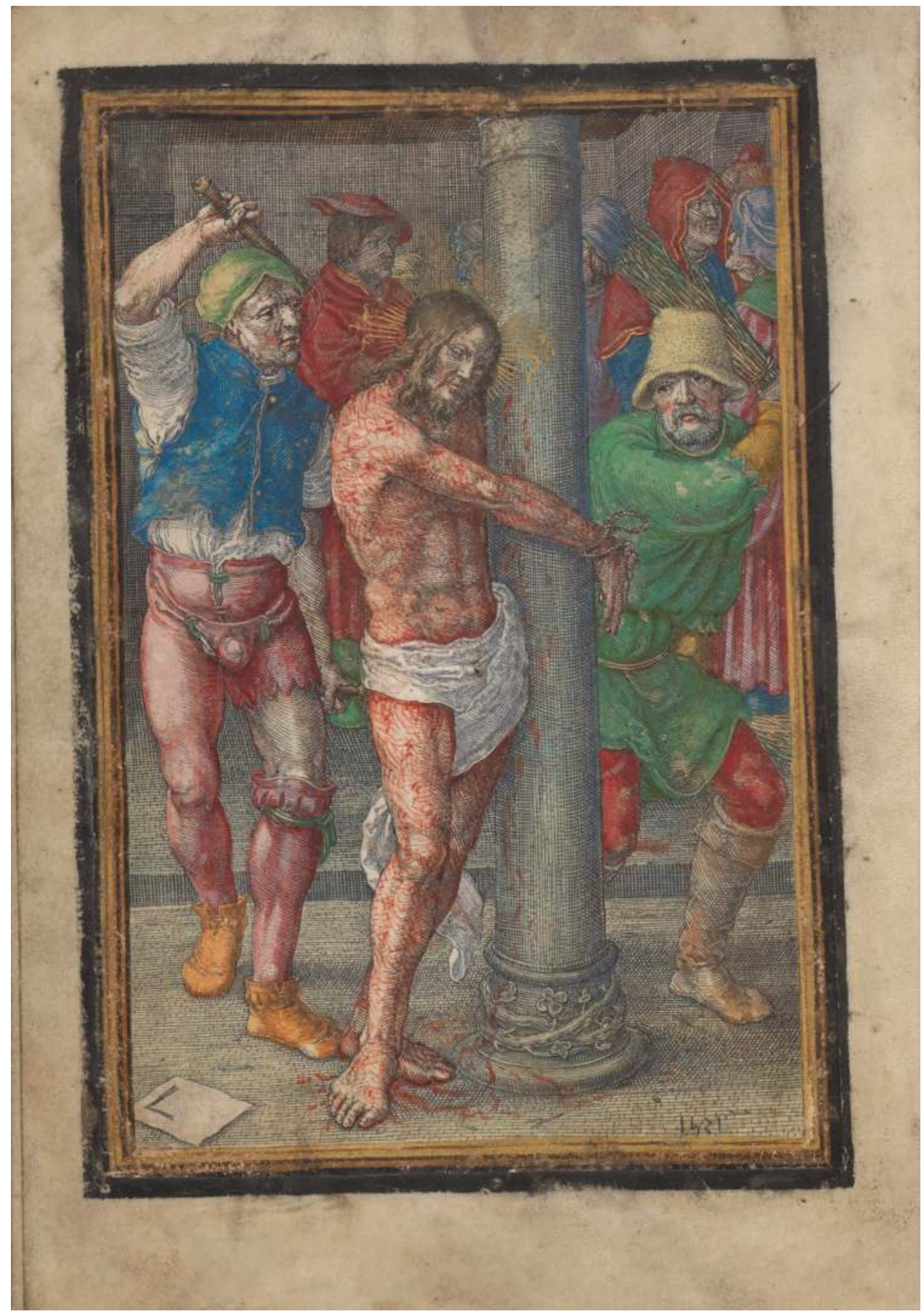

Plate 16 Lucas van Leyden, Flagellation, 1521, engraving, hand-coloured and pasted into prayer book manuscript c. 1530. Amsterdam, Rijksmuseum, RP-P-2011-115-5.

Photo: http://hdl.handle.net/10934/RM0001.COLLECT.505139, CC0 1.0. 


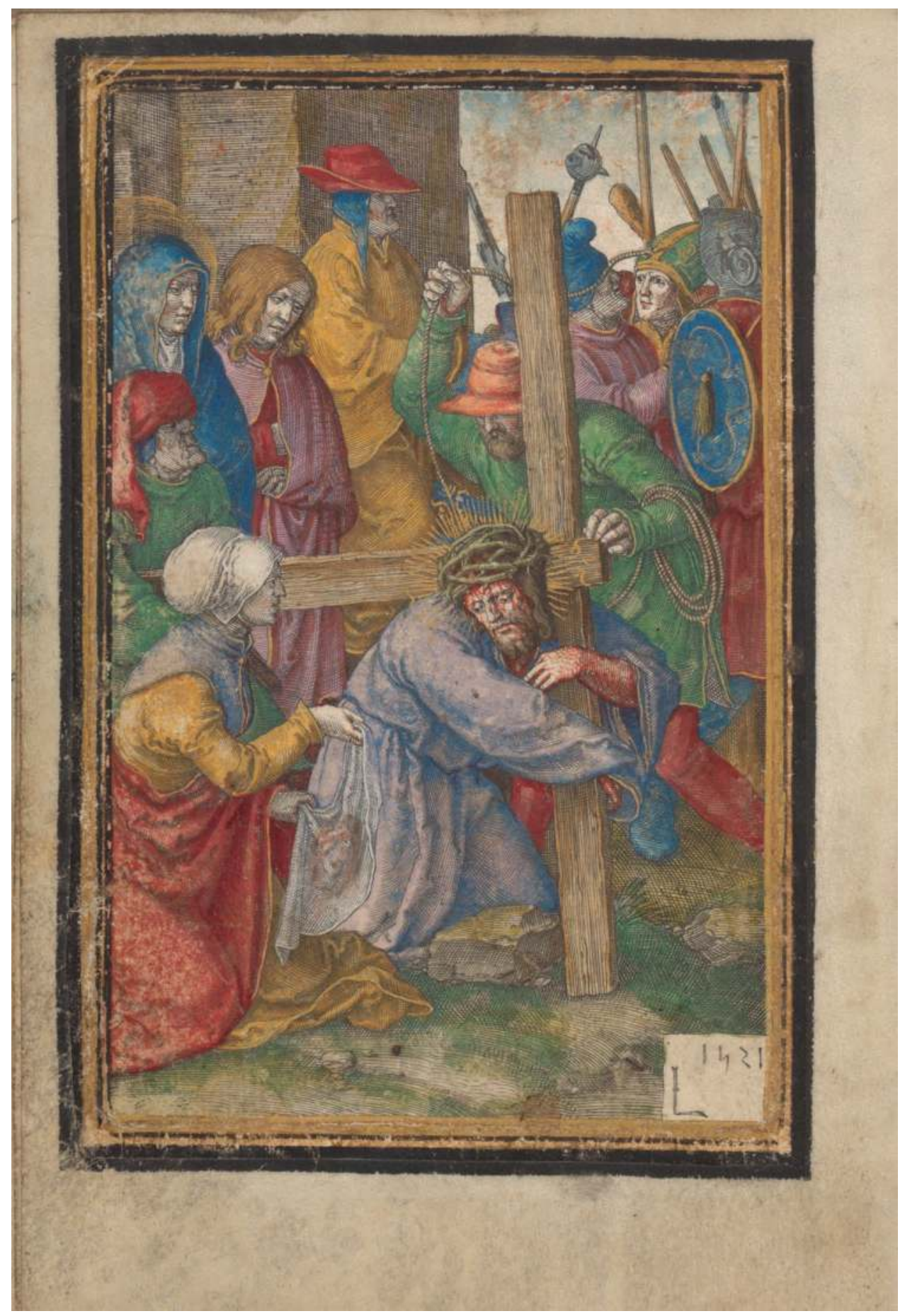

Plate 17 Lucas van Leyden, Carrying the Cross, 1521, engraving, hand-coloured and pasted into prayer book manuscript c. 1530. Amsterdam, Rijksmuseum, RP-P-2011-115-8.

Photo: http://hdl.handle.net/10934/RM0001.COLLECT.505142, CC0 1.0. 


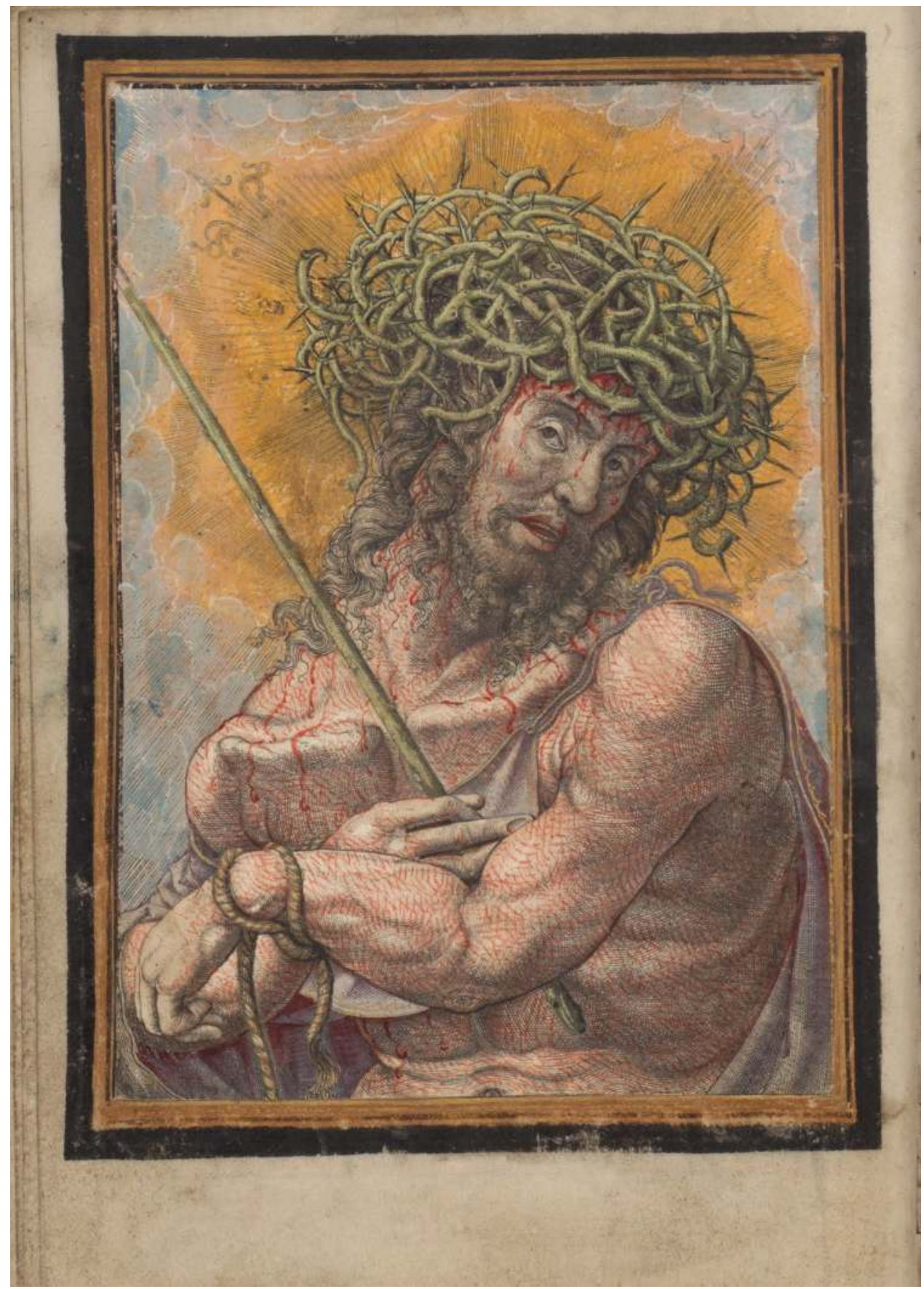

Plate 18 Frans Crabbe, Christ Mocked, c. 1520, engraving, hand-coloured and pasted into prayer book manuscript c. 1530. Amsterdam, Rijksmuseum, RP-P-2011-115-9.

Photo: http://hdl.handle.net/10934/RM0001.COLLECT.505143, CC0 1.0. 


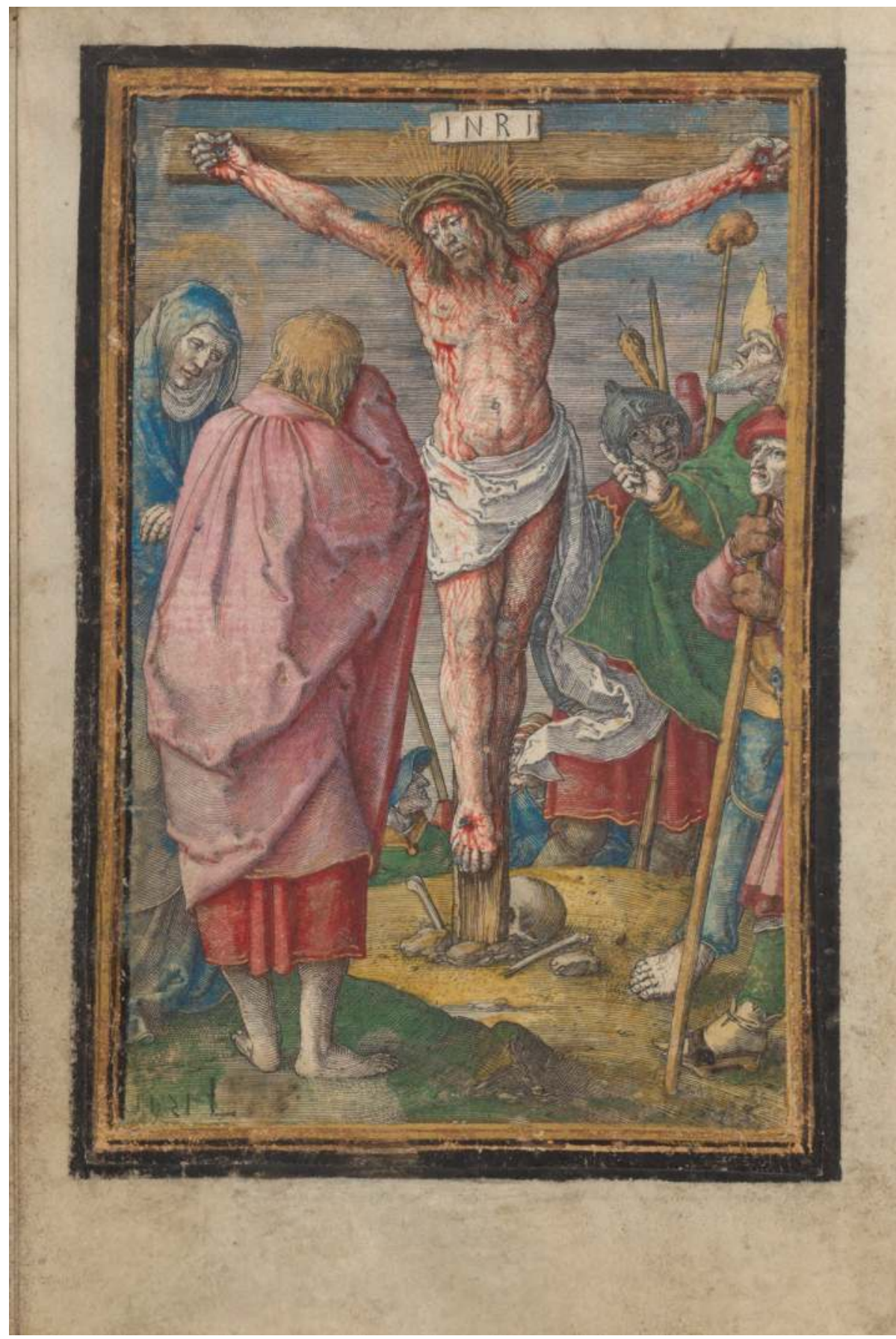

Plate 19 Lucas van Leyden, Crucifixion, 1521, engraving, hand-coloured and pasted into prayer book manuscript c. 1530. Amsterdam, Rijksmuseum, RP-P-2011-115-10.

Photo: http://hdl.handle.net/10934/RM0001.COLLECT.505144, CC0 1.0. 


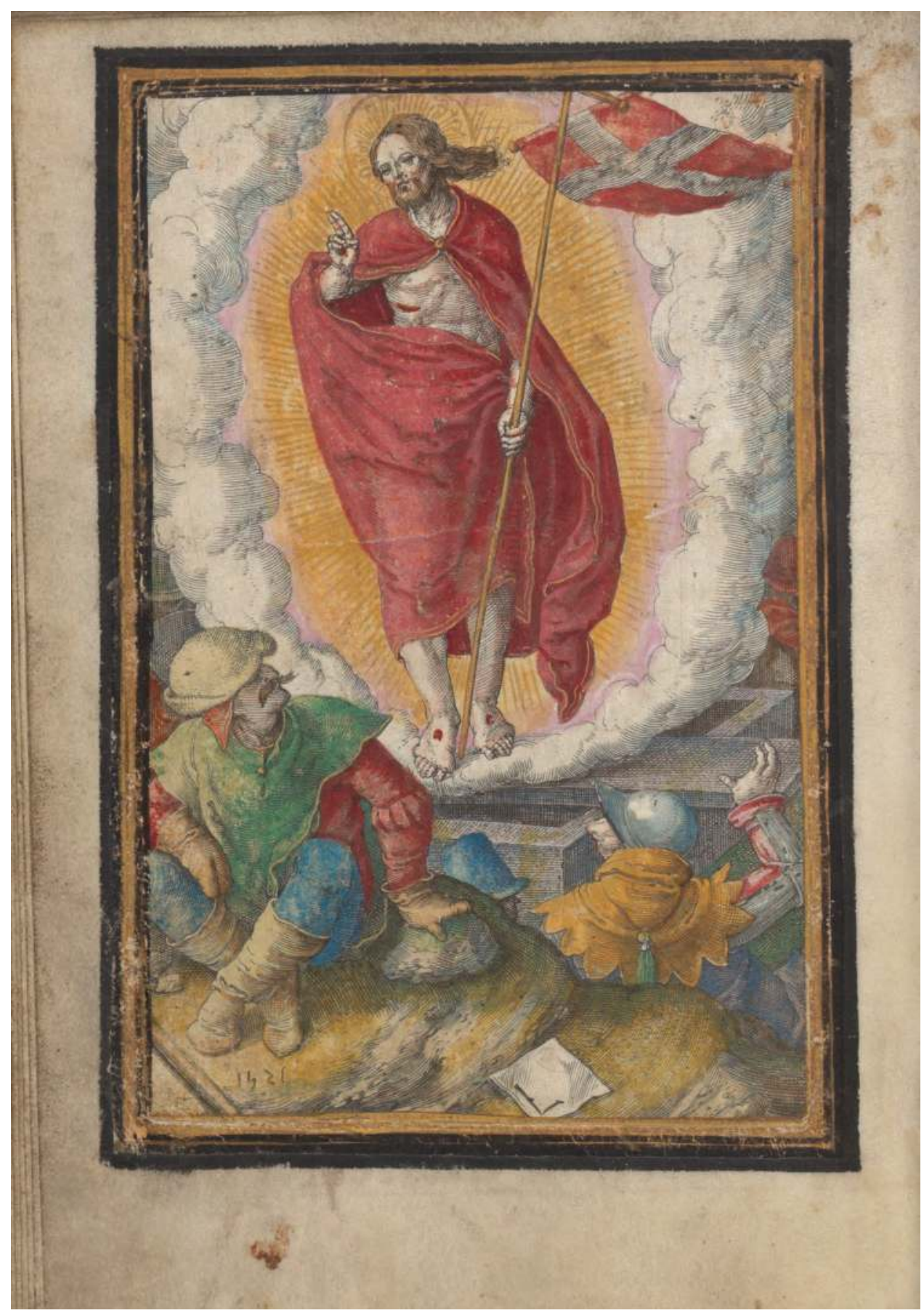

Plate 20 Lucas van Leyden, Resurrection, 1521, engraving, hand-coloured and pasted into prayer book manuscript c. 1530. Amsterdam, Rijksmuseum, RP-P-2011-115-14.

Photo: http://hdl.handle.net/10934/RM0001.COLLECT.505148, CC0 1.0. 


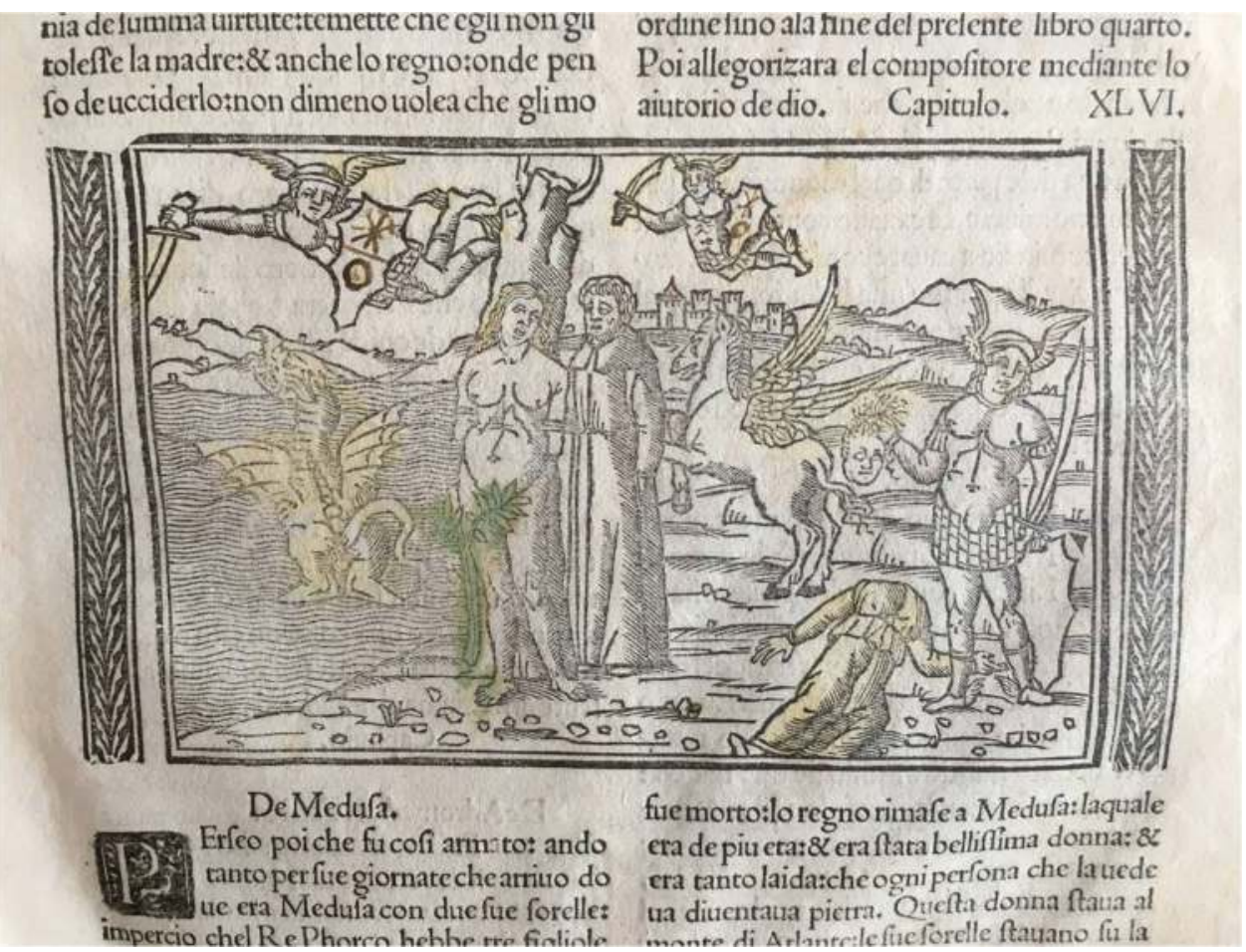

Plate 21 Liberation of Andromeda, 1522, woodcut in Giovanni Bonsignori, Ovidio Metamorphoseos vulgare (Venice: Giorgio Rusconi, 1522), fol. XXIXr. Fermo, Biblioteca Civica Romolo Spezioli, 2CC13/18593.

Photo: Author.

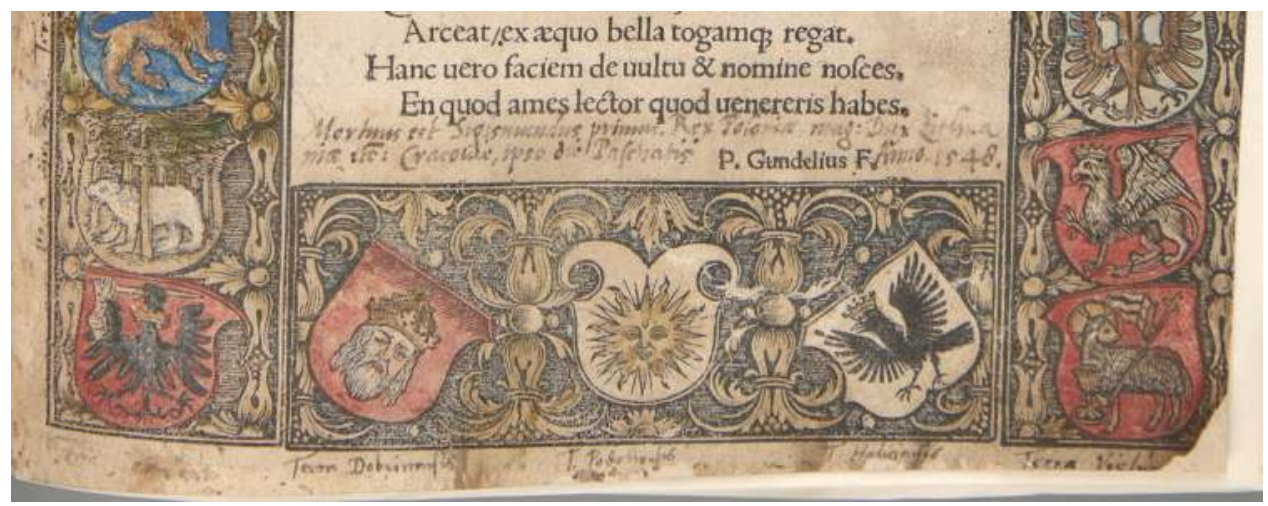

Plate 22 Fragment of the heraldic frame enclosing the likeness of Sigismund I with the handwritten identifications of the coats of arms of the Polish lands in Iodocus Decius, Contenta: De vetustatibus Polonorum liber I. . . (Cracow: Hieronim Wietor, 1521), unnumbered page, hand-coloured woodcut, handwritten notes in ink. Cracow, Muzeum Narodowe w Krakowie, VIII-XVI.33 adl.

Photo: Cracow, Muzeum Narodowe w Krakowie. 


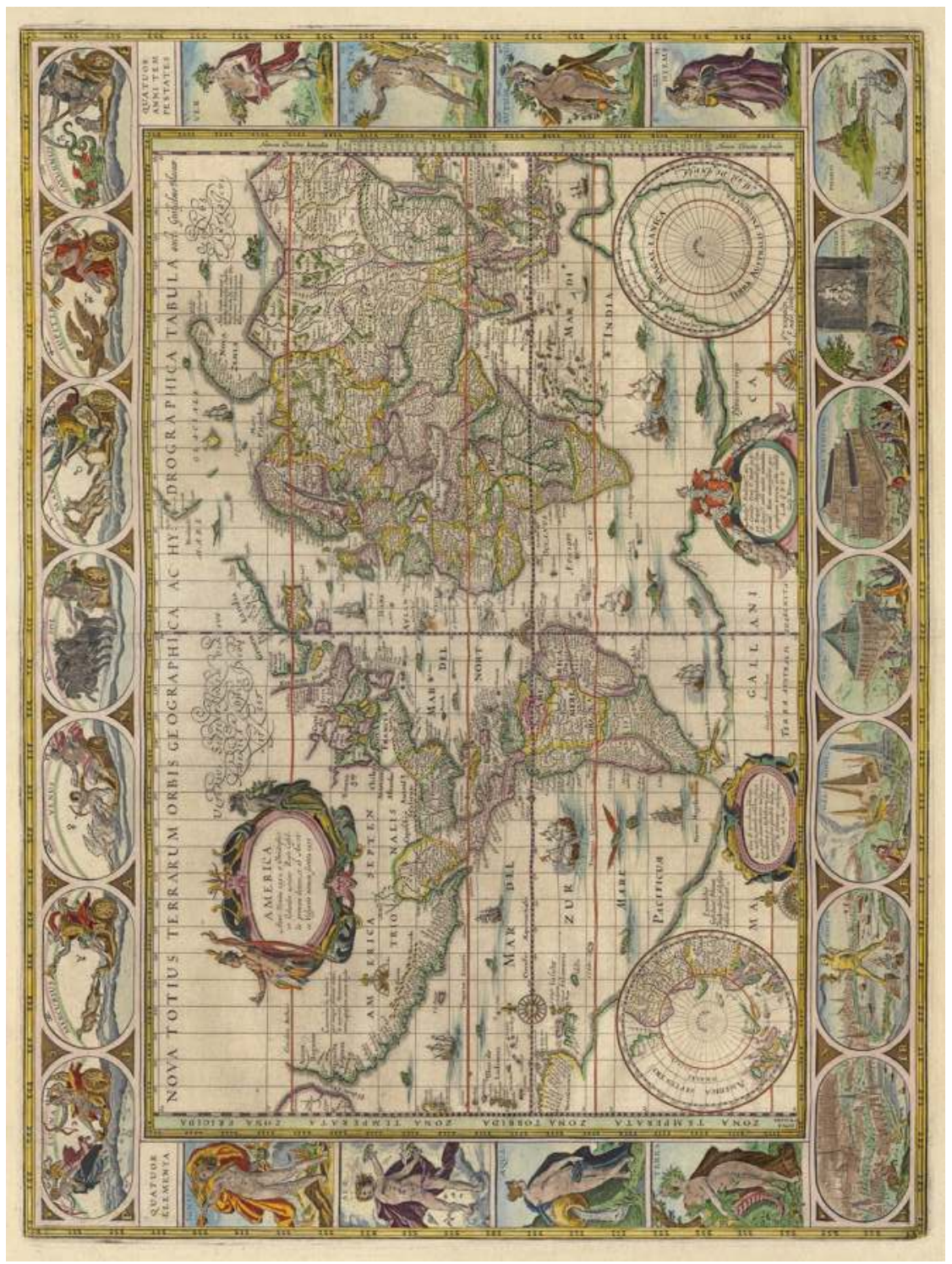

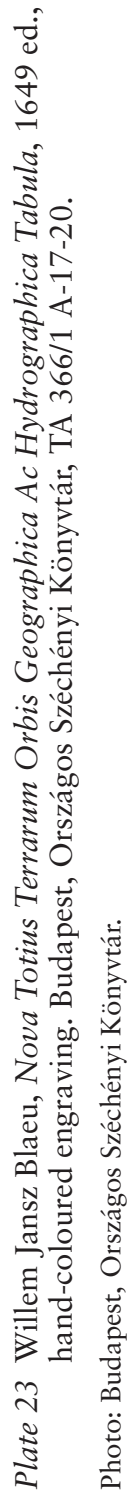




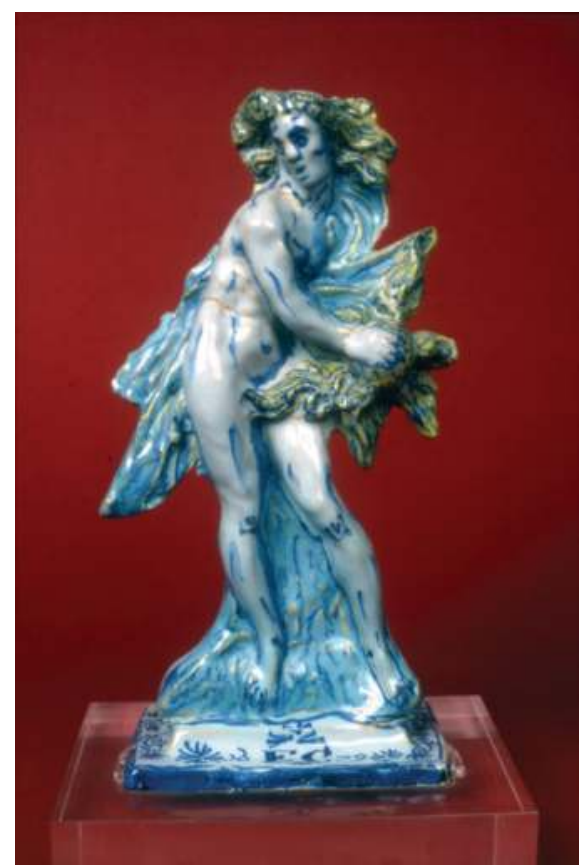

Plate 24 English, Ignis (Fire), 1679, tin-glazed earthenware. Alton, Allen Gallery (Hampshire Museums).

Photo: ( ) Hampshire County Council collections. Provided by Hampshire Cultural Trust.

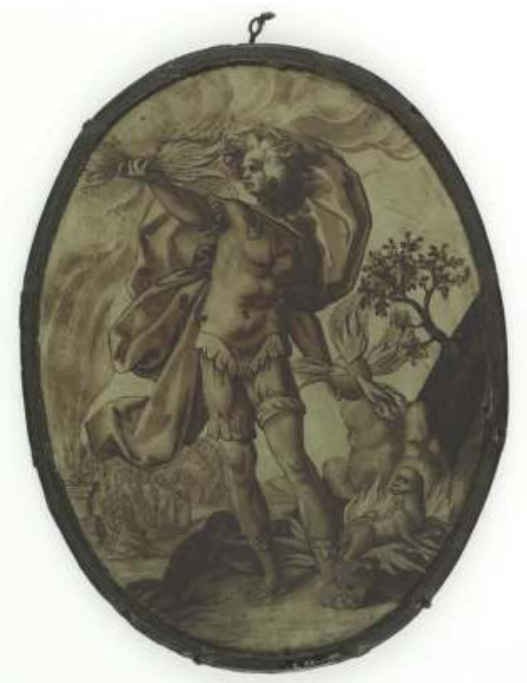

Plate 25 Flemish, Fire from a Set of Elements, c. 1600, stained glass decorated en grisaille with details etched with a needle. Cambridge, Fitzwilliam Museum, AA, C.341-1991.

Photo: () The Fitzwilliam Museum, Cambridge. 


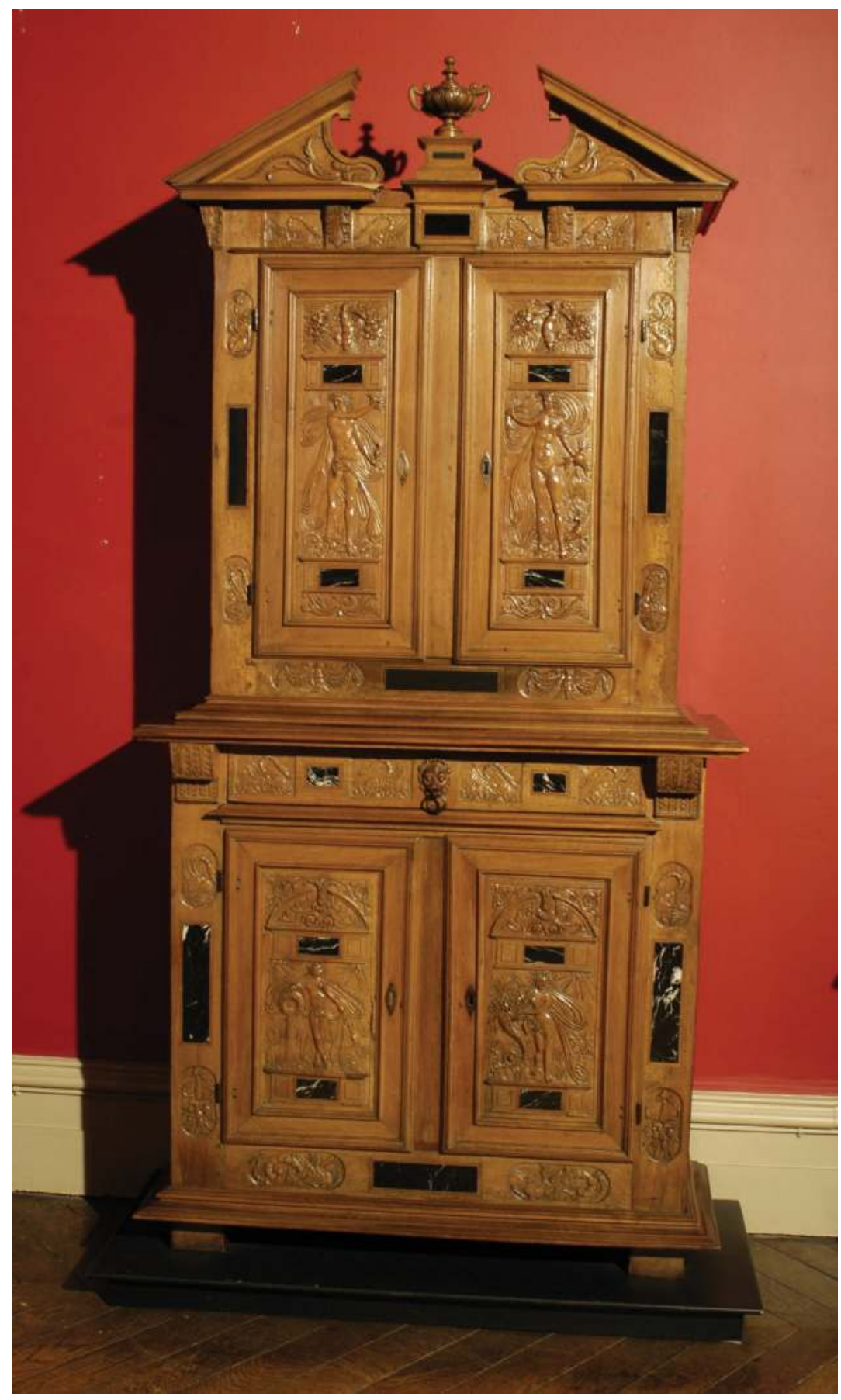

Plate 26 French, armoire à deux corps, c. 1600, walnut cabinet with carved decoration and inlay of black marble. County Durham, The Bowes Museum, FW.107.

Photo: () The Bowes Museum. 


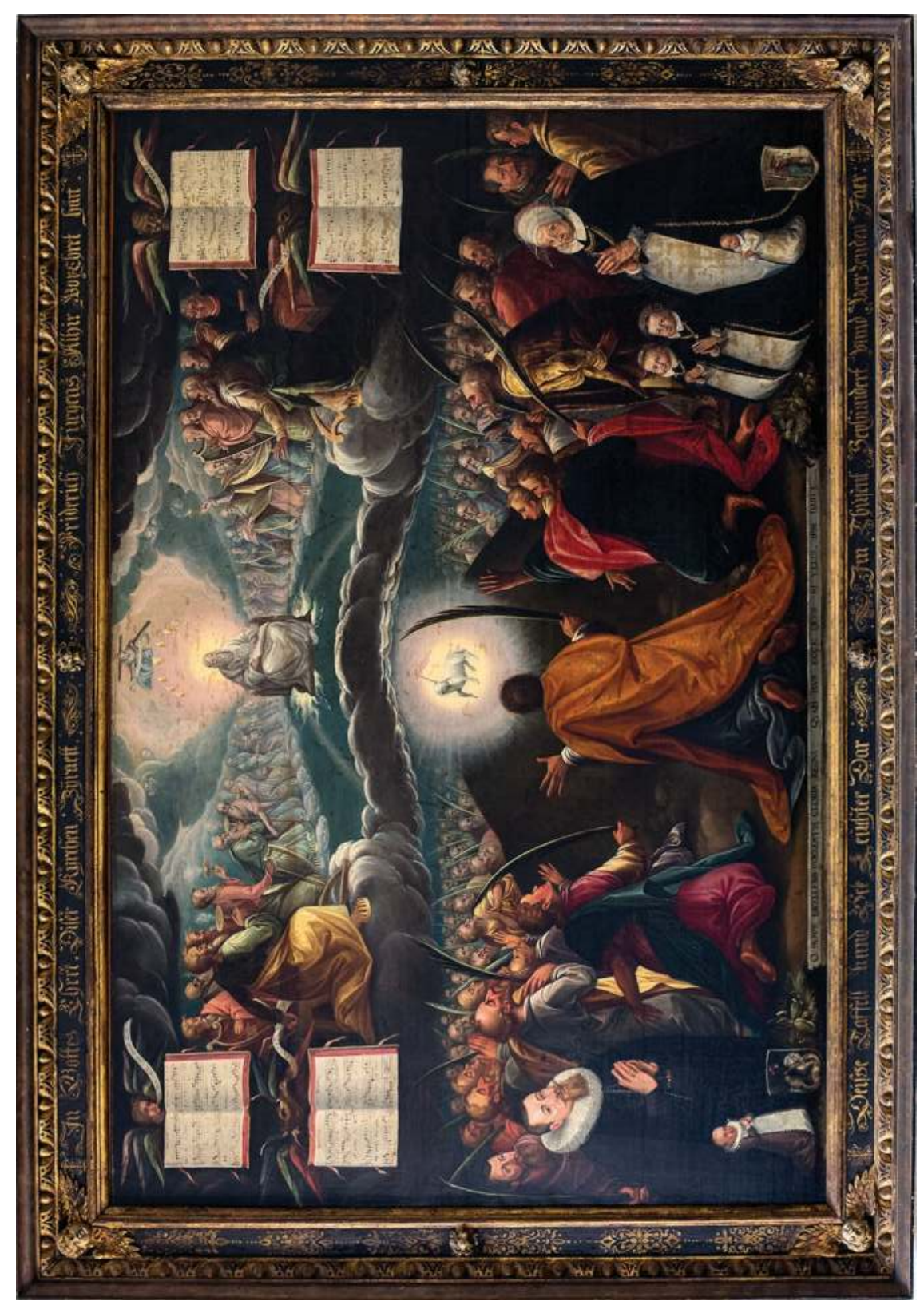

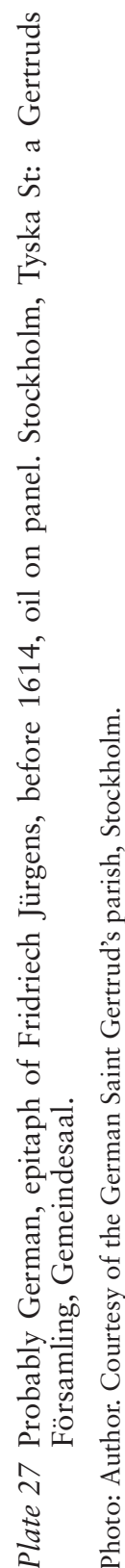




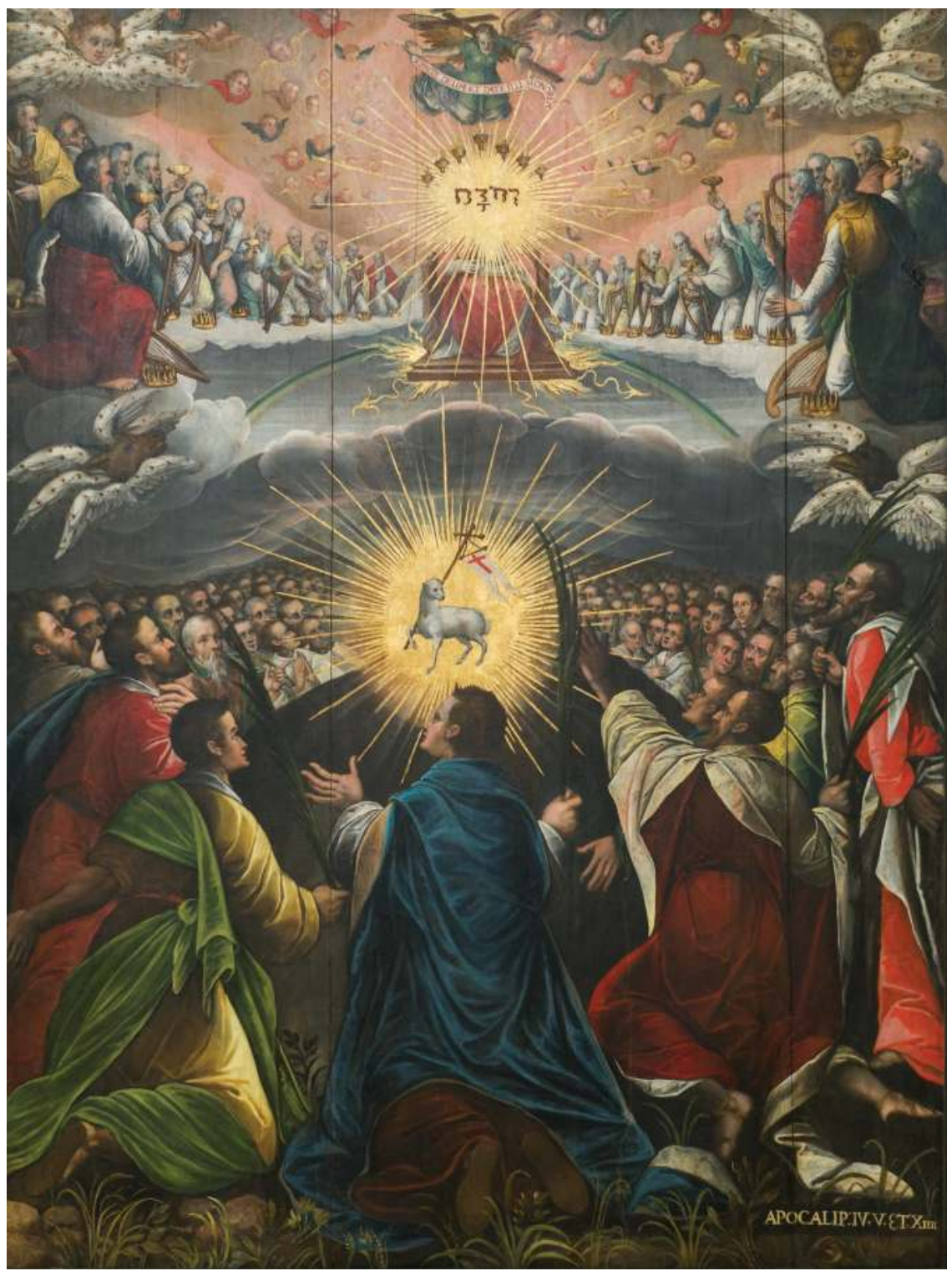

Plate 28 Polish, Adoration of the Lamb, after 1588, oil on panel. Torun, kościół św. Szczepana. Photo: ( $)$ Courtesy of the Evangelical Parish of the Augsburg Confession in Torun and the District Museum of Torun. Photo: Krzysztof Deczyński. 


\section{Index}

Africa 19, 268, 269, 279

Agnolo Ebreo 56

Agostini, Niccolò degli 118, 125 (fig. 6.8), 128n10

Akbar, Emperor 280

Alain de Lille 220

Alberti, Cherubino 173, 174 (fig. 9.1)

alchemy, alchemist 230, 232, 235, 240, $241 \mathrm{n} 4,241 \mathrm{n} 7$

Aldegrever, Heinrich 223, 224 (fig. 11.6), 226n27, 226n39

Aldrovandi, Ulisse 16, 17, 18 (fig. 0.9), 21nn49-50

Aleni, Giulio 280, 282 (fig. 14.11)

Allende 279

Altdorfer, Albrecht 218, 225n9, 226n27

altering prints see customizing prints

Ampleforth 98, 108, 110n4

Amsterdam 250, 251, 252 (fig. 13.4)

Amsterdam-Rijksmuseum 6, 101 (fig. 5.1) 104 (fig. 5.2) 105 (fig. 5.3) 106 (fig. 5.4), 110n4, 111n35, 169n37, 179 (fig. 9.4), 214 (fig. 11.1), 215 (fig. 11.2), 221 (fig. 11.6), 230-2 (fig. 12.1-4), 237, 238 (fig. 12.6), 239 (fig. 12.7), 245 (fig. 13.1), 251 (fig. 13.3)

Andreae, Hieronymus 225n8

Androuet du Cerceau, Jacques I 153, 156 (fig. 8.4), $168 \mathrm{n} 6$

Angermaier, Andreas 7

annotoating, annotations 27, 33, 147n24, $148 \mathrm{n} 46$

Antonio di Giovanni di ser Francesco 50

Antwerp 6, 17 (fig. 0.8), 21n45, 29, 30

(fig. 1.2), 91, 97, 107-9, 110n19, 157, 169n15, 232, 240, 244, 246, 247, 250, 275-276, 277 (fig. 14.9), 278, 279, 280, 284n 37,285 n 38

Apian, Peter 29, 30 (fig. 1.2), 32, 45n1

Appignano 122

Aretino, Pietro 182, 191n17

Argentoratensis, Iacobus 128n12, 266

Armenians, Armenia 247, 250-2, 255-6, 259n43, 279-80, 285n59-60

Assisi 55 astrolabe, printed scientific instruments 4 , 13, 27, 40, 42, 43 (fig. 1.10), 44, 162, 164, 165 (fig. 8.9), 166, 168, 170n48

Athens 122, 198

Atotonilco, Guanajuato 279

Augsburg 37 (fig. 1.5), 74, 187, 207, 219

Augsburg, Michael von 207

Aviz, Manuel I 269

Aztec art 272-3, 275 (fig. 14.8)

Aztec empire 272

Beham, Barthel 214, 218, 219 (fig. 11.5) 220, 225n15

Beham, Sebald 19, 213, 214 (fig. 11.1), 216 (fig. 11.3), 217 (fig. 11.4), 218-23, 225n8, 225n15, 226n 39

Bełza, Marcin 3

Bernardo, Felice 121

Bielany (near Cracow) 278

Bielski, Joachim 144

Bielski, Marcin 136, 144, 148n47, 148n51

Binck, Jacob 97

Blaeu Willem Jansz. 19, 232, 233, 237, 242n25, Pl. 25

blank, lost, missing, empty $6,27,28,32,40$, $45,45 \mathrm{n} 2$

Bocholt 64

Boemus, Matthias 44

Boethius 220, 221

Boleslaus the Brave (Bolesław Chrobry) 136

Bolivia 279

Bologna 16, 17, 56

Bonsignori, Giovanni 118, 122, 124, 128n9, 128n12, 128n18, 129n33, Pl. 21

books of hours see prayer book

Borcht, Peeter van der 7, 10 (fig. 0.3), 12 (fig. 0.4)

Bordone, Benedetto 128n12, 266-7, 266 (fig. 14.2)

Borromeo, Carlo 278

Bortoli, Anton 259n44

Bos Balthasar 169n15, 169n21

Bos, Cornelis 153, 157

Bronowski, Mikołaj 136, 137 
Brosamer, Hans 1

Brussels 161

Budapest 146n7, 223, Pl. 23

Buonarroti, Michelangelo see Michelangelo

Caldara (da Caravaggio), Polidoro 180

Calvin, Jean 247, 257n10, 260n56

Calvinist 247, 248, 255, 256

Canisius, Petrus 13, 186 (fig. 9.8), 189

(9.10), 184, 186 (fig. 9.8) 187, 189

(fig. 9.10), 190, 191n 20

Carracci, Agostino 247, 248, 258n17, 258n23

Catholic (Roman) 37, 72, 164, 167, 187, 198, 246, 247, 250, 254, 256, 257n11, 258n13-14, 278, 279, 283

censorship 11, 38, 39, 44, 81, 117, 118 , $121,122,124,126,127,128 \mathrm{n} 5,128 \mathrm{n} 7$, 128n13, 129n22, 130n43, 130nn45-6, 135

Cezary, Franciszek 8, 20n21, 148n53

Champaigne, Philippe de 278

Cheke, John 162

Cingoli 121

Clement VIII (pope) 276

Clovio, Giulio 172, 176, 177 (fig. 9.3), 187

Cock, Hieronymus 164, 169n21

Cola Giacomo D’Alibrando 180

Collaert, Adriaen 276

Collaert, Jan 276

collotype 33 (fig. 1.4), 35, 44, 45

Cologne 39, 145, 148n53

Colombia 279

Colonna, Francesco 267

coloring prints see colouring

colouring prints see customizing prints

Columbus, Ferdinand 273

Confessionalisation, Confessionalism 246, 256

Constantinople 198

copperplate, copper plate see matrix

Corfu 268

Cort, Cornelis 176, 177 (fig. 9.3), 186

(fig. 9.8), 187

Cortés, Hernán 272

Cortona 49

Coudenberghe, Jan van 103

Crabbe, Frans 6, 97, 102, 103, 105 (fig. 5.3), 106 (fig. 5.4), 107-9, Pl. 18

Cracow 1, 3, 4, 5 (fig. 0.1), 7-13 (fig. 0.2-4), 16, 20n10, 20nn21-3, 20-1nn23-7, 21n33, 33, 134-6 (fig. 7.1), 138, 139-43

(fig. 7.2-6), 144, 146, 146n4, 146n6, $146 \mathrm{n} 8,147 \mathrm{n} 11,147 \mathrm{n} 38,148 \mathrm{n} 40$, 148n44-6, 148nn48-9, 148nn51-3, 154, 205, 206, 207-8, 208n10, 209n23, 209n32, 210n43, Pl. 22

Cracow-Biblioteka Jagiellońska 3, 4, 9 (fig. 0.2), 10 (fig. 0.3), 18 (fig. 0.9), 20n8, 146n 7, Pl. 2
Cracow-Biblioteka PAN i PAU 153, 154, 169n17

Cracow-churches 278, 285n48

Cracow-Muzeum Narodowe w Krakowie 141 (fig. 7.4), 142 (fig. 7.5), 146n7, 147n38, 148 n40, Pl. 22

Cracow-Zamek Królewski na Wawelu 236, 242n23

Cranach the Elder, Lucas 1-4, 20n12, 42, 43 (fig. 1.10), 44, 137, 202, 202 (fig. 10.6), 203, Pl. 2

Crete 124

Creussen 231, 232, 238n20

culture elite see elite

customizing prints $3,98,99,102$; altering $11,70,71,73,92,97-102,107,108$, 117-27, 143, 153, 164, 178, 243, 244, 246, 250,251 ; colouring $6,11,35,36,42,76 \mathrm{n} 2$, 98, 99, 100, 102, 103, 107, 109, 138, 139, $145,147 \mathrm{n} 37$; cutting $6,29,40,75,98$

cutting prints see customizing prints

Czobor, Imrich I 206

D’Alibrando, Cola Giacomo cf. Cola Giacomo D'Alibrando

d'Angoulême, Charles 98

Danzig see Gdańsk

da Rocha, João 280

Dayue, Cheng 283

de Alvarado Huanitzín (Didacus), Diego 272

Dębno 206

de Bry Johann Theodor 28, 237, 239

(fig. 12.7), 248, 250

de Bry, Theodor 28, 242n29

de Cafaggiolo, Jacopo 268

Dee, John 164

Dei, Benedetto 268

de Kremer, Geert (Mercator, Gerard) 161, 162, 164, 169n37, 170n56, 170n64

de la Cueva y Toledo, Mencia 268

de la Cueva y Toledo, Pedro 267

De Laistre, Remy 88, 90 (fig. 4.2), 94n47

Delaune, Étienne 153

Delft 103, 107

Dembowski, Leon 11

de Speyer (da Spira), Johann (Giovanni) $94 n 52$

de Speyer (da Spira), Wendelin (Vindelino) $94 n 52$

Deutsch, Hans Rudolph Manuel 37, 46n18

Deutsch, Niklaus Manuel 222, 264

de Vos, Maerten 275-6

devotional books see prayer book

de Witte, Lieven 20n22

de Zurbarán, Francisco 278

Dharmapala 272

Dietz (Decius), Jost 138 (fig. 7.1), 136, 138, 139-43 (fig. 7.2-6), 147n11, 147n13, Pl. 22 
Długosz, Jan 136

Dolce, Lodovico 11, 118, 126 (fig. 6.9), 127, 128n11, 130n44

Donà, Tommaso 118

Dornaeus, Gerard 230, 241n3

du Bray, Toussaint 7, 20n20

Dudley, John (earl of Warwick, duke of Northumberland) 162, 168

Dürer, Albrecht 1, 2, 7, 19, 71, 72, 82, 86, 100, 108, 110n3, 195-210, 229; Apocalypse 264; Bagpipe Player 272, 284n26; Beheading of Saint John the Baptist 201; Engraved Passion 110n13; Knight, Death and the Devil 37; Nemesis 213, 215 (fig. 11.2), 218, 222, 223; Northern and Southern Celestial Hemispheres 42; Saint Georg Standing 195-210; Saint Georg on horseback 197, 197 (fig. 10.2); Standard Bearer 199, 200, 199 (fig. 10.3); Virgin and Child on a wooden bench, crowned by an angel 97; Virgin and Child with a Monkey 200, 200 (fig. 10.4); Self-portrait 201, 201 (fig. $10.5)$; writings $69,70,72,218,225 \mathrm{n} 4$

Ecuador 279

Eder, Wilhelm 7, 20n18

elite 49, 85, 98, 107, 157, 203, 206, 232, 247

Emilia-Romagna 57

empty $36,52,54,63,184$

enamel 84, 268

Erasmus of Rotterdam 82, 93n4, 100

eroticism 117-30, 219

Ethiopia 280-1, 286n71

fabric printing $35,45,92,94 \mathrm{n} 42$

Farnese, Alessandro (duke, 1545-92) 166

Fermo 118, 119-21 (fig. 6.1-4), 122, 124, 128nn8-9, Pl. 21

Fernandes, Valentim 269, 284n16

Ferrara 268

Ferreira, Gaspar 280

Flach, Martin 72, 78n59

Flanders 236, 240, 247

flap, flaps 4, 28, 32, 34, 36, 37, 37 (fig. 1.5), 38,38 (fig. 1.7), 40, 40 (fig. 1.8), 45, 46n19

Florence 48-50, 52, 55-7, 57n1, 57n9, $57 \mathrm{n} 11,170 \mathrm{n} 48,265,268$

Flötner, Peter 169n21

Fontainebleau 151, 154

Francis I of France 98, 154, 157

Franconia 3, 206

Frankfurt am Main 15 (fig. 0.6), 18 (fig. 0.9), 21n39, 21n50, 42, 108, 145, 148n53, 226n36, 234, 241n3, 242n29, 244, 247, 249 (fig. 13.2), 250, 258n13, 258n15, 259n32, 259n34
Frisius, Gemma 30 (fig. 1.2), 161, 162, 164, $170 \mathrm{n} 61$

Furió Ceriol, Fadrique 144, 148n48

Garwolczyk, Maciej 144, 148nn48-9, 209 n 23

Gdańsk 205, 206, 208, 278

Gemini, Thomas 13, 151-70

Gessner, Conrad 13, 14-17, 14 (fig. 0.5 and $0.7), 21 \mathrm{n} 37,21 \mathrm{n} 43,21 \mathrm{n} 45$

Ghent 98

Giolito de' Ferrari, Gabriel 118, 126 (fig. 6.9), 128n11

Giovanni da Modena 56, 59n52

Giusti, Giusto 49, 58n20

glue $2,27,32,36,49,58 \mathrm{n} 33$

Goa 270, 276, 280-1

Goltzius, Conrad 40, 40 (fig. 1.8)

Goltzius, Hendrick 19, 39, 230-242 (fig. 12.1-4), 250

Gormont, Hiérosme de 157, 169n23

Gourmont, Jean 168n21

Górecki, Wojciech 8

Graf, Urs 222, 226n36

Grenoble 277

Greuter, Matthias 38-40 (fig. 1.6-8)

Grévin, Jacques 161

Grunau, Simon 137

Guagnini, Alessandro 144, 148n52

Guarani sculpture 276

Habermel, Erasmus 166

Habsburg, House of 107, 157; Frederick II 198; Maximilian 36, 198, 199, 208n5, 209n35; Philip II (of Spain) 164

Haller, Jan 3, 4, 5 (fig. 0.1), 205, 207

Hamman, Johannes 86, 94nn39-40

Hampton Court 266

hand coloring see colouring

Hapsburg see Habsburg, House of

Hardouyn, Germain 81-94

Hardouyn, Gillet 81-94

Hartmann, Georg 41, 42

Hayreddin Barbarossa 157

Heinrich, Nikolaus 7, 20n17

Heitz, Paul 34-6, 44

Henneberg, Hermann VIII von 202

Herberstein, Sigismund von 14, 16, 17, 21n41

Hesiod 221

Heyden, Gaspar van der 164

Hirschvogel, Augustin 169n21

Hochfeder, Kaspar 3, 20n10, 63, 74, 75

Hoffaeus, Paul 276

Hohenzollern-Hechingen, Eitel Friedrich II von 202

Holbein the Younger, Hans 32, 46n7, 151, $160,168 \mathrm{n} 4$

Horae see prayer book 
Horteryn, Anna 8

Horteryn, Marcin 8, 9 (fig. 0.2), 21n29

Housebook Master 98

Hussowski, Mikołaj 16

Hyber, Sebastian 3

illuminating, illuminator $2,6,35,48,58 \mathrm{n} 34$, $58 \mathrm{n} 36,70,71,77 \mathrm{n} 42,82,84-6,88,91$, 92, 93n28, 98-100, 103, 108, 207; see also customizing prints

incunabula 91, 108

India 270, 272, 280, 285n61

Ingolstadt 7, 20n18, 184, 188 (fig. 9.9), 189 (fig. 9.10)

inscriptions $11,13,44,67-8,91,103,142$, 148n46, 172-91, 203, 229, 230, 232-4, $237,241 \mathrm{n} 2,246,253,256,267,272$

interactive, interaction $4,6,27,32,34,36-8$, $45,48,63,75,138,145$

Istanbul 268, 285n63

ivory 269,270 (fig. 14.4), 272, 273

(fig. 14.6), 276

Jacob of Strasbourg 128n12, 266 (fig. 14.2) Jagiellon, House of 19, 135, 136, 142-6, 195, 203, 205; Alexander 134, 135, 148n45; Casimir IV 205; Frederick 3, Sigismund I 136-9, 141 (fig. 7.4), 142 (fig. 7.5), 144, 148nn45-6, Pl. 22; Sigismund II Augustus 136, 138, 139 (fig. 7.3), 146; Wladislas II of Hungary 205, Władysław III of Varna $63,144,148 \mathrm{n} 45$

Jagiełło, Władysław 142, 144

Japan 264, 279-80

Jena 27, 42, 43 (fig. 1.10), 44

Jenson, Nicolaus $94 \mathrm{n} 52$

Jerzyczek, Jan 275

Jesuits 19, 172, 184, 187, 190, 276, 278, 280-1, 283

Jędrzejowczyk, Maciej 8

Johannes (carver, woodcutter) 1, 2

Jonston, Jan 13-16, 15 (Fig. 0.6), 17, 21n39, $21 \mathrm{n} 51$

Julius II 107

Jürgens, Friderich 253, 259n46, Pl. 27

Kalwaria Zebrzydowska 277

Kerver, Thielman 269-270, 271 (fig. 14.5), 272, 284n22

Kęszycka, Konstancja 11

Klemptzen, Nicolaus von 137

knots 28 (fig. 1.1), 29, 30 (fig. 1.2), 32, 34, $45 \mathrm{n} 2$

Koberger, Anton 68, 77n23, 77n25, 206

Koberger, Johann 264

Kobyliński, Wojciech 7-8, 9 (fig. 0.2), 21n29, $21 \mathrm{n} 33$

Köln, Hans von 265
Kórnik 9 (fig. 0.2), 10 (fig. 0.3), 11, 12

(fig. 0.4), 20n26, 21n $33,21 \mathrm{n} 35$

Krok 145

Kromer, Marcin 136

Krzysztoporski, Jan the Elder 137, 147n24

Krzysztoporski, Jan the Younger 147n24

Lafreri, Antonio 13, 172-92

Lancz von Kitzingen, Michael 207

Lasocki of Glewo, Stanisław 137

Lech 135, 145, 148n45

Leest, Anton van 6, 10 (fig. 0.3)

le Seney, Bastien 166, 170n67

Leszek II 136

Leuven 161, 162, 164, 166, 170n61

Leyden, Lucas van 6, 97, 100, 101 (fig. 5.1), 102, 108, 110n2, 229, 250, 272, Pl. 15-17, 19-20

Libuše 145

Liège 161, Pl. 1

Lily, George 164

Lily, William 164

Lindau 74 (fig. 3.6), 75, 78n73

Little Masters 213, 220, 225n15

Liturgical books 2-4, 5 (fig. 0.1), 7, 9, 12, 17, 20n8, 70-1, 75, 77n42, 91, Pl. 1, 2, 8

Lob, Mikołaj 8, 10 (fig. 0.3), 20n26

London 11, 110n4, 151, 152 (fig. 8.1-2), 153, 154, 155 (fig. 8.3), 156 (fig. 8.5), 160, 162, 163 (fig. 8.8), 233, 242n 32

London-British Library 94n40, 110n11, $284 n 22$

London-British Museum 36, 46n17, 56, 73 (fig. 3.5), 98, 107, 110nn11-12, 111n35, 166, 167 (fig. 8.10), 168n4, 168n9, 196 (fig. 10.1), 202 (fig. 10.6), 226n32, 233, $242 \mathrm{n} 32,258 \mathrm{n} 12,268$

London-National Maritime Museum 170n52

London-Victoria and Albert Museum 156 (fig. 8.5), 168n14, 169n17, 281 (fig. 14.10)

Longinus 176

Lorenzo the Magnificent see Medici, Lorenzo (il Magnifico)

lost 4, 6, 21n45, 27, 29, 32, 33, 38, 42, 44, $45,71,73,77 \mathrm{n} 42,78 \mathrm{n} 73,110 \mathrm{n} 2,147 \mathrm{n} 26$, $168 \mathrm{n} 10,273$

Loyola, Ignatius 274

Luther, Martin 1, 19n1, 36, 44, 249, 254

Lutheran, Lutheranism 162, 208, 247, 250, $254,256,258 \mathrm{n} 15$

Lviv 20n12, 278

Łaski, Jan 207

Maas-Rhine region 98

Maastricht 3, 110, 161, Pl. 1

Macerata 121-2, 123 (fig. 6.5-6), 124 (fig. 6.7), $128 \mathrm{n} 8$ 
Magnus, Olaus 137

Mair, Alexander 7

Mantegna, Andrea 199, 200, 266

Mantua 266

manuscript 2, 4, 6, 27, 32-3, 36, 44-5, 46n24, 48, 57n1, 51n3, 63, 65, 68, 70-2, 75, 76nn1-2, 77n42, 81-6, 91, 97-111 (figs. 5.1-4), 124, 129n28, 136, 225n20, 268, 273, 280, 281, Pl. 1, 6-8, 15-20

Mallery, Karel van 276

Marche 5, 57

Margaret of Austria 107

Margarita philosophica see Reisch, Georg

Mariette, Pierre I 168n15

Martinez de Pocasangre, Miguel Antonio 279

Massys, Cornelis 153, 159 (fig. 8.7)

Master ES 49, 68, 69 (fig. 3.4), 77n31, 98, 110n12, 230

Master f 154

Master FVB 70, 71, 78n44, 98

Master GG 168n21

Master JG 153

Master of Messkirch 206, 207 (fig. 10.8)

Master of the Apocalypse Rose 86

Master of the Banderoles 77n31

Master of the Berlin Passion 65, 68, 77n42, 91, 98

Master of the Dresden Prayerbook 94n60

Master of the Housebook 98

Master of the Kaufbeurer Sakristeischrank 264

Master of the Martyrdom of the Ten Thousand 98

Master of the Playing Cards 49

Master of the Putti (Putti Master) 91

Master of the Très Petites Heures of Anne de Bretagne 86

Master of the Vienna Passion 268

Master S 97, 103, 104 (fig. 5.2), 107-9, $111 \mathrm{n} 46$

Master W with a Key $78 \mathrm{n} 72$

matrix: copperplate $7,39,58 \mathrm{n} 12,70,94 \mathrm{n} 59$, $144,148 \mathrm{n} 53,161,164,172$; woodblock $1-11,10$ (fig. 0.3 ), 16-17, 20n10, 20n12, 20n26, 21nn29-30, 34, 40-5, 41 (fig. 1.9), 48-51, 55-7, 70, 73, 75, 84, 91-2, 117-18, 134-5, 142-4, 148nn44-5, 187, 250-1, 255, 259n41, 266

Maximilian I Habsburg see Habsburg, House of, Maximilian I

Mazali, Francesco 118, 119 (fig. 6.1), 120 (fig. 6.2-3), 121 (fig. 6.4), 123 (fig. 6.5-6), 124 (fig. 6.7), $128 \mathrm{n} 8$

Mechelen 97, 107-9

Meckenem, Israhel van 5, 63-78 (fig. 3.1-5), 98, 103, 110n11, 110n12, 110n18, 110n25, 273, 274 (fig. 14.7), Pl. 7
Medici family 28, 265; Medici, Lorenzo (il Magnifico) 49, 121, 129n24; Ferdinand II 170n48; Lorenzo il Magnifico 49, 121, $129 \mathrm{n} 24$

Mehmed II, sultan 268

Mekhitar Sebastatsi 248, 255n44

Melanchthon, Philip 36, 44, 137, 147n26

Mercator see de Kremer, Geert

Mercurian, Everard 276

Merian, Matthäus, the Elder 248, 249 (fig. 13.2), 250, 255, 257n6, 258n27, 258n 36

Merian, Matthäus, the Elder (heirs) 14, 15 (fig. 0.6), 17, 21n39

Metamorphoses see Ovidius

Mexico 272, 276, 279

Michael von Augsburg 208, 209n38

Michałowski, Andrzej 137

Michelangelo 13, 172, 182, 183 (fig. 9.6), 184, 190, 264

Miechowita (of Miechów), Maciej 11, 134-48

Mieszko I 143

Mieszko II 143

Mieszko III 138

Milan 49, 51, 58n35, 59n49, 278

miniature, miniaturist $1,3,4,6,65,71,75$, 77n42, 81-8, 91, 92, 93n23, 94n60, 97-9, 128n12, 223, 280, Pl. 1

missing 27, 32, 36, 37 (fig. 1.5), 42, 45, 57, $97,147 \mathrm{n} 26,153,154$

monogrammist ih 65

monogrammist bx8 76n14

monogrammist CBS 191

monogrammist MS 1

Morochowski Petrarchnowicz, Mikołaj 278

Mount Thabor Convent 107

Munich 7, 20n17, 236, 242n21, 258n15

Munich-Alte Pinakothek 208n5

Munich-BSB 29, 30 (fig. 1.2), 36, 37 (fig. 1.5), 42, 46n7, 46n19, 50, 76n1, 76n15, 79n76, 208n5, 225n21, 282 (fig. 14.11), Pl. 5-7

Munich-Bayerisches Nationalmuseum 40, 41 (fig. 1.9), 76n15

Munich-Ludwig-Maximilians-Universität $46,78 \mathrm{n} 69$

Munich-Staatliche Graphische Sammlung 74 (fig. 3.6), 76n14, 78n71

Münster 151, 152 (fig. 8.1-2), 153, 154, 167 (fig. 8.10), 168n2, 168n14

Münster, Sebastian 29, 39, 31 (fig. 1.3), 32, 40, 45-6nn2-6, 137, 142

Muscovy 14-16

mythology 117-30 (figs. 6.1-9), 213-26 (figs. 11.1-6), 229, 236, 268, Pl. 21

Nadal, Jerome 276, 277 (fig. 14.9), 278-81, 283, 284-5nn36-8, 285nn54, 59, 63

Nenninger, Matheus 7, 20n19 


\section{Index}

Neoplatonist 232

Neri de Alfaro, Luis Felipe 279

New Julfa 279

Nicholas of Cusa 72, 77n39, 78n60

Nicoletto da Modena 168n5, 221

Nuremberg 3, 19, 20n10, 41, 63-5, 76n23, 77n38, 53n53, 195, 202, 203, 205-6, 207, 213, 218, 222, 225n8, 234, 264

Nuremberg-Germanisches Nationalmuseum 35-6, 37 (fig. 1.5) 226n36, Pl. 3 and 4

Nyverd, Jacques 157

Oliwa 278

Oskan Yrevantsi (or Voskan of Yerevan) 250-1, 251 (fig. 13.4), 255, 259n41

Ottoman Turkey 63, 157, 198, 205-6, 251, 268

Ovidius 119 (fig. 6.1), 120 (fig. 6.2-3), 121 (fig. 6.4), 123 (fig. 6.5-6), 124 (fig. 6.7), 125 (fig. 6.8), 126 (fig. 6.9) 241n2, Pl. 21

Paets, Pieter Jacobsz 250

painted prints see colouring

Pampowski, Ambroży 19, 195, 203-7, 204 (fig. 10.7), 209nn25-8, 209n30, 209n38

Paprocki, Bartosz 136, 143-5, 203

Paracelsian 230, 232, 235

Paraguay 276, 279

parchment 3, 4, 48, 58n33, 84-5, 97-8, Pl. $1-2,8$

Paré, Ambroise 16

Paris 6, 7, 20n20, 21n49, 29, 81, 84-6, 90 (fig. 4.2), 93n13, 154, 157, 161, 169n23, 259n34, 271 (fig. 14.5), 284n22, Pl. 9-14

Paris-BnF 168n20, 186 (fig. 9.8), 189 (fig. 9.10), 191n20, 225n20

Paris-INHA 156 (fig. 8.4), 168n6

Paris-Louvre 59n55, 168n5

Paris-Musée des Arts Décoratifs 267, 267 (fig. 14.3)

Paris-Petit Palais 242n24

Paris-Val-de-Grâce 278

Parma 117-30 (fig. 6.1-8)

Parr, Catherine 168n 5

part book 244, 246-8, 250, 254, 256

Passau 7, 20n19

Patrusówna, Anna 11

Paul III, pope 272

Pellegrino, Francesco 154, 157, 159

Pencz, Georg 208, 221

Pera (Istambul) 268

Peru 276, 279

Perugia 55, 56

Petrarch (Petrarca, Francesco) 221, 226n33, 268

Pévernage, Andries 19, 245 (fig. 13.1), 246-7, 257n10
Peypus, Friedrich 265

Philip the Fair 103

photography $27,35,42,43$ (fig. 1.10), 44, 74 (fig. 3.6), 153

Piątkowski, Walerian 8-9, 9 (fig. 0.2), 10 (fig. 0.3)

Pichore, Jean 82, 85-6, 88, 90 (fig. 4.2), 91-2, 94n41, 94n47

Pio, Alberto III 157

Piotrkowczyk Family (printers) 8, 21n29, 144

Piotrkowczyk, Andrzej I 7-8, 10 (fig. 0.3), 12 (fig. 0.4), 20n26, 29, 143, 144, 148n44

Piotrkowczyk, Andrzej II 8, 21n29

Piotrkowczyk, Anna Teresa 21n30

Piotrkowczyk, Piotr 7

Piotrkowczyk, Stanisław Teodor 8

Pippi (Romano), Giulio 127

Pistorius, Johann 137, 147n29

Plantin, Christophe 2, 6-8, 17 (fig. 0.8)

playing cards 6, 48-59, 51 (fig. 2.1), 53 (fig. 2.2-3), 54 (fig. 2.4), 68, 77n31

Pole, Reginald 164

polyphony $244,247,254-6,257 \mathrm{nn} 10-11$

postils $8,20-1 \mathrm{n} 23$

Poznań 4, 5 (fig. 0.1), 11, 205, 209n27

Prague $145,148 \mathrm{nn} 54-5$

prayer book 6, 7-11, 9 (fig. 0.2), 10 (fig. 0.3 ), 12 (fig. 0.4), 20nn24-7, 29-32, 33-4, 35, 81-92, 89 (fig. 4.1), 90 (fig. 4.2), 93n1, 20, 94n56, 94n60, 97-109, 101 (fig. 5.1), 104 (fig. 5.2), 105 (fig. 5.3), 106 (fig. 5.4), 110n2, 110n4, 110n11, 110n13, $110 \mathrm{n} 18,111 \mathrm{n} 35,111 \mathrm{n} 40$; psalter 7,36 , $257 \mathrm{n} 10$

prices $8,35,85,98-9,136-7,147 \mathrm{n} 14$

print-assisted paintings see colouring

printing matrices see matrix

Protestant 1, 36, 44, 137, 162, 167, 247, 249-50, 253-54, 257n10, 258n15, 259n49, 256n56

Pruszcz, Piotr Jacek 143

Przemysł II 143

Publius Ovidius Naso see Ovidius

Pulci, Luigi 49

Putti Master 91

Raimondi, Marcantonio 92, 180, 181 (fig. 9.5)

Raphael 13, 92, 172, 178-82, 179 (fig. 9.4), 181 (fig. 9.5), 190, 191n10

Regio, Raffaele 118

Regiomontanus 35-6

Reisch, Gregor 220, 225n24

Ricci, Matteo 280

Romano, Giulio see Pippi (Romano), Giulio

Rome 13, 49, 58n21, 103, 128n14, 130n46, 148n53, 164, 172, 187, 205, 280 
Rota, Martino 182, 183 (fig. 9.6)

Rubens Peter Paul 240, 278

Rusconi, Giorgio de' 118, 126, 126 (fig. 6.9), 130n44, Pl. 21

Sachs Hans 220, 225n15

sacral music 244-7, 254, 256, 257nn9-11

Sadeler, Jan 19, 244, 247-8, 250, 253-6, 258n12, 258n16, 260n53

Safavid Persia 279-80

Salamanca, Antonio 172

Savonarola, Girolamo 49

Sawicka, Stanisława 33 (fig. 1.4), 44-5

Schaur, Johann 74, 78n70

Schedel, Hartmann 5, 63-5, 68, 74, 75-6, 76n2, 77n30, 135, 206, Pl. 6

Schedel, Krzysztof 21n29

Scheurl, Christoph 137

Schongauer, Martin 68, 86-7, 98, 200, 264-5, 265 (fig. 14.1)

Schreiber, Wilhelm Ludwig 34-5, 38, 273

Schulte, Bartholomäus 206

Schweiger, Jörg 260

Scorel, Jan van 92

Segers, Hercules 92, 94n59

Severýn of Kapí Hora, Pavel 148n55

Sforza, Bona 138 (fig.7.1), 135-38, 139 (fig. 7.2), 144, 148n46

's-Hertogenbosch 161

Sichem, Christoffel van 223

Sichem, Christoffel II van 250-2, 251

(fig. 13.3), 252 (fig. 13.4), 255, 259n41, $259 \mathrm{n} 43$

Siebeneicher (printers family) 7, 8, 20n21; Jakub 7, 8, 20n21; Siebeneicher, Mateusz $148 \mathrm{n} 51$

Sierra Leone 268-9, 270 (fig. 14.4), 284n16

Silvestris, Bernard 220

Simon of Cyrene 178

single-sheet prints, Einblattdrucke 1, 27, 32, $34,82,87,172,187,191$

Skalica 206

Smunck, Frans (Monarchus, Franciscus) 164

Solis, Virgil 153,168n15, 168n21

Sri Lanka 270, 272, 273 (fig. 14.6)

Stachowski, Władysław 11

Steiner, Georg Friedrich 254

Stockholm 145, 148n53, 253, 256, 259n47, Pl. 27

Stoss, Veit 203

Strasbourg 71-2, 78n51, 78n59, 220, 249, 266

Strzembosz, Jan 136

Stuchs, Georg 3, 20n10

Suleiman I 157

Sulzbach 145
Šuman, Jan (heirs of) 148n54

Susenyos I, Emperor 281

Süss von Kulmbach, Hans 207-8

Środa Wielkopolska 19, 195, 203, 204

(fig. 10.7), 205-6

Tagliente, Giovanni Antonio 154

tapestries 84, 107, 157, 268

Tauler, Johannes 71

Taurino, Gianpaolo 278

Taurino, Giovanni Giacomo 278

Thevet, André 16-17, 17 (fig. 0.8)

Tibaldi, Pelegrino 278

Titian (Tiziano Vecelli) 117, 175 (fig. 9.2)

Toruń 254-256, 259n49, Pl. 28

Treter, Tomasz 144-5, 148n53

Truchsess von Waldburg, Otto 187

Tudor, Edward VI 151, 161-3, 166, 167, 169 n35

Tudor, Elizabeth I 162, 165 (fig. 8.9)

Tudor, Henry VIII 151, 157, 159 (fig. 8.7), 160-1, 167, 168n5

Tudor, Mary I (of England) 164, 167

Tuscany 57

Umbria 55, 57

underdrawings $6,82,86,88-93,94 \mathrm{n} 56$, $94 \mathrm{n} 60$

Urbino 48-57

Valois-Angoulême, Charles 98

Valois-Angoulême, Francis I see Francis I of France

Valois-Angoulême, Henry II 157

Vasa, House of-Sigismund III 145, 146 Władysław IV 144, 146, 148n45; John Casimir 144, 148n45

Vasari, Giorgio 83

Vavassore, Giovanni Andrea 154

Vélez Blanco (near Granada) 267, 267 (fig. 14.3)

vellum 27,84

Veneziano, Agostino 157, 158 (fig. 8.6), 178, 179 (fig. 9.4), 191n12, 240

Venice 28 (fig. 1.1), 49, 94n 39, 94n 40, 94n52, 118, 121, 125 (fig. 6.8), 126 (fig.6.9), 128nn9-12, 154, 164, 199, 205, 247, 252, 259n44, 266-7, Pl. 21

Verard, Anthoine 84-5

Vesalius, Andreas 160-2, 164; see also Wesel, Andries van

Vest, Georg 234-6, 235 (fig. 12.5), 241n16

Vest, Johannes 234-6, 235 (fig.12.5), 241n16

Vienna 46n18, 77n31, 168n14, 168n15, 233

Vischer (workshop) 202-3, 205

Vitruvius 129-30n38, 218 


\section{Index}

volvelle 28-32, 34, 28 (fig. 1.1), 30 (fig. 1.2), 37,37 (fig. 1.5), 42, 43 (fig. 1.10), 46n18, Pl. 3-4

wallpaper 33 (fig. 1.4), 34, 45

Warsaw 27, 44

Warsaw-Biblioteka Narodowa 14 (fig. 0.5), 15 (fig. 0.6), 44, 139 (fig. 7.2), 140 (fig. 7.3), 143 (fig. 7.6), 146n7, 147passim, Pl. 13

Warsaw-Biblioteka Publiczna m.st. Warszawy 21n32, 146n7

Warsaw-Biblioteka Uniwersytecka w Warszawie 29, 33, 35-6, 44, 45, 134, 137, 138 (fig. 7.1), 146n4, 146n7, 147passim, 216-7 (fig. 11.3-4), 219 (fig. 11.5)

Warsaw-Muzeum Narodowe w Warszawie 200 (fig. 10.4)

Warsaw Uprising 44-5

Washington, DC, Library of Congress 252 (fig. 13.4)

Washington, DC, National Gallery of Art 5, 51,51 (fig. 2.1), 53 (fig. 2.3), 54 (fig. 2.4), 55, 64 (fig. 3.1), 274 (fig. 14.7)
Weiditz, Hans 221

Wesel, Andries van see Vesalius, Andreas

Wesel, Franciscus van 161-2

Wied, Anton 13, 16

Wierix, Antoon 276

Wierix, Hieronymus 275-6, 278

Wierix, Johan 276

Wieruski, Kasper 136

Wietor, Hieronim 134-6, 138 (fig. 7.1), 139 (fig. 7.2), 140 (fig. 7.3), 141 (fig. 7.4), 142 (fig. 7.5), 142-3, 143 (fig. 7.6), 144, 146n4, 146n8, 147n11, 148n44, 148n46, Pl. 22

Winghe, Joos van 19, 244, 245 (fig. 13.1), 247-8, 250, 253, 255

Wirzbięta, Maciej 144, 148n52

Wittenberg 42, 44

woodblock see matrix

World War II 4, 27, 35, 42, 43 (fig. 1.10), 44

Wosiński, Antoni 8, 10 (fig. 0.3)

Wtewael, Paulus 12 (fig. 0.4)

Zinner, Ernst 42, 43 (fig. 1.10), 44

Zoppino, Niccolò 118, 125 (fig. 6.8), $128 \mathrm{n} 10$ 